Beiträge zur Technikgeschichte Band 3.1 Studies in the History of Technology Vol.3.1

Regula Wahl-Clerici

\title{
Ouro Romano de \\ Tresminas (Portugal)
}

Prospeção - Mineração - Tratamento

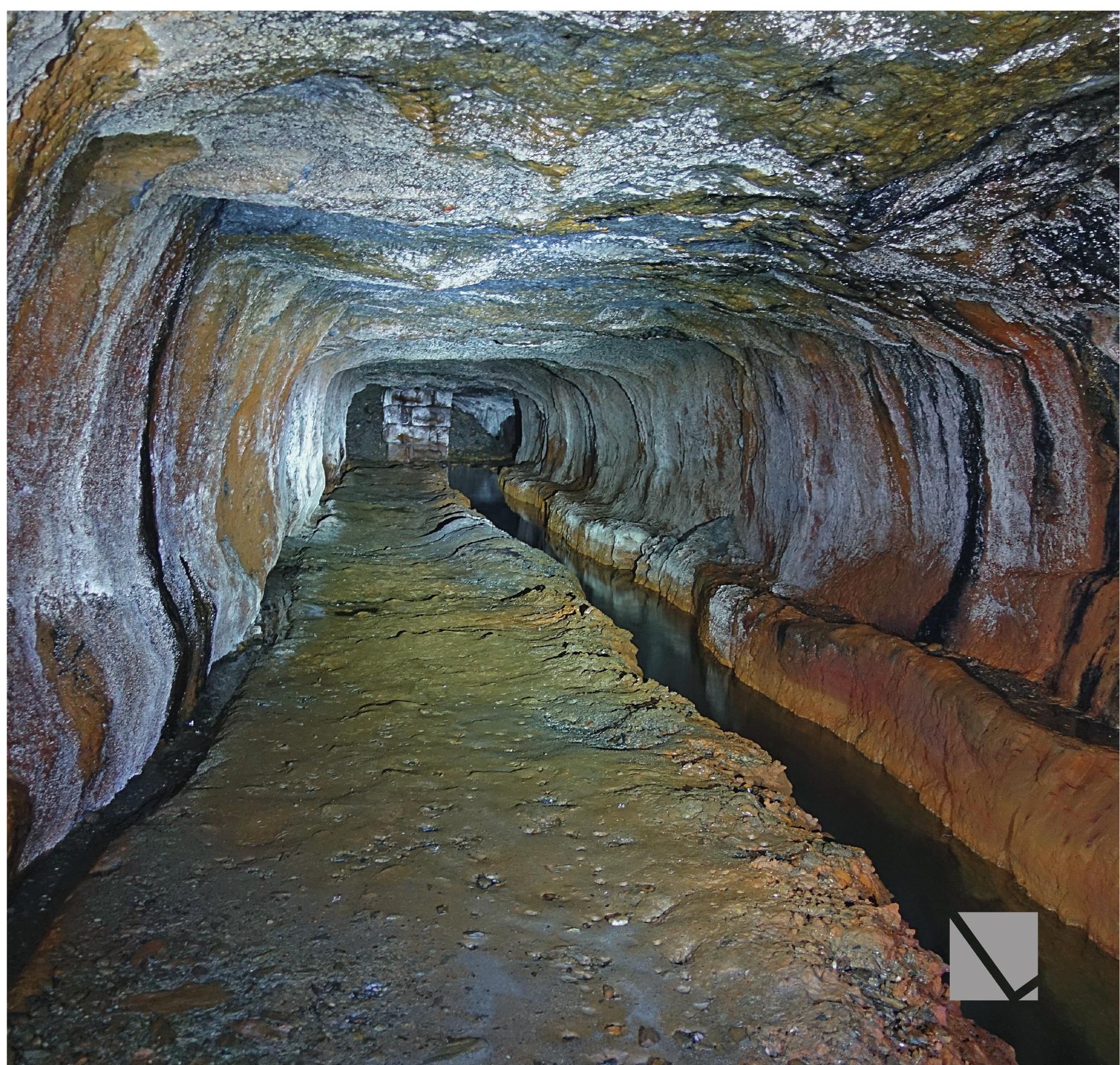


Regula Wahl-Clerici Ouro Roman de Tresminas (Portugal)

IN MEMORIAM JÜRGEN WAHL 
Editado por Dr.h.c. Alfred Mutz-Stiftung

für alte, insbesondere antike Technologie und Technikgeschichte, Basel 


\section{Ouro Romano de Tresminas (Portugal)}

Prospeção - Mineração - Tratamento 


\section{Esta publicação teve o apoio de:}

Dr. h. c. Alfred Mutz-Stiftung für alte, insbesondere antike Technologie und Technikgeschichte, Basel e patrocinadores particulares.

Revisão de pares: Peter A. Schwarz, Christoph Schneider (autores e fontes antigas), Basel Revisão de textos em Português: Patricia Machado

Tradução portuguesa: A. Costa, F. Cordoeiro e R. Sabo

Execução gráfica e composição tipográfica: Katja von Ruville, Frankfurt a. M.

Impressão: CPI buchbücher.de GmbH, Birkach (Alemanha)

ISBN: 978-3-906897-46-2

DOI: $10.19218 / 3906897462$

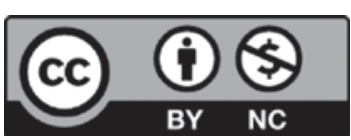

Ouro Romano de Tresminas (Portugal) by Regula Wahl-Clerici is licensed under a Creative Commons Attribution-NonCommercial 4.0 International License. www.creativecommons.org

Open-access at

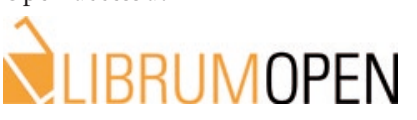

www.librumopen.com

Capa: Territorium metallorum Tresminas/Jales, Tresminas,

Galeria do Pilar: pilar e canal (foto R. Wahl-Clerici)

Contracapa: Territorium metallorum Tresminas/Jales, Tresminas, Galeria dos Morcegos

(foto R. Wahl-Clerici). 


\section{Conteúdos}

$\begin{array}{lr}\text { Agradecimentos } & 7\end{array}$

1.0 Introdução $\quad 9$

$\begin{array}{lr}1.1 \text { História das atividades científicas } & 18\end{array}$

2.0 A prospeção no territorium metallorum Tresminas / Jales 20

Os métodos para localizar uma jazida $\quad 20$

Discussão das condições no territorium metallorum Tresminas/Jales 22

A determinação do limite de uma jazida $\quad 22$

Exemplos de prospeção em Tresminas $\quad 22$

2.1 A catástrofe mineira e a ação de salvamento na mina de Tresminas 38

Discussão das causas possíveis para o desabamento local 39

Discussão das consequências do acontecimento mineiro no territorium metallorum

$\begin{array}{ll}\text { Tresminas/Jales } & 40\end{array}$

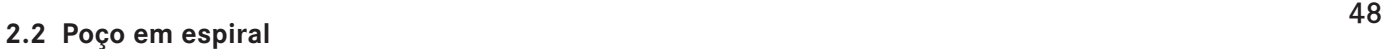

$\begin{array}{ll}\text { O poço em espiral } & 48\end{array}$

Galeria do Pastor $\quad 48$

A ligação entre o poço em escada e a Galeria do Pastor $\quad 49$

$\begin{array}{ll}\text { Resultados } & 49\end{array}$

3.0 Exploração das jazidas auríferas 58

Sinopse das zonas de extração $\quad 58$

$\begin{array}{lr}\text { Tresminas } & 58\end{array}$

As jazidas da Gralheira e de Campo de Jales $\quad 60$

3.0.1 A zona mineira de Lagoinhos 90

A atual área de exploração a céu aberto $\quad 90$

A área de exploração subterrânea $\quad 90$

$\begin{array}{ll}\text { Resultados } & 91\end{array}$

$\begin{array}{ll}3.1 \text { Técnicas de exploração } & 108\end{array}$

3.2 Progressos na extração na Corta de Covas 118

Observações: 119

3.2 Progresso na exploração na Corta de Covas (mina a céu aberto A) 120

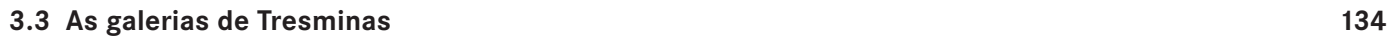

$\begin{array}{ll}\text { Corta de Covas } & 134\end{array}$

Entre a Corta de Covas e a Corta da Ribeirinha 134

$\begin{array}{ll}\text { Corta da Ribeirinha } & 134\end{array}$

3.3.1 Avanço e extensão das galerias e dos poços 159

As secções transversais $\quad 159$

$\begin{array}{ll}\text { Abertura das galerias } & 160\end{array}$

$\begin{array}{ll}\text { Os poços em escada } & 161\end{array}$

$\begin{array}{ll}\text { Os poços verticais } & 161\end{array}$ 
4.0 Tratamento do minério e fundição no territorium metallorum de Tresminas / Jales

Os mecanismos do processamento

Os processos de tratamento a seco 189

A lavagem de minério $\quad 191$

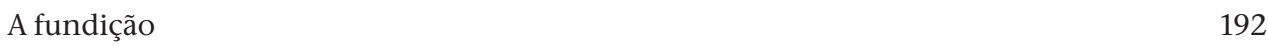

4.1 Locais de tratamento do minério $\quad 224$

Forno dos Mouros $\quad 224$

Locais de tratamento na área de exploração de Tresminas $\quad 224$

4.2 Os conteúdos de ouro nas jazidas de Tresminas,

Jales e Gralheira

O teor de ouro por tonelada de material explorado 230

$\begin{array}{ll}\text { Corta de Covas } & 231\end{array}$

Corta da Ribeirinha $\quad 231$

Lagoinhos $\quad 231$

Campo de Jales $\quad 232$

$\begin{array}{ll}\text { Resultado } & 232\end{array}$

$\begin{array}{ll}\text { O grau de pureza } & 232\end{array}$

O volume de exploração $\quad 232$

A relação entre o minério e as escombreiras 233

Resultados 233

5.0 Sistema Hidráulico: Distribuição e Aproveitamento da Água no Territorium Metallorum Tresminas / Jales

1 Armazenamento 240

2 Abastecimento 240

3 Aproveitamento 240

4 Escoamento 240

1 Armazenamento 241

$\begin{array}{ll}\text { Bacias hidrográficas (fig. 5.0-5) } & 241\end{array}$

2 Abastecimento $\quad 242$

3 Aproveitamento da água $\quad 242$

4 Escoamento 243

$\begin{array}{ll}6.0 \text { As pedreiras } & 274\end{array}$

$\begin{array}{ll}\text { Pedreiras de granito } & 274\end{array}$

$\begin{array}{ll}\text { O granito biotítico } & 274\end{array}$

$\begin{array}{ll}\text { O granito de duas micas } & 275\end{array}$

As pedreiras de xisto $\quad 276$

A cova de extração de material em Outeiro no Rio Tinhela 276

$\begin{array}{ll}\text { Resultados } & 276\end{array}$

$\begin{array}{ll}\text { Bibliografia } & 297\end{array}$

$\begin{array}{ll}\text { Antique sources } & 303\end{array}$ 
A investigação científica no territorium metallorum Tresminas / Jales não teria sido possível sem o estimável apoio de vários indivíduos e instituições, a quem se pretende agradecer expressamente.

À Direção Geral do Património Cultural, que tem vindo a acompanhar o projeto desde 1986, e cujas pessoas de contacto foram o Prof. Francisco Sande Lemos, o Dr. Orlando Sousa, o Dr. Rafael Alfenim, o Doutor Lino Tavares Dias, o Dr. Luís Pereira e o Doutor David Ferreira, que sempre se mostraram disponíveis para apoiar este projeto. A Arquiteta Paula Silva e o Dr. António Ponte foram os Diretores Regionais da Cultura Norte durante essa fase.

Sem o apoio dos presidentes da Câmara Municipal de Vila Pouca de Aguiar, Dr. António Gil, Doutor Carlos Ambrósio, Dr. Domingos Dias e Prof. António Alberto Machado, bem como dos respetivos Vereadores, nomeadamente, o Eng. Duarte Marques e a Dra. Rita Dias, que sempre apoiaram este projeto com dinamismo, não teria sido possível garantir o sucesso do mesmo. Agradece-se, igualmente, às unidades técnicas da Câmara Municipal de Vila Pouca de Aguiar, da AguiarFloresta, ao Engenheiro Manuel Machado e ao Engenheiro Duarte Marques, ao Serviço Florestal, nomeadamente, a Engenheira Arlete Paceres. O seu conhecimento da área e dos agentes florestais sempre nos ajudaram muito. Os bombeiros do Concelho de Vila Pouca de Aguiar também nos apoiaram nas nossas atividades.

Um importante parceiro ao longo de todos estes anos foi e é a população das freguesias e concelhos pertencente ao territorium metallorum Tresminas/Jales, que sempre nos apoiaram e nos acolheram com gentileza. Do concelho de Vila Pouca de Aguiar agradece-se aos presidentes da Freguesia de Tresminas, Fernando Marques e António Teixeira, da Freguesia de Alfarela de Jales, Eng. Manuel Fernando Monteiro Machado, e da Freguesia de Vreia de Jales, Norberto Paulo Xavier Pires. Os nossos agradecimentos estendem-se ainda a António Jesus da Costa, Presidente da Freguesia de Carrazedo de Montenegro, no concelho de Valpaços.

Durante o nosso trabalho de campo fomos ativamente apoiados por pessoas das aldeias de Tresminas, Granja, Covas, Ribeirinha e Vales. Deve-se a eles, e a outros habitantes das freguesias já referidas, muita informação relevante para o nosso trabalho de investigação.

Outras instituições que apoiaram ativamente o projeto foram o Instituto Alemão de Arqueologia em Madrid, a Direção-Geral de Energia e Geologia do Porto e Lisboa (antigo Serviço de Fomento Mineiro), o Museu Mineiro de Bochum (Deutsches Bergbau-Museum Bochum), o Instituto de Arqueologia da Universidade de Hamburgo, o Instituto de Ciências Arqueológicas da Goethe-Universität Frankfurt am Main, o Instituto de Ciências Mineralógicas (hoje: Instituto de Ciências Mineralógicas Aplicadas) da Rheinisch-Westfälische Technische Hochschule Aachen, da Hafen-City Universität Hamburg, Geodesia e Geoinformática, dos Amigos e Patrocinadores da Goethe Universität Frankfurt am Main, do Prof. Dr. Alexander Heising do Departamento de Arqueologia Romana Provincial da Albert-Ludwigs Universität Freiburg im Breisgau, Dr.Jens-Peter Schaefer e do Förderkreis Tresminas.

A lista de amigos e colegas cujo apoio possibilitou a criação desta obra é muito longa. A Dra.Annemarie Wiechowski (mineralogista) da RWTH Aachen, e o Dr. Rudolf Schindlmayr (físico) da Bergische Universität Wuppertal, que apoiaram a autora em tempos difíceis e cujo vasto conhecimento das áreas científicas teve um contributo essencial na compreensão do espaço. Além disso, o Dr. Markus Helfert e a Jun.-Prof. Dr. Britta Ramminger, que apoiaram com grande empenho as investigações em Tresminas na qualidade de responsáveis de projeto. A autora aproveita ainda esta oportunidade para expressar os seus sinceros agradecimentos ao MAThomas Schierl, que sempre a encorajou a continuar a escrever, e pelo seu constante empenho no projeto.

Além disso, o trabalho dos engenheiros topógrafos, Eng. Klaus Mechelke e Eng. Maren Lindstaedt (Hafen-City Universität Hamburg), que trouxe um importante estímulo a este projeto. Um agradecimento especial é dirigido ao Dr. Philine Kalb, antigo Instituto Alemão de Arqueologia em Madrid, e ao Prof. Dr. Martin Hoeck da Universidade da Beira Interior, que nos acompanharam desde a primeira fase deste trabalho. Agradece-se ainda o valioso apoio do Dr. Markus Scholz, da Goethe Universität Frankfurt am Main.

A autora aproveita ainda esta oportunidade para agradecer a João Moutinho e Vítor Gandra, assim como a outros membros do Alto Relevo Clube de Montanhismo em Valongo, pelo importante apoio à investigação nas áreas de difícil acesso das minas.

Um agradecimento especial cabe à Dra. Patrícia Machado, que graças ao seu incansável esforço ajudou a construir o Centro Interpretativo de Tresminas e o mantém a funcionar com a sua equipa.

Finalmente, dirijo os meus agradecimentos à minha família e a todos os meus colegas, amigos e conhecidos que me apoiaram ao longo dos anos. De referir ainda que não foram apenas as trocas de opiniões com peritos que provaram ser particularmente valiosas, mas igualmente as perguntas incómodas, que me encorajaram a refletir, promovendo assim o meu trabalho. 
Dirijo ainda um agradecimento especial ao Dr.h.c. Alfred MutzStiftung für alte, insbesondere antike Technologie und Technikgeschichte, na Basileia, e à editora LIBRUM Publishers \& Editors LLC, na Basileia e em Frankfurt a. M., por incluir este trabalho na série Estudos em História da Tecnologia. Gostaria ainda de agradecer ao Prof. Dr. Peter A. Schwarz da Universidade de Basileia e a Christoph Schneider pelas várias dicas e sugestões de melhoramento, sendo que este último também verificou as fontes antigas. Particularmente, o proveitoso intercâmbio científico com os colegas Professor Andrew Wilson da Universidade de Oxford e o Dr. Frank Hulek da Universidade Albertus-Magnus de Colónia. 
O depósito é determinante para todas as atividades e processos em qualquer tipo de extração de matérias-primas. Até há bem pouco tempo isto era válido para a mineração em todo o lado, sendo visível nos vestígios romanos no territorium metallorum Tresminas / Jales. No entanto, a influência de outros fatores não deve ser subestimada, podendo ser incluídos sob as seguintes palavras-chave: circunstâncias históricas, possibilidades técnicas e condições organizacionais ou administrativas. Os vestígios da mineração romana que descobrimos no territorium metallorum Tresminas / Jales são o resultado da soma destas condições, juntando-se ainda o feliz facto de os depósitos de Tresminas e Gralheira terem sido largamente poupados à mineração mais recente.

O presente volume relativo ao territorium metallorum Tresminas/Jales explora a mineração, o tratamento e a fundição de minérios em todos os seus aspetos. Além da apresentação de cada um destes processos, são ainda brevemente abordadas a prospeção, o abastecimento de água e a indústria de pedra, uma vez que são fundamentais para a exploração de ouro no territorium metallorum Tresminas / Jales e deixaram imensos vestígios (fig. 1.0-1). ${ }^{1}$

Os aspetos técnicos apresentados no livro serão complementados por uma breve introdução à história, administração e organização do espaço, o que inclui o povoado e os seus habitantes. Enquanto que os primeiros temas são fundamentalmente determinados por fatores exteriores, ou seja, pelas circunstâncias históricas, políticas e económicas, os segundos são essencialmente determinados pelos vestígios das populações locais, pelo menos na medida em que é possível registá-los a partir das fontes históricas, epigráficas e arqueológicas.

Quanto à história do complexo mineiro pode dizer-se o seguinte: Embora tenham sido encontrados indícios de atividade humana nas imediações mais amplas das três jazidas, pelo menos desde o Neolítico, não existem vestígios de mineração pré-romana nas jazidas primárias de Tresminas. O mesmo se aplica a Jales e à Gralheira, embora o Castro dos Mouros da Cidadelha (Freguesia de Alfarela de Jales), datado da Idade do Ferro, se encontre na proximidade imediata da jazida da Gralheira. ${ }^{2}$ No entanto, podemos assumir com certeza que se procedia à lavagem dos depósitos nos rios Tinhela e Curros, e seus afluentes, onde, devido às intempéries durante os vários períodos geológicos, se depositara e enriquecera o ouro libertado pelas jazidas primárias. ${ }^{3}$ Além disso, a população do oeste e noroeste da Península Ibérica já era conhecida por este tipo de mineração de ouro nos tempos pré-romanos. ${ }^{4}$

Podemos associar claramente o início da exploração nas jazidas primárias de Tresminas, Gralheira e Jales com a história da conquista romana. Após terem conquistado uma posição na Península Ibérica durante a Segunda Guerra Púnica (218 - 201 a. C.), os romanos foram estendendo gradualmente o seu domínio durante quase 200 anos, até que finalmente, em 30 a. C., no final da Guerra Civil Romana (133-30 a.C.), que também ocorreu em grande parte na península, apenas as áreas do norte e noroeste não faziam parte do Império Romano.

O que é notável na guerra da conquista iniciada em 27 a. C., no norte e noroeste da península, é que, aparentemente, deixou menos vestígios nas zonas montanhosas a oeste e sudoeste das áreas próximas de Leão, perto de Astorga (ambos Leão, E) e Benavente (Zamora, E), assim como no norte de Portugal, do que mais a leste, ou seja, nas Astúrias. ${ }^{5}$ Assim, esta zona ocidental estava claramente menos envolvida na guerra, tendo provavelmente sido pacificada antes de 16 a.C. e finalmente integrada no Império Romano (fig. 1.0-2). ${ }^{6}$

Neste contexto, passamos brevemente à questão da atribuição do territorium metallorum Tresminas / Jales a uma província. Segundo Estrabão $(3,4,20)$, em tempos idos os habitantes a norte do Douro eram chamados de Lusitanos, contudo, durante o seu período de vida ( 63 a. C. -23

1 Sínteses: Wahl 1988; Wahl 1993a; Wahl 1993b; Wahl/ Wahl-Clerici 1993b; Wahl 1999; Wahl / Wiechowski 2006; Wahl-Clerici 2008; Wahl-Clerici / Helfert 2017a; Wahl-Clerici 2018; Ramminger et al. 2011.

2 Batata et al. 2008, 14-21.

3 Isto corresponde à formação habitual de uma jazida secundária.

4 Strabon Geografia 3,2,9 menciona os Turdetanianos e os Artabianos que lavam ouro. Enumera $(3,3,4)$ o Tagus (Tejo), Mundas (Mundo), Vacua (Vouga), Durius (Douro), Lethe, „que algumas pessoas chamam de Limaeas, ou Belion«, Baenis „outros dizem ,Minius“" (Minho), no Oeste da Península Ibérica como rios ricos em ouro. De igual interesse é a referência de Plínio n.h. 33,76 seg. ao afirmar que a Espanha já tinha avançado muito para o mar devido à lavagem de ouro nas jazidas secundárias. (ac longe terras in mare his de causis iam promovit Hispania.)

5 Morillo Cerdán 2017; Bartenstein 2014, fig. 2.; Sánchez-Palencia etal. 2017; Pesquisas mais recentes referem-se à chamada castra aestiva, ou seja, a campos militares e campos de verão, na parte ocidental da área. Cronologicamente são atribuídos à república tardia, ou seja, ao séculoI d.C., veja-se Menéndez-Blanco etal. 2017, 68, apesar destas investigações, a fig. 3 mostra uma clara lacuna na área mencionada. Na melhor das hipóteses, as instalações no Alto da Cerca (Freg. Carrazedo de Montenegro, Conc. Valpaços, P), publicada por Fonte/ Costa-García em 2016, eram provavelmente um campo militar (tipo acampamento de marcha). Isto significa que a interpretação dos autores (p.55) das instalações como uma espécie de local de proteção ou de controle do territorium metallorum Tresminas / Jales é omitida.

6 Alarcão 1988, 25-30; Bartenstein 2014, 82-86, 122. 


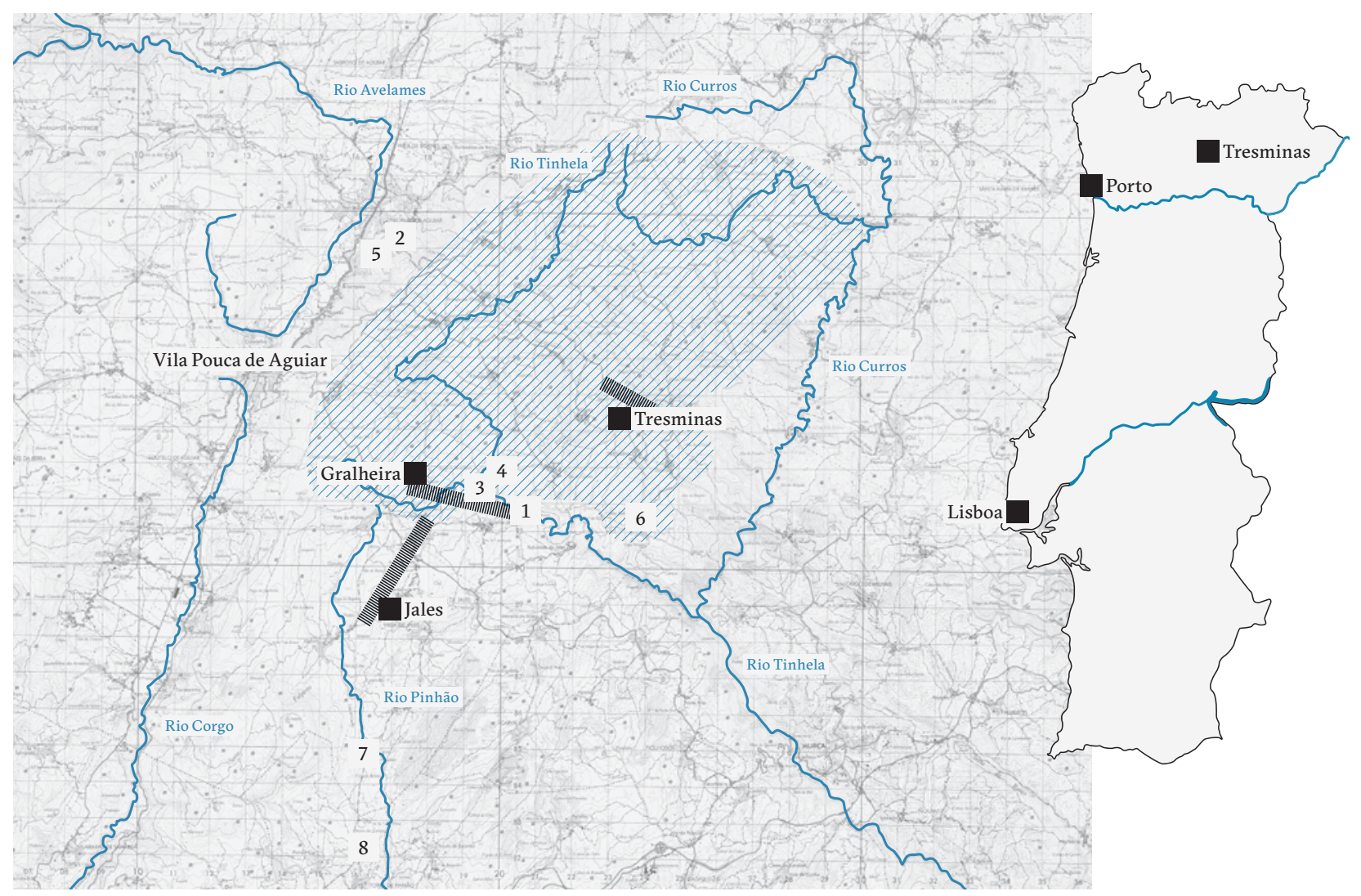

fig.1.0-1: Territorium metallorum Tresminas /Jales, mapa geral: 1 - Castelo dos Mouros, 2 - Castro de São Martinho de Bornes, 3 - Forno dos Mouros, 4-Fonte da Ribeira - Pedreira, 5-Bornes - Pedreira, 6-Vales - Quinta romana, 7-Ponte do Arco, 8-Ponte da Cheira. (Modelo: Carta Militar de Portugal 1:50000 folhas 6-2 e 10-1, desenho: R.Wahl-Clerici e S.Mathiuet). 


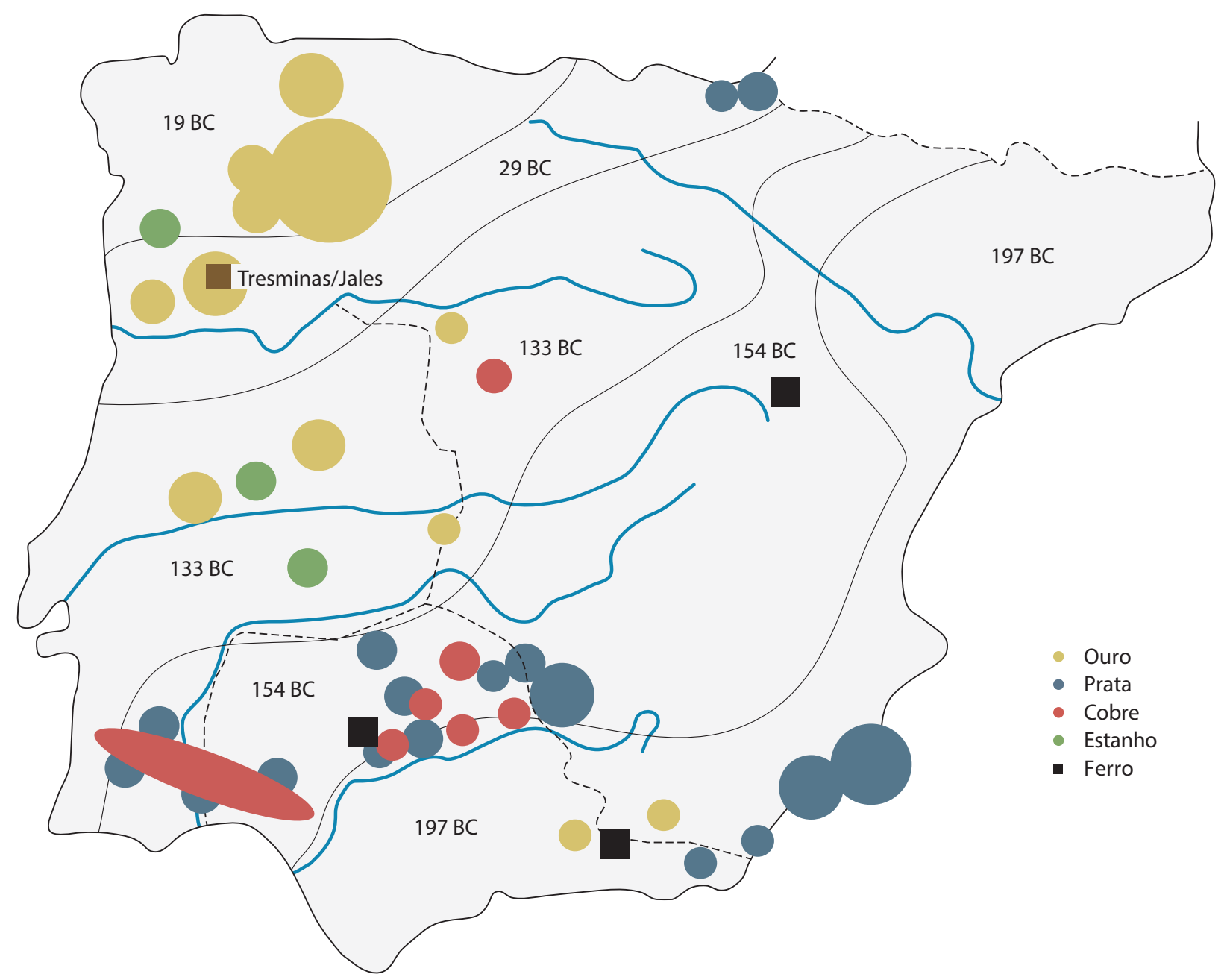

Fig.1.0-2: Visão geral das fases da conquista romana e das jazidas de minério na Península Ibérica (modelo C. Domergue 2008, Carta 4, execução: R.WahlClerici, desenho: S.Mathiuet) 
d.C.) eram chamados de Callaecers. Contudo, permanece em aberto, se a partir daqui é possível concluir que Tresminas era originalmente lusitana. ${ }^{7}$ Durante a conquista final da Península Ibérica, que começou apenas três anos após o fim da Guerra Civil Romana, a península foi dividida em duas províncias: Hispania Citerior e Hispania Ulterior. Esta últimas incluía a Lusitania, a Baetica e a Callaecia. Segundo Alföldy, isto impediu que as seis a sete legiões, que tinham estado na península em diferentes fases, se unissem sob o comando de um único governador provincial. ${ }^{8}$ Só a partir de 13 a. C. foram adicionados à Hispania Citerior, ou Tarraconensis, os últimos territórios conquistados. ${ }^{9}$

No âmbito da discussão sobre atribuição de Tresminas a uma província, deve-se mencionar ainda o edital de Augusto de Bembibre (Província de León, E), registado numa placa de bronze, na qual se menciona uma província transduriana. Alföldy assume durante o estudo desta referência única que a província foi fundada para estabelecer estruturas de administração, tendo sido integrada o mais tardar 13 a.C. na Hispania Citerior. Por razões geográficas, o territorium metallorum Tresminas / Jales ter-lhe-ia naturalmente pertencido. ${ }^{10}$

O mais tardar com a conquista do Noroeste, os vastos depósitos de ouro tornaram-se o foco de atenção dos romanos. Após Augusto, por volta de 27 a. C., ter elevado o aureus à moeda principal, a procura de ouro no Império Romano aumentou consideravelmente num curto espaço de tempo. ${ }^{11}$ Sabemos de fontes históricas que Augusto explorou sistematicamente a área recém-conquistada para obter uma visão geral dos depósitos de ouro. ${ }^{12}$

Conforme referido, a lavagem dos sedimentos do rio, que requer vastos recursos humanos, mas é tecnicamente menos complexa, tinha sido praticada pela população local desde há muito tempo, podendo ser um indício de que desta forma se tornara possível cobrir uma parte inicial do ouro devido a Roma após a conquista. Os vestígios do ouro pré-romano na Península Ibérica, apesar da sua variedade e beleza impressionantes, representam, muito provavelmente, apenas uma pequena fração da riqueza antecedente. ${ }^{13}$

No que diz respeito ao início da exploração de ouro nas jazidas primárias de Tresminas, Gralheira e Jales no territorium metallorum Tresminas / Jales, só é possível fazer especulações. Contudo, uma importante referência cronológica sobre as atividades romanas em Tresminas é o tesouro de moedas encontrado em 1894 em Vales (Freguesia de Tresminas, Concelho Vila Pouca de Aguiar), composto por denários de Augusto, destinados aos seus netos Gaio César (20 a. C. -4 a.C.) e Lúcio César (17 a.C. -2 a.C.), e que foi enterrado o mais tardar por volta do nascimento de Cristo. ${ }^{14}$ Mesmo que a quinta de Vales estivesse localizada nas proximidades dos depósitos de Tresminas (distância em linha reta aproximadamente $4 \mathrm{~km}$ ) e da Gralheira (distância em linha reta aproximadamente $4 \mathrm{~km}$ ), ainda não foi possível estabelecer uma ligação direta com a sua exploração.
Em contrapartida, existe uma clara ligação entre a mineração e os vestígios nas inscrições das sepulturas encontradas na área de Tresminas, a mais antiga com data do reinado do imperador Tibério (14-37). Estas primeiras estelas foram erguidas para os imigrantes da Colónia Clunia Sulpicia (Peñalba de Castro, província de Burgos, E) que tinham vindo para trabalhar na indústria mineira. ${ }^{15}$

A única data concreta, conhecida atualmente em relação ao territorium metallorum Tresminas/Jales, é a nomeação dos cônsules em 130 d. C. durante a consagração de um destacamento legionário do legio VII gemina a Júpiter. As outras duas inscrições militares eram igualmente pedras de consagração a Júpiter. Os soldados das coortes I Gallica equitata civium Romanorum construíram a sua consagração na primeira metade do século II. ${ }^{16}$ No entanto, a classifica-

7 Sobre a denominaçao das tribos pelo romanos veja-se Edmondson 1993, 13: «Primeiro, os Romanos criaram amplas identidades étnicas para os seus opositores, ignorando a complexa e altamente fragmentada geografia étnica e regional da área». https://www.researchgate.net/publication/42243082_Creating_a_provincial_ Landscape_Roman_imperialism_and_rural_change_Last view: 02.09.2019.

8 Alföldy 2000, 185. Este argumento é compreensível no contexto da Guerra Civil Romana, grande parte da qual teve lugar na Península Ibérica.

9 Bartenstein 2014, 71-123 com um estudo detalhado das fontes históricas e arqueológicas; LeRoux 1982, 74-77; Domergue 1990, 200 refere a menção de Plínio n.h. 33,78, sobre as 20000 libras de ouro, extraídas anualmente das Astúrias, Callaecia e Lusitânia. (vicena milia pondo ad hunc modum annis singulis singulis Asturiam atque Gallaeciam et Lusitaniem praestare quidam prodiderunt, ita ut plurimum Asturia gignat.). Só lhe é possível explicar esta quantidade pelo facto de as três terem formado uma única província entre 27 e 13 a. C., até a região a norte do Douro ser atribuída à Hispania Citerior; Veja-se ainda a distribuição das instalações militares na época agostiniana: Morillo Cerdán 2002, fig. 1 e 2; Alföldy 2000, 198.

10 Alföldy 2000, 198.

11 Drexhage et al. 2002, 47, com mais fontes.

12 Wahl-Clerici/Wiechowski 2013, 300: Segundo Florus (ca. de 100 d.C.), Augustus ordenou a prospeção organizada do Noroeste (Flor. epit. 2, 33, 59-60) Cerca de cem anos mais tarde, Cassius Dio (ca. de 150 a 235 d.C.) referiu-se a Maecenas (70-8 a.C.), o confidente mais próximo de Augusto em assuntos financeiros (Dio 52, 28, 4).

13 Sobre os achados de ouro pré-históricos na Península Ibérica ver García Castro, J.A. 1999; Blech etal. 2001; Trillmich etal. 1993; Alvarez Alcántara / Yugueros Yugueros sem data.

14 Russel Castro 1952, 16: O autor não exclui que outros tesouros de moedas da região a norte do Douro, compostos por denários republicanos, tenham sido escondidos em ligação com as campanhas de César nesta região por volta de 46 a. C. (Veja-se Russel Castro 1952, 6-37 e Castro Hipólito 1960 / 61, 28 com indicação de mais referências; Vales: „Próximo da povoação dos Vales, ..., descobriu, ainda no ano passado [1894] um lavrador, que arava o seu campo, boa porção de dinheiro romano, todo de Caio César e Lúcio César do reinado de Augusto«. Outra referência confirma que os nimismas são todos do mesmo cunho e que se trata do espécime que no

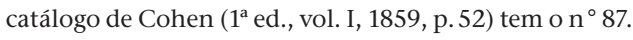

15 Wahl 1988, 239-240, nota 44; Redentor 2010, 142; Haley 1991; Holleran, sem data.

16 Wahl 1988, 240; Redentor 2010, 138. 
ção cronológica da pedra de consagração do soldado Quintus Annius Modestus, datada por um autor como sendo do último terço do século I e por outro de 197-211, é controversa. ${ }^{17}$

Os testemunhos para uma classificação cronológica da exploração na própria montanha são raros. ${ }^{18}$ Felizmente, em Tresminas, é pelo menos possível acompanhar as várias fases do progresso de exploração na Corta de Covas. Os vestígios de lucernas do cuniculum inicial, ao longo da parede oriental na Galeria do Pilar, comprovam que a drenagem através do canal aprofundado, na zona norte de exploração da Corta de Covas, teve lugar já no terceiro quartel do século I. ${ }^{19}$ As lucernas da Galeria do Texugo, construída $30 \mathrm{~m}$ mais abaixo e pertencente ao mesmo sistema, podem ser datadas do período Trajano, ou seja, do $1^{\circ}$ quartel do século II. Apesar de sintetizados, estes dados comprovam que a mineração na parte sul da Corta de Covas começou logo após a abertura da mina (fig. 1.0-3).

Por outro lado, não existem evidências cronológicas para a exploração mineira das jazidas na Corta da Ribeirinha e de Lagoinhos em Tresminas, bem como na Gralheira e Jales. Tendo em conta o contexto geral, podemos assumir que as principais fases de mineração ocorreram igualmente nos séculos I e II.

Em suma, pode dizer-se em relação à cronologia que a exploração sob o poder romano teve início na época anterior ao nascimento de Cristo. A ligação entre a quinta de Vales, com seu tesouro de moedas, e a exploração de ouro nas jazidas circunjacentes talvez possa ser apurada através de investigações futuras. Apesar de muito deteriorados, os denários republicanos de prata, recolhidos acidentalmente nos arredores do anfiteatro, também são importantes para a classificação cronológica e a importância deste lugar. ${ }^{20}$ Segundo os conhecimentos atuais, um dos principais períodos auges da mina situa-se provavelmente entre os anos 50 e 150, conforme comprovam as inscrições militares. Tal como J. Wahl suspeitava, o fim da mineração em estilo industrial deve muito provavelmente ser associada às mudanças económicas e organizacionais sob a dinastia dos Severos (193-235). ${ }^{21}$ No entanto, isto não descarta a continuação da exploração de ouro em pequena escala pela população remanescente. ${ }^{22}$

As áreas de povoamento no territorium metallorum Tresminas/Jales caracterizam-se pelas seguintes circunstâncias. O maior povoado conhecido encontra-se junto à mina a céu aberto, Corta de Covas, em Tresminas e estende-se essencialmente pelo planalto, a oeste da mina a céu aberto. Outro pequeno povoado foi encontrado no vale da Ribeirinha. ${ }^{23}$ As povoações romanas junto da jazida de Jales são mais difíceis de identificar. O único vestígio, atualmente existente, de um possível povoado é o capitel de uma coluna, cuidadosamente trabalhado, encontrado nos escombros de construção na berma de uma estrada em Campo de Jales.
Nem na área da jazida da Gralheira, nem no lugar de tratamento «Forno dos Mouros» existe qualquer evidência clara de atividades de um povoado. Pelo contrário, tudo indica que as edificações no Forno dos Mouros serviam puramente para fins industriais. Assim sendo, terá de permanecer em aberto se os trabalhadores da Gralheira e do Forno dos Mouros viviam no Castro da Cidadelha ou se se deslocavam de Tresminas.

As investigações realizadas até à data na zona do povoado de Tresminas revelaram que a construção das casas seguiu a construção em quadrado, tipicamente romana, sendo que as pesquisas geomagnéticas, levadas a cabo numa parte desta área, revelaram que as casas se encontravam alinhadas de ambos os lados de uma estrada, como era habitual no vici romano. ${ }^{24}$ É ainda de referir que, pelo menos no canto nordeste do povoado, as casas mais antigas estavam claramente cobertas por escombreiras. ${ }^{25}$ Como em qualquer área de mineração, as atividades de exploração têm prioridade sobre o povoado, que deve ceder se necessário.

O anfiteatro pode ser considerado um edifício excecional. ${ }^{26} \mathrm{O}$ estado atual de preservação comprova que pelo menos a sua fundação, e, provavelmente, partes da estrutura, eram constituídas por muros. Basicamente, os anfiteatros eram construções em pedra, situados em localidades maiores e mais importantes, ou em ligação com os campos militares. ${ }^{27}$ No noroeste, são conhecidos apenas os anfiteatros dos locais principais dos conventii Bracara Augusta (Braga,

17

Século 1: LeRoux 1982, 197, nº 91bis; Século 3: Redentor 2010, $138-139$.

18 Domergue 1990, 204: Inscrição do PUDENS libertado, de 97 d.C., num túnel de mineração em Rio Tinto (Huelva, E), CIL II 956; A inscrição de EMILIANUS (CIL XIII 4238) apenas nomeia o dia da abertura da mina, 7 de março, mas não o ano. Por conseguinte, esta inscrição só pode ser datada no período geral de funcionamento da mina, entre os séculos I e IV. Körlin 2010, 176; A inscrição SABALCO na Galeria do Texugo continua por certificar, Wahl 1988, 229.

19 Wahl 1988, 240 fig. 43b.

20 Denário de L.Calpurnius Frugi, cunhado em Roma em 90 a.C.; Denário de P. Crespius, cunhado em Roma 82 em a.C.; Denário de L. Rutilius Flaccus, cunhado em Roma em 77 a. C. As moedas não publicadas são exibidas no Centro Interpretativo em Tresminas/Vila Pouca de Aguiar.

21 Embora não haja investigação relevante a este respeito, não é de excluir que a peste Antoniniana $(165$ - 180 / 190) tenha provocado um primeiro corte sério nas estruturas sociais e económicas. (Devo esta dica a A. Wilson, Oxford).

22 Neste contexto, devem ser mencionadas as descobertas de ouro numa sepultura perto da Granja (freg. Tresminas). Trata-se de uma moeda do rei visigodo Ecija (cunhada em Sevilha em 685) e de um brinco de ouro perdido. Ver Parente 1980.

23 Wahl-Clerici/Helfert 2017, 55 fig. 4.

24 García Marcos/Morillo Cerdán 2015, fig. 6.

25 Wahl 1988, 234-236, quadro 48.

26 Wahl 1988, 237-238; Martins et al. 2011.

27 Wahl 1988, 237-238, fig. 2, com referências adicionais; Martins 2011. 


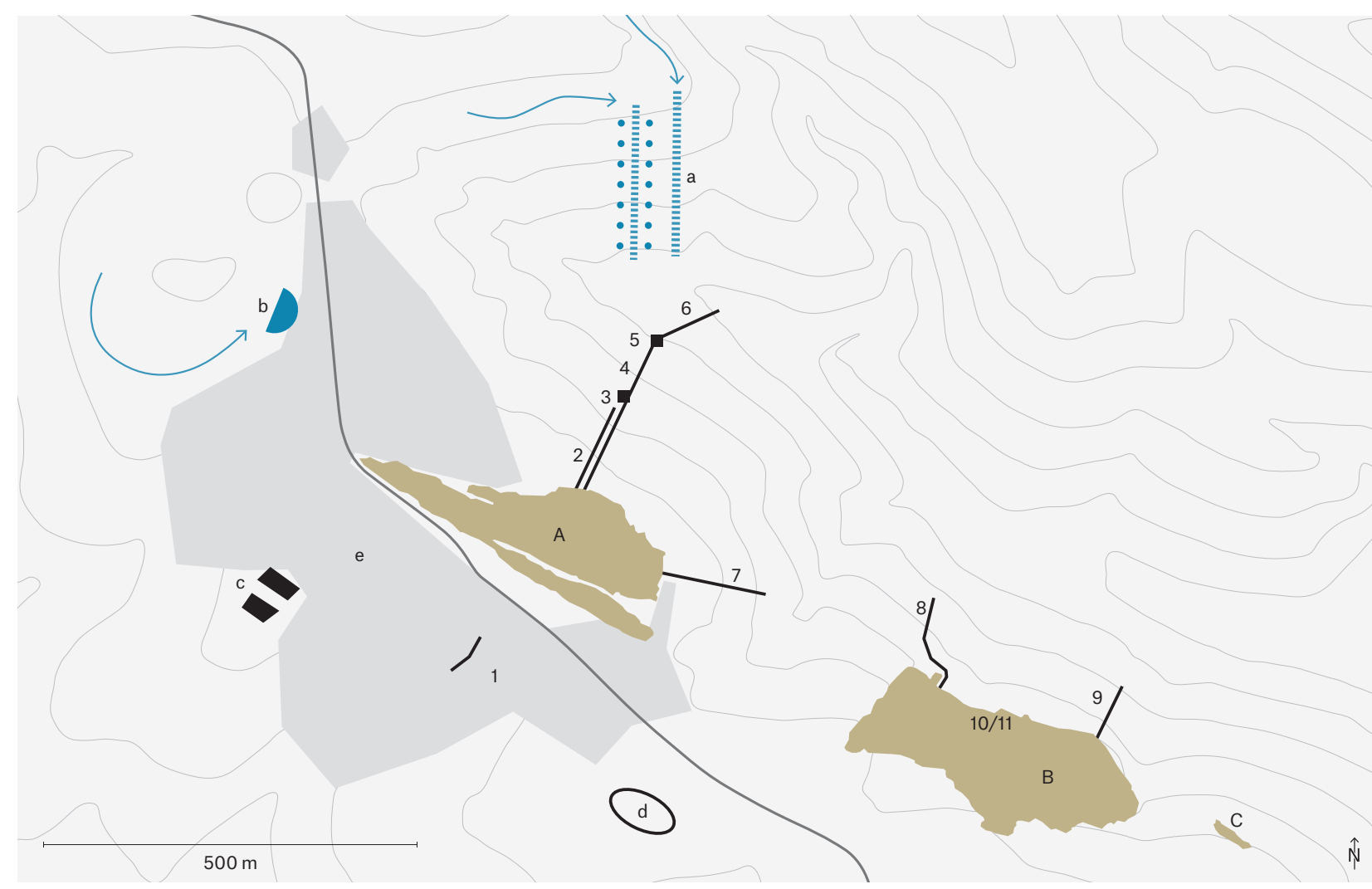

Fig.1.0-3: Territorium metallorum Tresminas / Jales. Vista geral da zona central de Tresminas: A - Corta de Covas, B - Corta da Ribeirinha, C - Lagoinhos 1 - Galeria Esteves Pinto, 2 - Galeria Jürgen Wahl, 3 - poço em frente à entrada da Galeria Jürgen Wahl para a Galeria do Pilar, 4-Galeria do Pilar, 5 - poço em frente à entrada da Galeria do Pilar para a Galeria do Texugo, 6 - Galeria do Texugo, 7 - Galeria dos Alargamentos, 8 - Galeria dos Morcegos, 9-Galeria Buraco Seco, 10 - escada em espiral, 11 - Galeria do Pastor. a - instalações de lavagem de minério, $b$ - tanque de água, $c$ - pedreiras de xisto, d-anfiteatro, e-povoado (Modelo: Ortofotomapa Câmara Municipal Vila Pouca de Aguiar 1:10000, execução: J.Wahl, R.Wahl-Clerici, M.Helfert, desenho: S.Mathiuet) 
P), Lucus Augusti (Lugo, E), Asturica Augusta (Astorga, E) e da sede da legio VII gemina (León, E). ${ }^{28}$ Esta concentração de anfiteatros no noroeste da Península Ibérica é impressionante, uma vez que no resto da província de Hispania Tarraconensis restam apenas outros quatro anfiteatros, Ampurias (província de Girona, E), Tarragona (província de Tarragona, E), Cartagena (província de Murcia, E), Segóbriga (província de Cuenca, E).

Contudo, de acordo com o atual estado de investigação, permanece em aberto, se, com a descoberta de vestígios de anfiteatros no territorium metallorum Tresminas / Jales, que por norma fazem parte das construções exclusivas de grandes cidades ou de espaços militares, é possível presumir que nos encontramos perante um lugar de particular importância, tanto em termos organizacionais e administrativos, como em termos de dimensão.

A designação moderna (em latim), territorium metallorum Tresminas/Jales pressupõe que todas as jazidas desta zona faziam parte de uma unidade. Todavia, ao tentar determinar a extensão deste território, deparámo-nos com dificuldades significantes. Graças às placas de bronze de Vipasca (Aljustrel, Distrito de Beja, P), exibidas sob o imperador Adriano, sabemos que, em princípio, a metalla ou territorium metallorum tinha limites claramente definidos, designados de fines metallorum, mencionados em vários parágrafos (§§ 10. 13. 17) em ligação com a proibição definitiva de entrada na mina, caso ocorresse alguma infração. ${ }^{29}$ Contudo, todos os exemplos de distritos mineiros nas várias províncias romanas têm em comum o facto de as fontes serem demasiado escassas para se poder determinar a dimensão dos territoria. ${ }^{30}$

A este respeito, é necessário ter em conta outro aspeto no estudo sobre o territorium metallorum Tresminas/Jales, nomeadamente, a referência de Plínio, o Velho, a um Gallaeciae metallum, quod vocant Albucrarense (n.h. 33, 80), ou seja, um metallum albucrarense em Callaecia. Devido à sua menção explícita sobre o baixo teor de prata no ouro, já se suspeitava tratar-se de Tresminas, embora não exista mais nenhum registo escrito quanto a este assunto. ${ }^{31}$ Até que ponto o nome alboc, encontrado em inscrições desde Valongo, perto do Porto, a oeste, até Salamanca (E), a leste, é indicativo da extensão de um metallum, não pode ser afirmado com certeza. ${ }^{32}$

No contexto do presente trabalho, parecem ainda significativas outras considerações sobre o tamanho de um territorium metalorum. Um primeiro ponto importante é o facto de o distrito mineiro romano de Tresminas/Jales ser um complexo industrial. Assim, colocamos em ênfase as condições sem as quais não teria sido possível manter em funcionamento a exploração mineira e que serão aqui apresentadas sucintamente.

Para além do povoado e dos seus habitantes ${ }^{33}$, que deixaram vestígios nas casas, nas sepulturas e nas inscrições já referidas, era essencial haver acesso a produtos agrícolas e florestais. Aqui apenas serão mencionados animais de tração e outros animais de trabalho, bem como produtos como couro, sebo, etc., que foram de importância fundamental para a extração e o tratamento dos minérios. O cânhamo, destinado à produção de cordas, tinha sempre de estar disponível em quantidades suficientes. As cestas e outros recipientes feitos de material orgânico e não orgânico também pertenciam ao inventário básico de uma exploração mineira. ${ }^{34}$ A importância do vale fértil de Vila Pouca de Aguiar, mencionado numa inscrição votiva que comemora o enterro de um raio, ainda não é conhecida. Até ao momento, não se conhecem muitos vestígios da época romana. ${ }^{35}$

Entre as indústrias mais importantes encontravam-se a silvicultura e a indústria da madeira, que inclui não só o processamento da madeira, mas também a queima de carvão vegetal. ${ }^{36}$ Este último era necessário não só para a fundição do minério tratado, mas também para os ferreiros, onde as ferramentas tinham de ser afiadas em breves intervalos, e para as oficinas do segeiros. ${ }^{37}$ De igual forma, eram necessárias quantidades enormes de lenha que tinham de estar disponíveis para o ataque por fogo. Era necessária madeira de alta qualidade para a entivação nas montanhas, bem como para as instalações mecânicas. ${ }^{38}$

28 No Castro de Monte Mozinho (concelho de Penafiel, distrito do Porto), algumas das estruturas descobertas recentemente, sugerem, por exemplo, que a praça principal poderia ser utilizada como anfiteatro, se necessário.

29 D'Encarnação 1984, 211-216.

30 Estudo detalhado em Hirt 2010, 48-82.

31 Rodríguez Colmenero 1999. Para a abordagem dos conteúdos de ouro, ver capítulo 4.2 .

32 Resumo da literatura sobre este tema: Redentor, A Cultura Epigráfica no Conventus Bracaraaugustanus (Pars Occidentalis), 504-505; Ver mapa em Daremberg / Saglio 1877-1919, 1848.

33 Para os habitantes de Tresminas: Redentor 2010. Podem ser encontradas mais informações nas placas de bronze de Vipasca, ver D‘Encarnação 1984, 204-211. As placas de cera dos arquivos das minas de ouro dacianas também fornecem informações sobre a composição da população. Veja-se Noeske 1977. A patir de Diodorus: 3,13,1 sabemos que os mineiros das minas de ouro núbias, com idade superior aos 30 anos, deixavam de trabalhar na montanha, para passar para o tratamento e a fundição.

34 Por exemplo: Gossé 1942, Lam. IV - VI. e ainda Domergue 1990, $440-460$.

35 Batata etal. 2008, 26-27.

36 As estimativas de Harris 2018, 216 para a produção de 80000 toneladas de ferro por ano em todo o Império Romano resultam numa procura florestal de $26000 \mathrm{~km}^{2}$, que é quase $30 \%$ da área de Portugal $\left(92212 \mathrm{~km}^{2}\right)$. Encontra-se em preparação uma abordagem global sobre o uso de madeira em minas antigas.

37 Compare-se a composição de um grupo de trabalho numa pedreira média, no deserto egípcio (data desconhecida): 36 pedreiros; 3 ferreiros; 6 homens para o fole de ferreiro; 2 supervisores; 1 encarregado; 1 homem para o trabalho de martelo: Peacock/Maxfield 1997, 200 (segundo Bülow-Jacobsen 1992, MC Inv. No. 0.1252.)

38 Vista geral das citações antigas: Wilson 2008, 337-339. 
Esta breve panorâmica das indústrias fornecedoras não inclui o fornecimento de géneros alimentícios básicos, uma vez que não dispomos de qualquer informação a este respeito. Todavia, pesquisas feitas no Egito, onde existe uma maior abundância de fontes escritas, revelaram que a sua organização era adaptada aos contextos locais. ${ }^{39}$

Estas condições, consideradas apenas sumariamente, comprovam que o territorium metallorum Tresminas/Jales era um verdadeiro distrito industrial, construído a partir do nada, pelo menos na zona das jazidas de ouro de Tresminas.

Podemos supor que, além das áreas mencionadas, pelo menos toda a bacia hidrográfica e o sistema de abastecimento de água faziam parte do territorium metallorum Tresminas/Jales, além das pedreiras de granito. Uma vez que o granito biotítico se encontra presente nas encostas dos vales dos rios Corgo e Avelames, ambos originários de Vila Pouca de Aguiar, onde também foram encontrados vestígios de pedreiras romanas, podemos concluir que esta área também fazia parte do territorium. ${ }^{40}$

Estas circunstâncias estão relacionadas com as questões de organização e gestão do territorium metallorum Tresminas / Jales. Por princípio, as terras recém-conquistadas e, portanto, as jazidas que delas faziam parte, passavam para o imperador que sucedia legitimamente aos anteriores regentes. Por outras palavras, o noroeste da Península Ibérica era propriedade de Augusto e dos seus sucessores, pois o Império Romano dificilmente distinguia entre a propriedade pessoal do imperador (fiscus) e a propriedade estatal (aerarium).$^{41}$

Uma das principais dificuldades deste estudo prende-se precisamente com o facto de não podermos assumir que a mesma forma de organização se manteve inalterada durante os 200 anos de funcionamento do territorium metallorum Tresminas/Jales.

Contudo, pode concluir-se o seguinte sobre o territorium metallorum Tresminas/Jales: Era certamente uma mina imperial e fiscal sob o regime denominado por Domergue de régie directe. Neste caso, um procurator, geralmente um membro livre da família imperial, era responsável pela operacionalização e todo o lucro era transferido para o tesouro imperial. ${ }^{42}$ Mesmo que não existam fontes escritas, podemos considerar a planificação em grande escala das galerias, tal como as encontramos em Tresminas, como prova clara de uma forma central de organização. Destaca-se o sofisticado sistema das diversas galerias e poços para facilitar a extração de minério na Corta de Covas. O esforço feito para fornecer a água também aponta para uma forma central de organização. ${ }^{43}$

Outra forma de organização é-nos revelada pelos painéis de bronze da Vipasca e pelos painéis de cera dos arquivos das minas de Daciano. Eles testemunham o sistema engenhoso de locação sob a direção de um procurator imperial $^{44}$, em que por norma toda a responsabilidade era transferida para os locatários, que, por sua vez, a impunham aos seus trabalhadores na medida do possível. ${ }^{45}$ Deste modo, o estado era indemnizado através das rendas da concessão ${ }^{46}$, pois com o sistema de aluguer os romanos garantiam ao Estado a rentabilidade da mina. ${ }^{47}$

Uma vez que o ouro também era extraído nas minas dacianas, o argumento de que a exploração de ouro ocorria sempre sob a administração direta do Estado perde o seu valor. No entanto, não existem ainda indicações sobre um sistema de arrendamento no noroeste da Península Ibérica.

A partir dos vestígios arqueológicos e do referido decreto de Augusto de Bembibre foi possível identificar outra forma de organização. ${ }^{48}$ Supõe-se que a mineração era realizada por uma população local comprovadamente leal. Diz-se que o ouro era extraído sob a direção da aristocracia dos clãs, tendo de ser paga uma certa quantia como tributo. O resto ficava na posse do clã, ou seja, da aristocracia. Esta forma de organização baseava-se no conhecido modelo romano, no qual a classe alta local era deliberadamente integrada e designada para tarefas executivas. Esta forma de decomposição das estruturas sociais anteriores ia de encontro aos interesses romanos. ${ }^{49}$ Todavia, salienta-se que no territorium metallorum Tresminas / Jales não existe qualquer referência a estes procedimentos.

39 Para o fornecimento de gêneros alimentícios básicos no deserto egípcio, veja-se Hirt 2010, 214-217 e Friedmann 2013. Sobre os preços dos produtos individuais nas minas dacianas, veja-se Mrozek 1971.

40 Uma consagração não datada a Júpiter Fulgur de Castelo (Freguesia Telões, conc. Vila Pouca de Aguiar), esculpida numa placa de argila cozida, pode ser vista em ligação com a extração de granito biotítico. Foi encontrada na fenda de um bloco de granito rebentado e depois entregue a Francisco Martins Sarmento pelo Padre Josef Brenha em outubro de 1898. O local onde embatia um raio era selado e marcado como túmulo de Júpiter. Ver CIL II $262=\mathrm{AE}$ 1947.8.

41 Ausbüttel 1998, 14-16.

42 Uma abordagem detalhada sobre os procuradores de minas pode ser encontrada em: Domergue 1990, 280-307, Hirt 2010, 76-79 e Heil 2012; Wahl 1988, 241-242. Devido à sua situação especial, as pedreiras no deserto egípcio podem ser designadas de caso extremo. Graças às inscrições preservadas, Hirt foi capaz de descobrir uma forma apertada de organização governamental sob direção militar: Hirt, 2010, 51-53.

43 Domergue já se refere a isto em 1990, 303.

44 As suas tarefas encontram-se enumeradas nas placas de bronze da Vipasca. d'Encarnação 1984, 204-216; Noeske 1977.

45 Noeske 1977, 396-403: Nas placas TCIX, CILIII, p.948, e TC X. CILIII, p. 948, afirma que os trabalhadores tinham de vir trabalhar em plena posse das suas forças. Se não o fizesse, fosse por doença ou acidente, o trabalhador tinha de pagar 5 sestércios e 8 ases / dia ao locador.

46 De acordo com a Lex metallis dicta, tinham de ser pagos 4000 sestércios pelo aluguer de uma mina (parágrafo 2) antes do início dos trabalhos.

47 Veja-se Günther 2012, 152

48 Para a descoberta do édito de Augusto de Bembibre, em 1999, ver Domergue 1990, 305; Orejas / Sánchez Palencia 2002, 589_591; Sánchez-Palencia et al. 2017.

49 Galsterer (1979: 456) menciona na nota 1 as „escolas de príncipe» romanas, onde os filhos da aristocracia dos clã eram educados seguindo o estilo romano. Plutarco, Sertorius 14, 2-3: Mas acima 
O quadro cronológico deste tipo de organização permanece pouco claro. ${ }^{50}$ As dúvidas surgem quando se consideram os requisitos técnicos que surgiam no caso de todas as minas maiores, tanto em jazidas primárias como secundárias ${ }^{51}$, ou em zonas de alteração. ${ }^{52}$ Embora a população celtiberiana tivesse uma longa experiência e vastos conhecimentos e competências na exploração de ouro ${ }^{53}$, era necessário um apoio técnico pelos romanos, pelo menos no início da exploração em grande escala, por exemplo, no que diz respeito à topografia exterior e subterrânea. ${ }^{54} \mathrm{~A}$ partir de outras fontes, como a inscrição de Nonius Datus, podemos assumir que os militares não apenas assumiam tarefas soberanas, como também eram responsáveis por questões técnicas. ${ }^{55}$

Até que ponto este tema está relacionado com a questão da rentabilidade das minas de ouro romanas, terá de ser abordado num estudo adicional. Domergue refere-se explicitamente à desproporção flagrante entre o esforço e o rendimento em Las Médulas, quando se leva em conta todo o trabalho adicional necessário para a exploração de ouro. ${ }^{56}$ Aqui é possível verificar que o princípio apresentado por Hirt sobre a organização de minas e pedreiras romanas pode ser aplicável na maioria dos casos, mas não em todos:

«The guiding principle of the Roman mining and quarrying administration was to keep imperial involvement to a minimum without renouncing control of these ventures. ${ }^{57}$

Pois não só em Las Médulas mas também, por exemplo, na zona central de Tresminas no territorium metallorum Tresminas/Jales, o esforço e o rendimento apresentavam uma vasta disparidade.

Uma das principais dificuldades situa-se em determinar a quantidade de ouro extraído, uma vez que se tem sempre de partir dos conteúdos nas zonas não exploradas, pelo que se mantém um elevado fator de incerteza. Outro fator de incerteza é o volume de material rentável e estéril extraído. O equilíbrio entre esta situação e as despesas inevitáveis com a engenharia hidráulica, a transformação e as indústrias de abastecimento também suscitou dúvidas em Tresminas quanto à sua rentabilidade no sentido moderno. ${ }^{58}$

Neste ponto é necessário discutir brevemente as diferentes condições dos depósitos de Tresminas e Gralheira, assim como de Campo de Jales. Ambos tinham veios de minério claramente definidos em que os minérios polimetálicos com elevado teor de ouro estavam embutidos em depósitos de quartzo. Apenas uma pequena quantidade de material estéril teve de ser extraída adicionalmente para a sua extração. O processamento era também menos complexo, como mostram os vestígios no Forno dos Mouros. ${ }^{59}$ Embora o teor de ouro nestes dois depósitos fosse significativamente mais baixo do que em Tresminas, podemos, contudo, assumir que estas minas eram muito provavelmente rentáveis. ${ }^{60}$
A apresentação superficial dos aspetos da história e da forma de organização do territorium metallorum Tresminas / Jales comprovam que se pode presumir tratar-se de um lugar com importância em diferentes fases e cujas jazidas foram provavelmente exploradas antes da Era de Cristo e durante os séculos I e II, já sob controlo direto dos romanos. Não é, contudo, possível determinar até que ponto o ouro continuou a ser explorado após as reformas económicas sob o reinado do imperador Severo (193-235), e com que forma de organização. ${ }^{60 a}$

É de salientar que o excelente estado de conservação das zonas mineiras de Tresminas, com os seus vastos vestígios, constitui uma base importante para a compreensão mais profunda da exploração de ouro numa jazida primária no Alto Império.

de tudo eles [os celtiberianos] foram cativados pelo que ele [Sertorius] fez com os seus rapazes, nomeadamente, os de nascimento mais elevado, que recolheu juntos de vários povos, em Osca, uma grande cidade. Colocou sobre eles professores de grego e romano; assim na realidade fez deles reféns, enquanto os educava ostensivamente, com a garantia de que, quando se tornassem homens, lhes daria uma função na administração e autoridade. Assim, os pais ficaram maravilhosamente satisfeitos por ver os seus filhos em togas de cor púrpura, indo muito decorosamente às suas escolas, e Sertorius pagando-lhes as suas propinas, realizando exames frequentes, distribuindo prémios aos merecedores, e apresentando-lhes os colares de ouro a que os romanos chamam «bullae». Veja-se ainda Tacitus Annalen 3,43,1; Tacitus Agricola 21,2.

50 Resumo da literatura: Hirt 2010, 228-232, ibid. 356-369.

51 Por exemplo, em Las Médulas (Prov. León, E).

52 Por exemplo, Maciço-Teleno (Prov. León, E), Alto del Palo (Prov. Astúrias, E), Vale do Bustantigo (Prov. Astúrias, E).

53 Veja-se a este respeito: Wahl-Clerici/Wiechowski 2013, 299.

54 Para além das condutas de água, por vezes muito longas, que constituíam um desafio particular, as complexas passagens subterrâneas de Las Médulas, agora acessíveis aos visitantes, também faziam parte do projeto.

55 Veja-se a construção do túnel do aqueduto de Saldae (Bejaia, Argélia) e o papel do veterano Nonius Datus. Grewe 1998, 134-139.

56 «Quand on pense aux travaux qu'a nécessités une telle exploitation (aménagement et maintien des réseaux d'aqueducs chargés d'acheminer l'eau des rivières environnantes vers le site, construction des réservoirs de stockage et d'exploitation, travaux préparatoires à l'abattage, lavage, évacuation des stériles, etc.), on peut s'étonner que tant de travaux aient été entrepris pour un si mince résultat.» Domergue 2012, 114. Em Las Médulas (Prov. León, E), terá sido extraído um total de cerca de 4,6 toneladas de ouro. Domergue 2008, 209.

57 Hirt 2010, 368.

58 Wahl-Clerici (no prelo), Considerations on the Profitability of Roman Gold Mining in the Northwest of the Iberian Peninsula during the 1st and 2nd Centuries A.D.

59 Wahl-Clerici/Wiechowski 2012; Wahl-Clerici et al. 2012b.

60 A veia de Campo de Jales foi novamente explorada entre 1932 e 1990. A prospeção voltou a ser feita repetidamente na veia de minério da Gralheira.

60a O sarcófago medieval de Tresminas indica também a continuidade do povoado nesta área (fig.6.0-9b), Batata et al. 2008, 28-30. 


\subsection{História das atividades científicas}

Neste primeiro volume de uma série de publicações científicas sobre o territorium metallorum Tresminas/Jales, pretende-se apresentar os vestígios e monumentos deixados pelo trabalho dos mineiros romanos numa mina de ouro em jazidas primárias. É importante notar que tanto a zona de exploração de Tresminas como a da Gralheira são exemplos raros, pois não foram alterados pela exploração mineira moderna. Desde 1997 Tresminas é Imóvel de Interesse Público. ${ }^{61}$ Os vastos e bem preservados vestígios permitem aos arqueólogos de mineração obter uma visão geral dos vários componentes e dos métodos de trabalho numa mina de ouro da antiguidade.

Os vestígios das minas romanas de Tresminas foram descritos pela primeira vez pelo clérigo português Jerónimo Contador de Argote (1676-1749), aquando da sua visita à diocese do Arcebispo de Braga, tendo resumido os resultados na sua monumental obra «Memórias para a História Eclesiástica do Arcebispado de Braga, Primaz das Espanhas» (1734). ${ }^{62} \mathrm{O}$ primeiro ensaio moderno sobre a exploração mineira em Tresminas foi escrito por H. Botelho, em 190763, ao qual se seguiram outros autores, incluindo engenheiros de minas que trabalharam em Tresminas, Gralheira e Campo de Jales. Na sua grande maioria tratava-se de pequenas publicações em que diferentes aspetos de Tresminas eram considerados isoladamente. ${ }^{64} \mathrm{Em} \mathrm{1970,} \mathrm{D.F.de}$ Almeida apresentou o primeiro resumo dos achados em conformidade com os conhecimentos da época. ${ }^{65}$

A geologia e mineralogia dos depósitos de Tresminas, Gralheira e Jales foram recentemente investigadas com recurso a métodos modernos. D.R.N. Rosa (2001) abordou este tema de forma particularmente aprofundada na sua dissertação «Metallogenesis of the Jales golddistrict, northern Portugal». ${ }^{66}$ Outras pesquisas foram feitas por L.F.Viegas e L.P.Martins (1992), F.Noronha, M.Cathelineau, M.-.C.Boiron, D.A.Banks, A.Dória, M.A. Ribeiro, P. Nogueira e A.Guedes (2000), D.R.N.Rosa e S.B.Romberger (2003), P. Machado, S. Barbosa, A. Dória, M. A. A. Ribeiro (2006), M. A. Ribeiro, A.Dória e F.Noronha (2006), J.M. Farinha Ramos (2017) e J. I. Ferrão de Paiva Martins e C. M. Braz Martins (2017).

Uma síntese dos granitos e da sua exploração no Concelho de Vila Pouca de Aguiar foi publicada em 2012 por L. Sousa e seus alunos da UTAD em Vila Real.

A mais importante fonte antiga sobre a exploração de ouro no noroeste da Península Ibérica pode ser encontrada na História Natural de Plínio, o Velho (23-79), que, como procurador financeiro da província de Hispania Tarraconensis, durante os anos 72-74, supervisionou as minas, economicamente importantes, e inspecionou pessoalmente a região nessa função. No $33^{\circ}$ livro, seções $62-80$, compilou as suas informações detalhadas sobre a exploração de ouro, descrevendo várias possibilidades de mineração e tratamento de minério. Desta forma, deixou um tesouro valioso para a posteridade, que qualquer arqueólogo de minas agradece poder consultar.

Por ocasião de uma primeira exploração de Tresminas, em 1985, Jürgen Wahl (†2007) e a autora reconheceram o potencial histórico deste espaço de mineração. Um ano depois, deram início a uma investigação sistemática do local. Entre 1986 e 1988, as primeiras investigações no campo aconteceram como parte de um projeto do departamento de Madrid do Instituto Alemão de Arqueologia. Em 1986, iniciou-se uma colaboração com o Museu Alemão da Mineração de Bochum. Os resultados da investigação foram publicados em 1988 em forma de um relatório preliminar na revista Madrider Mitteilungen do Instituto Alemão de Arqueologia, em que foram apresentados os resultados de inquéritos e escavações, ao mesmo tempo que se procedeu à integração da área mineira no seu contexto histórico, organizacional e administrativo, com base em descobertas e fontes epigráficas.

Graças à sistemática e intensiva investigação no local durante as inspeções anuais, J. Wahl (até 2006) e a autora, em cooperação com H.-G.Bachmann, entre 1990-1993 e, a partir de 1992, com A. Wiechowski, Mineralogista da

61 A classificação do conjunto arqueológico de Tresminas como «Imóvel de Interesse Público», Decreto n. ${ }^{\circ} 67$ / 97, DR, I Série-B, n ․ 301, de 31-12-1997.

62 Em relação a Tresminas veja-se o vol. II, pp. 473-482.

63 Botelho 1907

64 L de Albuquerque e Castro 1963, Tresminas - Arqueologia Mineira, Separatum: Actas do Congresso Internacional de Etnografia, 1. F. de Almeida 1970, em: Legio VII Gemin. pp.291-296.; H. Botelho 1907, APort 12, pp.26-31; M. Cardozo, Guimar, RGuimar 64, 1954, 120-133; C. A. Ferreira Almeida 1973, em: XII Congresso Nacional de Arqueologia 1971, 553-562; C. García Merino, HispAnt 3, 1973, 19-22; F. A. Harrison 1933, The Mining Magazine 14, 142-144.; J. Leite de Vasconcelos 1936, Revista de Arqueologia 3, 193-195.; J. Parente 1980, em: Actas do Seminário de Arqueologia do Noroeste Peninsular III, 131-140; H. Quiring 1933, Zeitschrift für das Berg-, Hütten- und Salinenwesen im Preußischen Staat 81, 276-277; J. Silva Carvalho, O.da Veiga Ferreira 1954, Estudos, Notas e Trabalhos do Serviço do Fomento Mineiro 9, 30-33.; A. Tranoy 1981, La Galice romaine. Recherches sur le nord-ouest de la peninsule ibérique dans l'Antiquité, Publications du Centre Pierre Paris 7. Collection de la Maison des pays ibériques 7, 222-224.

65 De Almeida 1970

66 Rosa 2001. 
Universidade RWTH Aachen University, e R.Schindlmayr, da Universidade Bergische Universität Wuppertal, foi possível adquirir vastos conhecimentos sobre a mineração na antiguidade, a geologia e a mineralogia, bem como sobre questões metalúrgicas no terreno. Em 2005, o Presidente da Câmara Municipal de Vila Pouca de Aguiar, Domingos Dias, e o Presidente da Junta de Freguesia de Tresminas, F. Marques, fundaram um parque arqueológico sob a direção científica de J. Wahl. A partir de 2010, B. Ramminger (Universidade de Hamburgo) e M. Helfert (Universidade de Hamburgo / Universidade Goethe de Frankfurt a. M.), dois arqueólogos com valiosa experiência em pesquisa de campo não invasiva, juntaram-se às investigações neste local. H.-M.von Känel e o seu sucessor M. Scholz (Arqueologia e História das Províncias Romanas, Universidade Goethe de Frankfurt a. M.) também acompanharam cientificamente o projeto. Desde 2017, as investigações são ainda apoiadas pelos topógrafos Dr. T. Kerstens, K. Mechelke e M.Lindstaedt (todos do departamento de geodesia da Universidade Hafencity de Hamburgo). O trabalho foi ainda apoiado por J. Moutinho e V. Gandra e pelos membros do Alto Relevo Clube de Montanhismo de Valongo nas áreas de difícil acesso das zonas de exploração de Tresminas.

De 2007 a 2010, C. Batata realizou novamente escavações na área do povoado, na zona do suposto cemitério a noroeste da mina a céu aberto A, no local de tratamento «Forno dos Mouros» e no Castro da Cidadelha. ${ }^{67}$ Sob a direção de C. M. Braz Martins, Universidade do Minho, foram realizadas investigações por Georadar em pequena escala na área do anfiteatro, em 2010. ${ }^{68}$ A publicação de F.J.Sánchez Palencia, escrita no âmbito de uma remodelação do Centro Interpretativo, pouco contribuiu para o conhecimento do terreno. ${ }^{69}$

Sob a direção do Presidente A. Machado e da Vereadora Dra. Ana Rita Dias, a Câmara Municipal de Vila Pouca de Aguiar acolheu o $1^{\circ}$ Simpósio Internacional sobre o territorium metallorum Tresminas/Jales em 2014. Na publicação que o acompanhou (2017), aglomeraram-se aspetos fundamentais sobre este espaço. Juntamente com M. Helfert, a autora publicou a primeira síntese dos achados arqueológicos sobre mineração nas zonas de mineração de Tresminas, após a publicação fundamental de J. Wahl (1988/1993). ${ }^{70}$ Nesta síntese, A. Redentor apresentou e analisou ainda as inscrições do territorium metallorum Tresminas/Jales, que apenas foram abordadas sucintamente por J.Wahl em 1988. ${ }^{70 a}$

Por ocasião de outro simpósio, em 2017, sob a direção da Câmara Municipal e da Associação AOURO, foram abordadas investigações mais recentes e inaugurada uma exposição itinerante. A autora apresentou uma breve introdução à mineração romana em cinco painéis diferentes e a Dra. Patrícia Machado apresentou um documentário sobre a igreja medieval de Tresminas.

Além de encontrar e documentar os monumentos da exploração mineira, J. Wahl e a autora preocuparam-se ainda em localizar sistematicamente os vastos e complexos vestígios do sistema de abastecimento de água e dos locais de extração de pedra, pelo que foi dada particular ênfase à documentação de detalhes notáveis e à identificação dos respetivos contextos, de forma a permitir a publicação dos primeiros resultados. ${ }^{71}$ Neste volume estes temas são abordados sumariamente, dado que as apresentações mais abrangentes se encontram em preparação para outros volumes desta série.
70 Wahl-Clerici, Helfert 2017. Outros contributos: Farinha Ramos, Geologia; Martins, Arqueometalurgia; Machado, Paróquia de Tresminas; Martins / Martins Ouro em Jales; Gaspar Nero, Recuperação das áreas mineiras em Portugal.

70a Redentor 2010.

71 Construção de estruturas de conduta de água: Wahl 2003, Wahl-Clerici 2013, Wahl-Clerici 2016, Wahl-Clerici 2017, Wahl-Clerici, Helfert 2017. Pedreiras: Wahl-Clerici et al. 2015. 


\subsection{A prospeção no territorium metallorum Tresminas / Jales ${ }^{72}$}

Durante a descoberta das jazidas na época romana, já era possível recorrer a uma vasta fonte de experiência. A mais antiga palavra conhecida para prospeção de ouro, sementi, vem do Egito pré-dinástico (por volta de 3200 a. C.). ${ }^{73} \mathrm{~A}$ atividade de prospeção dos romanos difere da adotada pelos seus antecessores, principalmente na sua aplicação consistente, bem como na sua execução sistemática e eficiente.

A necessidade de prospeção realizada após a conquista do noroeste da Península Ibérica foi referida, por exemplo, por autores antigos como Floro (por volta de 100 d.C.) e Dião Cássio (cerca de 150-235 d.C.). Assim, Dião Cássio $(52,28,4-5)$ relata uma conversa entre Augusto (63 a. C. -14 d.C.), o seu general Agripa (64-12 a.C.) e o seu assessor em questões financeiras, Mecenas (70-8 a. C.), em que o último mostrou que era essencial para o orçamento do Estado obter primeiro uma visão geral das fontes lucrativas, nas quais ele incluía as minas.

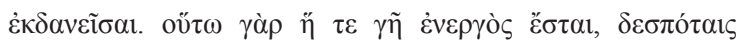

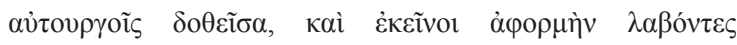

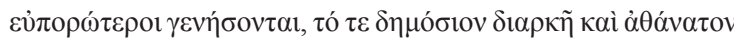

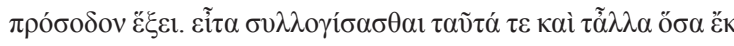

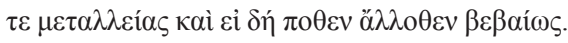

Desta forma, a terra vendida aos proprietários, que eles próprios administram, será cultivada e com o apoio que receberam, eles gerarão riquezas cada vez maiores, enquanto o tesouro do estado recebe receitas permanentes que serão suficientes para as suas necessidades. Segundo, aconselho-o a fazer uma estimativa da receita desta fonte e qualquer outra receita que possa ser obtida com certeza das minas ou de outras fontes, e depois comparar este resultado com a estimativa de todas as despesas, não apenas as do exército, mas também todas aquelas que pertencem ao bem de um estado e, além disso, aquelas que são absolutamente essenciais para eventos inesperados e as outras que possam surgir em tempos de necessidade.

Esta declaração é interpretada como uma diretriz para uma atividade de prospeção abrangente. Por sua vez, Floro (98-117 d. C.), que também se dedicou à era augustana e à exploração mineira, fez a falsa suposição de que a população nativa havia aprendido sobre os recursos minerais apenas através dos romanos.

Favebat consilio natura regionis; circa enim omnis aurifera et chrysocollae miniique et aliorum colorum ferax. Itaque exerceri solum iussit. Sic Astures nitentes in profundo opes suas atque divitias, dum aliis quaerunt, nosse coeperunt.
As vantagens naturais do local favoreciam o seu plano; pois todo o distrito tem ouro e é rico em crisocola, vermelhão e outros pigmentos; portanto, ordenou que o solo fosse lavrado. Assim, ao escavar profundamente no solo em busca de riquezas para outros, os Ástures alcançaram o primeiro conhecimento sobre os seus próprios recursos e riquezas.

(Publius Aenneus Florus, Epitoma de Tito Livio $2,33,60)$

O trabalho de prospeção pode basicamente ser dividido em duas fases, nem sempre diferenciáveis pelo objecto em causa.

- Encontrar uma jazida;

- Determinar o limite da jazida.

Na literatura antiga, os métodos para localizar jazidas com diferentes metais são descritos com frequência, enquanto a determinação do limite das jazidas é raras vezes mencionada. Nos achados de Tresminas encontram-se preservados em abundância vestígios desta determinação.

\section{Os métodos para localizar uma jazida}

Um dos métodos mais simples e eficientes consistia na procura de ouro nos depósitos dos rios. Referindo-se a Posidónio (135-51 a. C.), o geógrafo Estrabão (ca. de 63 a. C.-19 d.C.), um contemporâneo de Augusto, descreve sucintamente o conhecimento das areias auríferas do rio entre a população local (Geografica 3,2,9).

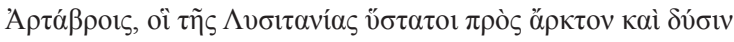

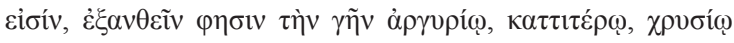

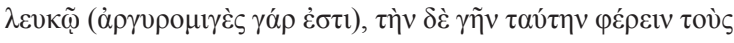

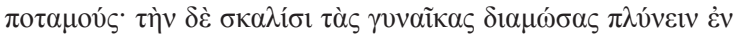

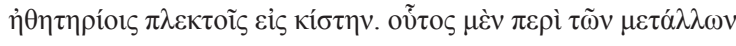

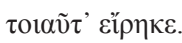

Entre os Artabri, que são os últimos Lusitanos a norte e oeste, ele [Posidónio] conta-nos, que a terra se encontra polvilhada com pó de prata, estanho e ouro branco, isto é, misturado com prata. A terra trazida pelo rio é

72 Por extenso em Wahl-Clerici / Wiechowski 2013.

73 Zick etal. 1998. 
raspada pelas mulheres com pás e lavada em peneiras, tecidas como as cestas. Esta é a substância da qual [Posidónio] nos fala das minas [da Ibéria].

Estrabão (Geografica 3: 2, 8) também refere que as jazidas de ouro são frequentemente localizadas em zonas áridas. Isso só é verdade na medida em que foram mais facilmente encontradas devido à cobertura vegetal menos densa. Finalmente, observa que se obtinha mais ouro ao lavar a areia do que através da exploração mineira. ${ }^{74}$

O Tagus / Tejo aurífero foi cantado por Catulo (século I a. C.) na canção $29 .{ }^{75}$ Os outros rios auríferos na Lusitânia eram, segundo Estrabão, o Mondego, o Vouga e o Douro, que nasce perto de Numância, e o Minho. ${ }^{76}$

Em relação ao territorium metallorum Tresminas/Jales, é sobretudo importante a referência ao Douro, o que impõe a possibilidade da descoberta das jazidas do territorium metallorum Tresminas/Jales através do sistema fluvial do Douro, nomeadamente, através dos rios Tua, Tinhela e Curros. No Rio Tinhela a acumulação de ouro resultou da meteorização das jazidas de Jales e Gralheira ao longo de milhões de anos, no Rio Curros, através da meteorização da jazida de Tresminas.

Outro método antigo para localizar jazidas consistia na busca sistemática de minas abandonadas. De facto, manteve-se preservado um testemunho correspondente da antiguidade pré-romana. Assim, ficamos a saber por Séneca o mais novo (ca. 4-65 d.C.) nas Quaestiones Naturales que Filipe da Macedónia (ca. 382-336 a.C.) tinha conhecimento de uma mina há muito abandonada, mas mesmo assim enviou pessoas para determinar o rendimento de uma nova exploração (Q Nat. 5, 15, 1):

Nunc mihi permitte narrare fabulam. Asclepiodotus auctor est demissos quam plurimos a Philippo in metallum antiquum olim destitutum, ut explorarent quae ubertas eius esset, quis status, an aliquid futuris reliquisset vetus auaritia; descendisse illos cum multo lumine et multos duraturo dies, deinde longa uia fatigatos vuidisse flumina ingentia et conceptus aquarum inertium vastos, pares nostris nec compressos quidem terra supereminente sed liberae laxitatis, non sine horrore visos.

Permitam-me que vos conte uma pequena história. $\mathrm{Eu}$, Asclepiodotus, atesto a veracidade desta história. Numa altura, um grande grupo de mineiros foi enviado por Filipe [da Macedónia, pai de Alexandre o Grande] para uma mina antiga, há muito abandonada, para examinar as perspetivas de sucesso e as condições, assim como para observar se a avareza dos antigos havia deixado algo que os seus sucessores pudessem aproveitar. Desceram com um grande abastecimento de tochas, suficiente para durar muitos dias. Passado algum tempo, exaustos da longa viagem, avistaram algo que os fez estremecer: rios enormes e vastos reservatórios de águas calmas, iguais aos nossos acima do solo, porém, não eram esmagados pela terra que se estendia sobre eles, pois tinham um vasto espaço livre por cima.

Conforme a observação da descoloração do solo ou das diferenças nas rochas, as jazidas de ouro ocorrem frequentemente nos veios de quartzo que são muito visíveis no terreno, como é o caso dos veios de Gralheira e do Campo de Jales (fig. 2.0-1). ${ }^{77}$ A vegetação também pode levar ao surgimento de uma jazida, pois certas plantas desenvolvem-se principalmente em solos que contêm metais pesados sendo, portanto, adequadas como marcadores de jazidas. Por exemplo, durante a primavera a Serra de Santa Justa, perto de Valongo (distrito do Porto, Portugal) encontra-se repleta de rumex bucephalorus (um género de labaça) em tom vermelho, mas até agora apenas foi possível encontrar esta planta ocasionalmente no territorium metallorum Tresminas/Jales.

Em época romana não havia relutância em abrir sistemas de prospeção abrangentes caso houvesse suspeita de que na área se encontravam jazidas possíveis de explorar. $\mathrm{O}$ exemplo de «Cabezas de los Pastos» (província de Huelva, Espanha) na Andaluzia, onde foram feitas tentativas para manter a jazida por baixo da zona de meteorização dos filões com recurso a cerca de 300 poços, mostra a eficácia do procedimento, mesmo que por fim não tenham alcançado o sucesso pretendido. ${ }^{78}$

74 Ver também Sánchez-Palencia et al. 2006.

75 Na sua canção 29 Catulo critica vários conhecidos devido ao seu mau comportamento. Em alguns versos é referido o Tagus / Tejo: Primeiro perdeu a propriedade da família, a seguir o espólio de Pontus, depois o da corrente dourada do Tagus da Ibéria, e agora a Gália e a Grã-Bretanha estão em perigo.

A sua propriedade ancestral foi primeiro desfeita em pedaços; depois veio o prémio monetário de Pontus, depois, em terceiro lugar, veio o de Espanha, do qual o rio Tejo, que leva ouro, nos pode falar.

76 Estrabão, Geografica 3,3,4. - Compilação de referências de Fernandez Nieto 1971.

77 Agricola apresenta diferentes métodos de prospeção (fig. 2.0-2).

78 Domergue 1989, 231-232; Domergue 1990, fig. 18; Os poços foram criados para perfurar a desagregação que cobre as jazidas na faixa piritosa. Veja-se também as minas de Cabezo de los Silos perto de La Zarza, província de Huelva, Domergue 1989, H19; assim como Sotiel Coronada perto de Valverde del Camino, província de Huelva, Domergue 1989, H20 e Domergue 1990, fig. 16; Além disso, a espessura da desagregação de Vipasca / Aljustrel, Distrito de Beja, Domergue 1989, POR 2, é indicada com 10 a $15 \mathrm{~m}$ Domergue 1989, 495. 


\section{Discussão das condições no territorium} metallorum Tresminas / Jales

As três principais jazidas no territorium metallorum Tresminas/Jales devem ser discutidas separadamente no que diz respeito à sua descoberta. Certamente, os habitantes do Castro de Cidadelha conheciam o filão da Gralheira com mais de 2,5 km de extensão (fig. 2.0-3) e é provável que isso também se aplique ao filão de Jales, que fica a apenas 400 metros de distância. Se tinham conhecimento sobre a jazida de Tresminas, não pode ser determinado neste momento, dada a existência de outros castros na área, cujas fases de ocupação apenas foram investigadas pontualmente.

Em nenhum ponto das três jazidas foi possível encontrar vestígios de exploração mineira pré-romana, e se alguma vez existiram, teriam certamente sido destruídos durante a extração romana. Além disso, ainda não foi possível observar as acumulações típicas de matéria estéril ao longo dos cursos de água que surgem durante a lavagem das areias do rio. ${ }^{79}$

\section{A determinação do limite de uma jazida}

Depois de encontrada uma jazida, era dado início à exploração o mais rapidamente possível, pelo que se tornava importante para os procuradores determinar os limites da jazida. Como regra geral, pode dizer-se que cada etapa da mineração dependia da próxima sondagem dos conteúdos possíveis de explorar.

O significado destas prospeções torna-se claro na Lex metallis dicta de Vipasca pelas disposições associadas. ${ }^{80}$

\section{$\S 15$ :... Procurator explorandi novi metalli causa ternagum a cuniculo agere / permittito ita ut ternagus non plures lati- tudinis et altitudinis quam quaternos pedes habeat.}

$\S 15$... O procurador permitirá que um concessionário, a fim de explorar a nova mina, abra uma galeria de ligação que comunique com o dito canal, mas de modo que tal galeria não tenha de largura e de altura mais de quatro pés. ${ }^{81}$

§16: Venam intra quinos denos pedes ex utroque latere a cuniculo quaerere caedereve ne liceto.

$\S 16$ Não é permitido procurar um filão ou prosseguir as escavações a menos de quinze pés dum e doutro lado do canal de escoamento de águas. ${ }^{82}$

As distâncias especificadas estão relacionadas com a segurança subterrânea, especialmente visível no caso do §16, e servem principalmente para questões de segurança.
Um aspeto importante ao observar as estruturas de prospeção prende-se não apenas com a estabilidade das montanhas, mas também com a complexidade das jazidas. Assim, na área de exploração de Tresminas manteve-se um número elevado de estruturas de prospeção, o que não foi o caso da Gralheira. Até ao momento, apenas foi possível identificar pontos de amostragem isolados na Gralheira, enquanto que em Tresminas mantiveram-se preservados sistemas inteiros (figs. 2.0-4-2.0-6). Estes vestígios permitem compreender, pelo menos em termos gerais, as reflexões e os procedimentos dos romanos.

Ao investigar as estruturas de prospeção, deve ter-se naturalmente em conta que só se mantiveram aquelas onde não foram encontrados conteúdos a explorar. Um número elevado, portanto, aponta para a complexidade de uma jazida, o que obrigava os mineiros a redefinir os limites.

\section{Exemplos de prospeção em Tresminas}

Os vestígios de amostras de superfície são particularmente raros, o que se deve em grande parte ao facto de - senão por acaso - eles só poderem ser descobertos através de uma pesquisa sistemática das áreas rochosas em declives inteiros. Muitas vezes, trata-se de marcas de escavação quase irreconhecíveis, que também podem ter sido feitas pelo martelo de um geólogo moderno. Em Tresminas, só foi possível classificar os vestígios como antigos através de uma típica construção romana, caracterizada por uma depressão cuidadosamente trabalhada na rocha (figs. 2.0-7, 2.0-8). Uma vez que esses vestígios não são sempre claramente reconhecíveis no territorium metallorum de Tresminas/Jales e muitas vezes encontram-se cobertos por vegetação ou entulho, pode partir-se do pressuposto de que outrora foram provavelmente muito mais numerosos.

No outro extremo do espectro estão os sistemas de prospeção em grande escala, através dos quais foram analisadas montanhas inteiras em diferentes altitudes. Os seus vestígios mantiveram-se especialmente preservados nas montanhas entre as duas grandes minas a céu aberto, Corta de Covas e Corta da Ribeirinha (figs. 2.0-5, 2.0-6). O maior e mais complexo sistema incluía os dois poços atualmente visíveis no talude leste da Corta de Covas, assim como a Galeria dos Alargamentos com as várias estruturas que provinham dela (figs. 2.0-9-2.0-12). ${ }^{83}$

Nas camadas mais baixas, entre as duas minas a céu aberto, também foram construídas estruturas de prospeção. Sabe-se que a continuação da Galeria do Texugo, a leste, corresponde a um túnel com a largura de um homem, onde foram escavados poços adicionais em vários sítios.
79

80
Sánchez Palencia et al. 2006, 271, fig. 9.

d'Encarnação 1984, 213-215.

d'Encarnação 1984, 215.

d'Encarnação 1984, 215.

Wahl-Clerici et. al 2012a. 
Os grandes poços que podem ser identificados através dos seus montes de entulho foram abertos entre as duas minas a céu aberto.

No caso da pequena galeria estamos perante outra construção de prospeção, localizada acima do tecto da Galeria do Pilar. A acumulação notável de entulho indica a existência de uma ligação com o poço que termina sobre o pilar na Galeria do Pilar (fig. 2.0-13).

Uma aglomeração notável de estruturas de prospeção situa-se no declive a sul da zona de exploração norte da Corta de Covas, pois era difícil de imaginar que essa área seria estéril (fig. 2.0-5)

$\mathrm{Na}$ Corta da Ribeirinha mantiveram-se igualmente estruturas de prospeção. ${ }^{84}$ Assim, foi feito um corte de vários níveis, paralelamente à antiga entrada ocidental, com pelo menos um túnel adicional saindo da parede a oeste (figs. 2.0-14, 2.0-15). A procura só foi abandonada depois de, no sistema da Galeria dos Morcegos, situado abaixo, não se ter encontrado qualquer minério, especialmente no poço nela aberto (fig. 2.0-16). Das construções de prospeção na zona nascente da Corta da Ribeirinha manteve-se apenas a galeria NN, através da qual se procedeu à prospeção da zona estéril em direção a Lagoinhos (fig. 2.0-17).

Através do encontro das zonas de prospeção, que foram abertas a partir das áreas de exploração ocidentais e orientais da Corta da Ribeirinha, manteve-se uma estrutura de minas particularmente complexa. Na parte ocidental foi construído na rocha um poço em espiral (fig. 2.0-18); na parte oriental, continuou-se a construção a um nível mais baixo. ${ }^{85}$

A maior concentração de procura pelos limites da jazida encontra-se em Lagoinhos, para a qual se procedeu a abertura de construções de prospeção horizontais e verticais (figs. 3.0.1-6, 3.0.1-12, 3.0.1-13a / b). ${ }^{86}$

Os poços gémeos preservados no extremo sudeste da Corta da Ribeirinha foram aprofundados diretamente um ao lado do outro e estão apenas separados por uma faixa de pedra com uma largura de cerca de $30 \mathrm{~cm}$ (fig. 2.0-19). Devido à sua posição, não se pode excluir que estes poços circulares estivessem originalmente localizados fora da zona mineira romana e fossem utilizados para a prospeção da área.

Resumindo, pode afirmar-se que as estruturas necessárias para a prospeção não são diferentes daquelas usadas para fins de exploração. Além do mais, na definição dos resultados, deve-se sempre ter em mente que as estruturas de prospeção poderiam certamente ser usadas para a extração e a drenagem.

Contudo, é possível determinar características típicas das estruturas de prospeção:

- Geralmente, trata-se de uma combinação de túneis, poços e poços com degraus (figs. 2.0-10, 2.0-15, 2.0-16, 2.0-20, 2.0-21).

- Outra característica é a acumulação de várias estruturas tendencialmente pequenas numa zona claramente definida (figs. 2.0-5, 2.0-6, 2.0-10, 2.0-15, 2.0-16, 2.2-1, 2.2-2, 3.0.1-12, 3.0.1-13a / b, 3.0.1-16).

- Além disso, há uma tendência para uma disposição abrangente das construções em áreas maiores (figs. 2.0$5,2.0-6)$.
Wahl-Clerici et al. 2019

Wahl-Clerici et al. 2019.

Wahl-Clerici et al. 2017. 


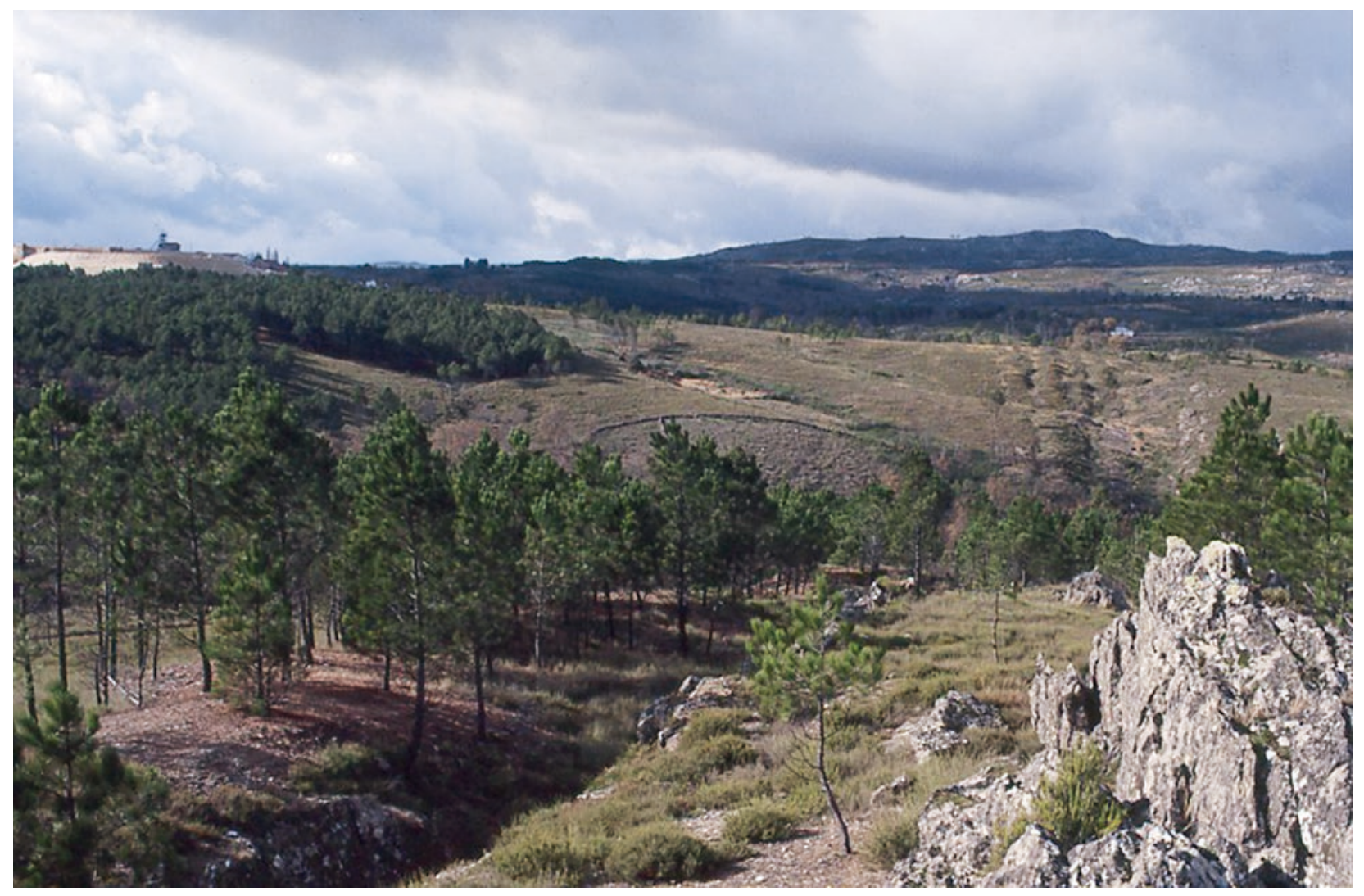

Fig. 2.0-1: Territorium metallorum Tresminas / Jales, Gralheira visto de leste: ao fundo são visíveis as longas valas e escombreiras da veia de minério, que neste momento se divide em pelo menos cinco veias separadas (fotografia: J. Wahl).

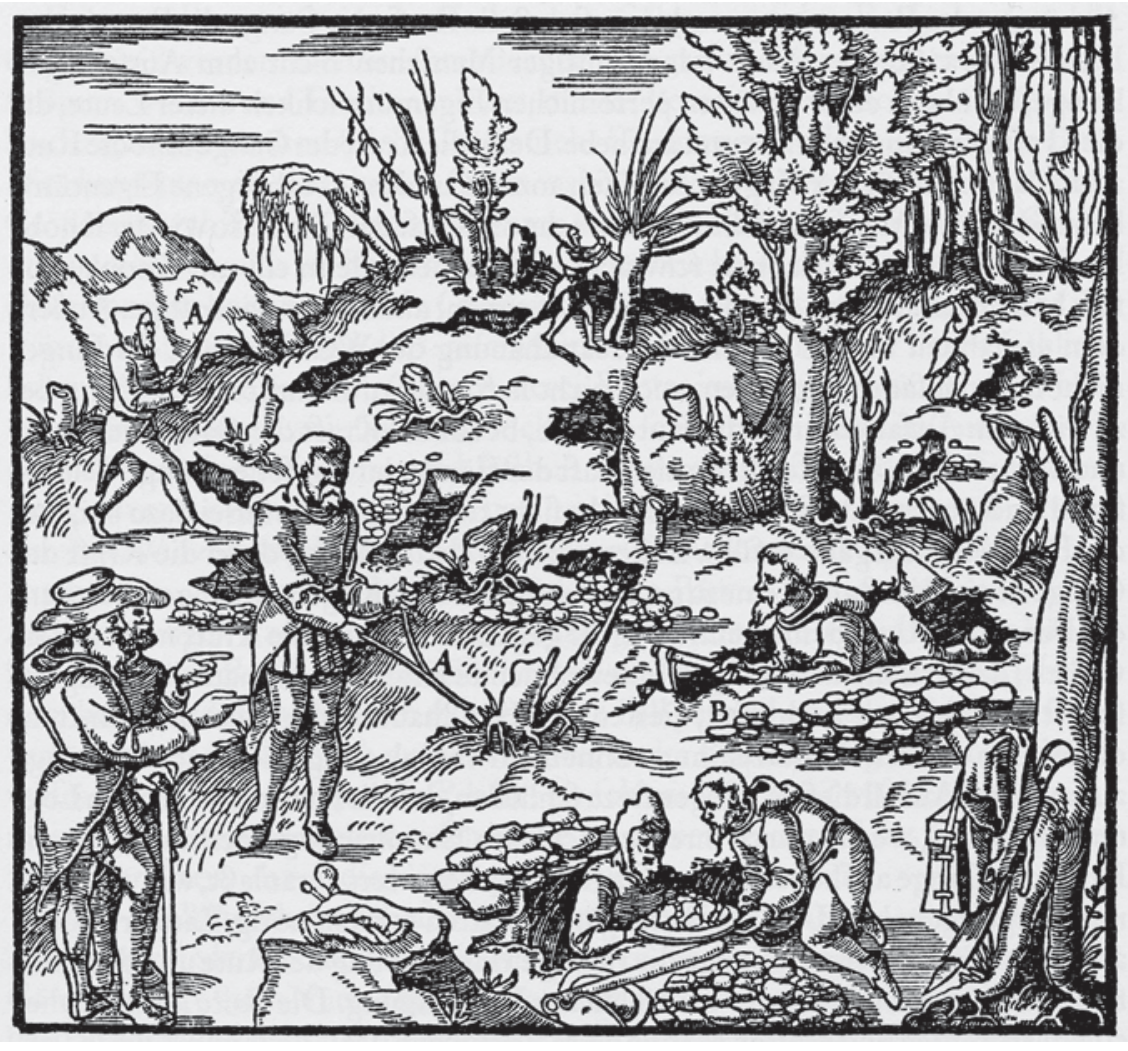

Fig. 2.0-2: Métodos de prospeção segundo Agricola 1556/1984, 32 


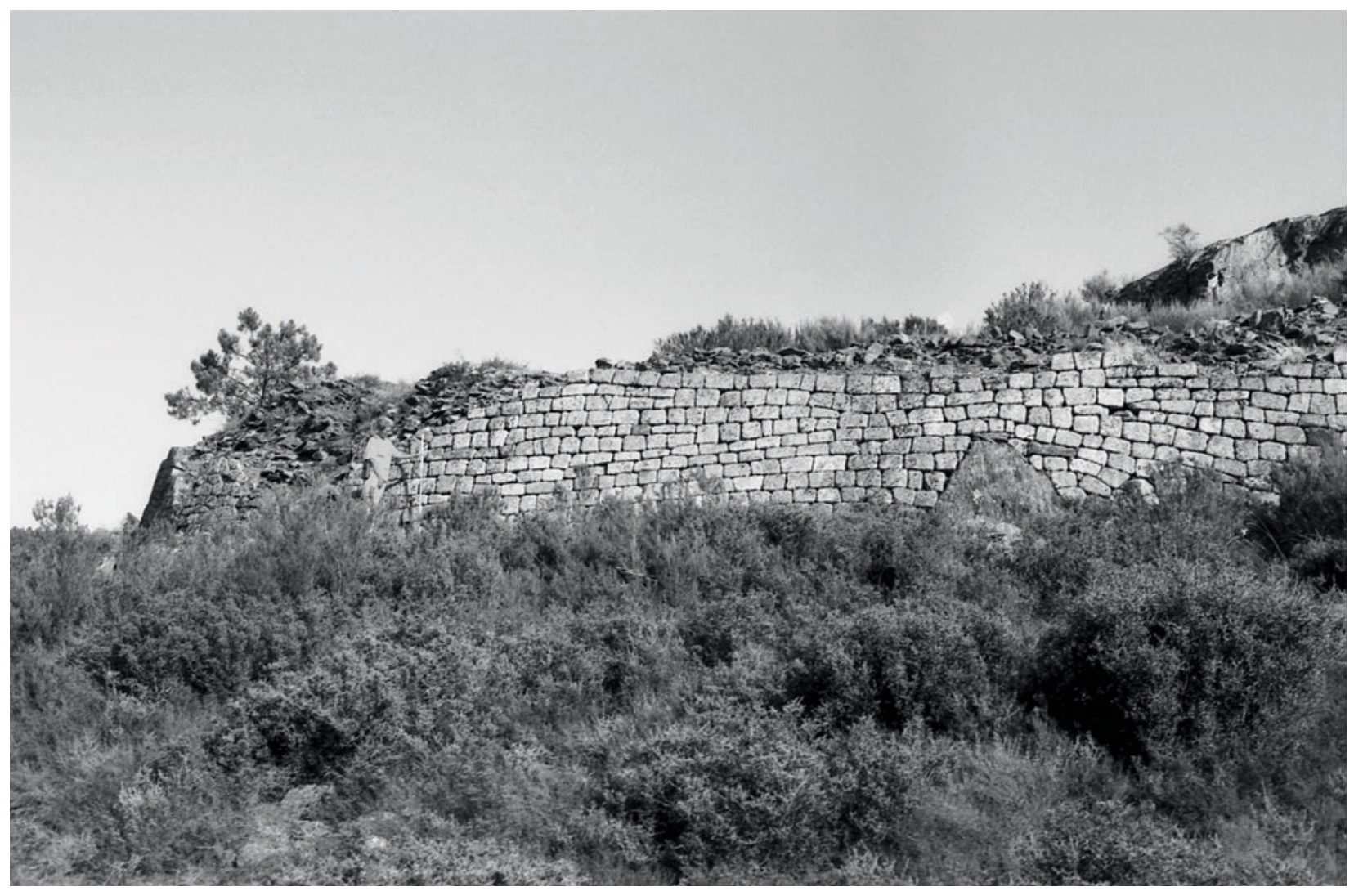

Fig. 2.0-3: Territorium metallorum Tresminas / Jales, o Castro Celtibérico de Cidadelha visto de norte: secção da parede do recinto junto à entrada à esquerda (fotografia: J.Wahl). 


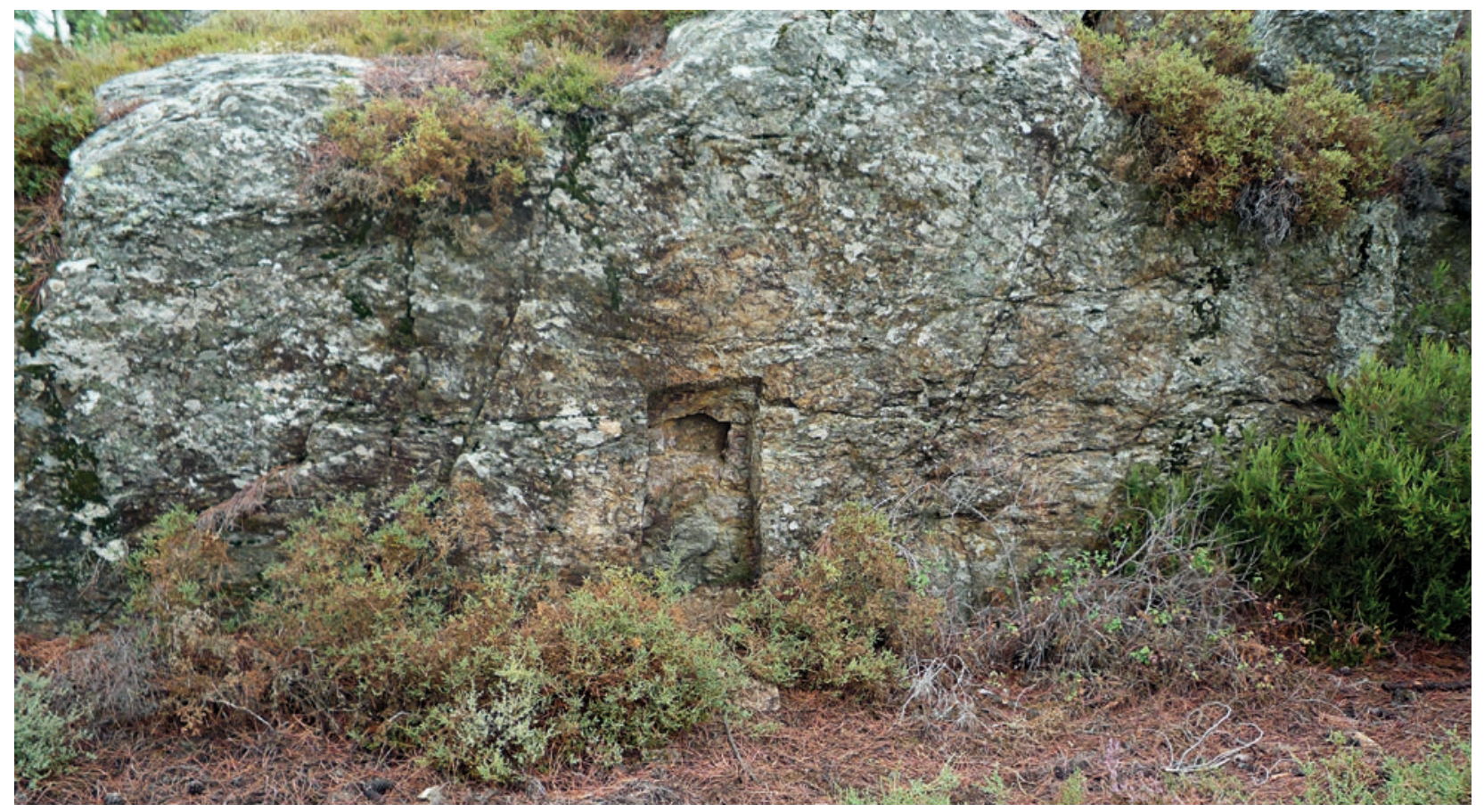

Fig. 2.0-4: Territorium metallorum Tresminas / Jales, jazida da Gralheira: pequena extensão de prospeção escavada lateralmente à zona de exploração (fotografia: R. Wahl-Clerici).

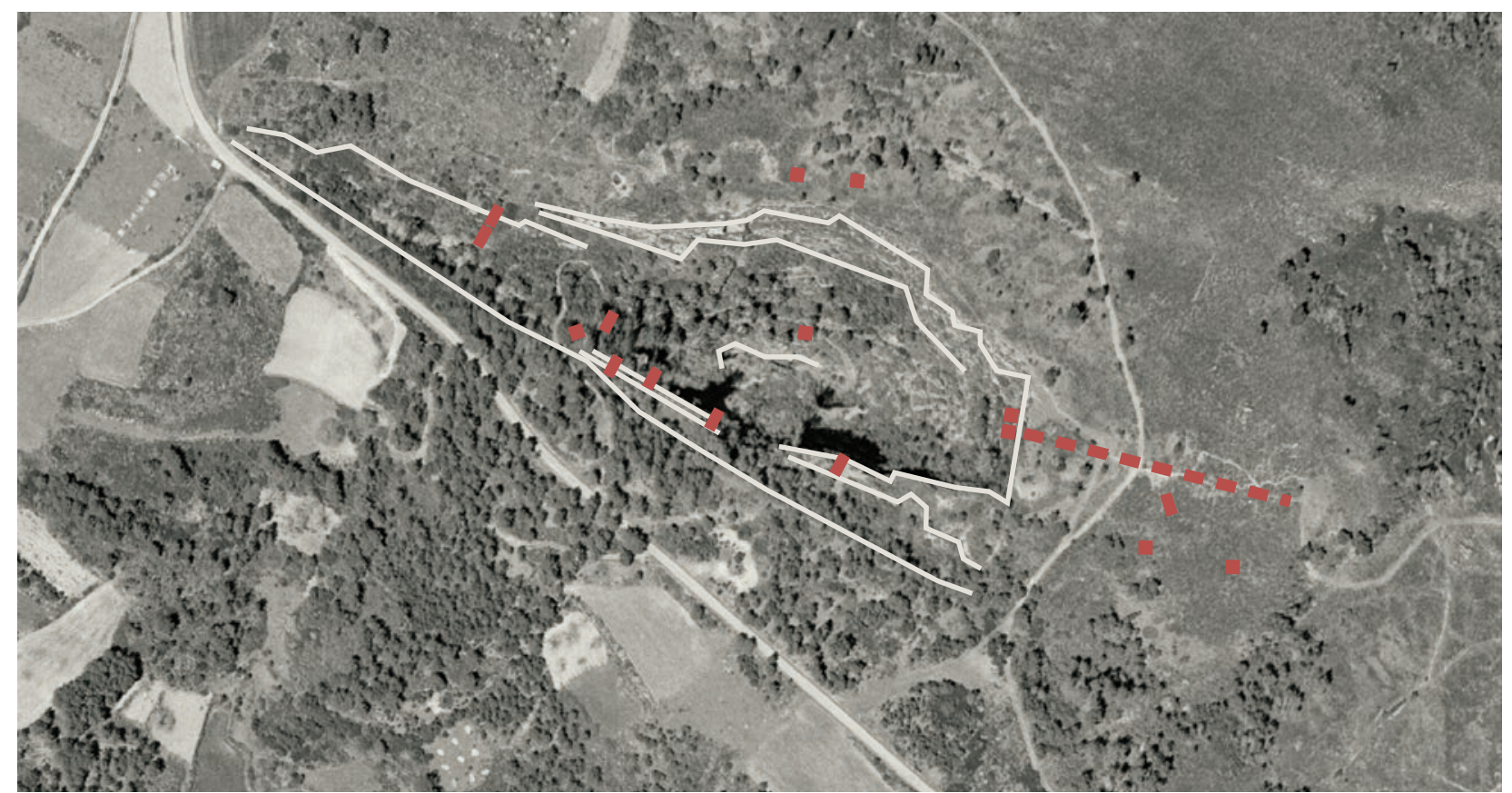

Fig. 2.0-5: Territorium metallorum Tresminas / Jales: vista sobre a Corta de Covas com os poços e extensões de prospeção (modelo: Ortofotomapa 1: 5000 Vila Pouca de Aguiar, ilustração: R. Wahl-Clerici, execução: S. Mathiuet). 


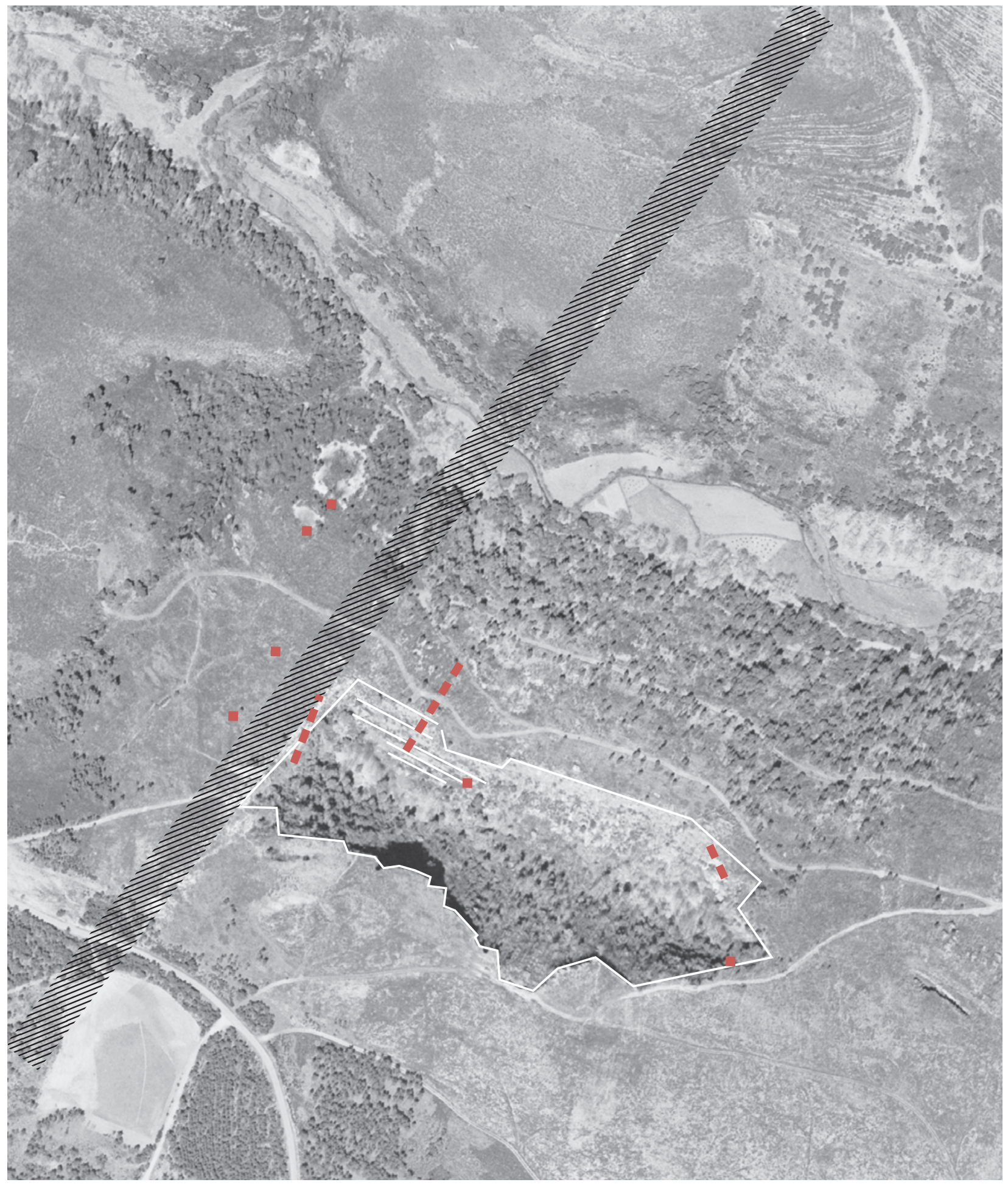

Fig. 2.0-6: Territorium metallorum Tresminas / Jales, Tresminas: vista sobre a Corta da Ribeirinha com os poços e extensões de prospeção (modelo: Ortofotomapa 1: 5000 Vila Pouca de Aguiar, ilustração: R. Wahl-Clerici, execução: S. Mathiuet). 

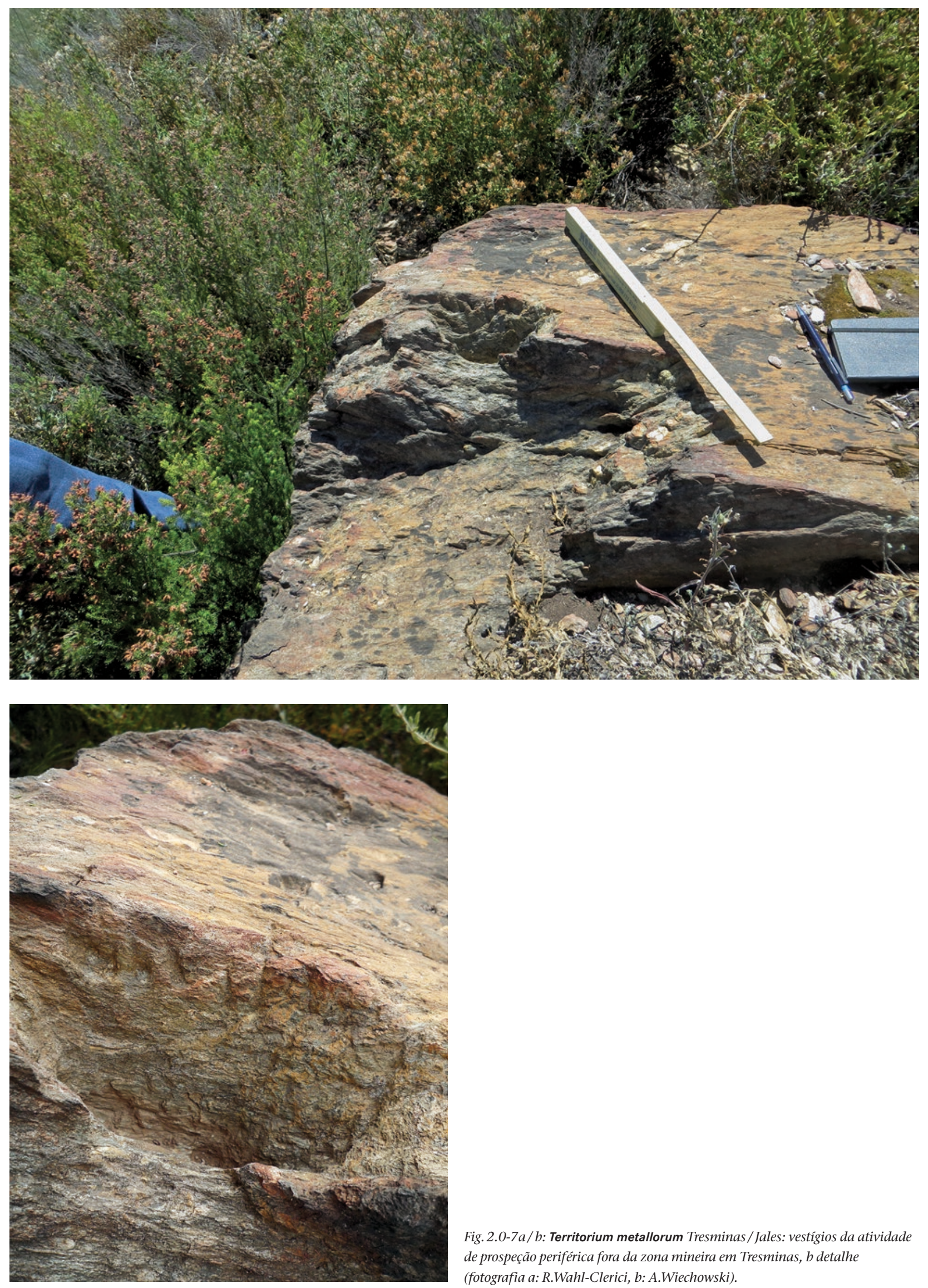

Fig. 2.0-7a/b: Territorium metallorum Tresminas / Jales: vestígios da atividade de prospeção periférica fora da zona mineira em Tresminas, $b$ detalhe (fotografia a: R.Wahl-Clerici, b: A.Wiechowski). 


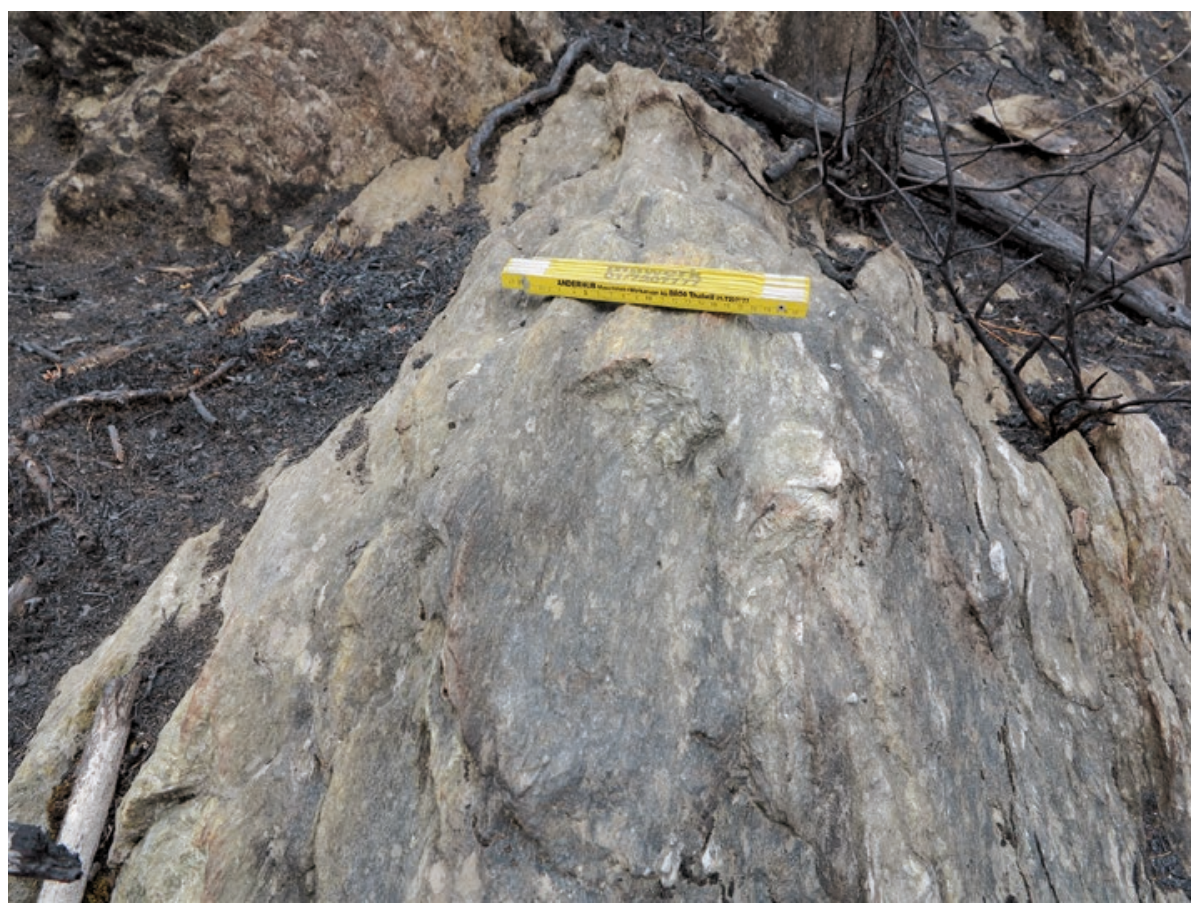

Fig. 2.0-8: Territorium metallorum Tresminas / Jales, Tresminas: micro-prospeção exterior à zona de exploração (fotografia: R. Wahl-Clerici).

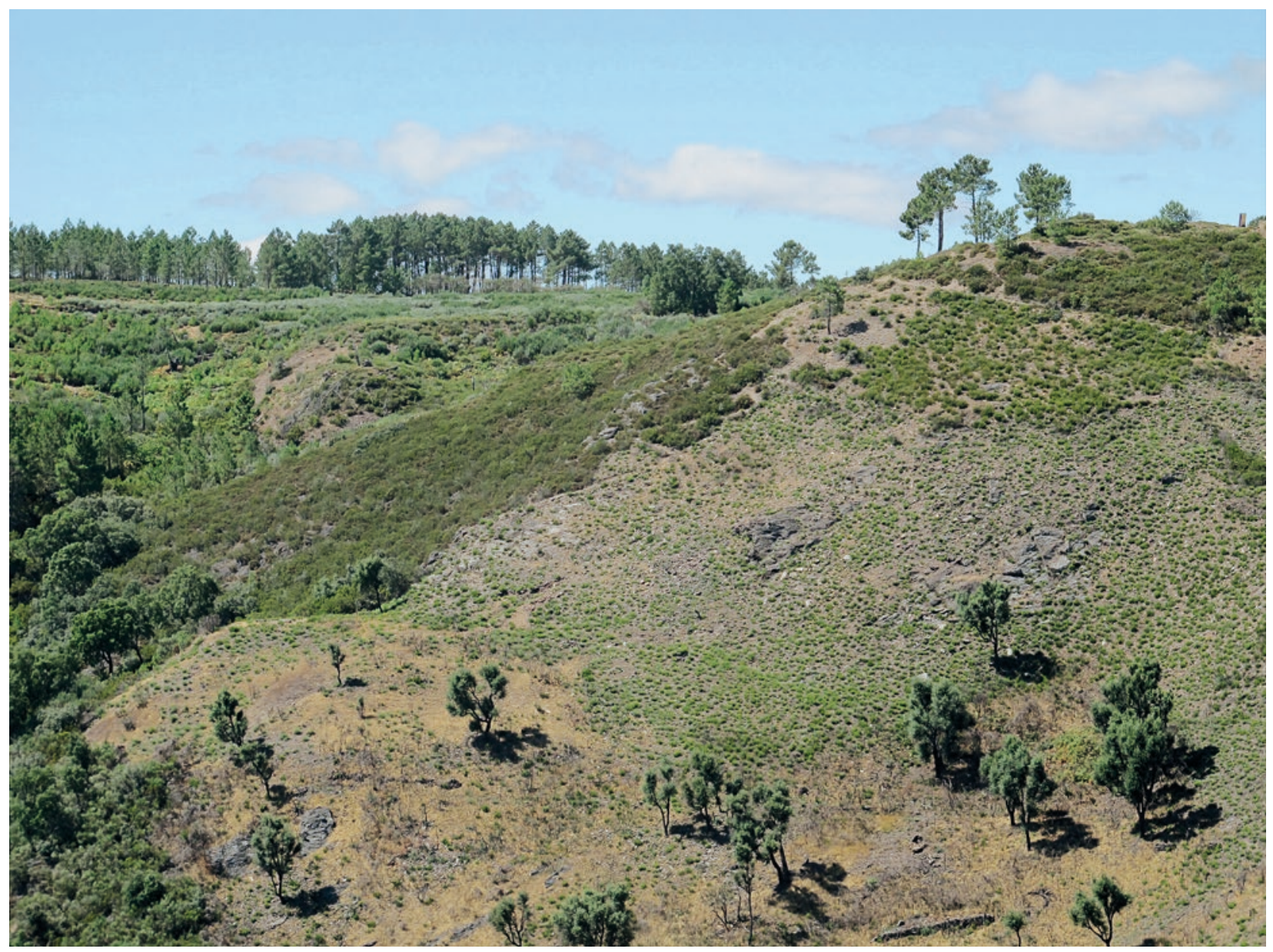

Fig. 2.0-9: Territorium metallorum Tresminas/Jales: Tresminas, Galeria dos Alargamentos: vista de norte sobre a escombreira. A galeria encontra-se abaixo do afloramento rochoso (fotografia: $R$. Wahl-Clerici). 


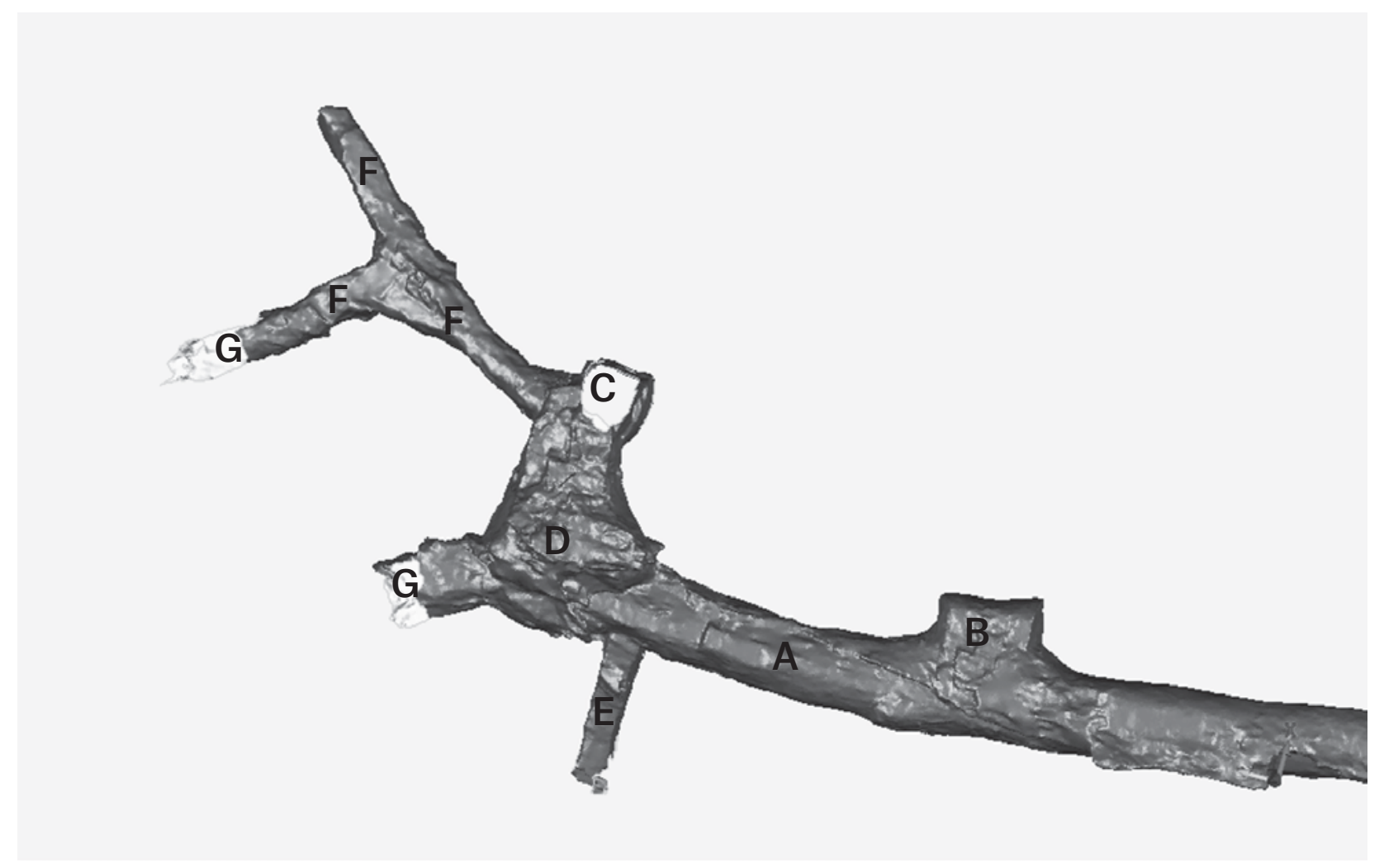

Fig. 2.0-10: Territorium metallorum Tresminas /Jales: Tresminas, Galeria dos Alargamentos, digitalização a laser 3D (gravação e processamento: M.Helfert). A Galeria, B extensão, C poço a norte, D câmara final, E poço em escada (ver 2.1), F galeria de prospeção antiga, G galeria de prospeção moderna, F outras prospeções (possivelmente extensões de um edifício antigo (gravação e edição: M.Helfert). 


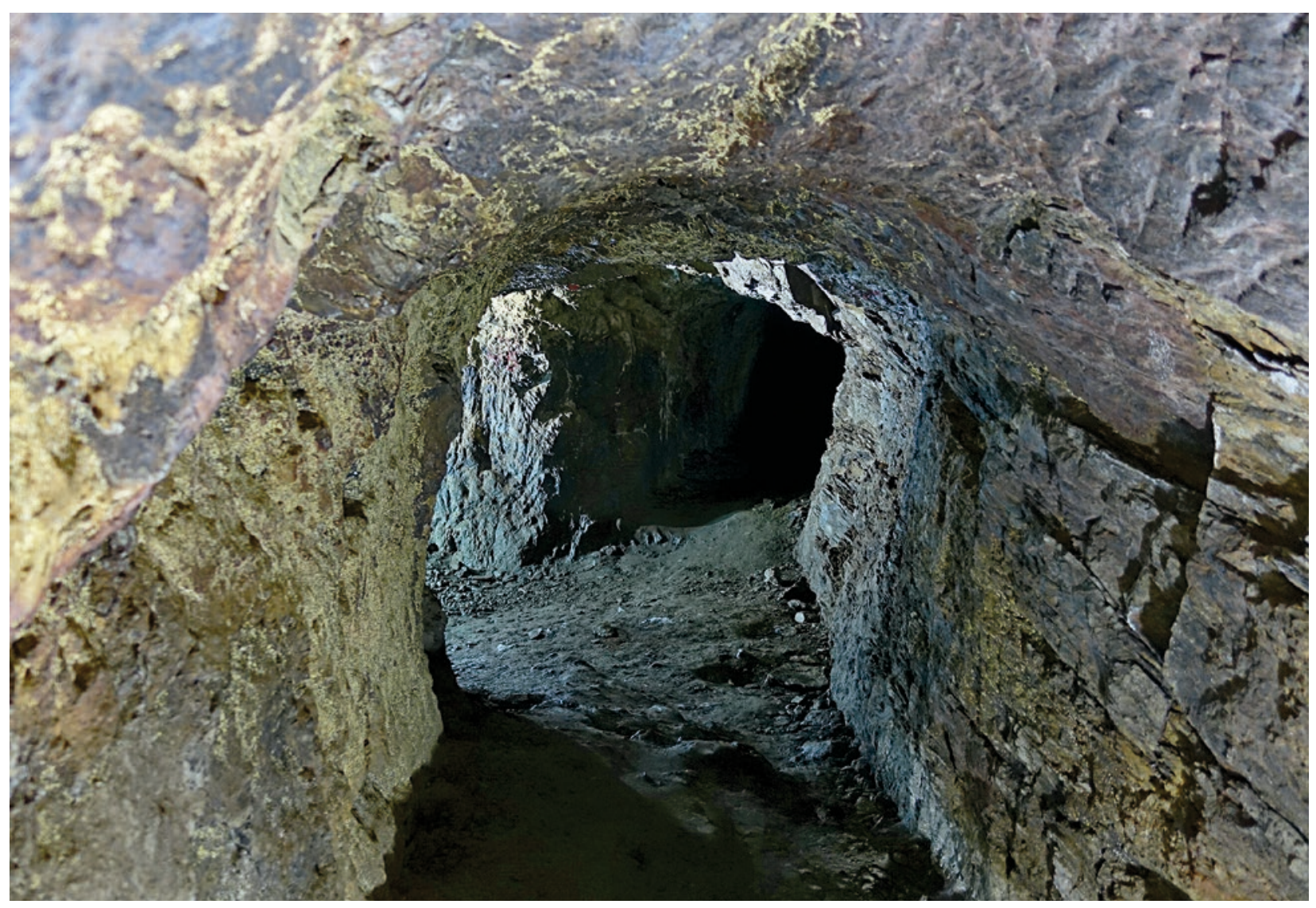

Fig. 2.0-12: Territorium metallorum Tresminas / Jales, Tresminas, Galeria dos Alargamentos: vista para o eixo noroeste (F) que parte da câmara final (fotografia: $R$. Wahl-Clerici). 


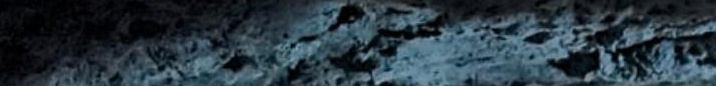

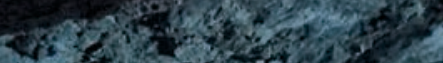

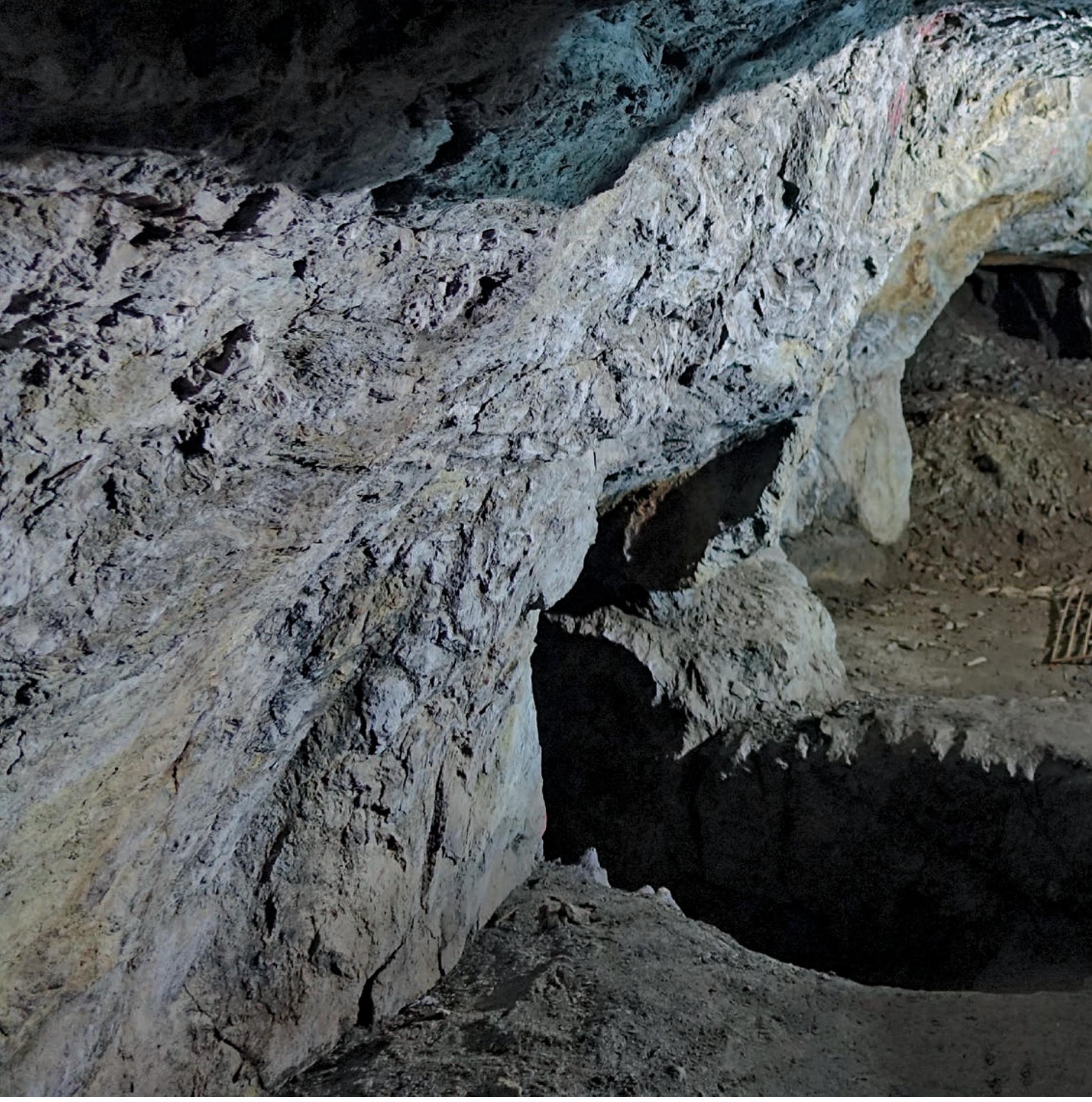




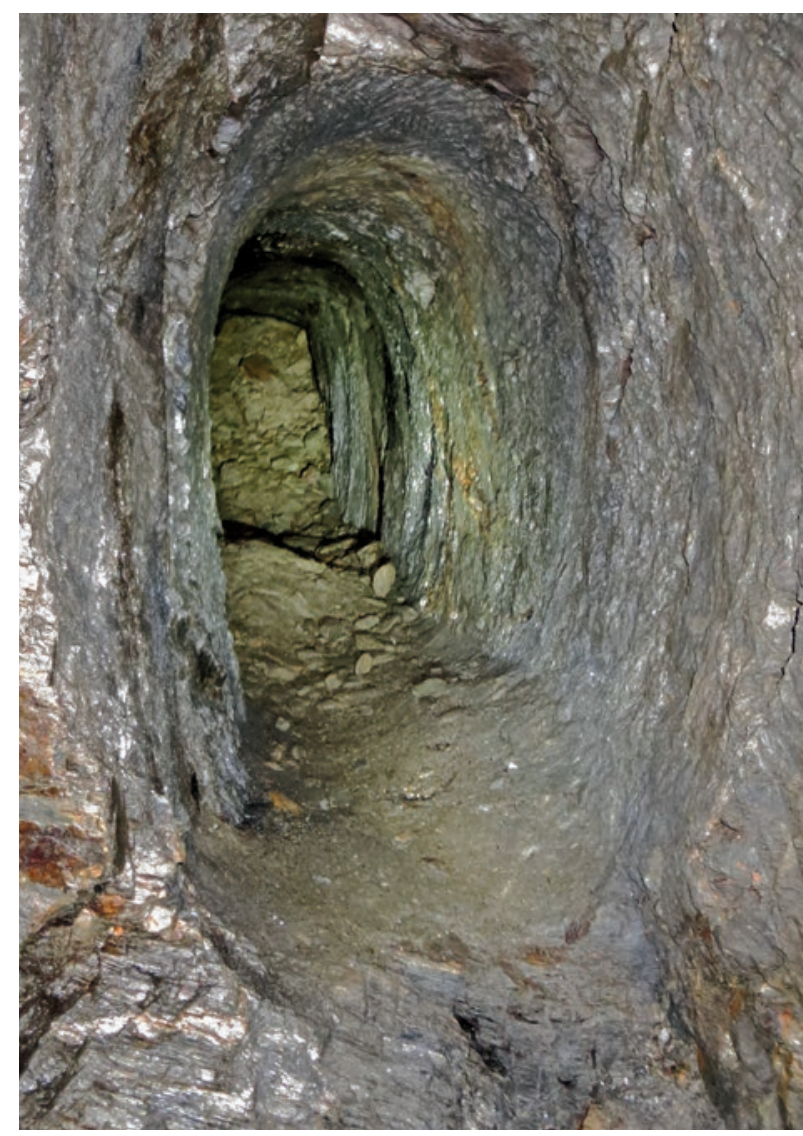

Fig. 2.0-13: Territorium metallorum Tresminas / Jales, Tresminas, Galeria do Pilar: o túnel de prospeção encontra-se diretamente por cima da galeria, vista de sul (fotografia: R. Wahl-Clerici).

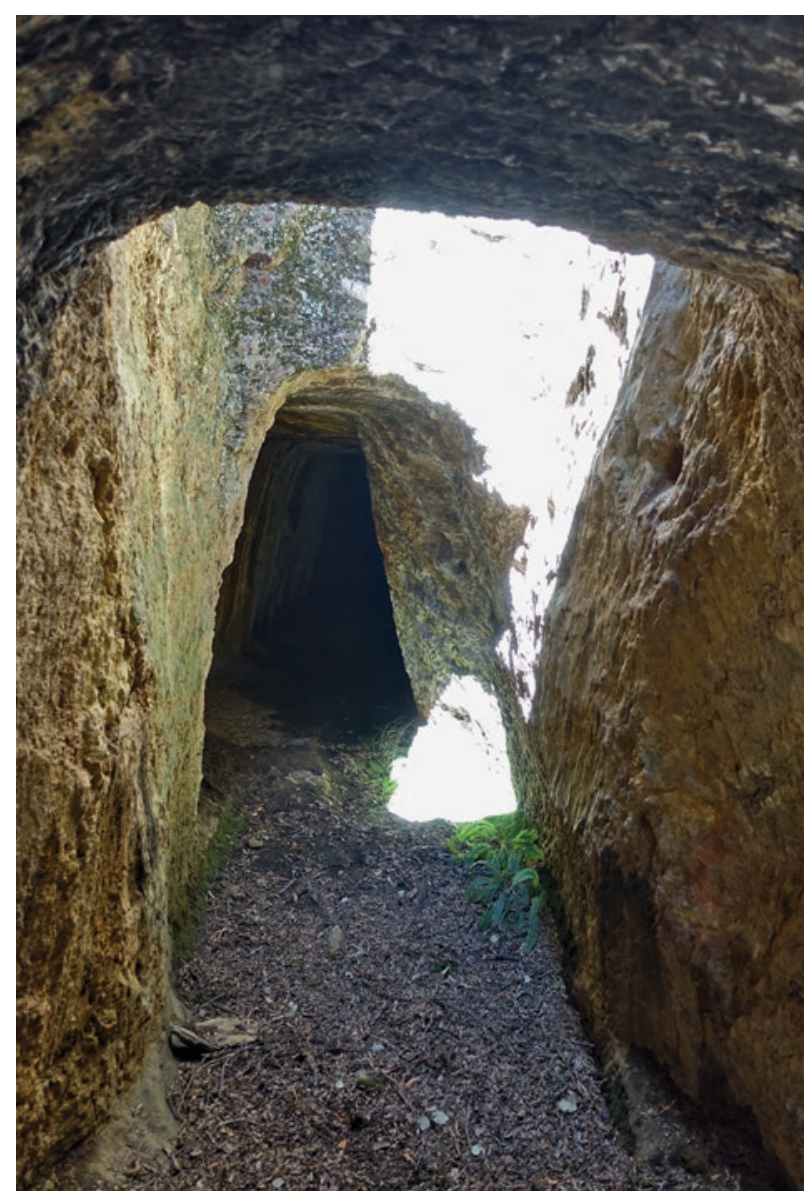

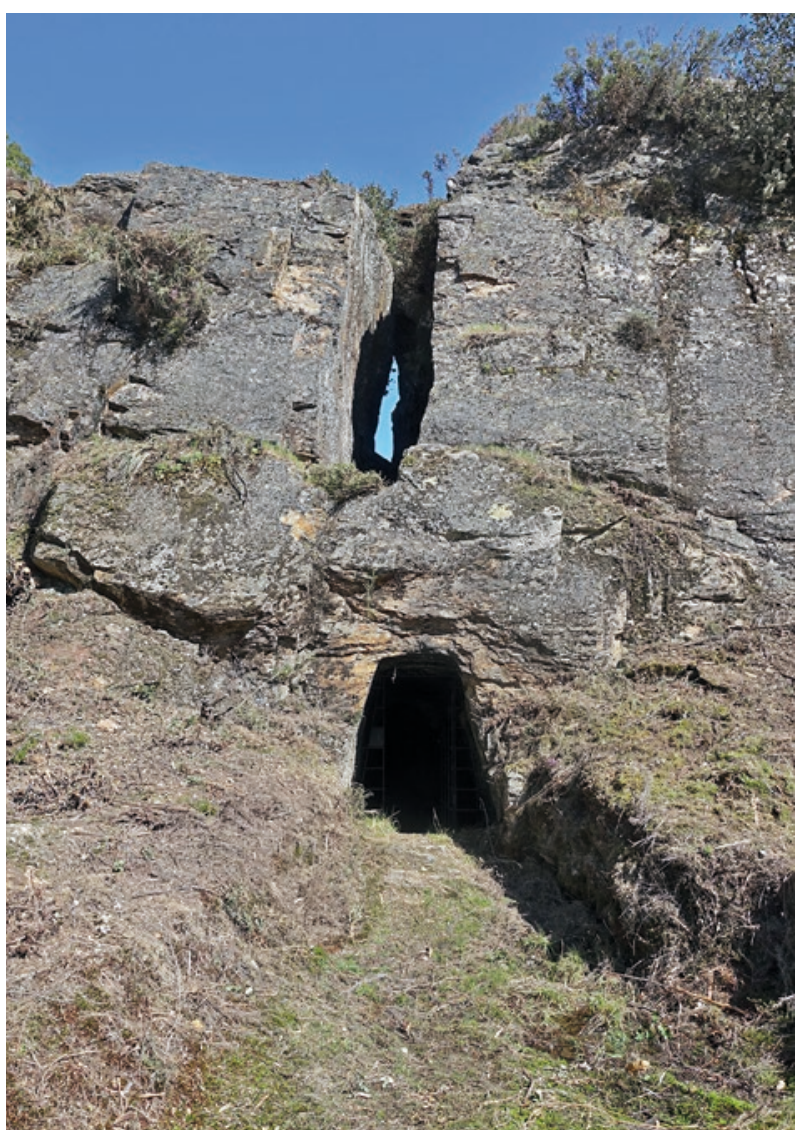

Fig. 2.0-14: Territorium metallorum Tresminas/Jales. Tresminas,

Corta da Ribeirinha, construção de prospeção na área da antiga da entrada oeste, vista de sul (fotografia: R. Wahl-Clerici).
Fig. 2.0-15: Territorium metallorum Tresminas/Jales, Tresminas,

Corta da Ribeirinha, detalhe das estruturas de prospeção na Fig. 2.0-14 (fotografia: R. Wahl-Clerici). 


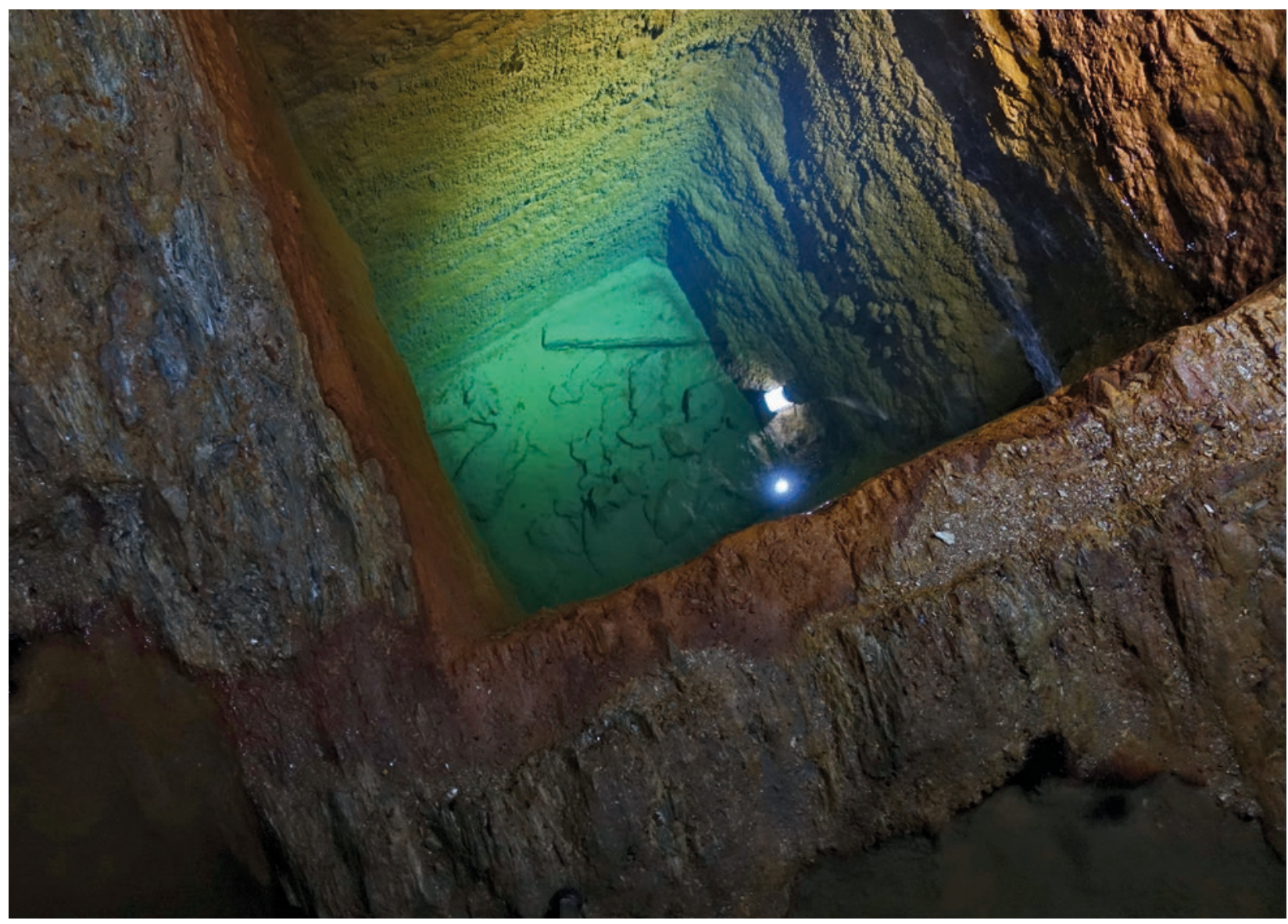

Fig. 2.0-16: Territorium metallorum Tresminas/Jales, Tresminas. Corta da Ribeirinha, Galeria dos Morcegos: poço de prospeção na parede oriental. Paralelamente ao percurso norte-sul da galeria, abriu-se outra galeria no solo (fotografia: $R$. Wahl-Clerici).

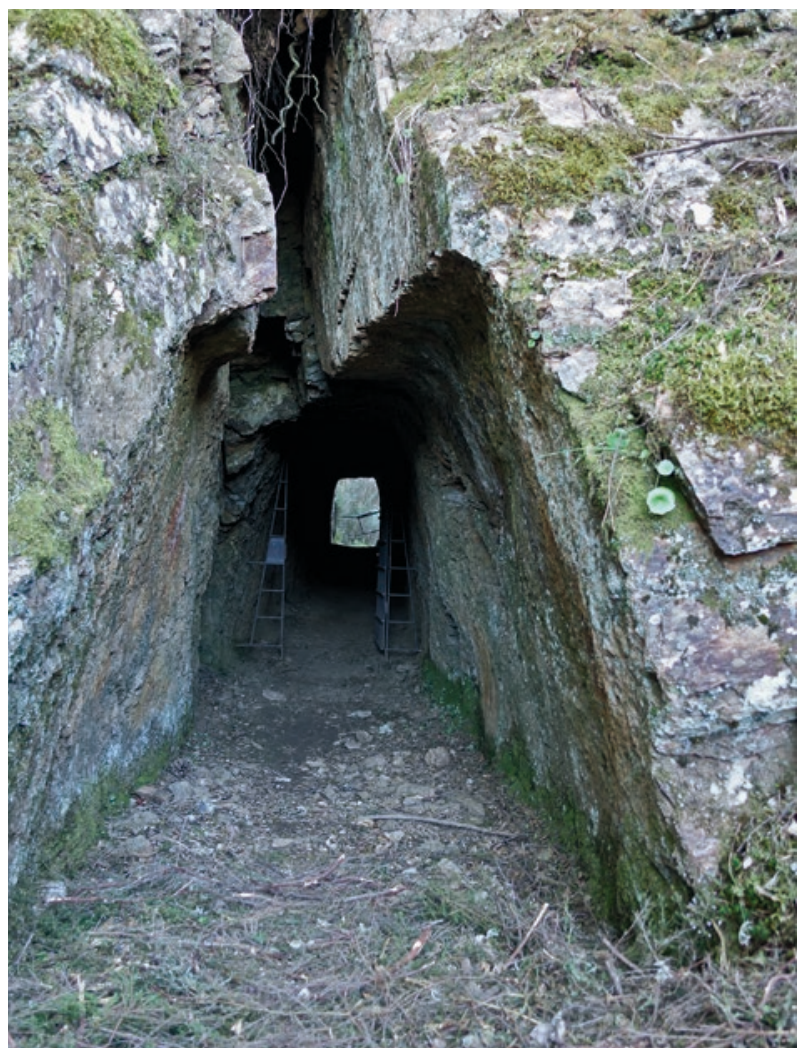

Fig. 2.0-17: Territorium metallorum Tresminas/Jales, Tresminas,

Corta da Ribeirinha: galeria para a prospeção da área leste da Corta

(fotografia: R. Wahl-Clerici).

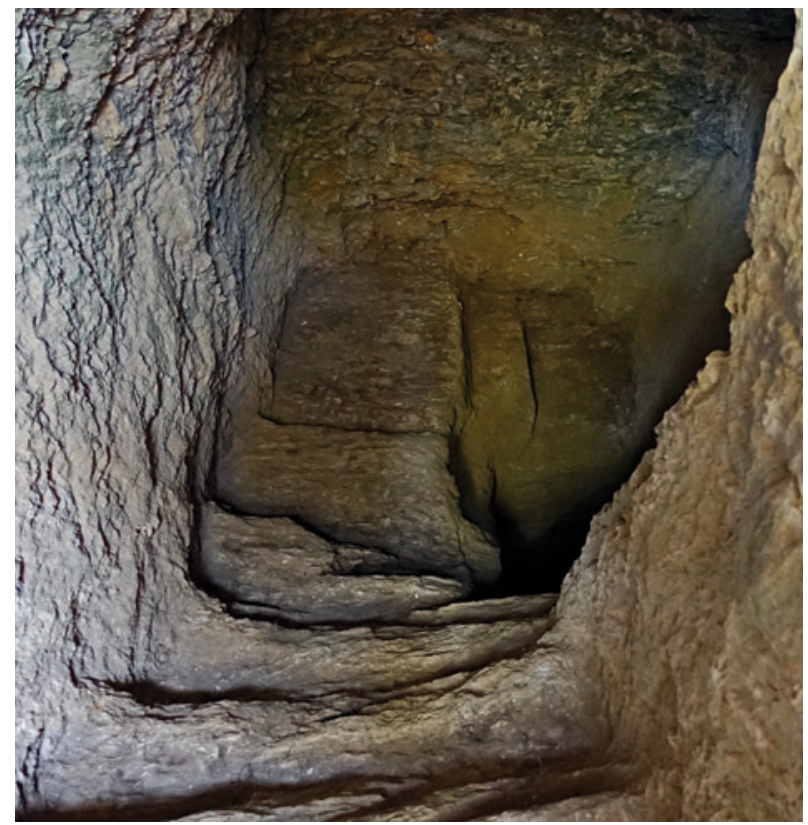

Fig. 2.0-18: Territorium metallorum Tresminas / Jales, Tresminas, Corta da Ribeirinha: escada em espiral vista de sul (fotografia: R.Wahl-Clerici). 


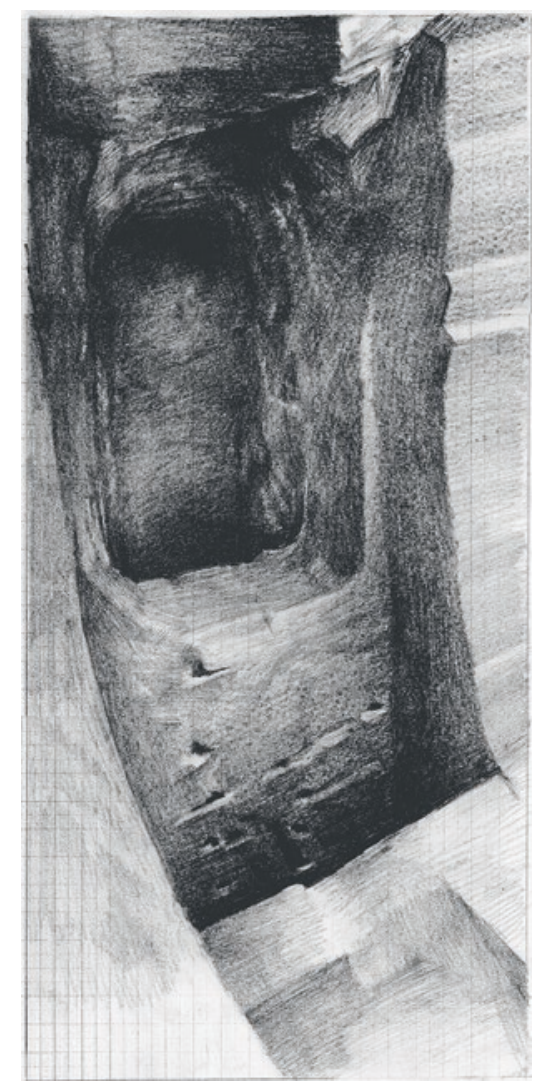

Fig. 2.0-19: Territorium metallorum Tresminas / Jales, Tresminas, Corta da Ribeirinha: poços gémeos no estremo sudeste da corta (desenho: P.Moser).

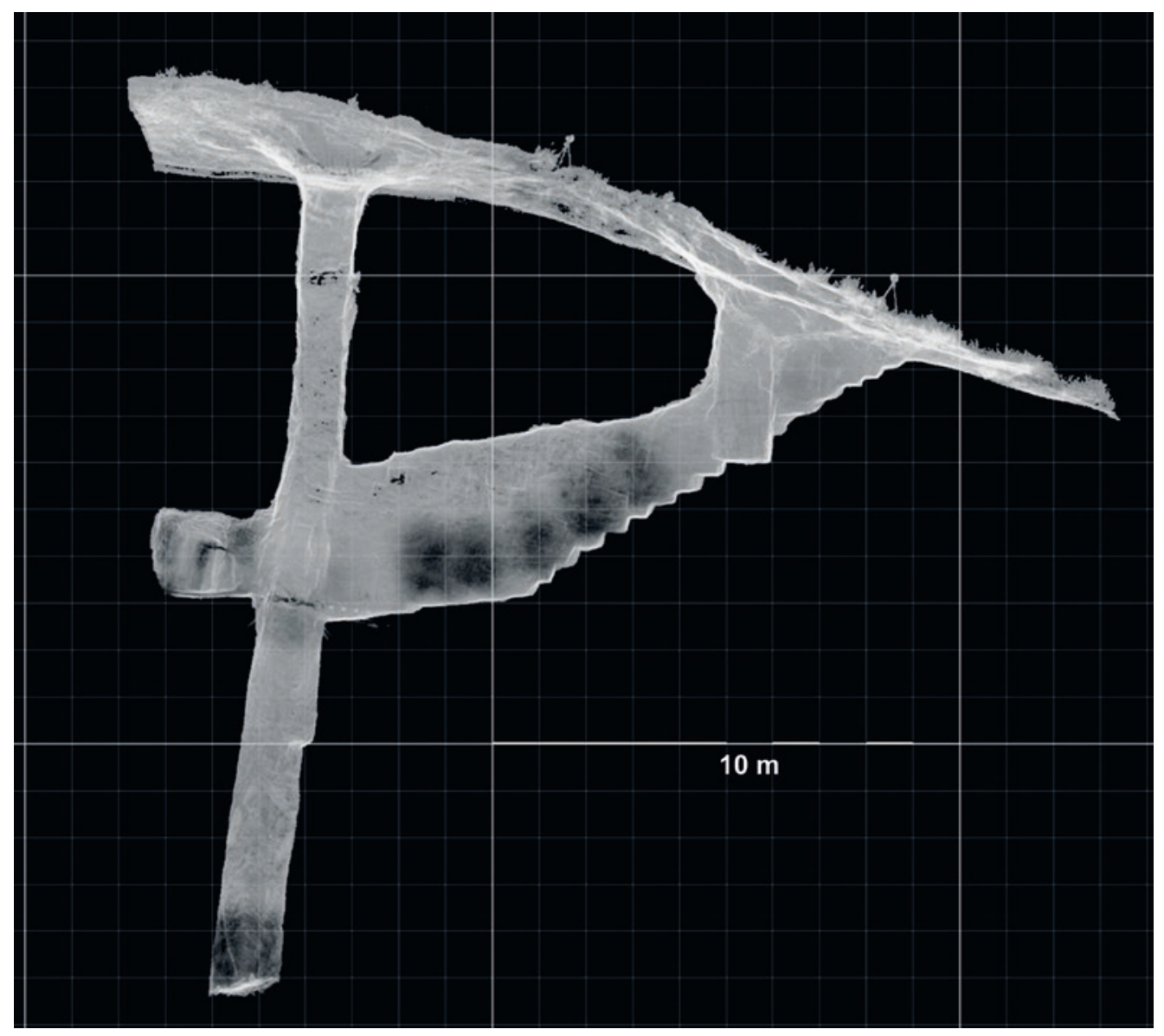

Fig. 2.0-20: Territorium metallorum Tresminas / Jales, Tresminas: túnel de prospeção típico com uma combinação de poço, poço em escada e túnel (varrimento e desenho: K.Mechelke, M.Lindstaedt). 


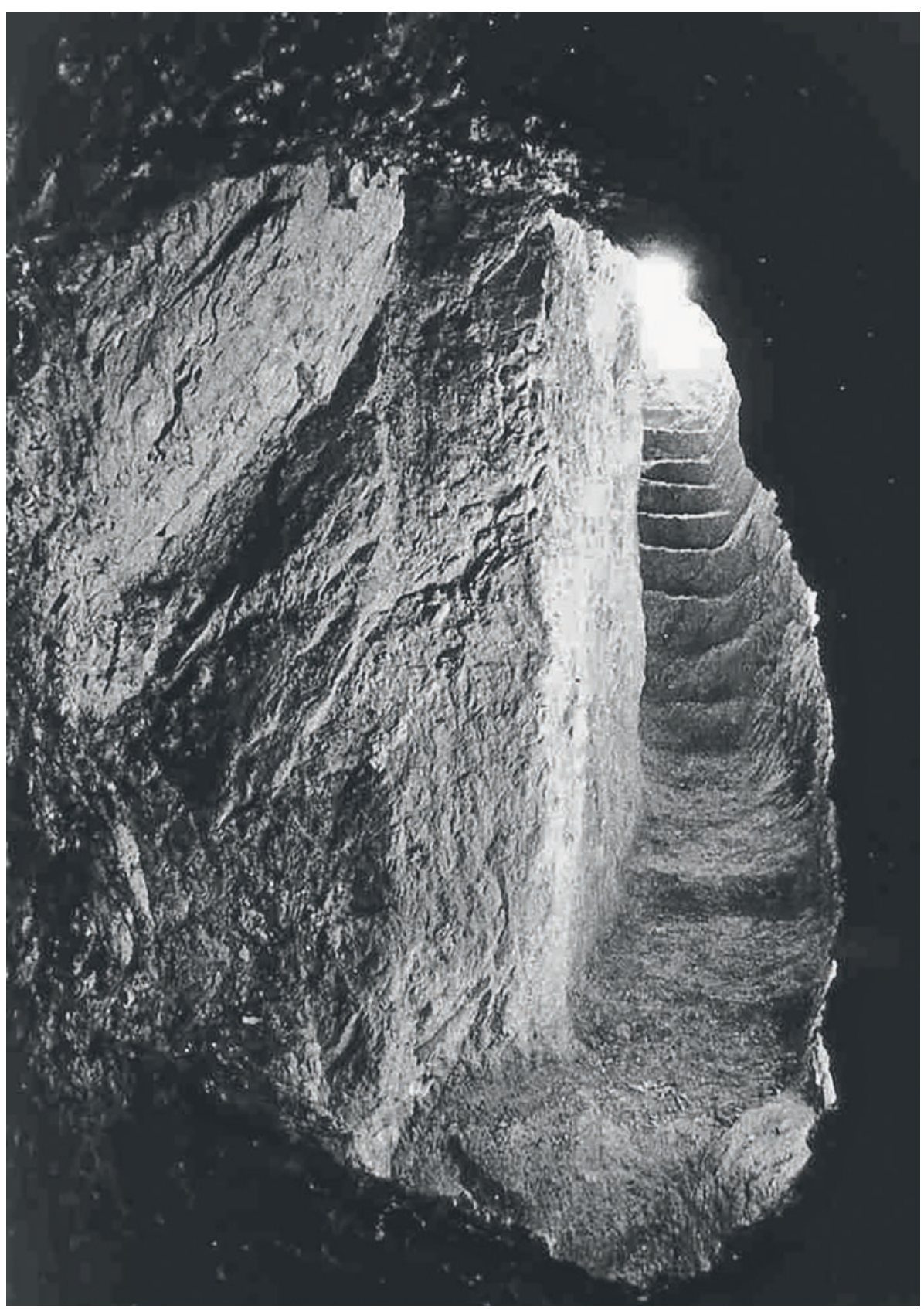

Fig. 2.0-21: Detalhe da fig.2.0-20, visto de oeste (fotografia: J.Wahl) 


\subsection{A catástrofe mineira e a ação de salvamento na mina de Tresminas ${ }^{87}$}

\begin{abstract}
... haud aliter collis scrutator Hiberi, cum subiit longeque diem uitamque reliquit, si tremuit suspensus ager subitumque fragorem rupta dedit tellus, latet intus monte soluto obrutus, ac pentitus fractum obtritumque cadauer indignantem animam propriis non reddidit astris. acrior hoc Tydeus, animisque et pectore supra est.
\end{abstract}

Assim como quando o mineiro ibérico penetra sob uma colina deixando muito para trás a luz do dia e a vida ordinária. Se o solo suspenso sobre ele treme e a terra se abre com um estrondo súbito, sobrepujado pela montanha que se abate e o esconde, o seu cadáver completamente despedaçado e esmagado nem a alma indignada devolve ao céu de que é oriundo.

Públio Papínio Estácio (ca.45-ca.95), Thebaid $6.880-885$

A fim de prospetar minuciosamente a montanha entre as duas explorações a céu aberto, foram executadas a Galeria dos Alargamentos e as suas construções anexas (fig. 1.0-3). A estas novas construções de prospeção, juntou-se o poço de escadas, que foi cortado na parede meridional da galeria. Devido à sua posição, sabemos que só foi possível abri-lo depois da suspensão da Galeria dos Alargamentos, caso contrário, o trânsito de carros teria sido consideravelmente condicionado (figs. 2.1-1 e 2.1-2).

Do poço de escadas, que não foi executado totalmente em linha reta e descreve uma ligeira curva para nascente, são visíveis ainda hoje14 degraus (figs. 2.1-3a/b). O diâmetro interior é de $1,15 \mathrm{~m}$, enquanto a altura interior varia entre 1,60 m (degrau 2), 1,90 m (zona fraturada no tecto junto ao degrau 3) e1,55 m (degrau 13). Com os degraus venceu-se uma distância de aproximadamente $5 \mathrm{~m}$ e uma altura de $2,75 \mathrm{~m}$, o que significa que a inclinação foi quase exatamente de $45^{\circ}$.

Depois do degrau 14, que se conservou apenas na sua parte oriental, verifica-se uma rutura da escada, com uma fenda de cerca 40 a $50 \mathrm{~cm}$ de largura (figs. 2.1-4a/b). Aqui, um bloco de rocha de $5 \mathrm{~m}$ de comprimento, bloco 1 , abateu, juntamente com o respetivo poço de escadas. O fenómeno ocorreu ao longo de fendas que se estendem quase perpendicularmente umas às outras. Em primeiro lugar, as fendas que correspondem à estratificação e às camadas sedimentares das rochas (sensivelmente NNO-ESE, inclinação $120^{\circ}$ ) caíram abruptamente em direção NNE $\left(75^{\circ}\right)$. Em segundo lugar, as fendas, alinhadas aproximadamente para NNO-SSE (inclinação $20^{\circ}$ ), também ruíram $\left(75^{\circ}\right.$ ) e estenderam-se mais ou menos paralelamente ao poço. No caso das últimas, trata-se de fendas transversais, que se encontram em toda região (p. ex. parede oriental da exploração a céu aberto A, fig. 3.0-12).

Descendo os 14 degraus do poço avista-se a parede que é a superfície da falha geológica junto à qual a escada abateu sensivelmente $2 \mathrm{~m}$ a $2,20 \mathrm{~m}$. A fissura que aqui teve origem, já foi mencionada, está preenchida por fragmentos rochosos. Um bloco de rocha entalado na fissura por cima da escada impediu desde então mais desabamento de material rochoso. O poço abatido prolonga-se mais um pouco (figs. 2.1-4a e 2.1-6). Embora o chão do poço não seja visível devido ao entulho, o tecto e a parede ocidental são cuidadosamente trabalhados, ao passo que a parede oriental se encontra fortemente fragmentada, estendendo-se até à próxima fissura. Aproximadamente $5 \mathrm{~m}$ mais à frente, na direção do poço de escadas, ocorreu, com uma outra fissura de cerca de $30 \mathrm{~cm}$ de largura, mais um desabamento do poço, desta vez a 1,40 m de profundidade. Assim, o bloco de rocha (fig. 2.1-7, bloco 2) não só abateu juntamente com o poço de escadas, mas também $40 \mathrm{~cm}$ na direção nascente. $\mathrm{O}$ tecto do poço de escadas rebaixado é visível no rochedo. A partir daqui o poço de escadas está completamente preenchido por entulho.

Após o desabamento, o poço de escadas foi novamente acedido. Indicação disso mesmo são os três nichos de lucernas colocados na parede junto à primeira fissura e que são visíveis a partir da Galeria dos Alargamentos (fig. 2.1-5). Esses nichos só podem ter sido abertos depois do acontecimento, uma vez que o bloco só ficou exposto com o desabamento da área. Junto do ponto de rutura mais baixo foram também abertos nichos na parede exposta após o desabamento (figs.2.2-6-2.1-7). Trata-se de duas aberturas arredondadas com um diâmetro de $11 \mathrm{~cm}$ cada, dispostas a uma distância de $14 \mathrm{~cm}$. Até à data não foi possível determinar a função das mesmas. Aproximadamente a meio, entre as duas aberturas e $20 \mathrm{~cm}$ acima das mesmas, foi escavado na rocha um nicho de lucerna. Além disso, só depois do desabamento foi possível construir um muro de pedra seca junto a B-C, para evitar que proviesse mais entulho da fissura do desabamento.

Todas estas averiguações só podem ser explicadas se, após o desabamento, tiver sido executada uma ação de salvamento para o resgate dos mineiros e dos utensílios que no momento da catástrofe se encontravam no poço de escadas. A favor dessa interpretação joga o facto de o poço de escadas nunca mais ter sido recuperado para posterior uti- 
lização. Por essa razão, a passagem não alargada de B para C ficou inalterada na sua forma desmoronada (figs. 2.1-4a / b, 2.1-7).

Indicativos de uma ação de salvamento são igualmente as duas cavidades junto ao degrau 14, executadas diretamente por baixo do tecto em frente, que ajudaram a fixar uma trave com $6 \mathrm{~cm}$ de diâmetro máximo (fig. 2.1-8). Trata-se de uma cavidade de $6 \mathrm{~cm}$ de altura e $9 \mathrm{~cm}$ de comprimento na parede oriental. Na parede ocidental, a cavidade foi executada em forma de ranhura para fixar e segurar a trave. Essa trave servia provavelmente para fixação de um guincho de corda, o qual terá sido construído para o transporte do entulho acumulado fora do poço de escadas. Dentro da Galeria dos Alargamentos e junto à área do poço de escadas encontram-se, pelo menos, três cavidades, situadas abaixo das cavidades identificadas como nichos de lucernas. Aquelas serviam provavelmente para apoio da estrutura, necessária para segurar o guincho de corda. É de supor, que imediatamente depois do acontecimento a parte inferior do poço de escadas não estivesse tão obstruída como agora, sendo verosímil que o entulho tenha entrado no poço durante os séculos seguintes.

\section{Discussão das causas possíveis para o desabamento local}

O duplo desabamento através das duas formações rochosas no poço de escadas só podia ter lugar se sob esse ponto existisse um espaço vazio. No entanto, nesta velha e compacta montanha de orogenia hercínica e uma idade aproximada de 250—420 milhões anos, não se encontram espaços vazios naturais. Sendo assim, temos de considerar outras possíveis origens dos espaços vazios. É admissível pensar num terramoto ou numa gruta artificial como causa. Ambas as possibilidades serão seguidamente debatidas.

Uma causa possível para o desabamento no poço de escadas poderia ser um sismo provocado por movimentos tectónicos. Todavia, a região do territorium metallorum de Tresminas/Jales constitui uma zona particularmente estável da Península Ibérica, com fraca atividade sísmica. Como, além disso, as redondezas próximas da Galeria dos Alargamentos não apresentam vestígios de atividade sísmica na superfície, a hipótese deve ser rejeitada. ${ }^{88}$ Qualquer que tenha sido a causa, podemos testemunhar os esforços dos mineiros romanos para salvar ou, pelo menos, recuperar os camaradas atingidos. Em princípio, é difícil comprovar fenómenos sísmicos somente com base em achados arqueológicos, como mostram os exemplos apresentados durante o Workshop interdisciplinar de 14 e 15 de maio 2004 com o tema «Terramotos da antiguidade na zona alpina e circum-adjacente».89

O mais provável, aparentemente, é que sob a zona de desabamento no poço de escadas se encontrasse um es- paço vazio artificial. Não é possível avaliar se esse espaço vazio correspondia a uma galeria de prospeção inferior ou ao avanço do procedimento de mineração subterrânea, iniciado na extração a céu aberto de Corta de Covas. De qualquer maneira, deveriam ter-se registados fortes abalos no terreno circundante e, naturalmente, sobretudo na zona diretamente acima, devendo o acontecimento ter provocado estragos semelhantes aos de um terramoto. ${ }^{90}$

O que quer que tenha causado o colapso, os cortes na rocha são testemunhas dos esforços dos mineiros romanos para salvar ou pelo menos recuperar os mineiros soterrados.

Neste contexto remetemos para uma passagem de Plínio, o Velho (N. H. 33, 70.72), onde se descreve a exploração com recurso aos arrugiae:

arrugias id genus vocant. siduntque rimae subito et opprimunt operatos, ut iam minus temerarium videatur e profundo maris petere margaritas atque purpuras. tanto nocentiores fecimus terras! relinquuntur itaque fornices crebri montibus sustienendis. ... (72) praeacto opere cervices fornicum ab ultimo caedunt.

Esse tipo (de galerias) é chamado arrugiae. De repente abrem-se fendas e os trabalhadores ficam soterrados, de modo que parece menos arrojado, buscar pérolas e púrpuras do fundo do mar. Tão mais perigosa, conseguimos tornar a terra! Por isso se erguem muitas vezes arcos de abóboda para amparar as montanhas ... Concluídos os trabalhos, são cortados os suportes dos arcos, começando com o mais distante...

Por outras palavras, a rocha-mãe era minada com o propósito de provocar um desabamento, para facilitar o trabalho da extração, mesmo que assim fossem colocadas em risco vidas humanas. É conveniente referir, que, até à data, esta técnica só pôde ser comprovada na exploração de jazidas

Segundo a informação cordialmente disponibilizada por carta pelo professor universitário Dr. K. Reicherter, da área de ensino e investigação sobre neotectónica e geoperigos, RWTH Universidade Aachen, não são conhecidas atividades sísmicas nos arredores de Tresminas nos tempos romanos. No entanto, não se pode excluir de todo esta hipótese, dado que a oeste da área mineira existe uma zona de rutura, que se estende em direção NNE-SSW, e em cuja parte setentrional existem fontes termais. - Esta afirmação foi confirmada pelo Prof. Dr. Luís Sousa da UTAD, Vila Real.

89 Waldherr/Smolka 2007. Nomeadamente os seguintes ensaios: J. Ganzert, Der Mars-Ultor-Tempel in Rom - ein Seismograph?; R. Schatzmann, Anmerkungen zur Annahme eines Erdbebens um die Mitte des 3. Jahrhunderts in Augusta Raurica; C. S. Sommer, Vetustate conlapsum, enemy attack or earthquake; H. Dolenz, Ein Erdbeben in der Stadt Alt-Virunum auf dem Magdalensberg?; M. Kandler/K. Decker/G. Gangl, Archäologische Befunde von Erdbebenschäden im Raum von Carnuntum und ihre seismotektonische Interpreation; K.-G. Hinzen, Archäoseismologische Untersuchungen im Rheinland.

90 Waldherr 1997, 75. 
aluviais, sendo o exemplo da mina de Las Médulas o mais referenciado. ${ }^{91}$

No entanto, o facto de os dois desabamentos aqui descritos serem limitados a uma área muito pequena, contesta a possibilidade de interpretar as mesmas como resultado de uma escavação sistemática. Assim, não foram atingidos pelo desabamento, por exemplo, os elementos da Galeria dos Alargamentos mais próximos da exploração a céu aberto, isto é, a câmara final com as construções anexas (figs. 2.0-10, 2.0-11, 2.1-1).

Deste modo, não foi possível, até agora, estabelecer uma causa inequívoca para esta catástrofe mineira. Por essa razão, o nosso interesse concentra-se nas consequências deste tipo de acontecimentos e na questão da viabilidade da identificação das mesmas no distrito mineiro de Tresminas/Jales.

\section{Discussão das consequências do acontecimento mineiro no territorium metallorum Tresminas / Jales}

A disponibilização de auxílio estatal em casos de catástrofe dependia basicamente da conjuntura política e social, que nos séculos I eIId.C. se pode qualificar como particularmente estável. ${ }^{92}$ Podemos, assim, partir do princípio de que uma ajuda prática seria considerada como natural, representando mesmo para o soberano uma oportunidade para se destacar como um cuidadoso pater patriae. ${ }^{93}$ Segundo escreve Suetónio, Caligula 31, o imperador Calígula ter-se-ia queixado por durante o seu reino acontecerem tão poucas catástrofes.

Queri etiam palam de condicione temporum suorum solebat, quod nullis calamitatibus publicis insignirentur; Augusti principatum clade Variana, Tiberi ruina spectaculorum apud Fidenas memorabilem factum, suo oblivionem imminere prosperitate rerum; atque identidem exercituum caedes, famem, pestilentiam, incendia, hiatum aliquem terrae optabat.

Costumava queixar-se abertamente sobre o desfavor do seu tempo, não sendo esse premiado com casos de calamidades públicas. O reinado de Augusto ficara memorável pela derrota de Varo e o de Tibério pela derrocada do anfiteatro de Fidena; o seu reinado ameaçava cair no esquecimento por causa do bem-estar reinante por toda a parte. Assim, ansiava repetidamente por derrotas dos exércitos, fome, peste, incêndios ou um terramoto qualquer.

Na maioria das vezes, o apoio consistia em donativos monetários, anulação de impostos ou disponibilização de pessoal técnico qualificado para a reconstrução. ${ }^{94}$ Afinal, para além da obrigação, pelas razões já mencionadas, era também do maior interesse do soberano eliminar os vestígios da catástrofe o mais depressa possível.

Neste contexto, levanta-se a questão: quem providenciou a ação de salvamento? A solidariedade entre mineiros tem longa tradição, pelo que, neste caso, talvez tenha sido prioritária. Por outro lado, é de tomar em consideração que as catástrofes naturais nos tempos romanos eram percebidas como epifenómenos de desenvolvimentos negativos ao nível do Estado. Por este motivo, teria sido preocupação importante por parte do procurator responsável, nas suas funções de tutor enviado pelo imperador, garantir o devido prosseguimento dos trabalhos na mina e eliminar os vestígios do acontecimento mais rapidamente possível.

Os achados indicam que, depois da presumível ação de salvamento, o avanço da galeria no poço de escadas foi provavelmente interrompido. Além disso, não há maneira de verificar se a prospeção na área da Galeria dos Alargamentos terminou com o acontecimento. Depois da paragem dos trabalhos na Galeria dos Morcegos, que foi abandonada por a exploração a céu aberto B (Corta da Ribeirinha) ter deixado de ser rentável, foi possivelmente colocado um altar na área da entrada, o que é sugerido por uma cavidade no chão. ${ }^{95}$ Se foi também este o caso na Galeria dos Alargamentos, já não é possível afirmar, devido ao entulho na área da entrada. Finalmente, nada sabemos sobre o êxito da ação de salvamento. Não é de excluir que debaixo do entulho no fim do poço de escadas se encontrem os restos mortais de mineiros romanos.

Desconhecemos se o acontecimento no poço de escadas da Galeria dos Alargamentos foi o que motivou o texto do poeta Estácio, inicialmente citado. No entanto, essa hipótese também não é de excluir, em função dos dados biográficos do poeta (ca. 45 -ca. 95 d.C.). Mas podemos afirmar, que os mineiros e a população de Tresminas interpretaram o abalo da terra e o desmoronamento, independentemente da sua causa, como um terramoto em sentido lato.

Na zona de exploração C, em Lagoinhos, ocorreu uma catástrofe semelhante, pelo que o texto de Estácio poderá aplicar-se igualmente a este acontecimento.
91 Domergue 2008, 138.

92 Sonnabend 1999, 235

93 Winter 1998, 149. Relativamente à discussão quanto aos mecanismos de instrumentalização política de catástrofes naturais, ou melhor, às relações dos soberanos com as mesmas, ver Waldherr 1998, 63.

94 Sonnabend 1999, 219, 245.

95 Wahl-Clerici 2008, 54. 


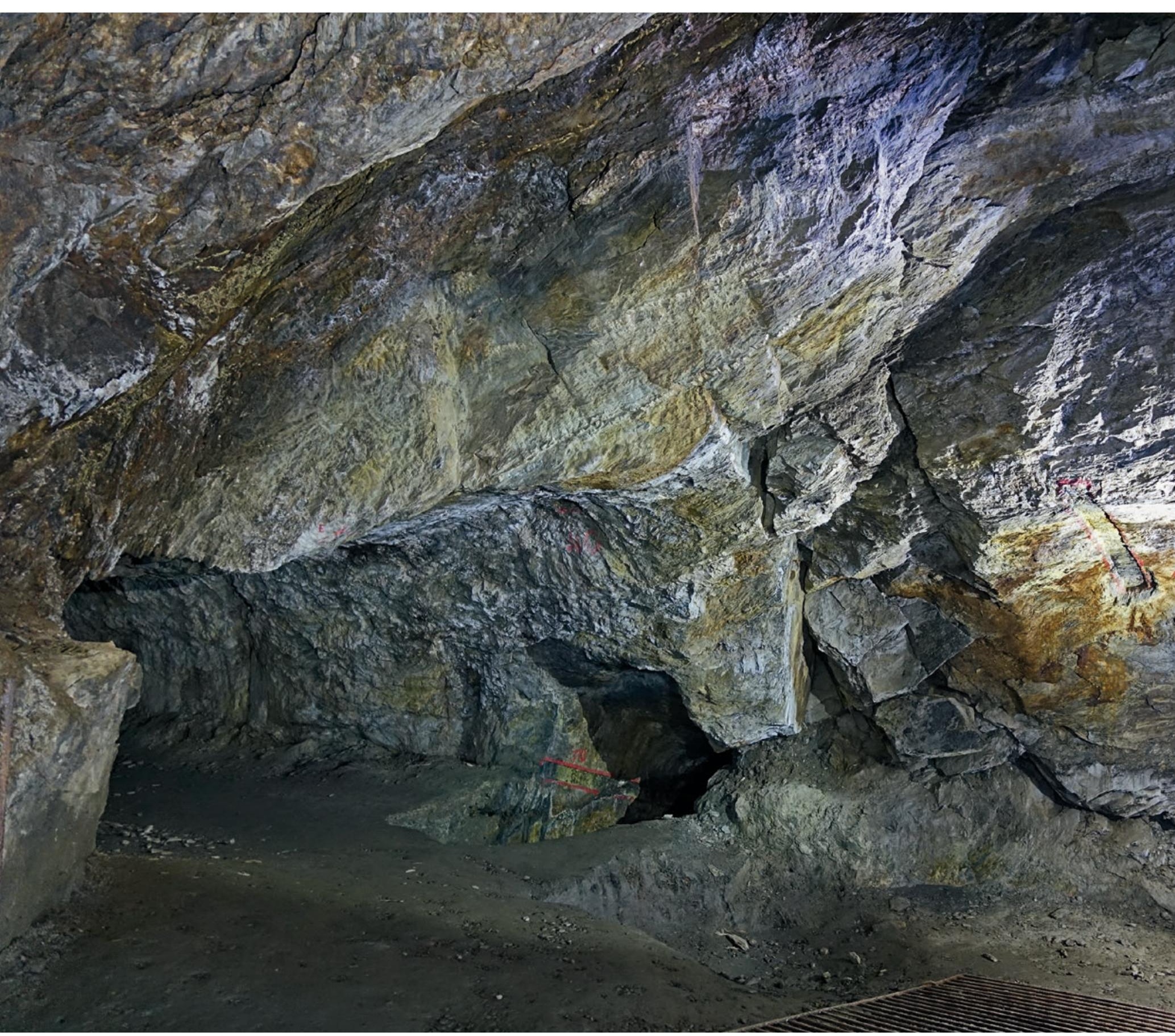

Fig. 2.1-1: Territorium metallorum Tresminas/Jales, Tresminas, Galeria dos Alargamentos: a entrada do poço em escada prolonga-se em parte no solo da Galeria de Alargamentos (fotografia: R. Wahl-Clerici). 


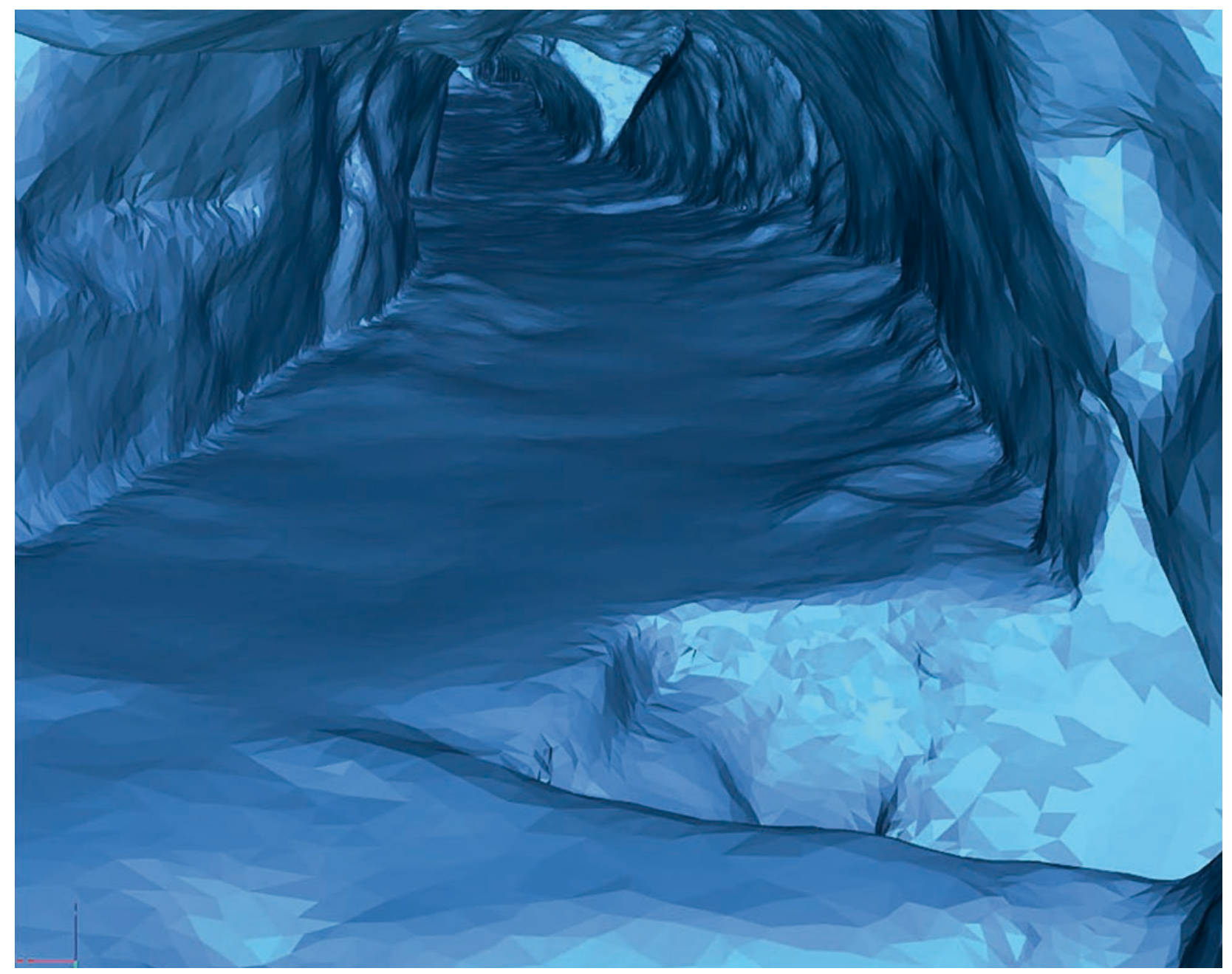

Fig. 2.1-2: Territorium metallorum Tresminas / Jales, Tresminas, Galeria dos Alargamentos: a construção da galeria destruiu parte do solo do poço em escada (digitalização a laser 3D: M. Helfert e B. Ramminger, edição: M. Helfert). 


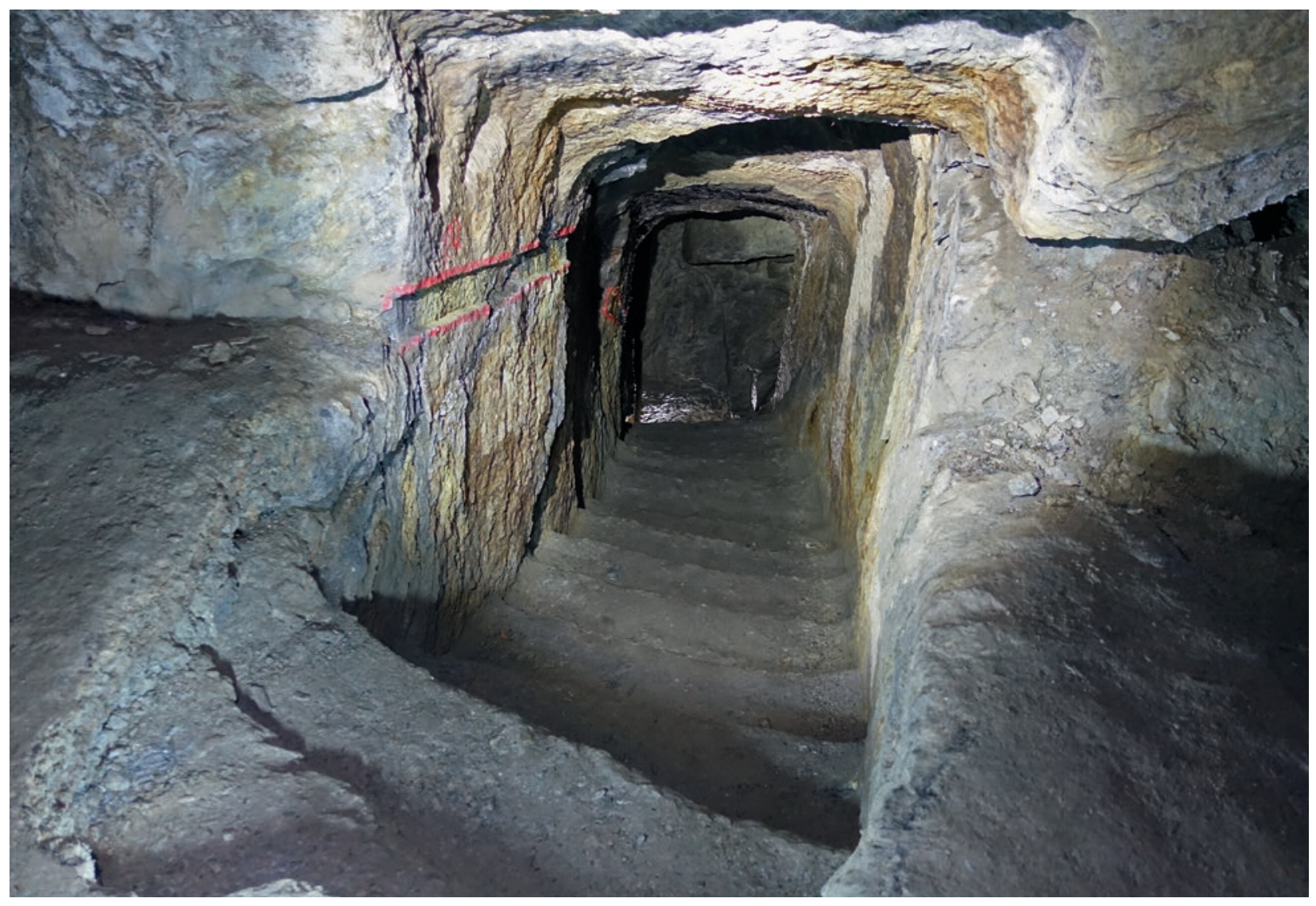

Fig. 2.1-3a: Territorium metallorum Tresminas /Jales, Tresminas, Galeria dos Alargamentos: vista de norte para o poço em escada (fotografia: R. Wahl-Clerici).

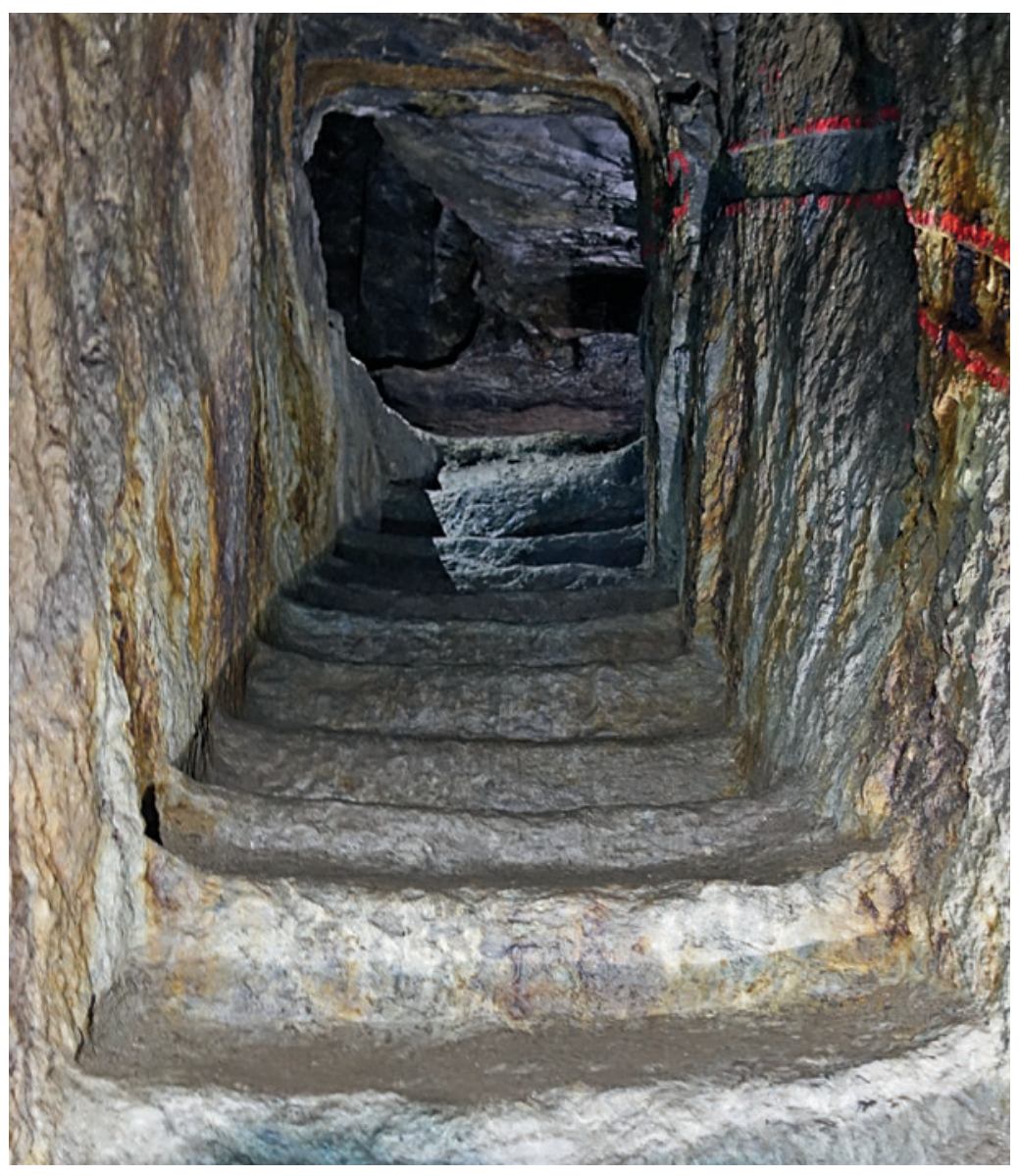

Fig. 2.1-3b: Territorium metallorum Tresminas/Jales, Tresminas, Galeria dos Alargamentos: vista de sul para o poço em escada (fotografia: $R$. Wahl-Clerici). 


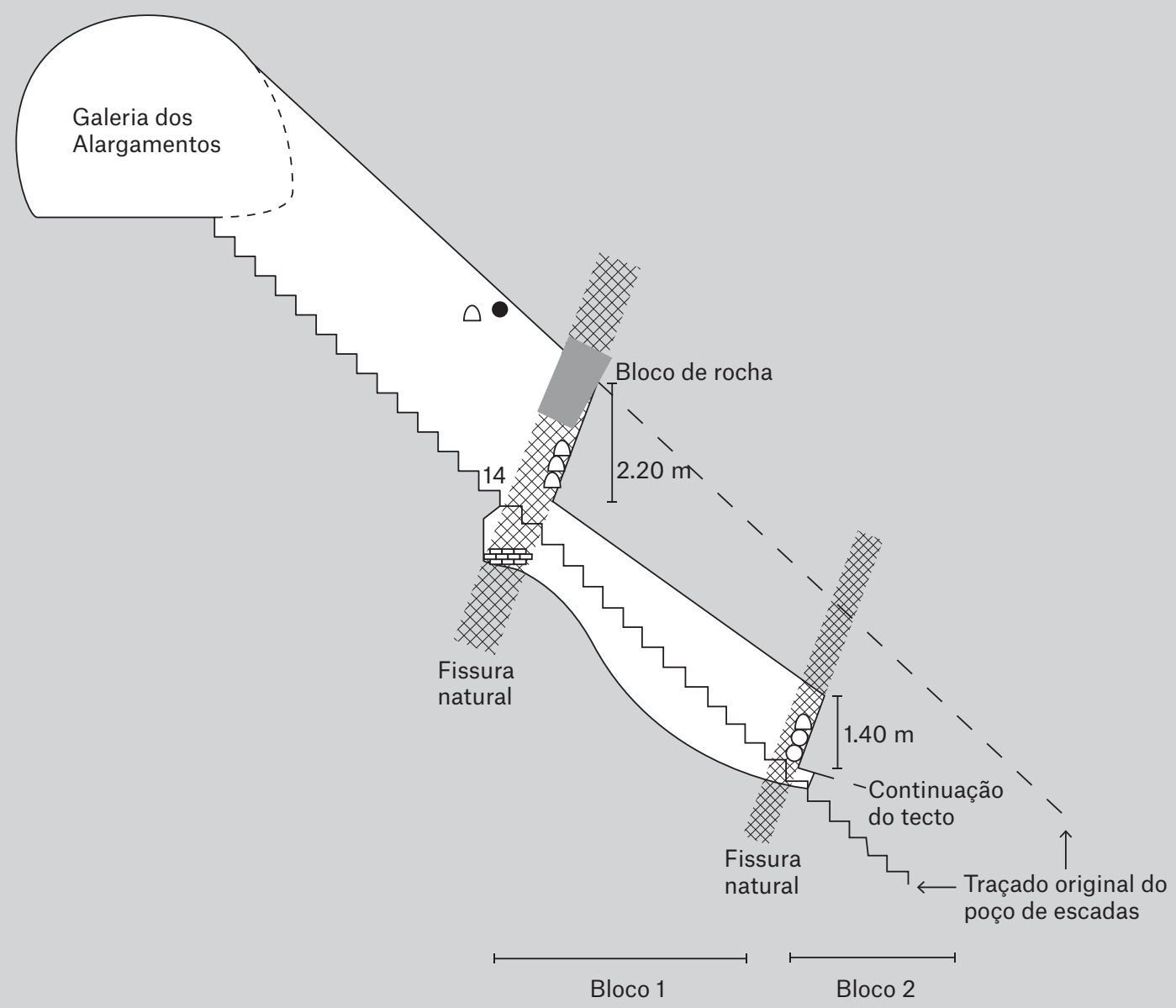

Fig. 2.1-4a: Territorium metallorum Tresminas/Jales, Tresminas, Galeria dos Alargamentos: perfil esquematizado do poço em escada (R. Wahl-Clerici).

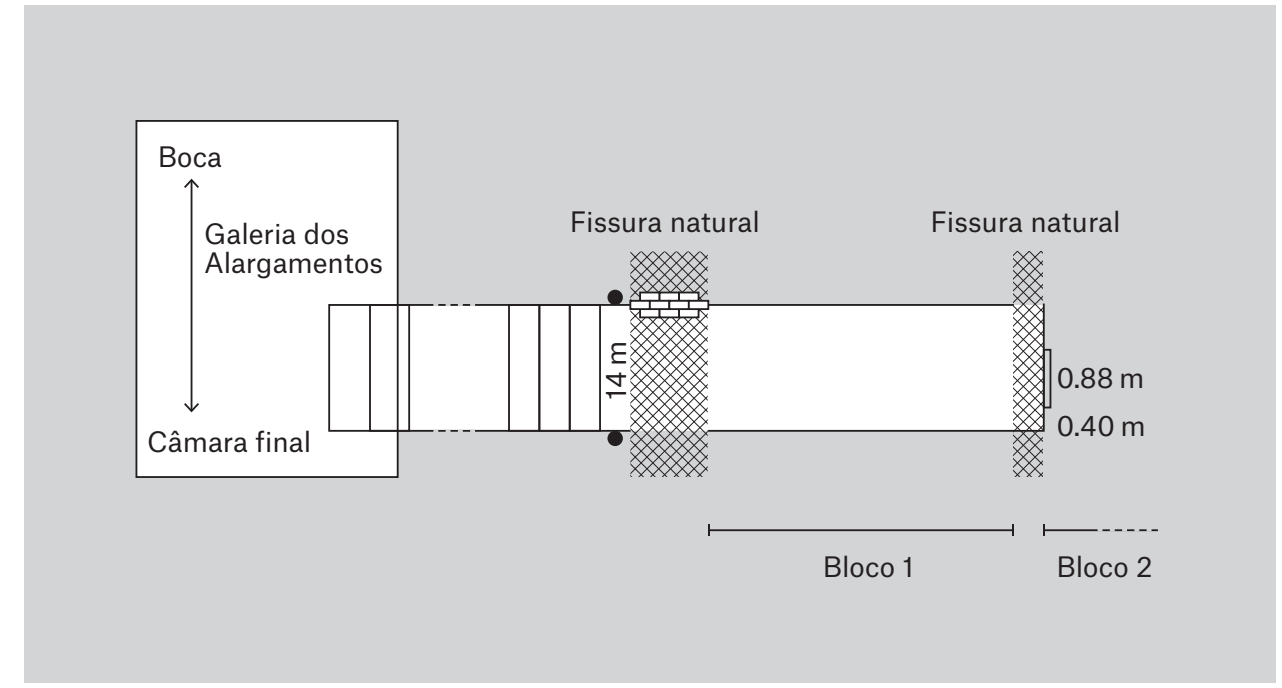

Fig. 2.1-4b: Territorium metallorum Tresminas /Jales, Tresminas, Galeria dos Alargamentos: planta esquemática do poço em escada (R. Wahl-Clerici). 


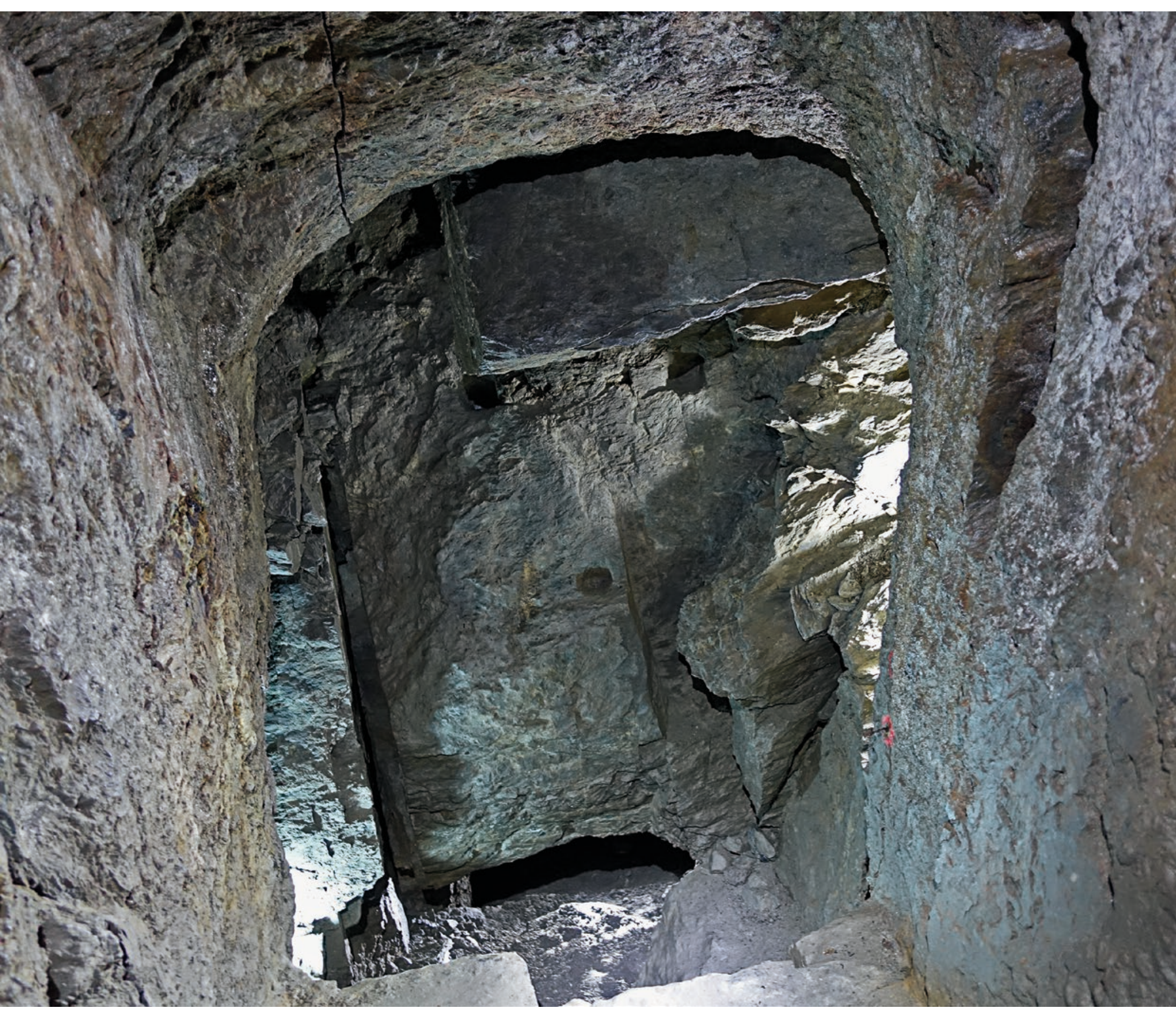

Fig. 2.1-5: Territorium metallorum Tresminas / Jales, Tresminas, Galeria dos Alargamentos: vista sobre a rocha na posição B. Os nichos para as lucernas são claramente visiveis. (fotografia: $R$. Wahl-Clerici) 


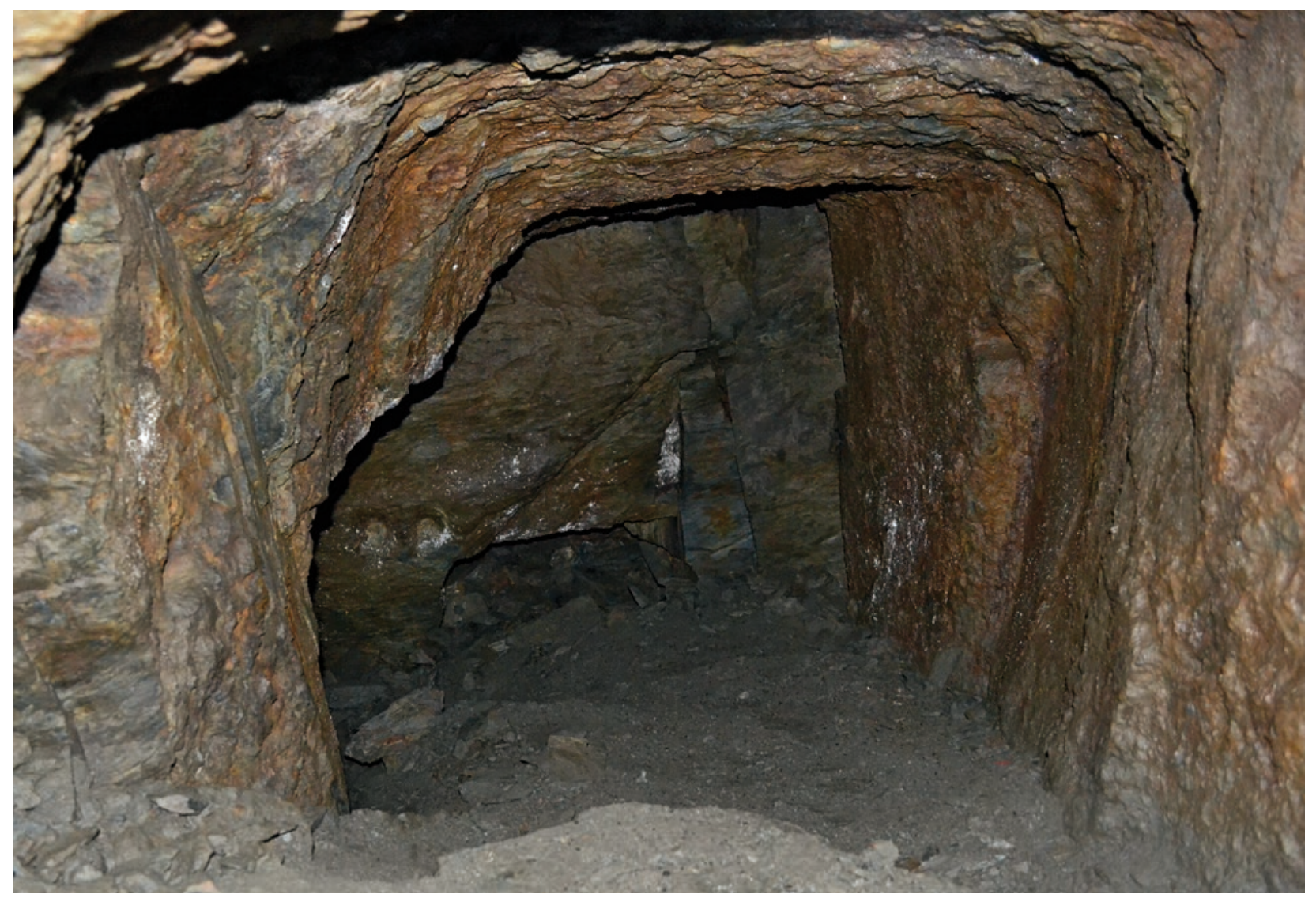

Fig. 2.1-6: Territorium metallorum Tresminas / Jales, Tresminas, Galeria dos Alargamentos: vista para o poço em escada da posição C em direção a D, o solo encontra-se completamente coberto (fotografia: $R$. Wahl-Clerici).

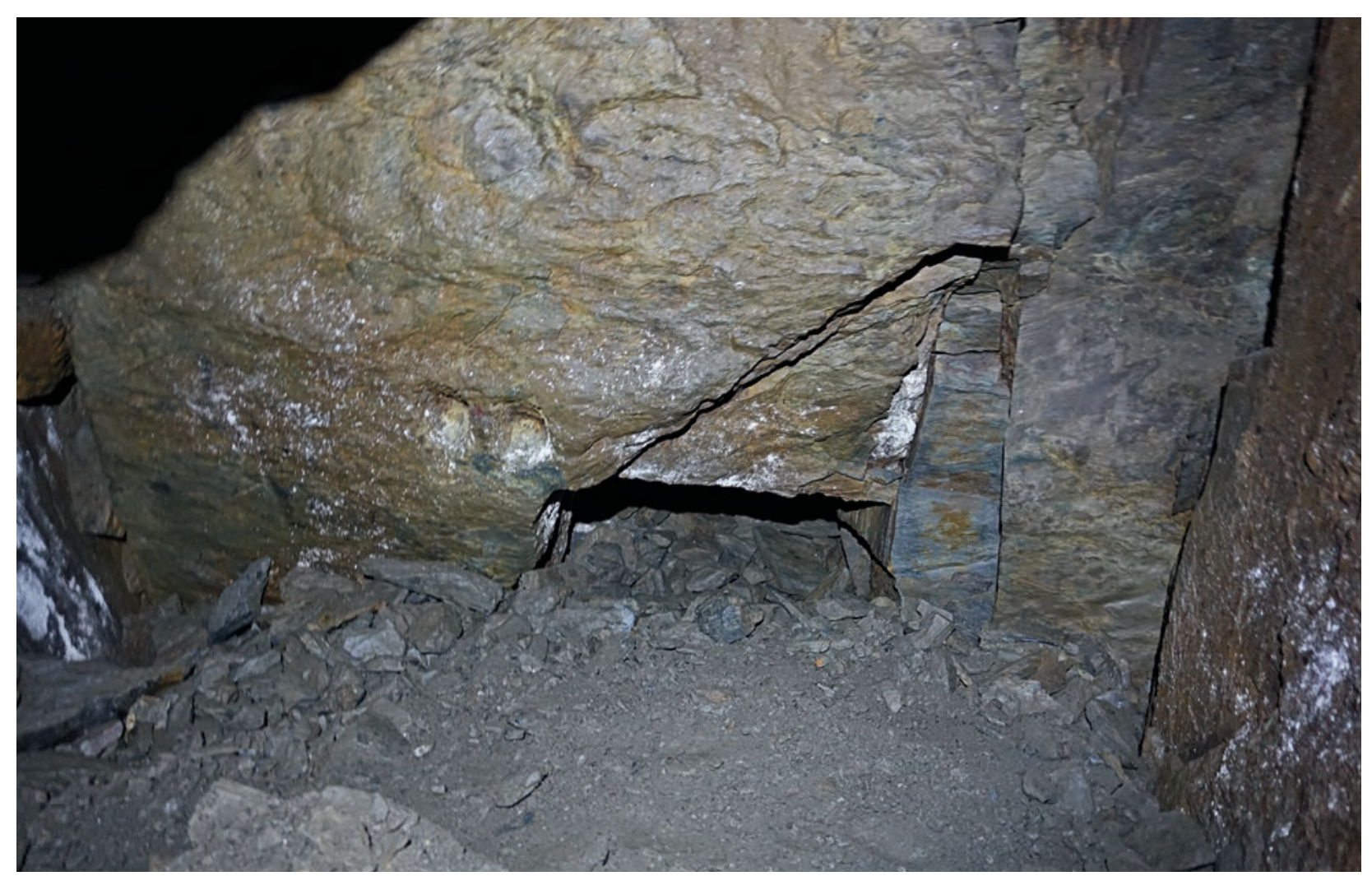

Fig. 2.1-7: Territorium metallorum Tresminas / Jales, Tresminas, Galeria dos Alargamentos: vista sobre o tecto desmoronado no poço em escada na posição D; são visiveis duas das três cavidades no bloco 2 (fotografia: $R$. Wahl-Clerici). 


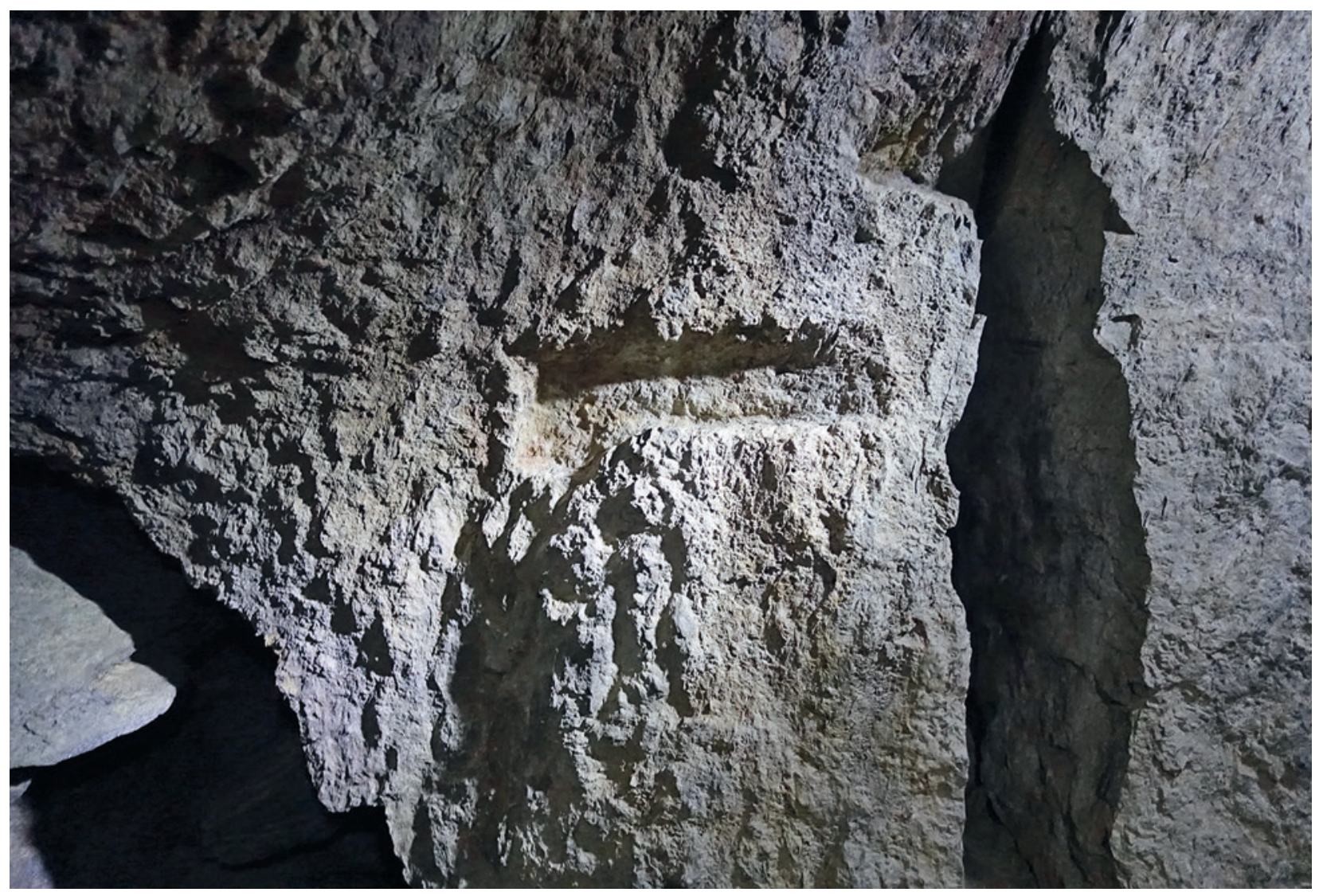

Fig. 2.1-8: Territorium metallorum Tresminas / Jales, Tresminas, Galeria dos Alargamentos: cavidade para a fixação de uma viga, usada para a aplicação de um carretel, utilizado nos trabalhos de resgate (fotografia: $R$. Wahl-Clerici). 


\subsection{Poço em espiral96}

A extraordinária diversidade das estruturas de prospeção inclui ainda um sistema constituído essencialmente por duas componentes, que se situa aproximadamente a meio do talude norte da Corta da Ribeirinha (fig. 1.0-3 10/11). A partir de duas áreas de mineração distintas, foram usados um poço em espiral e uma galeria para prospetar os conteúdos na área circundante, imediatamente adjacente às áreas de mineração. Na área aqui apresentada, é visível a sua sobreposição.

A investigação destes vestígios únicos obrigou-nos a contextualizá-los face às condições presentes na Corta da Ribeirinha (veja-se ainda o capítulo3.0 - Corta da Ribeirinha) e rapidamente se tornou evidente que a mina a céu aberto foi originalmente explorada em duas zonas de mineração independentes, unidas somente após a construção dos espaços em análise. Assim sendo, sem ter em conta esta condição e sem o recurso aos modelos criados a partir das medições a laser 3D, dificilmente se compreenderia estas estruturas, que ainda se encontram no seu estado original (figs. 2.2-1-2.2-3).

\section{O poço em espiral}

O poço em escada retangular foi aberto na parede norte de uma das longas trincheiras no flanco norte da Corta da Ribeirinha (fig. 2.2-4). A sua forma corresponde a dois ou três lances de escada lineares em ângulos retos. A área de entrada em linha reta e a sua continuação, construída paralelamente a pouca distância, serviam sobretudo para superar as diferenças de nível, sendo que se encontravam ligadas por uma pequena secção intermédia (fig. 2.0-18).

A configuração da área da boca indica que a intenção original consistia em prospetar a jazida por meio de um túnel horizontal (figs. 2.2-3-2.2-5). Este tinha uma altura original de aproximadamente $130 \mathrm{~cm}^{97}$, mas em pouco tempo foi aprofundado em $40 \mathrm{~cm}$, criando um vão de aproximadamente $170 \mathrm{~cm} \times 110 \mathrm{~cm}$. Os vestígios de uma extensão horizontal só podem ser encontrados nos primeiros $90 \mathrm{~cm}$ do tecto da área de entrada ${ }^{98}$; por conseguinte, e conforme mostram os avanços inacabados e as cavidades irregulares no ponto mais alto do tecto, conclui-se que neste ponto se deu por terminado o avanço na horizontal, tendo-se convertido o túnel numa escada. Os degraus pouco gastos são indicadores de uma construção de prospeção.

Ao centro, onde surge uma pequena câmara com $160-190 \mathrm{~cm}$ de largura, criada pelos lances em ângulos retos, a escada estende-se por um pequeno degrau plano e largo, com $15 \mathrm{~cm}$ de altura, adjacente a uma plataforma de $80 \mathrm{~cm} \times 97 \mathrm{~cm}$ (fig. 2.2-6 A, B), o que resulta num pequeno espaço com uma altura mínima de $145 \mathrm{~cm}$, cujo piso, com os seus degraus planos, contrasta com o impressionante lance de entrada íngreme. Após a primeira volta a leste, a escada continua com dois degraus uniformes de $29 \mathrm{~cm}$ de altura (Fig. 2.2-6 C) e um segundo patamar com $50 \mathrm{~cm} \times$ $48 \mathrm{~cm}$ (Fig. 2.2-6 D). Apenas um degrau virado a sul, que não corresponde a toda a largura do poço inclinado, manteve-se preservado cerca de $60 \mathrm{~cm}$ abaixo da pequena plataforma, marcando uma antiga continuação íngreme da escada (Fig. 2.2-6 E). Não pode haver dúvidas sobre a sua existência devido à orientação do tecto do poço projetado de forma oblíqua (fig. 2.2-7).

Na área da pequena câmara anteriormente descrita, as cavidades verticais e uma abertura retangular, quase quadrada, apontam para a anterior existência de um poço, ou de uma secção de um poço, vertical e aprofundado (fig. 2.2-6 F), cuja extremidade inferior foi provavelmente destruída pela inserção da Galeria do Pastor. No entanto, sem indicações sobre a posição e a forma da extremidade inferior do poço em vertical, não é possível determinar inequivocamente a sua função nem a sua sequência construtiva (fig. 2.2-8).

\section{Galeria do Pastor}

A Galeria do Pastor, hoje ligada à parte inferior da escada, foi aberta de leste a partir de uma área de mineração a mais ou menos $4 \mathrm{~m}$ de profundidade. Os vestígios da rocha escavada acima da boca testemunham o progresso original da exploração deste lado (fig. 2.2-9). As estruturas rochosas preservadas mostram que o nível de extração foi descendo

96 Resumo da primeira publicação: Regula Wahl-Clerici, Thomas Schierl, Klaus Mechelke, Markus Helfert, M. Lindstaedt 2019. The Roman spiral stairwell in the territory metallorum Tresminas / Jales (freg. Tresminas; distr. Vila Real/P). Archäologisches Korrespondenzblatt 49, pp. 109-125.

97 Em Tresminas, os pés-direitos em construções de prospeção são comparativamente baixos. Por exemplo, em Lagoinhos encontra-se o remanescente de uma galeria de prospeção com uma altura máxima de apenas 1,15 m (Wahl-Clerici/Wiechowski 2013, 321 -323). A galeria de prospeção, localizada diretamente abaixo do poço em escada, também tem uma altura relativamente baixa de $1,45 \mathrm{~m}$.

98 A este respeito veja-se ainda: Cauuet 2005, 40, figs. 3-4. 
gradualmente. Em contraste com os vestígios de mineração acima da boca, que hoje são apenas superficiais, a Galeria do Pastor, projetada como estrutura de prospeção, foi construída mais profundamente na montanha, estreitando-se cerca de $5 \mathrm{~m}$ após a boca. Atualmente é difícil reconstruir os diferentes níveis de exploração com base nos poucos vestígios existentes, uma vez que toda a galeria foi aprofundada mais tarde. Apesar das extensas escavações, realizadas no início dos anos 90, ainda não foi encontrado o piso (fig. 2.2$10)$.

O tecto bem trabalhado da boca até à área da abertura do poço em escada sugere que, no decurso da sua construção, a parte inferior do poço, cujo tamanho e forma já não podem ser determinados, foi cortada. O pequeno poço de prospeção (fig. 2.2-11) aberto na parede sul tem o mesmo nível no tecto, pelo que muito provavelmente pode ser atribuída a uma fase inicial de construção da Galeria do Pastor, enquanto que a sua posição desfasada em relação à extremidade inferior do poço em escada indica não haver uma ligação direta entre os mesmos. Permanece em questão se a escada plana e ligeiramente curvada, que levava à galeria de prospeção inferior, estava ligada ao poço em espiral.

\section{A ligação entre o poço em escada e a Galeria do Pastor}

A projeção de todas as construções num plano oeste-leste (figs. 2.2-1, 2.2-2) e norte-sul (fig. 2.2-3) mostra as várias unidades de construção preservadas na zona, sendo que o seu posicionamento divergente não permite reconhecer um conceito de construção coordenado. Pelo contrário, confirma antes a impressão já obtida no decurso do estudo de cada elemento de construção: a unidade espacial só foi criada através da abertura da secção inferior da escada, ou do poço falso, entre o poço em escada e a Galeria do Pastor. Devido à posição das duas construções na transição entre as zonas ocidental e oriental da Corta da Ribeirinha (fig. 2.212), não se pode excluir que tenham sido abertas em função do progresso de exploração específico das respetivas zonas e, presumivelmente, em momentos diferentes. No entanto, atualmente já não é possível determinar qual o intervalo de tempo. É provável que a planificação e/ ou abertura da Galeria do Pastor a partir de leste tenha surgido mais ou menos em simultâneo com a obtenção de resultados da prospeção no poço em escada.

\section{Resultados}

O poço em espiral, bem como a Galeria do Pastor, foram abertos para a prospeção da zona mais profunda das áreas já exploradas da Corta da Ribeirinha. ${ }^{99}$ A continuação da zona de exploração oriental através da Galeria do Pistor corresponde aos procedimentos habituais na mineração romana, enquano que os poços em espiral são bastante raros. Nas minas de ouro dacianas, por exemplo, existe uma déscenderie hélicoïdale subterrânea, que deve antes ser considerada como escada em ângulo. ${ }^{100} \mathrm{Na}$ área da mina de ouro romana, ou seja, na área de prospeção adjacente à zona mineira do «Fojo das Pombas» (Valongo, distrito do Porto, P) foram abertos dois poços em escada redondos (fig. 2.213). ${ }^{101}$

Uma vez que, em princípio, este procedimento de poupança de espaço não teria sido absolutamente necessário na área aqui apresentada, temos de assumir que os prospetores esperavam encontrar mais conteúdos de ouro dignos de exploração mineira na secção mais profunda da montanha.

As duas construções são ainda de particular importância para a compreensão da abordagem romana na exploração da Corta da Ribeirinha. No início, a mina a céu aberto, que hoje se apresenta como uma unidade, foi dividida numa parte oriental, possivelmente mais antiga, e uma parte ocidental. Somente após a abertura da Galeria do Pastor e do poço em espiral é que se procedeu à ligação das duas zonas de exploração. Apesar deste estudo nos fornecer apenas uma pista cronológica relativa, este exemplo permite-nos obter um conhecimento mais profundo da história mineira e dos mineiros romanos.

99 A amostragem do Serviço de Fomento Mineiro, registada em 1979, plano 1988, revelou apenas vestígios de ouro.

100 Cauuet 2005, 40, fig.3.

101 Gostaríamos de agradecer a J. Moutinho e V. Gandra (Alto Relevo - Clube de Montanhismo, Valongo/P), que nos tornaram acessíveis estas construções inéditas de prospeção e que nos apoiaram durante o seu registo. Os achados no Fojo das Pombas, constituídos principalmente por vasos de bronze, datam, o mais tardar, do século II(Mendes Pinto 2000, 403); Rosumek 1982, 67-68 refere-se às escadas em espiral em Laurion (Lavrio, Attika/GR), numa pedreira em Pellenz (Lkr. Mayen-Koblenz/D) e na mina de Cala (prov. Múrcia/E). No entanto, estas já não vêm mencionadas na literatura. 


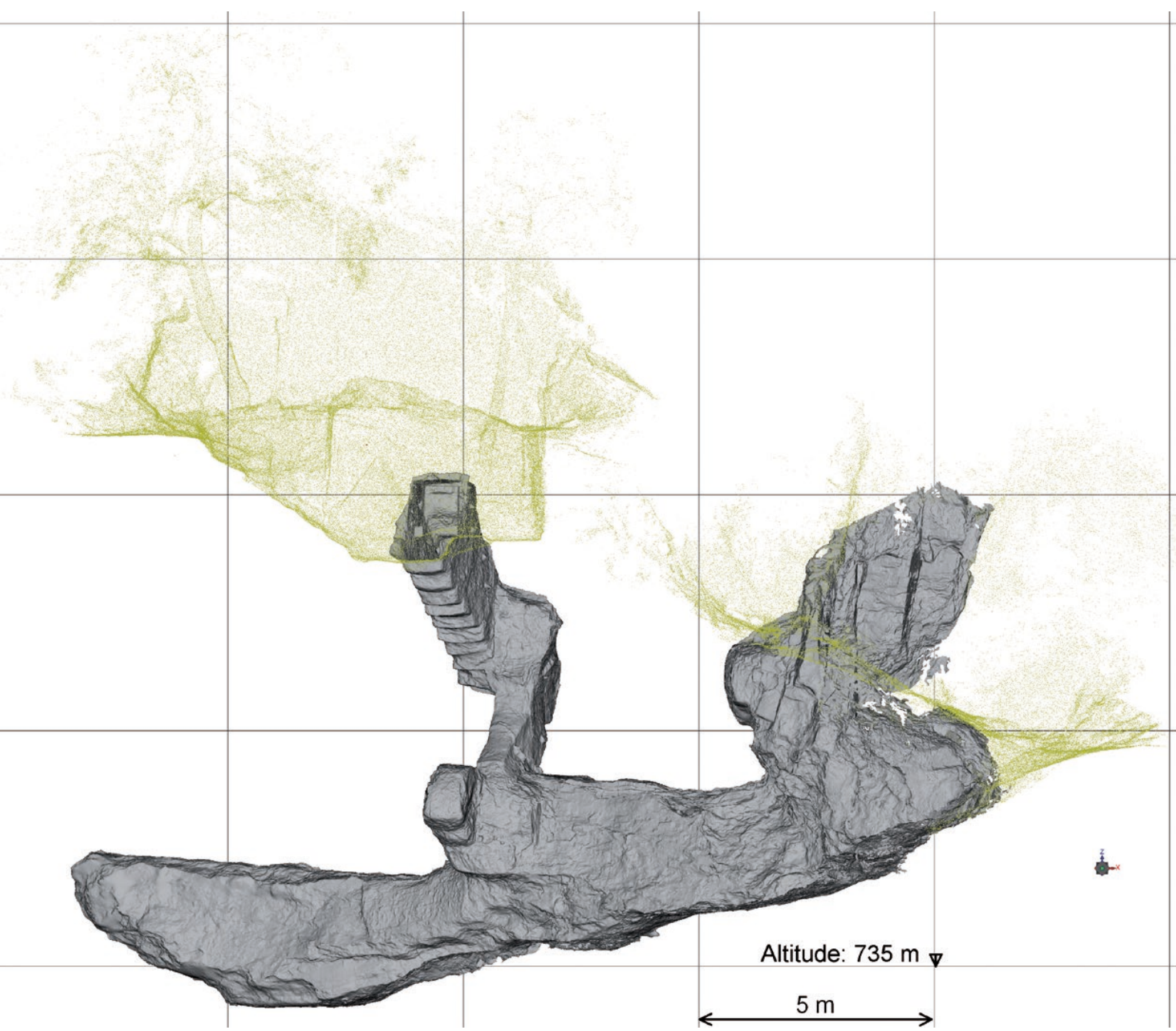

Fig. 2.2-1: Territorium metallorum Tresminas / Jales, Tresminas, Corta da Ribeirinha: perspetiva geral (modelo 3D) do poço em espiral e da Galeria do Pastor, vista de sul (registo e desenho: K. Mechelke e M. Lindstaedt). 


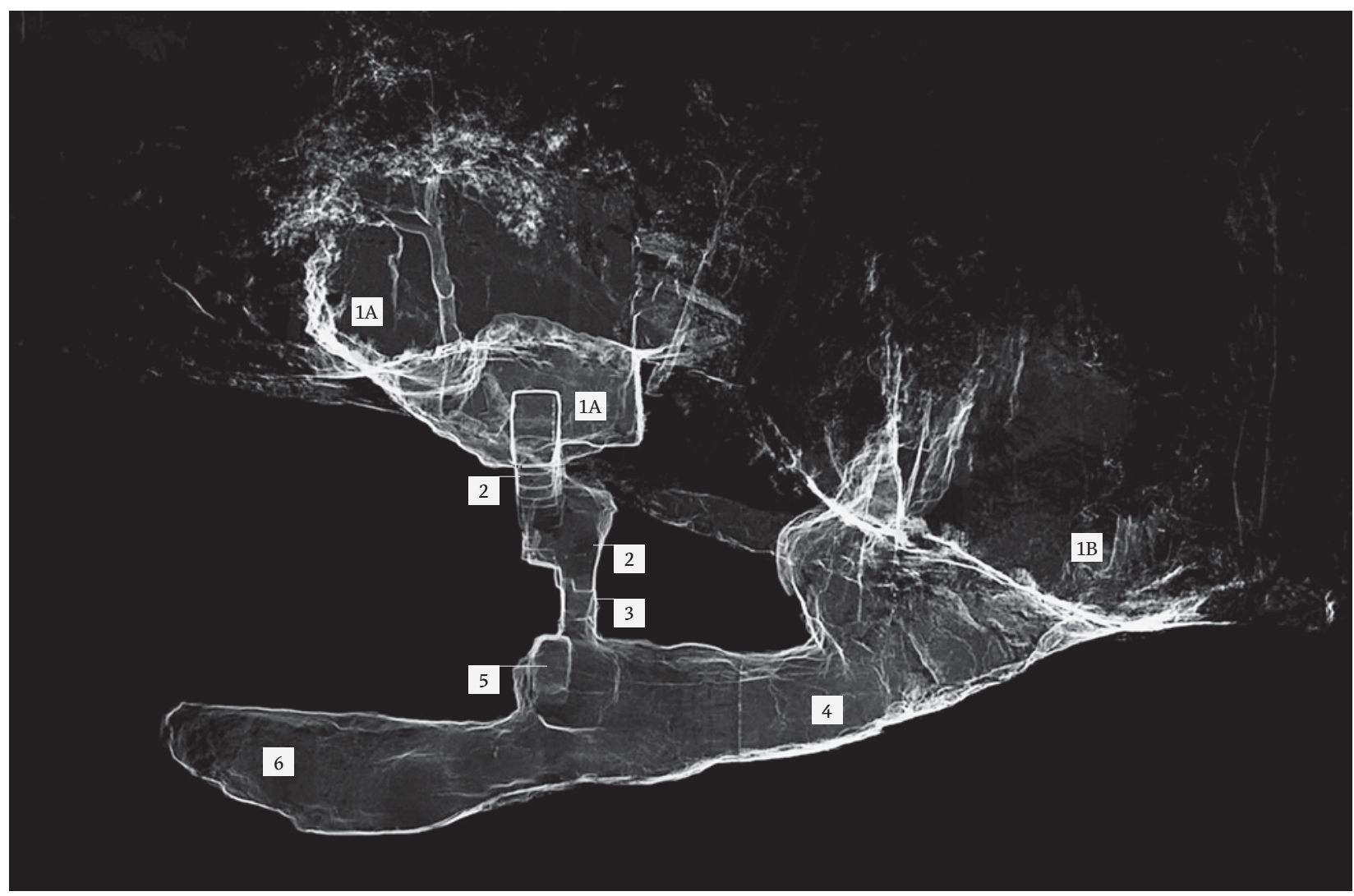

Fig. 2.2-2: Territorium metallorum Tresminas / Jales, Tresminas, Corta da Ribeirinha: nuvem de pontos; corte transversal do poço em espiral (em cima) e o início da Galeria do Pastor (em baixo).

1 A Corta da Ribeirinha - lado oeste; $1 B$ Corta da Ribeirinha - lado este; 2 Poço em espiral; 3 Poço; 4 Galeria do Pastor; 5 Prospeção; 6 Extensão / Prospeção (documentação: K. Mechelke, M. Lindstaedt, designações R. Wahl-Clerici).

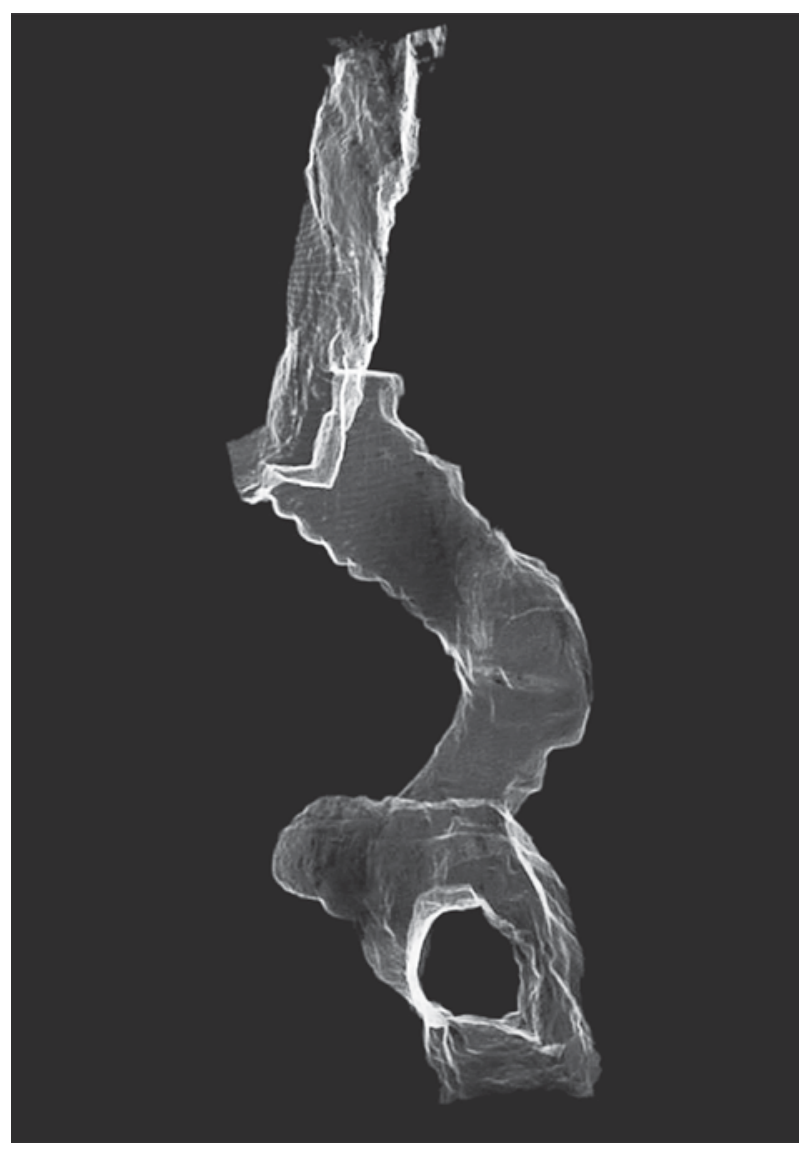

Fig. 2.2-3: Territorium metallorum Tresminas /Jales, Tresminas, Corta da Ribeirinha: projeção num plano da nuvem de pontos do poço em espiral com a boca (acima) e da Galeria do Pastor (abaixo). Vista de leste (K. Mechelke, M. Lindstaedt). 


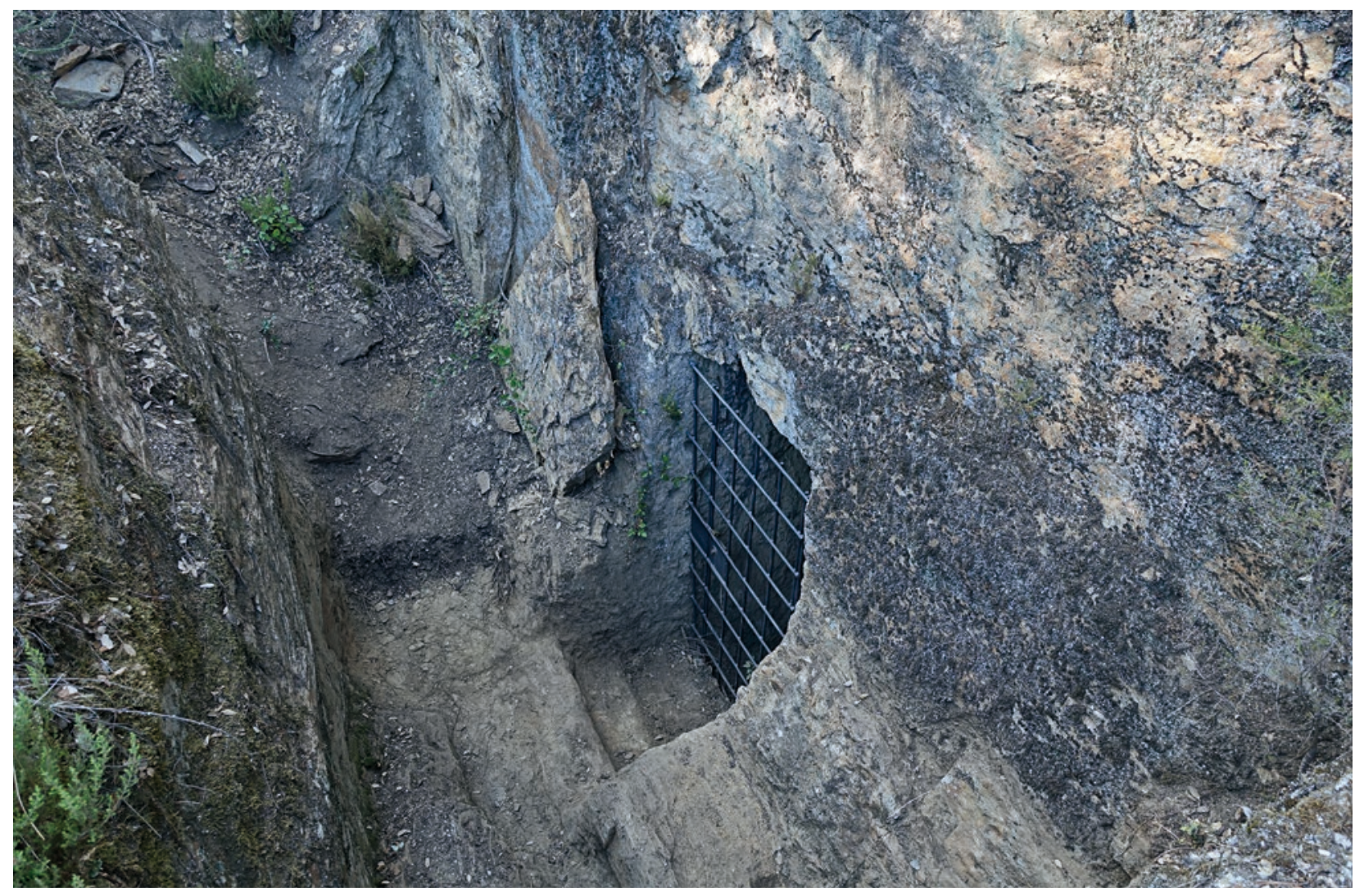

Fig. 2.2-4: Territorium metallorum Tresminas/Jales, Tresminas, Corta da Ribeirinha: a boca do poço em espiral foi aberta numa das zonas alongadas de mineração. Vista de sudeste (fotografia: R. Wahl-Clerici).

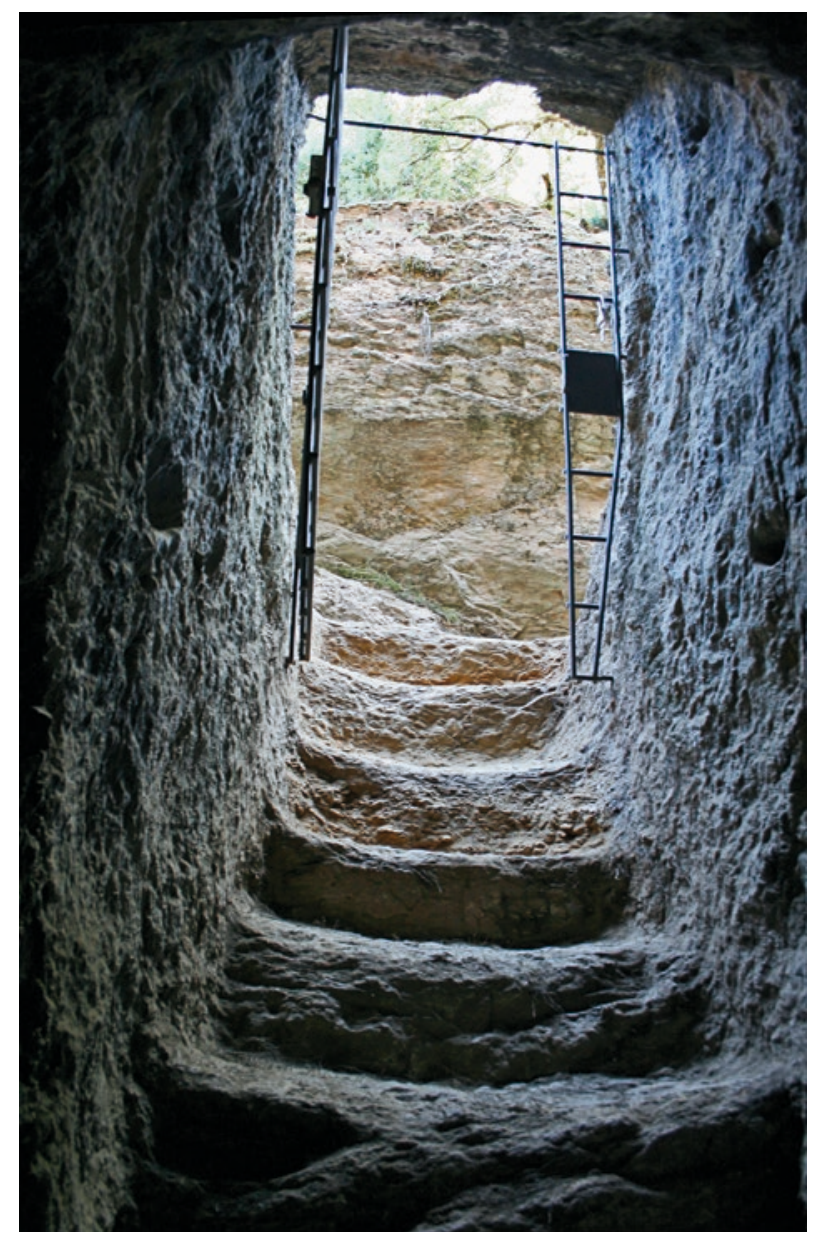

Fig. 2.2-5: Territorium metallorum Tresminas/Jales, Tresminas, Corta da Ribeirinha: vista interior da área de entrada do poço em espiral. Vista em direção à boca (fotografia: Th. Schierl). 


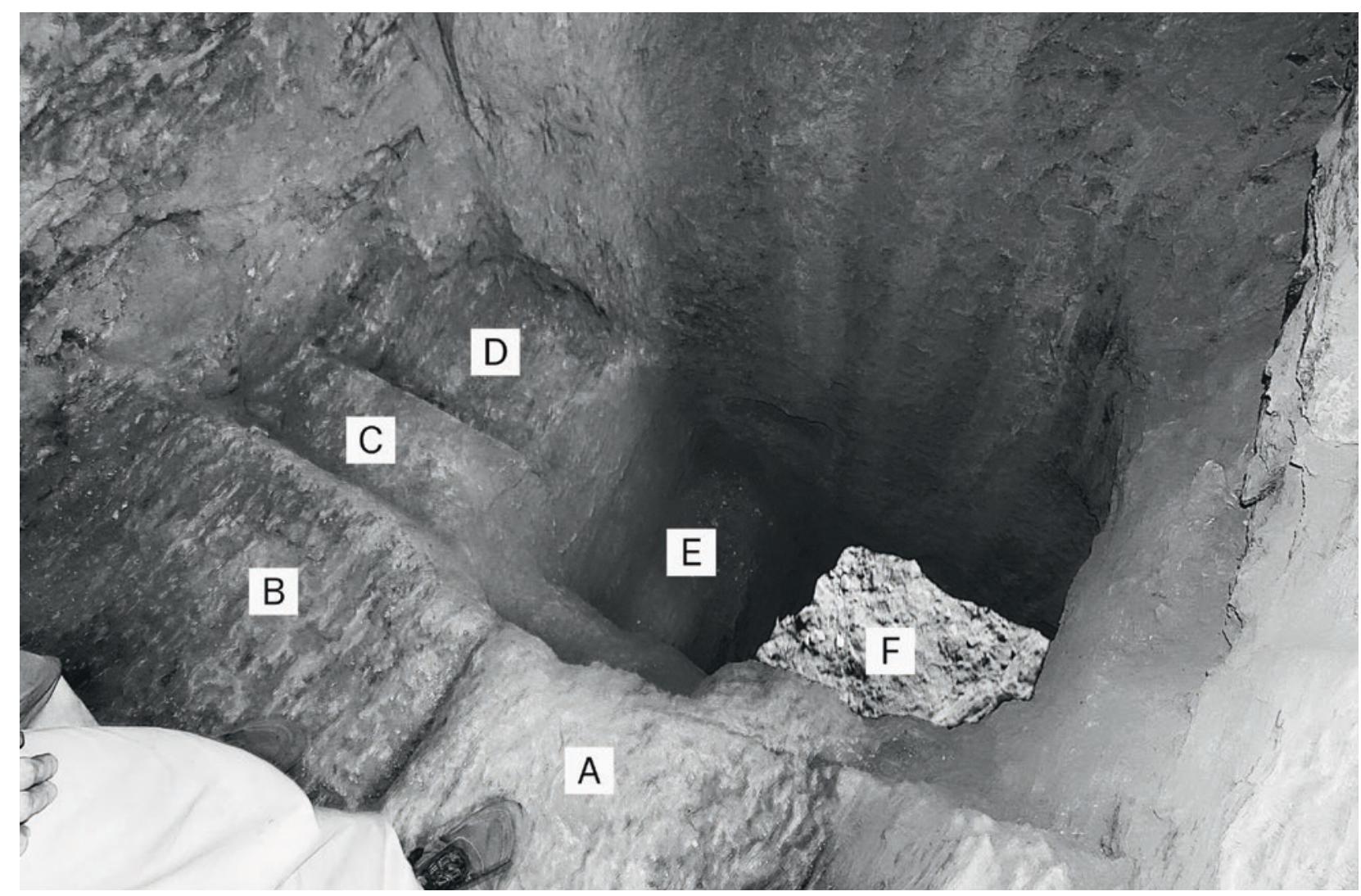

Fig. 2.2-6: Territorium metallorum Tresminas / Jales, Tresminas, Corta da Ribeirinha: a parte inferior do poço em escada com as designações mencionadas no texto e com vista para a zona mineira da Galeria do Pastor a oeste. A-E degraus. F poço falso da escada em espiral para a Galeria do Pastor (fotografia: R. WahlClerici).

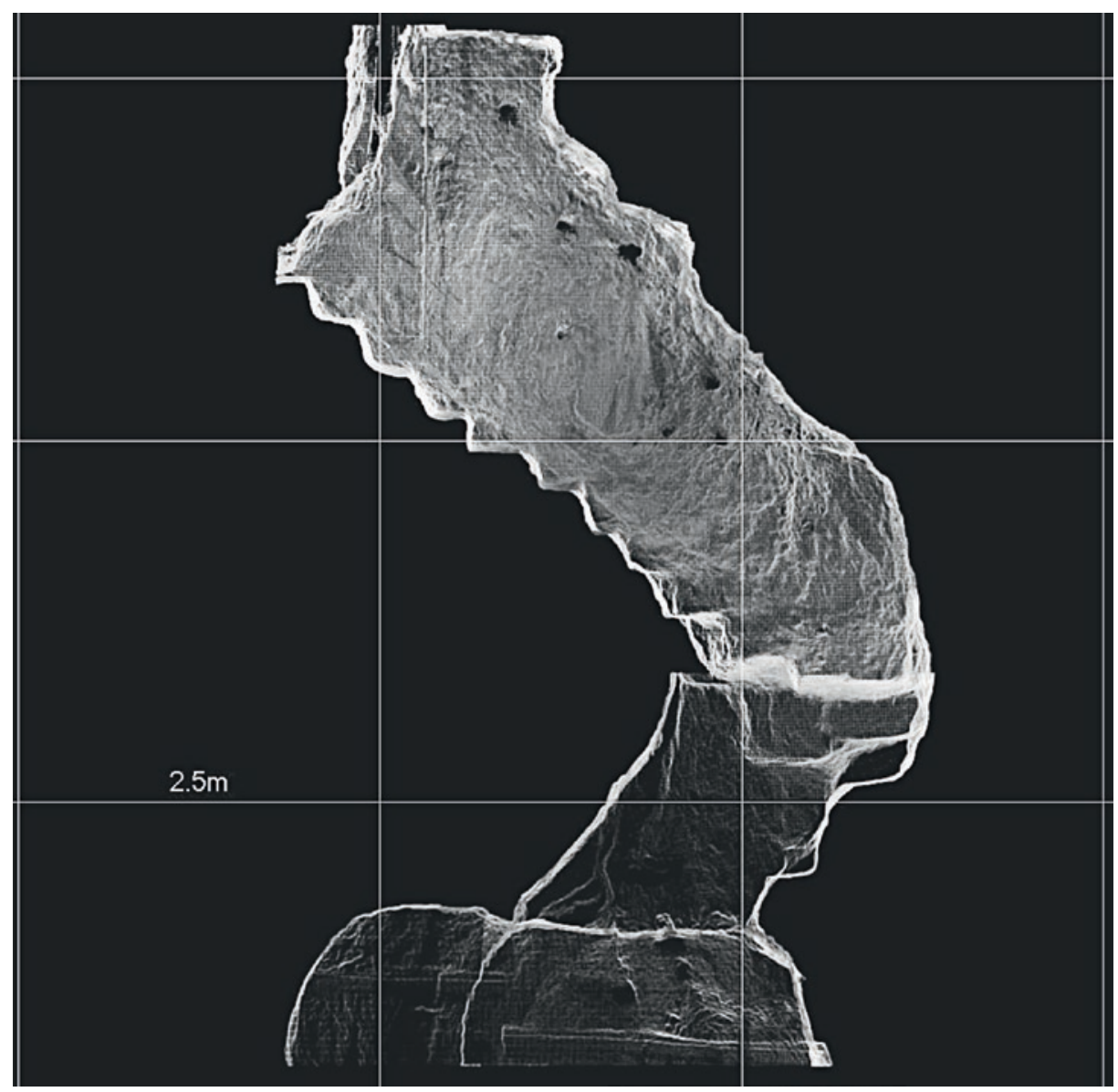

Fig. 2.2-7: Territorium metallorum Tresminas / Jales, Tresminas, Corta da Ribeirinha: corte da nuvem de pontos do poço em espiral. Vista de leste. Os degraus são claramente visíveis, bem como as diferentes fases no tecto e o poço de ligação à Galeria do Pastor (registo e imagem: K. Mechelke, M. Lindstaedt). 


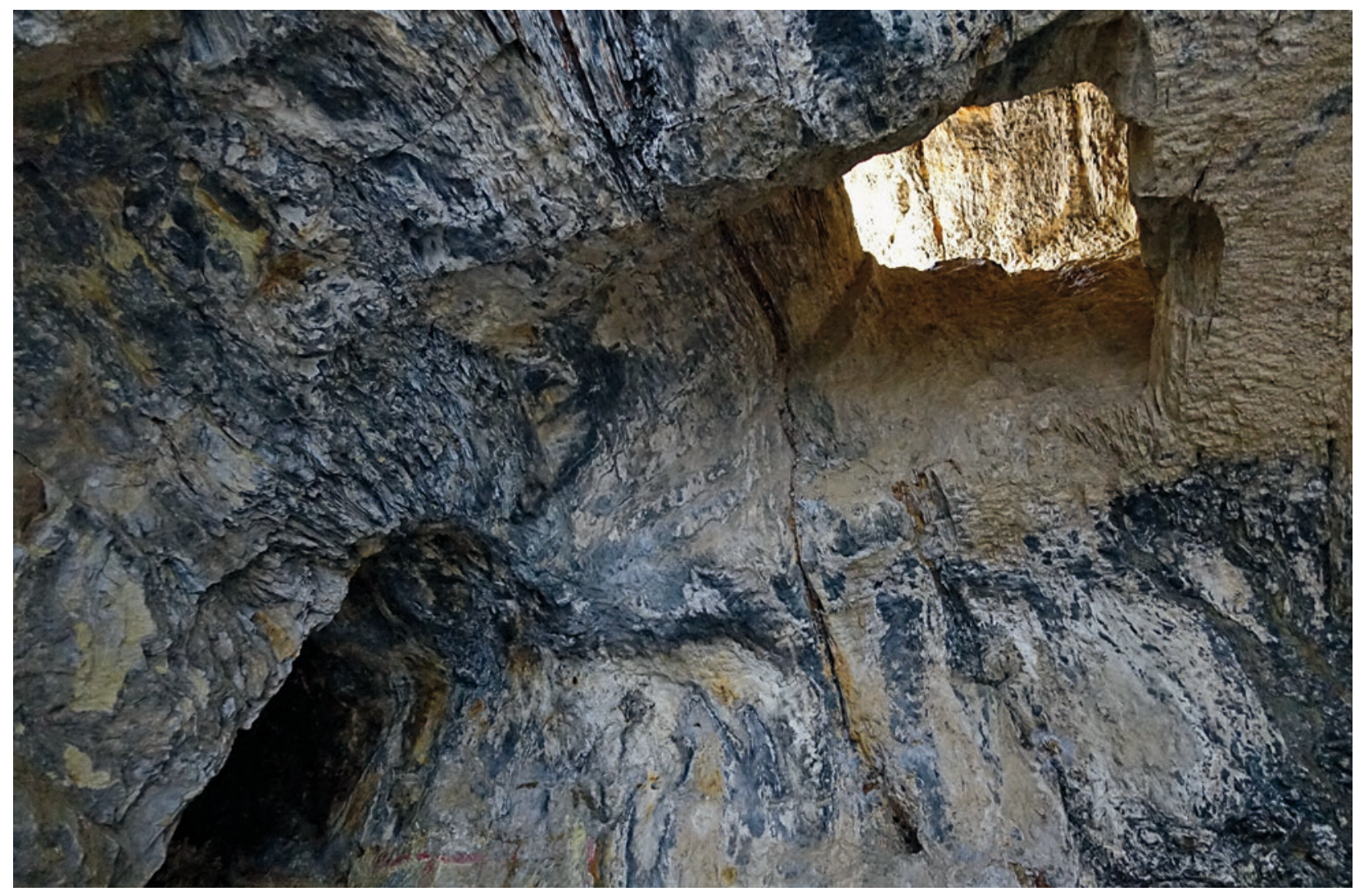

Fig. 2.2-8: Territorium metallorum Tresminas / Jales, Tresminas, Corta da Ribeirinha: zona de transição entre o poço em escada original (acima) e a zona de mineração da Galeria do Pastor. São claramente visiveis o poço falso e o tecto inclinado, que originalmente pertencia ao poço em escada. Provavelmente, parte do tecto teve de ser cortada na vertical para o poço falso. Na parte inferior da imagem pode ver-se um túnel de prospeção com aproximadamente 1,30 $\mathrm{m}$ de profundidade, bem como uma parte antecedente da área de mineração na Galeria do Pastor (fotografia: $R$. Wahl-Clerici).

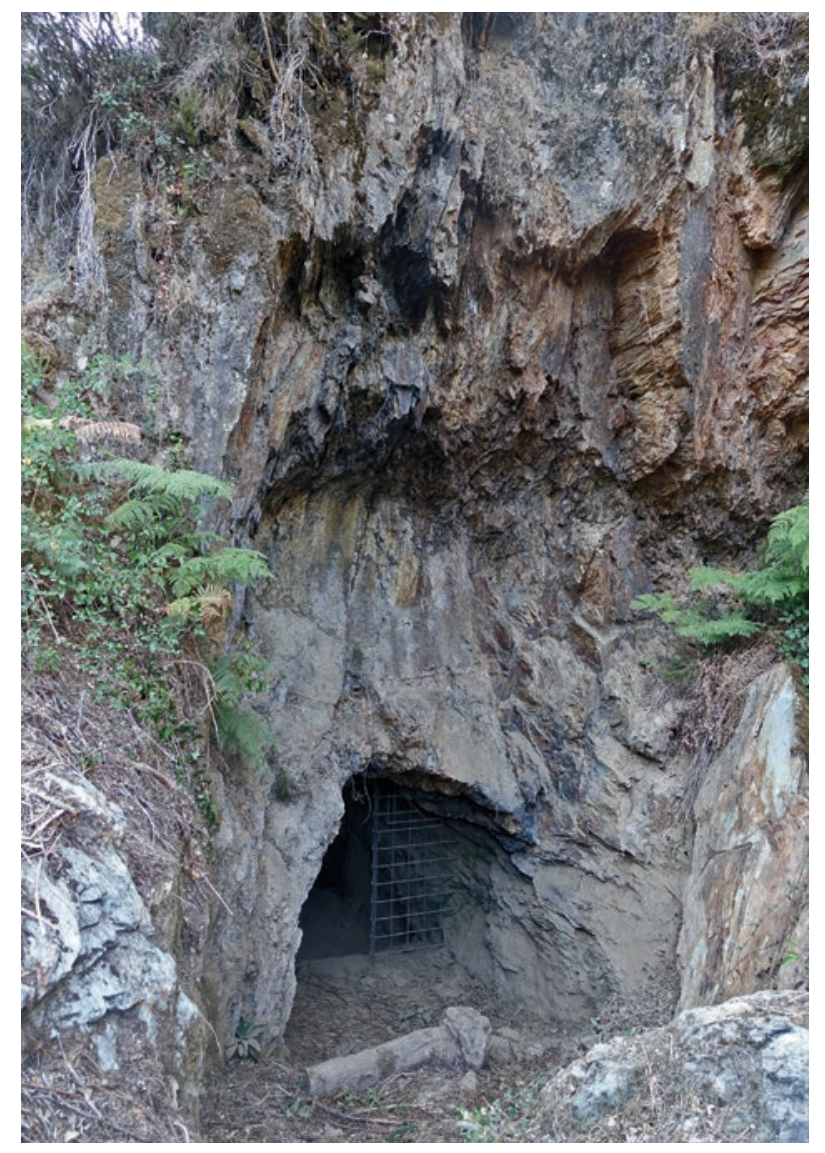

Fig. 2.2-9: Territorium metallorum Tresminas / Jales, Tresminas, Corta da Ribeirinha, Galeria do Pastor: os vestígios do progresso da mineração acima da boca são claramente visíveis. Esta zona da Galeria já tinha sido explorada, enquanto que as áreas inferiores da Galeria consistiam apenas de uma galeria para prospeção. Vista de sudeste (fotografia: $R$. WahlClerici). 


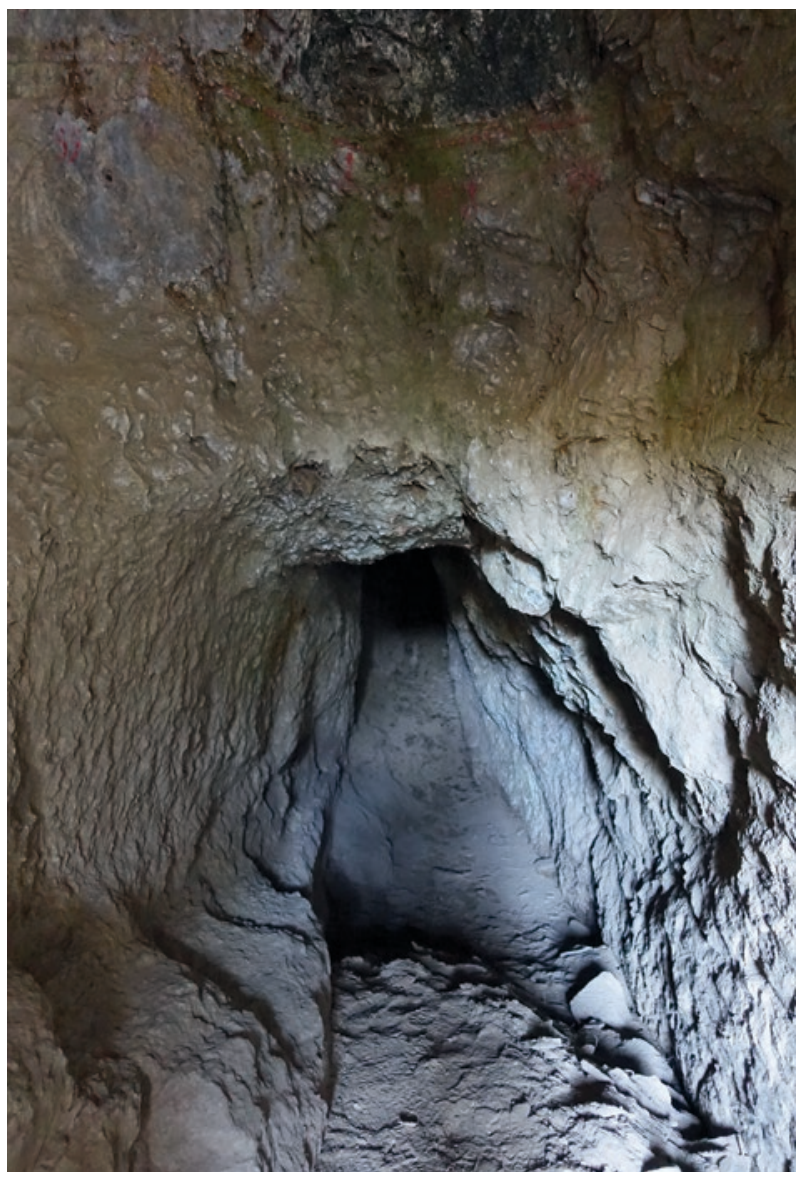

Fig. 2.2-10: Territorium metallorum Tresminas / Jales, Tresminas, Corta da Ribeirinha: vista de leste para a continuação da Galeria do Pastor. O piso original desta zona de exploração ainda não foi descoberto. Na parte inferior esquerda da imagem são visíveis os restos dos degraus, que, de acordo com o conhecimento atual, não estão relacionados com o poço em espiral (fotografia: R. Wahl-Clerici).

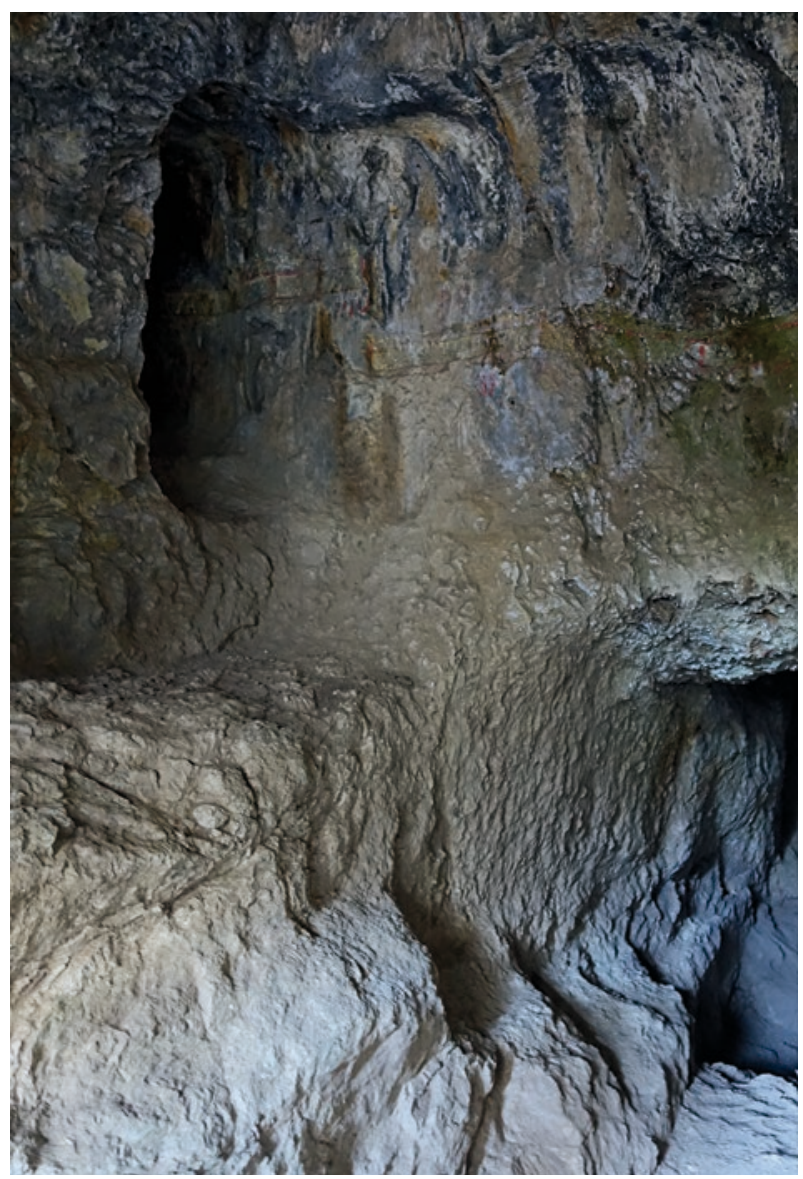

Fig. 2.2-11: Territorium metallorum Tresminas/Jales, Tresminas, Corta da Ribeirinha: vestígios da parede ocidental preservados na Galeria do Pastor, visto de leste, com a galeria de prospeção (esquerda) e os degraus na parte inferior da Galeria do Pastor (em baixo) (fotografia: R. Wahl-Clerici). 


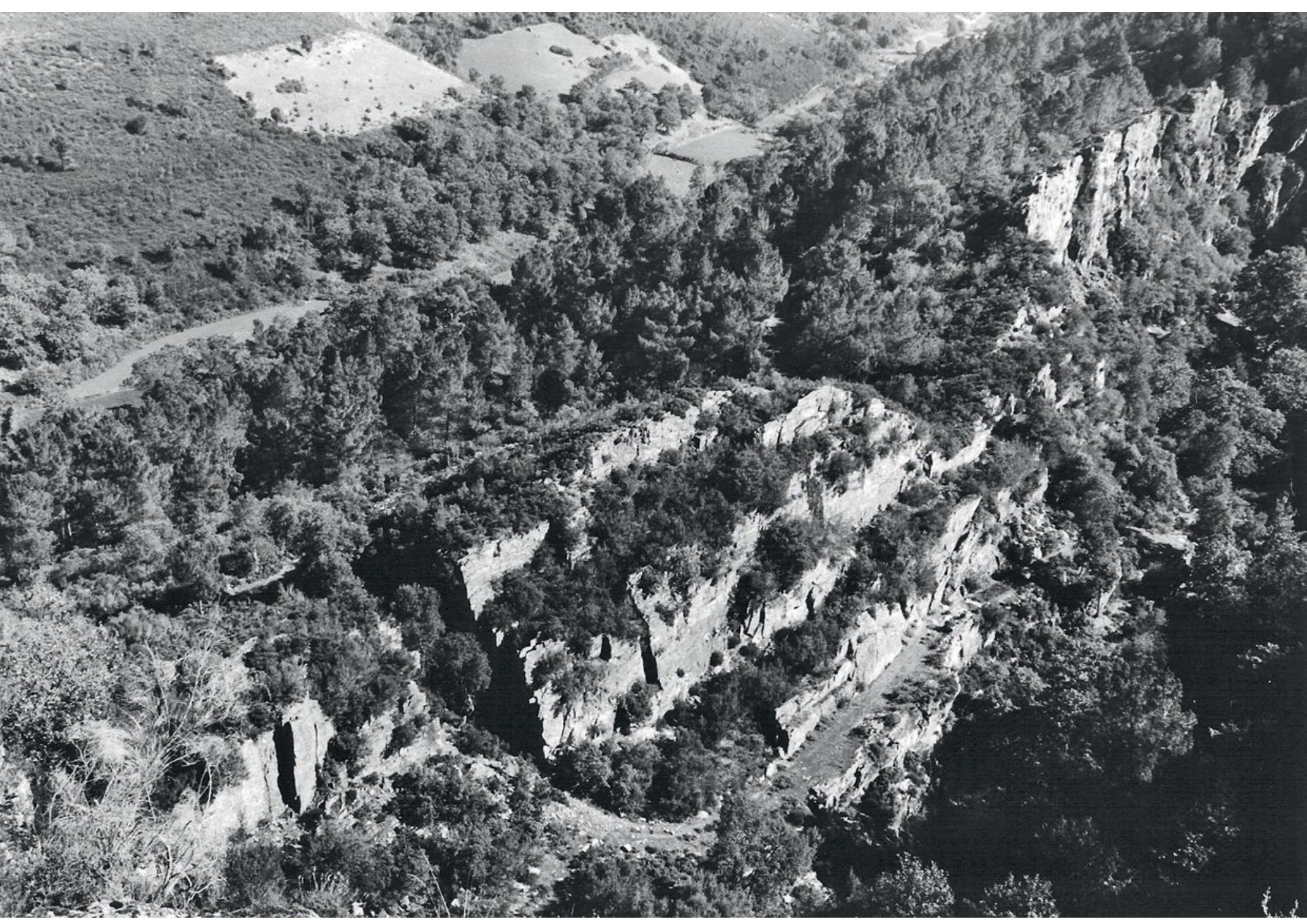

Fig. 2.2-12: Territorium metallorum Tresminas / Jales, Tresminas, Corta da Ribeirinha: a encosta norte da mina a céu aberto. São claramente visíveis as partes das rochas preservadas na zona de mineração oeste e em ambos os lados da antiga área de acesso (lado inferior esquerdo), bem como a extremidade norte escarpada na zona leste (lado superior direito). Vista de sudoeste (fotografia: J. Wahl). 


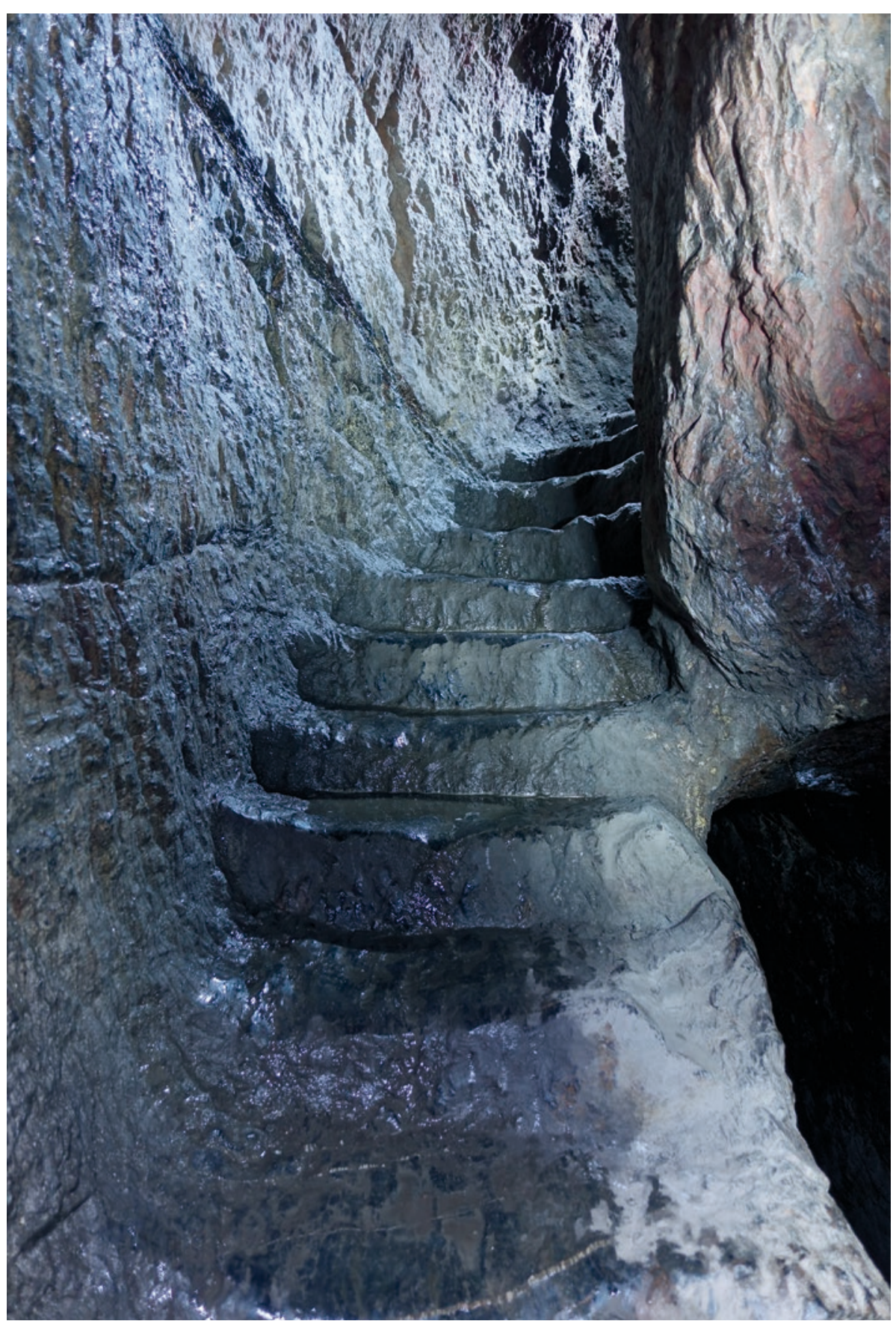

Fig. 2.2-13: Serra da Santa Justa. Valongo (conc. Valongo, distr. Porto). Fojo os Pombas: poço redondo em escada. A seguir à secção inferior a escada continuou a ser construída em linha reta (fotografia: $R$. Wahl-Clerici). 


\subsection{Exploração das jazidas auríferas ${ }^{102}$}

As três mineralizações, Tresminas, Gralheira e Campo de Jales, situadas no territorium metallorum de Tresminas/Jales, encontram-se entre os exemplos mais importantes de exploração romana de ouro em jazidas primárias. Felizmente, as jazidas de Tresminas e Gralheira apenas foram minimamente sujeitas a atividades de mineração recente, pelo que, graças à abundância dos vestígios existentes, é possível atualmente criar uma imagem sobre as várias formas de operação na exploração mineira.

No territorium metallorum de Tresminas/Jales existem comprovadamente jazidas em que predominam os minérios prata e estanho. Uma vez que estas jazidas se encontram nas proximidades de restos de exploração romana, de aquedutos romanos e até de uma necrópole, pressupõe-se que os minérios eram extraídos nesta área. Até ao momento, não foi possível determinar a sequência cronológica destas áreas de extração, pelo que não são apresentadas neste trabalho. Vários documentos medievais fazem referência à extração de estanho em Tresminas, sem, todavia, fazer menção ao ouro. ${ }^{103}$

\section{Sinopse das zonas de extração}

No territorium metallorum de Tresminas existem três zonas auríferas distintas (fig. 3.0-1):

- Tresminas

- Gralheira

- Campo de Jales.

As jazidas no distrito das minas foram exploradas fundamentalmente recorrendo ao trabalho com martelo e picareta, utilizando por vezes como técnica auxiliar o desmonte com ataque por fogo.

\section{Tresminas}

As jazidas de Tresminas dividem-se em três zonas de extração (fig. 3.0-2):

1. Corta de Covas $=$ Corta $\mathrm{A}$

2. Corta da Ribeirinha $=$ Corta $B$

3. Lagoinhos = Zona de Exploração C

As Cortas de Covas e Ribeirinha foram exploradas maioritariamente a céu aberto; em Lagoinhos, de acordo com os mais recentes trabalhos de investigação, o minério foi extraído exclusivamente em exploração subterrânea.
As jazidas auríferas de Tresminas foram exploradas nas duas grandes zonas de desmonte a céu aberto, a Corta de Covas e a Corta da Ribeirinha, e em Lagoinhos pelo método de exploração subterrânea, até estarem praticamente esgotadas. ${ }^{104} \mathrm{~A}$ mineralização estava provavelmente associada a quartzito e quartzofilito que se estendia numa faixa até $150 \mathrm{~m}$ de largura, paralela à formação de xisto dos metassedimentos silúricos. ${ }^{105} \mathrm{~A}$ xistosidade vertical estendia-se de WNW para ESE. As áreas de mineralização encontravam-se predominantemente em xistos clorítico-moscovite-sericita, fortemente silicificados. Os principais minerais são o quartzo, a pirite, a arsenopirite e a pirrotite. ${ }^{106} \mathrm{O}$ ouro, em granulado fino $(1-170 \mu \mathrm{m})$, encontra-se hospedado nestes minerais e contém até cerca de $20 \%$ de prata (fig. 3.0-3). As três zonas de desmonte situam-se ao longo de uma linha paralela à formação das rochas. ${ }^{107}$

Da complexidade das jazidas de Tresminas resultou a existência de um riquíssimo espólio, graças ao qual é possível não só reconstituir detalhadamente a atividade de prospeção romana, como documentar a evolução do trabalho de extração e ainda as várias fases do tratamento do minério. Além disso, os vestígios de exploração mineira revelam-nos que o ouro se concentrava em estruturas alongadas e finas em forma de lentilha.

\section{Corta de Covas $=$ Corta $A{ }^{108}$}

A Corta de Covas tem um comprimento aproximado de $430 \mathrm{~m}$ e largura até $140 \mathrm{~m}$. A maior profundidade visível

102 A fundamentação para a apresentação mineralógico-geológica provém de Annemarie Wiechowski. - Veja-se ainda Noronha et al. 2000; Rosa 2001; Rosa / Romberger 2003; Ribeiro et al. 2006; Farinha Ramos 2017 e Martins / Martins 2017.

103 Sobre os documentos medievais, cf. P. Machado 2017. Comprovase a existência de duas zonas de exploração da prata. Uma vez que se situam um pouco a norte da pedreira da Fonte da Ribeira, supõe-se que foram exploradas na época romana. Uma outra mina, provavelmente de estanho, fica nas proximidades da necrópole romana, portanto os romanos devem ter tido conhecimento dela. Contudo, não sabemos se o estanho foi explorado na época romana. O mesmo se aplica para a mina de estanho de Revel, que foi em parte explorada no sec. XX, e para os restos de mineração na zona do Alto da Capelinha por onde passava um aqueduto, a leste de Covas.

104 Wahl-Clerici 2008; Wahl-Clerici 2011; Wahl-Clerici etal. 2011; Wahl-Clerici et al. 2017; Helfert et al. 2019.

105 A era silúrica tem aproximadamente 390-430 milhões de anos.

106 Rosa 2001; Noronha etal. 2000; Ribeiro et al. 2006; Machado et al. 2006.

107 Wahl-Clerici et al. 2012b, 111.

108 Wahl-Clerici 2010; Wahl-Clerici/Helfert 2017, 65-67; Helfert et al. 2019. 
hoje em dia é de $60 \mathrm{~m}$, a uma cota de $786 \mathrm{~m}$. A sua configuração atual corresponde só parcialmente ao estado em que os romanos a deixaram.

Uma escarpa acentuada separa a Corta de Covas em duas zonas de exploração principais (figs. 3.0-4, 3.0-5). Para a drenagem da zona sul mais antiga, construiu-se a Galeria Esteves Pinto a partir do flanco da encosta sul. Aparentemente, as concentrações de ouro a norte foram muito rapidamente descobertas através das construções de prospeção efetuadas no topo da fragmentação na rocha. Prova disso é o poço em escada preservado, que atravessa a fragmentação da rocha e foi aberto de sul em direção a norte (figs. 3.0-6, 3.0-7). A grande depressão na zona da fragmentação da rocha pode ser uma indicação de que, numa fase inicial de exploração, a Galeria Esteves Pinto servia igualmente para a drenagem da zona norte.

A dimensão da zona de extração a sul corresponde ainda em grande medida ao que era na Antiguidade. A profundidade atingida pode ser determinada através da Galeria Esteves Pinto com o canal escavado na rocha no piso da galeria a uma cota de $810 \mathrm{~m}$ (fig. 3.0-8). A concentração notável de moinhos de pilão e moinhos de minério perto da mina a céu aberto aponta para um acesso antigo à mina, utilizado antes da abertura da Galeria Esteves Pinto e coberto com entulho ainda na época romana, sendo destruído em grande parte durante a construção moderna de estradas.

Na zona norte, é possível distinguir as áreas de mineração individuais, graças às sondagens do Serviço de Fomento Mineiro efetuadas na década de 1980 (fig. 3.0-9). O corte transversal indica que a profundidade máxima alcançou pelo menos $722 \mathrm{~m}$ acima do nível do mar, quase exatamente a profundidade máxima do canal utilizado para a drenagem da mina da Galeria do Pilar. Para as zonas inferiores, foi necessário criar instalações próprias. ${ }^{109}$

As encostas na zona de mineração meridional mantêm, em grande parte, a sua forma original, enquanto que o desmoronamento de rochas na zona norte tem vindo a alterar a aparência da mina a céu aberto (fig. 3.0-10). O mesmo aplica-se à escarpa rochosa a leste da mina a céu aberto, criada pelo corte da rocha ao longo de uma fenda natural. ${ }^{110} \mathrm{Na}$ época romana os poços gémeos na encosta encontravam-se no interior da montanha e estavam ligados à Galeria dos Alargamentos, embora não à mina a céu aberto (figs. 3.0-11, 3.0-12). Por conseguinte, na altura da conclusão das obras romanas, a Corta de Covas apresentava uma forma um pouco mais curta e muito mais estreita, mas em alguns pontos duas vezes mais profunda.

Os trabalhos de sondagem do Serviço de Fomento Mineiro efetuado nas décadas de 50 a 80 do século passado ajudam-nos ainda a perceber mais sobre as áreas da Corta de Covas cobertas sob o material do desmonte da rocha. Em contrapartida e com base em trabalhos arqueológicos podemos ainda apontar para problemas que essas sondagens, feitas somente com intuitos de prospeção, não abordaram.
Deste modo sabemos, a partir do nível do piso da Galeria Esteves Pinto (cota de $810 \mathrm{~m}$ ), que a zona de exploração a sul apresenta uma profundidade de mais de $30 \mathrm{~m}$. Uma vez que desconhecemos a profundidade-base do canal, é possível ter sido explorada mais uns metros. Perante a possibilidade de se fazer a drenagem com recurso a uma nora, a base do canal da Galeria Esteves Pinto poderá não indicar definitivamente a profundidade desta zona (fig. 3.0-9).

A acumulação de locais de ataque por fogo no ponto mais baixo da mina a céu aberto A é importante. Devido às seções transversais do Serviço de Fomento Mineiro, parece-nos que a situação atual corresponde ao estado na fase final da exploração (figs. 3.0-13-3.0-15).

Não se pode excluir que a partir da mina a céu aberto os trabalhos de exploração tenham progredido em algumas áreas para o subsolo. Prova disso pode ser principalmente o desmoronamento ocorrido no poço em escada na Galeria dos Alargamentos.

\section{Corta da Ribeirinha $=$ Corta $B$}

A Corta da Ribeirinha também não apresenta a mesma configuração que teria quando os romanos a abandonaram após o fim da sua exploração. Isso deve-se principalmente às derrocadas no lado sul da vertente da escarpa. Contudo, pode partir-se do princípio que, originalmente, seria mais íngreme, sendo a zona de extração mais estreita (fig. 3.0-16). Todos os vestígios da exploração encontram-se, portanto, na encosta norte e nas áreas limítrofes (figs. 3.0-17a / b / c, 3-0-18). O ponto mais fundo da extração situava-se no túnel de drenagem «Buraco Seco», ou seja, a uma cota de $724 \mathrm{~m}$ e assim mais ou menos ao mesmo nível da profundidade máxima atingida na Corta de Covas.

Originalmente, o ouro na Corta da Ribeirinha era extraído em duas minas a céu aberto, cujo limite pode ser localizado principalmente devido à situação na área da Galeria do Pastor e ao poço em espiral (fig. 3.0-2 10/11). Também é impressionante a diferença na aparência da encosta norte entre as duas partes. Finalmente, foi possível identificar os antigos acessos ocidental e oriental às áreas de mineração (figs. 3.0-19 e 3.0-20). Enquanto que o acesso ocidental ainda é usado atualmente, já não é possível utilizar o acesso oriental, uma vez que ao extrair ouro na parte exposta a céu aberto ocorreu o desmoronamento da rocha.

Paralelamente ao acesso ocidental, foi criado um sistema de túneis, poços e poços transversais para a prospeção das montanhas, sendo que o ponto mais alto apresenta uma secção transversal tipicamente trapezoidal e muito bem trabalhada (figs.3.0-21-3.0-23). Para dar continuidade à prospeção, aprofundou-se gradualmente o seu piso, e as paredes tornaram-se mais cada vez mais irregulares.

109 Altura do piso na entrada da Galeria do Pilar: $744 \mathrm{~m}$. Subida até à área a céu aberto ca. $3 \mathrm{~m}$. Profundidade do canal $23 \mathrm{~m}$. Cálculo: $724 \mathrm{~m}$ acima do nível do mar.

110 Rosa 2001, fig. 9. 
Parece-nos que na parte mais funda da Corta foi encontrado um depósito de ouro mais rico, tendo sido construído a Galeria dos Morcegos para o poder explorar. Esta galeria atinge nos primeiros $50 \mathrm{~m}$ uma largura de $4 \mathrm{~m}$, no entanto, nunca foi concluída, o que prova que as expectativas dos romanos das reservas de ouro não corresponderam à realidade.

O poço em espiral e a Galeria do Pastor que atualmente se encontram ligados a nível subterrâneo, foram igualmente construídos para prospeção (fig. 3.0-2 10/11). Graças a uma análise precisa do sistema construído pelos romanos, podemos concluir que as duas construções surgiram independentes uma da outra, ou seja, foram construídas separadamente, a partir das duas minas a céu aberto. Provavelmente, acabaram por se unir posteriormente.

Finalmente, foi possível identificar dois locais pertencentes à Corta da Ribeirinha, onde o minério era submetido a tratamento.

\section{As jazidas da Gralheira e de Campo de Jales}

As jazidas da Gralheira e de Campo de Jales são filões em que o minério está associado a filões longitudinais de quartzo (figs. 2.0-1, 3.0-1,3.0-24, 3.0-25). Estes filões foram descritos por Diodoro Sículo, primeira metade do séc. I a. C., (3.12.1).

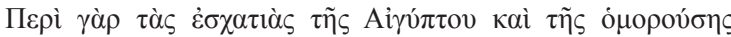

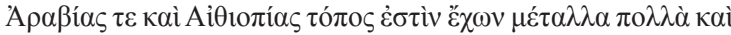

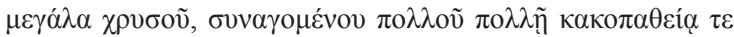

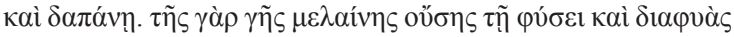

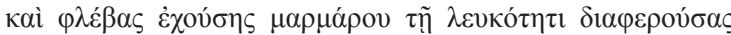

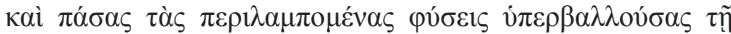

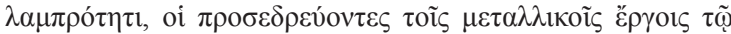

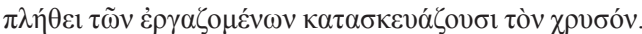

Diod. 3,12,1: Na extremidade do Egito e no território contíguo da Arábia e da Etiópia situa-se uma região que contem muitas minas de ouro grandes, onde o ouro é extraído em vastas quantidades com muito sofrimento e a grande custo. A terra é naturalmente preta e contém filões e veios de um mármore que é extraordinariamente branco e cujo brilho supera tudo o que brilha intensamente por natureza. Aqui os supervisores do trabalho nas minas obtêm o ouro com a ajuda de uma multidão de trabalhadores.

Aquilo que ele designa por mármore é, de facto, quartzo. Cerca de cem anos depois, Plínio (N.H.33,68) ainda lhe chamava assim:

Quod puteis foditur, canalicium vocant, alii canaliense, marmoris glareae inhaerens, non illo modo, quo in oriente sappiro atque Thebaico aliisque in gemmis scintillat, sed micans amplexu marmoris. vagantur hi venarum canales per latera puteorum et huc illuc, inde nomine invento.
O ouro escavado dos poços é chamado de canalicium ou canaliense, e vem ligado ao cascalho de mármore, mas não da forma como brilha no Oriente sobre o lápis-lazúli e a pedra de Tebano e outras pedras preciosas, pois cintila no exterior do mármore. Estas passagens dos veios percorrem as paredes dos poços, ou seja, para cá e para lá, de onde vem o nome.

A mineralização aurífera de Jales está associada maioritariamente ao granito varisco porfiróide de duas micas de grão grosseiro (idade +/ - 12 milhões de anos), em filões perpendiculares de quartzo com a orientação NNE-SSW ou NE-SW. Estes filões têm uma grossura de $0,01-2 \mathrm{~m}$ e um comprimento que chega a atingir $2 \mathrm{~km}$. Nas superfícies de contato entre o granito e o xisto, mudam de direção para leste, atravessando os metassedimentos, onde se podem ramificar. Estes dois filões, o do Campo de Jales e o do Desvio, foram explorados pela sociedade mineira «Minas de Jalles, Lda.» entre 1933 e 1992. O filão de Campo de Jales já tinha sido explorado pelos romanos até $120 \mathrm{~m}$ de profundidade (figs. 2.0-1, 3.0-24). Os filões de quartzo contêm, para além do quartzo, arsenopirite. O ouro e o electrum (ouro com mais de $20 \%$ de prata), de granulado entre 1 e $35 \mu \mathrm{m}$, estão associados a quartzo, arsenopirite, sulfitos e sulfossais. A prata encontra-se em minerais como argentite, galena, tetrahedrite e argyrite (fig. 3.0-3).

A jazida da Gralheira é composta por um número de filões, veios ou aglomerados de veios de quartzo, que atravessam os xistos ordovícicos. A mineralização é detetável numa faixa de $5 \mathrm{~km}$ de comprimento e tem 1 a $50 \mathrm{~m}$ de largura. Os romanos exploraram-nas em zonas até $50 \mathrm{~m}$, em média, e atingiram uma profundidade máxima de $140 \mathrm{~m}$. O teor metalífero corresponde praticamente ao do filão de Campo de Jales.

\section{Gralheira}

Todo o filão da Gralheira estende-se por mais de 3,5 km, embora nem todas as partes contivessem ouro e tivessem sido exploradas. O filão ramifica-se várias vezes, chegando a atingir 5 veios (figs. 2.0-1, 3.0-25). A jazida da Gralheira tem sido sujeita a prospeção repetidas vezes desde os anos 30 . Os teores de ouro relativamente altos colocam em risco esta extraordinária herança cultural, um dos raros exemplos da exploração de uma jazida, preservado desde a antiguidade. ${ }^{111}$

De acordo com o conhecimento atual, a exploração mineira ocorreu exclusivamente a céu aberto, para a qual

111 Harrison 1931; Os registos da Direção Geral de Geologia e Minas ( $\left.\mathrm{L}^{\circ} \mathrm{AP} / 211, \mathrm{~N}^{\circ} 08292,1985\right)$ são fundamentações importantes; As prospeções levadas a cabo pelas empresas mineiras St. Elias, Kernow release Jales/Gralheira survey results. 2005-03-09 16:49 ET - News Release. - www.resourceworld.com, Edição de agosto de 2007; Em 1990 a Sociedade Mineira Rio Artezia, S.A., Bureau de Recherches Géologiques e Minieres, Consórcio Gralheira, apresentou um plano extensivo de exploração da jazida de Gralheira. 
foram abertas escavações trincheiras (figs. 3.0-26, 3.0-27) e aprofundados poços (fig. 3.0-28). Essas trincheiras são frequentemente preenchidas até a superfície da encosta e, por esse motivo, são em grande parte apenas identificáveis através dos vestígios de trabalho ou das escombreiras (figs. 3.0-29, 3.1-5). Em certos pontos, as paredes desmoronaram, algumas das quais tiveram de ser fortemente apoiadas em tempos romanos (fig. 3.0-30), dando a impressão de um processo de mineração subterrâneo (figs.3.0-31a, 3.0-32). Além disso, as vastas marcas do desmonte manual e as cavidades para o posicionamento de instalações técnicas (figs. 3.0-31b, 3.0-33, 3.0-34) atestam o procedimento cuidadoso e eficiente dos romanos. Esses testemunhos não se encontram exclusivamente nas zonas de mineração de fácil reconhecimento, portanto, deve-se presumir que uma investigação completa poderá revelar tesouros inesperados (figs. 3.0-35, 3.0-36).

Tanto quanto se sabe, para o escoamento da zona de extração aproveitava-se a sua altura natural. Ao fazer o desmonte de cima para baixo assegurava-se sempre um escoamento natural através da diferença de altura. Nas camadas mais fundas era necessário abrir galerias suplementares para esse efeito. A Galeria Minhoteira, transversal ao filão do minério, escoava as águas da zona de desmonte para o rio Tinhela. Em finais do séc. XX, foi utilizada para grandes trabalhos de sondagem, pelo que os vestígios do antigo túnel de drenagem foram destruídos. Em mapas antigos constam ainda mais duas galerias, mas ainda não foi possível identificá-las.

\section{Campo de Jales}

As jazidas de Campo de Jales foram exploradas no séc. XX pela Sociedade das Minas de Jalles, Lda., em exploração subterrânea, tendo-se destruído a maior parte dos vestígios da mineração romana. Com efeito, na atualidade somente se observam à superfície restos da zona de extração a sul da estrada N212 que faz a ligação entre Vila Pouca de Aguiar e Murça (fig. 3.0-37). Outros vestígios que estavam à vista no outro lado da estrada, paralelamente à estrada 1172-1 foram soterrados por entulho nos finais do último milénio.

Felizmente nos mapas da mina estão assinaladas as zonas de extração da Antiguidade, o que nos permite reconstituir sumariamente a mineração romana (fig. 3.0-24). O mapa assinala escavações irregulares nas áreas em que provavelmente era possível extrair minério com alto teor aurífero. A profundidade máxima atingida foi cerca de $125 \mathrm{~m}$ e o filão estendia-se por aproximadamente $1300 \mathrm{~m}$.

Infelizmente o mapa não nos permite reconhecer os detalhes da exploração, bem como outros pormenores técnicos, tais como o sistema de drenagem, o transporte do minério das profundezas até à superfície, instalações para a circulação na mina e partes do filão que não foram extraídas por questões de estabilidade, entre outras. Precisamente a drenagem devia constituir um grande problema logístico no caso do filão de Campo de Jales, porque a topo- grafia plana do terreno impedia a instalação de um sistema de drenagem até à superfície por meio de túneis, como acontecia em Tresminas e na Gralheira. 


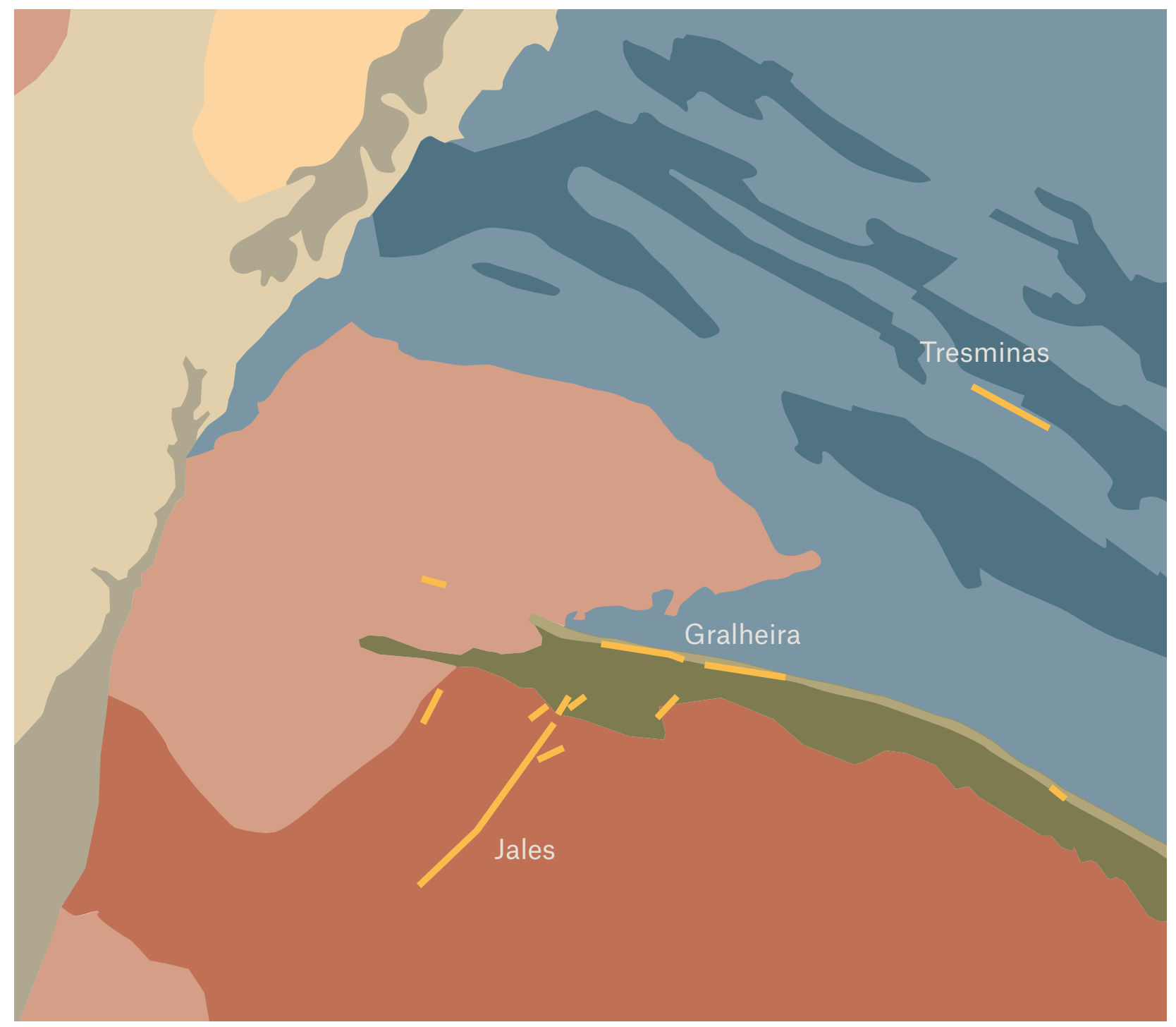

Unidade de Curros

(Silúrico Superior - Devónico):

filitos doríticos e xistos

Unidade de Fragas Negras e equivalentes (Silúrico Inferior): filitos cinzentos e negros e quartzitos negros

Granito porfiróide de duas micas, grão médio a grosseiro

Granito de tendência porfiróide de duas micas, grão médio a grosseiro

Veio quartzo-sulfetado aurífero

Fig. 3.0-1: Mapa geológico com as jazidas auríferas. (De acordo com Rosa / Romberger (2003) e o excerto da Carta das Ocorrência minereis folha 2 - Trás-os-Montes, escala 1:200000).
Pré-Ordovício: Grupo Douro

Ordovício: quartzitos e micaxistos

Granito porfiróide, grão médio a fino

Granito porfiróide biotitco, grão médio a grosseiro

Aluvião 


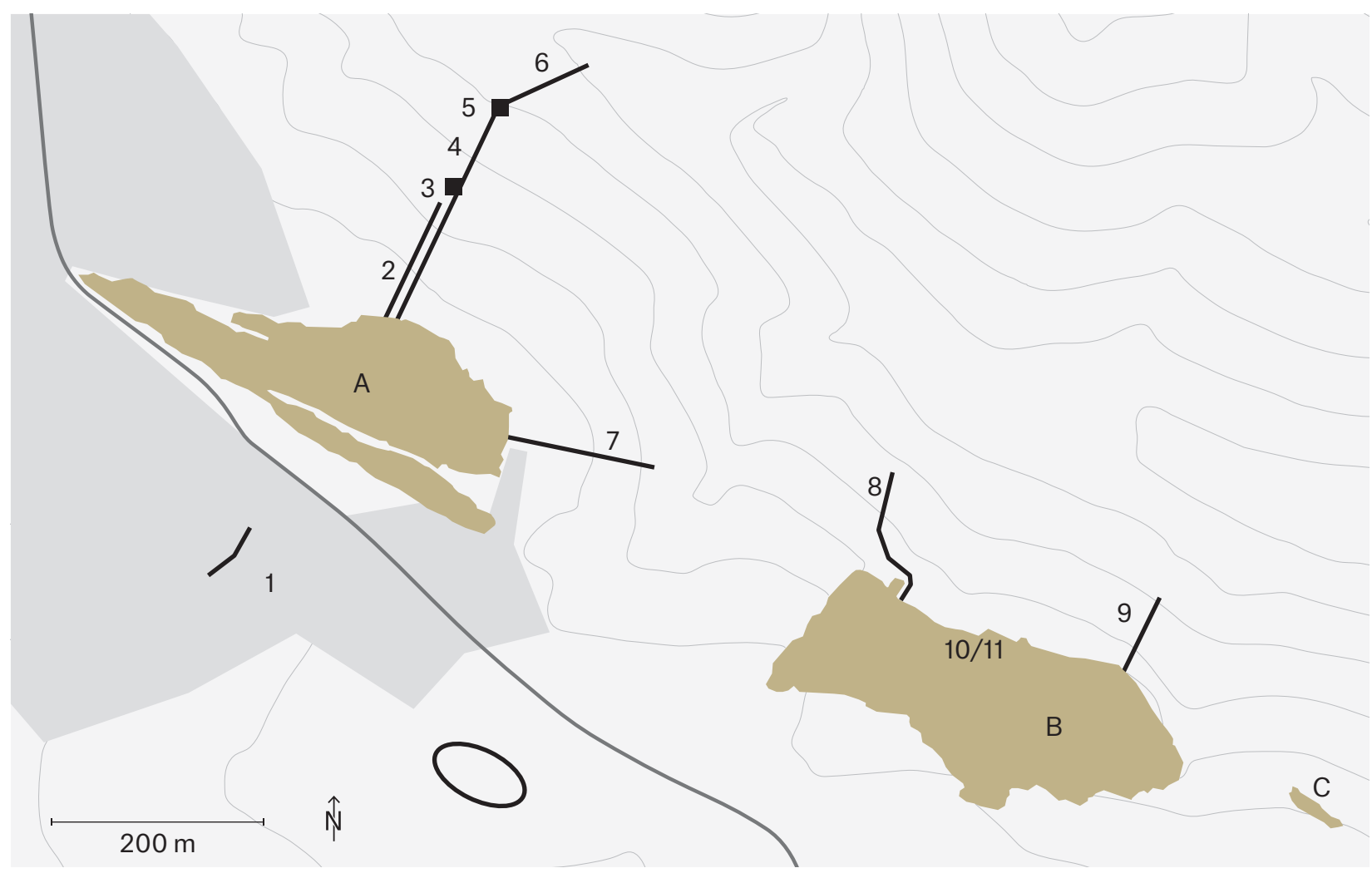

Fig. 3.0-2: Territorium metallorum Tresminas/Jales. Visão geral da zona central de Tresminas: A - Corta de Covas, B - Corta da Ribeirinha, C - Lagoinhos 1-Galeria Esteves Pinto, 2-Galeria Jürgen Wahl, 3-Poço em frente à extensão da Galeria Jürgen Wahl para a Galeria do Pilar, 4-Galeria do Pilar, 5-Poço em frente à extensão da Galeria do Pilar para a Galeria do Texugo, 6-Galeria do Texugo, 7-Galeria dos Alargamentos, 8-Galeria dos Morcegos, 9-Galeria Buraco Seco, 10 - Poço em Espiral, 11 - Galeria do Pastor. (Modelo: Ortofotomapa Câmara Municipal Vila Pouca de Aguiar 1:10000, plano: J.Wahl, R.Wahl-Clerici, M.Helfert, desenho: S.Mathiuet).

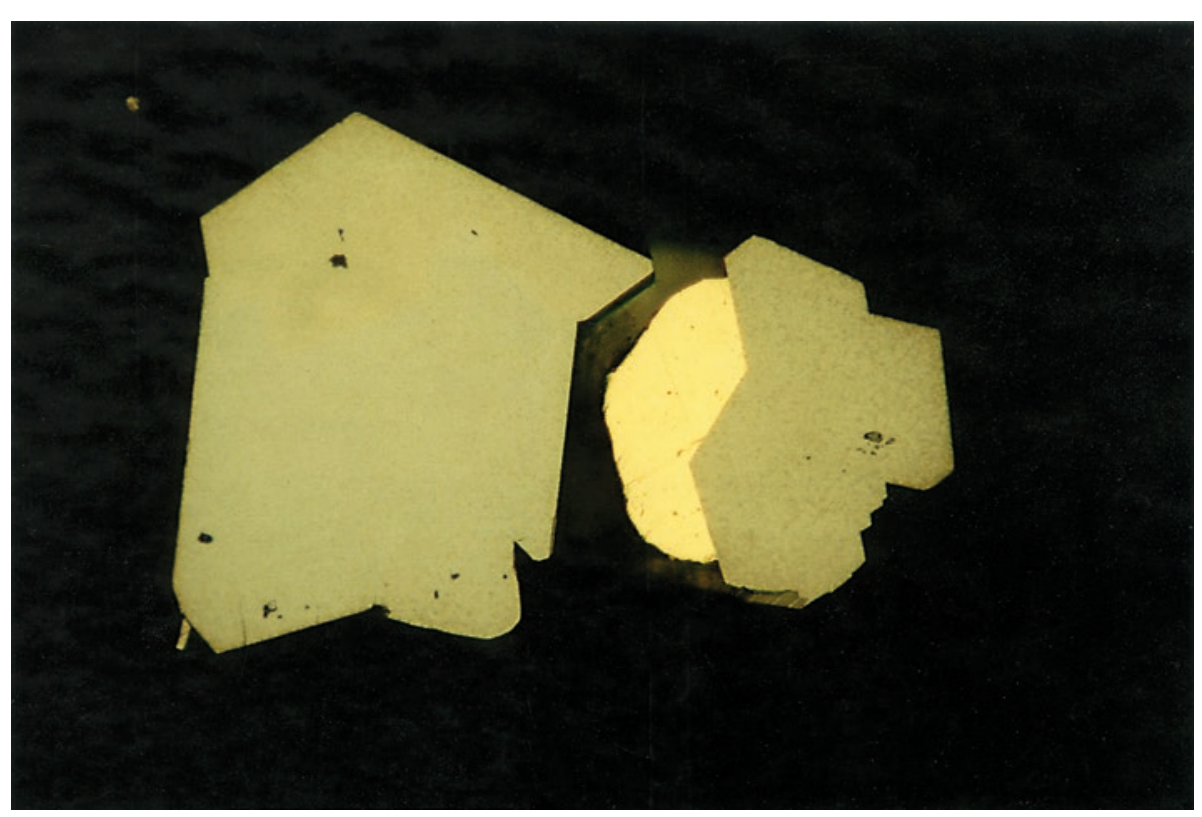

Fig. 3.0-3: Territorium metallorum Tresminas / Jales, Campo de Jales: Ouro (amarelo) em contacto com arsenopirita. Preto: minerais não metálicos. Secção fina, imersão em óleo. Limite longo da imagem: $342 \mu \mathrm{m}$ (fotografia: RWTH Aachen/Alemanha). 


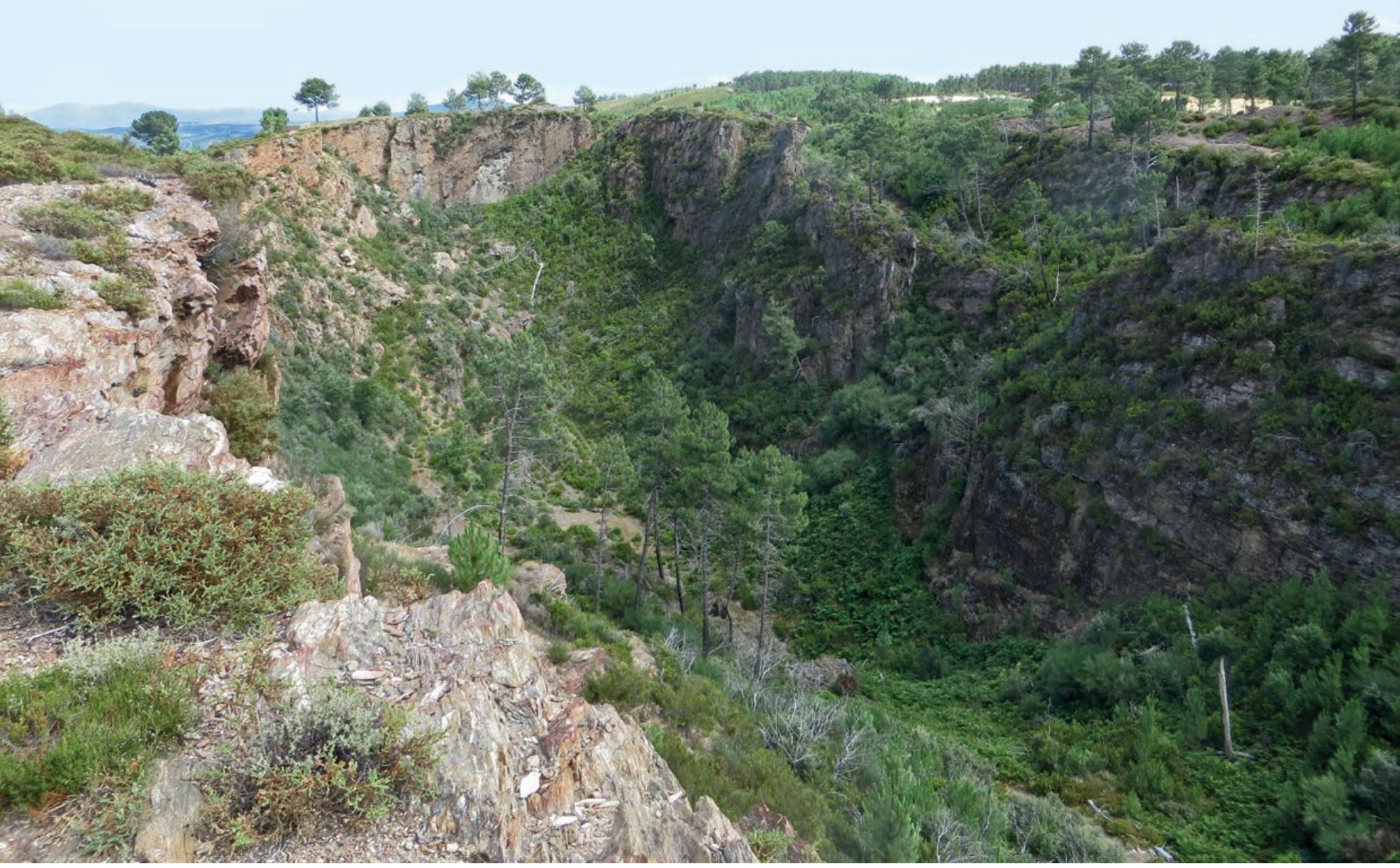

Fig. 3.0-4: Territorium metallorum Tresminas / Jales, Tresminas, Corta de Covas vista de oeste. Em primeiro plano a zona de extração norte, à direita a zona de extração sul, separada pela rocha remanescente (fotografia: R.Wahl-Clerici). 


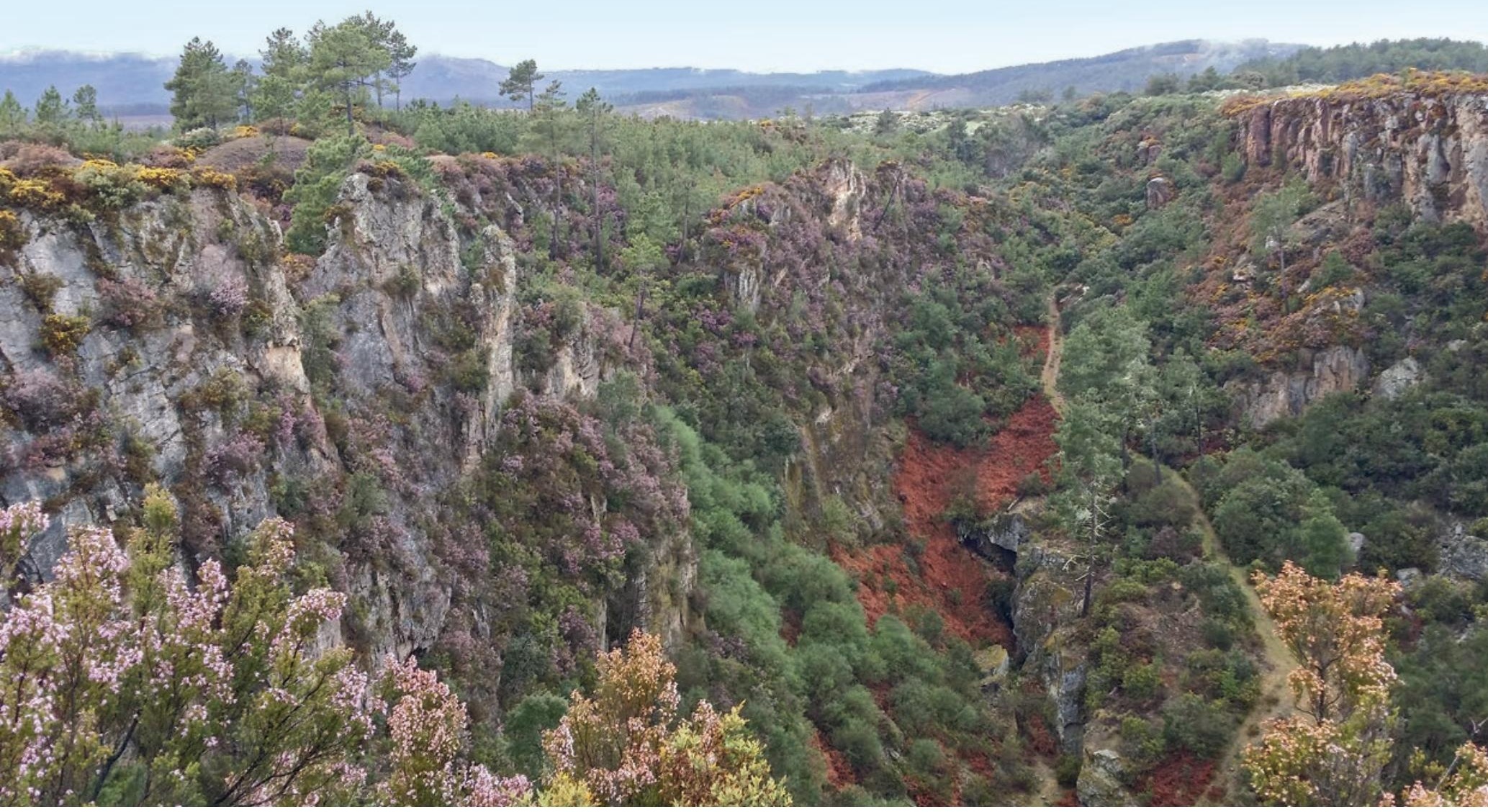

Fig. 3.0-5: Territorium metallorum Tresminas /Jales, Tresminas, Corta de Covas visto de leste: vista sobre a zona de extração norte com rocha em direção à zona de extração sul (fotografia: R.Wahl-Clerici). 


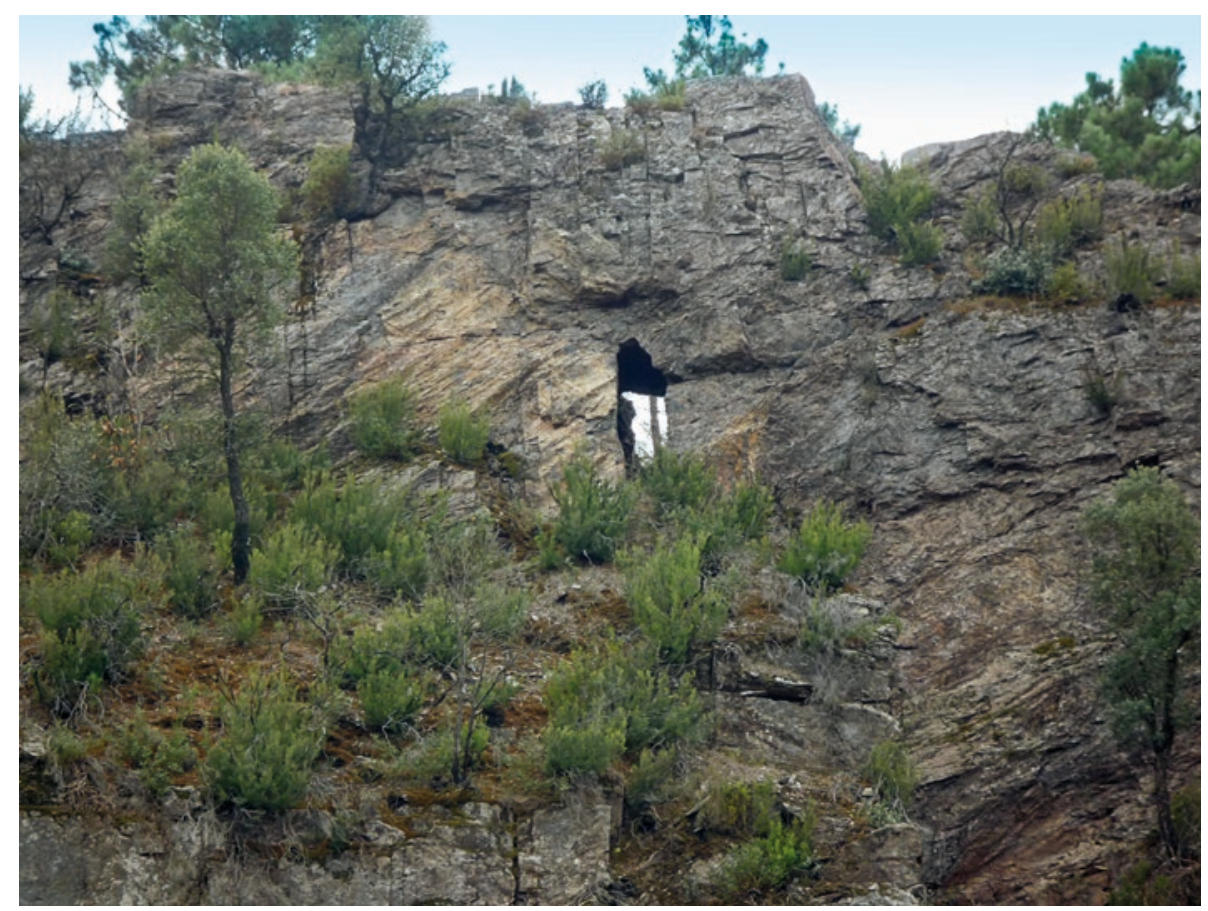

Fig. 3.0-6: Territorium metallorum Tresminas / Jales, Tresminas, Corta de Covas visto do norte: vista sobre a rocha estéril entre as duas zonas de extração com o poço em escada aprofundado para prospeção (fotografia: A.

Wiechowski).

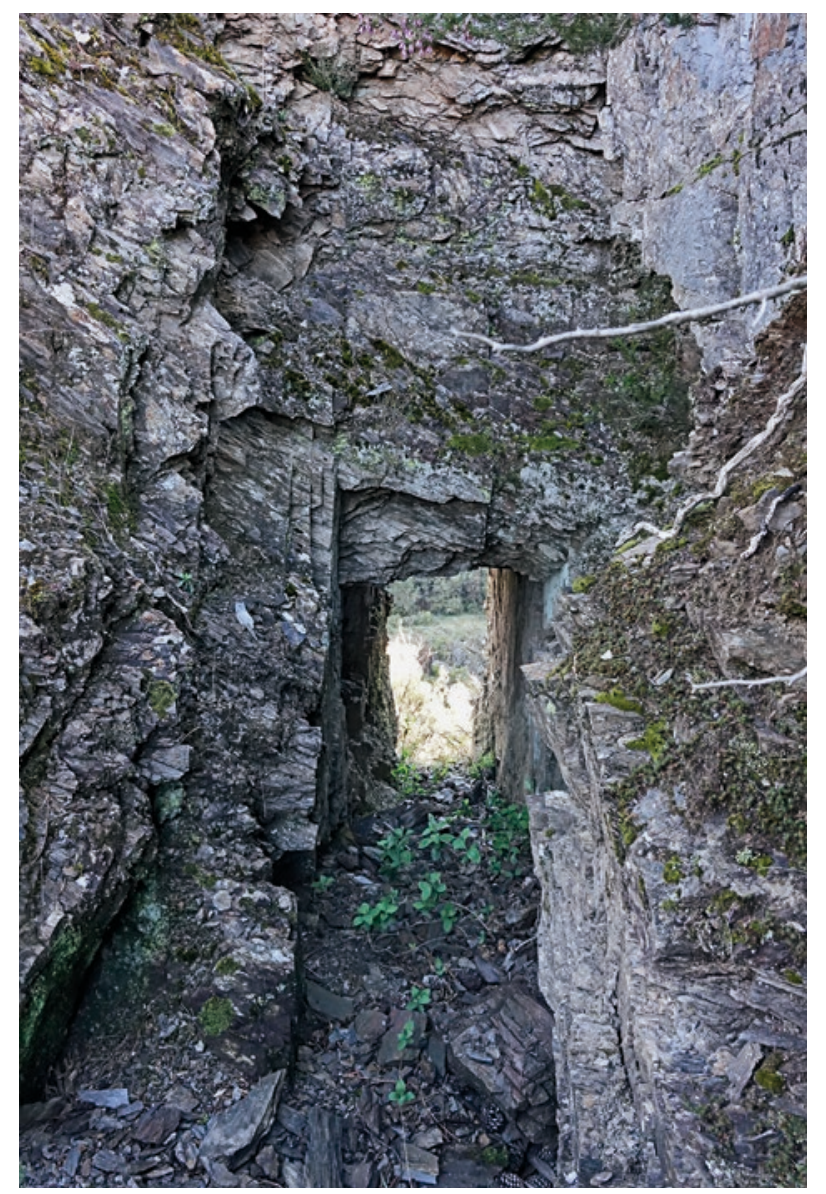

Fig. 3.0-7: Territorium metallorum Tresminas/Jales, Tresminas, Corta de Covas visto do sul: vista sobre o poço em escada para prospeção (fotografia: R.WahlClerici). 


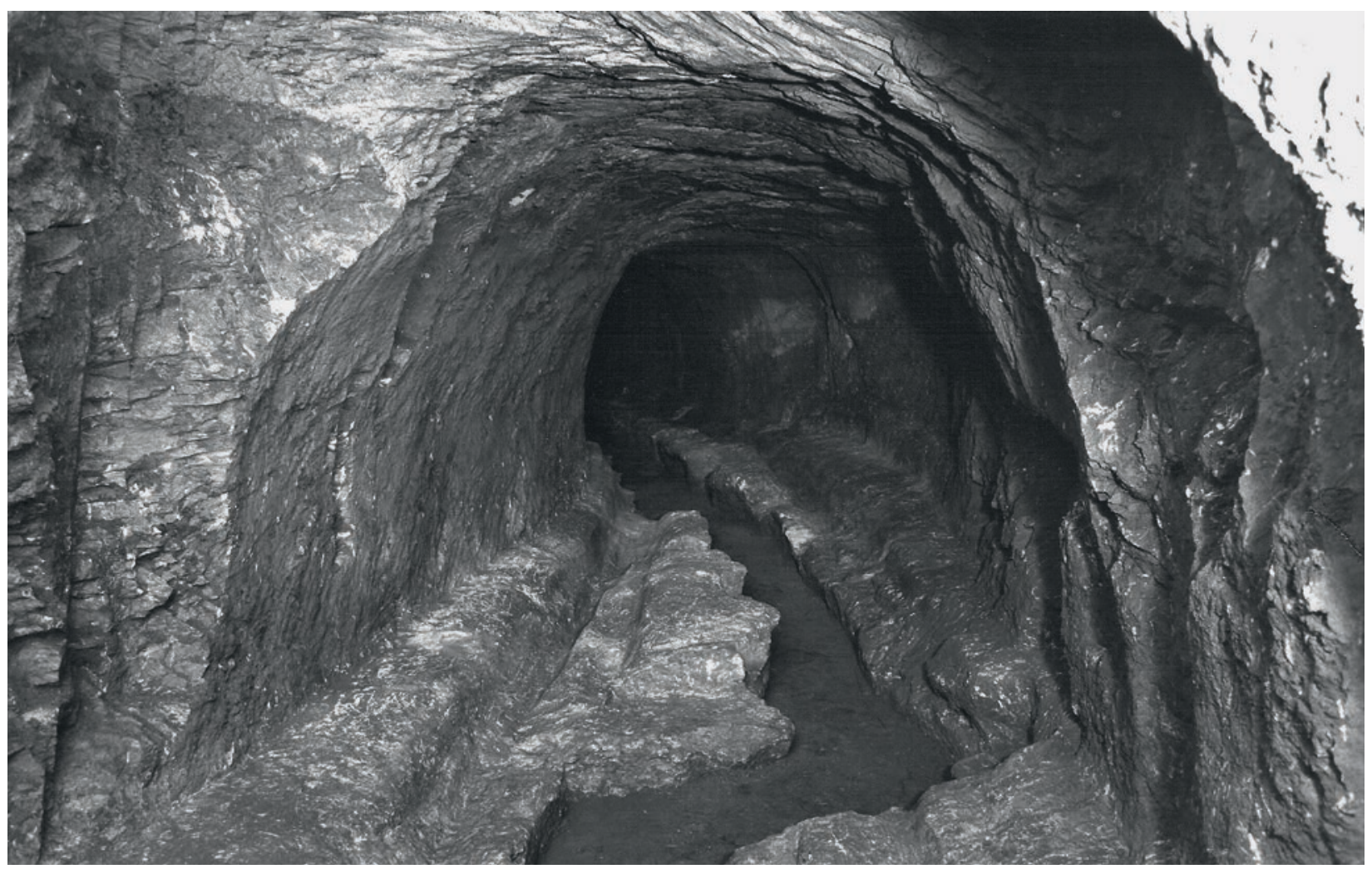

Fig. 3.0-8: Territorium metallorum Tresminas/Jales, Tresminas, Corta de Covas, Galeria Esteves Pinto: piso com sulcos e canal escavado na rocha. Visto de sul (fotografia: J. Wahl).

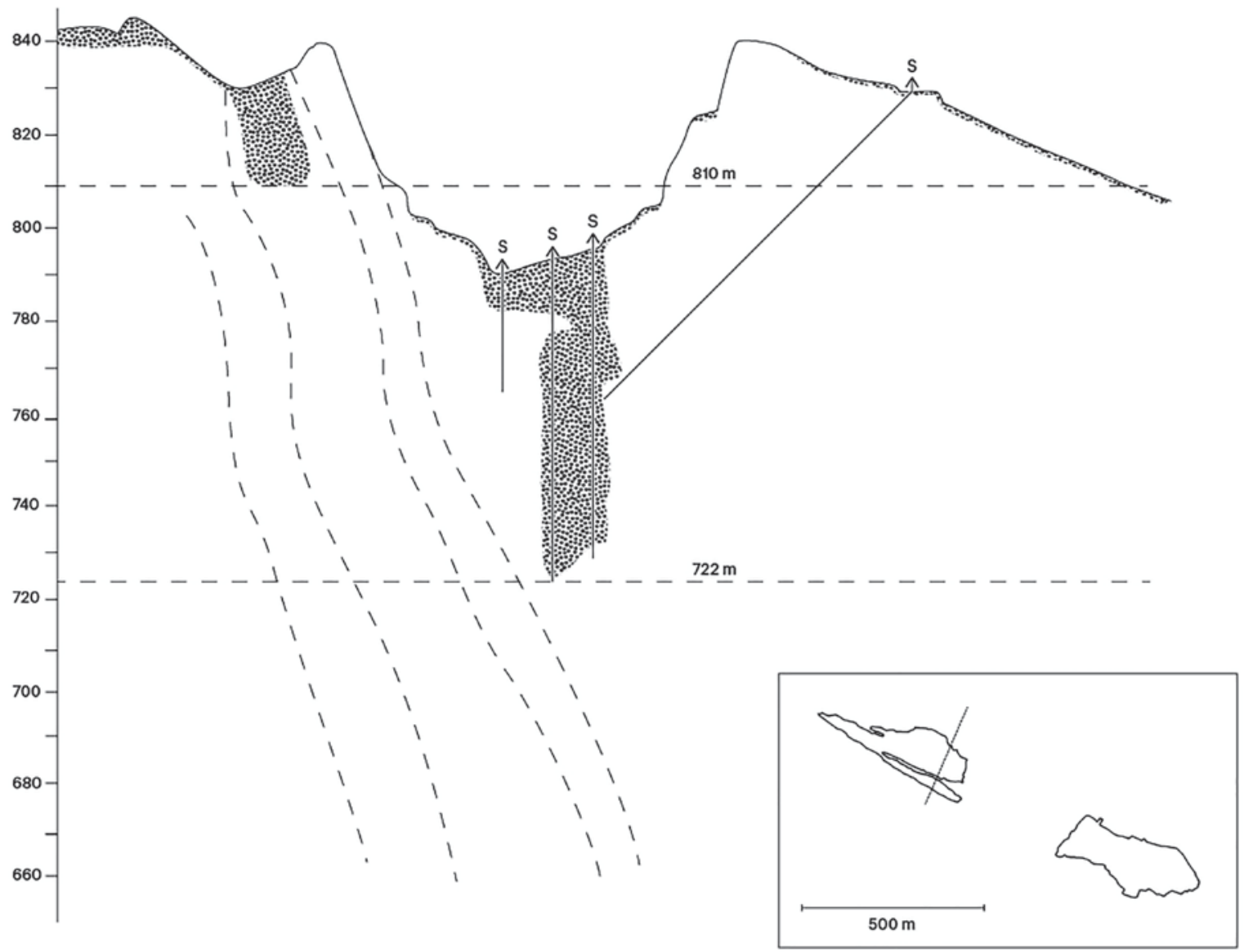

Fig. 3.0-9: Territorium metallorum Tresminas / Jales, Tresminas, Corta de Covas: secção Norte-Sul através da Corta, na área de sondagem mais profunda $(S=$ sondagem). A profundidade da zona de mineração a sul foi ajustada ao nível da Galeria Esteves Pinto. Canto inferior direito: localização da sondagem (de acordo com a Direção Geral de Geologia e Minas. Serviço de Fomento Mineiro. Divisão de Prospeção de Minérios Metálicos. SFM SPE-1987-88, desenho: R. Wahl-Clerici, S. Mathiuet). 


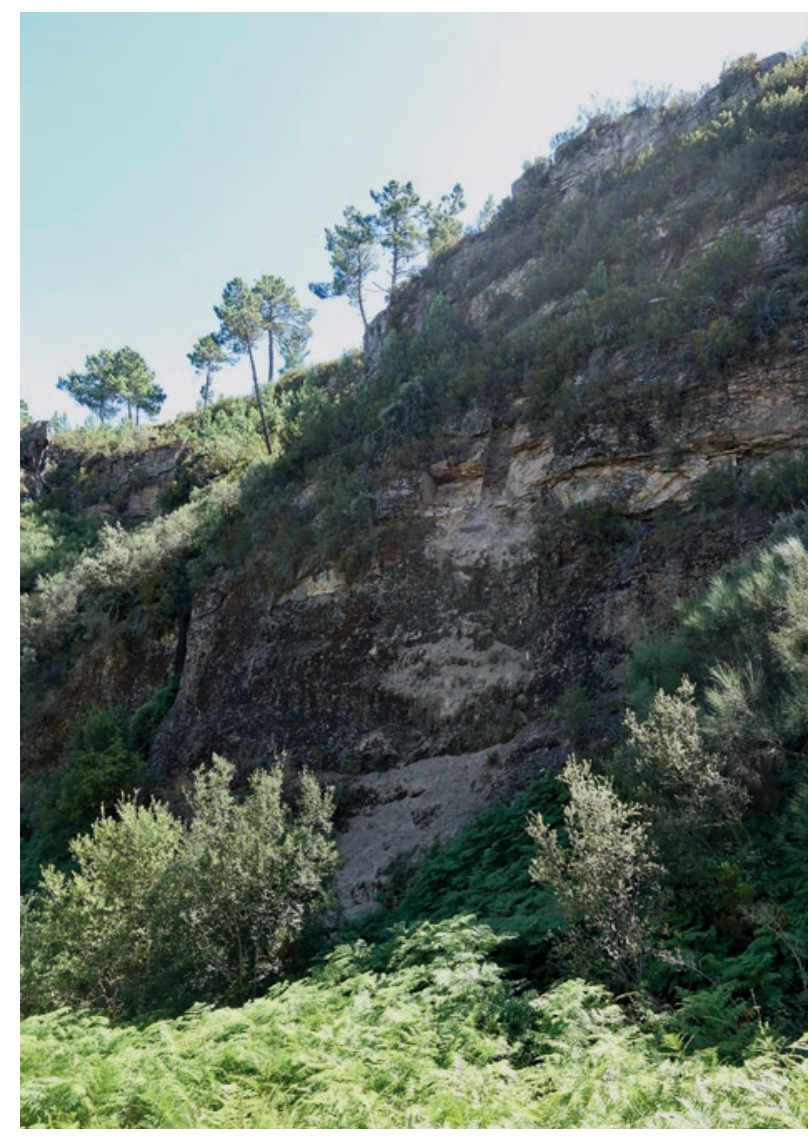

Fig. 3.0-10: Territorium metallorum Tresminas / Jales, Tresminas, Corta de Covas: desmoronamento de rocha em 2019 (fotografia: R. Wahl-Clerici).

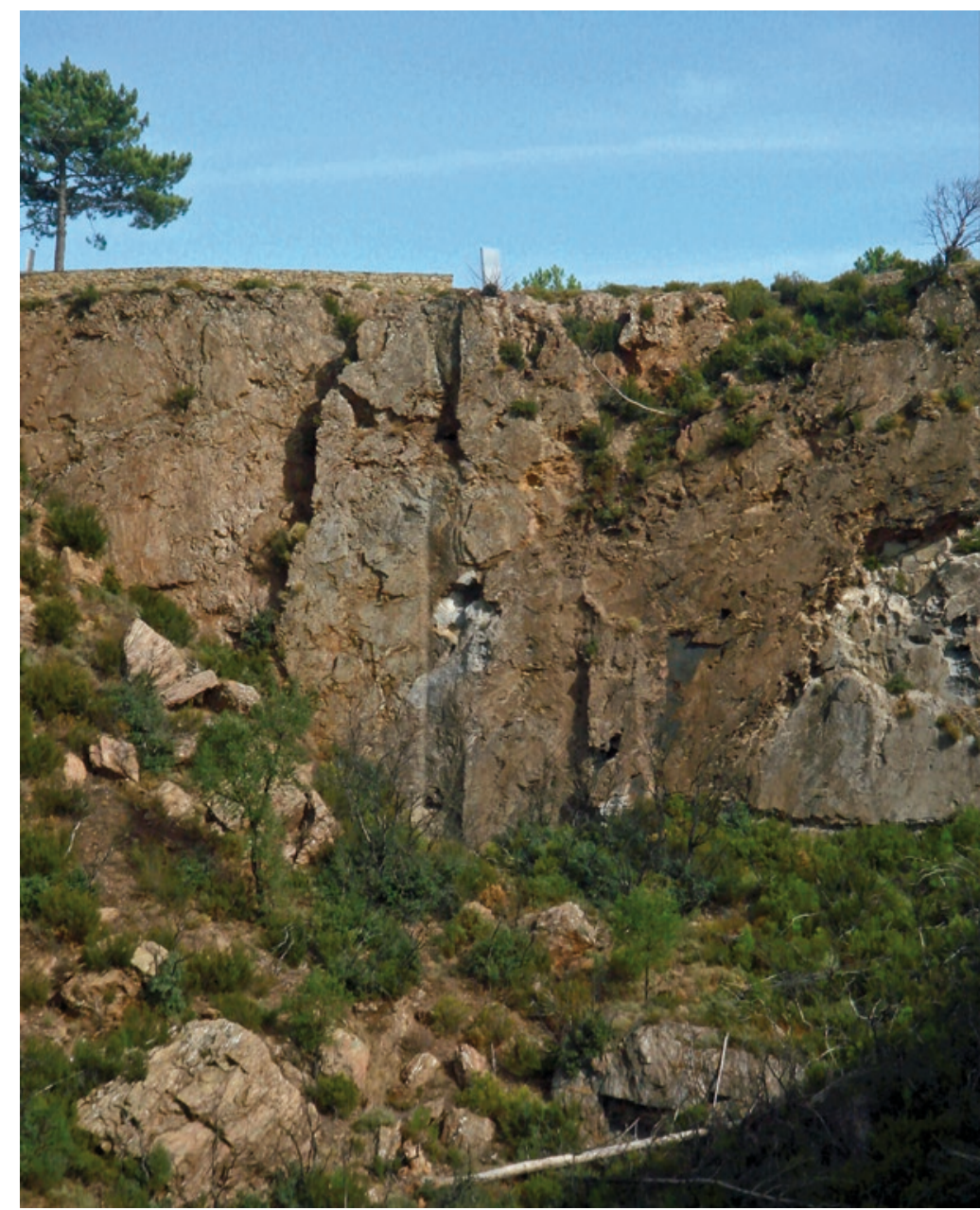

Fig. 3.0-11: Territorium metallorum Tresminas / Jales, Tresminas, Corta de Covas: encosta oriental com os dois poços gémeos, ligados por tuneis em vários níveis, vista de oeste (fotografia: $R$. Wahl-Clerici). 


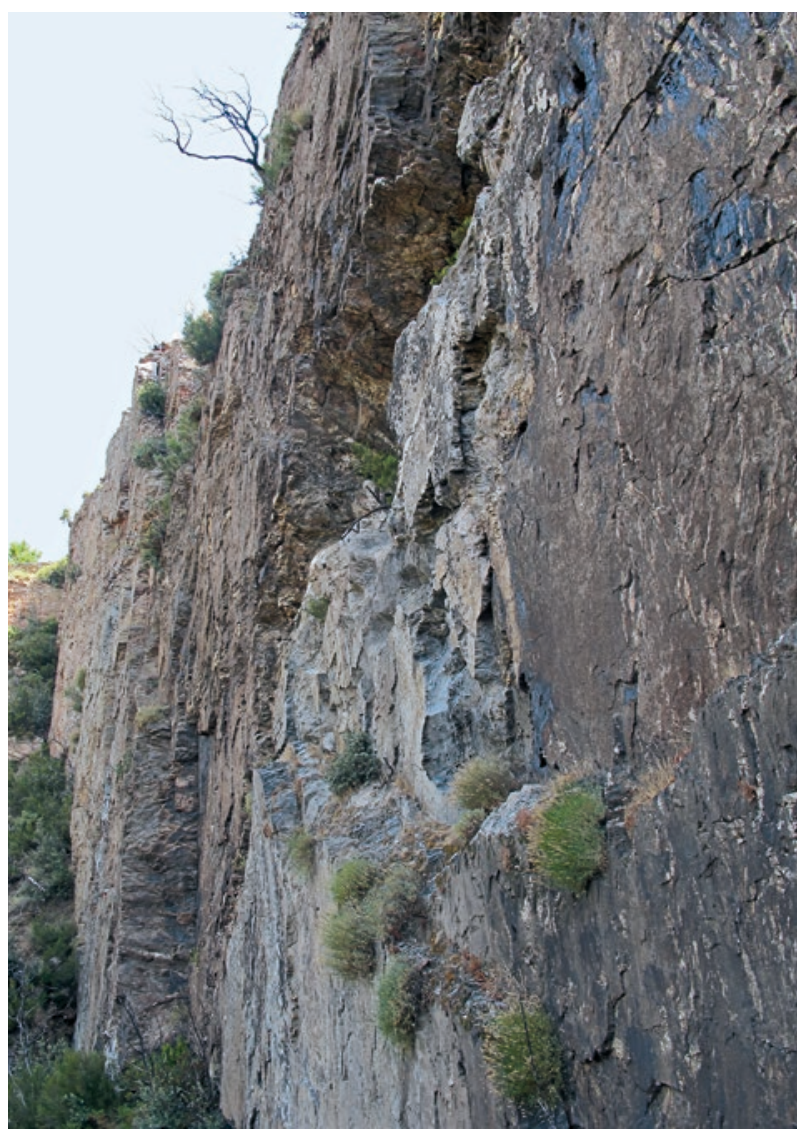

Fig. 3.0-12: Territorium metallorum Tresminas/Jales, Tresminas, Corta de Covas: detalhe das fendas na encosta oriental (fotografia: R. Wahl-Clerici).

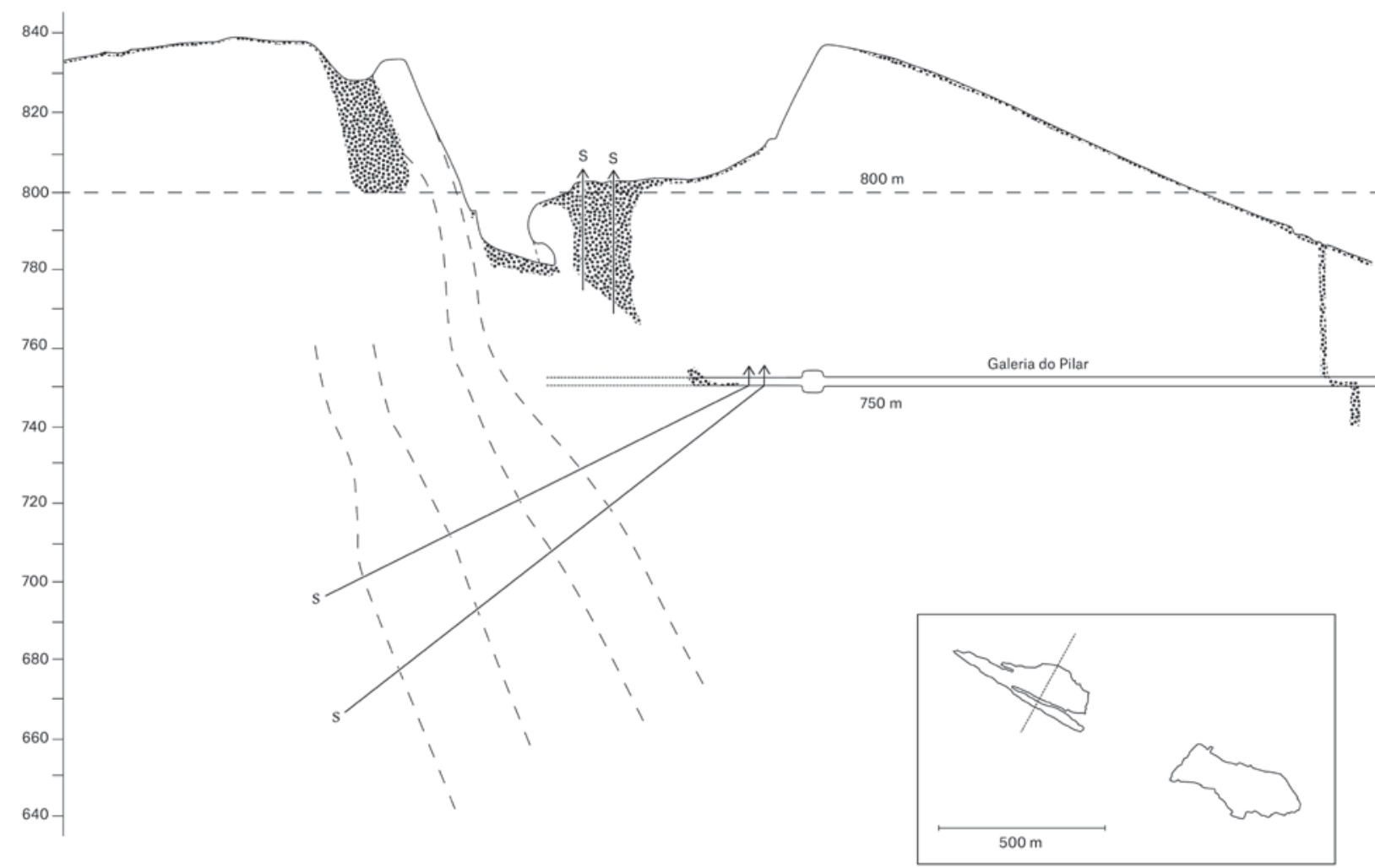

Fig. 3.0-13: Territorium metallorum Tresminas / Jales, Tresminas, Corta de Covas: secção norte-sul através da Corta, na área de ataque por fogo. Canto inferior direito: localização da sondagem (de acordo com a Direção Geral de Geologia e Minas. Serviço de Fomento Mineiro. Divisão de Prospeção de Minérios Metálicos. SFM-SPE-1987-88, desenho: R. Wahl-Clerici, S. Mathiuet). 


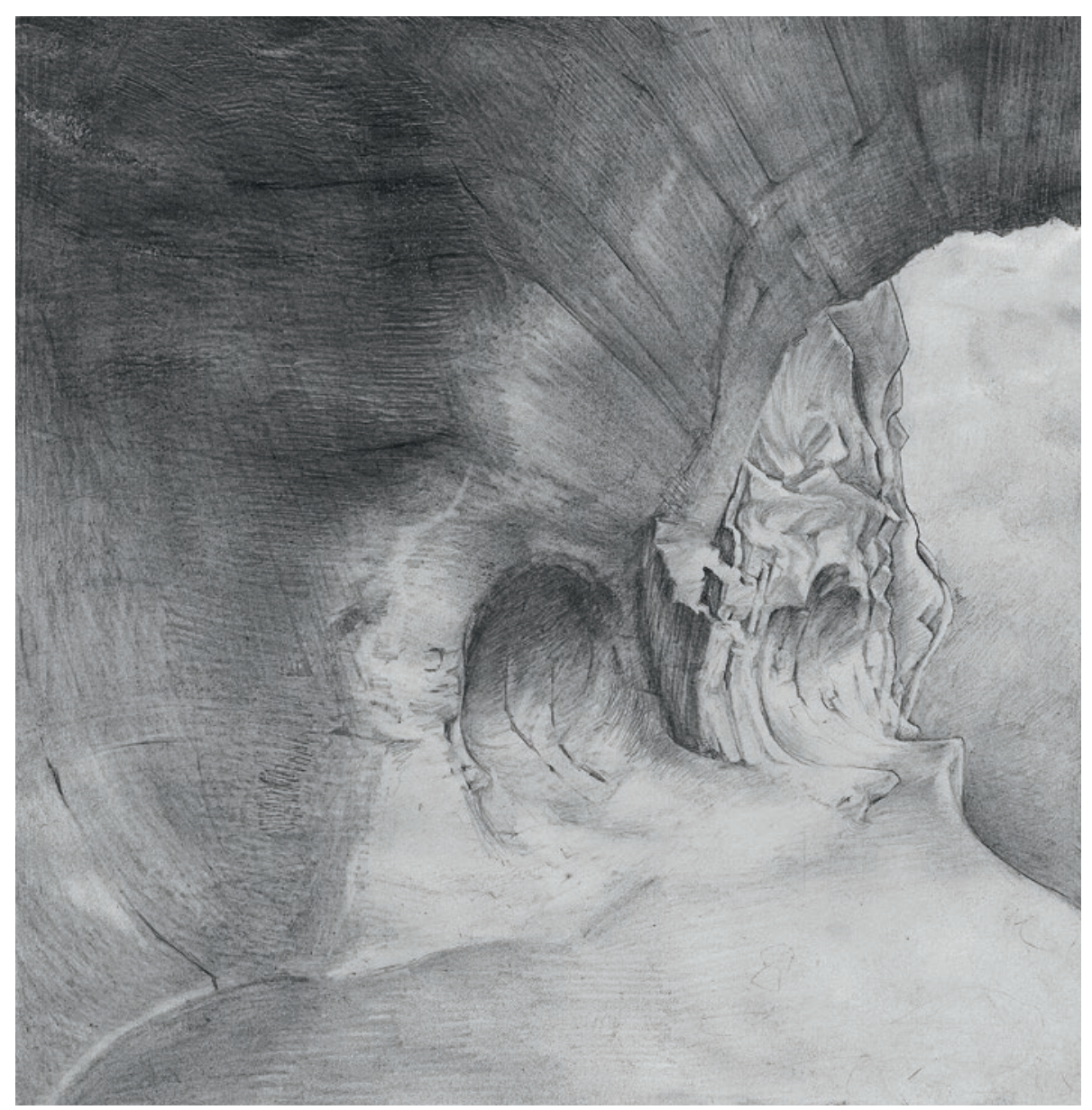

Fig. 3.0-14: Territorium metallorum

Tresminas / Jales, Tresminas, Corta de Covas: áreas de ataque por fogo (desenho: P. Moser).

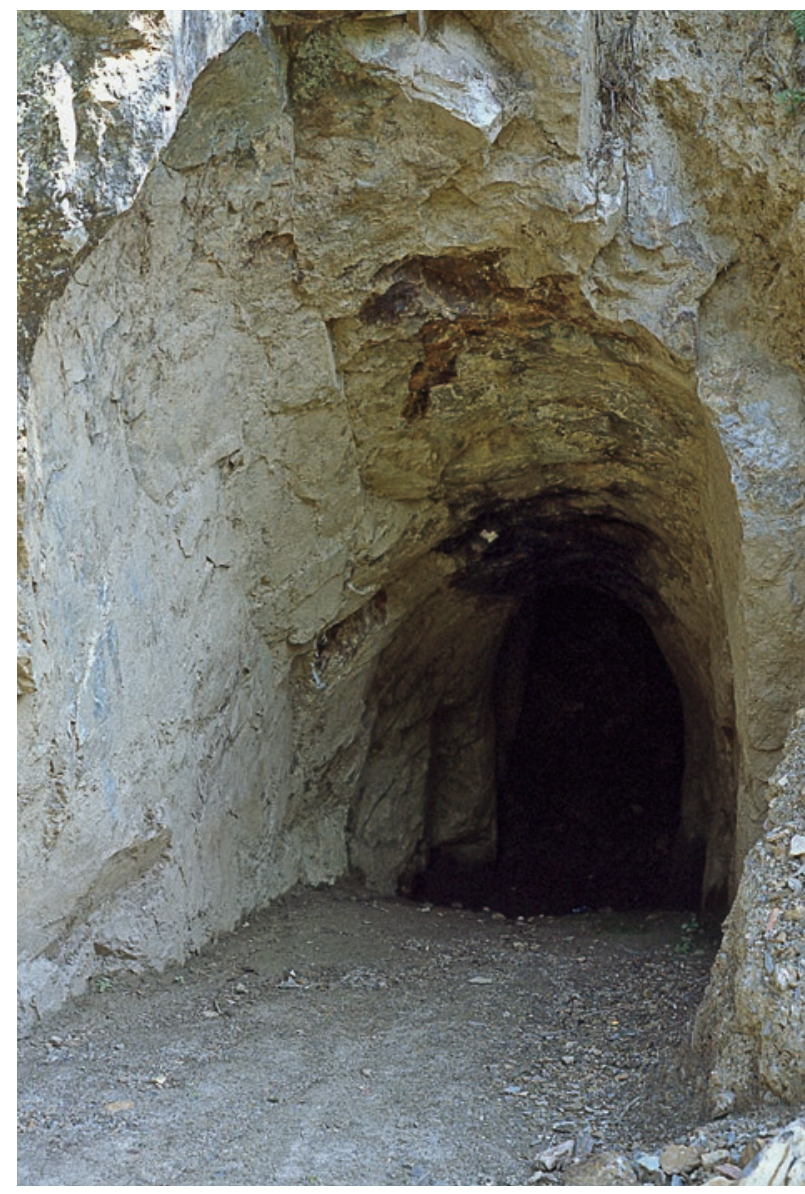

Fig. 3.0-15: Territorium metallorum Tresminas/Jales, Tresminas, Corta de Covas: abertura de um túnel por meio de ataque por fogo (fotografia: R. Wahl-Clerici). 


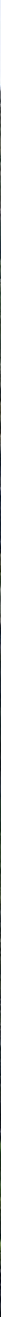

Fig. 3.0-16: Territorium metallorum Tresminas/Jales, Tresminas, Corta da Ribeirinha: vista sobre a encosta a norte, com os vestígios da exploração mineira nas partes oeste e leste. Visto de sudoeste (fotografia: $R$. Wahl-Clerici) 


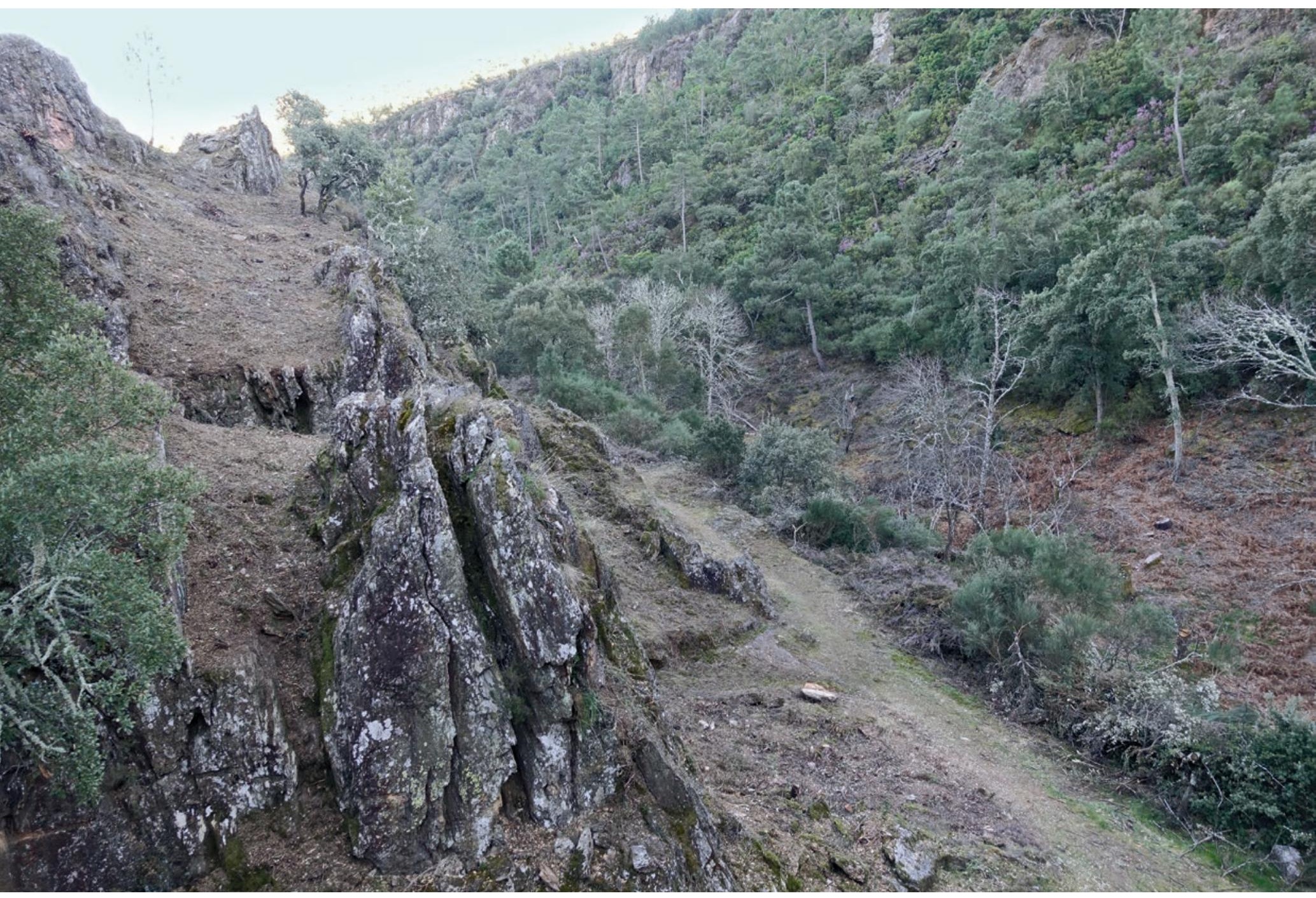

Fig. 3.0-17a: Territorium metallorum Tresminas / Jales, Tresminas, Corta da Ribeirinha: do lado esquerdo, a encosta a norte com os vestígios da exploração. Do lado direito, a encosta criada através do desmoronamento da rocha (fotografia: $R$. Wahl-Clerici). 

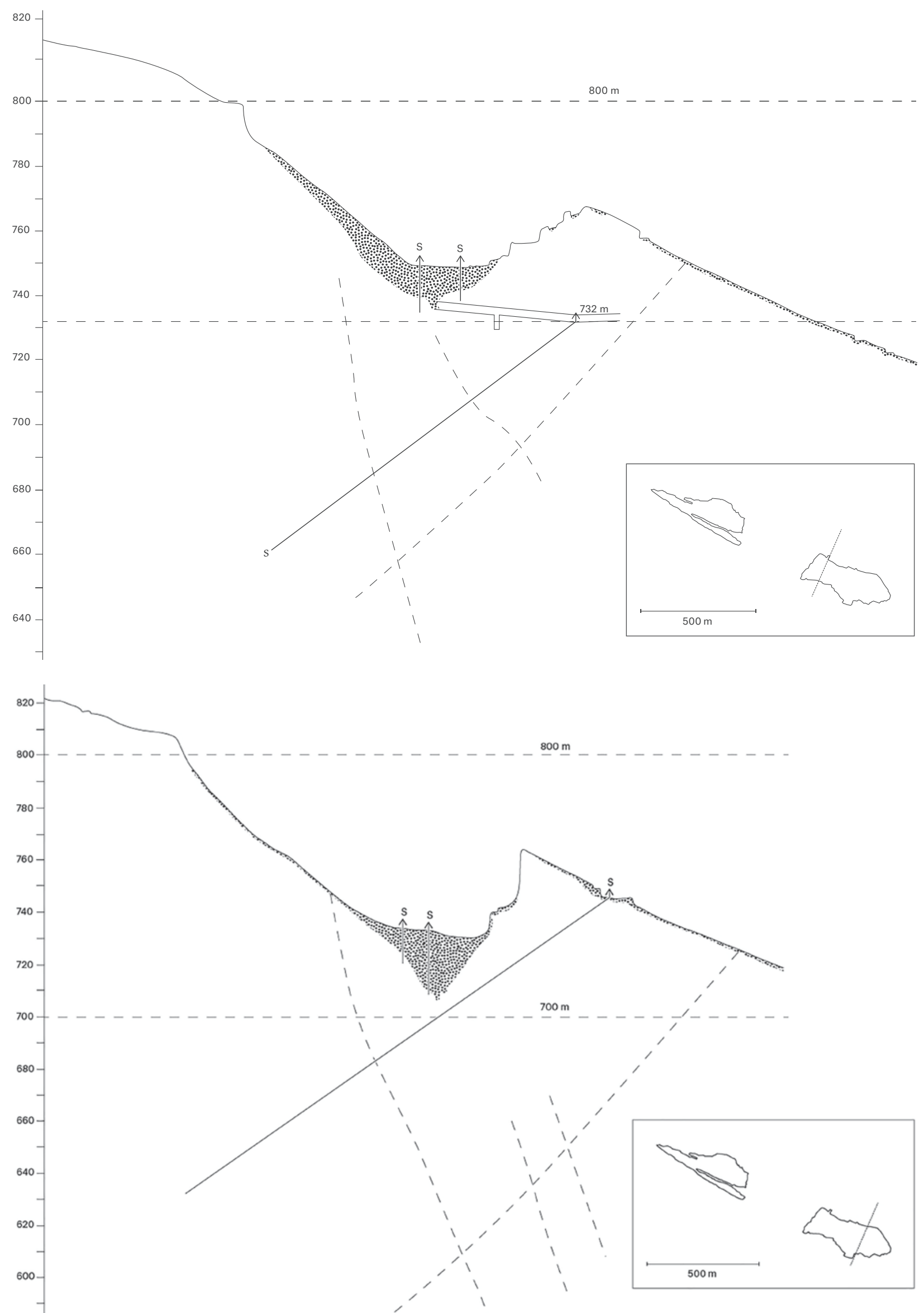

Fig. 3.0-17b/c: Territorium metallorum Tresminas/Jales, Tresminas, Corta da Ribeirinha: secção norte-sul através da Corta, nas zonas este e oeste. Em baixo à direita: localização da sondagem (de acordo com a Direção Geral de Geologia e Minas, Serviço de Fomento Mineiro, Divisão de Prospeção de Minérios Metálicos, SFM-SPE-1987-88, desenho R. Wahl-Clerici, S. Mathiuet). 


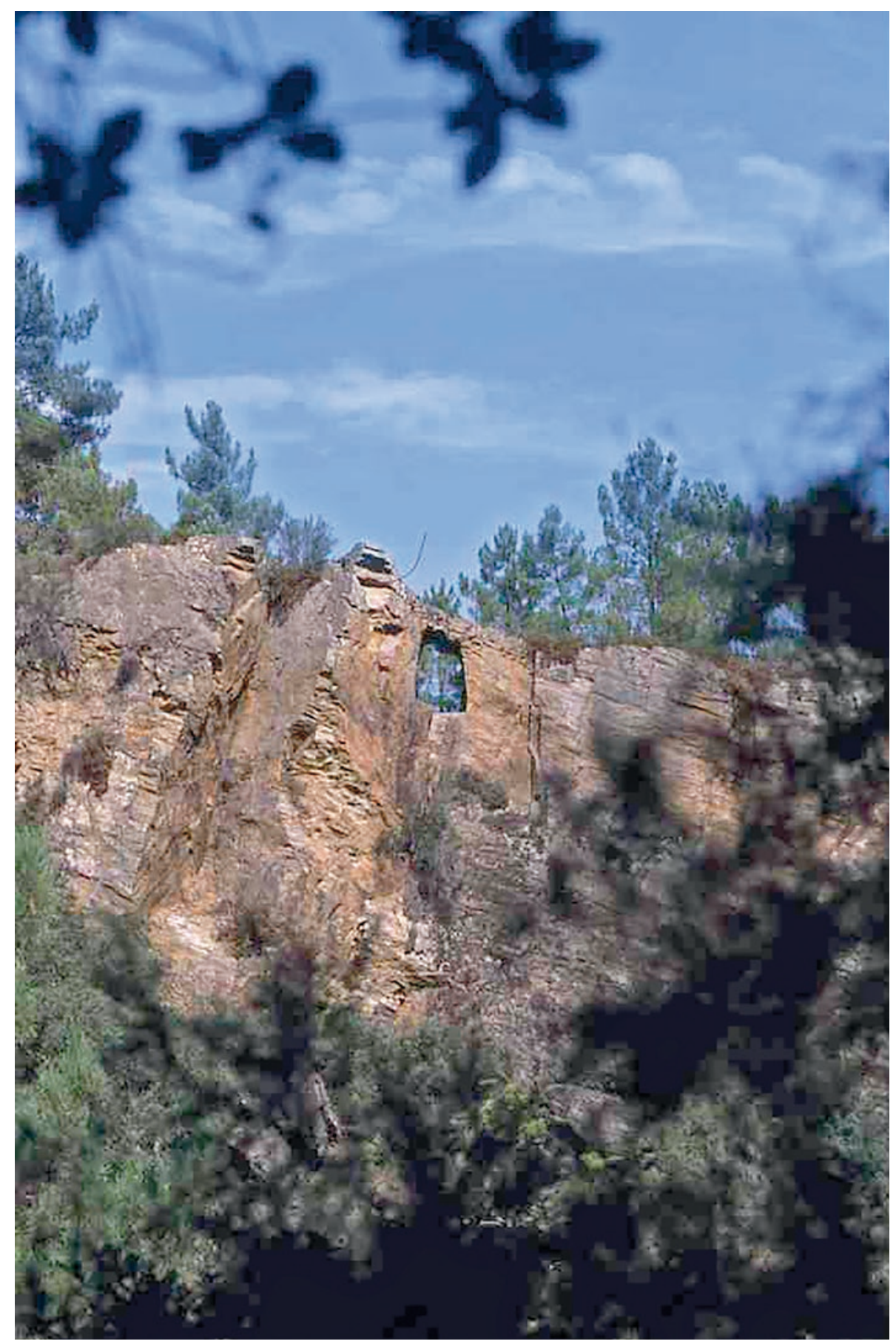

Fig. 3.0-18: Territorium metallorum Tresminas / Jales, Tresminas, Corta da Ribeirinha: zona oriental da encosta norte com os vestígios de um dos primeiros túneis (fotografia: $R$. Wahl-Clerici). 


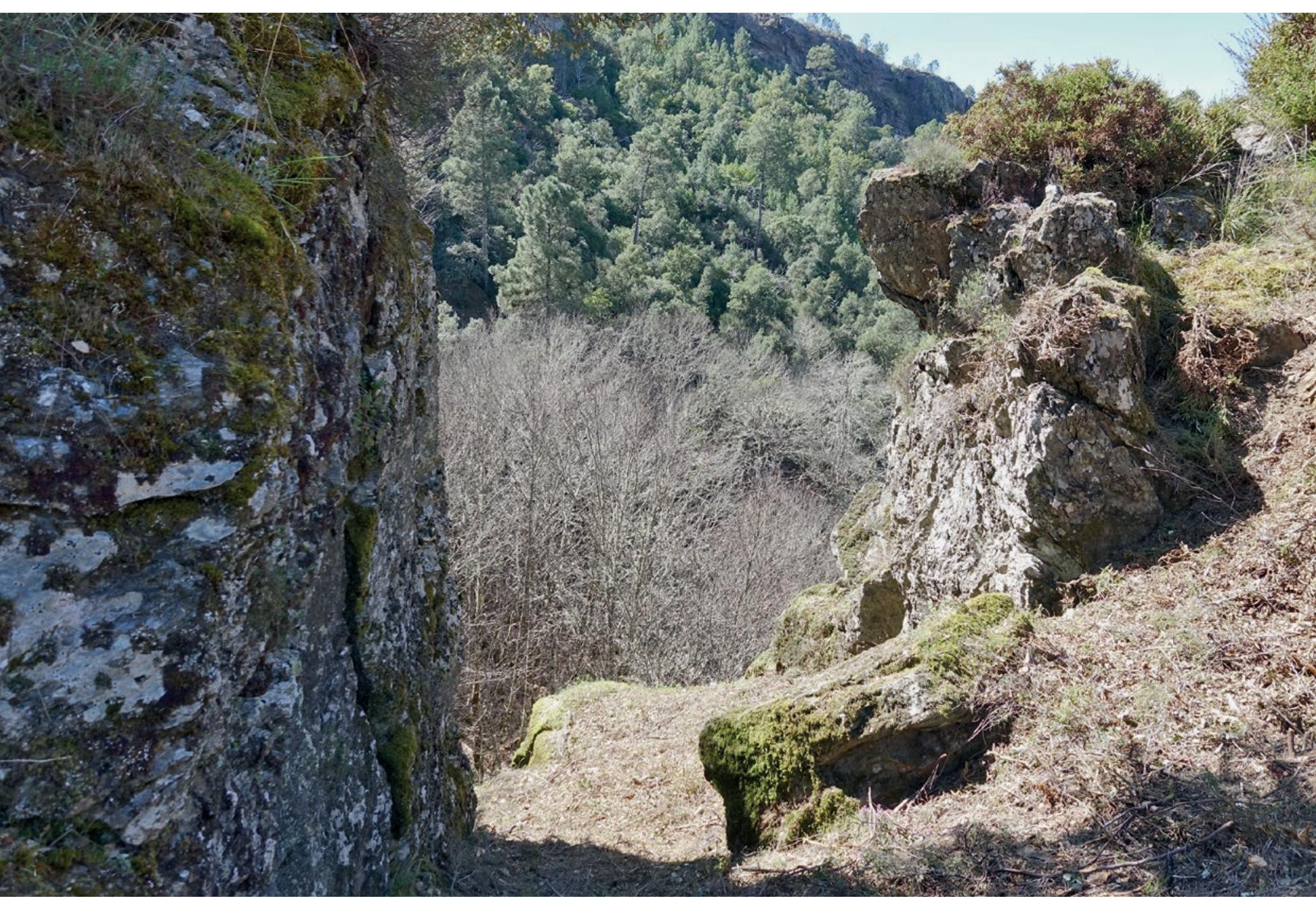

Fig. 3.0-19: Territorium metallorum Tresminas /Jales, Tresminas, Corta da Ribeirinha: a antiga entrada oriental para a mina a céu aberto. Visto de norte (fotografia: R. Wahl-Clerici). 


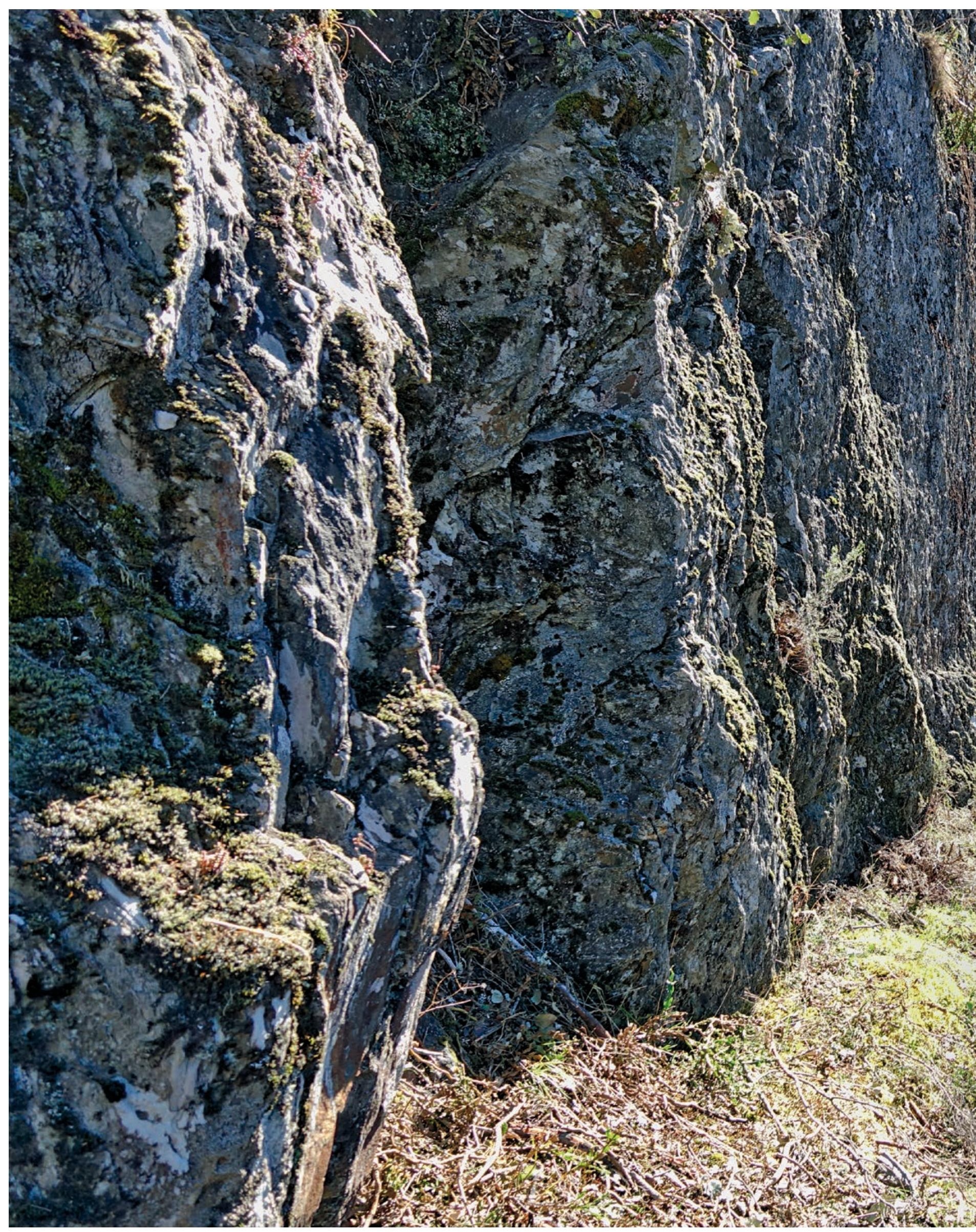




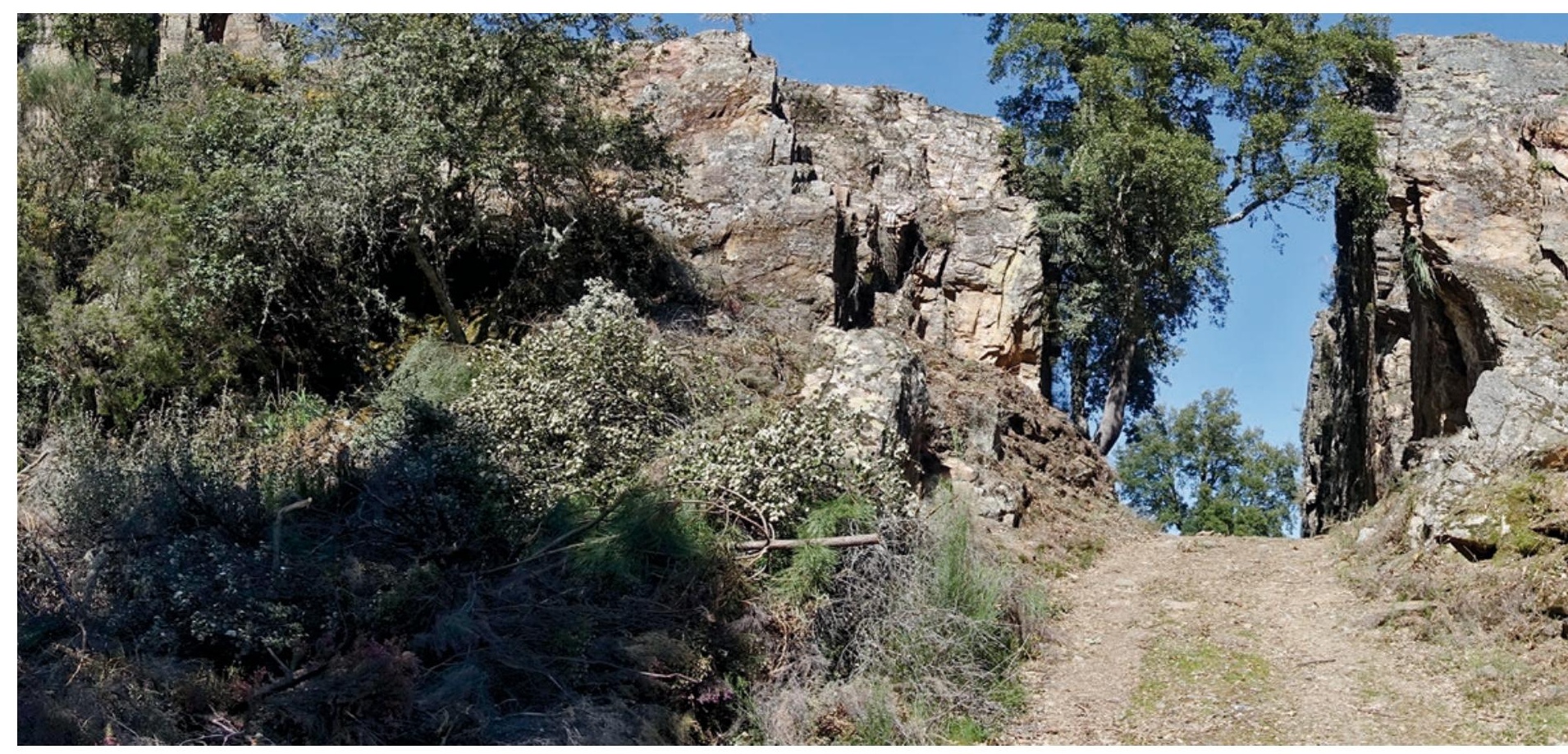

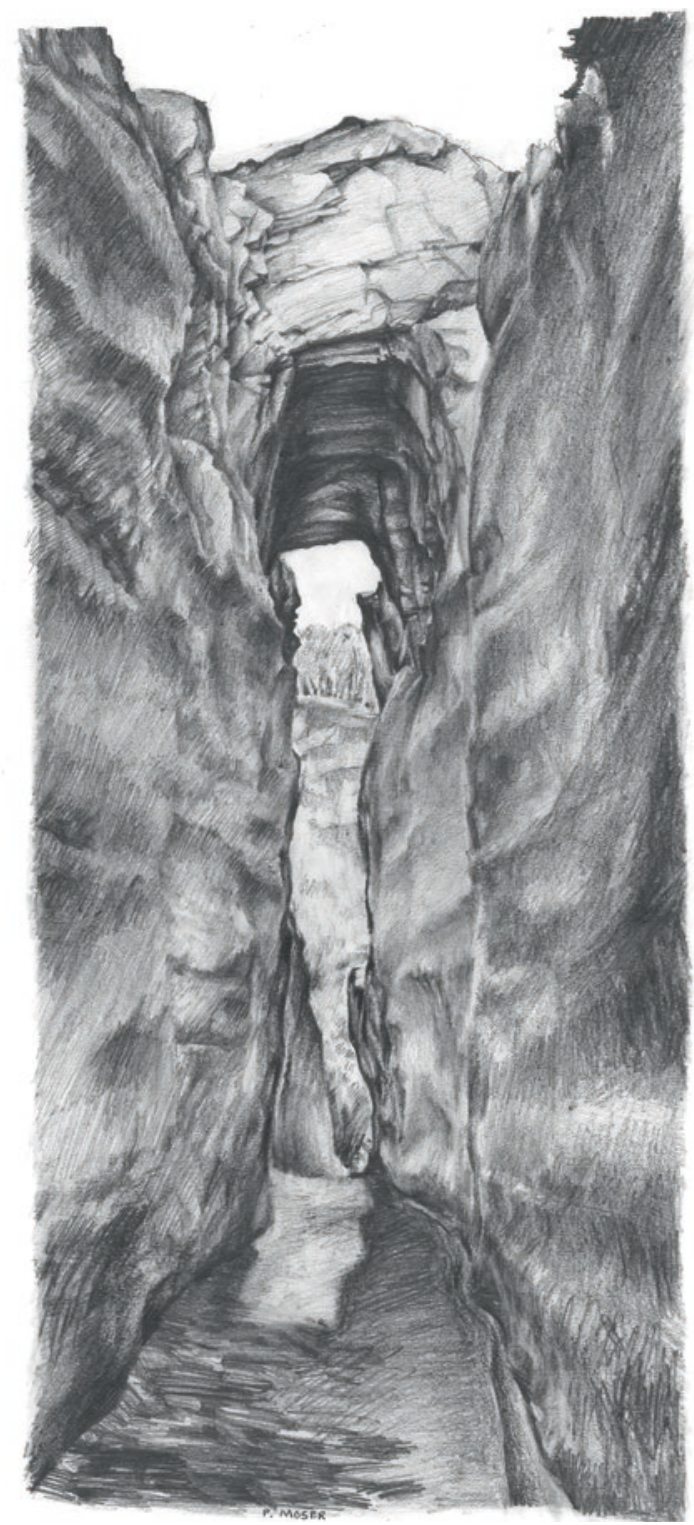

Fig. 3.0-22: Territorium metallorum Tresminas / Jales, Tresminas, Corta da Ribeirinha: a parte superior do sistema de prospeção na entrada oeste. É bem visível o mais antigo túnel trapezoidal, cuidadosamente escavado e gradualmente aprofundado (desenho: P. Moser). 
SSE

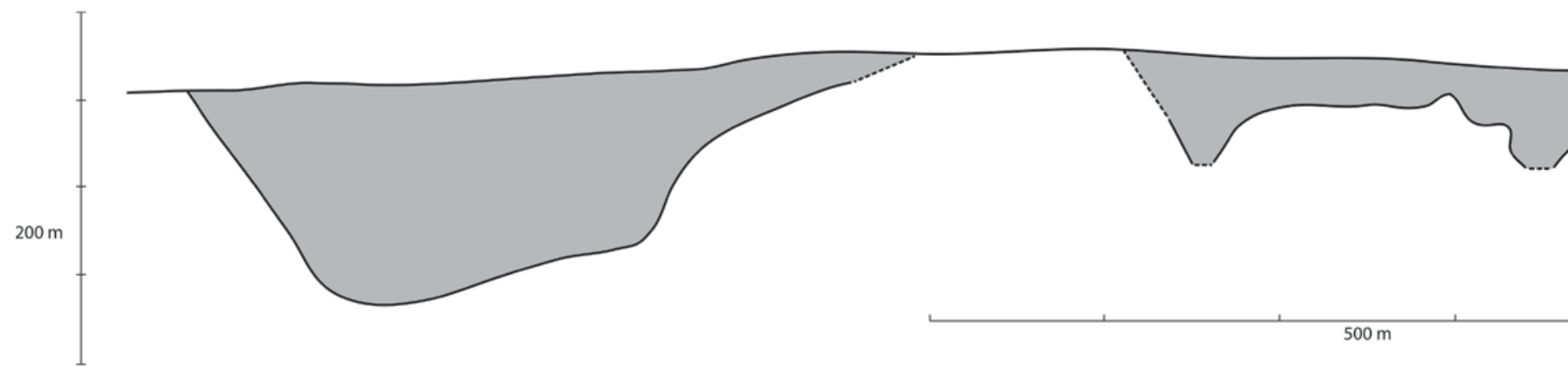

Fig. 3.0-24: Territorium metallorum Tresminas / Jales, Campo de Jales: corte transversal da jazida de Jales, tendo em conta a mineração romana. (Modelo: Minas de Jalles Ltda., adaptação: J. Wahl)

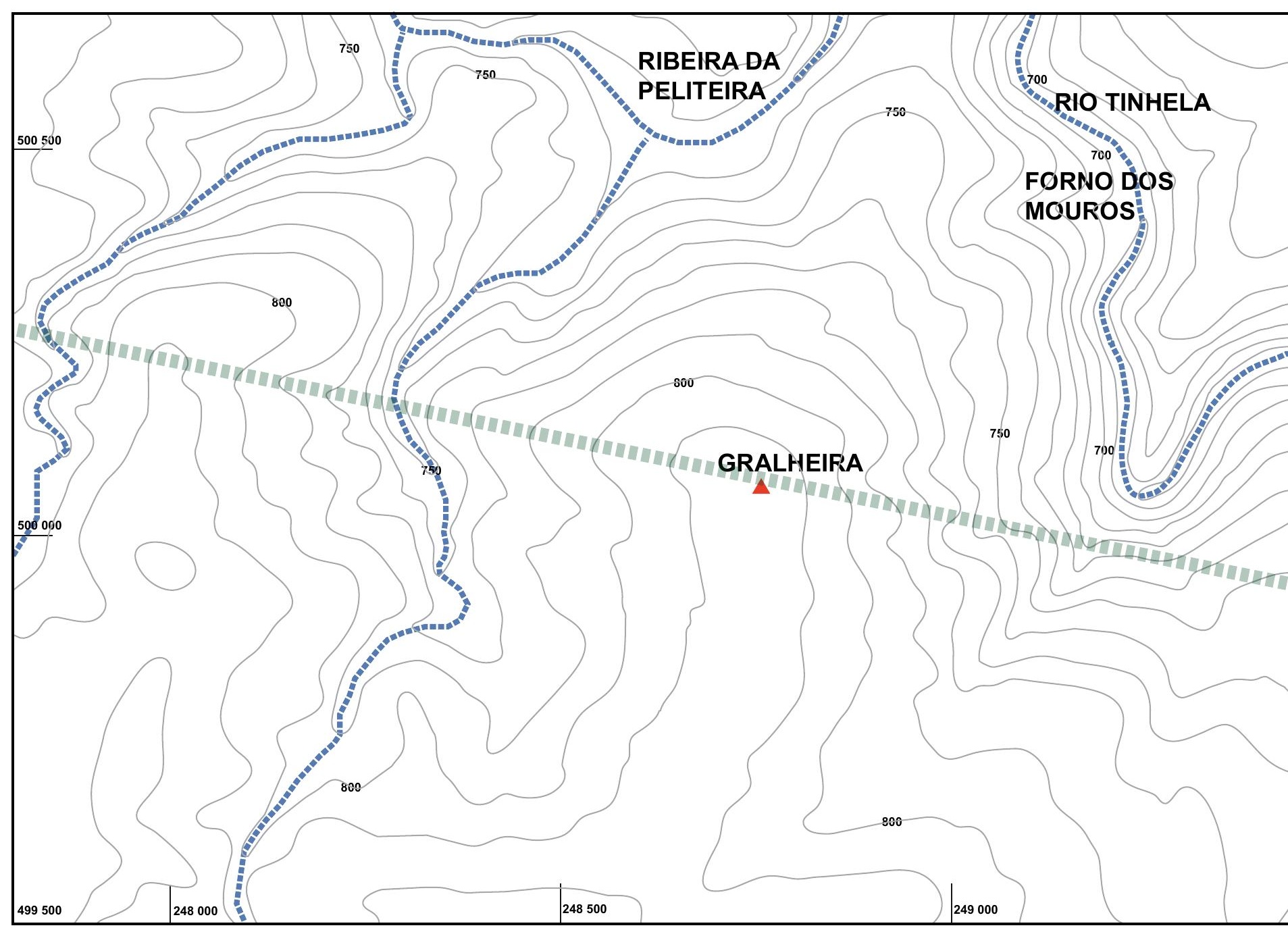

Fig. 3.0-25: Territorium metallorum Tresminas /Jales, Gralheira: plano esquematizado da jazida (Modelo: Orthophotomapa 1:10000 Câmara Municipal de Vila Pouca de Aguiar, RTZ, Sociedade Mineira Rio Artezia, SA, Serviço de pesquisas geológicas e de mineração, Consórcio Gralheira, 12.06.1990, desenho: R. Wahl-Clerici). 
NNW
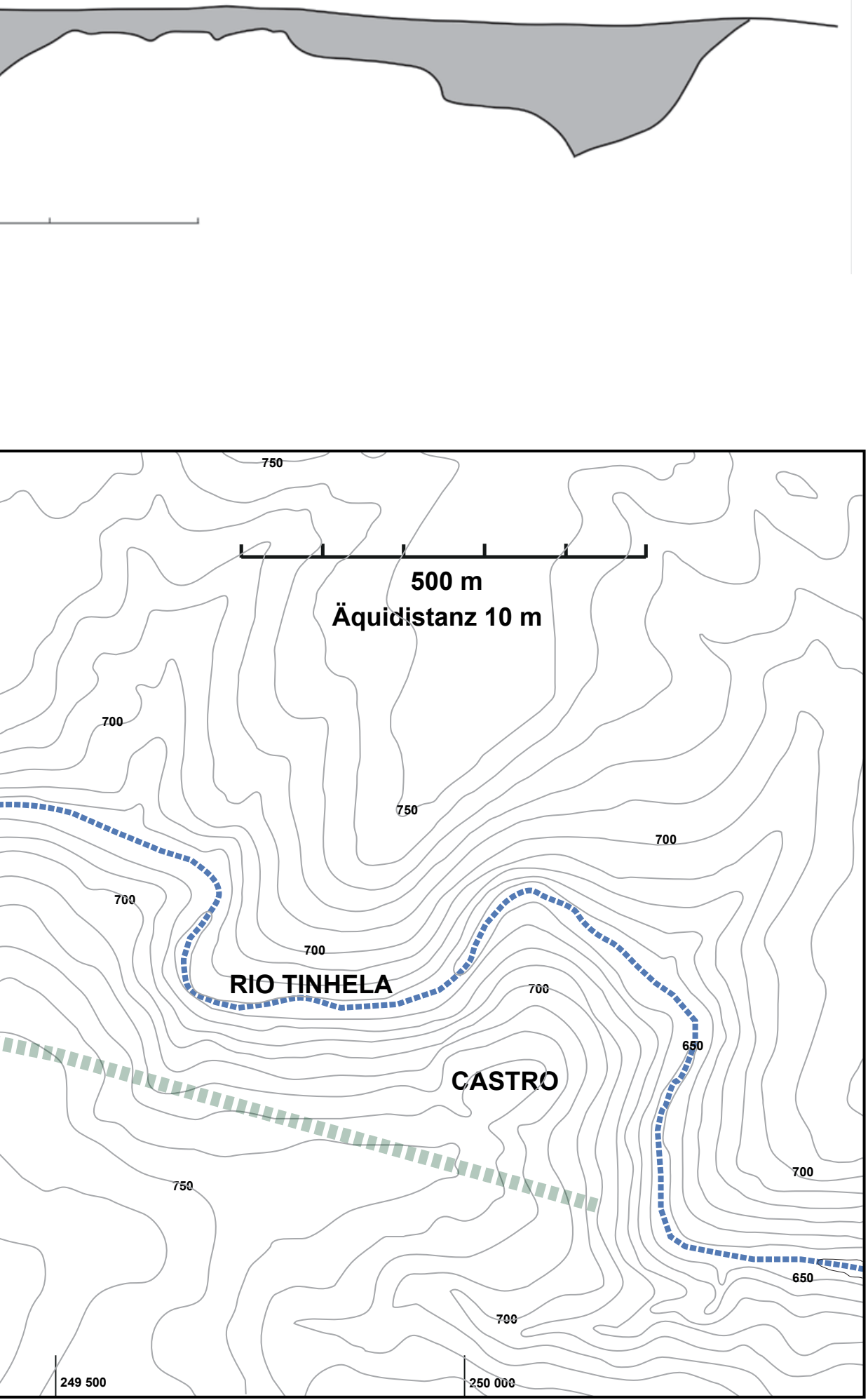


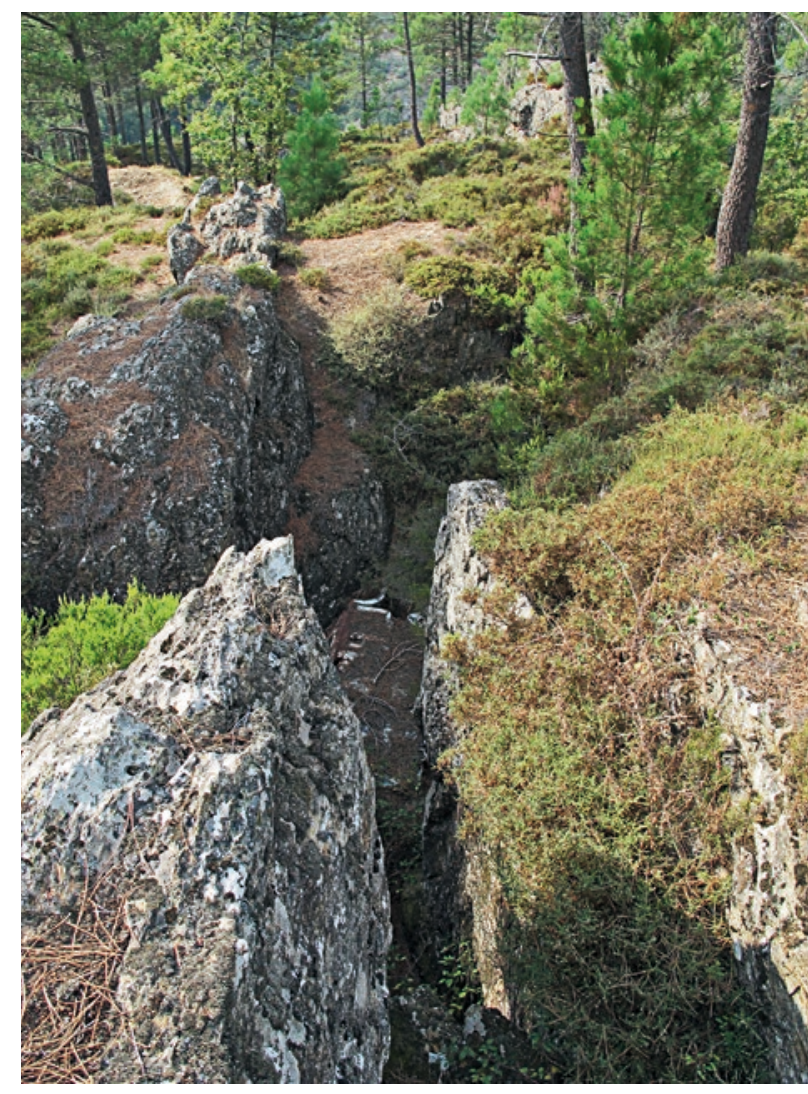

Fig. 3.0-26: Territorium metallorum Tresminas/Jales, Gralheira: intersecção de duas jazidas de quartzo com minérios polimetálicos. A sul da área de escavação encontram-se os remanescentes do afloramento rochoso. Vista de és-nordeste (fotografia: $R$. Wahl-Clerici).

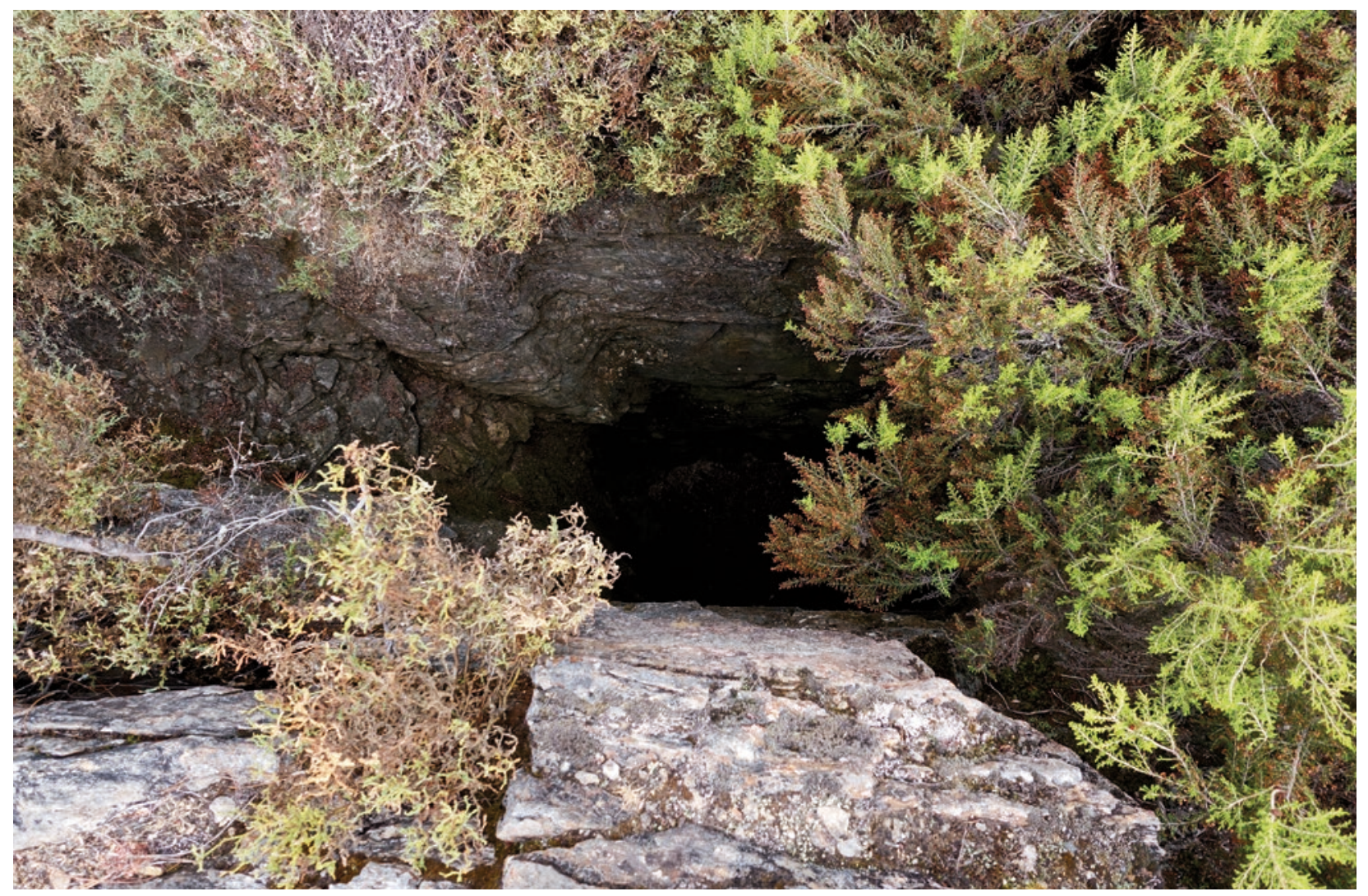

Fig. 3.0-28: Territorium metallorum Tresminas/Jales, Gralheira: é visível um poço, mais largo do que a zona de exploração posterior (fotografia: R. WahlClerici). 


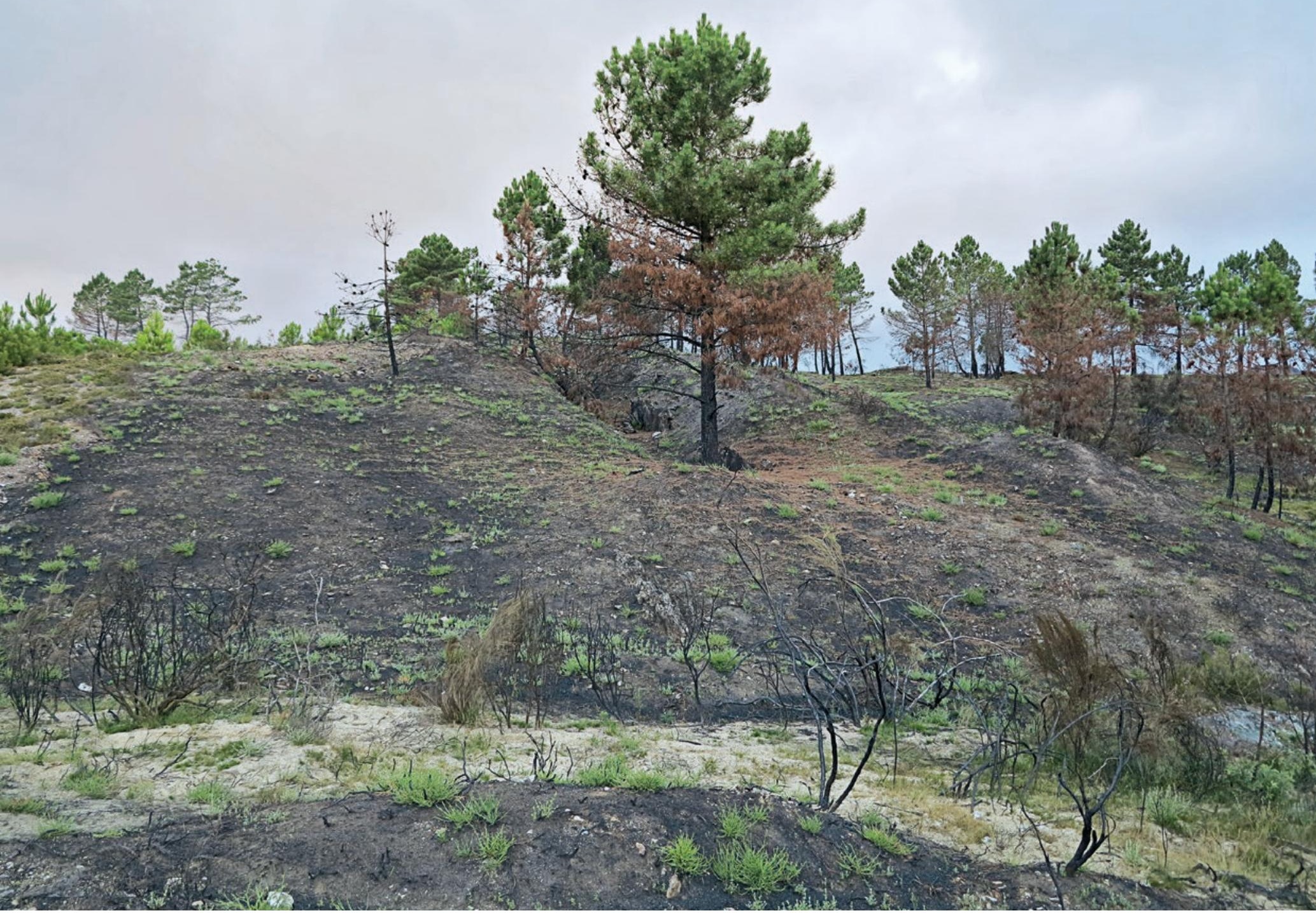

Fig. 3.0-27: Territorium metallorum Tresminas / Jales, Gralheira: zona de exploração mineira com os remanescentes das áreas de escavação e das escombreiras (fotografia: R. Wahl-Clerici). 


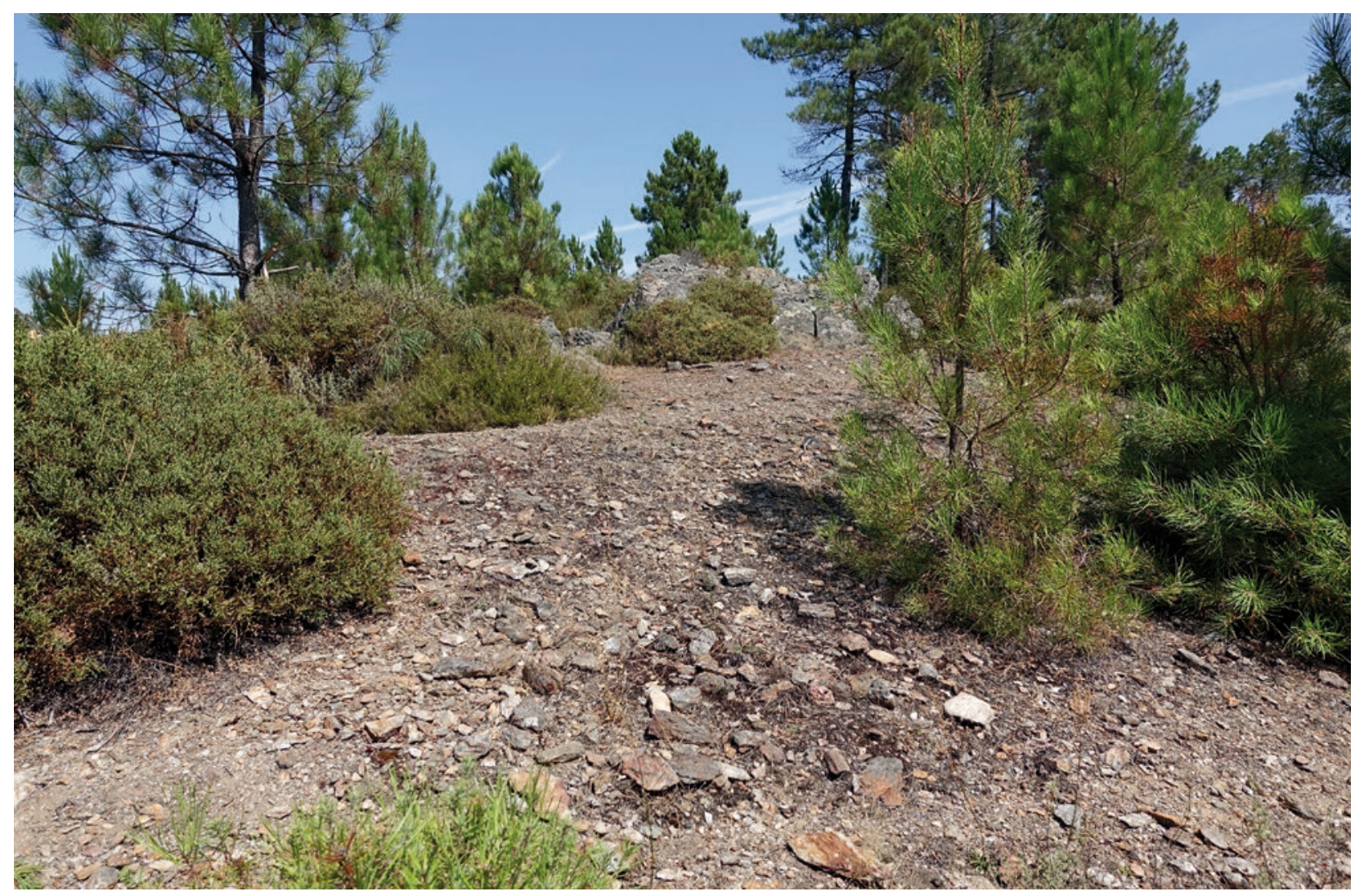

Fig. 3.0-29: Territorium metallorum Tresminas /Jales, Gralheira: escombreiras (fotografia: $R$. Wahl-Clerici).

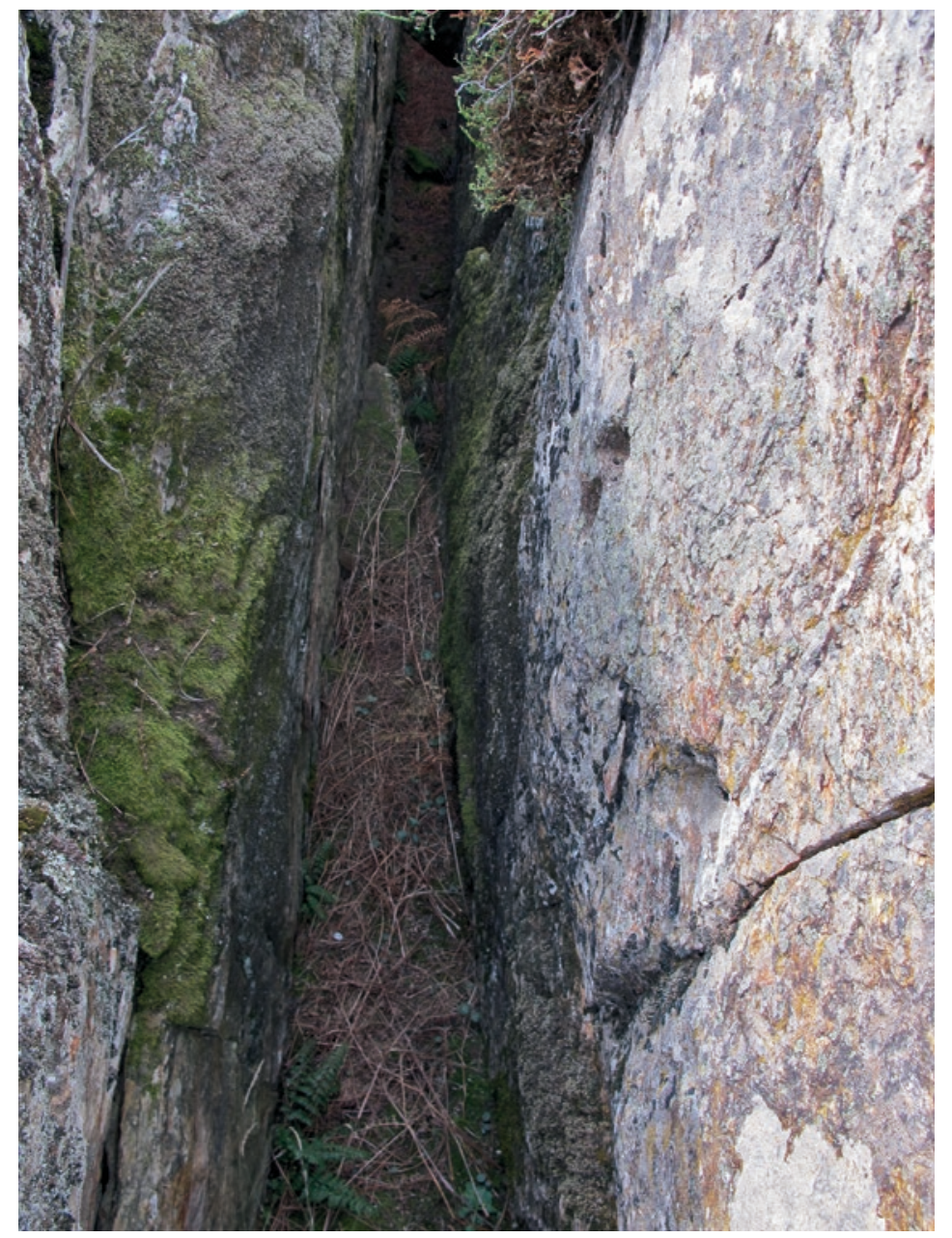

Fig. 3.0-30: Territorium metallorum Tresminas / Jales, Gralheira: zona de exploração mineira não totalmente colapsada com cavidades para fixação de estruturas de apoio em madeira (fotografia: $R$. Wahl-Clerici). 


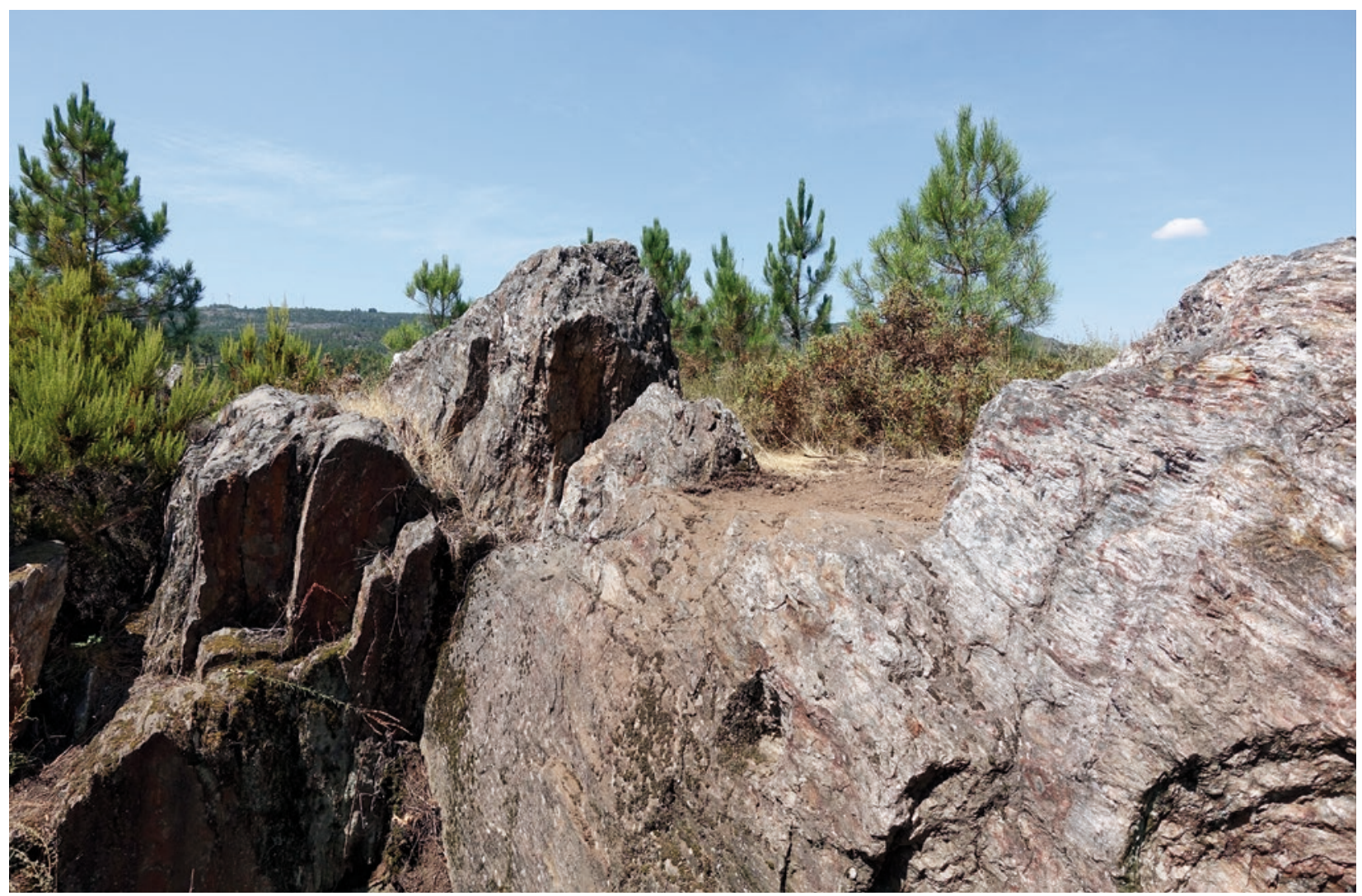

Fig. 3.0-31a: Territorium metallorum Tresminas /Jales, Gralheira: a antiga mina a céu aberto, completamente desmoronada, com os remanescentes de um acesso na parede norte. Visto de sudeste (fotografia: $R$. Wahl-Clerici).

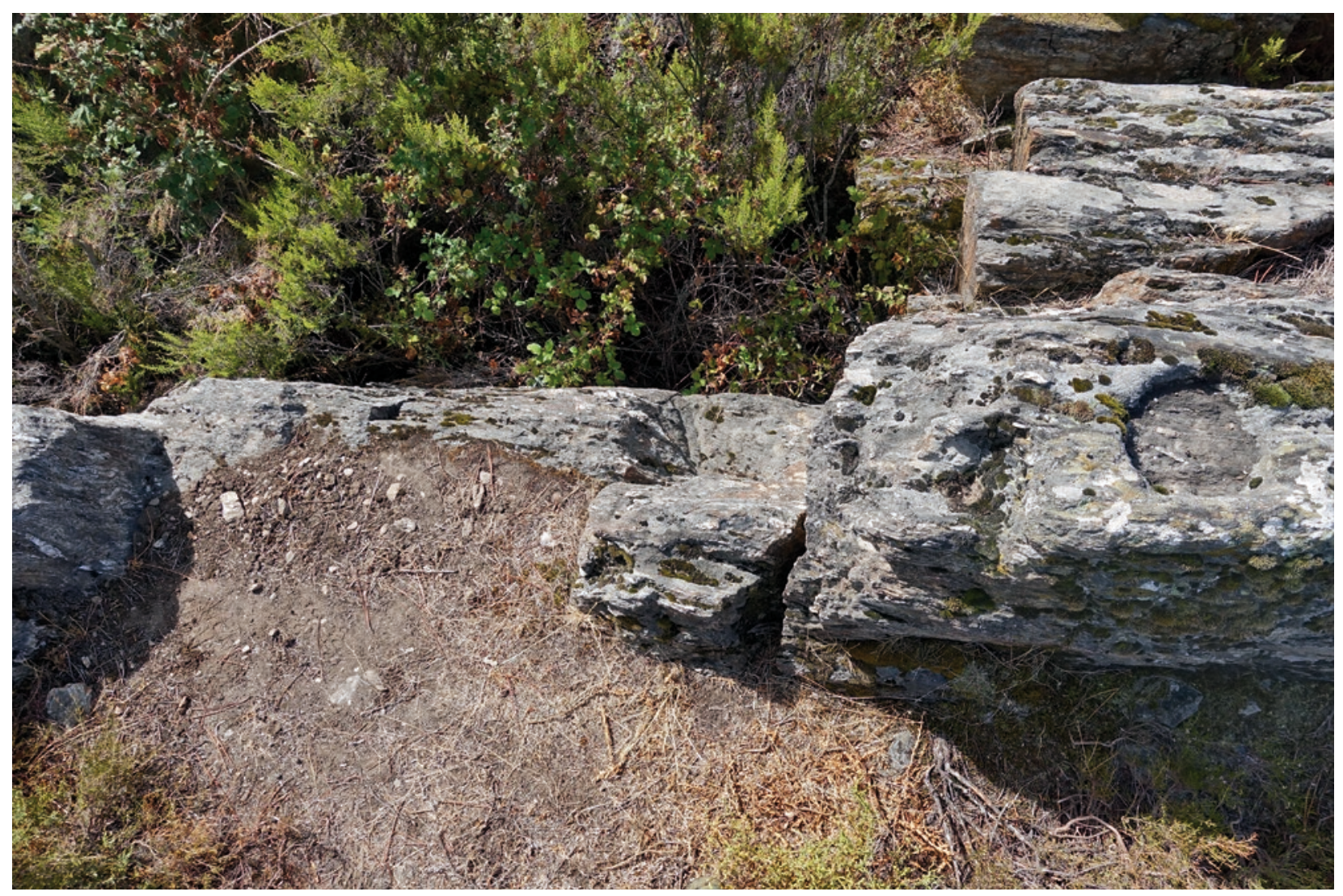

Fig. 3.0-31b: Territorium metallorum Tresminas /Jales, Gralheira: detalhe da Fig. 3.o-33a: vestígios da construção de uma porta? (fotografia: R. Wahl-Clerici). 


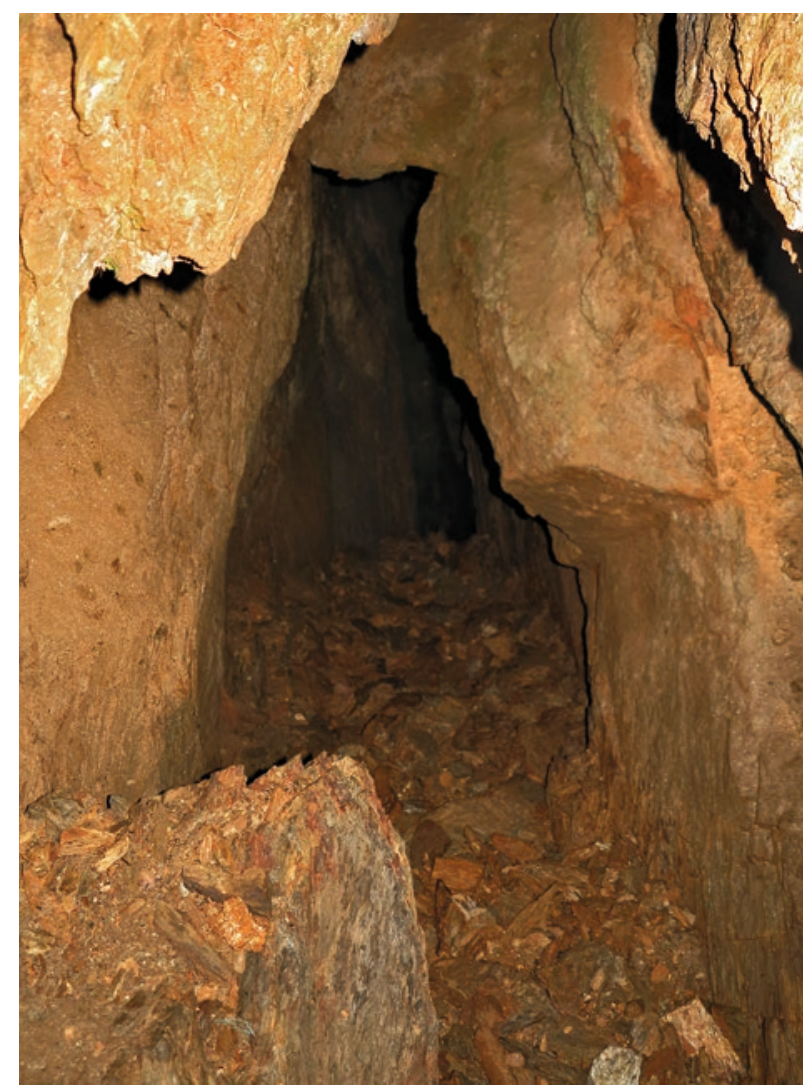

Fig. 3.0-32: Territorium metallorum Tresminas/Jales, Gralheira: zona de mineração completamente desmoronada (fotografia: $R$. Wahl-Clerici).

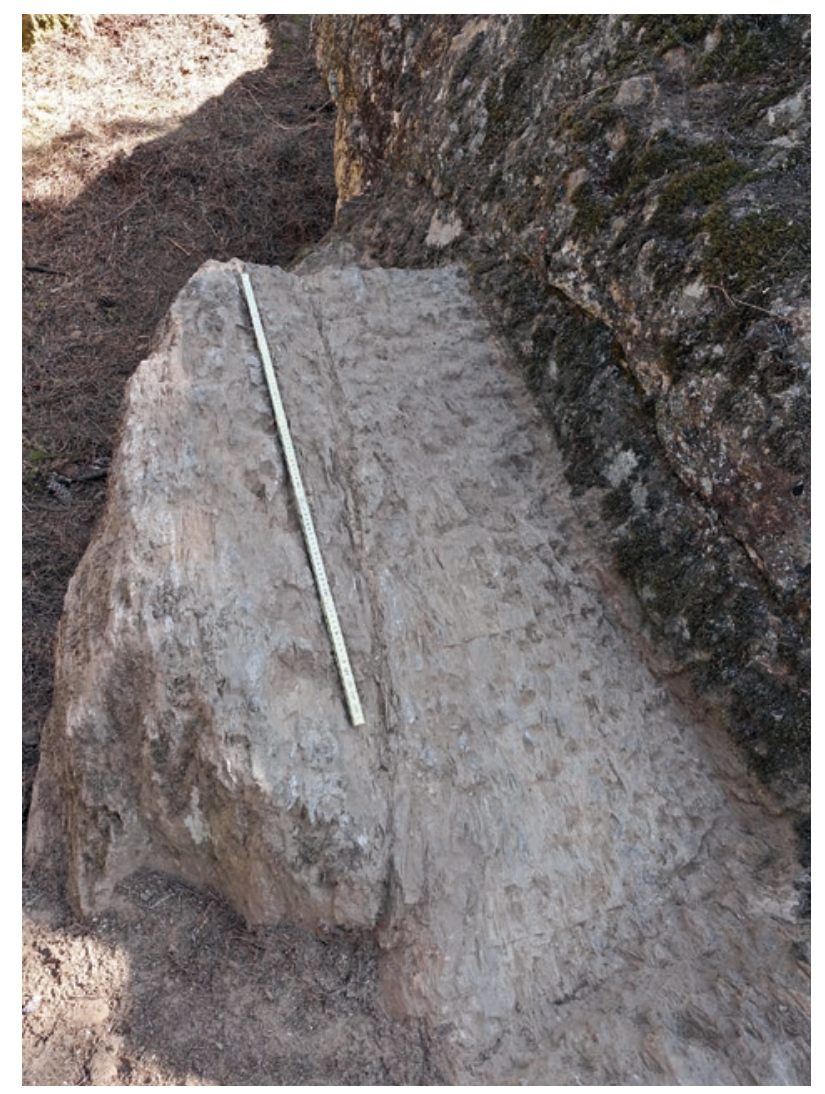

Fig. 3.0-33: Territorium metallorum Tresminas/Jales, Gralheira: rocha completamente explorada dentro da zona de mineração. Os vestígios de desmonte indicam que esta secção não era utilizada como zona de passagem (fotografia: M. Lindstaedt). 


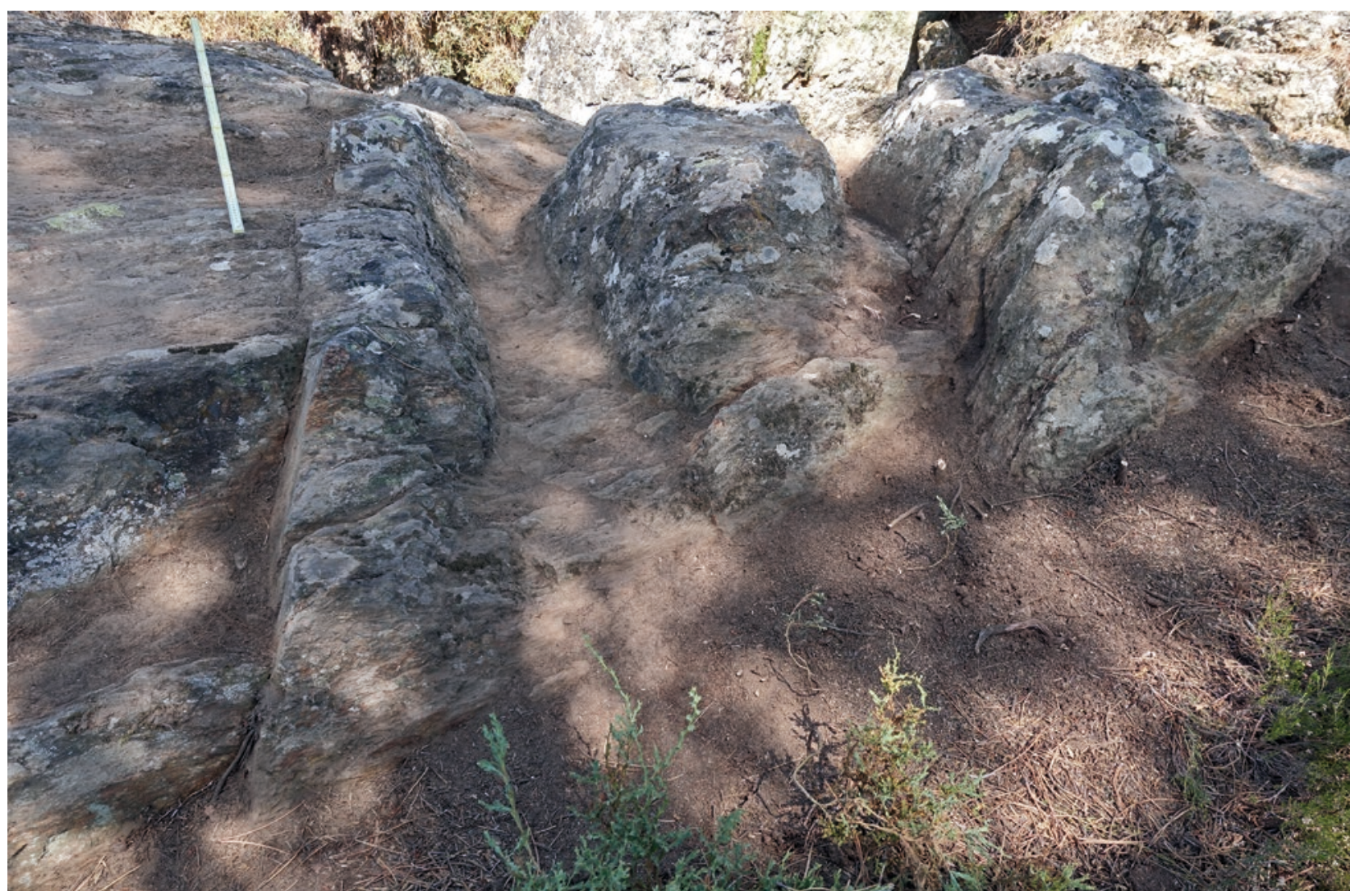

Fig. 3.0-34: Territorium metallorum Tresminas /Jales, Gralheira: pequenos canais, usados provavelmente para uma instalação na rocha aplanada (fotografia: M. Lindstaedt).

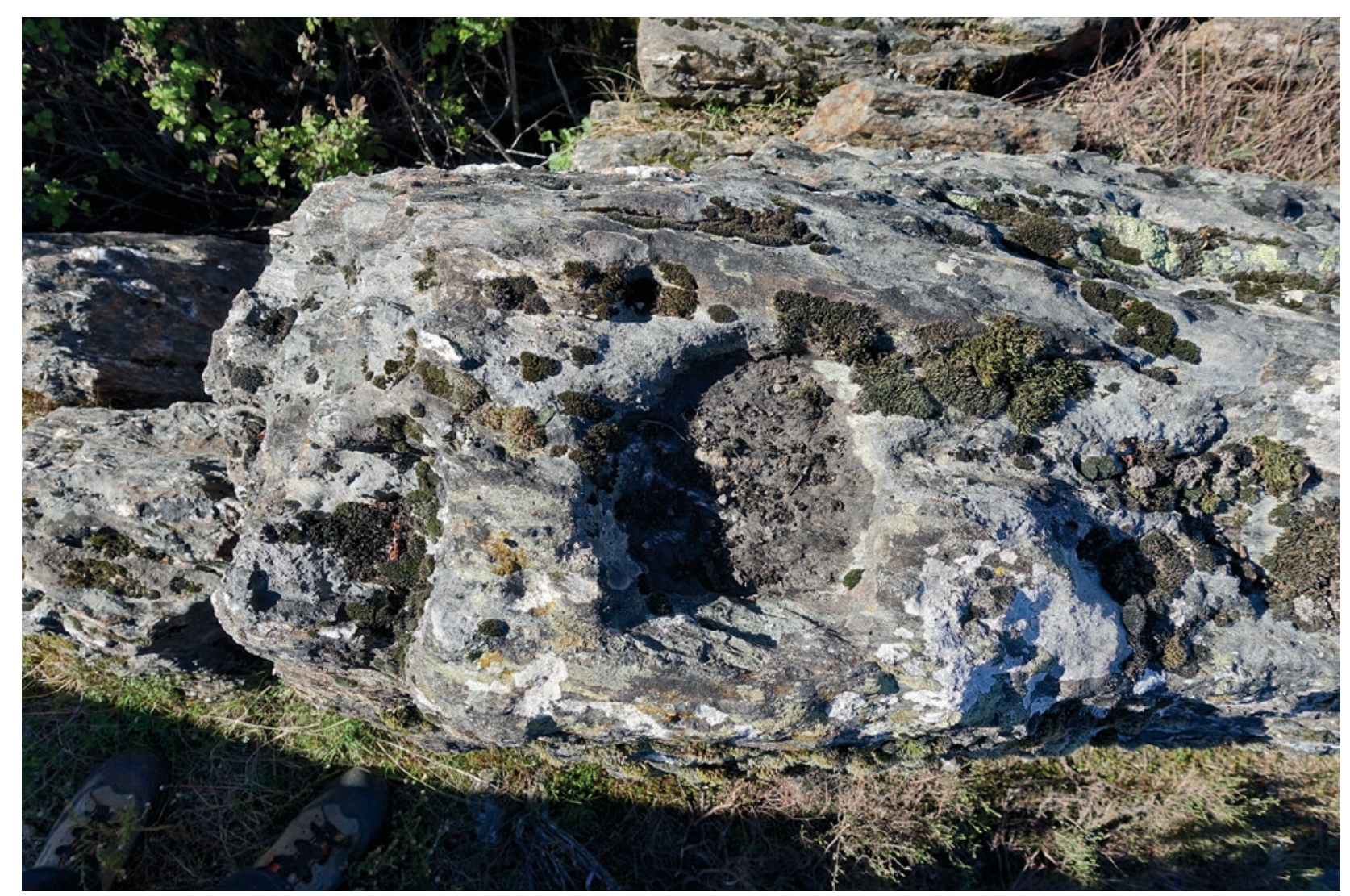

Fig. 3.0-35: Territorium metallorum Tresminas/Jales, Gralheira: cavidade na rocha para a fixação de uma estrutura (fotografia: R. Wahl-Clerici). 


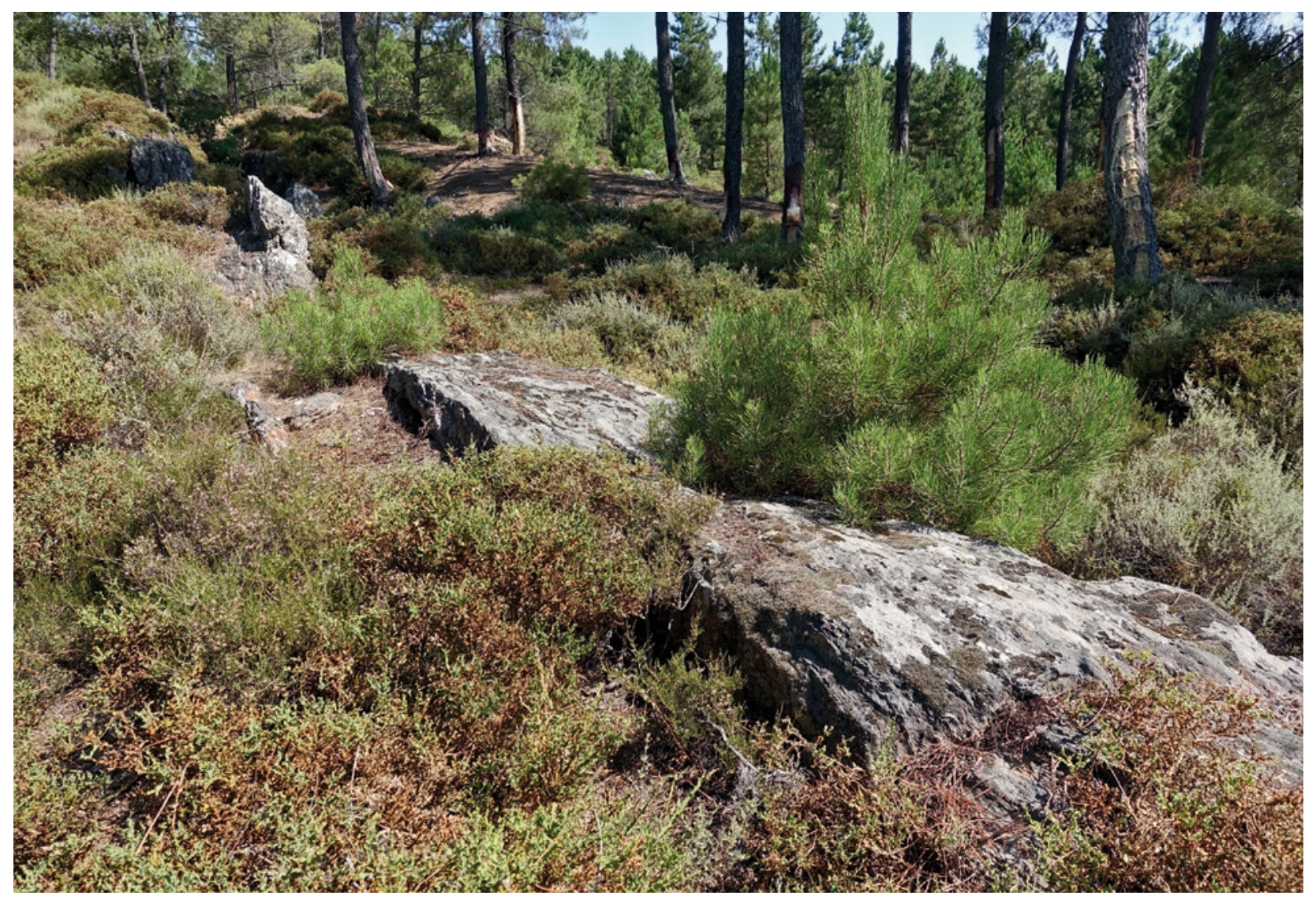

Fig. 3.0-36: Territorium metallorum Tresminas / Jales, Gralheira: vista sobre a rocha desmontada a norte da área de exploração, visivelmente aplanada e de função desconhecida (fotografia: R. Wahl-Clerici). 


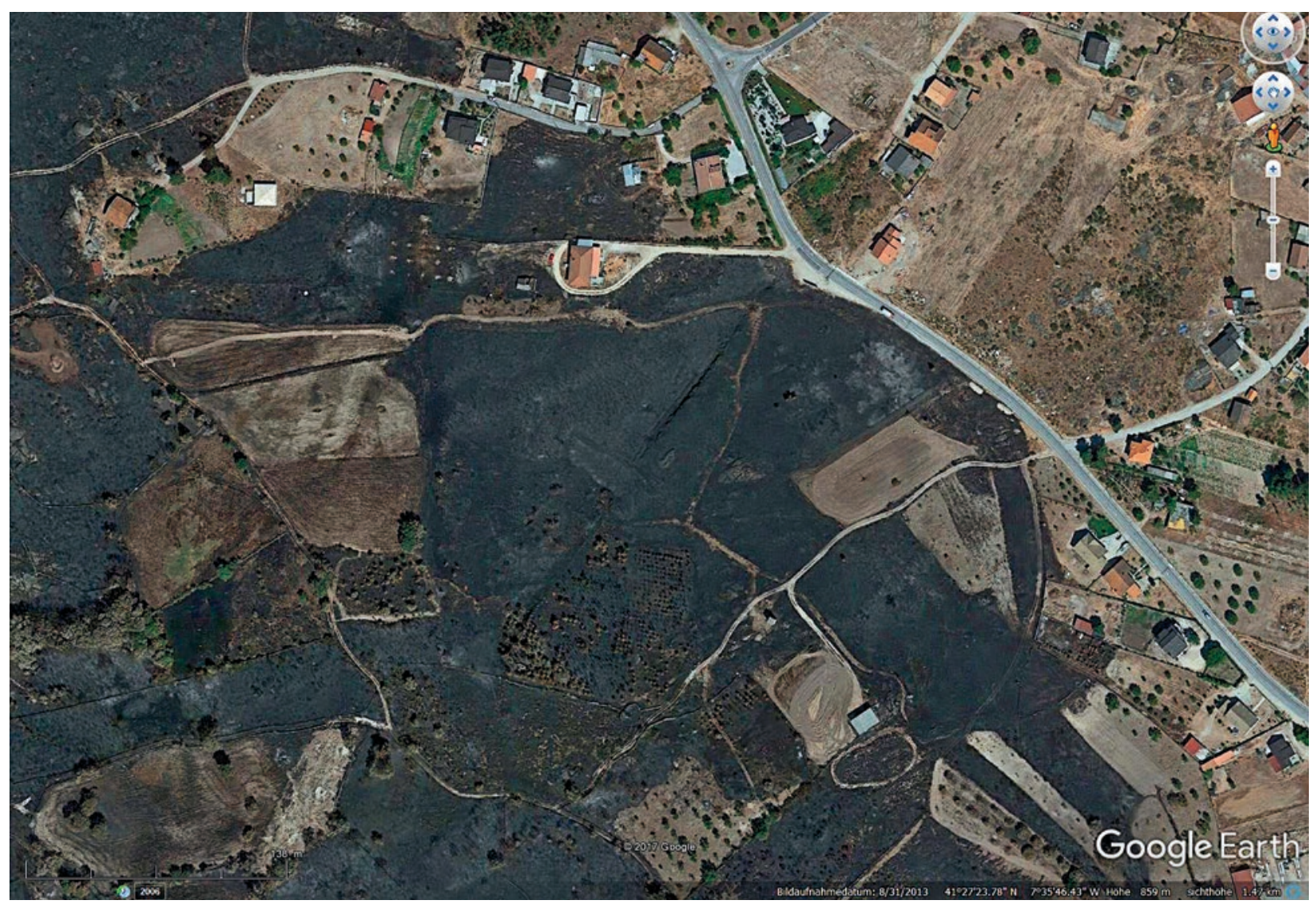

Fig. 3.0-37: Territorium metallorum Tresminas / Jales, Campo de Jales. a sudoeste da estrada de Vila Pouca de Aguiar para Murça (N212), é visível um último remanescente da mineração romana na jazida de Campo de Jales (Google Earth, registo fotográfico de 31.08.2013). 


\subsubsection{A zona mineira de Lagoinhos ${ }^{112}$}

Além das duas grandes minas a céu aberto, Corta de Covas e Corta da Ribeirinha, também foi extraído minério aurífero em Lagoinhos que, conforme os veios de xisto e as jazidas nele contido, se localiza a leste. Durante muito tempo, Lagoinhos foi considerada uma mina a céu aberto, todavia, apenas as investigações mais detalhadas dos últimos anos mostraram que toda a área foi explorada no subsolo (figs. 3.0.1-1, 3.0.1-2)

Através de novas e decisivas descobertas, levadas a cabo pelo grupo de espeleólogos do Alto Relevo, Clube de Montanhismo de Valongo (distrito do Porto / Portugal) durante as descidas de 2015 e 2016, foi possível alcançar zonas de mineração mais profundas que, embora conhecidas, nunca haviam sido percorridas (fig. 3.0.1-3).

As condições complexas de exploração em Lagoinhos e o desabamento da cobertura geológica ${ }^{113}$, juntamente com o desabamento parcial do talude a sudoeste, nas áreas superiores e subterrâneas de exploração, dão uma impressão desorganizada da área. A interpretação do avanço da exploração é dificultada pelos, no mínimo, quatro pisos distinguíveis na área subterrânea de exploração e pelas demais ruturas (figs. 3.0.1-2, 3.0.1-4-3.0.1-5a/b).

Basicamente, a zona de exploração de Lagoinhos pode dividir-se numa área a céu aberto e numa área subterrânea. Sem ajudas adicionais a mina é acessível ao longo de uma distância de cerca $90 \mathrm{~m}$ e uma largura máxima de 8,30m. A zona de exploração mais profunda foi percorrida pela primeira vez com maior rigor em 2015 e encontra-se ligeiramente deslocada para nordeste, em grande parte por baixo da área limitada sob a marcação do eixo $X-X^{\prime}$ nas figuras 3.0.1-4-3.0.1-10. O desvio da zona de exploração depende da inclinação da rocha "ganga» (rocha sem valor)- $85^{\circ} \mathrm{e}$ $70^{\circ}$, respetivamente, para nordeste (figs. 3.0.1-7, 3.0.1-10).

$\mathrm{Na}$ área de exploração de Lagoinhos é possível observar uma acumulação notável de construções de prospeção (figs. 3.0.1-11-3.0.1-14). Isto prova que essa jazida foi rigorosamente sondada em todas as direções, mesmo que os conteúdos exploráveis estivessem essencialmente limitados a uma zona de profundidade longa e bastante estreita, até então desconhecida (fig. 3.0.1-15). ${ }^{114}$

\section{A atual área de exploração a céu aberto}

Os vestígios das ferramentas mantiveram-se preservados sobretudo no talude a nordeste. Na maior parte dos casos não é possível seguir o seu rasto até à superfície da encosta, o que significa que o minério desta área era obtido através da exploração subterrânea, tendo resultado no colapso da cobertura geológica.

As figuras 3.0.1-13a/b mostram a situação no talude a nordeste. No lado esquerdo da imagem (fig. 3.0.1-13b), a seguir à primeira extremidade na rocha, é visível a abertura formada pelo cruzamento da exploração com um poço de prospeção mais antigo. À direita, vê-se nitidamente a zona com as marcas de picagem. Essa área encontra-se claramente separada pela antiga cobertura geológica. Aproximadamente a meio da imagem sobressai o grande declive. À sua direita, como abaixo do mesmo, continuam os vestígios de trabalho. $\mathrm{O}$ estado atual das investigações não nos permite ainda determinar se se trata de remanescências de uma ligação, nomeadamente, de uma estabilização entre duas zonas de extração.

\section{A área de exploração subterrânea}

O início desta zona de exploração é marcado pelo poço 1 (P1) com secção transversal alongada que, apesar de mudanças subsequentes devido à exploração e a desabamentos, pode ser percorrido a partir da superfície da mina até uma profundidade de cerca de $28 \mathrm{~m}$. Plínio já havia mencionado as abóbadas para melhorar a estabilidade (fig. 3.0.1-16). ${ }^{115}$ A parede sudeste deste poço, com as suas múltiplas extensões cuidadosamente picadas, é particularmente notável. Até hoje, a entrada para os pisos inferiores tem sido possível através deste poço, apesar da derrocada, isto é, «do desabamento do tecto geológico ou cobertura geológica na cova de mineração» ${ }^{116}$, que confere uma impressão do piso $1(\mathrm{~N}$ 1) fortemente distorcida (fig. 3.0.1-17).

O piso $1(\mathrm{~N}-1)$ continua com uma inclinação de cerca de $30 \mathrm{~m}$ no interior da montanha. É de salientar, sobretudo, a parede lateral a nordeste, onde são visíveis marcas de picagem até uma altura de pelo menos $5 \mathrm{~m}$ (fig. 3.0.1-10). A zona de exploração foi abandonada em vários níveis. $\mathrm{O}$ limite a sudeste é marcado pelo local de amostragem 174 . Por conseguinte, é possível identificar outros níveis mais ou menos acentuados, assim como o limite entre a zona de exploração e a parede lateral desabada a sudeste (fig. 3.0.117). O limite da zona de exploração é delineado por duas extremidades de exploração localizadas mais abaixo e em diferentes níveis, assim como por três linhas de prospeção (PR-2-4) ${ }^{117}$, que serviam para a sondagem da montanha em todas as direções (fig. 3.0.1-18).

Na zona de extração no piso (N-1), acessível a partir da atual área a céu aberto, concentram-se os locais de amostragem do Serviço de Fomento Mineiro do governo português,

112 Este capítulo é uma versão resumida do artigo de Regula Wahl-Clerici et al. 2017

113 Cobertura geológica: A montanha por cima de uma área de mineralização, Weisgerber 1985, 241.

114 Wahl-Clerici/Wiechowski 2013

115 Pliny, N.H. 33,71: relinquuntur itaque fornices crebri montibus sustinendis (As arcadas são frequentemente deixadas de pé para suportar as montanhas).

116 Weisgerber 1995, 240.

117 As estruturas de prospeção são descritas de forma diferente nas figs. 3.0.1-4 e 3.0.1-5. As estruturas de prospeção PR-1 correspondem a A2 e PR2 = L. Não existem mais sobreposições. 
hoje conhecido como Instituto Geológico e Mineiro. Este instituto realizou um trabalho de prospeção minucioso durante a década de 1980. As suas marcações em forma de quadrados vermelhos em torno dos locais de amostragem permaneceram visíveis até hoje. Os resultados obtidos para Lagoinhos são do nosso conhecimento. O Plano na figura 3.0.1-6 mostra que, com uma exceção, todas as amostras auríferas vêm da antiga zona de mineração, sendo que os geólogos não fazem distinção entre as áreas de exploração propriamente ditas e as zonas de derrocada.

As condições são particularmente complexas na área dos pisos mais profundos, nomeadamente, 2, 3 e $4(\mathrm{~N}-2$, $\mathrm{N}-3, \mathrm{~N}-4)$ (figs. 3.0.1-4, 3.0.1-10, 3.0.1-15), acessíveis apenas através do poço 1 (P-1). A grande cova que vemos hoje foi criada durante a expansão da exploração vinda de cima. É de salientar ainda que, ao percorrer a área leste do piso 3 (N$3)$, verificou-se a existência de, pelo menos, mais um acesso através de um poço interior (P-3?) ${ }^{118}$ entre os pisos 1 e 2 (N1, $\mathrm{N}-2$ ). Os remanescentes de uma linha de prospeção (PR-6), assim como um desnível na superfície lateral ${ }^{119}$ sudeste são indicações da continuação do piso antigo (N-3) e confirmam o nível anterior de extração ainda presente na parte sudeste (N-3). Na extremidade sudeste são visíveis vestígios de um poço (P-4?).

O piso mais fundo ( $\mathrm{N}-4)$ está fortemente assoreado e encontra-se parcialmente abaixo do nível da água que se acumula nesta zona devido à falta de escoamento, uma vez que a água apenas pode escoar através das pequenas fissuras no xisto (figs. 3.0.1-2, 3.0.1-5a / b , 3.0.1-15). ${ }^{120}$ Pode assumir-se que os romanos garantiam a drenagem através de instalações artificiais de elevação de água. ${ }^{121}$

As linhas pontilhadas no mapa geral (fig. 3.0.1-4) indicam possíveis zonas de exploração, não se descartando a possibilidade de as duas áreas de entrada dos poços 1 (P-1) e 2 (P-2) se localizarem no exterior.

As montanhas foram exploradas em direção a nordeste com ajuda da bem desenvolvida linha de prospeção PR-5 (fig. 3.0.1-12).

As escombreiras acumuladas a norte da zona de exploração são notavelmente pequenas em relação às das minas a céu aberto Corta de Covas e Corta da Ribeirinha (fig. 3.0.1-19). Em Lagoinhos também é notável a ausência de fragmentos de moinhos de pilão e moinhos de minério, tal como foram encontrados em massa nas outras áreas de exploração e zonas de processamento. Embora a maior parte dos moinhos de pilão e moinhos de minério tivessem muito provavelmente sido transportados para a Ribeirinha, era possível assumir-se que ainda restassem alguns fragmentos nesta área. Assim sendo, é de notar que ainda não nos é possível afirmar onde era preparado o material de exploração em Lagoinhos ${ }^{122}$.

\section{Resultados}

Esta breve visão geral sobre os novos resultados obtidos em Lagoinhos vem complementar o conhecimento sobre a mineração romana no territorium metallorum Tresminas / Jales, que até então se tem baseado particularmente nas grandes minas a céu aberto em Tresminas. Por conseguinte,

- Lagoinhos era exclusivamente uma mina subterrânea;

- além do material local não era necessário extrair praticamente qualquer material estéril;

- o processamento ocorria excecionalmente fora do local.

118 Poço interior: Um eixo de conexão vertical dentro da mina que liga dois ou mais pisos, Weisgerber 1985, 240.

119 Superfície lateral: Parede lateral de uma cavidade de exploração, Weisgerber 1985, 242.

120 Os membros do grupo de Alto Relevo entraram neste poço em setembro 2015, em outubro de 2016, em setembro de 2017.

121 Domergue 1990, 440—460.

122 Wahl-Clerici 2012a; Wahl-Clerici / Helfert 2017. 

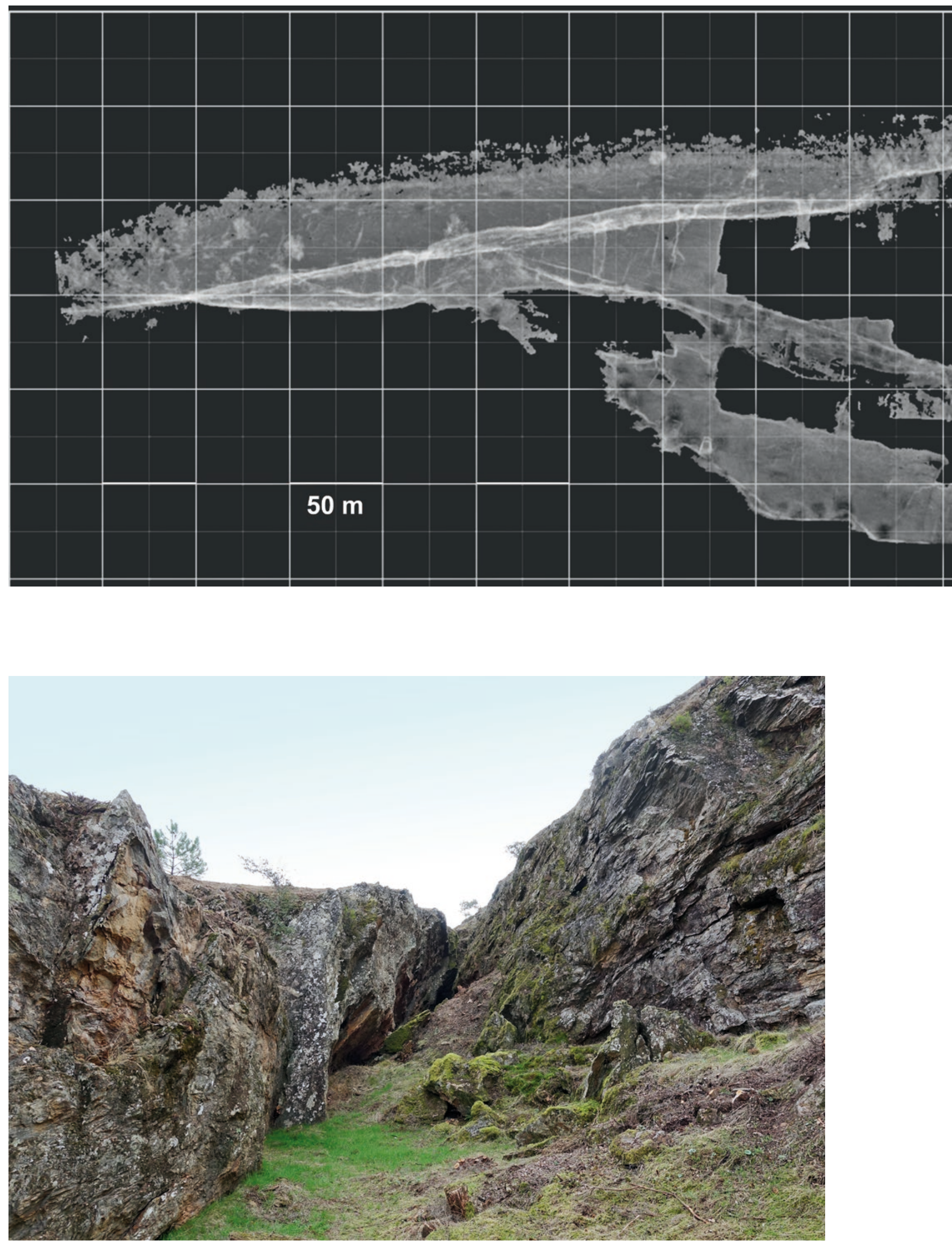


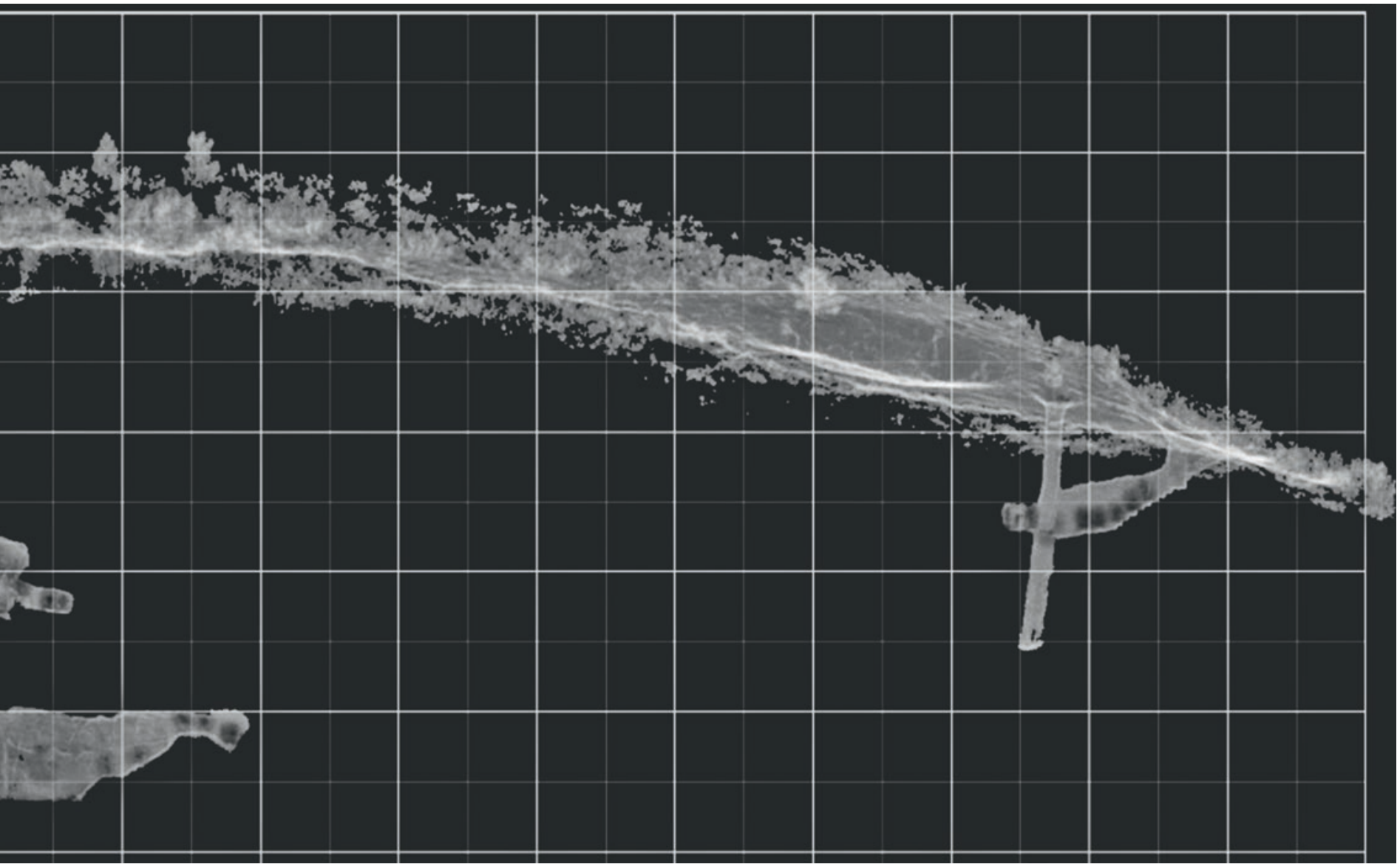

Fig. 3.0.1-2: Territorium metallorum Tresminas/Jales, Tresminas, visão geral sobre a mina romana de Lagoinhos e a prospeção a leste (figs.2.0-23, 2.0-24), Y-Y' marca a seç̧ão na fig.3.0.1-6 (digitalização e desenho: K.Mechelke, M.Lindstaedt). 


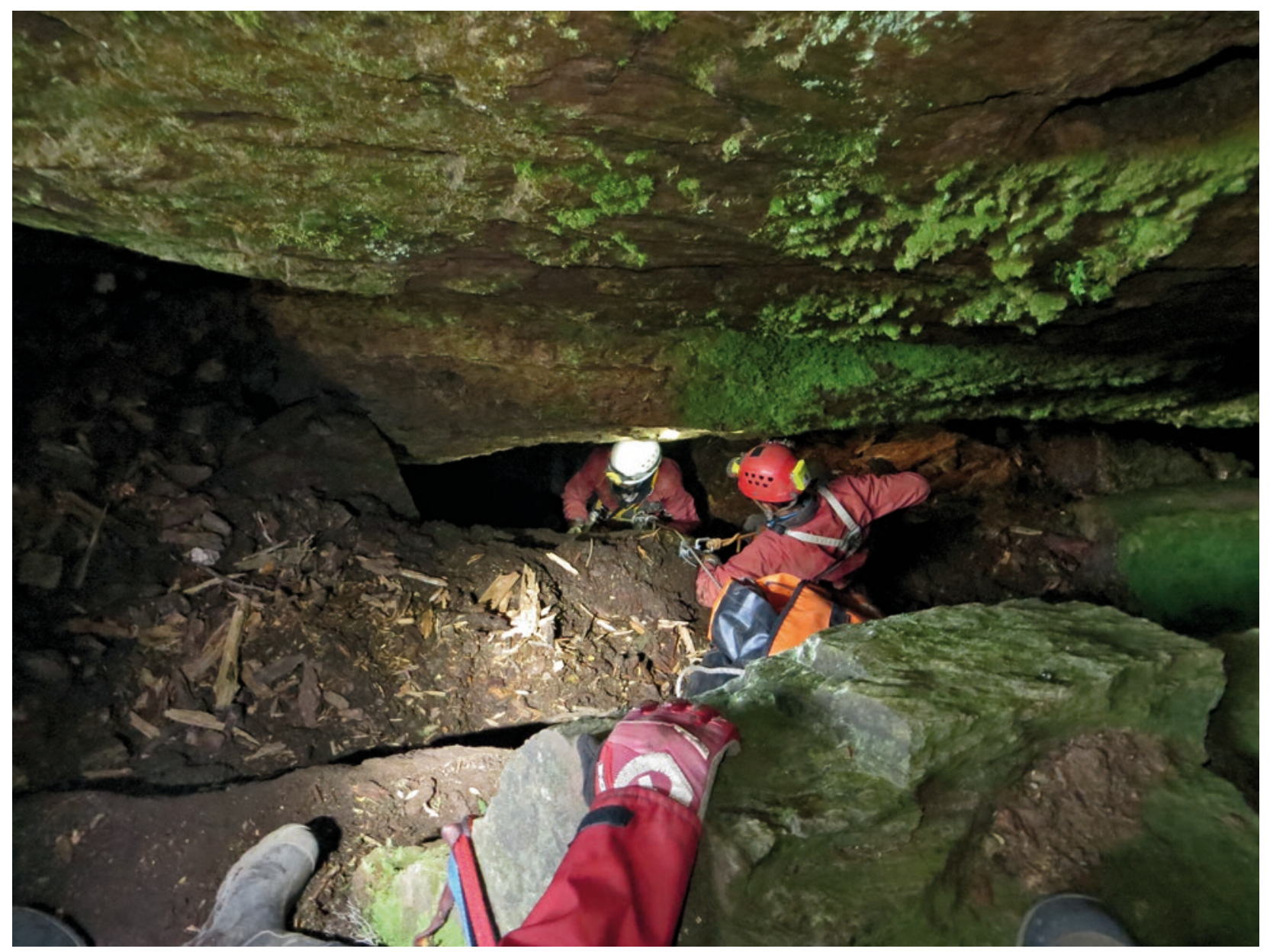

Fig. 3.0.1-3: Territorium metallorum Tresminas/Jales, Tresminas, Lagoinhos: entrada para a área subterrânea através do poço P1 (fotografia: R. Wahl-Clerici). 

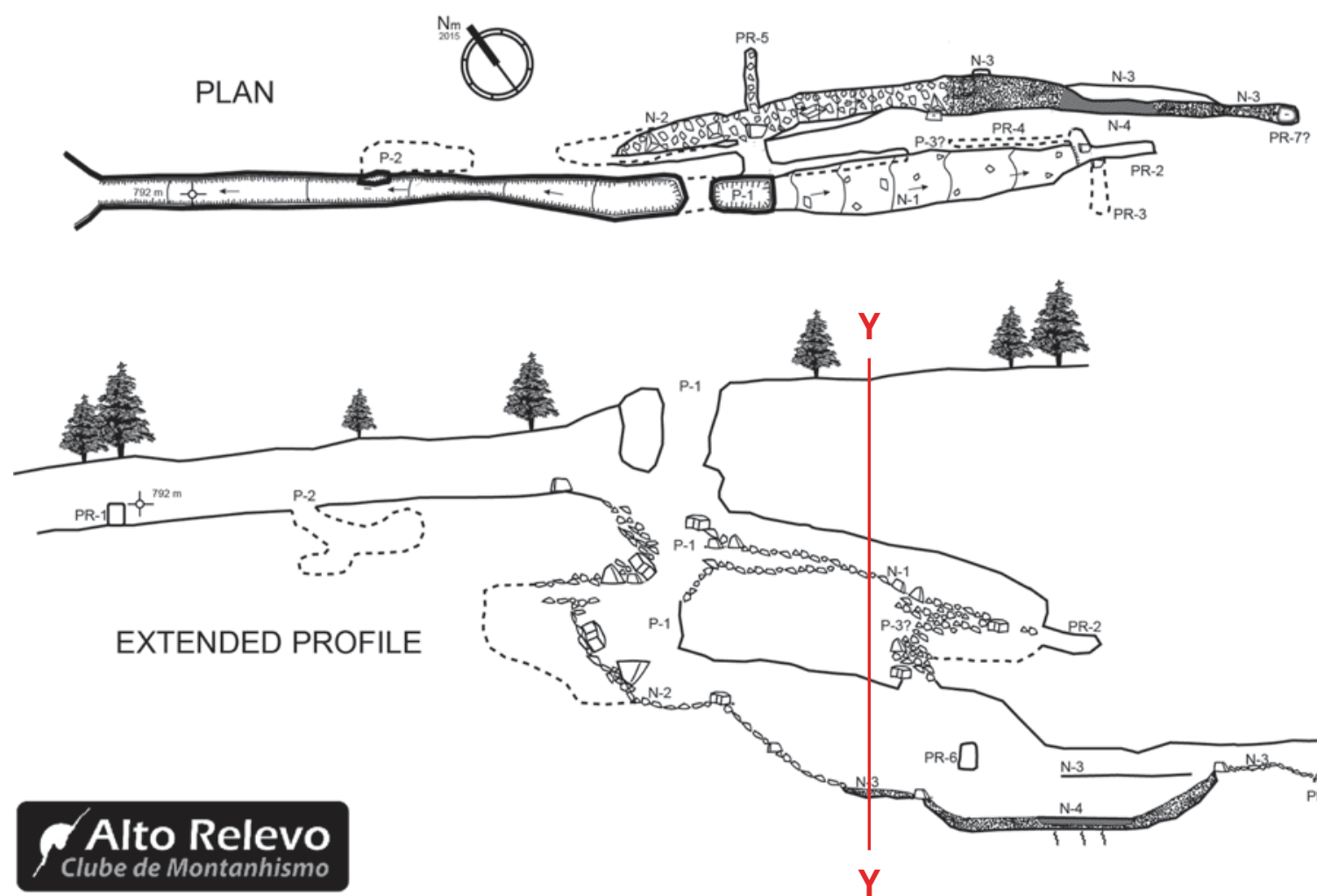

www.altorelevo.org

Corta de Lagoinhos

N 41,493278 W -7,515167 (WGS84)

Vila Pouca de Aguiar - Portugal

Cavity ID: id292

Development: $121 \mathrm{~m}$

Topographic team:Carlos Mendes, Hugo Santos, João

Moutinho, Luis Sousa, Vitor Gandra

Topography date: 30 Ago 2015

Equipment: Disto $\mathrm{A} 3(\mathrm{x})$ Leica

Final drawings: Vítor Gandra
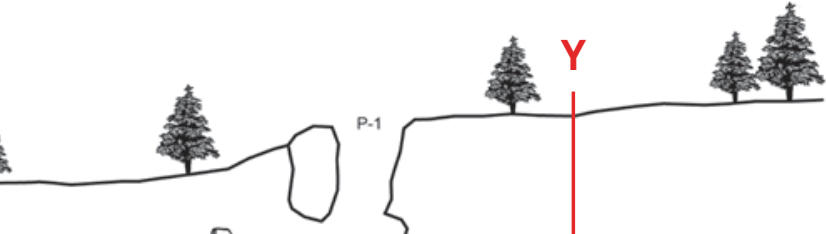

ILE

Fig. 3.0.1-4: Territorium metallorum Tresminas / Jales, Tresminas, Lagoinhos: planta do piso (superior) e esboço do contorno (fundo) de Lagoinhos com indicação dos poços (P) e estruturas de prospeção (PR). Y- Y marca a secção nas figs. 3.0.1-6 and 3.0.1-7 (registo: V. Gandra/J. Moutinho, ARCM Valongo; execução: V.Gandra/R. Wahl-Clerici). 


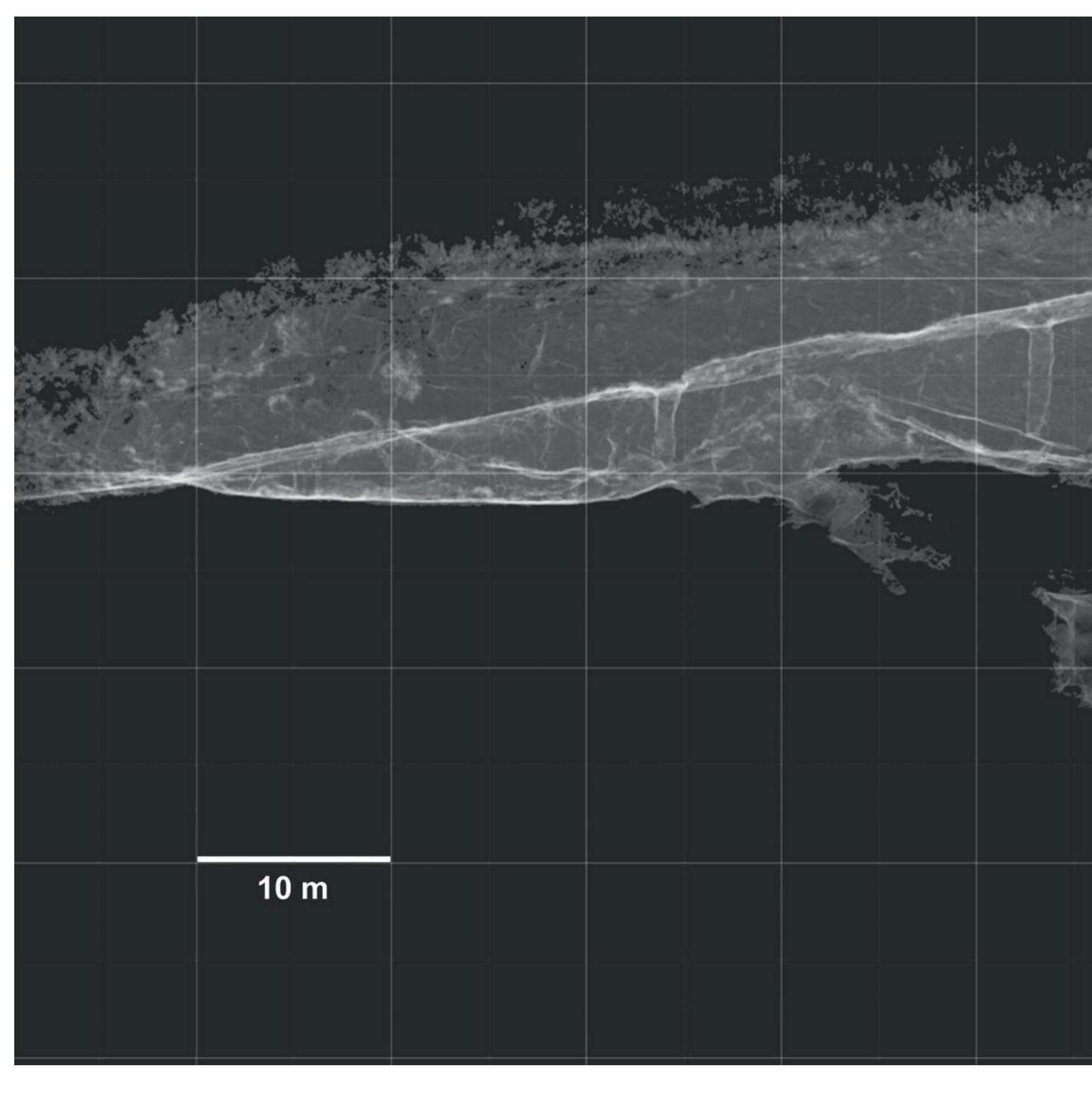




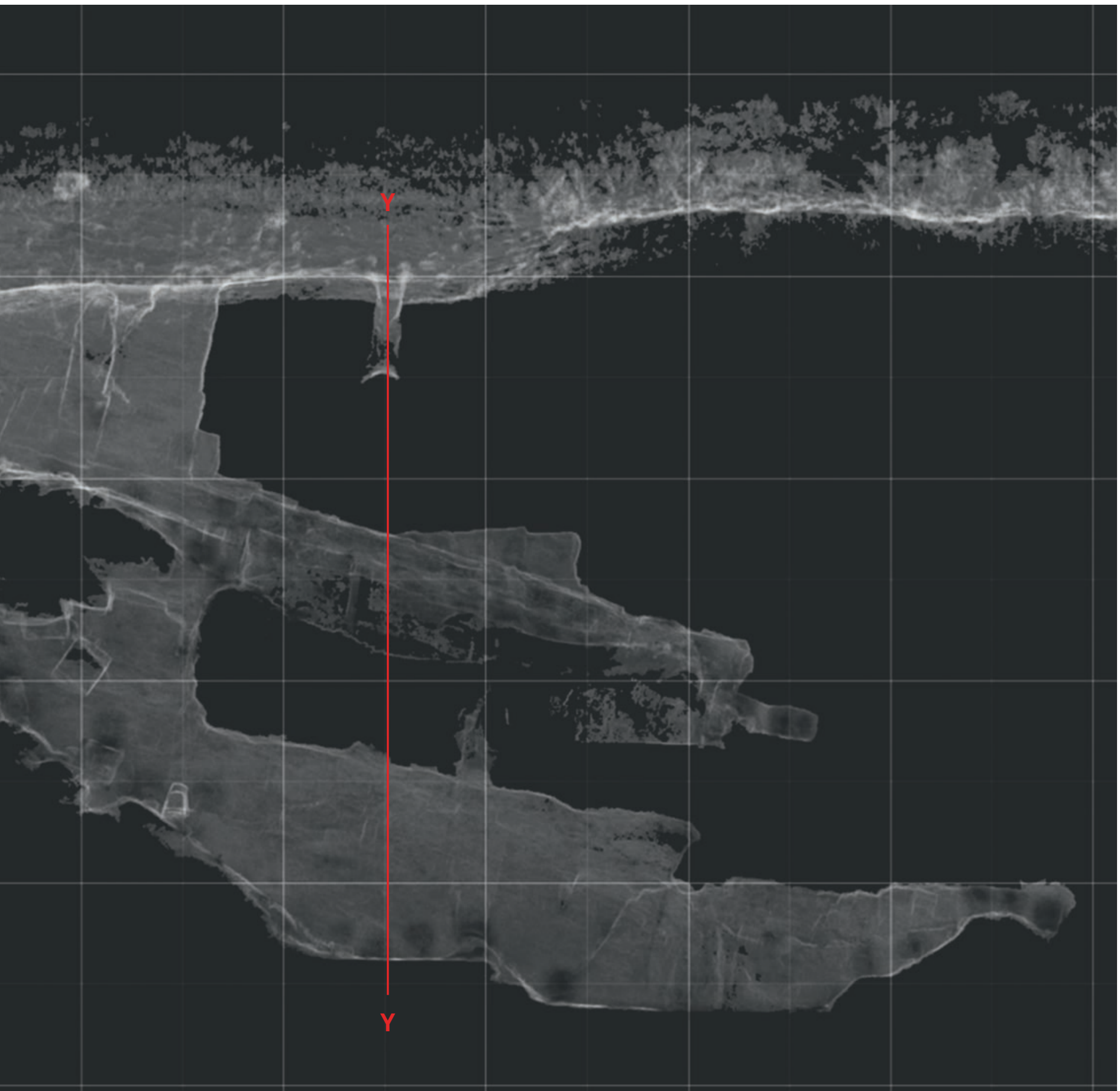

Fig. 3.0.1-5a: Territorium metallorum Tresminas/Jales, Tresminas, Lagoinhos: a parte da exploração mineira romana, Y - Y marca a secção nas Figs.3.0.1-6 e 3.0.1-7 (digitalização e desenho: K.Mechelke, M.Lindstaedt). 


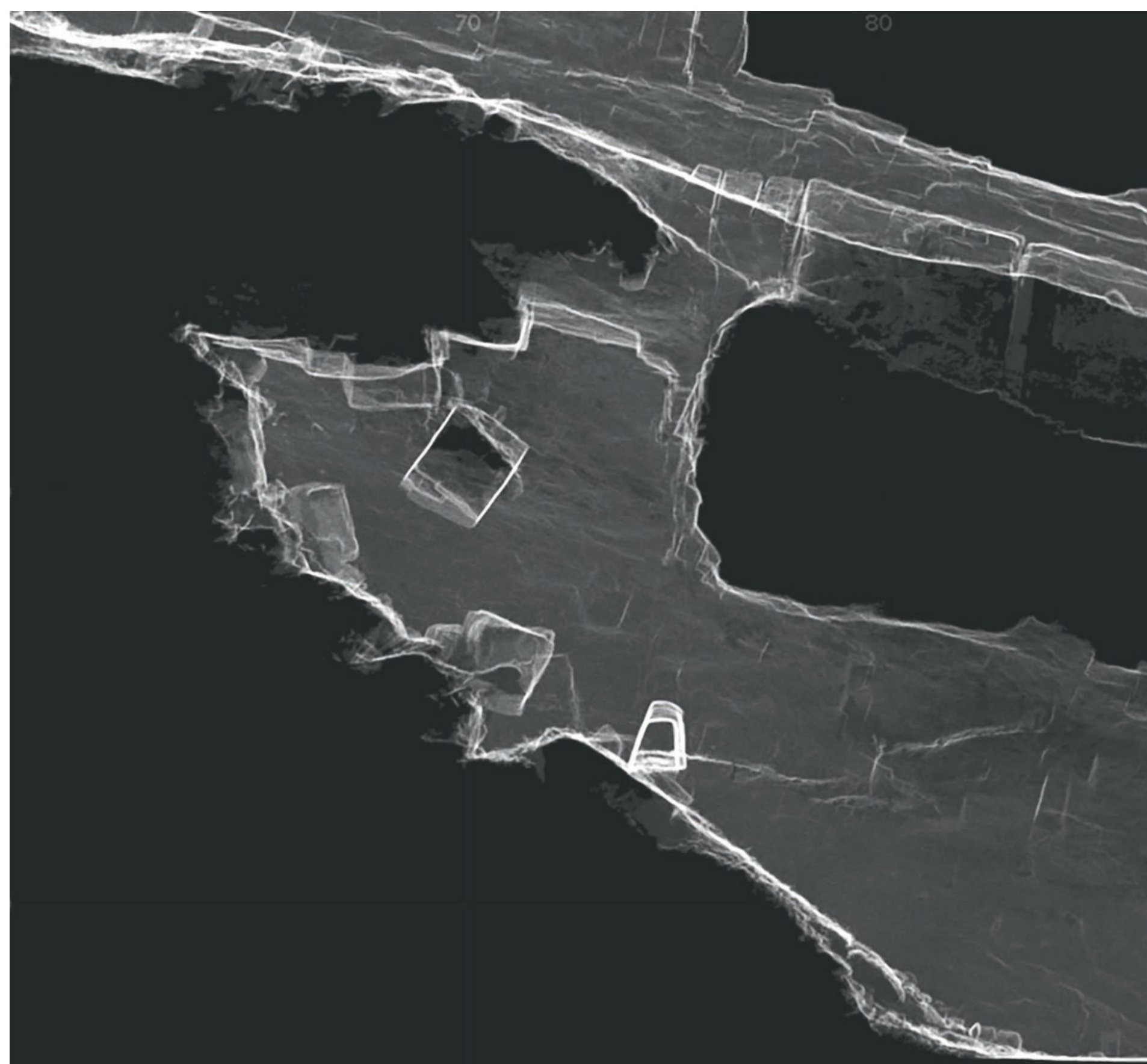




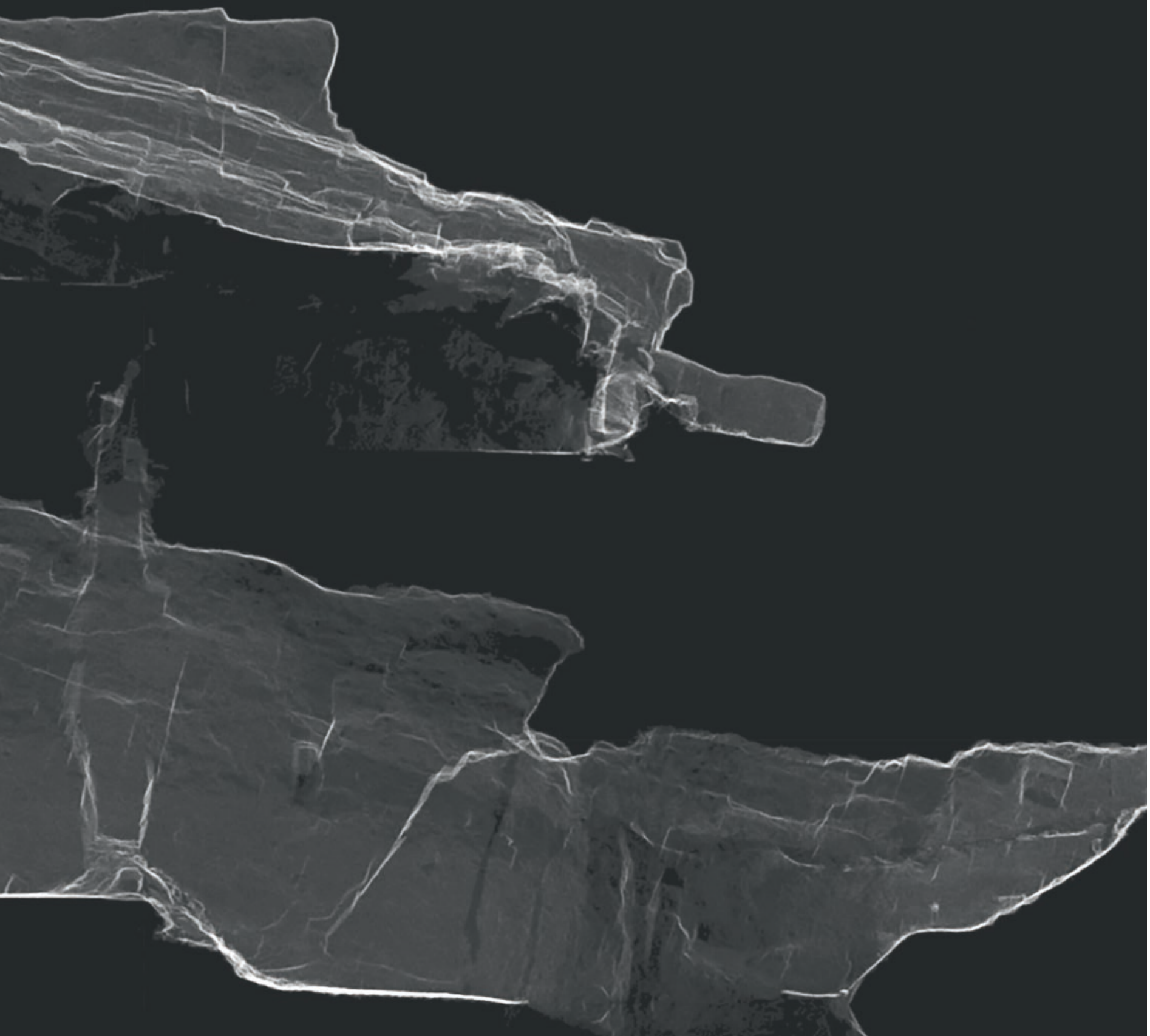

Fig. 3.0.1-5b: Territorium metallorum Tresminas / Jales, Tresminas, Lagoinhos: seç̧ão longitudinal da parte central da mina romana (detalhe da fig.3.0.1-5a). As várias prospeçães e as estruturas do xisto são bem visíveis (digitalização e desenho: K.Mechelke, M.Lindstaedt). 


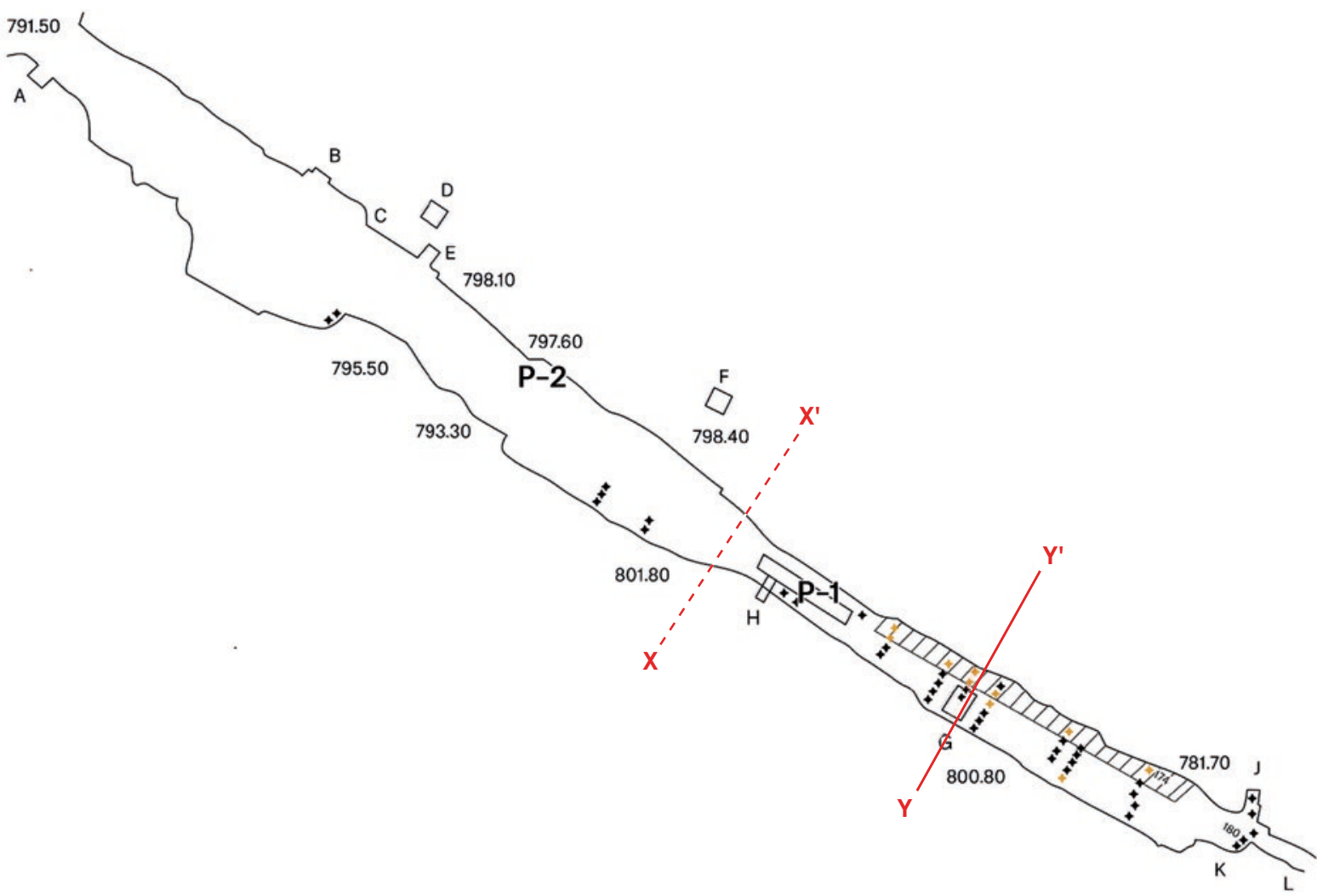

Fig. 3.0.1-6: Territorium metallorum Tresminas/Jales, Tresminas, Lagoinhos: plano da zona mineira de Lagoinhos. Sombra: a zona mineira romana. Os vestígios do trabalho de prospeção romana e os poços P-1 e P-2 (cf. Fig.3.0.1-4) estão registados. Os pontos de amostragem estão marcados com asteriscos, os que contêm ouro estão marcados a amarelo. As amostras 147 e 174 encontram-se destacadas devido ao seu elevado teor em ouro. X- X' marca o limite entre a parte a céu aberto e a parte subterrânea, Y- Y' marca a secção na fig.3.0.1-6 (modelo Serviço de Fomento Mineiro, execução, R.Wahl-Clerici).

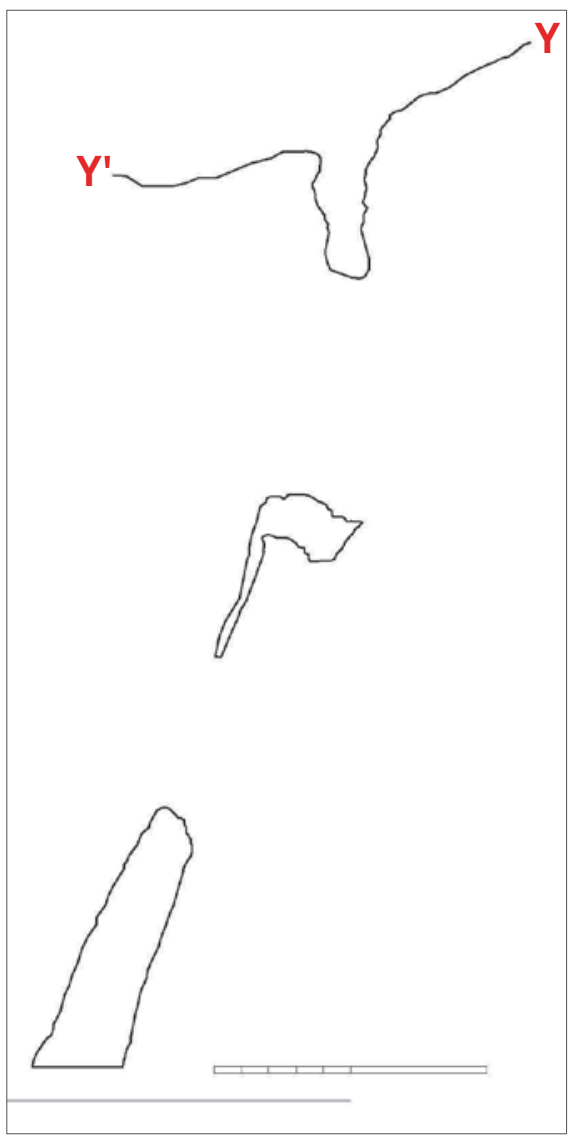

Fig. 3.0.1-7: Territorium metallorum Tresminas / Jales, Tresminas, secção Y- $Y^{\prime}$ de Lagoinhos (digitalização e desenho: K.Mechelke e M.Lindstaedt). 


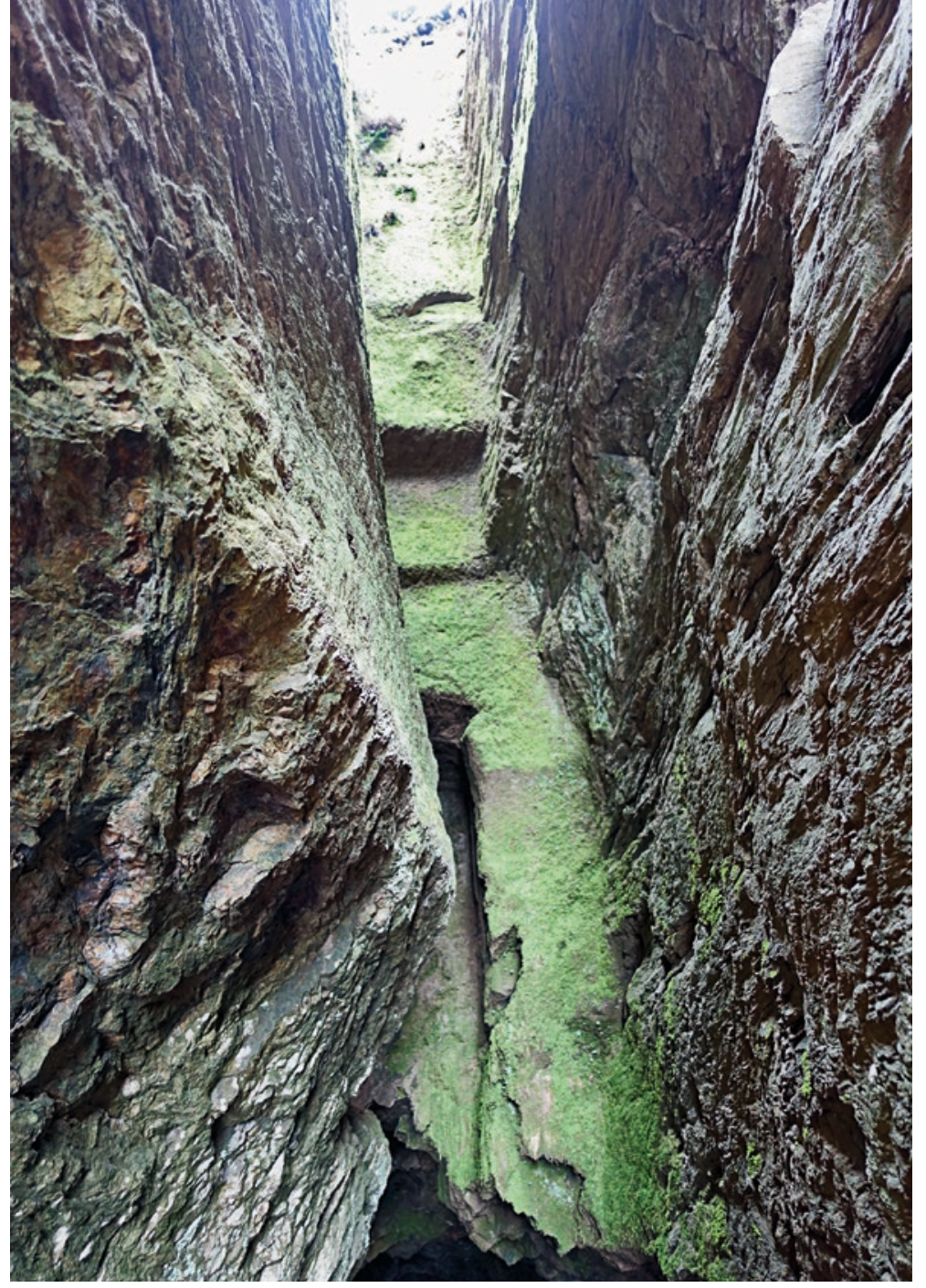

Fig. 3.0.1-8: Territorium metallorum Tresminas /Jales, Tresminas, Lagoinhos: transição entre a área de mineração a céu aberto e a subterrânea. Nesta zona, existe um número impressionantemente grande de cortes que foram feitos para a inserção de apoios em madeira para a segurança da mina. Vista de oeste (fotografia: R.Wahl-Clerici).

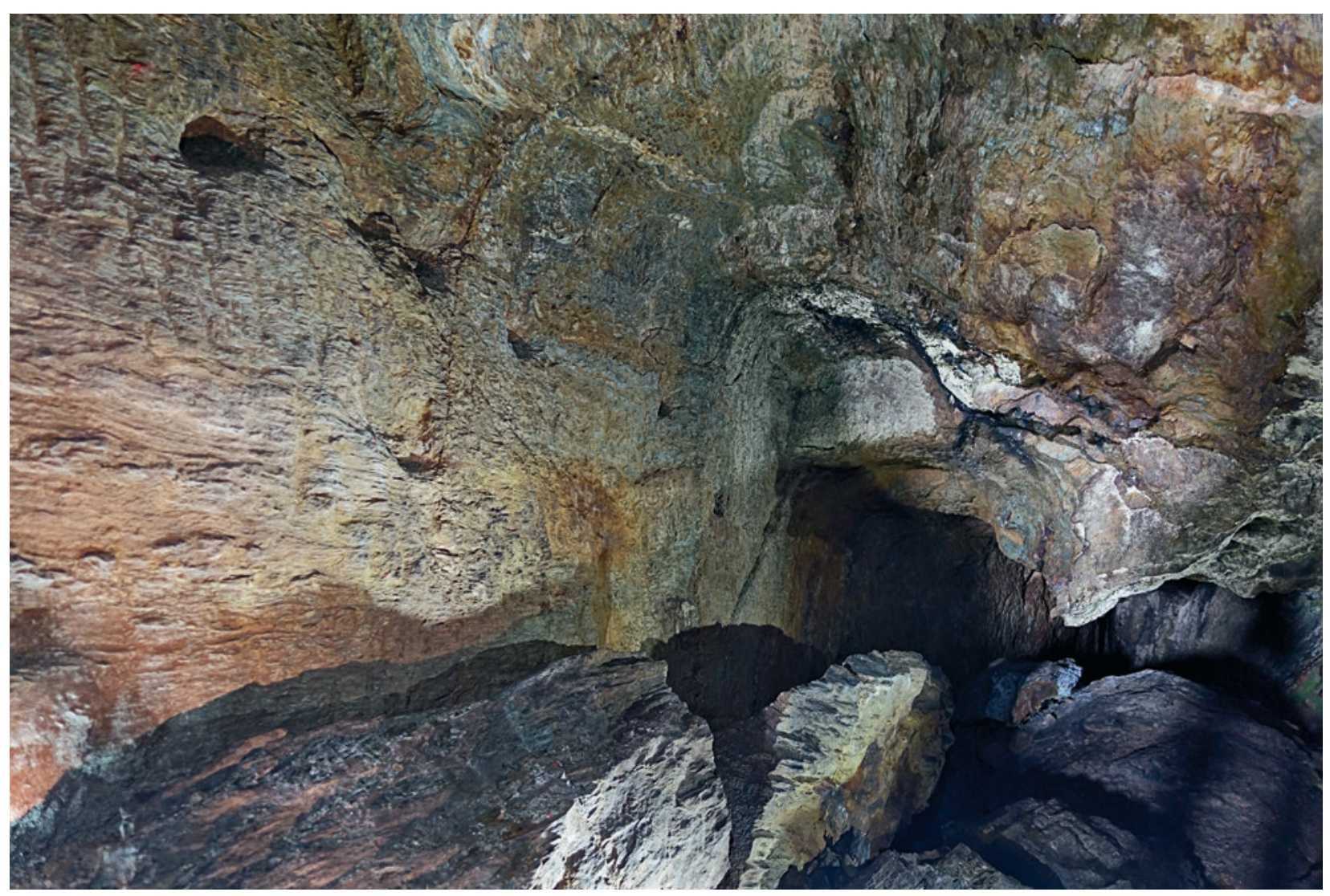

Fig. 3.0.1-9: Territorium metallorum Tresminas/Jales, Tresminas, Lagoinhos: zona de extração bem preservada com marcas de ferramentas e nichos para as lucernas na parede norte-nordeste (fotografia: R.Wahl-Clerici). 


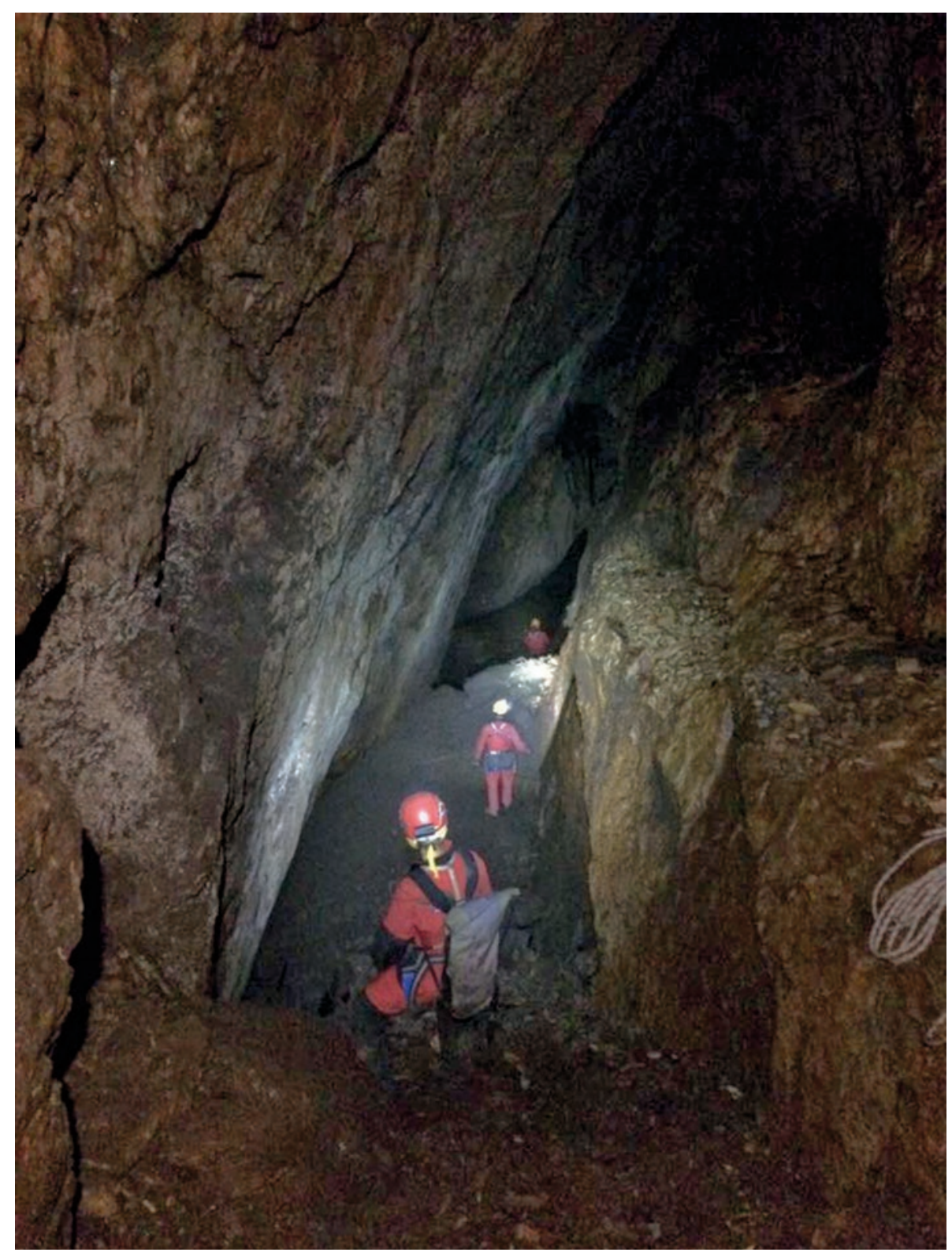

Fig. 3.0.1-10: Territorium metallorum Tresminas/Jales, Tresminas, Lagoinhos: vista de oeste para a zona de mineração subterrânea. Nas figs.3.0.1-4, 3.0.1-5 as pessoas encontram-se entre $\mathrm{N}-2$ e N-3 (fotografia: J. Moutinho/ACRM Valongo). 


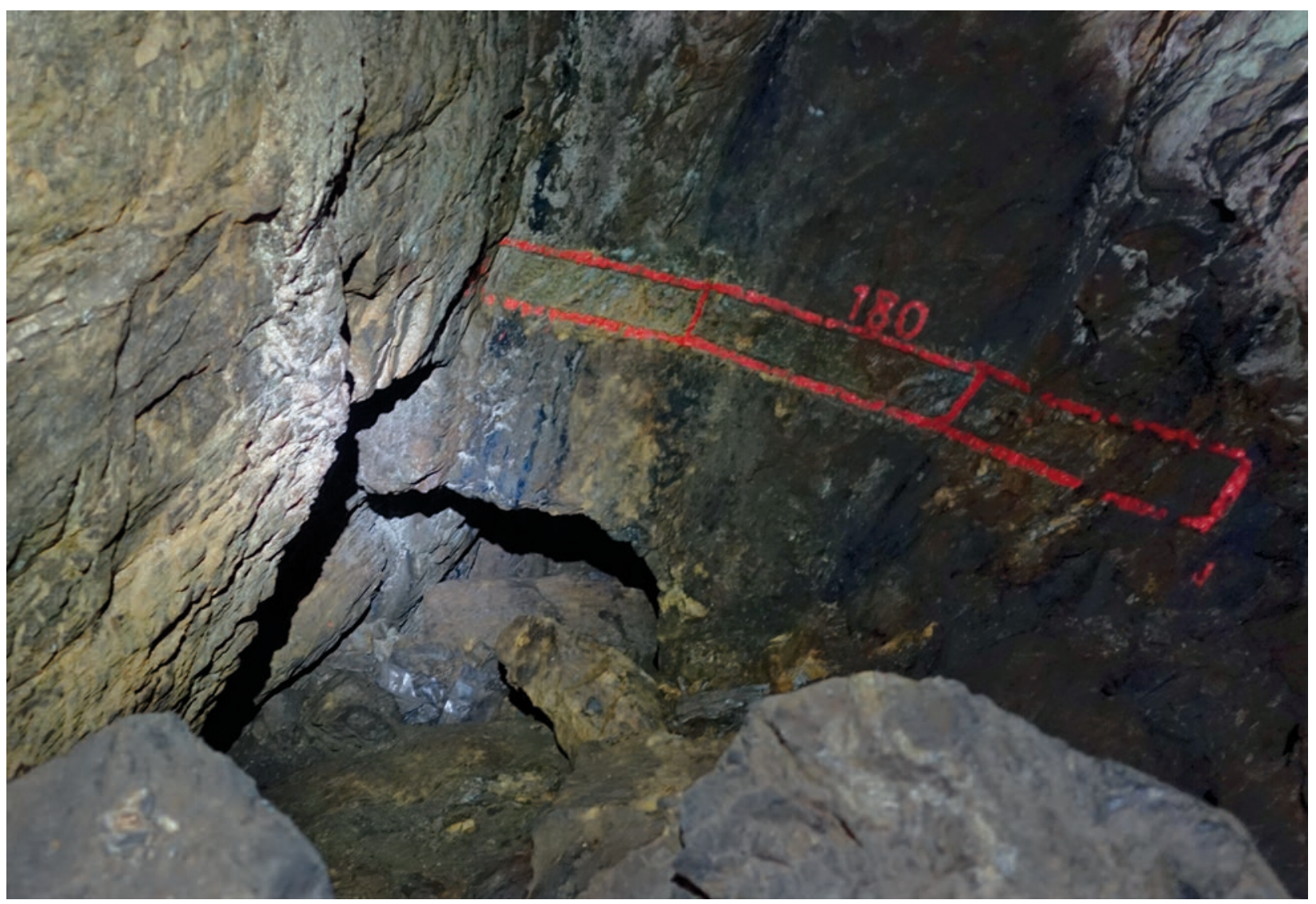

Fig. 3.0.1-11: Territorium metallorum Tresminas/Jales, Tresminas, Lagoinhos. Vista sobre a abertura para expansão com a amostra estéril 180. Por baixo, são visiveis as seções de prospeção PR-2 e PR-4 (fotografia: R. Wahl-Clerici).

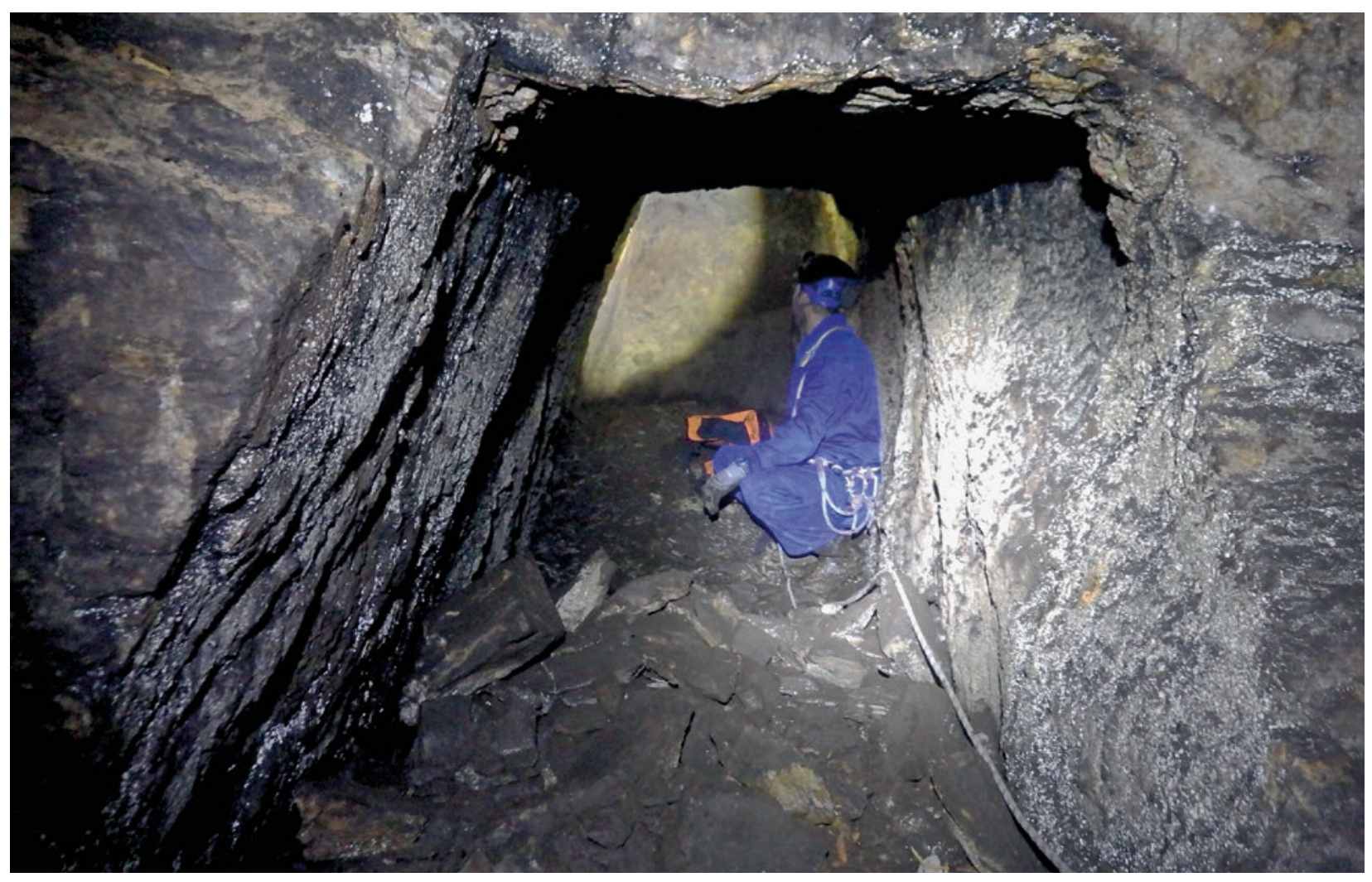

Fig. 3.0.1-12: Territorium metallorum Tresminas/Jales, Tresminas, Lagoinhos: vista do sul para a estope de prospeção PR-5 (foto: J.Moutinho/ACRM Valongo). 

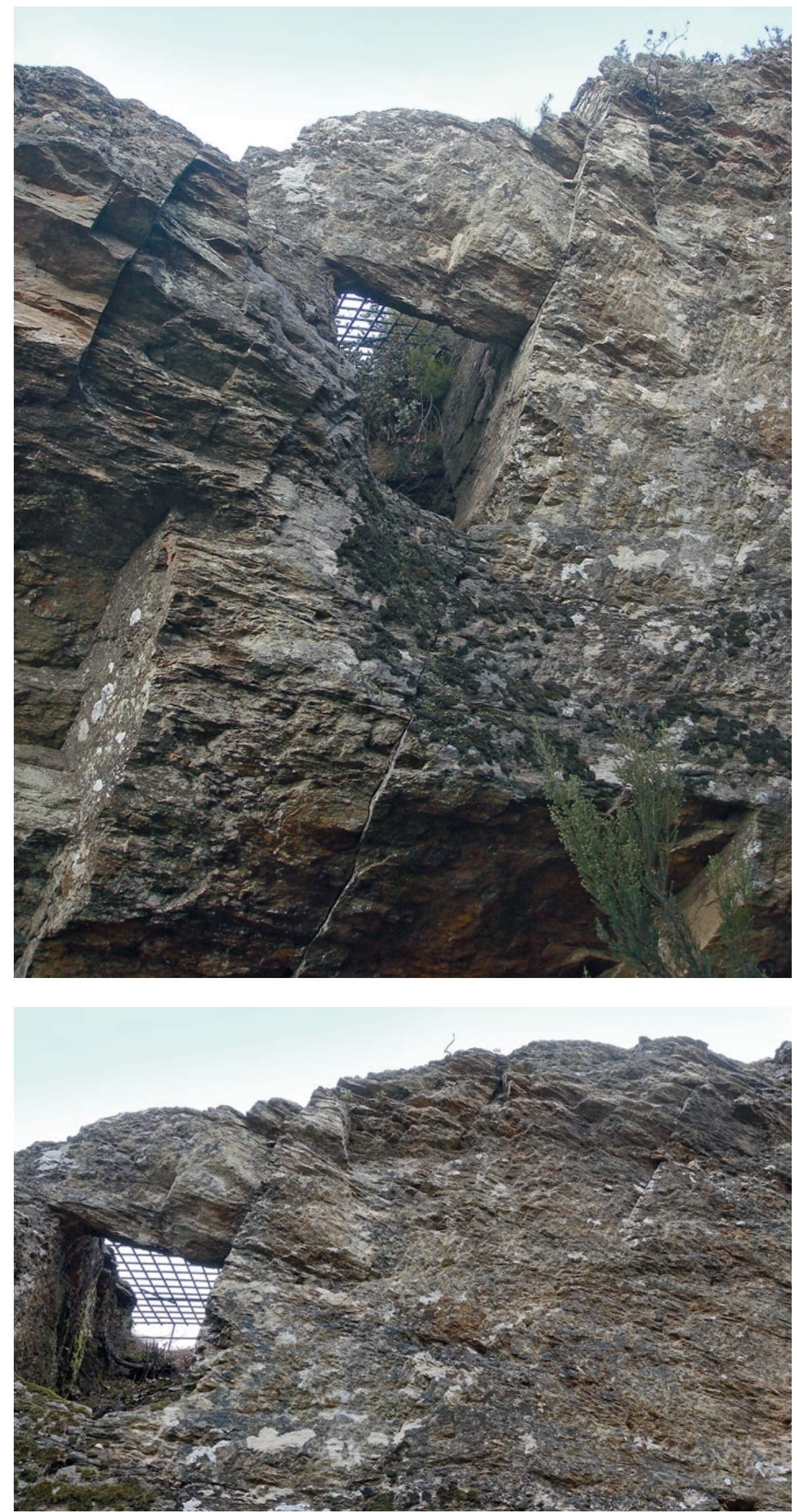

Fig. 3.0.1-13a/b: Territorium metallorum Tresminas / Jales, Tresminas, Lagoinhos: vista para um antigo poço de prospeção (E) na encosta Norte-Nordeste, alterada por extrações posteriores. É visível que a mineração não atingiu a superfície do declive (fotografia: R.Wahl-Clerici). 


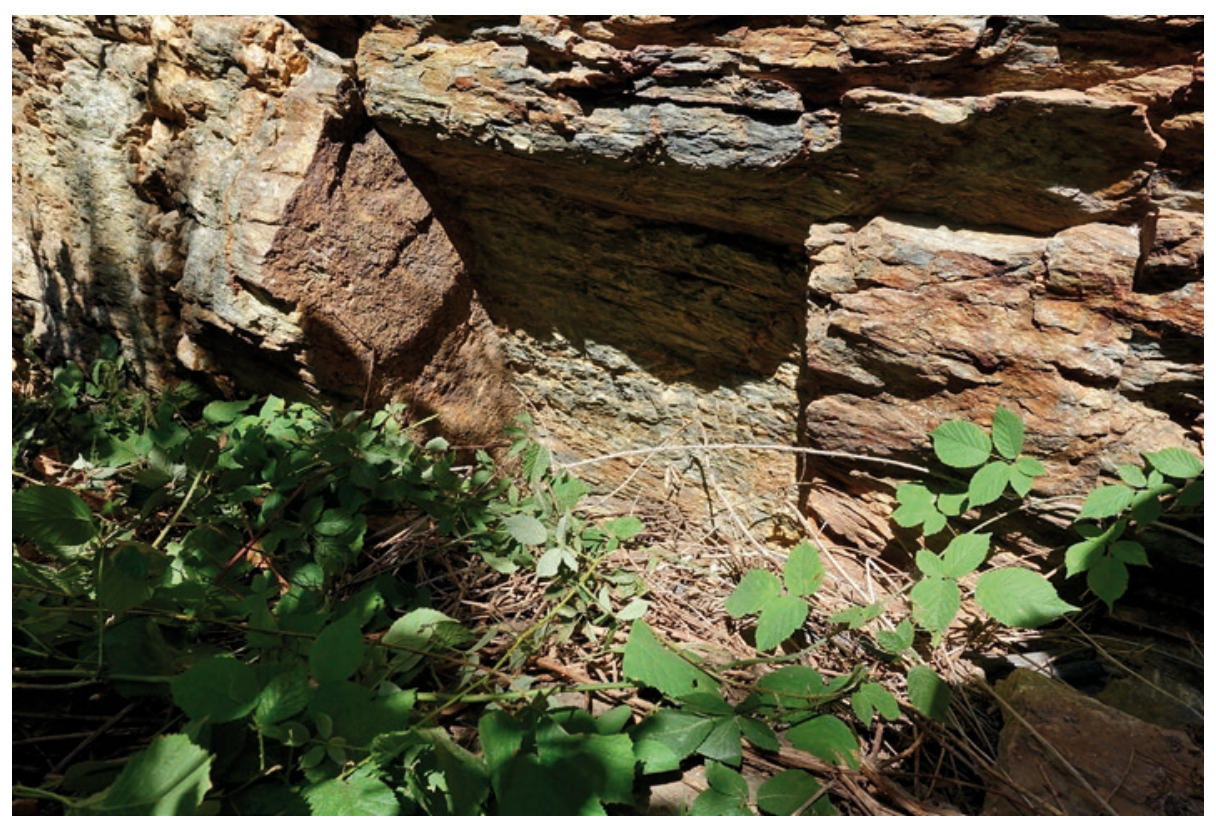

Fig. 3.0.1-14: Territorium metallorum Tresminas / Jales, Tresminas, Lagoinhos: vista dos túneis de prospeção E, utilizados para a amostragem da rocha em direção a norte (fotografia: R.Wahl-Clerici).

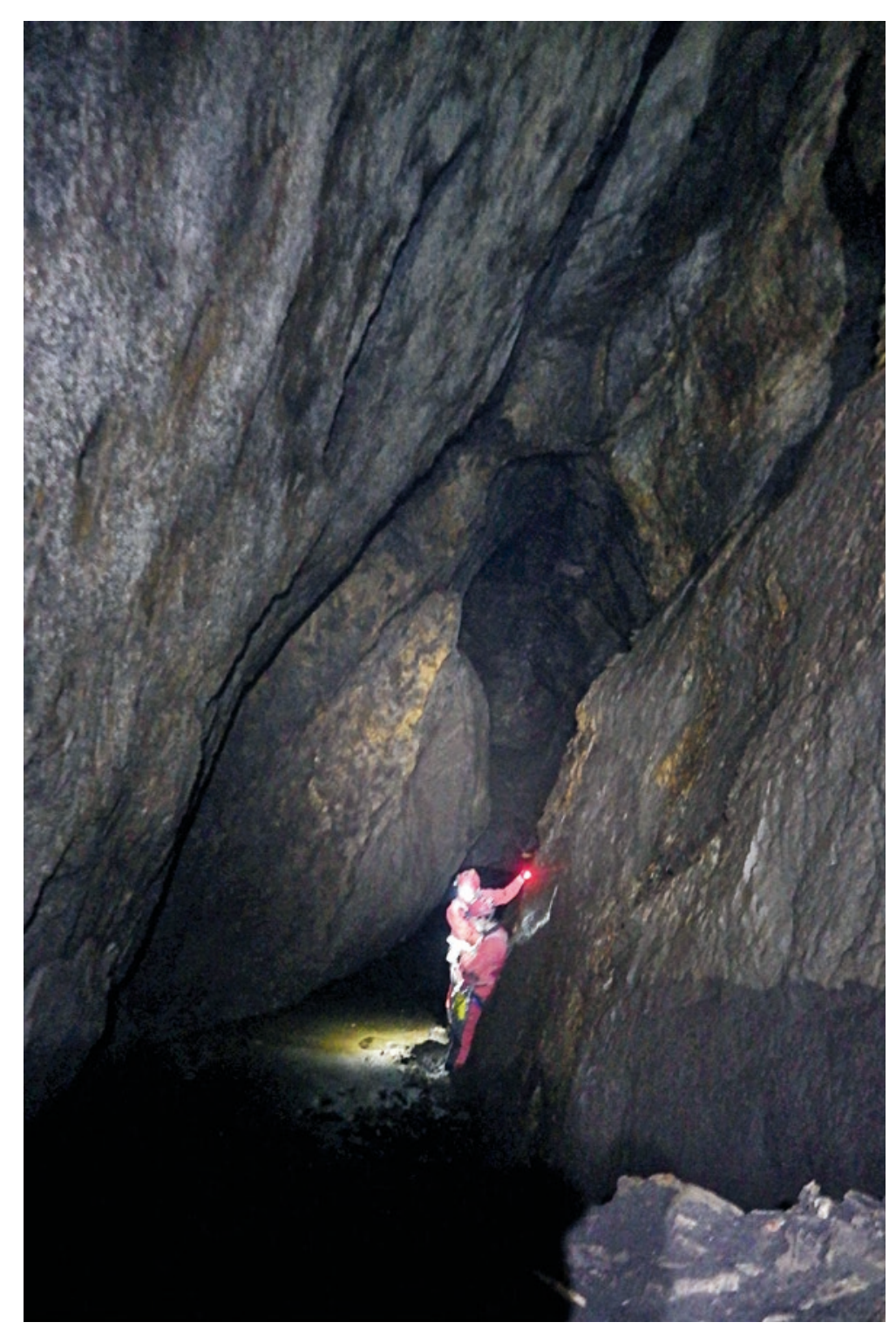

Fig. 3.0.1-15: Territorium metallorum Tresminas/Jales, Tresminas, Lagoinhos: vista de oeste para o nível N5. É claramente visivel o perfil de uma galeria de extração antiga (estope) (fotografia: J. Moutinho / ACRM Valongo). 


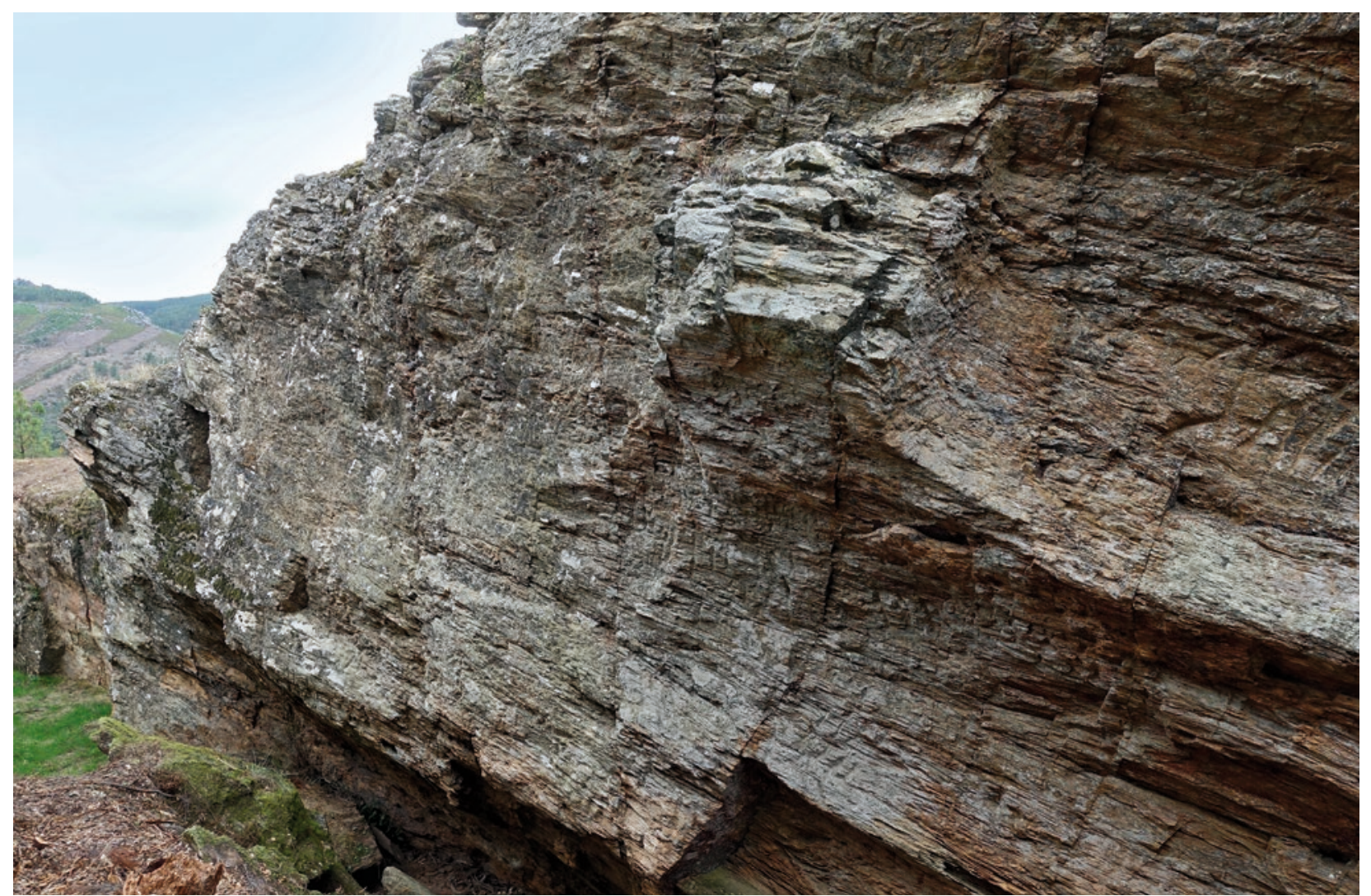

Fig. 3.0.1-16: Territorium metallorum Tresminas / Jales, Tresminas, Lagoinhos: vista atual da parede lateral a NNE na área a céu aberto. Bem reconheciveis são os vestígios de picagem que terminam cerca de $50-70 \mathrm{~cm}$ abaixo da rocha. A rocha em primeiro plano foi muito provavelmente deixada em pé por questões de estabilidade (fotografia: $R$. Wahl-Clerici).

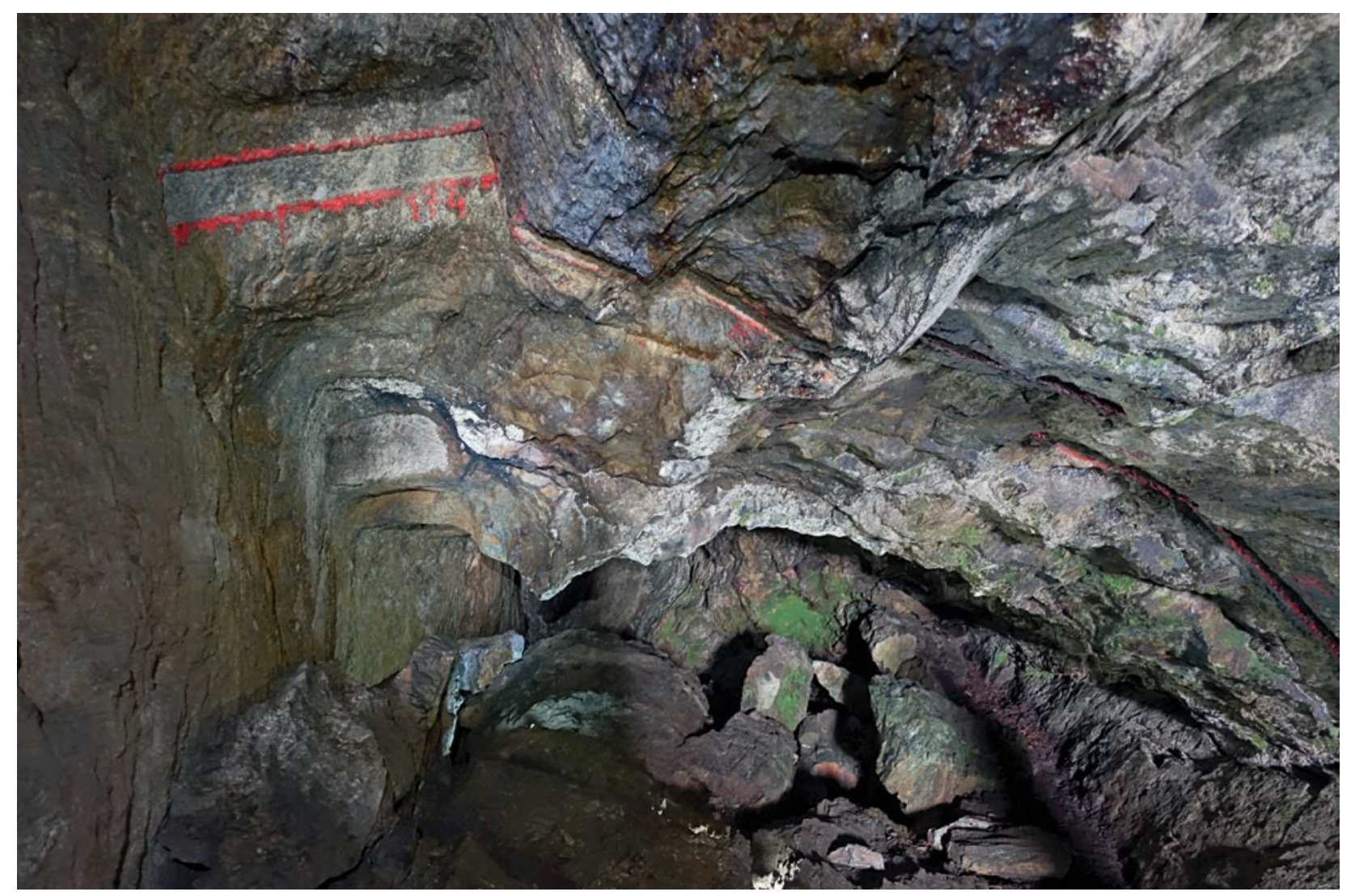

Fig. 3.0.1-17: Territorium metallorum Tresminas/Jales, Tresminas, Lagoinhos: vista sobre o fim gradual da extração (esquerda). No lado direito da imagem é visivel a queda natural da rocha (fotografia: R.Wahl-Clerici). 


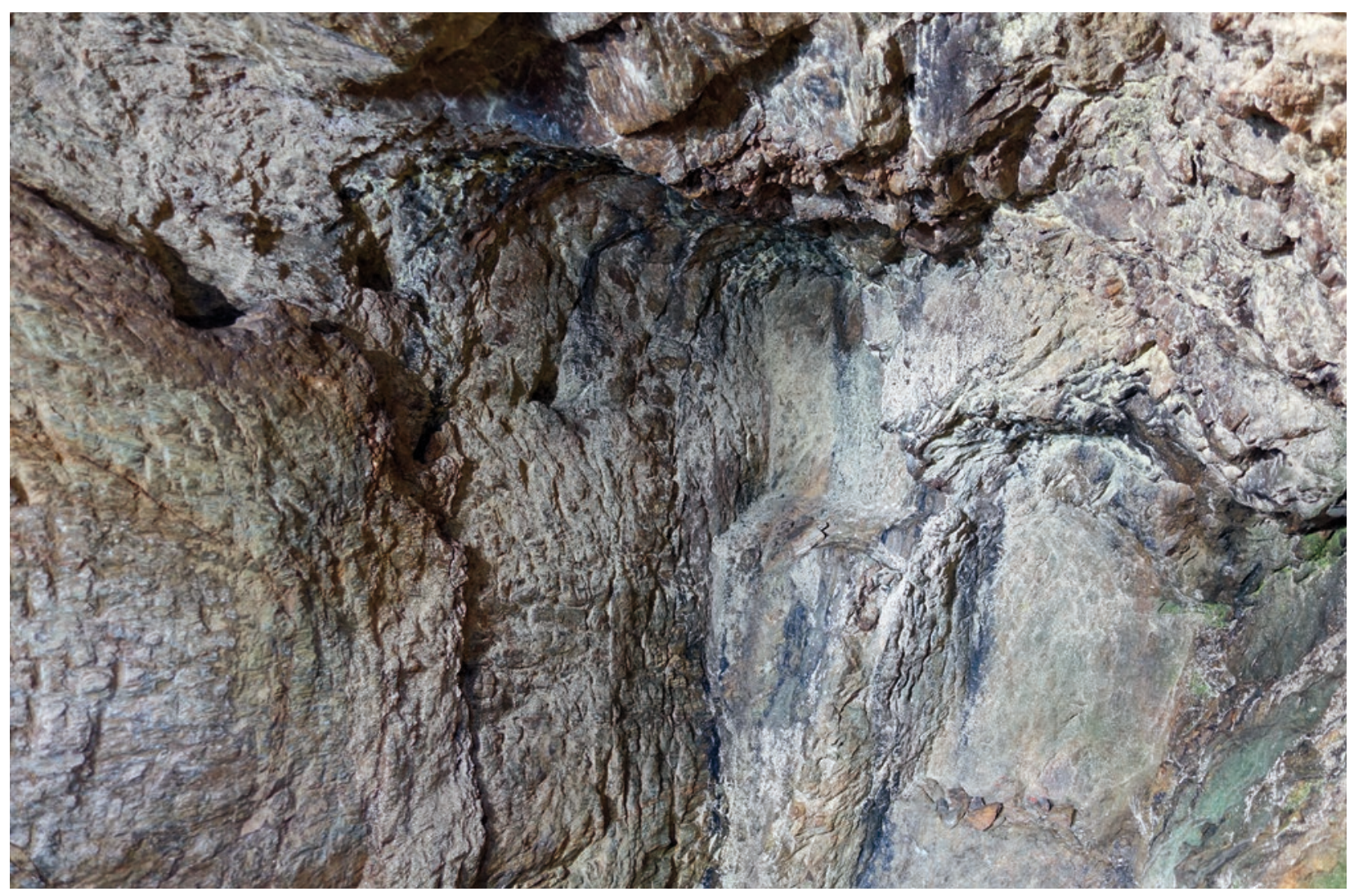

Fig. 3.0.1-18: Territorium metallorum Tresminas/Jales, Tresminas, Lagoinhos: fim da zona de extração com dois pontos de trabalho em paralelo, com os nichos para as lucernas na parede que não foi alterada (fotografia: R.Wahl-Clerici).

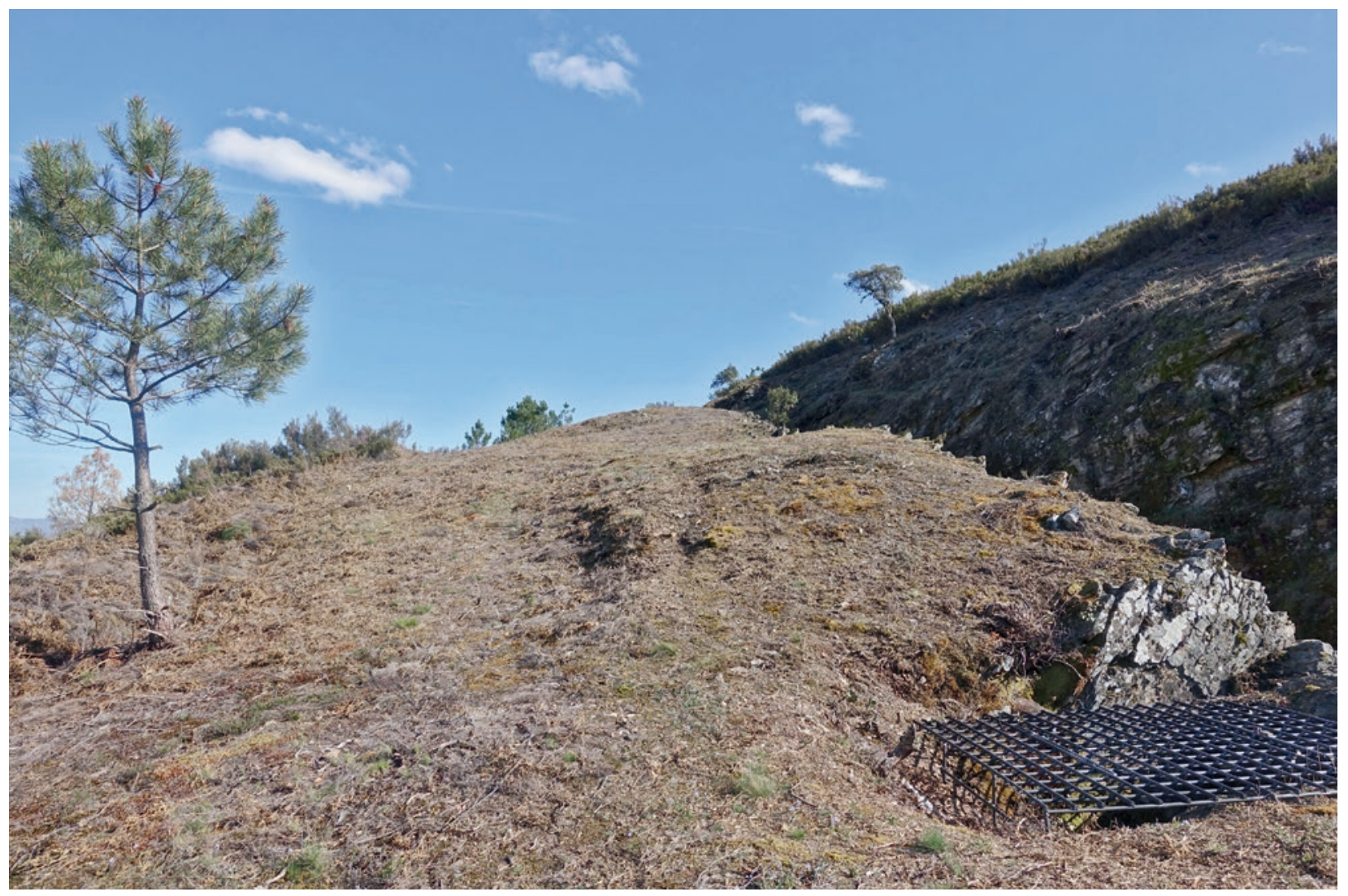

Fig. 3.0.1-19: Territorium metallorum Tresminas / Jales, Tresminas, Lagoinhos: vista de noroeste para a área das escombreiras em Lagoinhos (fotografia: R. Wahl-Clerici). 


\subsection{Técnicas de exploração}

... hos igne et aceto rumpunt, saepius vero, quoniam id cuniculos vapore et fumo strangulat, caedunt fractariis cl libras ferri habentibus egeruntque umeris noctibus ac diebus per tenebras proximis tradentes;

... rochas; estas abatiam-se com fogo e vinagre, mas, como este método leva a asfixia por vapor e fumo no interior dos túneis, são frequentemente desfeitas com marretas, compostas por 150 libras de ferro, e transportam-se [as rochas] de noite e de dia nos ombros para o exterior, passando-as de mão em mão na escuridão.

É assim que Plínio (N.H.33,71) descreve as duas técnicas de exploração usadas nas jazidas primárias. Como de costume, fornece-nos algumas palavras-chave que, em seguida, pretendemos relacionar com as nossas descobertas. Neste excerto Plínio fala de martelos de ferro com um peso de 150 libras, ou seja, 48,75 kg. Da mesma forma, a descrição de que as rochas eram transportadas de dia e de noite exclusivamente aos ombros, dificilmente se aplica a Tresminas, pois os trilhos preservados nas galerias contam uma história diferente (figs. 3.3-2, 3.3-4, 3.3-11-3.3-13).

Além da Galeria do Buraco Seco, apenas uma grande parte das estruturas de prospeção é estreita demais para o transporte com carros, pelo que nestes casos o material tinha realmente de ser carregado manualmente para o exterior (fig. 3.1-1). Na mina de Campo de Jales encontraram-se várias partes de aros com asas em ferro. Estes serviam de pega para sacos de couro onde se transportavam pedras e água até à superfície (figs. 3.1-2, 3.1-3). ${ }^{123}$ Os cestos feitos de material orgânico raramente se mantiveram preservados e somente nas minas em redor de Cartagena (E) ${ }^{124}$ encontraram-se cestos feitos de capim-esparto.

\section{Martelo e picareta}

Os vestígios preservados da exploração mineira romana no territorium metallorum Tresminas / Jales são típicos do trabalho com martelo e picareta, cujos símbolos ainda hoje são válidos para a mineração. Grande parte destes vestígios ajudam-nos a documentar as ações dos mineiros (figs. 3.0.1$13 \mathrm{~b}, 3.0 .1-16,3.1-4,3.1-5)$ e a compreender as variadas formas com que se procurava facilitar o trabalho, por exemplo, ao aproveitar as fissuras naturais existentes na rocha (fig. 3.1-6). No entanto, esse tipo de ajuda é raramente encontrado nos locais de exploração e nas galerias grandes. Nestes casos, o trabalho de exploração seguia escrupulosamente a planificação, o que provavelmente está relacionado com o impressionante nível de trabalho topográfico, dado que os mais pequenos erros durante a execução acarretavam grandes consequências.
Do equipamento mantiveram-se preservados martelos, cinzis e uma picareta (figs. 3.1-7a / b / c/ d, 3.1-8) que, de acordo com as atuais pesquisas metalúrgicas no territorium metallorum, eram produzidos do ferro que se extraia como subproduto na exploração de ouro. ${ }^{125}$ As ilustrações de ferramentas podem ser encontradas, por exemplo, no relevo dos mineiros da mina de «Los Palazuelos» (Carboneros, Prov. Jaén, E) (fig. 3.1-9).

\section{$O$ ataque por fogo}

A técnica de ataque por fogo, já comprovadamente utilizada no Neolítico, facilitava significativamente o trabalho, tendo sido o método de explosão utilizado até ao surgimento dos materiais explosivos. ${ }^{126}$ Os vestígios dessa técnica ainda só foram identificados na zona de exploração a céu aberto de Tresminas (figs.3.1-10, 3.1-11). Os vestígios subterrâneos desta técnica mineira demonstram que já era utilizada no $3^{\circ}$ milénio a.C., conforme mostra o exemplo de Kestel (TR), que também é conhecida das minas romanas da Serra de Santa Justa (Valongo, Porto / P). ${ }^{127}$ Essas cavidades resultam depois de percutir a rocha moída que se desintegra facilmente sem necessidade de muita força.

Os testemunhos dos séculos XVIII e XIX fornecem-nos descrições detalhadas do método de ataque por fogo. Assim, o «vice-comandante da montanha〉 de 1785 de Saxónia e Zellerfeld (D), Friedrich Wilhelm Heinrich von Trebra, explica o recurso a esta tecnologia da seguinte forma:

1123 Alarcão 1997, 106-112; Agrícola 1556/1994, 129; Os ferros foram encontrados no filão de Campo de Jales durante a exploração moderna pelas Minas de Jalles Ltda. e armazenados no pequeno museu. Hoje encontram-se expostos no Museu Municipal Padre José Rafael Rodrigues de Vila Pouca de Aguiar.

124 Alarcão 1997, 110, 9 de Aljustrel (Distr. de Beja, P); Gossé 1942, 53 e Lam. IV, 3 de Mazarrón; Domergue 1990, Pl. 17a de Mazarrón; Pl. 20a de Pedreras Viejas (ambas Prov. de Múrcia, E).

125 Martins 2017, 104-105.

126 Outras fontes: Diodorus Siculus 12,4; Vitruvius 8,3,19: «Assim também pérolas; e pedras, que nem o ferro nem o fogo podem dissolver, quando aquecidas com fogo e polvilhadas com ácido, partem-se e dissolvem-se». Outras fontes também no contexto da travessia dos Alpes por Aníbal: Py et al. 2012, 133-136; A.Gundelwein, Bergbautechnik, em Roseneck 2001, fig.155 em baixo (fogo neolítico no País de Gales) e 156 com mais literatura e exemplos da era neolítica e do bronze; B. Heublein, Goethe und der Montantourismus am Rammelsberg, em Roseneck, 2001, 206-214; A. Gundelwein, Feuer und Wasser, em Roseneck 2001, 160-171; Craddock 1995, 54, fig. 2 .221 da mina Monte Gabriel (IRL) da idade do bronze; Craddock 1995, 33-37 figs.2.6-2.7.

127 B. Heublein 2001, 209. Rammelsberg, perto de Goslar, na Baixa Saxónia (D). 
«O ataque por fogo ... em Rammelsberg ... é a única forma de conquistar as rochas quase invencíveis. Pó e aço fazem-se pouco. Há pontos sólidos no xisto, em que para atravessar um único Lachter são necessários 6000 furos. ... É precisamente essa solidez que dificulta e impede as vastas tentativas de explosão nesta montanha... ${ }^{127 a}$

Naquela época, a visita aos pontos de ataque por fogo em Rammelsberg, nas minas de cobre do Harz (D), fazia parte de uma viagem educacional, não sendo de admirar que famosos filósofos e poetas, como Gottfried Wilhelm Leibniz (1646-1716), Charles de Montesquieu (1689-1755), Johann Wolfgang von Goethe (1749-1832), Heinrich von Kleist (1777-1811) e Hans Christian Andersen (1805-1875), entre outros, nos deixaram os seus testemunhos pictóricos. ${ }^{128}$

Em Goslar, dirigimo-nos para Rammelsberg, onde nas grandes covas o minério é queimado com troncos incendiados e onde todos trabalham nus devido ao calor. Quase se crê estar no inferno ou pelo menos na oficina de Ciclopes.

Heinrich von Kleist, 1801. ${ }^{129}$

Outra possível técnica de exploração mineira antiga é-nos descrita na literatura por Plínio como o método ruina montium. ${ }^{130}$ Todavia, até ao momento, não existem provas de um procedimento correspondente em Tresminas. ${ }^{131}$

Além disso, a suposição de que a exploração era apoiada pelo uso de energia hidráulica deve ser rejeitada. Não existem os menores vestígios que possam comprovar um método correspondente, além do mais, a ardósia cristalina não é adequada para tal método. Se em muitos locais de exploração já não é possível identificar marcas do desmonte manual, isso deve-se à meteorização da superfície da rocha.

De igual modo deve ser rejeitada a suposição de que o canal na Galeria do Pilar servia para evacuar o material explorado. ${ }^{132}$ Isso exigiria uma enorme quantidade de pressão de água que nunca existiu com o sistema de abastecimento de água presente. Além disso, não foi possível encontrar nenhum tanque na zona de exploração. ${ }^{133}$ 127a B. Heublein 2001, 210. 1 Lachter = aprox. 1,8 m.

128 B. Heublein 2001, 210.

129 Em K. Liebmann, Heinrich von Kleist und der Harz. Zum 150. Geburtstag des Dichters. In: Der Harz, 10, 1927, 175-176.

130 Plínio n.h. 33,66, 33,72-73.

131 Domergue 1990, 479 indica que esta técnica também pode ter sido aplicada em Tresminas, embora apenas seja possível ter a certeza através de pesquisas adicionais.

132 Domergue 1990, 480.

133 Errado p.ex. Sánchez Palencia 2015. 


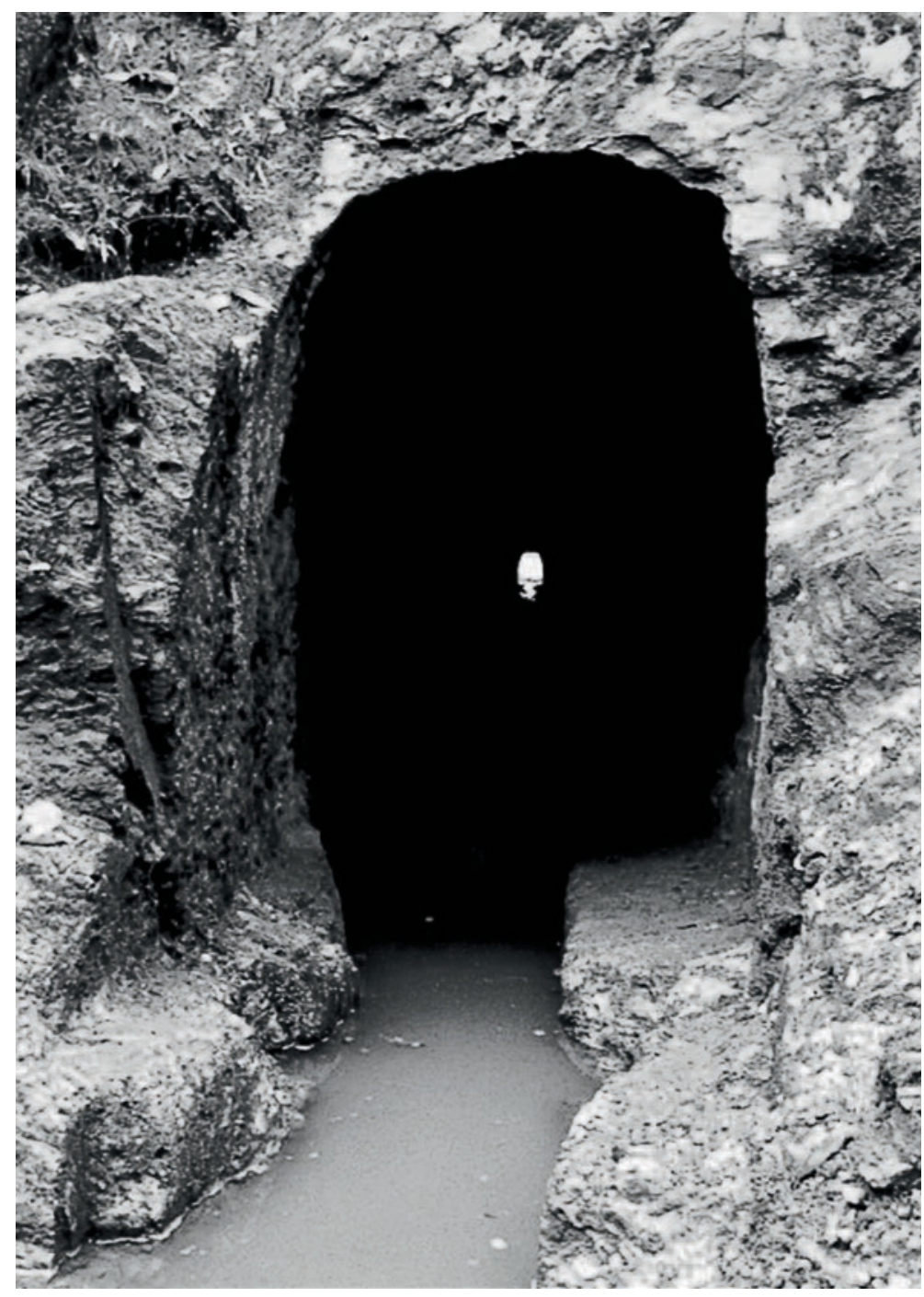

Fig. 3.1-1: Territorium metallorum Tresminas/Jales, Tresminas, Corta da Ribeirinha, Galeria do Buraco Seco: zona de entrada na Corta (fotografia: J. Wahl). 


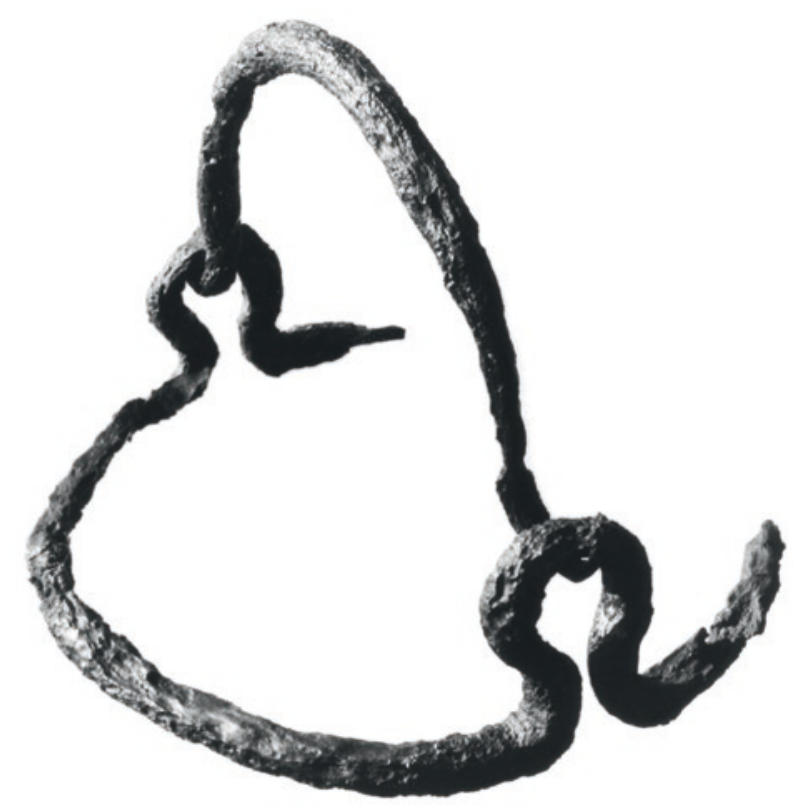

Fig. 3.1-2: Territorium metallorum Tresminas / Jales: aro com asa de ferro de Campo de Jales, agora no Museu Municipal Padre José Rafael Rodrigues Vila Pouca de Aguiar (fotografia: J. Wahl).

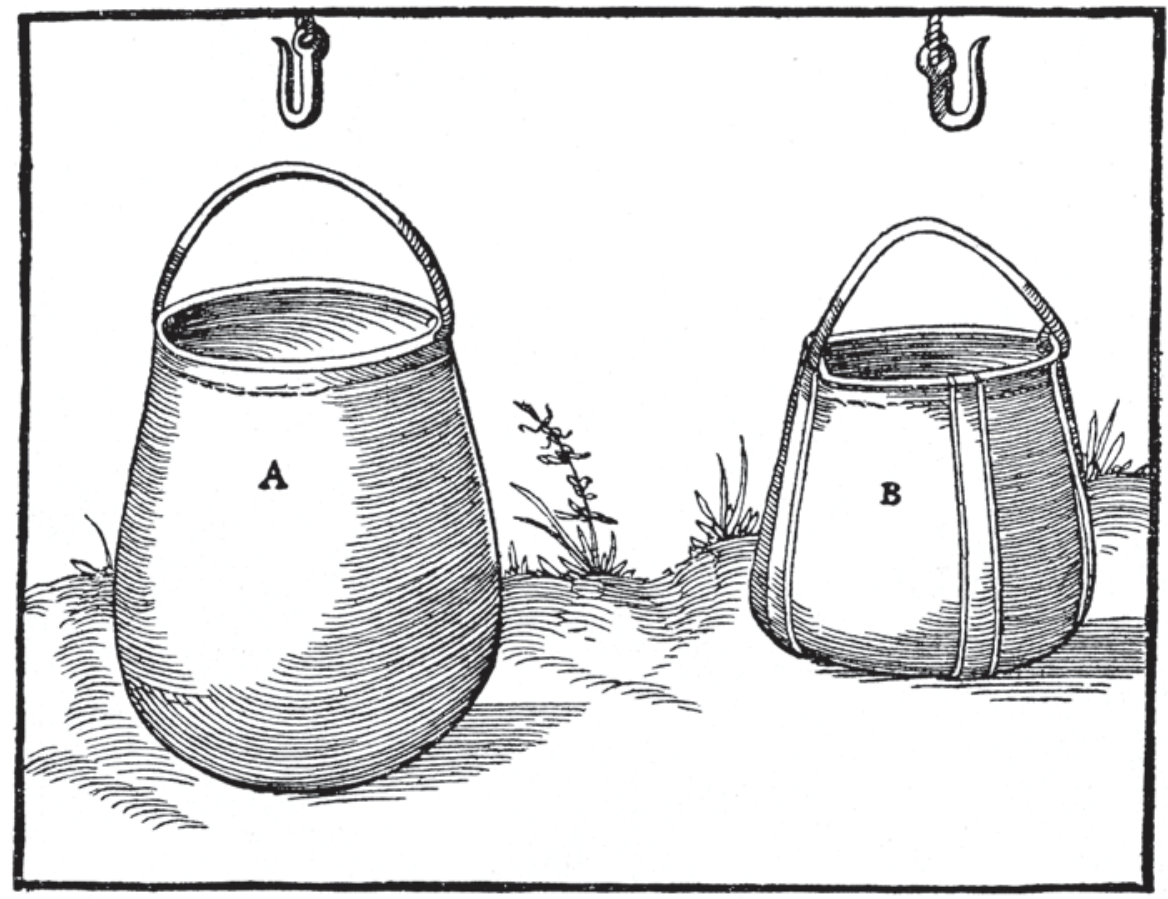

Die Ringebulge A. Die Streichbulge $B$.

Fig. 3.1-3: Baldes de couro com anéis de ferro (conforme Agricola 1556/1984, 129). 


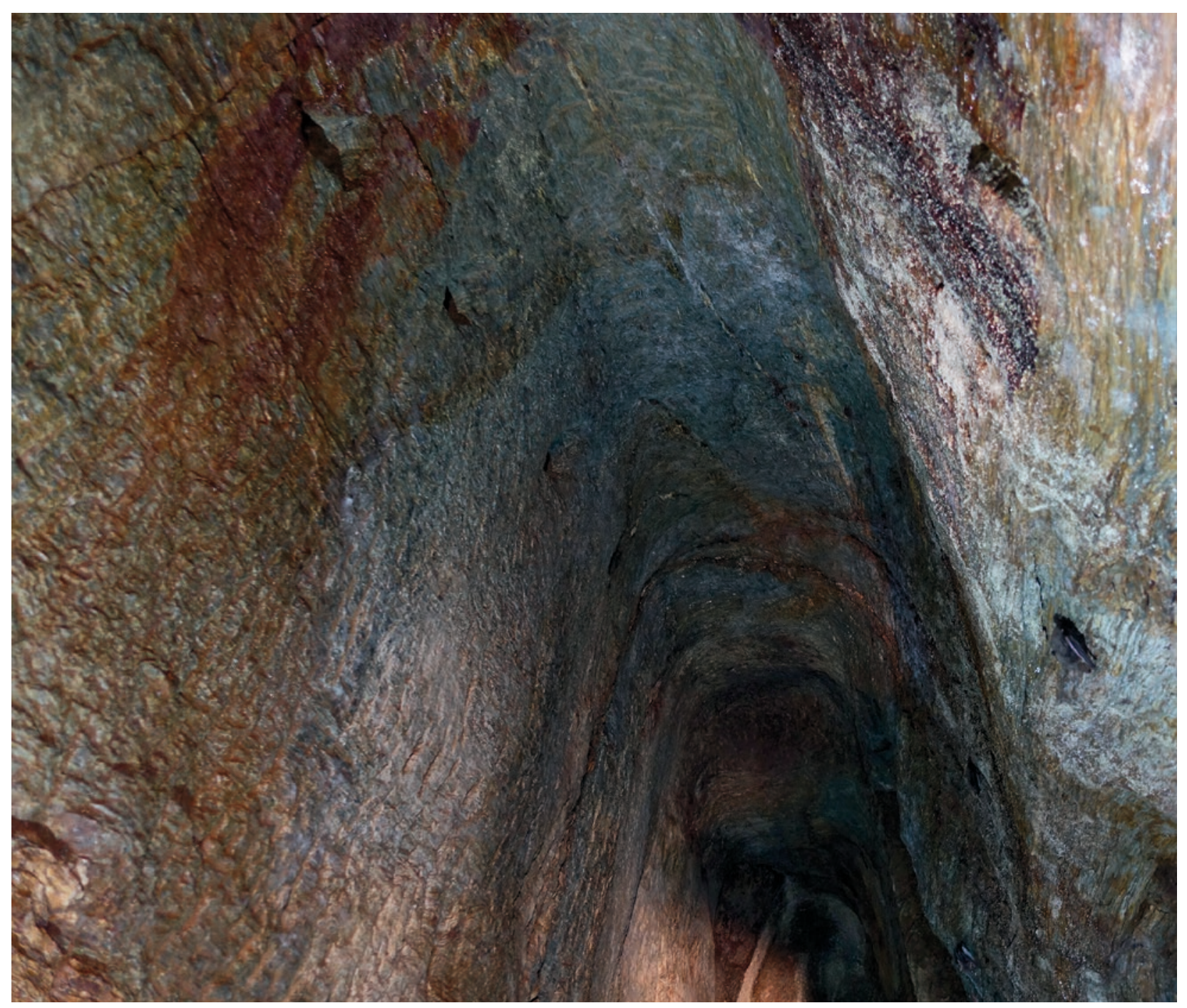

Fig. 3.1-4: Territorium metallorum Tresminas /Jales, Tresminas, Lagoinhos: marcas de desmonte manual na zona de exploração subterrânea com nichos para as lucernas, imediatamente abaixo do tecto, o que torna impossivel que este lado tenha sido trabalhado desde o piso até ao tecto (fotografia: $R$. Wahl-Clerici).

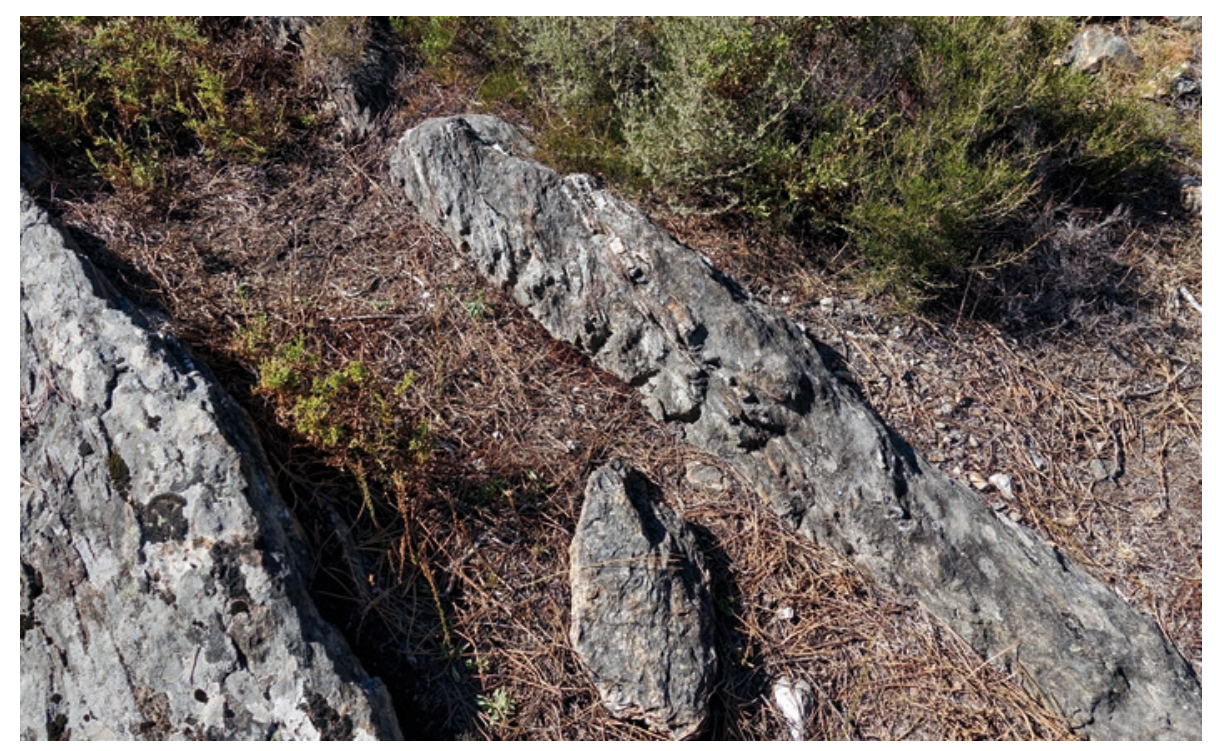

Fig. 3.1-5: Territorium metallorum Tresminas / Jales, Gralheira: marcas próprias do uso de ferramentas (fotografia: R. Wahl-Clerici). 


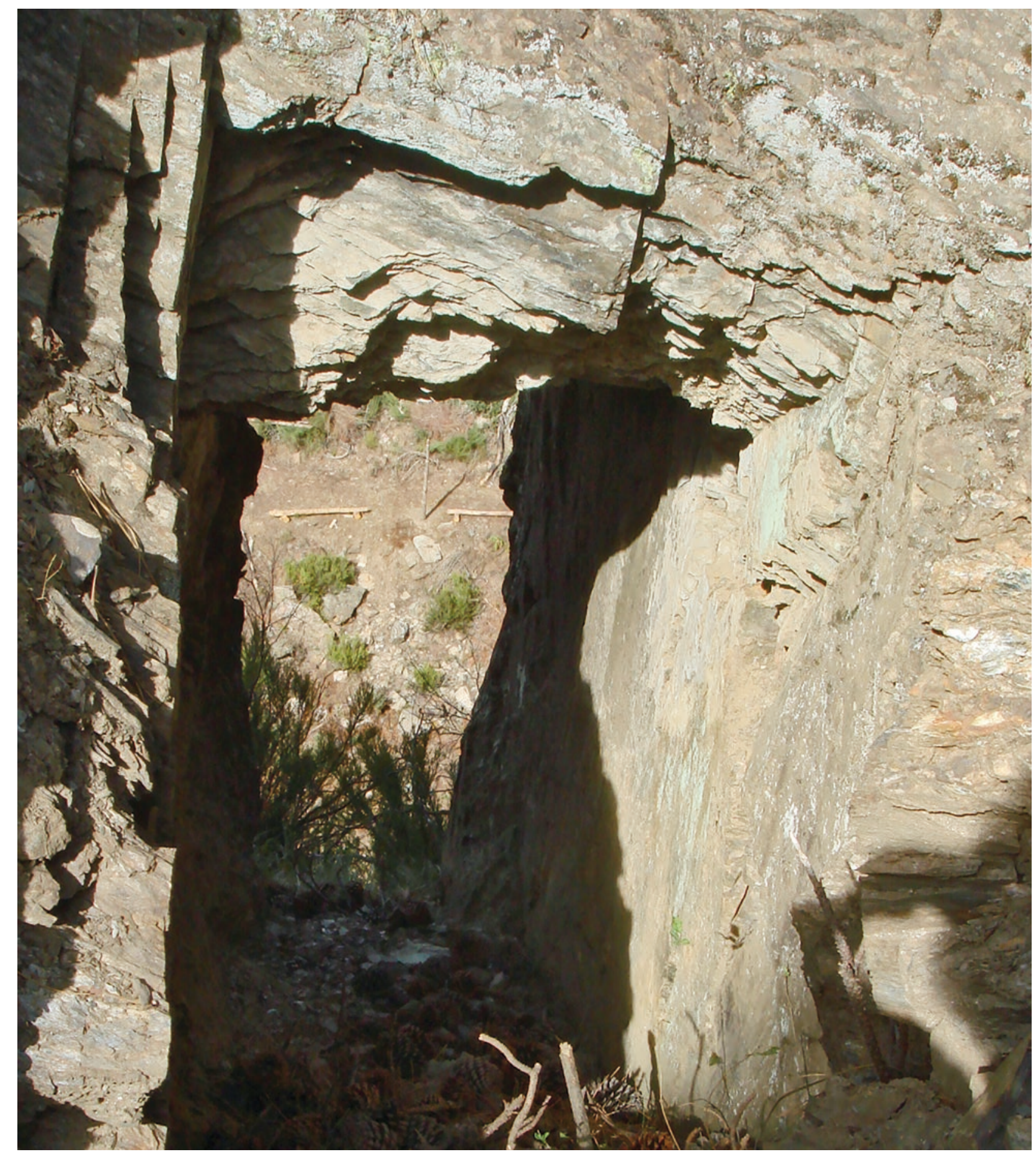

Fig. 3.1-6: Territorium metallorum Tresminas / Jales, Tresminas, Corta de Covas: poço em escada para prospeção. Aproveitou-se uma fenda natural para a construção da parede oriental (fotografia: $R$. Wahl-Clerici). 


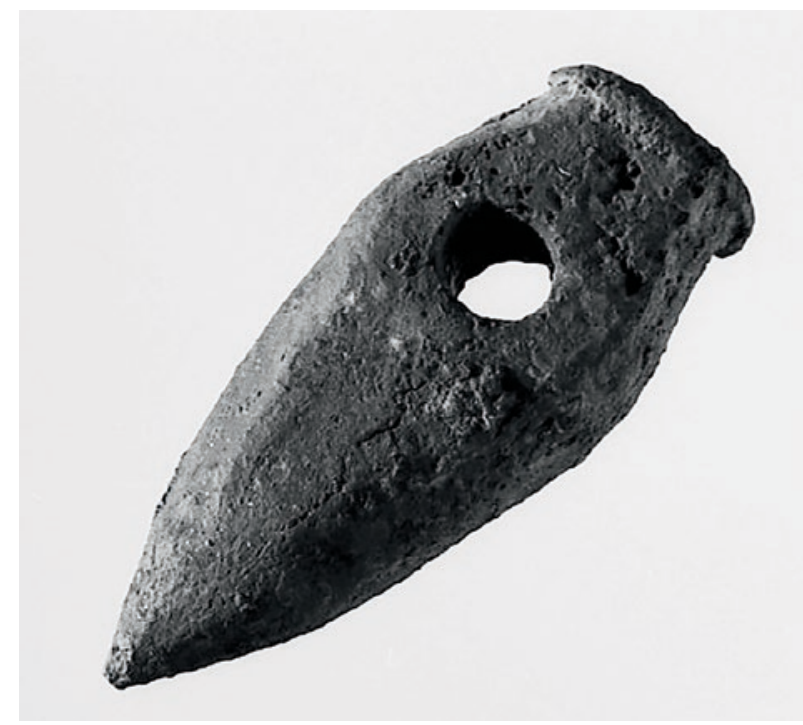

Fig. 3.1-7a: Territorium metallorum Tresminas /Jales, Jales: picareta gasta, comprimento $17,6 \mathrm{~cm}$, largura máxima $7,35 \mathrm{~cm}$, altura máxima $5,45 \mathrm{~cm}$, 2588 g, agora no Museu Municipal Padre José Rafael Rodrigues Vila Pouca de Aguiar (fotografia: J.Wahl).

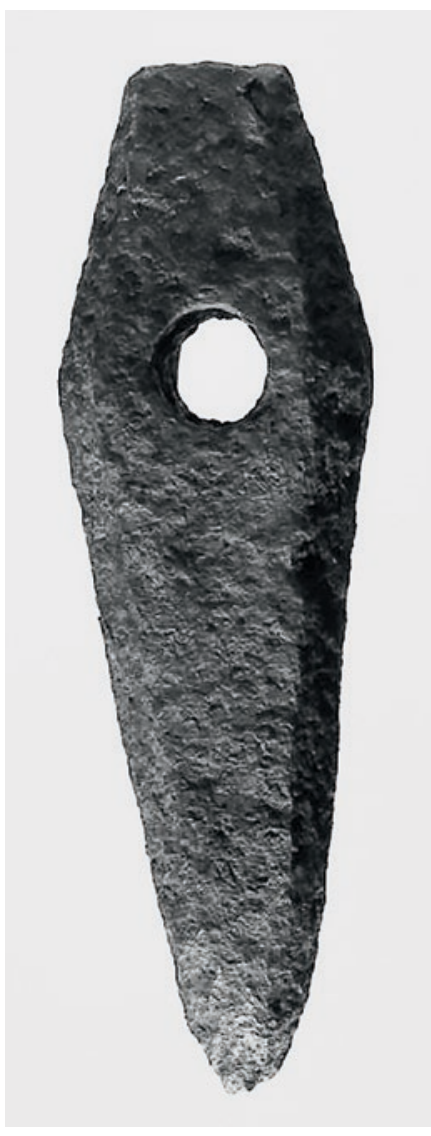

Fig. 3.1-7b: Territorium metallorum Tresminas/Jales, Jales: picareta, comprimento $28 \mathrm{~cm}$, largura máxima $8,4 \mathrm{~cm}$, altura máxima $6,0 \mathrm{~cm}, 5045 \mathrm{~g}$, agora no Museu Municipal Padre José Rafael Rodrigues Vila Pouca de Aguiar (fotografia: J. Wahl).

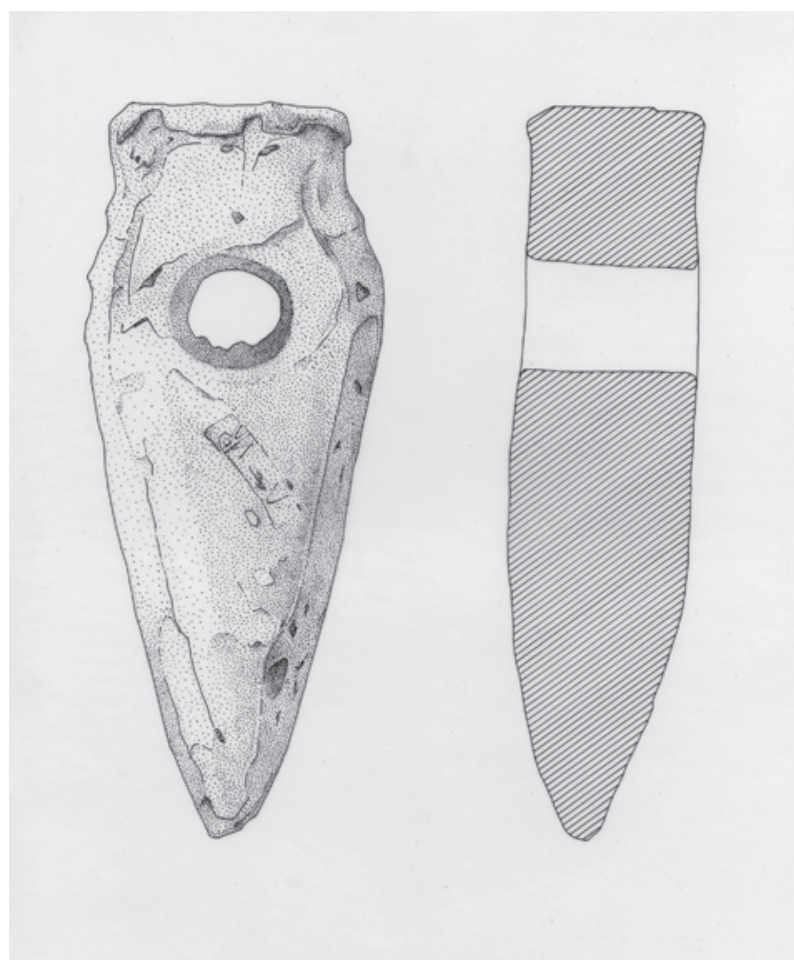

Fig. 3.1-7d: Territorium metallorum Tresminas / Jales, Jales: picareta gasta marcas em ambos os lados, não legíveis, comprimento 19,3 cm, largura máxima $5,2 \mathrm{~cm}$, altura $5,2 \mathrm{~cm}, 2884 \mathrm{~g}$, agora no Instituto Geológico Mineiro, Col. Serv. Geol. Lisboa (desenho: R.Heer). 

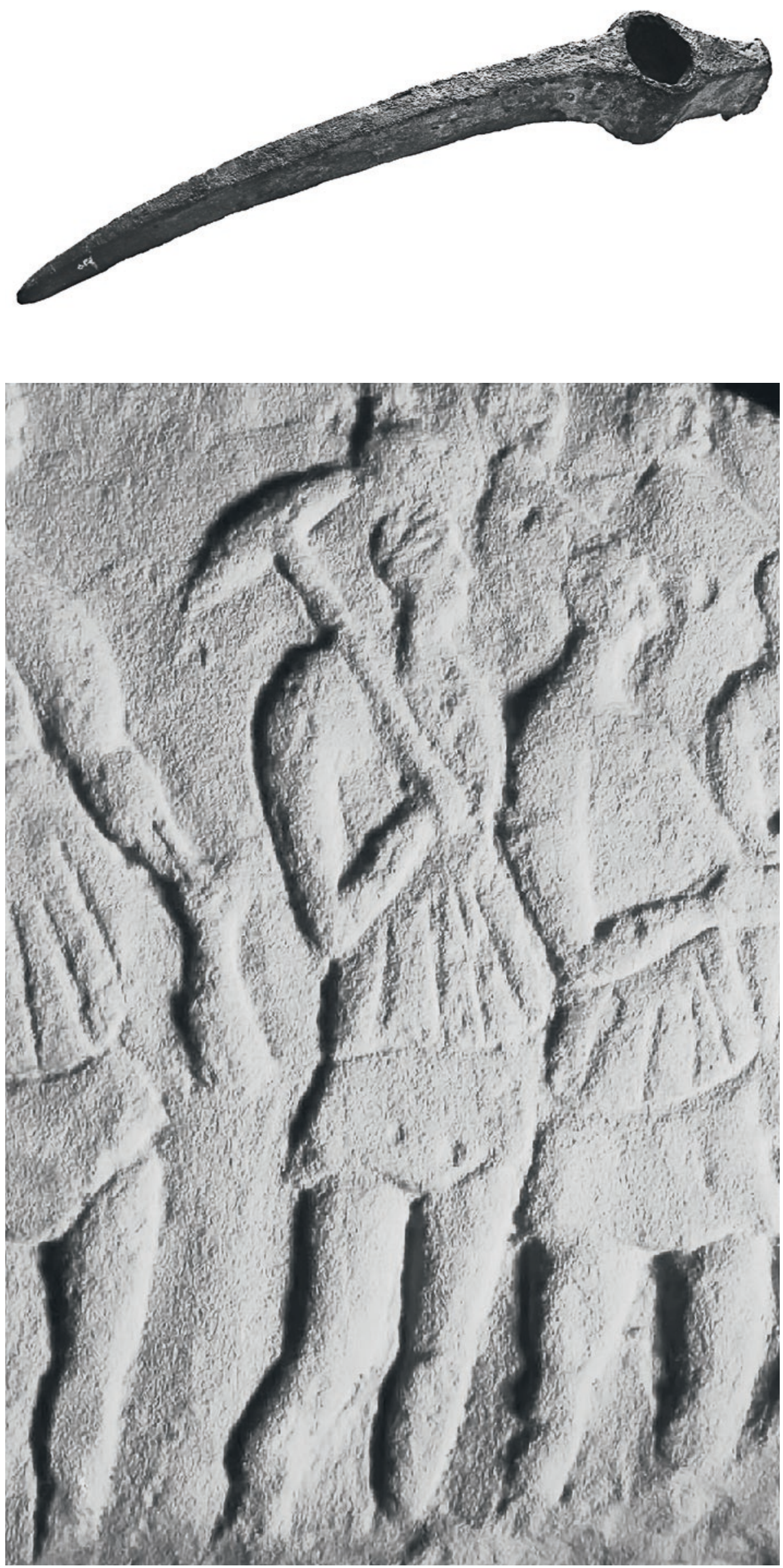

Fig. 3.1-8: Territorium metallorum

Tresminas /Jales, Jales: picareta bastante utilizada, comprimento $51,7 \mathrm{~cm}$, largura máxima $7,25 \mathrm{~cm}$, altura máxima $6,0 \mathrm{~cm}$, 3914 g, agora no Museu Municipal Padre José Rafael Rodrigues Vila Pouca de Aguiar (fotografia: J.Wahl)
Fig. 3.1-9: Los Palazuelos (Jaén, E): mineiros (Bergbaumuseum Bochum/D). 


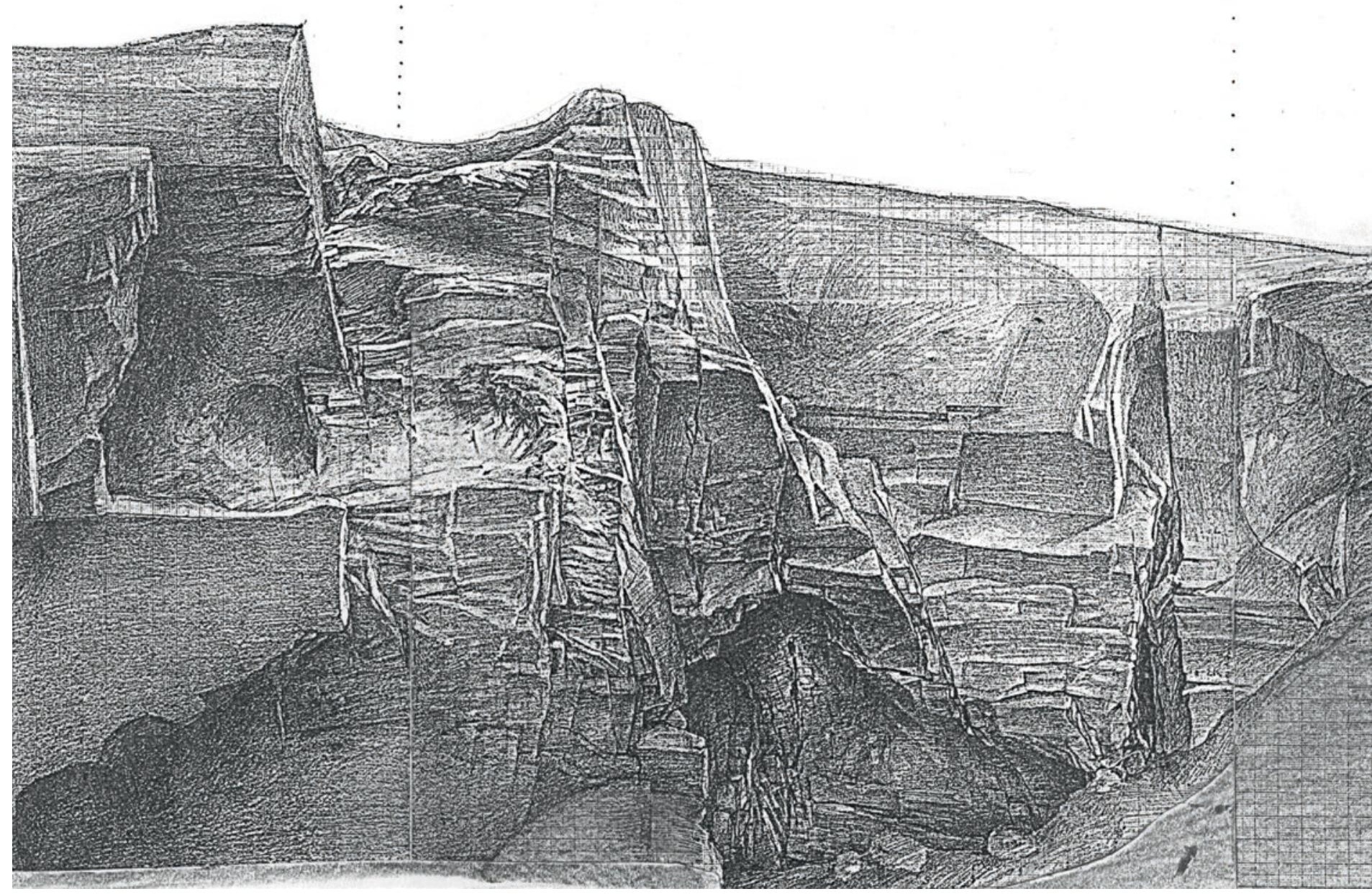




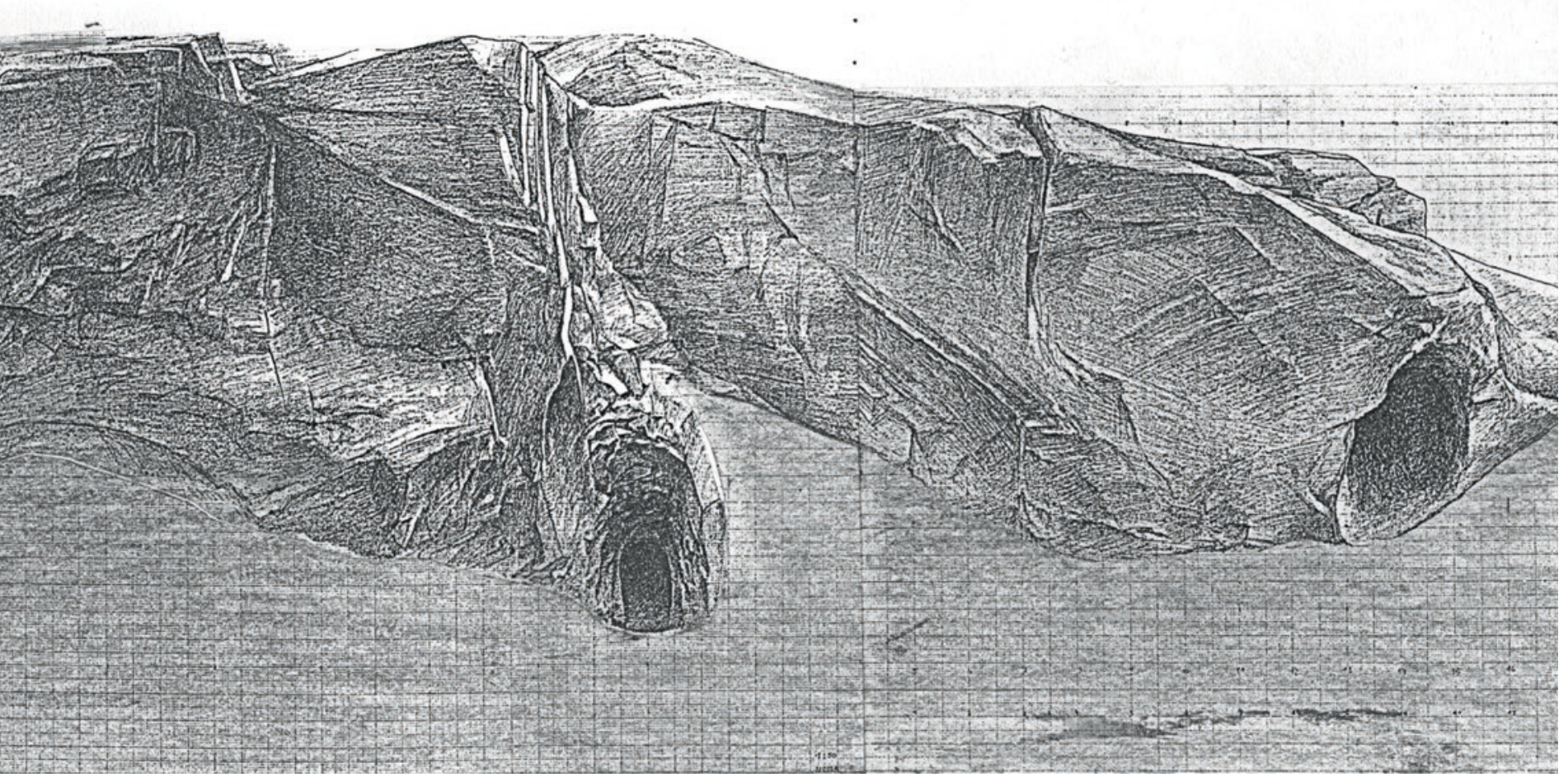

Fig. 3.1-10: Territorium metallorum Tresminas/Jales, Tresminas, Corta de Covas: frente da rocha com marcas de ataque por fogo (desenho: P. Moser).

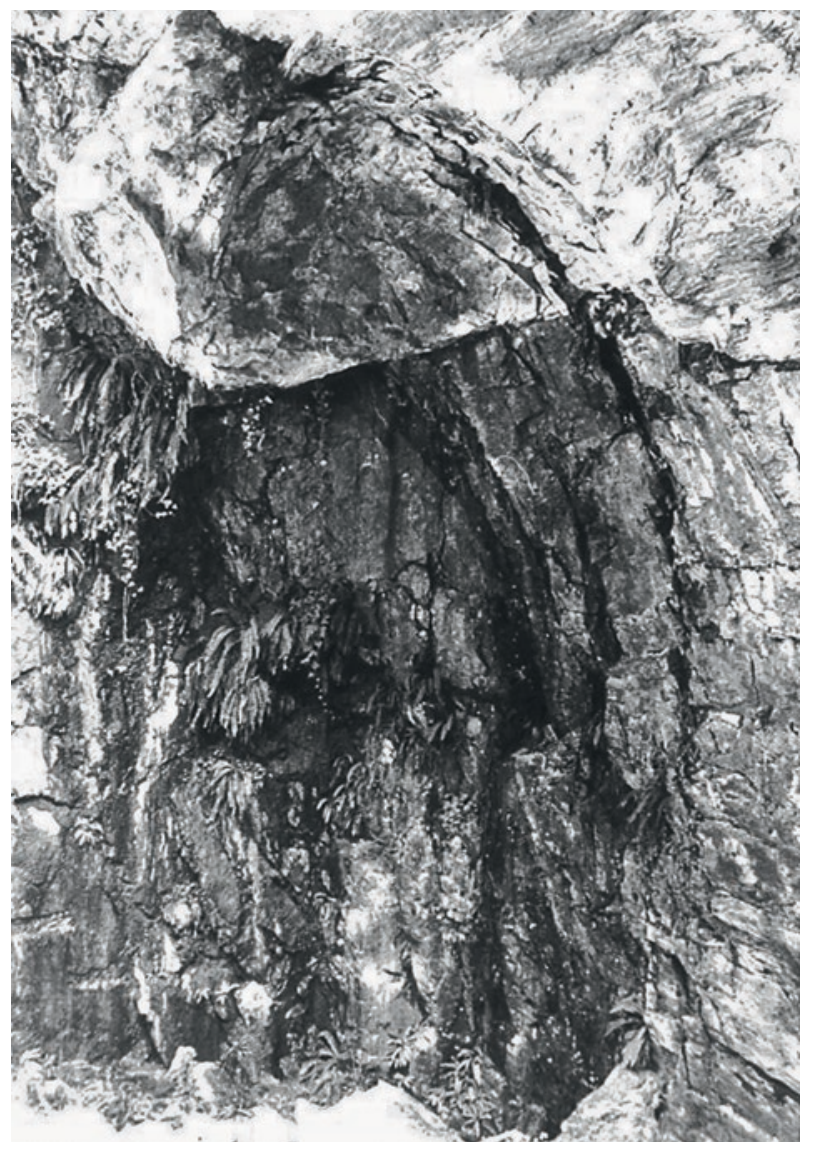

Fig. 3.1-11: Territorium metallorum Tresminas/Jales, Tresminas, Corta de Covas: zona de ataque por fogo com os típicos vestígios em forma de cúpula na rocha (fotografia: J. Wahl). 


\subsection{Progressos na extração na Corta de Covas ${ }^{134}$}

O extraordinário estado de conservação dos vestígios de mineração na Corta de Covas permite, pela primeira vez, entender de forma diferenciada o progresso da exploração de uma jazida numa mina a céu aberto maior, desde o início da exploração até ao seu abandono. A condição fundamental para esse efeito reside no entendimento das relações entre os diferentes componentes, pois apenas assim será possível descrever os diferentes progressos com maior detalhe.

Para documentar esse acontecimento dinâmico, decidimos dividir os processos no esquema de apresentação em «medidas» e «unidades funcionais». As medidas (M) denotam o trabalho realizado efetivamente pelos romanos, enquanto que as unidades funcionais [UF] se referem aos elementos que funcionavam em conjunto durante uma determinada fase.

É de notar que nem sempre é possível estabelecer uma sequência clara entre as diferentes ações, como é o caso, por exemplo, das ações (M03) e (M04).

As várias galerias para extração e drenagem foram escavadas na zona mais pequena da colina e, portanto, sensivelmente ao mesmo nível.

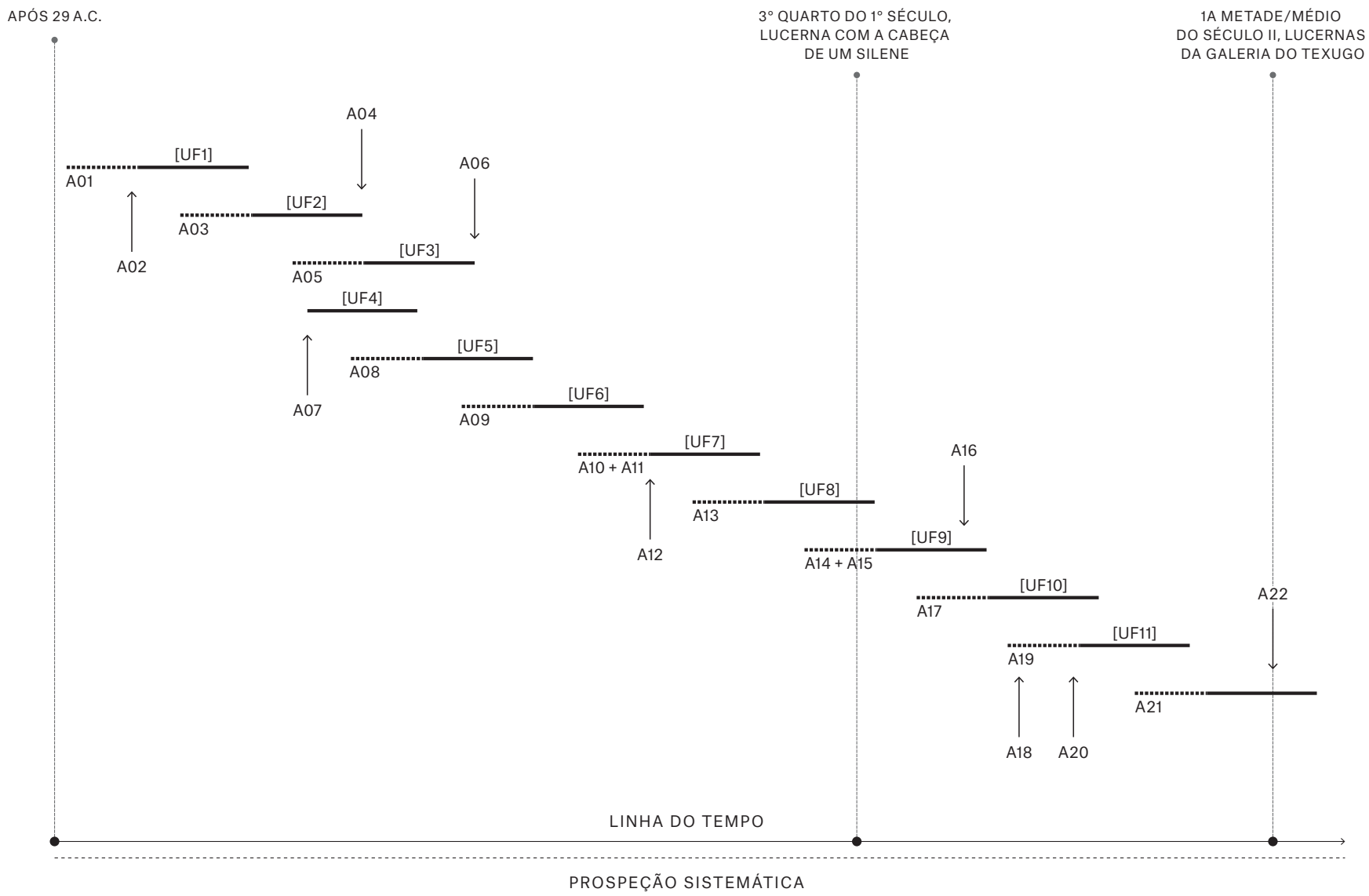

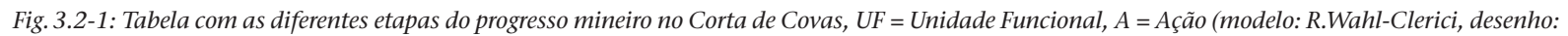
S.Mathiuet).

134 Wahl-Clerici 2010; Wahl-Clerici 2013; Wahl-Clerici / Helfert 2017, $65-69$. 


\section{Observações:}

A duração idêntica das fases das medidas e das unidades funcionais torna-se problemática nesta tabela, o que provavelmente não corresponde à realidade antiga. Porém, como ainda não é sequer possível determinar aproximadamente a duração das fases individuais, consideramos útil manter esta representação esquemática.

Na Corta de Covas não só podemos colocar as várias ações tomadas durante a exploração mineira numa sequência cronológica, como também é possível datá-las de forma aproximada. Os poucos indicadores cronológicos que nos ajudam a fazer isto encontram-se inseridos no esquema, sendo determinantes a conquista final da área de Tresminas em 29 a. C., bem como os fragmentos de lucernas recuperados na Galeria do Texugo, que podem ser datados até à primeira metade/meados do século II. Uma lucerna com volutas, decorada com um sileno no disco e encontrada num cuniculus, tornado obsoleto pelo colapso do canal, fornece um ponto de referência cronológico para a construção do canal. Os cuniculi eram limpos enquanto se encontravam em uso e a lucerna teria muito provavelmente sido removida durante esse processo. A extração já devia ter atingido uma dimensão substancial no final do século I, como provado pelas áreas escavadas até essa altura. ${ }^{135}$ Pelo que parece, o depósito em poço aberto A deve ter sido esvaziado por volta de meados do século II, para depois ser abandonado.

Uma vez que a extração de um depósito deve ser sempre adaptada às condições, dificilmente se pode partir do princípio de que todo o sistema de construção já se encontrava planeado com este rigor quando foram escavadas as primeiras galerias.

Contudo, temos de considerar como muito bem pensada e elaborada a sequência ou interação das várias galerias e poços, conforme demonstra a otimização do processamento, para a qual se atirava o material recém extraído através de poços, com uma profundidade de mais de 30 e $40 \mathrm{~m}$. Este método reduziu significativamente a quantidade de trabalho envolvido no processo de trituração (cf. Processamento). 


\subsection{Progresso na exploração na Corta de Covas} (mina a céu aberto $A$ )

Medidas

3.2 Unidades funcionais (figs. 3.2-2a / b)

(M01) Prospeção geral e especial do terreno.

(M02) Abertura da zona de exploração a sul na mina a céu aberto A.

(M03) Construção da Galeria Esteves Pinto (tempo de construção de aproximadamente 5 anos e meio)

(M04) Início de vários trabalhos de prospeção, incluindo o poço em escada no flanco norte da zona de exploração a sul (cf. 2.0 Prospeção).

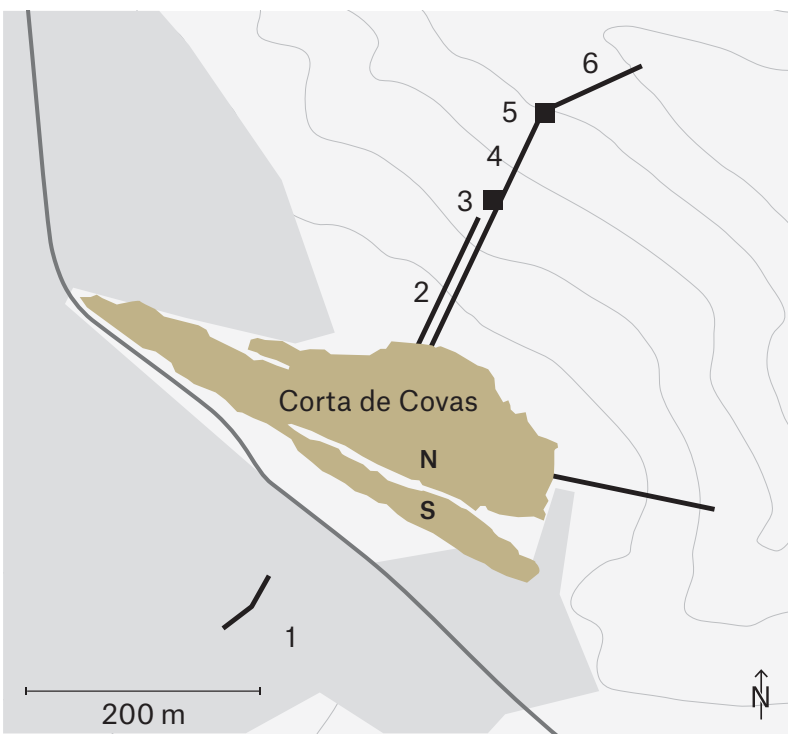

Fig. 3.2-2a: Territorium metallorum Tresminas /Jales. $A$ - Corta de Covas (( $\mathrm{C}=$ zona sul, N = zona norte) 1 - Galeria Esteves Pinto, 2 - Galeria Jürgen Wahl, 3 poço em frente à extensão da Galeria Jürgen Wahl para a Galeria do Pilar, 4 Galeria do Pilar, 5 - poço em frente à extensão da Galeria do Pilar para a Galeria do Texugo, 6 - Galeria do Texugo, 7 - Galeria dos Alargamentos (modelo: Ortofotomapa Câmara Municipal Vila Pouca de Aguiar 1:10000, desenho: J. Wahl, R.Wahl-Clerici, M.Helfert, desenho: S.Mathiuet)

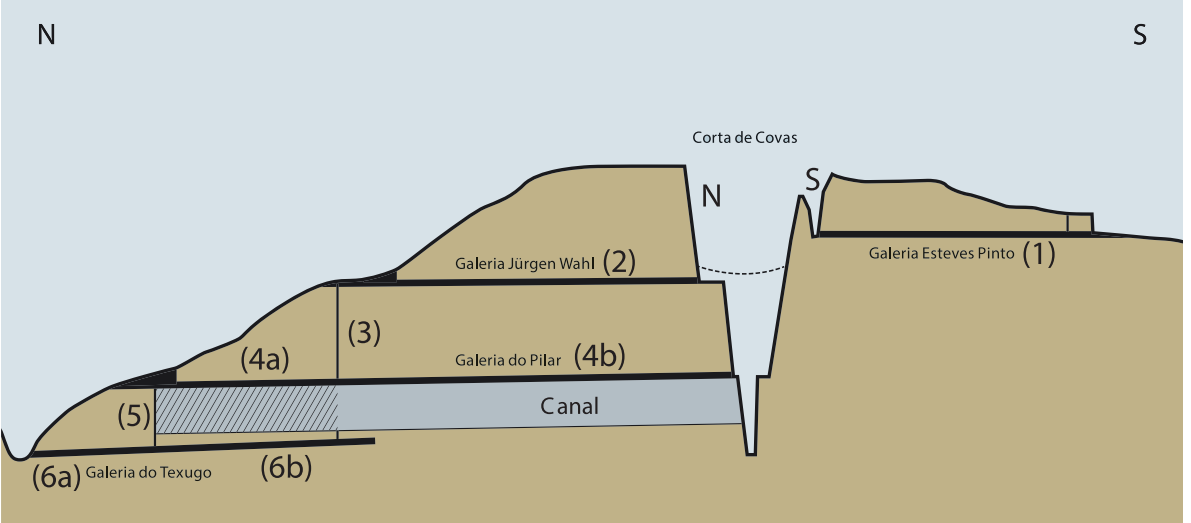

Fig. 3.2-2b: Territorium metallorum Tresminas / Jales. Corte transversal do Corta de Covas, completo (modelo: J. Wahl, R.Wahl-Clerici, desenho: $S$. Mathiuet). 


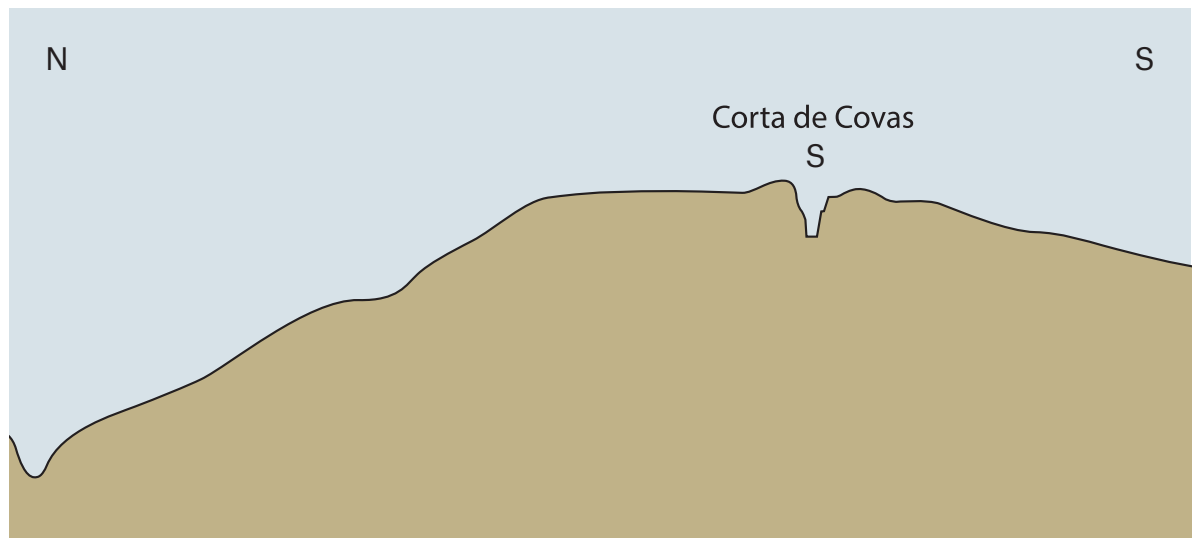

Fig. 3.2-3: Territorium metallorum Tresminas/Jales, Tresminas, Corta de Covas, secção transversal: início da extração na zona sul [UF1].

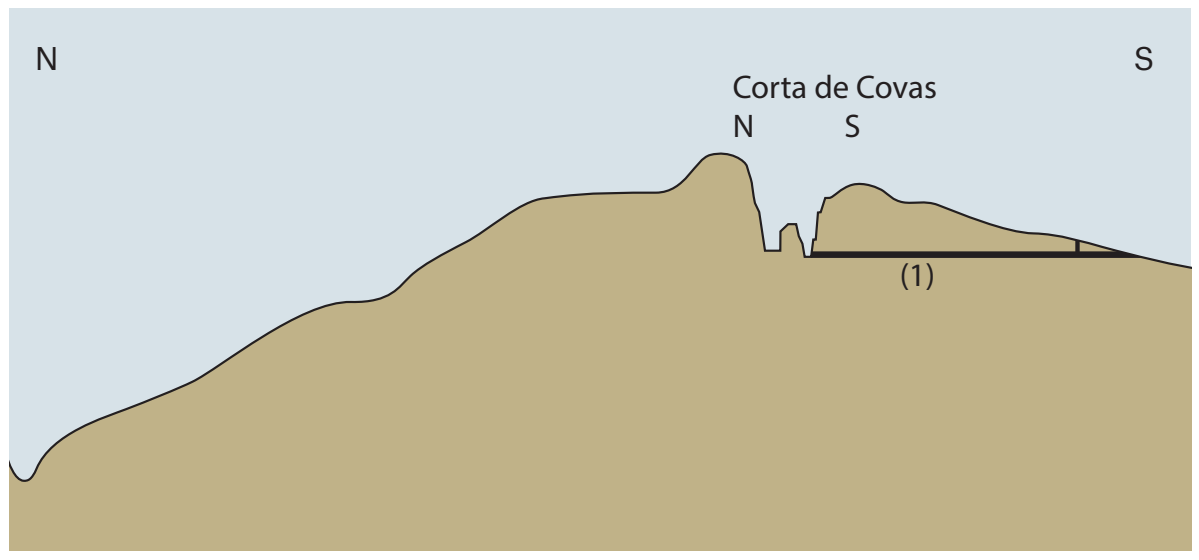

Fig.3.2-5: Territorium metallorum Tresminas/Jales, Tresminas [UF2/3].

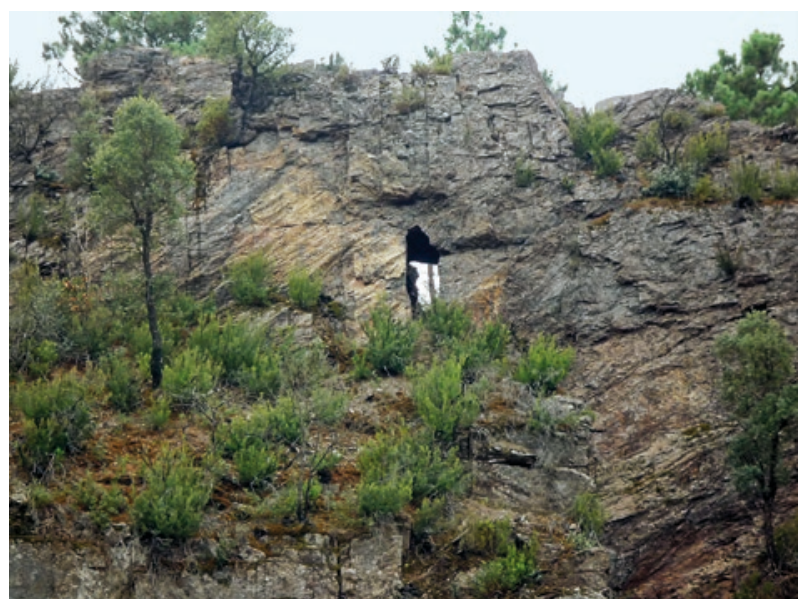

Fig. 3.2-4: Territorium metallorum Tresminas/Jales, Tresminas, Corta de Covas, seç̧ão transversal: continuação da extração na zona sul. Início da extração na zona norte após terem sido identificados níveis de ouro extraíveis através da prospeção no poço em escadas (figs.3.0-7, 3.1-8) [UF2].

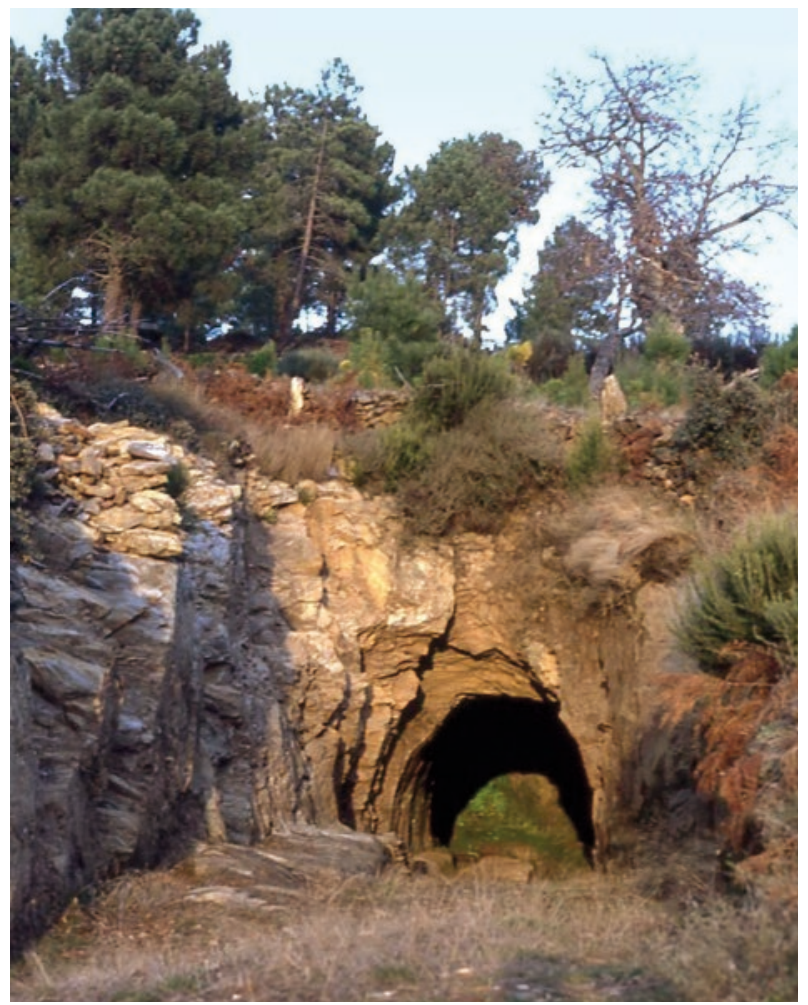

Fig. 3.2-6: Territorium metallorum Tresminas / Jales, Tresminas, Corta de Covas: abertura da Galeria Esteves Pinto, entrada sul [UF2 /3] (fotografia: R.Wahl-Clerici). 
(M05) Construção do canal no piso da Galeria Esteves Pinto.

(M06) Suspensão da exploração mineira na zona sul da mina a céu aberto A e da Galeria Esteves Pinto.

(M07) No limite, foi nesta altura que se deu início à exploração na área norte da Corta de Covas.

(M08) Construção da Galeria Jürgen Wahl (tempo de construção de aproximadamente 6 anos)
[UF 3] Graças ao canal, foi possível afundar a exploração na área sul da mina a céu aberto Corta de Covas. As construções para a cobertura do canal provam que a Galeria Esteves Pinto continuou a ser usada para extração (figs. 3.2-7, 3.2-8).

[UF 4] Exploração na área norte da mina a céu aberto Corta de Covas. A extração e drenagem da zona de exploração era inicialmente levada a cabo por instalações na superfície ou por drenagem na zona de exploração a sul, portanto pela Galeria Esteves Pinto. A depressão marcante na divisão entre as duas zonas pode ser indicadora disso (fig. 3.2-9).

[UF 5] Abertura da Galeria Jürgen Wahl para a extração e drenagem da zona de exploração, após atingir uma profundidade de pelo menos $40 \mathrm{~m}$. Os escombros foram amontoados em frente à boca da galeria (fig. 3.2-10b).

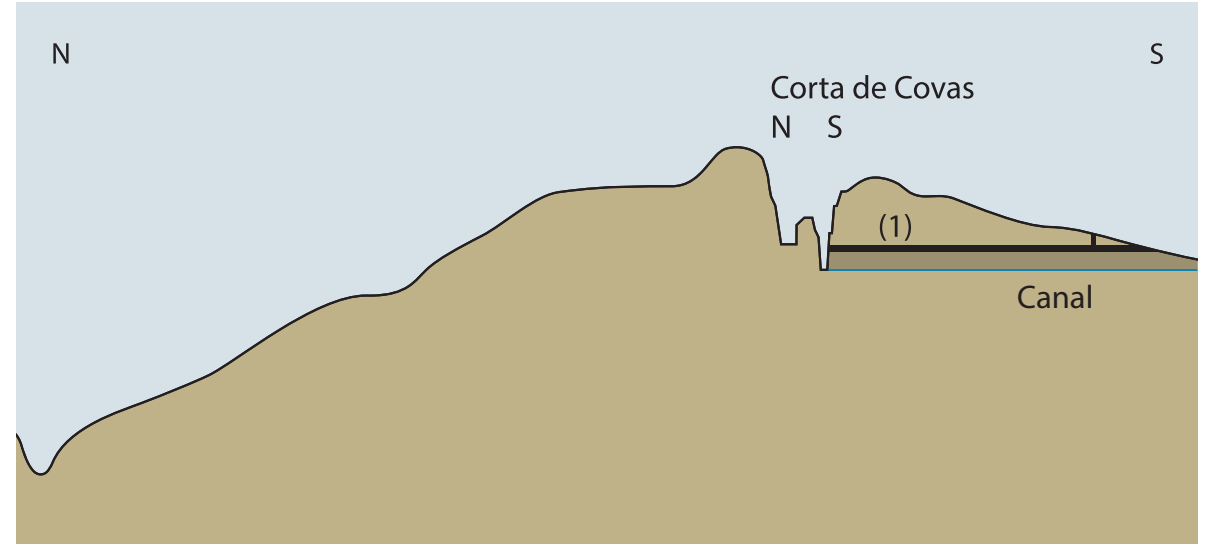

Fig. 3.2-7: Territorium metallorum Tresminas / Jales, Tresminas, secção transversal com o canal na Galeria Esteves Pinto [UF4]. 


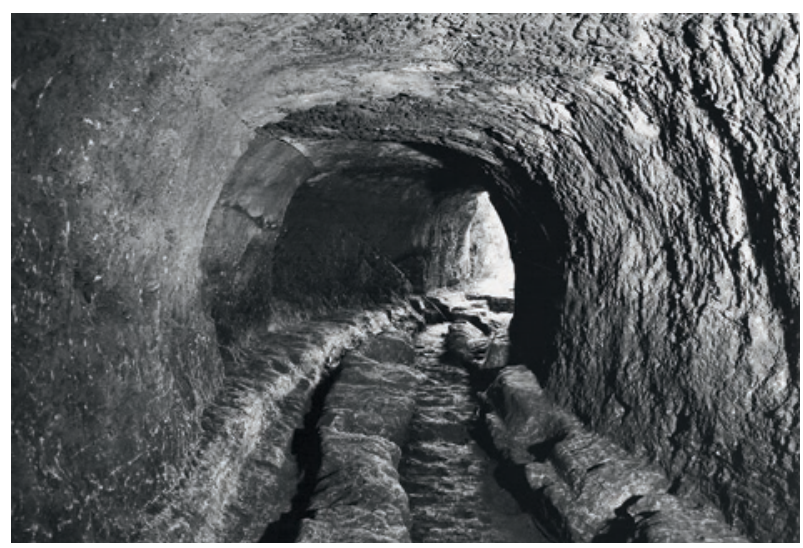

Fig. 3.2-8: Territorium metallorum Tresminas / Jales, Tresminas, Corta de Covas, Galeria Esteves Pinto: no piso são visíveis os sulcos dos carros, o canal e os cortes para a cobertura do canal [UF3/4] (fotografia: J.Wahl).

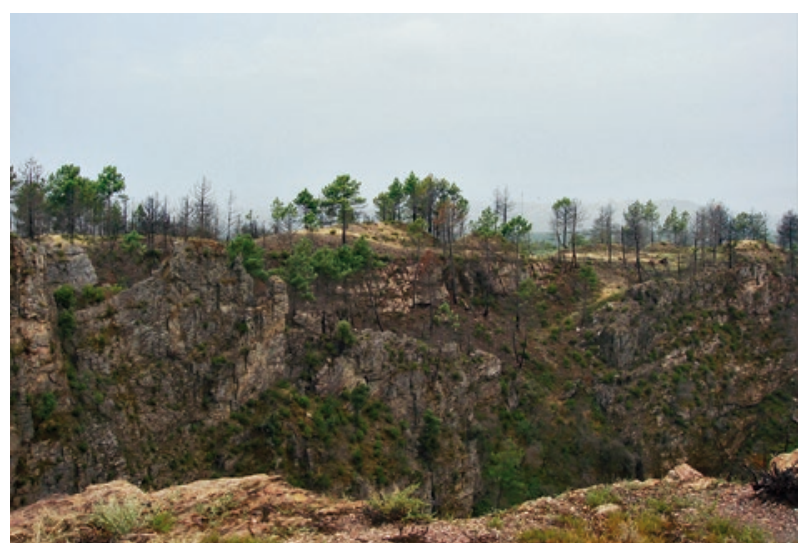

Fig. 3.2-9: Territorium metallorum Tresminas/Jales, Tresminas, Corta de Covas: vista do norte da encosta entre as duas zonas mineiras com a evidente alteração a meio [UF4] (fotografia: R.Wahl-Clerici).

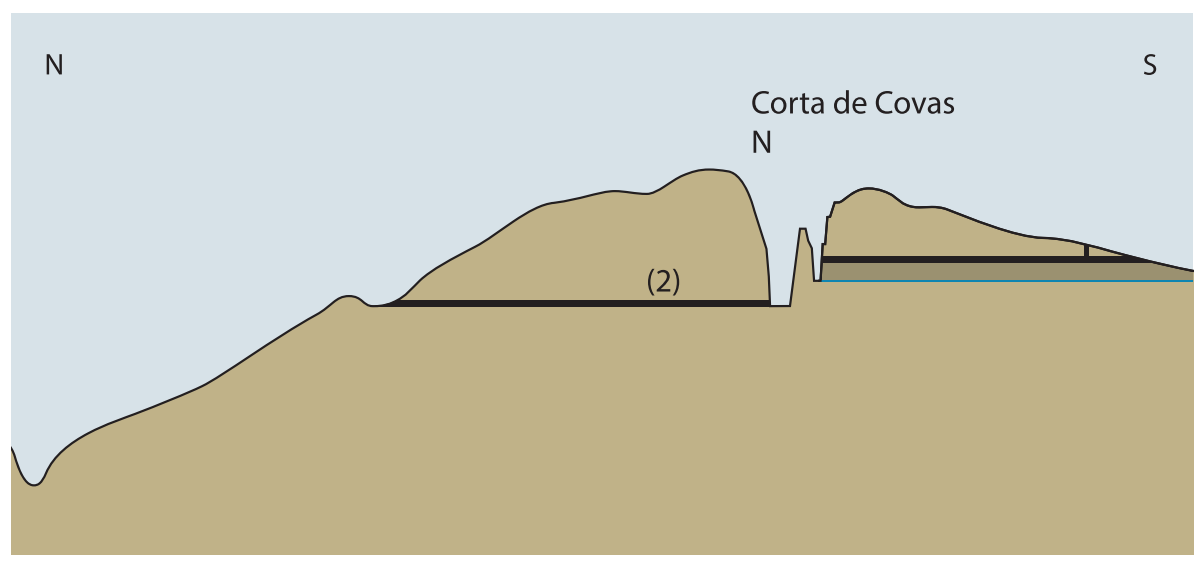

Fig. 3.2-10a: Territorium metallorum Tresminas/Jales, Tresminas, Corta de Covas: unidades funcionais [UF4] e [UF5].

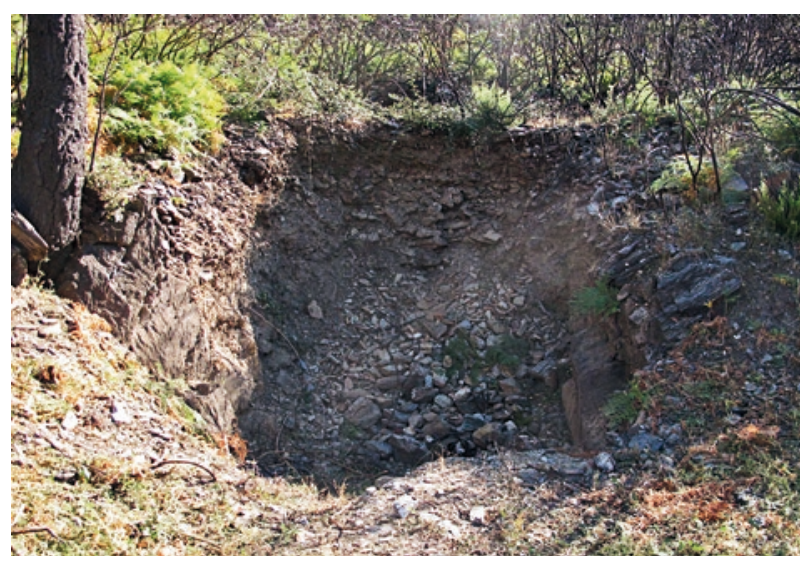

Fig. 3.2-10b: Territorium metallorum Tresminas / Jales, Tresminas, Corta de Covas: vista do norte para a antiga área de entrada da Galeria Jürgen Wahl, completamente coberta com escombros [UF5] (fotografia: R.Wahl-Clerici). 
(M09) Construção simultânea do poço e do percurso entre a boca da Galeria do Pilar até ao poço (tempo de construção de aproximadamente 3 anos e meio). Durante o aprofundamento do poço, o túnel de prospeção foi aberto no cume da Galeria do Pilar (cf. 3.3.1). ${ }^{136}$

(M10) Abertura da Galeria do Pilar até à mina a céu aberto A.

(M11) Construção do pilar na Galeria do Pilar para proteção contra a queda de materiais da escombreira, bem como da extensão necessária da galeria a oriente para garantir a circulação dos carros.

(M12) Abandono da Galeria Jürgen Wahl. trada da Galeria do Pilar e escavação da Galeria do Texugo até ao poço (tempo de construção aprox. 2 1⁄2 anos).
[UF 6] Continuação da exploração na área norte da mina a céu aberto Corta de Covas. O material extraído é trazido à superfície da encosta através da Galeria Jürgen e lançado através do poço para o nível da Galeria do Pilar, num processo chamado «tratamento por lançamento» e daí transportado por um carrinho até à superfície. Dá-se início ao amontoamento ao escombros em frente à Galeria do Pilar (figs. 3.2-11a/b/c).

[UF 7] Extração através da Galeria do Pilar desde a mina a céu aberto até à boca. Numa fase inicial a drenagem ocorria através de dois canais pequenos, construídos a partir das saliências (figs. 3.2-12a / b).

[UF 8] O transporte de material pela Galeria do Pilar, o poço na área da boca (tratamento por lançamento) e a Galeria do Texugo até à superfície da mina. Este processo correspondia ao processo do nível superior com a Galeria Jürgen Wahl, o poço e a Galeria do Pilar (figs. 3.2-13a / b). ${ }^{137}$
136 É de salientar que o poço teve de ser aprofundado através dos escombros da Galeria Jürgen Wahl, constituindo um grande obstáculo durante a construção. Porém, devido à topografia, não era desejável uma posição diferente para a Galeria do Pilar e para o poço.

137 Helfert et al. 2019 


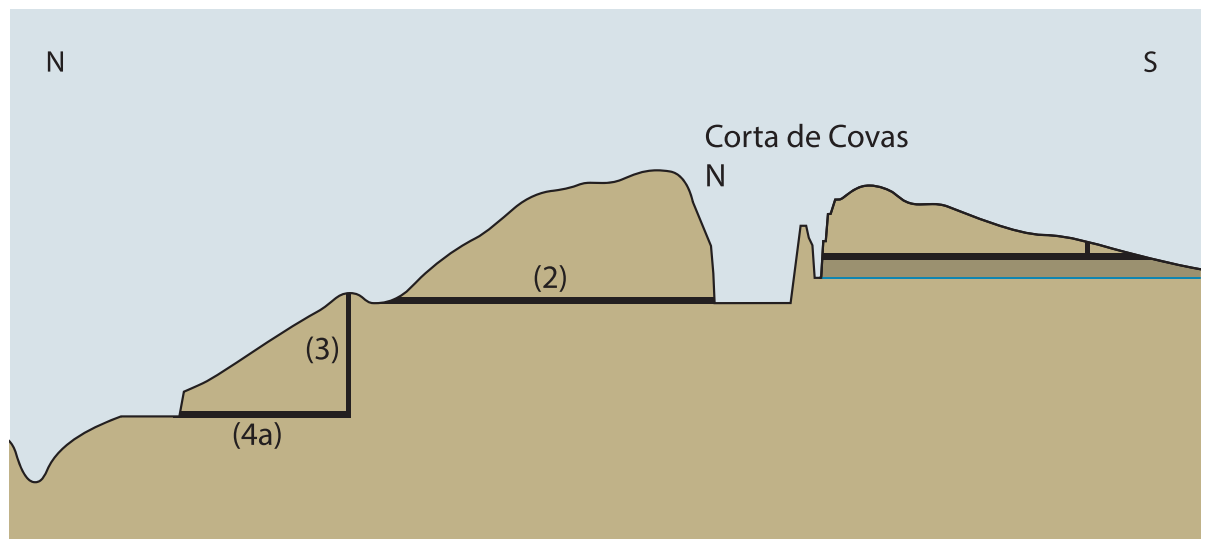

Fig. 3.2-11a: Territorium metallorum

Tresminas /Jales, Tresminas, Corta de Covas: unidade funcional [UF6].

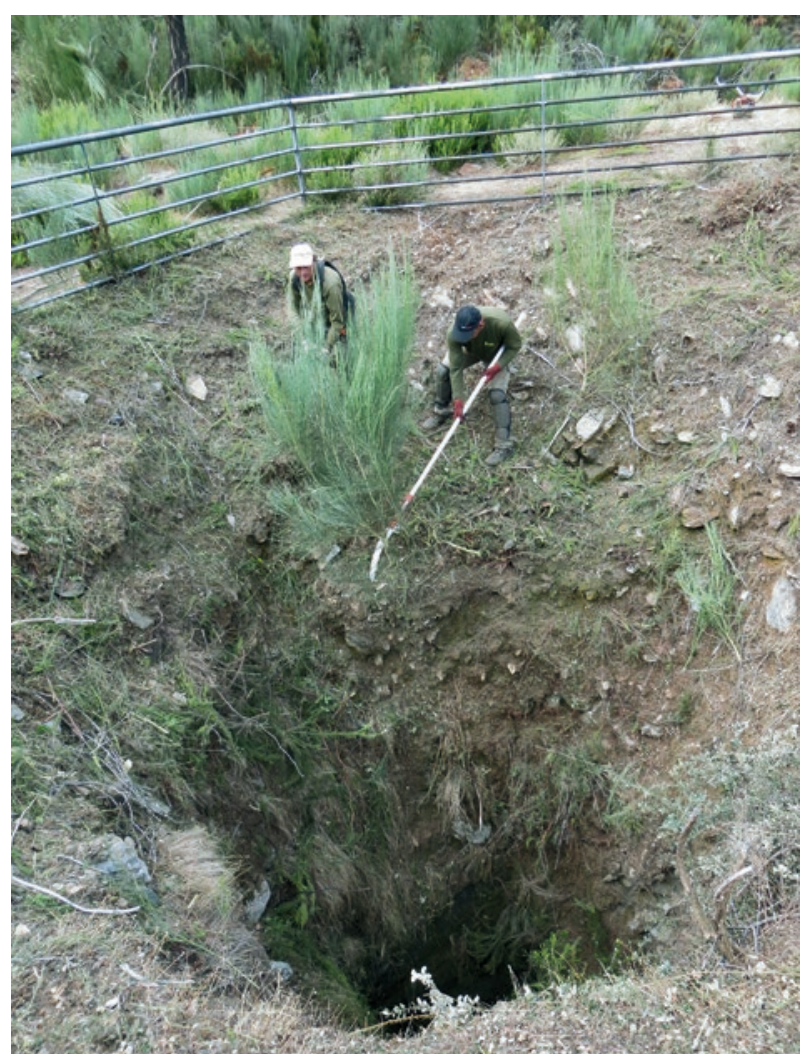

Fig. 3.2-11b: Territorium metallorum Tresminas/Jales, Tresminas, Corta de Covas: boca do poço em frente à Galeria Jürgen Wahl [UF6] (fotografia: R.Wahl-Clerici).

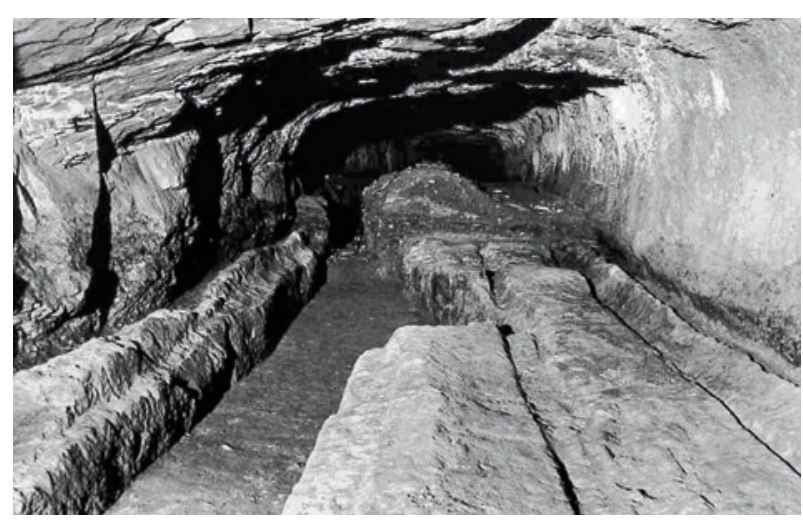

Fig. 3.2-11c: Territorium metallorum Tresminas/Jales, Tresminas, Corta de Covas: zona de entrada da Galeria do Pilar. Nesta fase de utilização da Galeria, os pequenos canais em ambos os lados entre o piso e a parede eram suficientes para a drenagem [UF6] (fotografia: J.Wahl). 


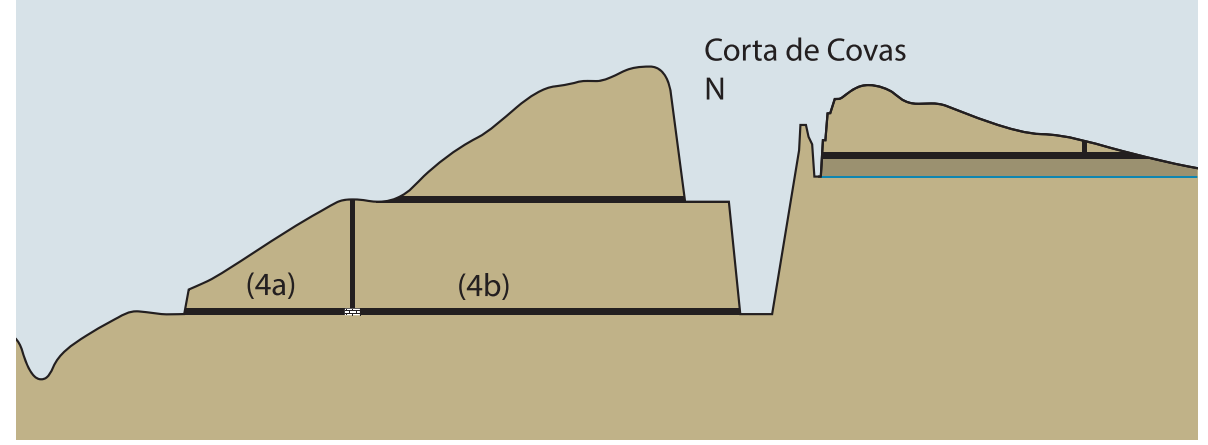

Fig. 3.2-12a: Territorium metallorum Tresminas/Jales, Tresminas, Corta de Covas: unidade funcional [UF7].

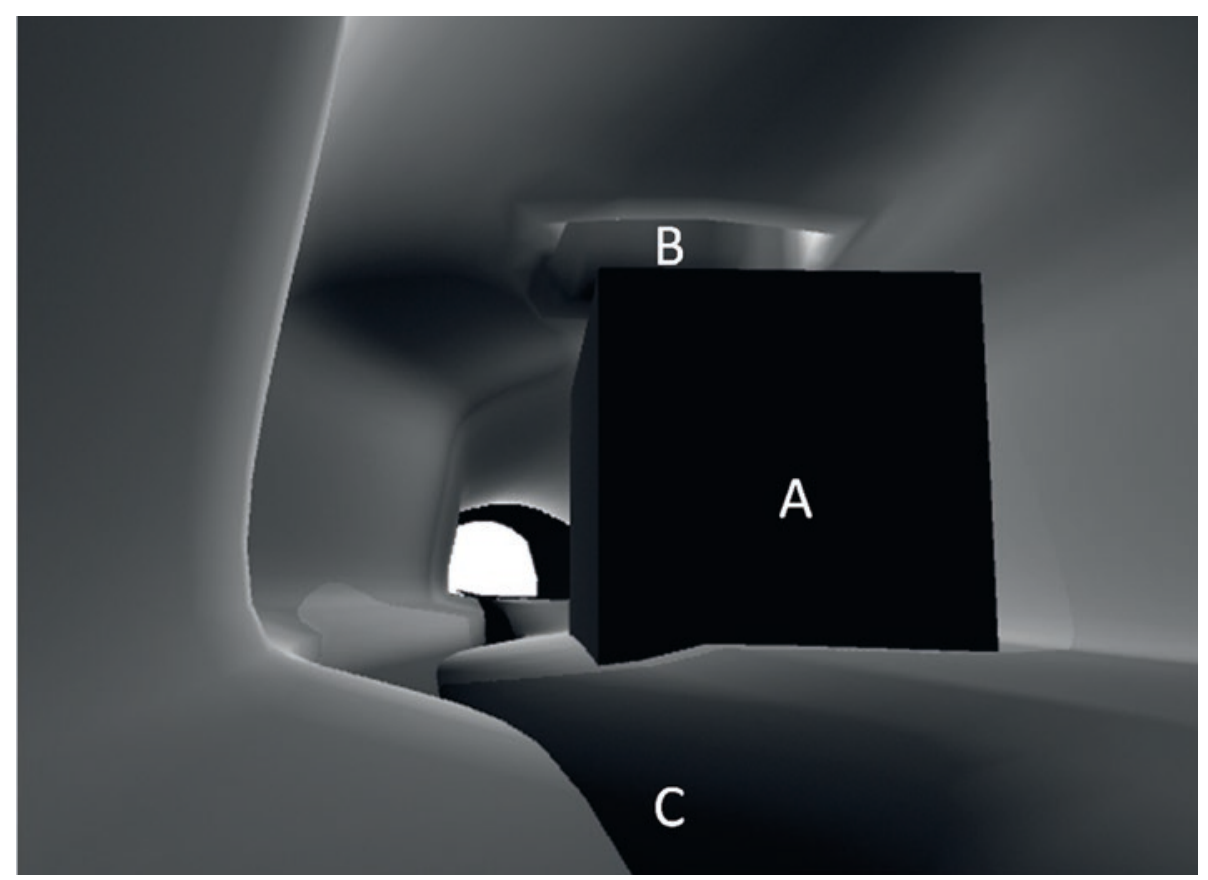

Fig. 3.2-12b: Territorium metallorum Tresminas/Jales, Tresminas, Corta de Covas, do norte em direção à mina a céu aberto: para a construção do pilar por baixo do poço entre a Galeria Jürgen Wahl e a Galeria do Pilar foi necessário aumentar a área de passagem na parede do lado leste [UF7] (modelo J.Wahl, R.WahlClerici, desenho: C. Wahl). 


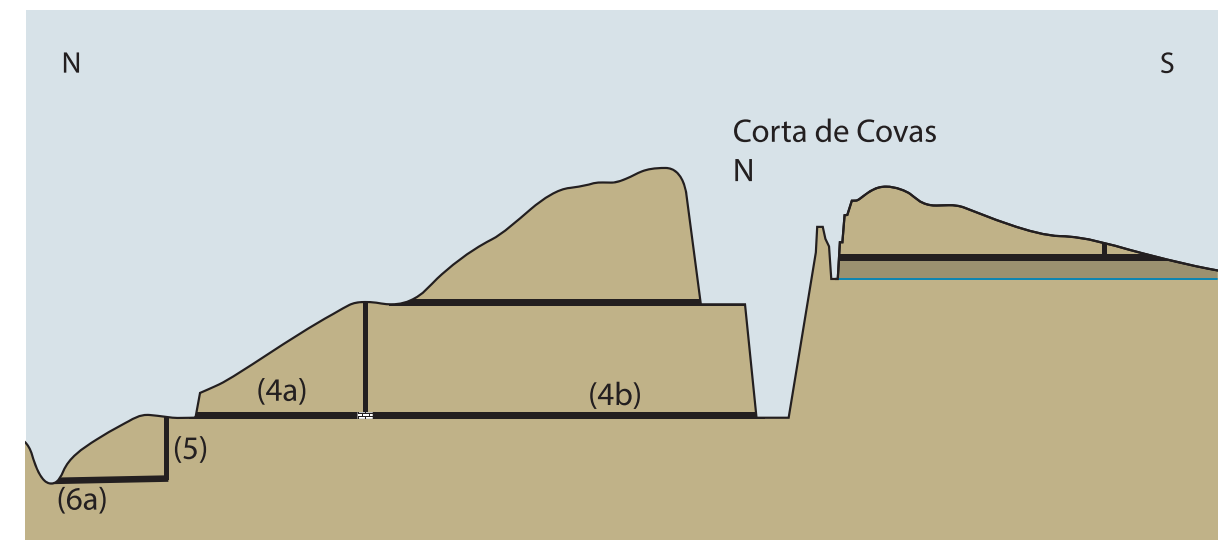

Fig. 3.2-13a: Territorium metallorum Tresminas/Jales, Tresminas, Corta de Covas: unidade funcional [UF8].

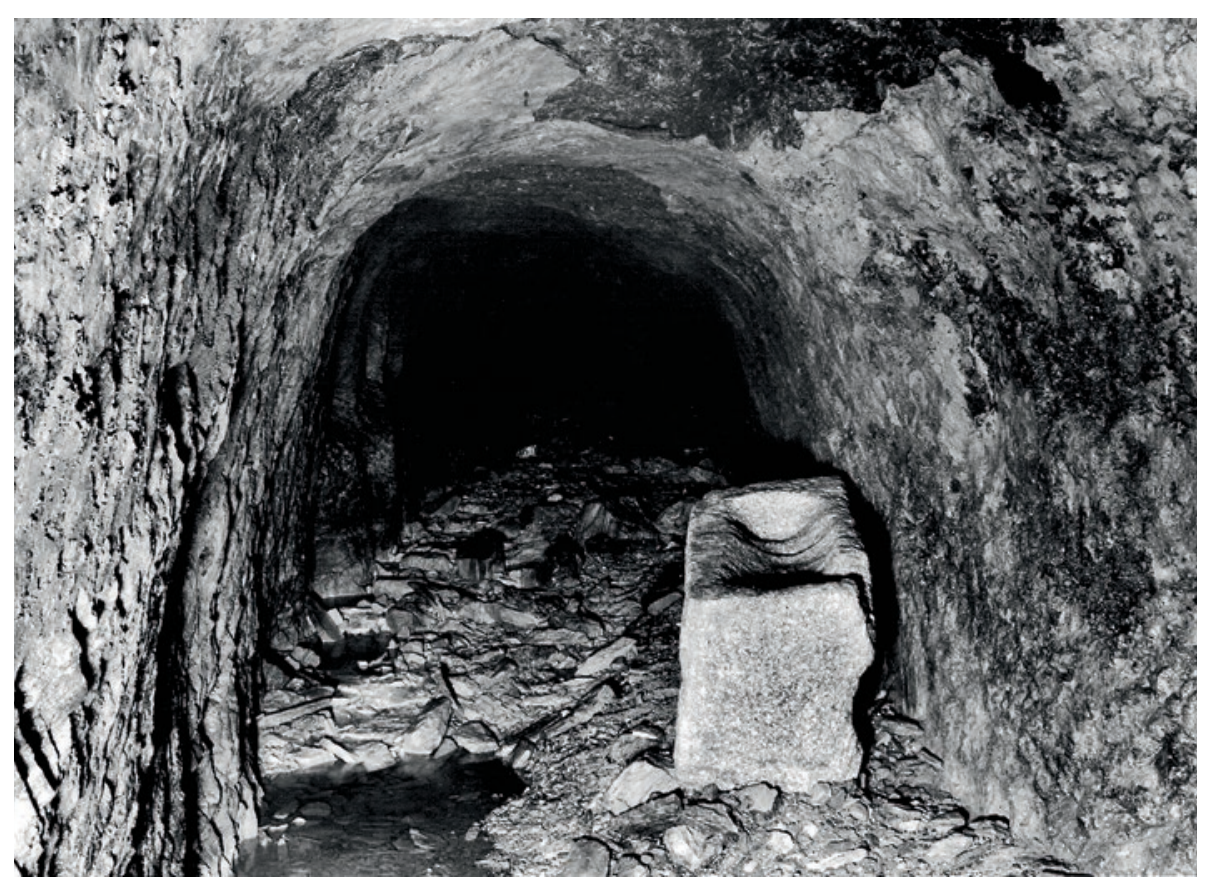

Fig. 3.2-13b: Territorium metallorum Tresminas/Jales, Tresminas, Corta de Covas, Galeria do Texugo (fotografia: J.Wahl). 
(M14) Abertura e aprofundamento gradual do canal na Galeria do Pilar.

(M15) Abandono dos cuniculi ao longo das saliências da Galeria do Pilar.

(M16a) Instalação de um dispositivo de elevação na Galeria do Pilar, na zona de transição para a mina a céu aberto. ${ }^{138}$

(M16b) Preparação para a instalação de um dispositivo de elevação, acionado por um cabrestante, nunca concluída.

(M16c) Construção de um segundo cabrestante, posicionado um pouco mais perto da entrada, e que foi utilizado.

(M17) Abertura da Galeria do Texugo até à área do pilar da Galeria do Pilar.
[UF 9] Construção de um canal na Galeria do Pilar, após ter sido alcançada na mina a céu aberto A uma profundidade abaixo do piso da Galeria do Pilar. A profundidade foi gradualmente ajustada ao nível de exploração na mina (fig. 3.2-14).

[UF 10] Elevação do material, provavelmente, por meio de um guincho, nomeadamente, um dispositivo de elevação acionado por cabrestante, até o nível da Galeria do Pilar. De lá, era levado para a área da boca e lançado para a Galeria do Texugo, cf. [UF 8] (figs. 3.2-15a/b/c, 3.2-16, 3.2-17a / b, $3.2-18,3.2-19)$.

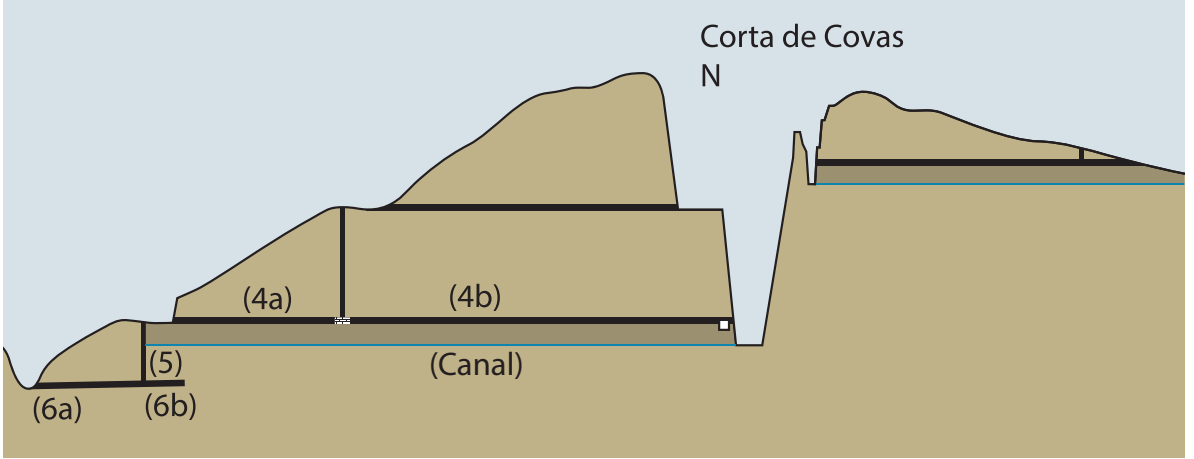

Fig. 3.2-14: Territorium metallorum Tresminas / Jales, Tresminas, Corta de Covas: unidade funcional [UF9] 

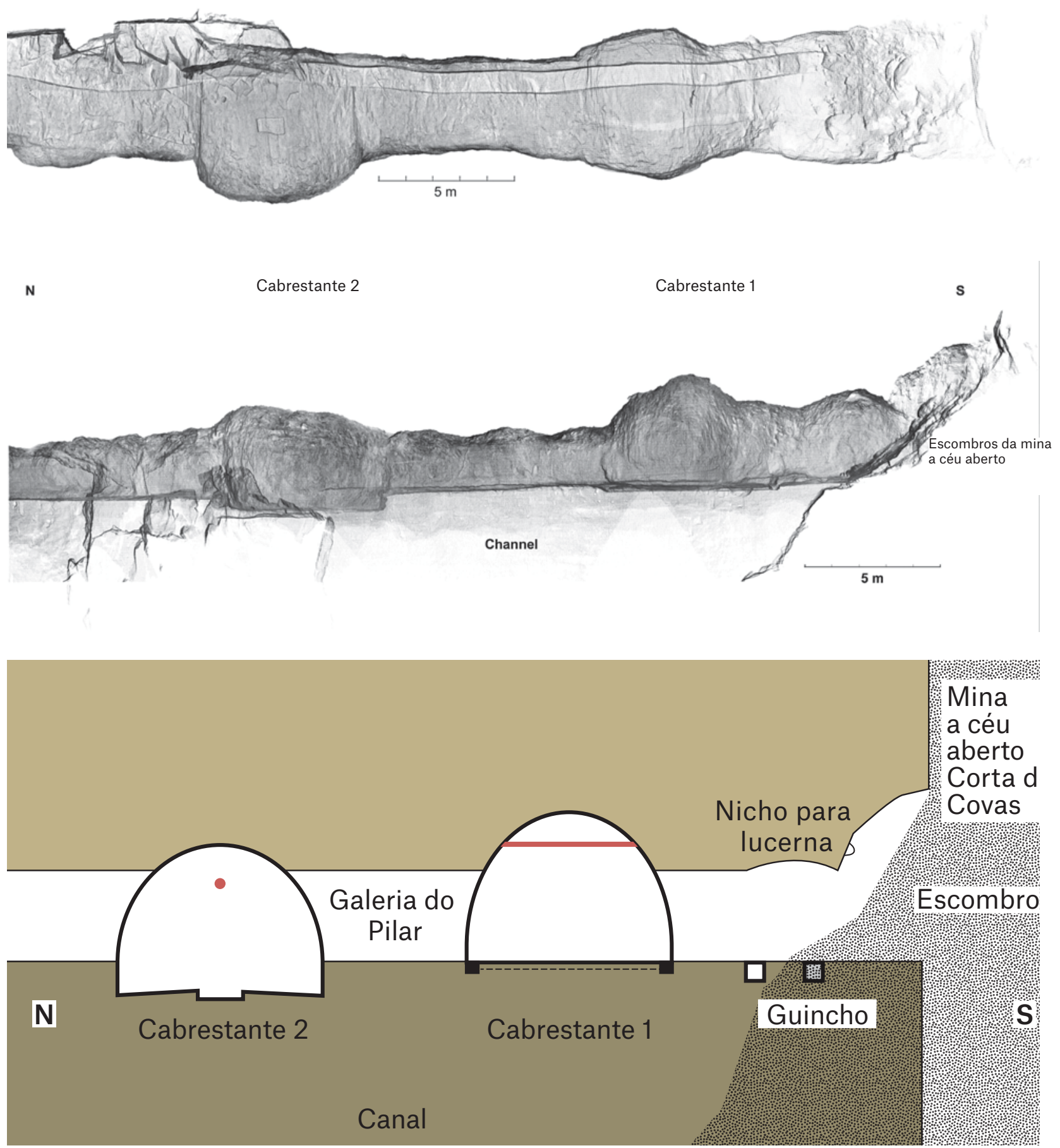

Fig. 3.2-15a / b / c: Territorium metallorum Tresminas / Jales, Tresminas, Corta de Covas: a / b nuvens de pontos da imagem de digitalização a laser 3D da situação na área final em direção à mina a céu aberto na Galeria do Pilar, c representação fortemente esquematizada da situação (a / b gravação e desenho: K.Mechelke e M.Lindstaedt, desenho: R.Wahl-Clerici). 


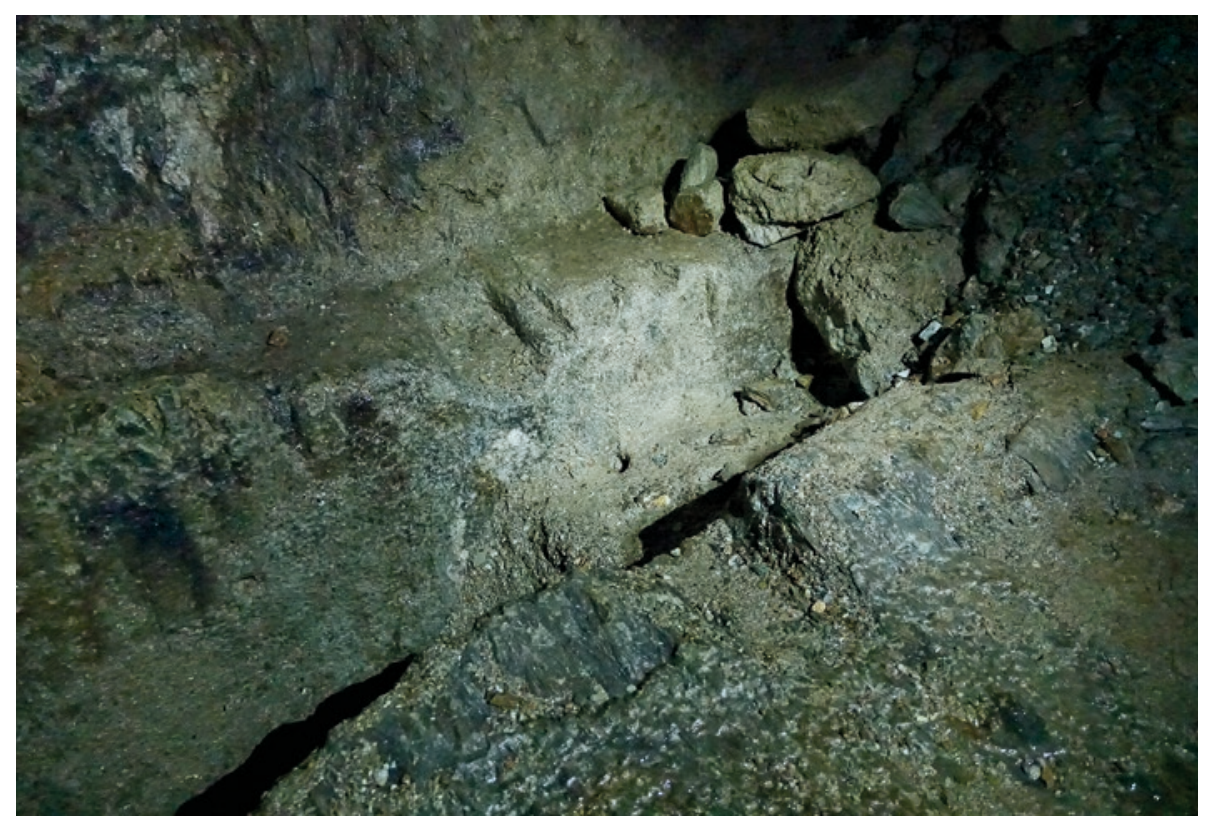

Fig. 3.2-16: Territorium metallorum Tresminas/Jales, Tresminas, Corta de Covas: vestígios da fixação de um guincho. Unidade funcional [UF10a] (foto: R.Wahl-Clerici).
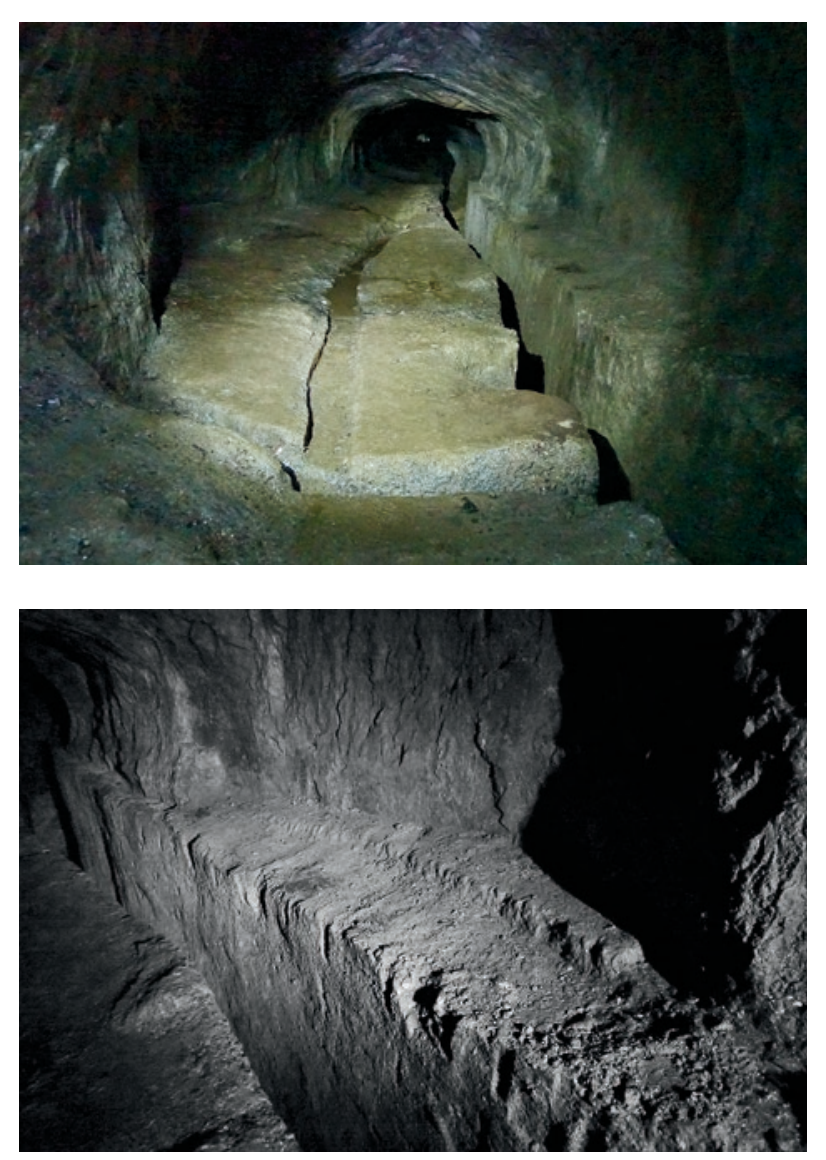

Fig. 3.2-17a/b: Territorium metallorum Tresminas/Jales, Tresminas, Corta de Covas, Galeria do Pilar: extensão inacabada para um dispositivo de elevação, acionado por um cabrestante [UF10b] (fotografia: R.Wahl-Clerici). 


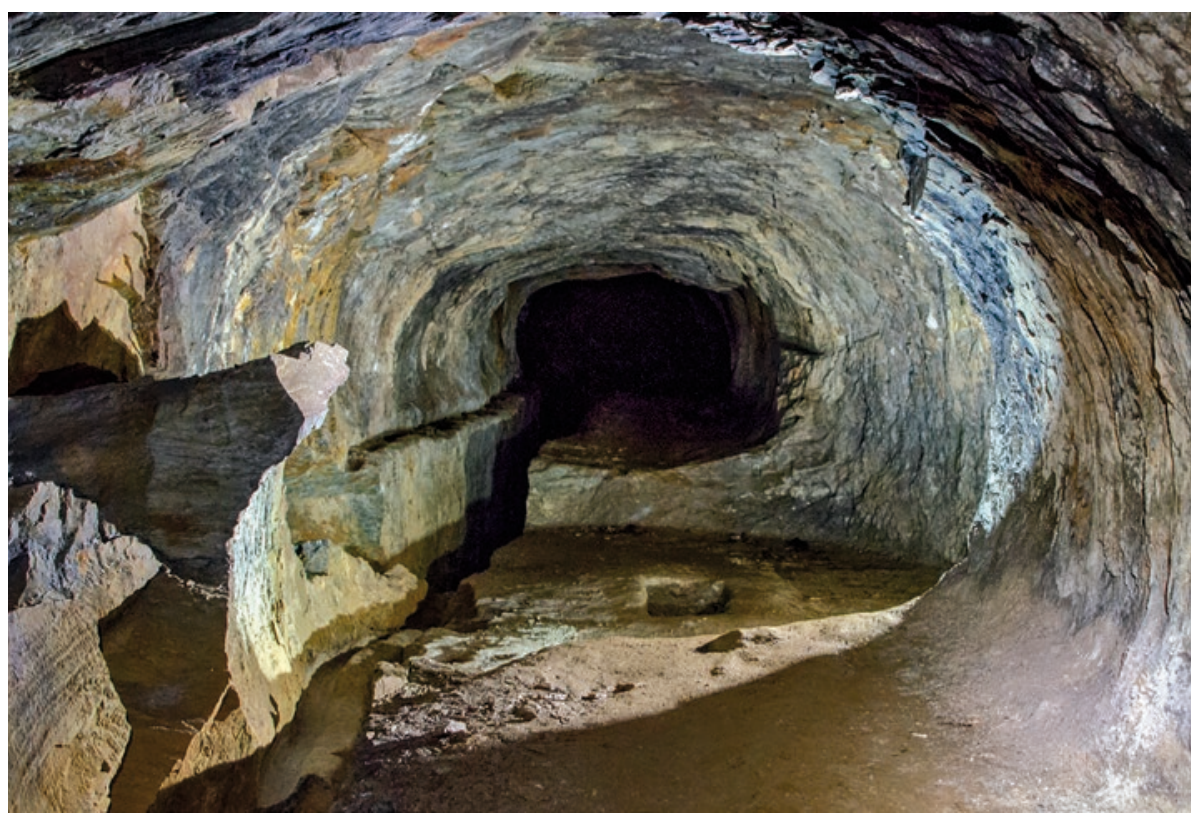

Fig. 3.2-18: Territorium metallorum Tresminas / Jales, Tresminas, Corta de Covas: cortes na rocha para instalação de um dispositivo de elevação, acionado por um cabrestante [UF1Oc] (fotografia: A.Wilson).

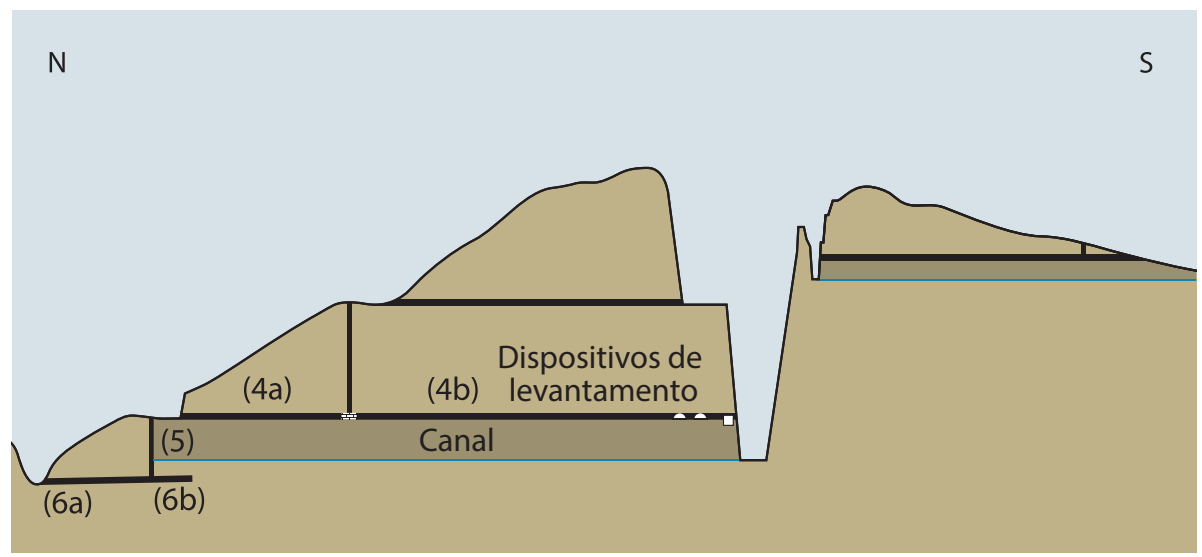

Fig. 3.2-19: Territorium metallorum Tresminas / Jales, Tresminas, Corta de Covas, aprofundamento adicional do canal na Galeria do Pilar. 
(M18) Perfuração de um poço interior entre a Galeria do Texugo e o canal na Galeria do Pilar.

(M19) Enchimento intencional da área do canal entre o poço interior e o poço em frente à boca da Galeria do Pilar. Formou-se um novo piso entre o pilar e a boca da galeria.

(M20) Possibilidade de instalação de um sistema de drenagem mecânica, por exemplo em forma de uma roda de água ou nora, na mina a céu aberto A, para garantir um aprofundamento adicional.

(M21) Abertura da Galeria do Texugo em direção a leste, para prospeção da montanha.

(M22) Data máxima para o abandono da mina a céu aberto

A.
Pilar entre o poço em frente à entrada da Galeria do Pilar para a Galeria do Texugo até à área do pilar, onde foi construído um poço cego. A drenagem da mina a céu aberto A passou a fazer-se através do canal, do poço cego e da Galeria do Texugo (figs.3.2-20a / b). 

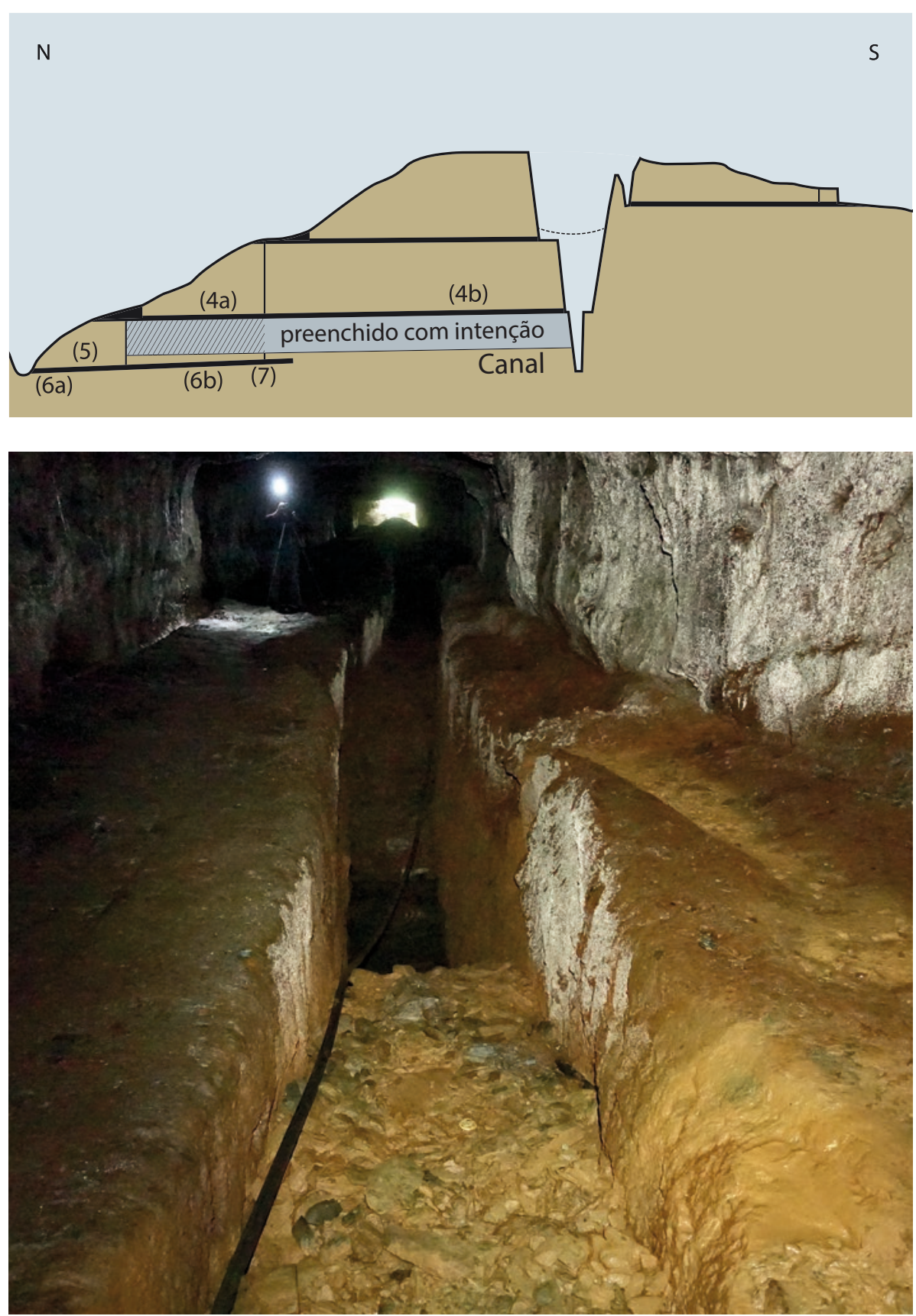

Fig. 3.2-20a / b:Territorium metallorum Tresminas/Jales, Tresminas, Corta de Covas, Galeria do Pilar: zona entre a entrada e o poço cego, intencionalmente preenchida, entre a Galeria do Pilar e a Galeria do Texugo [UF11] (fotografia: R.Wahl-Clerici). 


\subsection{As galerias de Tresminas}

Devido às suas dimensões, as galerias de Tresminas conseguem impressionar tanto os seus visitantes como investigadores. Estas minas subterrâneas são únicas e, graças à estabilidade das montanhas, encontram-se em excelente estado de conservação, pelo que são da maior importância para o entendimento das técnicas de exploração mineira romana (fig.3.3-1). ${ }^{139}$

As grandes galerias fazem parte dos trabalhos de prospeção e de exploração nas duas grandes minas a céu aberto, a Corta de Covas e a Corta da Ribeirinha (fig. 3.3-2). De acordo com o que se sabe atualmente, a exploração mineira subterrânea em Lagoinhos era levada a cabo apenas por via de poços (fig. 3.3-3).

\section{Corta de Covas}

- Galeria Esteves Pinto (fig. 3.3-4)

- Galeria Jürgen Wahl (fig. 3.2-10b)

- Galeria do Pilar (fig. 3.3-5)

- Galeria do Texugo

\section{Entre a Corta de Covas e a Corta da Ribeirinha}

- Galeria dos Alargamentos (fig. 3.3-6)

\section{Corta da Ribeirinha}

- Galeria dos Morcegos (fig. 3.3-7)

- Galeria Buraco Seco (fig. 3.3-8)

Com exceção da Galeria do Texugo, estas galerias são, de facto, túneis, o que significa que, tanto na área de extração, como no lado da encosta, se encontra uma abertura. A Galeria dos Alargamentos representa um caso especial, dado que a câmara final no interior da montanha se encontra ligada à superfície por um poço (figs. 3.3-9 e 3.3-10).

As galerias assumem várias funções; inicialmente planeadas como túneis, as galerias Esteves Pinto, Jürgen Wahl, do Pilar, dos Morcegos e, principalmente, a Galeria do Texugo serviram sempre de drenagem e para a exploração. Até hoje, o Buraco Seco continua a drenar a Corta da Ribeirinha. O capítulo sobre o progresso na extração na Corta de Covas trata da função e das relações entre as galerias. Contudo, ainda são muito escassas as informações sobre os progressos na extração na Corta da Ribeirinha. As suas duas entradas sugerem que a Corta se encontrava originalmente dividida entre uma parte ocidental e uma parte oriental. As investigações sobre as descobertas nas duas minas subterrâneas, o poço em espiral e a Galeria do Pastor, que se encon- tram na ligação entre essas duas partes, vieram confirmar o que anteriormente já se suspeitava.

Nos pisos das Galerias Esteves Pinto, dos Alargamentos, do Pilar e, possivelmente, do Texugo ${ }^{140}$ encontram-se os sulcos que, muito provavelmente, acabaram por ser aprofundados com o uso dos carros. (figs. 3.3-2, 3.3-4 e 3.311). Na intersecção dos dois eixos de extensão da Galeria dos Alargamentos, regista-se o quadro típico de uma zona com sulcos, que continuam a aprofundar-se gradualmente (fig. 3.3-12).

\section{A Galeria Esteves Pinto}

Esta grande galeria de Tresminas, que dava acesso à área de extração no sul da Corta de Covas, foi descoberta em 1992 por Jürgen Wahl, altura em que a sua área de entrada, com uns impressionantes 20,40 m de comprimento, se encontrava completamente obstruída pelo escombros das encostas (fig. 3.2-6). Esta galeria permitia o acesso à área de exploração a sul na Corta de Covas. A sua posição e nível (810 m de altitude) remetem para uma cronologia recuada. ${ }^{141}$ Não sabemos o motivo pelo qual o poço de observação, necessário para a medição e construção do túnel, tem mais profundidade que o piso futuro. Pois assim, só era possível assegurar o transporte com carros nos sulcos recorrendo a instalações em madeira. (fig. 3.3-13).

\section{A Galeria Jürgen Wahl}

Este túnel mais antigo, que garantiu o acesso e, provavelmente, a drenagem para a área de exploração no norte da Corta de Covas, a um máximo de $787 \mathrm{~m}$ de altitude, foi também descoberto em 1995 por Jürgen Wahl. A impressionante densidade de vestígios do tratamento de minério (fig. 4.0-3), ou seja, moinhos de pilão e fragmentos de mós, bem como a escombreira em frente à galeria para o poço, que conduz à Galeria do Pilar, protegida nesta altura pela construção do pilar (ver Galeria do Pilar), foram as primeiras coisas a atrair a atenção. A posição da área de entrada da Galeria Jürgen Wahl resultou da observação de uma ligeira depressão na encosta. (figs. 3.2-10b e 3.3-14).

139 Wahl 1988; A confusão criada por Harrison, em 1931, Fig. 4, entre as galerias «do Pilar « e «do Texugo", acabou por ser difundida por outros autores (cf. Quiring 1932, Fig. 2) com a errada designação de «Arrúgia da Gralheira (Pedras Salgadas), no norte de Portugal».

140 Nunca foi possível investigar o piso desta galeria, que está inacessível desde 1988.

141 Wahl 1998, 60-61, Fig. 4. 
Depois de proceder à limpeza de uma pequena parte dos escombros na área da entrada, conseguiu-se localizar as paredes ao longo de um breve percurso, não tendo sido possível, até hoje, chegar ao piso. Esta galeria tem uma largura de 2,65 m, e o seu comprimento, de pelo menos $120 \mathrm{~m}$, apenas pode ser determinado por meio de levantamentos topográficos. Relativamente à sua construção, não é possível adiantar qualquer informação.

\section{A Galeria do Pilar}

As extraordinárias dimensões e os detalhes de construção da Galeria do Pilar fazem dela um tesouro de conhecimento sobre a mineração romana. A área de entrada tem $4,20 \mathrm{~m}$ de largura e toda a galeria atinge um comprimento de mais de 250 m (figs. 3.3-2 e 3.3-5). Além do mais, a passagem entre a galeria e a mina a céu aberto revela detalhes técnicos importantes. A visão sobre a zona de abertura na encosta não é clara devido à quantidade de entulho da encosta e ao nivelamento da antiga escombreira. Na época romana a zona aberta tinha pelo menos $10 \mathrm{~m}$ de comprimento, incluindo o poço de ligação à subjacente Galeria do Texugo. A área de abertura da Galeria do Pilar fica $744 \mathrm{~m}$ acima do nível do mar, ou seja, cerca de $40 \mathrm{~m}$ abaixo da Galeria Jürgen Wahl e a $31 \mathrm{~m}$ acima da Galeria do Texugo (figs. 3.3-15 e 3.3-16).

De particular interesse reveste-se a instalação de um pilar, através do qual não só era evitada a queda dos escombros, vindo do poço de ligação obsoleto que conduz à área de entrada da Galeria Jürgen Wahl, como a consequente obstrução no acesso à parte de trás da galeria (figs. 3.3-5, 3.3-17 e 3.2-12b). ${ }^{142}$ Neste espaço comprova-se igualmente que o canal com $23 \mathrm{~m}$ de profundidade, que segue ao longo da parede oriental, é mais recente do que a estrutura do pilar, pois é claramente estreito e foi construído ao longo da extensão do lado oriental. Esta extensão permitia a passagem com carros em todo o trajeto e os vestígios das construções de suporte em madeira ainda são visíveis no canal (fig. 3.3-18). O próprio canal também era apoiado por um vasto conjunto de vigas em madeira, conforme é visível na zona de desabamento, junto da área de extensão para a instalação do dispositivo de elevação acionado por cabrestante (fig. 3.3-19).

De grande interesse para a mineração antiga são as estruturas preservadas na Galeria do Pilar, na área da transição para a exploração a céu aberto. Graças à construção de uma ponte, este espaço foi reaberto em 2018, pela primeira vez desde 1990, e, na medida do possível, liberto dos escombros da mina a céu aberto (fig. 3.3-20). ${ }^{143}$

Perto da boca em direção à mina a céu aberto, mantiveram-se preservadas inúmeras cavidades na rocha. Por enquanto, não foi possível determinar a sua relação, podendo muito provavelmente ter servido para instalar dispositivos de segurança, por exemplo, no mínimo três construções de elevação diferentes, um carretel e duas construções acionadas por cabrestante (figs. 3.3-15a/b/c). O guincho encontrava-se mais próximo da mina a céu aberto (fig. 3.3-16).
De particular interesse são os vestígios de uma estrutura de elevação acionada por cabrestante nunca utilizada e abandonada numa fase de construção bastante avançada, por razões ainda não explicáveis. Após conclusão da cúpula relativamente alta e dos pontos de fixações para a viga de suporte, era necessário aprofundar o piso, pelo que se determinaram os limites e criaram-se as cavidades para dispor de um maior número possível de pontos de ataque, reduzindo assim o tempo de construção (figs. 3.3-21 e 3.3-22). Esta estrutura de elevação abandonada encontra-se $8 \mathrm{~m}$ mais próxima da mina a céu aberto do que aquela utilizada durante mais tempo, conforme comprovam os sinais de desgaste no piso (figs. 3.3-23 e 3.3-24).

\section{(4) A Galeria do Texugo (figs. 3.2-13b e 3.3-25)}

Para a construção da Galeria do Texugo (715 m acima do nível do mar) foi necessário cumprir três condições. Por um lado, teve de ser construída em cota bastante mais baixa do que a Galeria do Pilar, o que implicava apenas um único local, ligeiramente deslocado para leste do eixo dessa galeria. Por outro lado, era novamente intenção dos romanos proceder a um sistema de construção com recurso à escavação de um poço, tal como tinha sido feito entre a Galeria Jürgen Wahl e a Galeria do Pilar. A terceira condição implicava que o canal com uma profundidade provavelmente considerável, no qual não era de excluir o possível risco de um desabamento devido à fratura natural, deveria ser parcialmente obstruído para que a água escorresse, através de um poço lateral (após 175 m) entre as duas galerias, em direção à Galeria do Texugo. Finalmente, após 199 m, procedeu-se à prospeção da montanha a oriente, por via de um túnel de aproximadamente $25 \mathrm{~m}$ de comprimento com poços laterais (fig. 3.3-16). ${ }^{144}$

\section{(4) A Galeria dos Alargamentos (fig. 3.3-1)}

A Galeria dos Alargamentos tem $157 \mathrm{~m}$ de comprimento e foi construída $791 \mathrm{~m}$ acima do nível do mar, representando a peça central das atividades de prospeção entre as duas minas a céu aberto, embora nunca ligada à Corta de Covas. Para a sua construção procedeu-se à abertura por dois lados (figs. 3.3-26 e 3.3-27). ${ }^{145}$

A sua principal característica, à qual deve o seu nome, são as quatro extensões, sistematicamente planeadas e cuidadosamente escavadas na parede a norte, cuja função ainda não foi possível determinar. Devido à correspondente falta de vestígios de desgaste, pode-se excluir apenas que se tratava de zonas de alargamento para facilitar a circulação dos carros (figs. 3.3-6, 3.3-11 e 3.3-12). Apesar do cuidadoso trabalho de aperfeiçoamento no tecto e nas pa-

142 Wahl 1988, 226-229; Wahl-Clerici 2011; Wahl-Clerici 2013.

143 Helfert et al. 2019.

144 Wahl 1988,229.

145 Wahl 1988, 229-230; Wahl-Clerici et al. 2011; Helfert et al. 2013. 
redes, mantêm-se visíveis vestígios de um poço de avanço, do qual partiu a extensão da galeria para ambos os lados. Igualmente interessante é o facto de apenas surgirem sulcos na secção que parte da superfície da encosta.

A grande câmara final em forma de cúpula foi criada por uma extensão a partir do poço. Mais tarde, instalou-se uma construção de elevação por cabrestante, da qual resta a típica área arredondada e um buraco para a viga. A partir desta câmara, foram construídos túneis de prospeção em todas as direções (figs. 3.3-10, 3.3-28 e 2.0-10).

Uma das descobertas mais importantes na Galeria dos Alargamentos formam os vestígios de um desabamento ocorrido no poço em escada a sul, que, aparentemente, foi construído em parte a partir do piso da galeria, após esta ter sido abandonada (fig. 2.1-1).

\section{A Galeria dos Morcegos}

Este túnel tem cerca de $160 \mathrm{~m}$ de comprimento e encontra-se $727 \mathrm{~m}$ acima do nível do mar. Nunca foi concluído (figs. 3.3-7, 3.3-29-3.3-12) e segue uma rota com vários ângulos, muito provavelmente devido às suas condições topográficas (figs. 3.3-29 e 3.3-30). O percurso mais curto teria seguido através de um pequeno vale onde se haviam espalhado os escombros da Corta da Ribeirinha. Como é evidente, preferiu-se evitar esta situação com a escolha de um ponto de partida diferente, assumindo para isso as dificuldades de medição e extensão. Parece ter sido uma preocupação dos romanos percorrer de novo, com a ajuda da Galeria dos Morcegos e a um nível mais fundo, a zona atravessada pela entrada a oeste que em áreas mais altas já havia sido explorada e cuidadosamente sujeita a prospeção.

A Galeria dos Morcegos media na zona da entrada $3,85 \mathrm{~m}$ de largura, o que teria permitido a passagem com carros em ambas as direções. Além disso, a montanha acima da Galeria dos Morcegos não era suficientemente estável na área da entrada, pelo que foi necessário reforçá-la. As cavidades para o suporte das construções em madeira encontradas na rocha são prova disso (fig.3.3-31).

\section{A Galeria do Buraco Seco}

A Galeria do Buraco Seco tem 90 metros de comprimento e até hoje liberta a Corta da Ribeirinha (723 metros acima do nível do mar) das águas pluviais e das águas da montanha (figs.3.3-8 e 3.3-32). Para conseguir um túnel completamente linear, foi provavelmente necessário proceder à medição a partir do lado oposto do vale, conforme havia sido feito na Galeria do Pilar. Pelo que parece, o túnel foi aberto exclusivamente para fins de drenagem, dado que a sua largura não permitia a passagem com carros. 


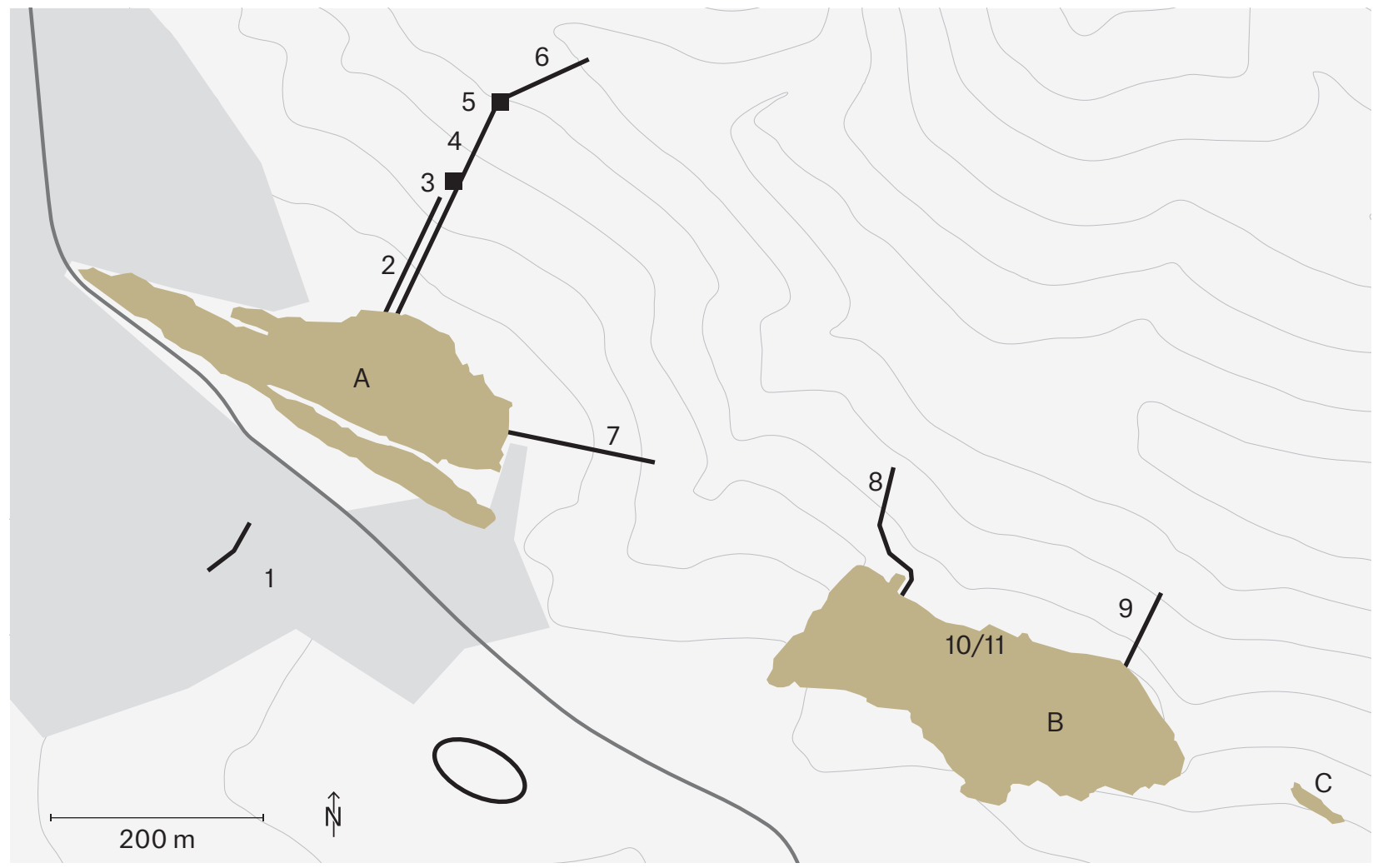

Fig. 3.3-1: Territorium metallorum Tresminas / Jales. Vista geral da zona central de Tresminas: A — Corta de Covas, B - Corta da Ribeirinha, C - Lagoinhos 1 - Galeria Esteves Pinto, 2 - Galeria Jürgen Wahl, 3 - Poço em frente à extensão da Galeria Jürgen Wahl para a Galeria do Pilar, 4 - Galeria do Pilar, 5-Poço em frente à extensão da Galeria do Pilar para a Galeria do Texugo, 6 - Galeria do Texugo, 7 - Galeria dos Alargamentos, 8 - Galeria dos Morcegos, 9-Galeria Buraco Seco, 10 - Poço em espiral, 11 - Galeria do Pastor. (Modelo: Ortofotomapa Câmara Municipal Vila Pouca de Aguiar 1:10000, plano: J.Wahl, R.Wahl-Clerici, M.Helfert, desenho: S.Mathiuet).

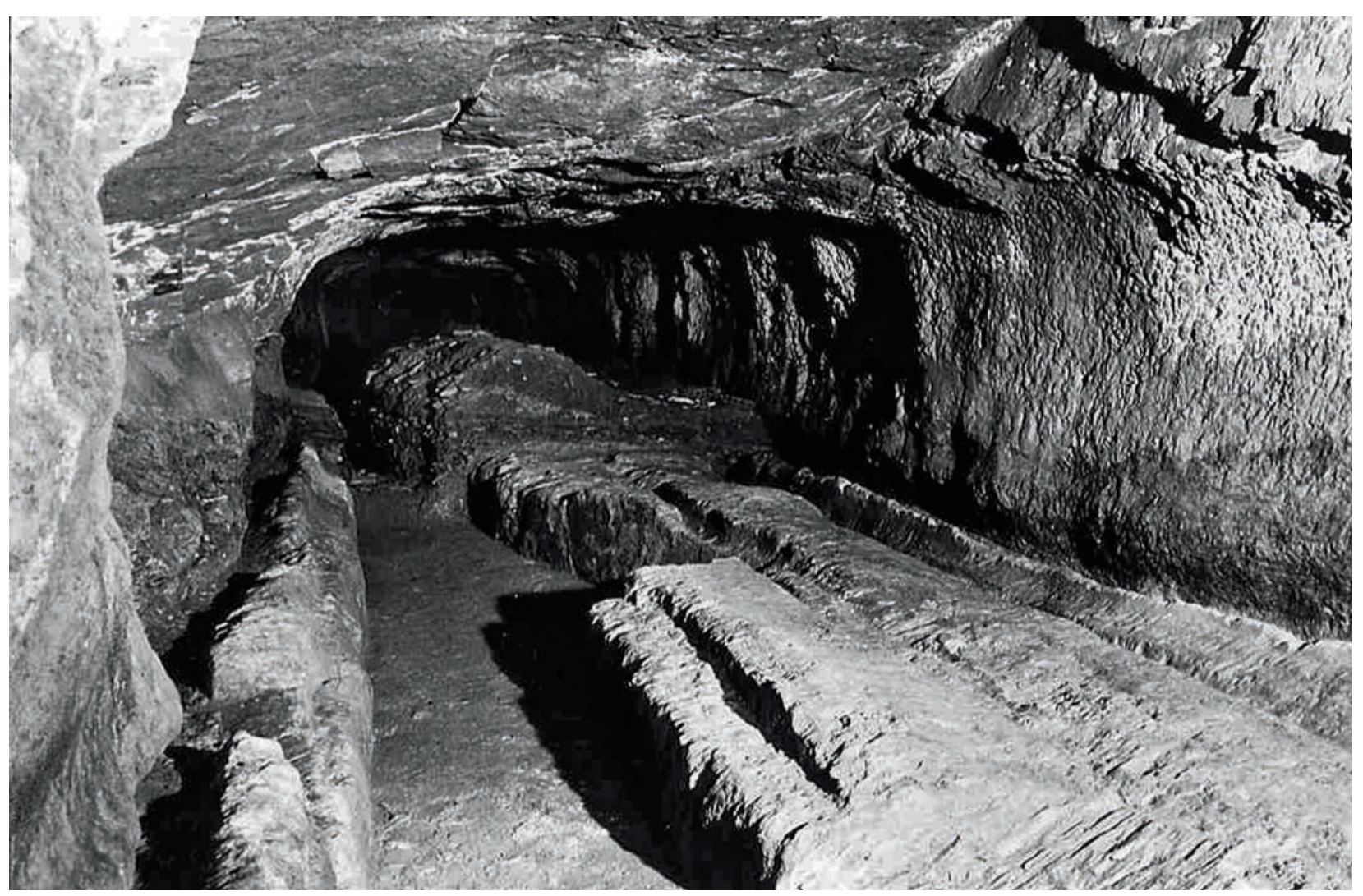

Fig. 3.3-2: Territorium metallorum Tresminas / Jales, Tresminas, Galeria do Pilar: área de entrada com rodados de carro e canal de drenagem. Ao longo das paredes são visíveis os canais de drenagem mais antigos. Visto de norte (fotografia: J. Wahl). 


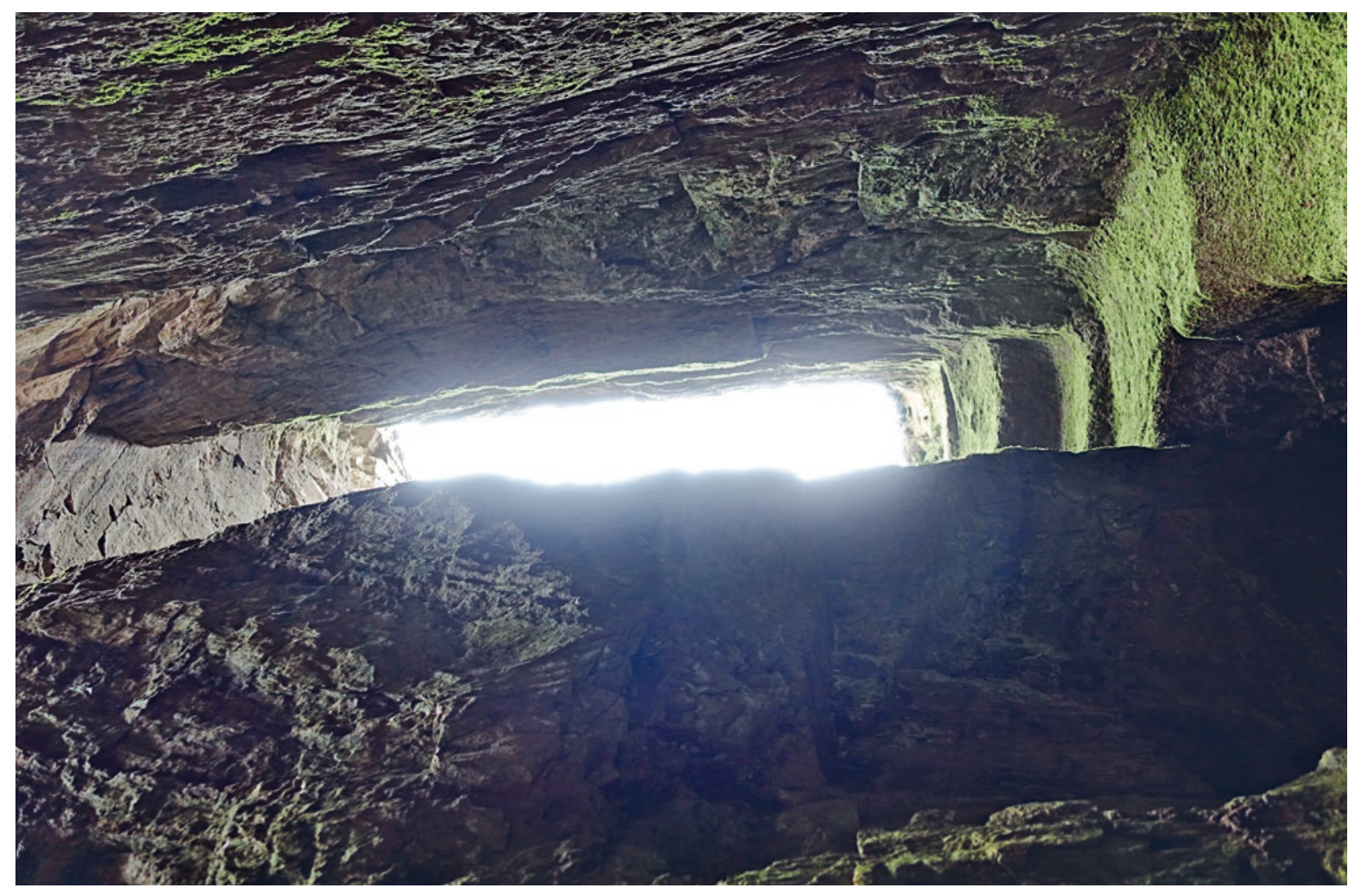

Fig. 3.3-3: Territorium metallorum Tresminas /Jales, Tresminas, Lagoinhos. poço de acesso (fotografia: J. Wahl). 


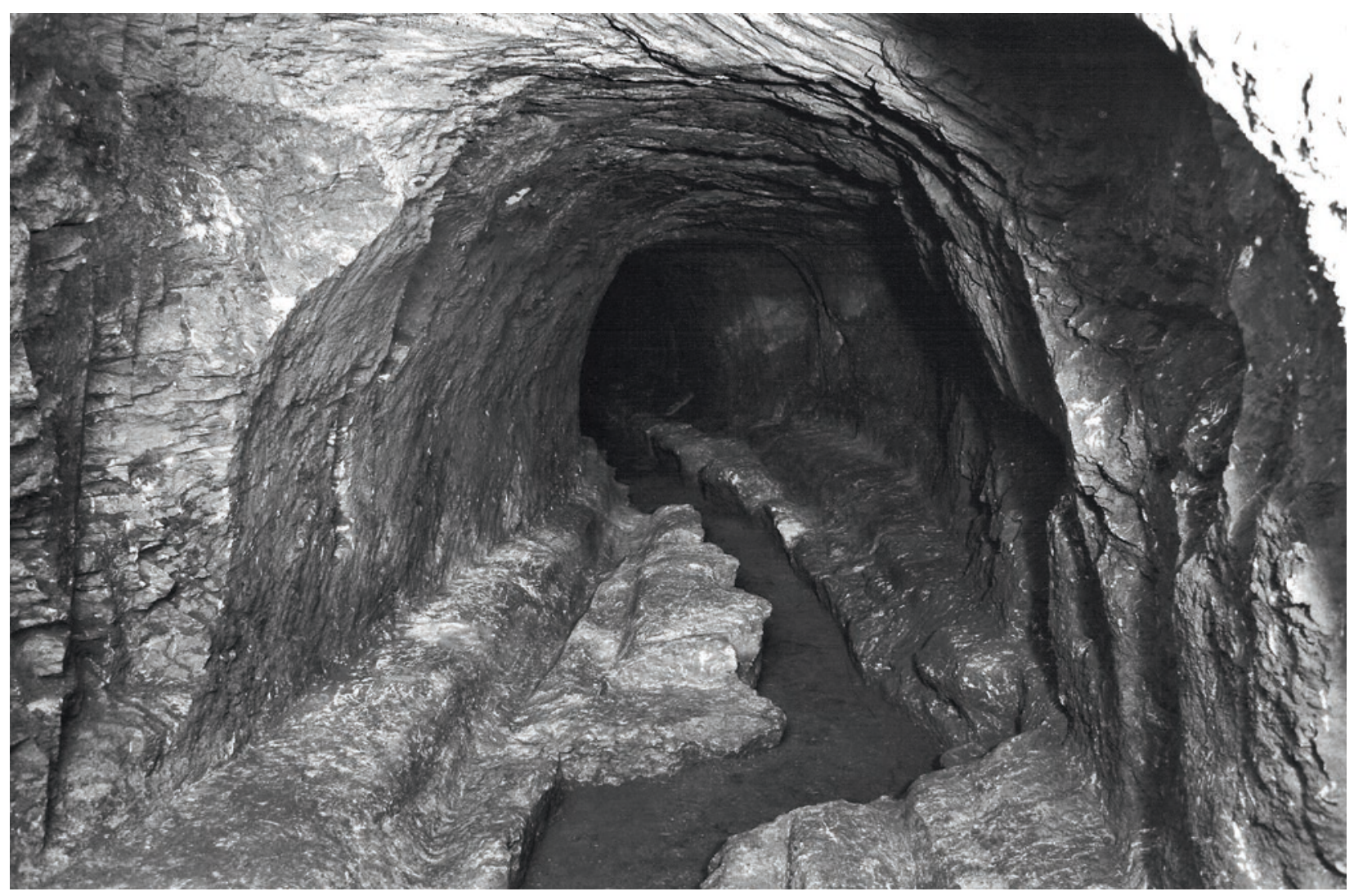

Fig. 3.3-4: Territorium metallorum Tresminas / Jales, Tresminas, Corta de Covas, Galeria Esteves Pinto. área de entrada com rodados de carro e canal de drenagem. Vista de sul (fotografia: J. Wahl). 


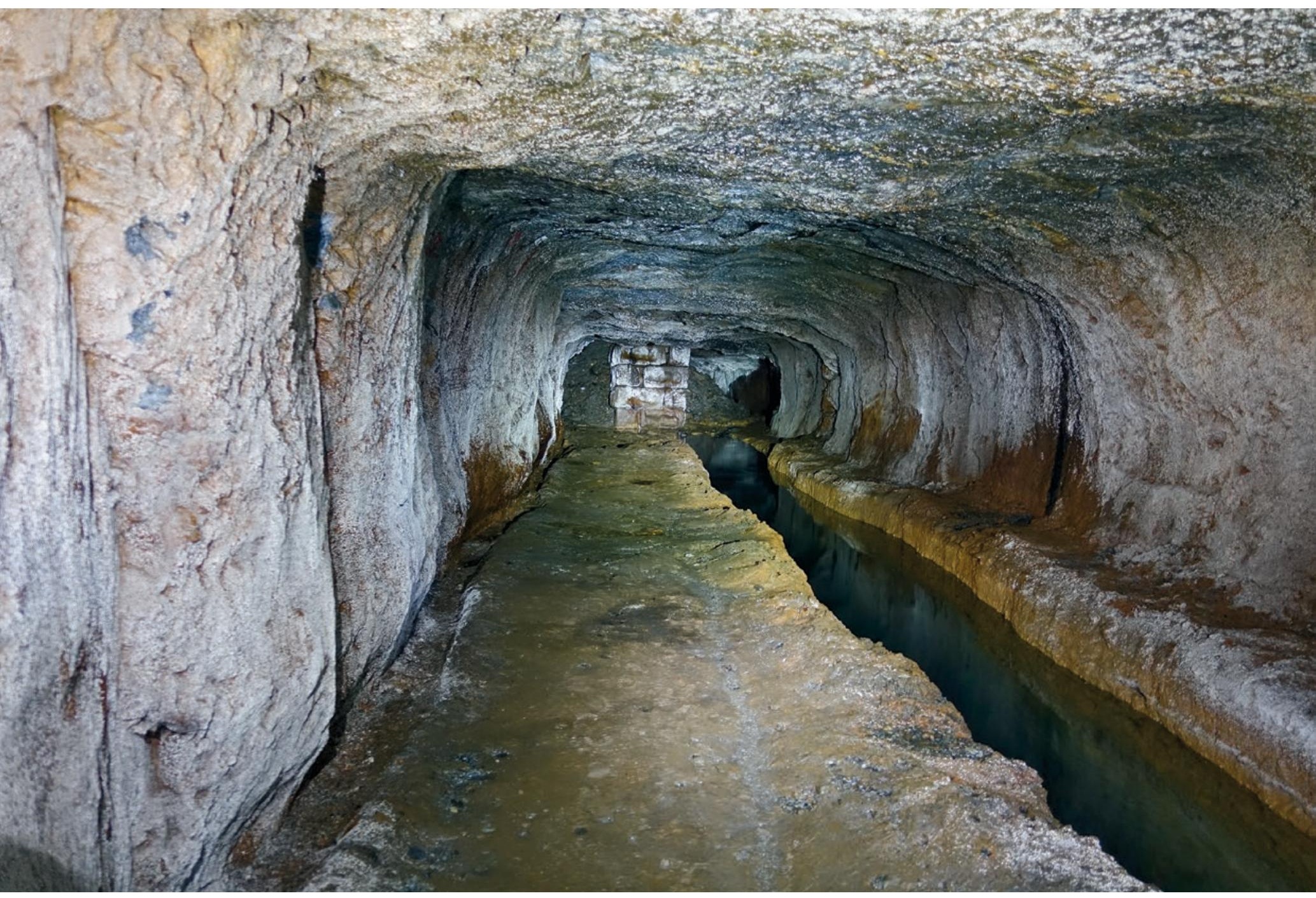

Fig. 3.3-5: Territorium metallorum Tresminas / Jales, Tresminas, Corta de Covas, Galeria do Pilar: vista do pilar epónimo com o canal de drenagem ao longo da parede oriental (fotografia: $R$. Wahl-Clerici). 


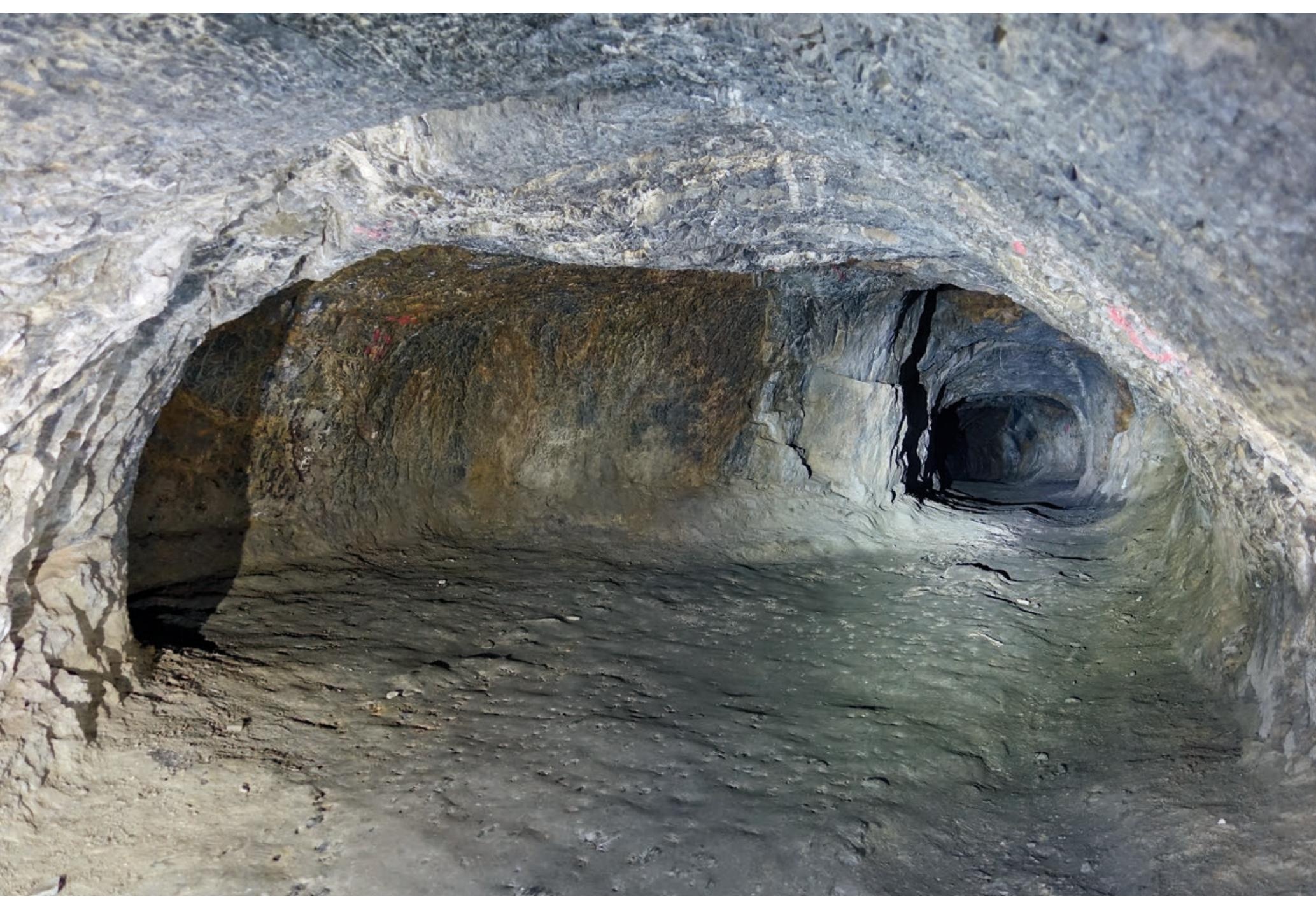

Fig. 3.3-6: Territorium metallorum Tresminas / Jales, Tresminas, Galeria dos Alargamentos: do lado direito encontra-se a galeria, à esquerda uma das quatro extensões (fotografia: R. Wahl-Clerici). 


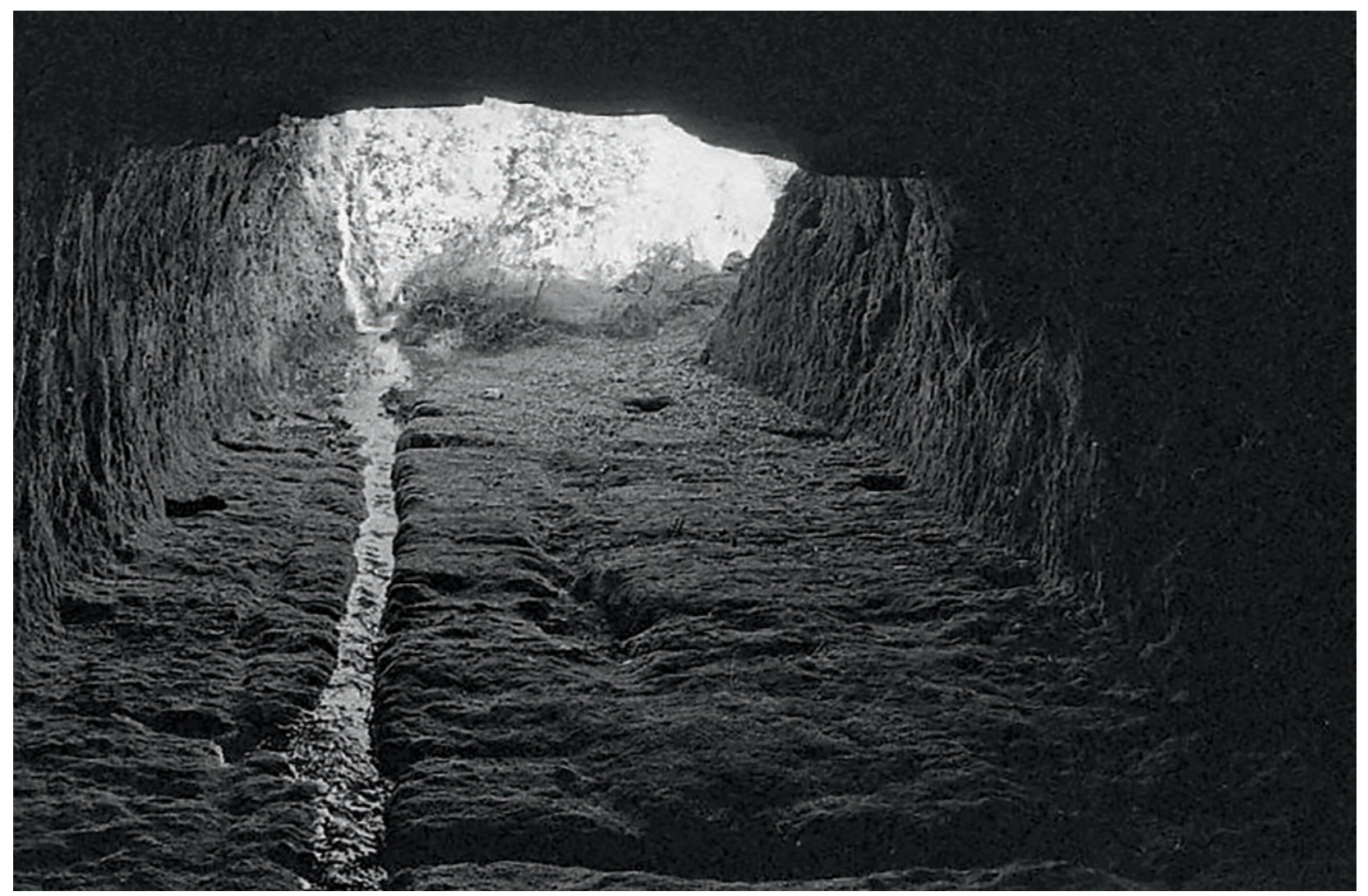

Fig. 3.3-7: Territorium metallorum Tresminas/Jales, Tresminas, Corta da Ribeirinha, Galeria dos Morcegos: zona de entrada com as cavidades entre o piso e as paredes, destinada à entivação em madeira para suporte do tecto. Igualmente bem visível é a cavidade no solo, provavelmente destinada à colocação de uma ara votiva após o abandono (fotografia: J. Wahl).

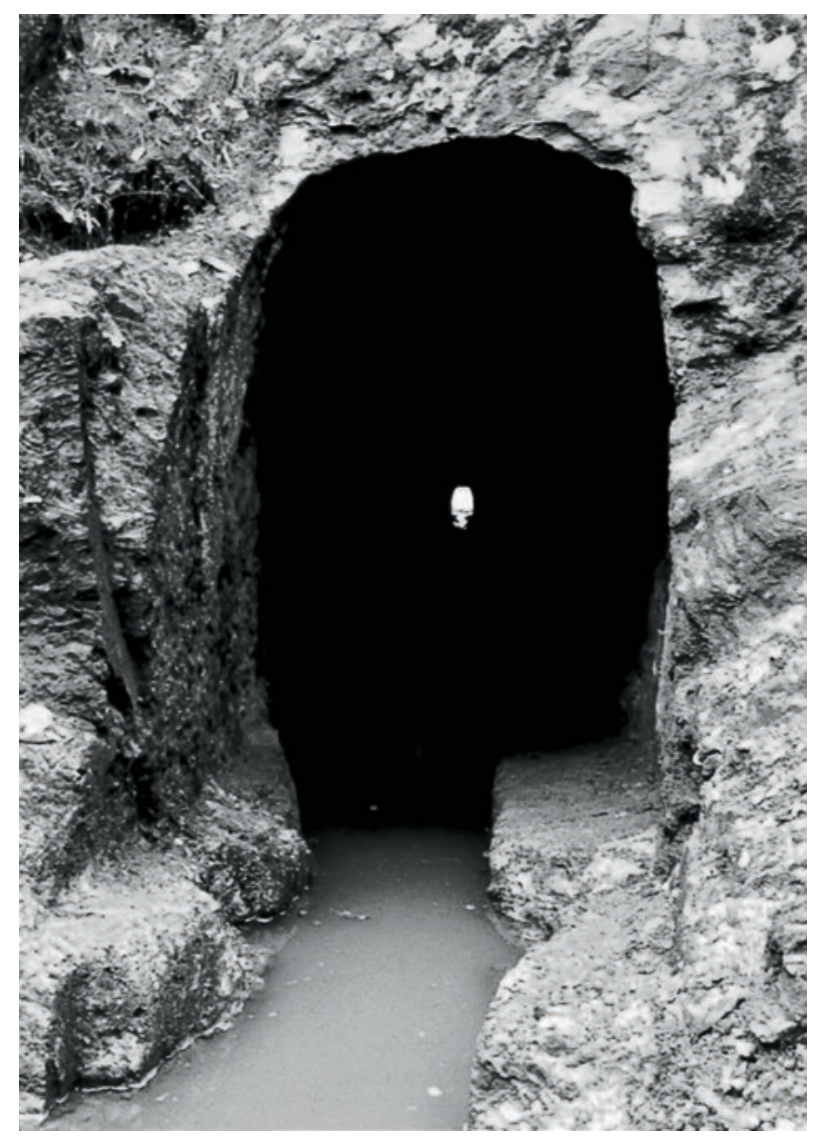

Fig. 3.3-8: Territorium metallorum Tresminas/Jales, Tresminas, Corta da Ribeirinha, Galeria do Buraco Seco: área de entrada na mina a céu aberto (fotografia: J. Wahl). 


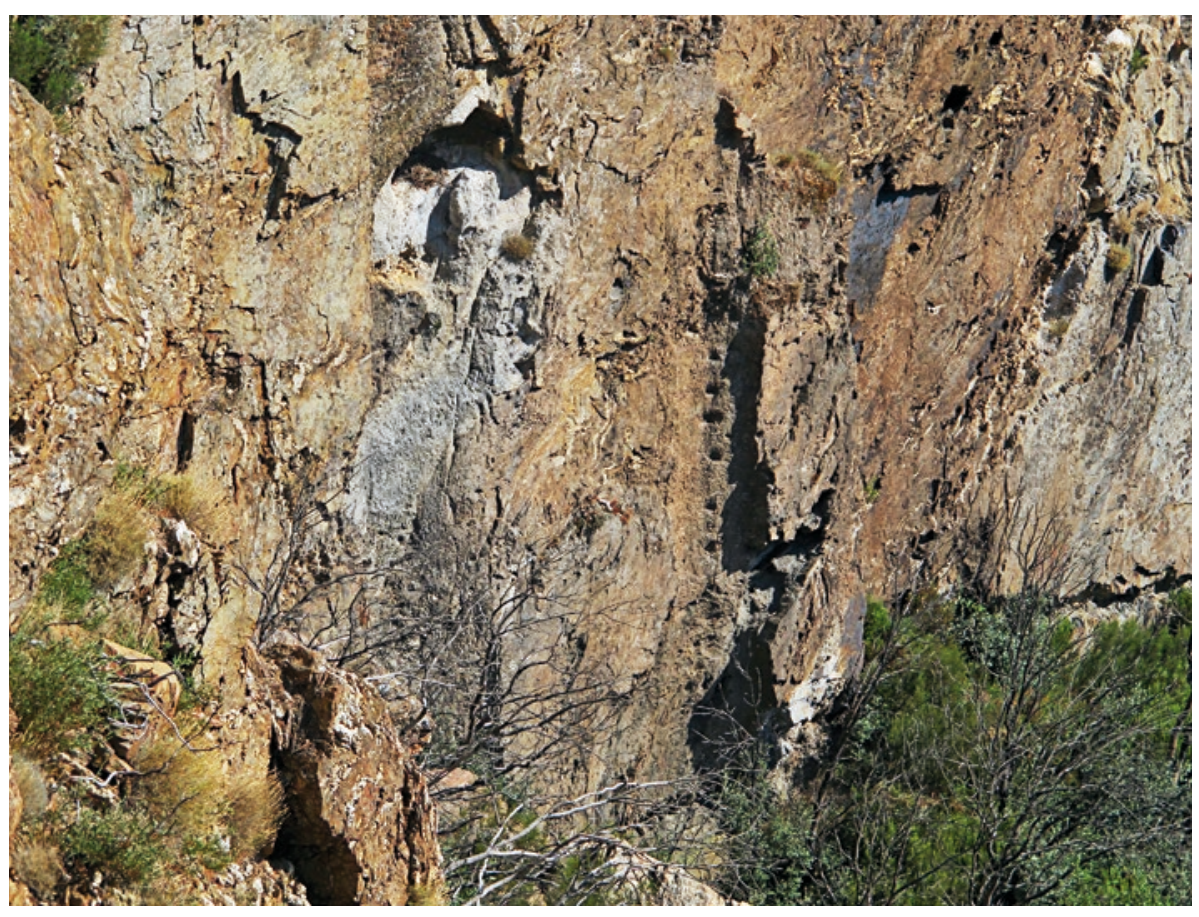

Fig. 3.3-9: Territorium metallorum

Tresminas/Jales, Tresminas, Corta de

Covas: encosta oriental com os poços gémeos, que se encontravam dentro da montanha na época romana. À direita: poço de subida com os cortes para os dispositivos de elevação. À esquerda: poço de extração. Este último penetra a câmara final da Galeria dos

Alargamentos (fotografia: R.WahlClerici).

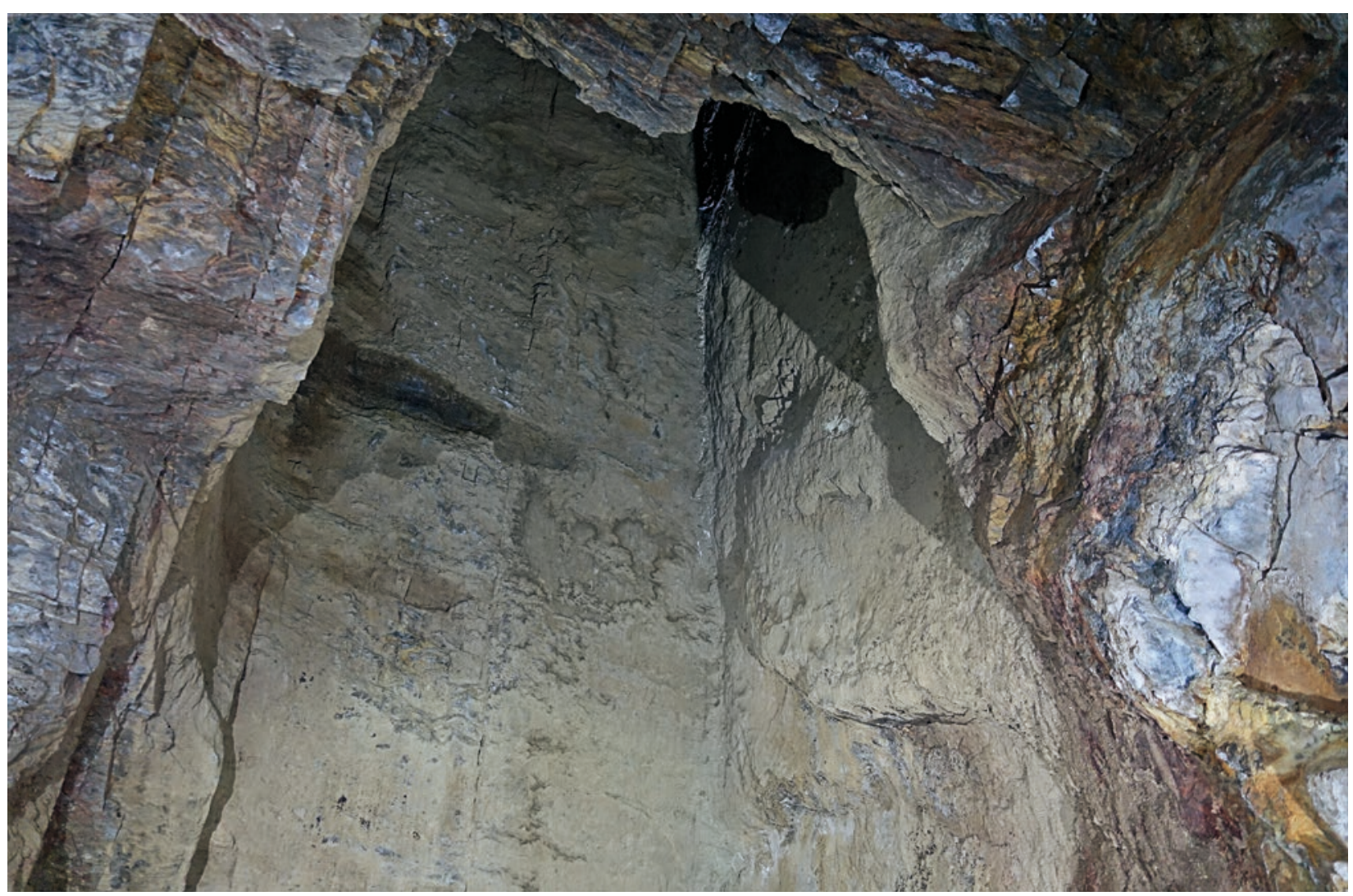

Fig. 3.3-10: Territorium metallorum Tresminas /Jales, Tresminas, Galeria dos Alargamentos: poço de exploração na câmara final (fotografia: R. Wahl-Clerici). 


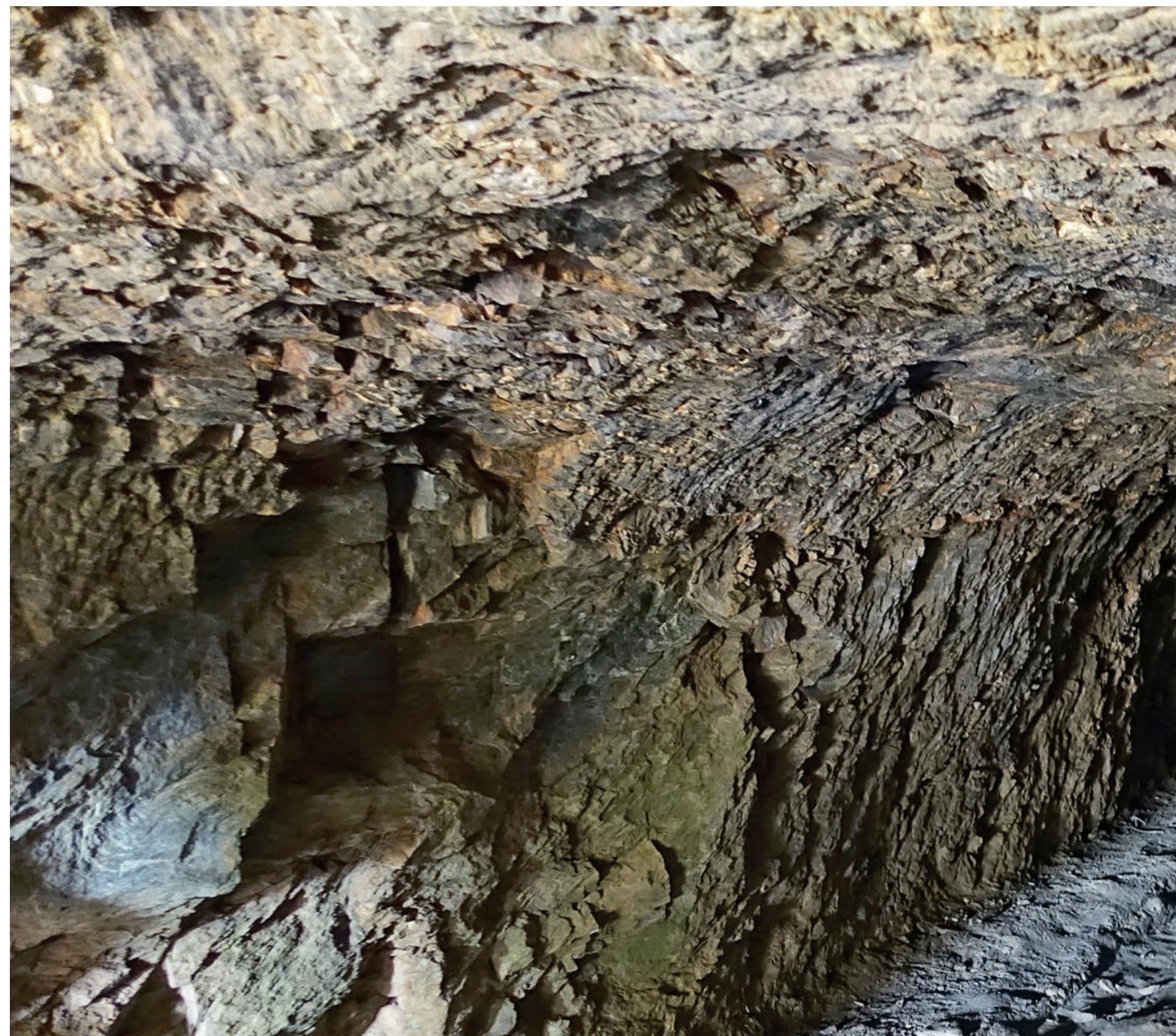

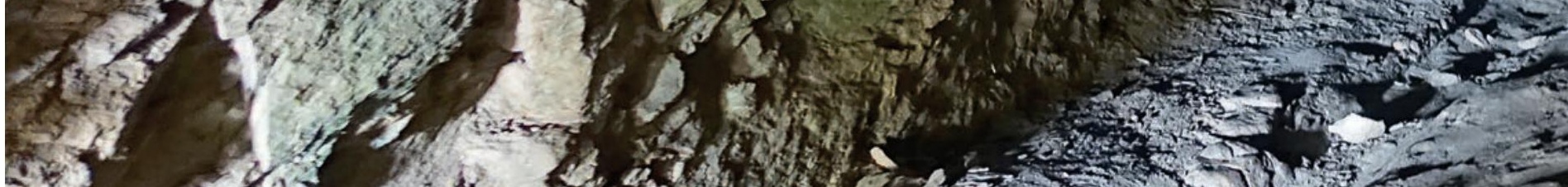

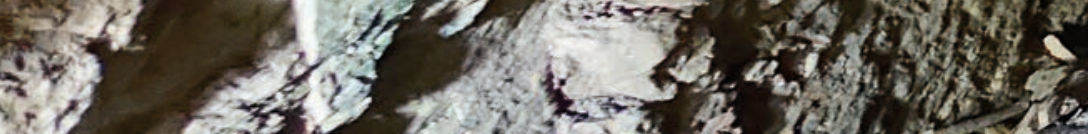

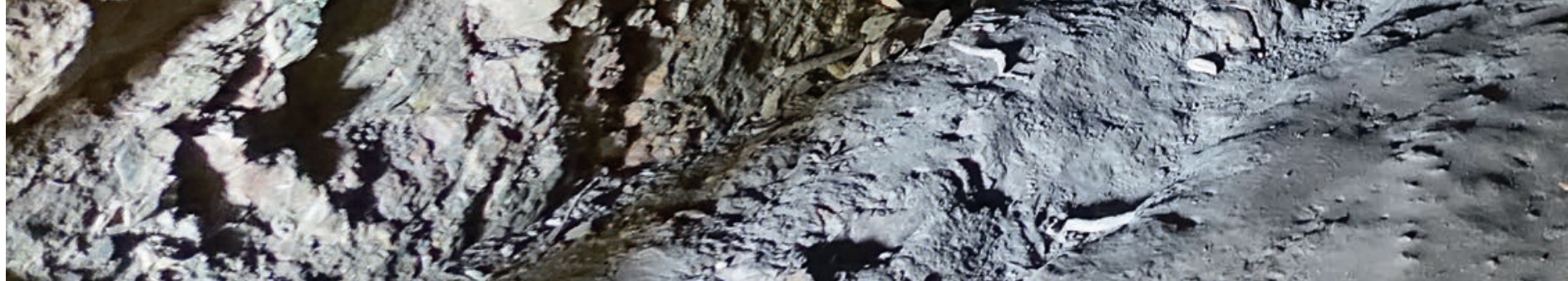

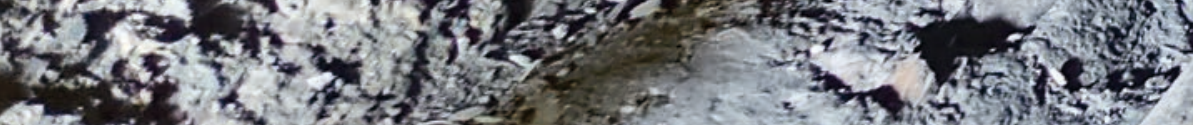

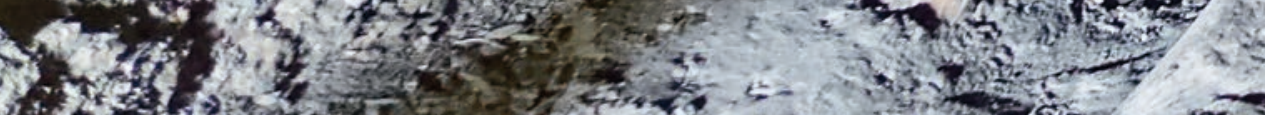

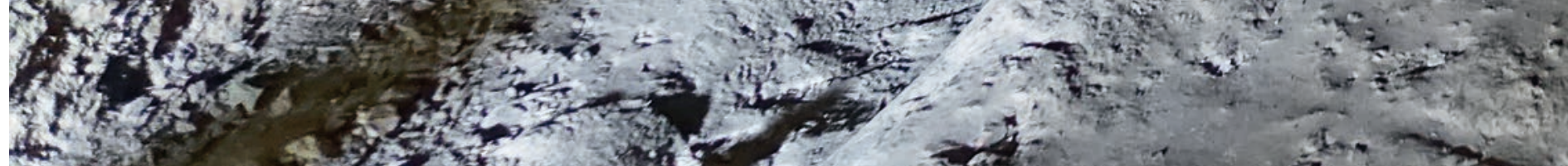

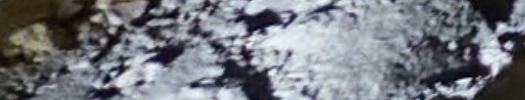
i. तोistis

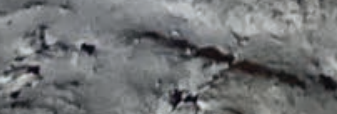




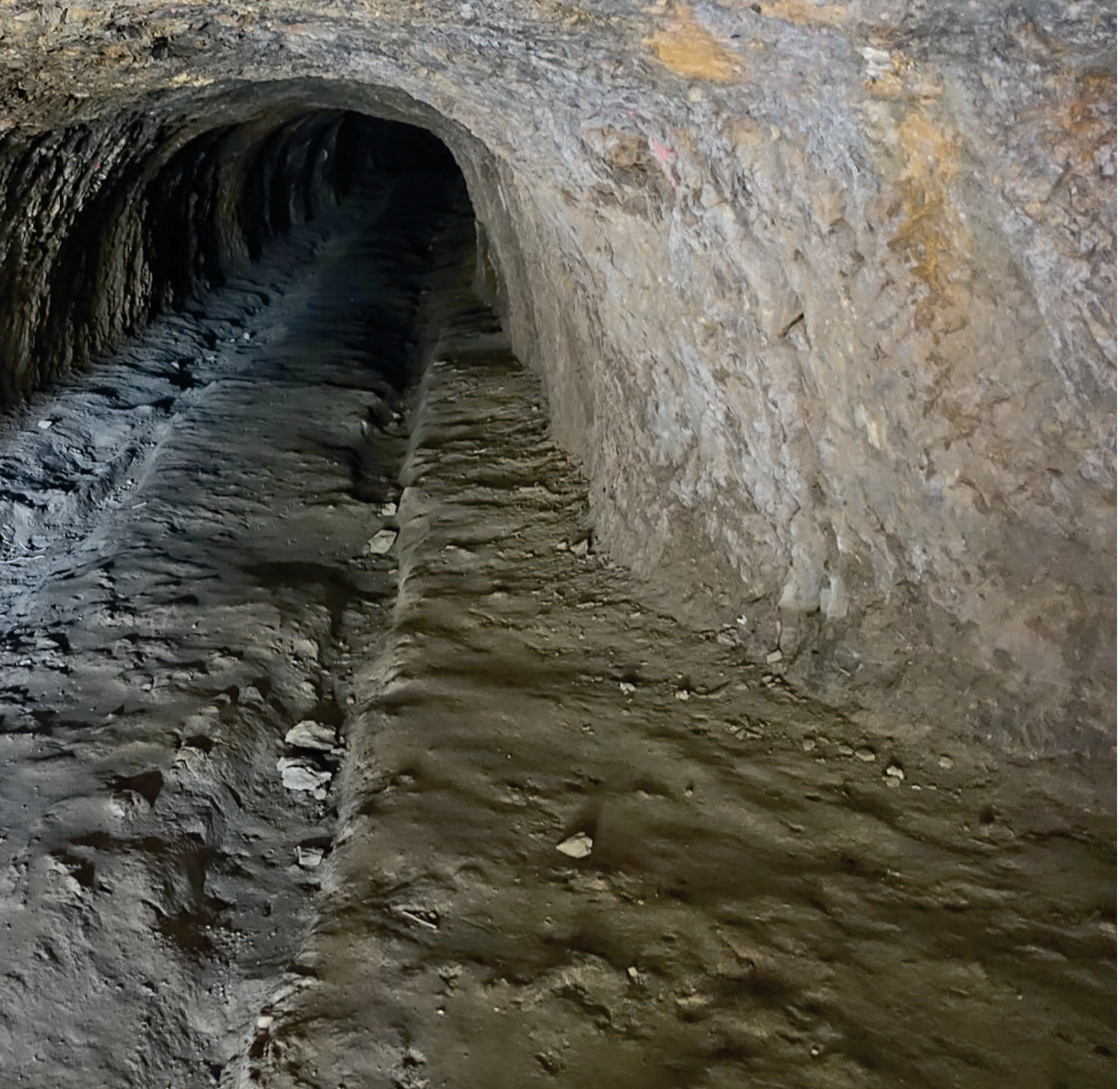

Fig. 3.3-11: Territorium metallorum Tresminas / Jales, Tresminas: Galeria dos Alargamentos com extensão (do lado direito). Os sulcos no piso não tocam em nenhuma das quatro extensões (fotografia: $R$. Wahl-Clerici). 


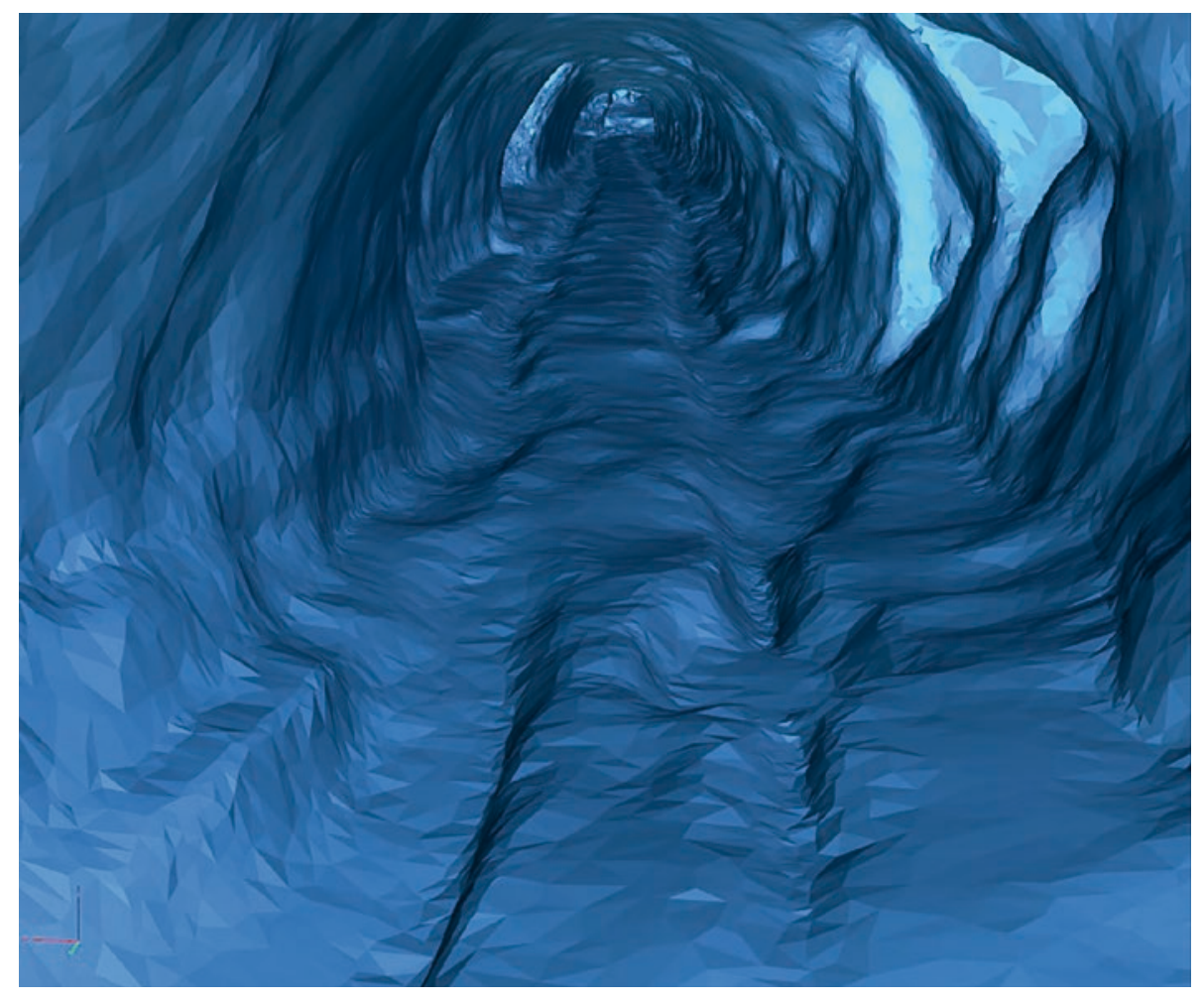

Fig. 3.3-12: Territorium metallorum

Tresminas/Jales, Tresminas, Galeria dos Alargamentos: em algumas partes, os sulcos não foram abertos com a devida profundidade (digitalização e apresentação: M. Helfert).

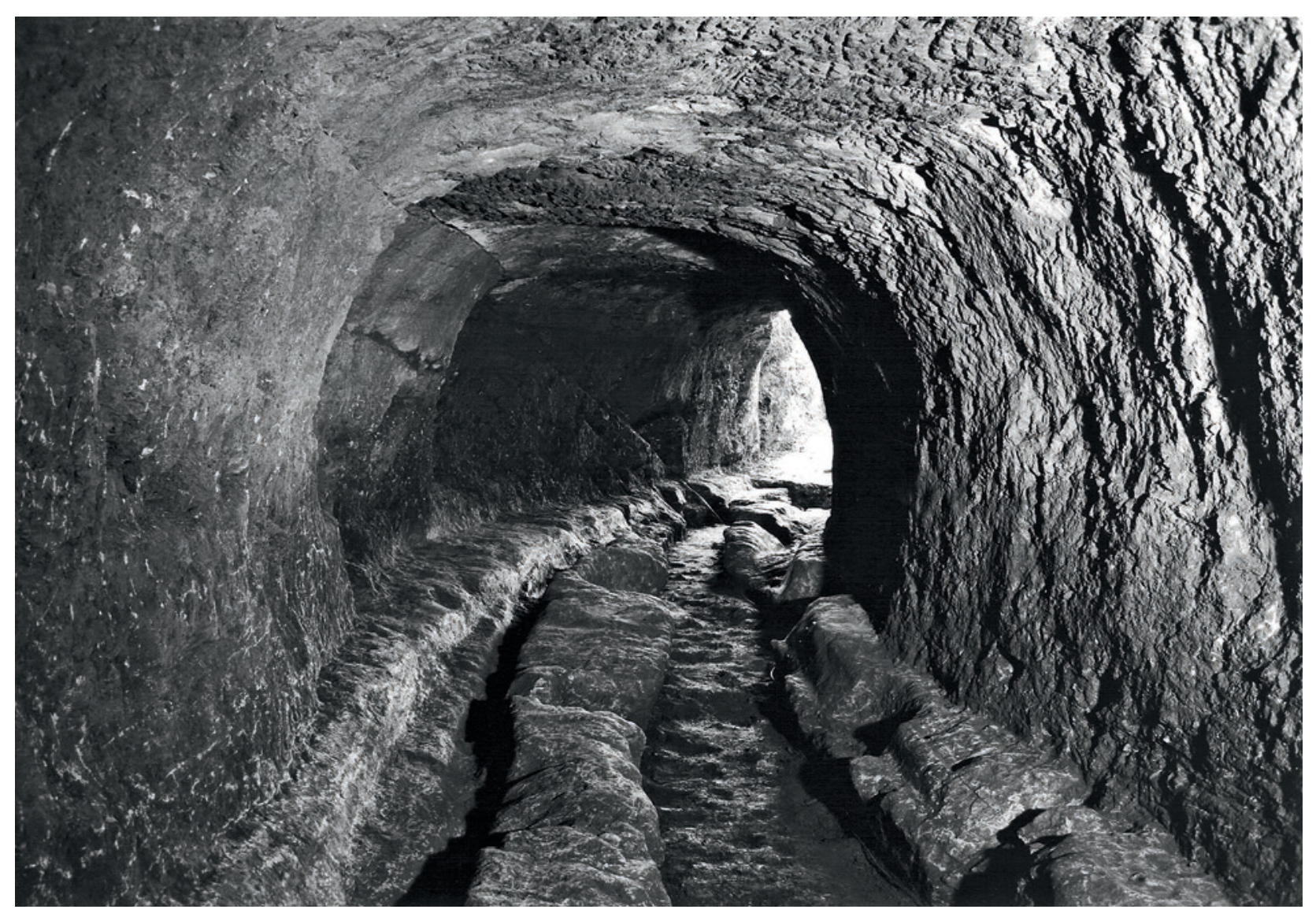

Fig. 3.3-13: Territorium metallorum Tresminas / Jales, Tresminas, Corta de Covas, Galeria Esteves Pinto: do lado direito são visíveis o poço de observação e as cavidades para a colocação da cobertura do canal. Vista em direção à boca do lado da encosta (fotografia: J. Wahl). 


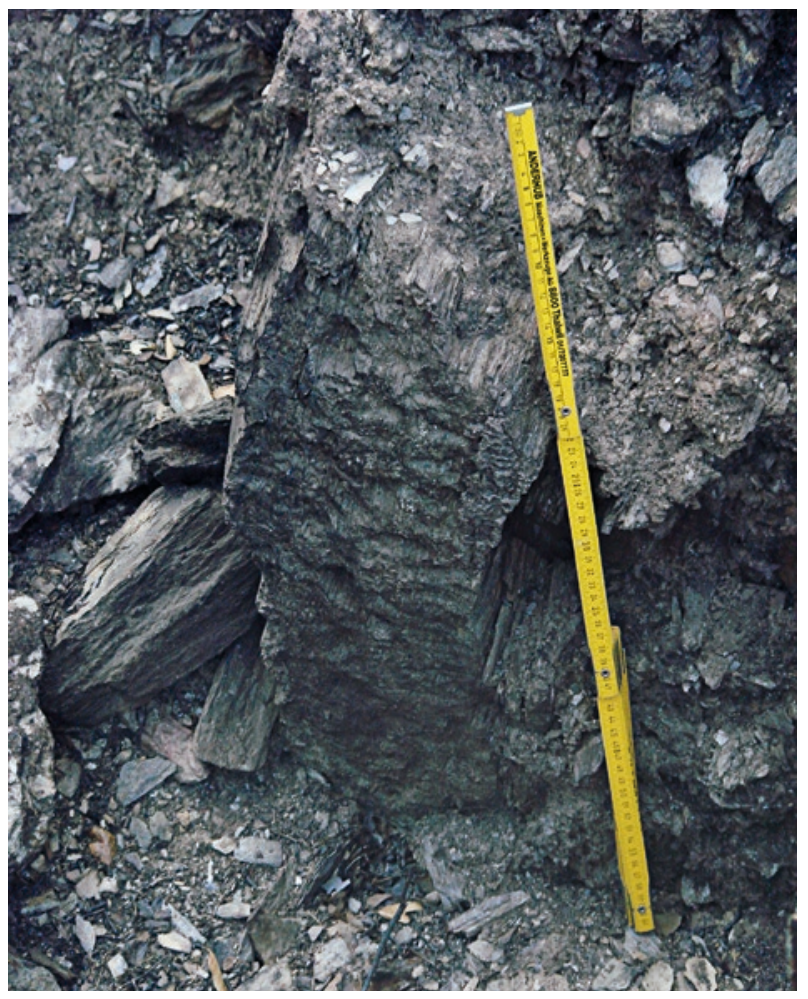

Fig. 3.3-14: Territorium metallorum Tresminas/Jales, Tresminas, Corta de Covas, Galeria Jürgen Wahl: vestígios de desmonte na parede ocidental (fotografia: $R$. Wahl-Clerici).

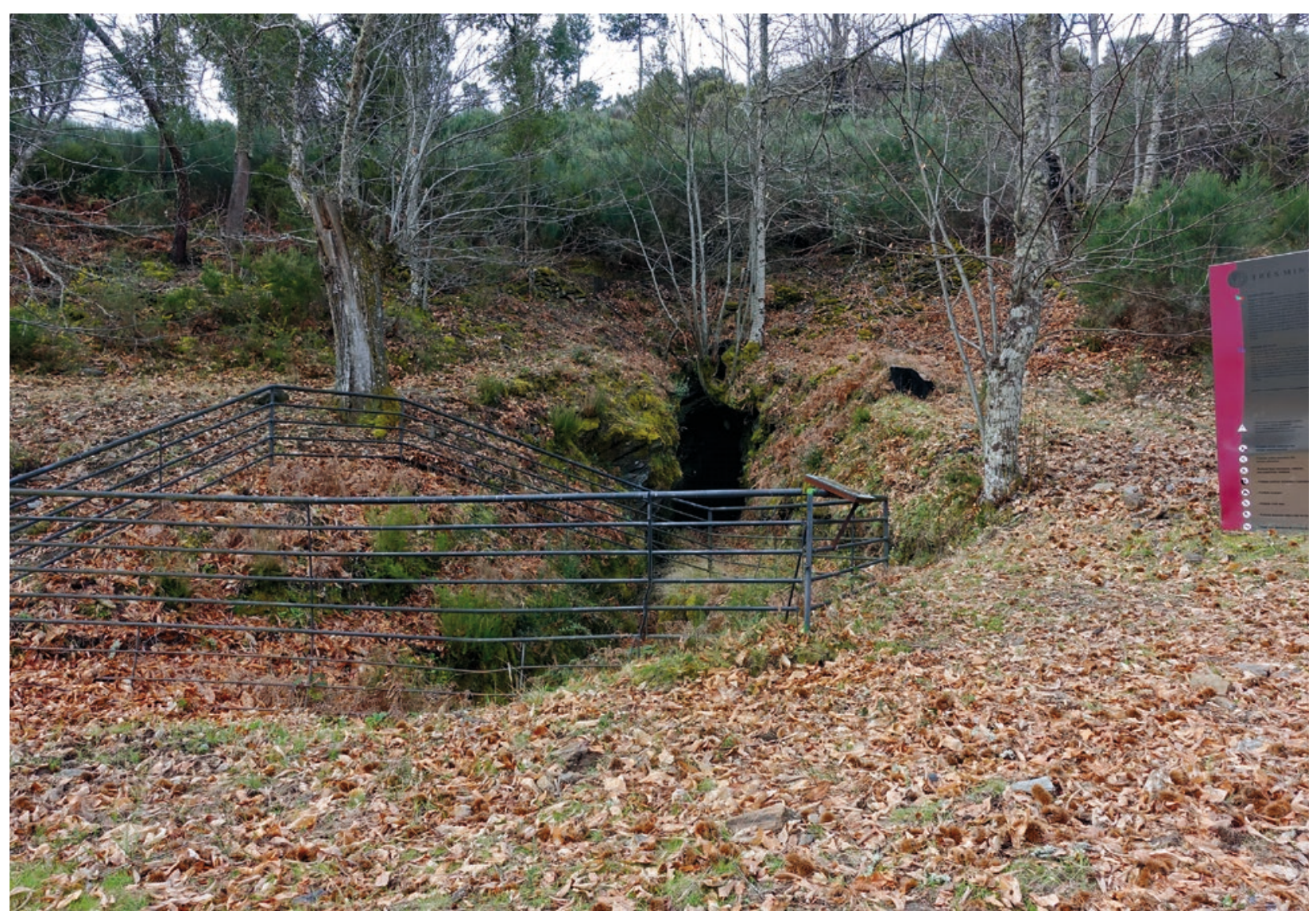

Fig. 3.3-15: Territorium metallorum Tresminas / Jales, Tresminas, Corta de Covas, Galeria do Pilar: a área de entrada, obstruída pelos escombros da encosta, apenas foi parcialmente exposta. A cerca serve de proteção ao poço de ligação à Galeria do Texugo (fotografia: R. Wahl-Clerici). 
2

Ga/er

$d_{0} T_{e}{ }_{4}$<smiles>C=[V]</smiles> 
$a^{2}$

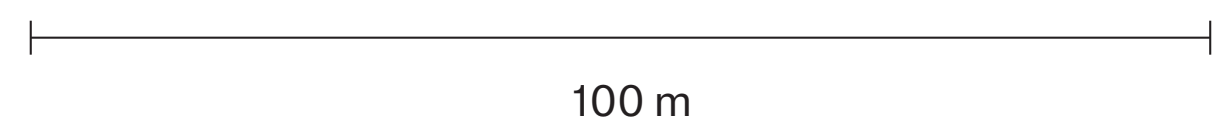

Fig. 3.3-16: Territorium metallorum Tresminas / Jales, Tresminas, Corta de Covas: a entrada da Galeria do Texugo teve de ser construída no lado do vale, longe da escombreira da Galeria do Pilar, o que significava que o anterior eixo das galerias na encosta norte do Corta de Covas já não podia ser utilizado (modelo: Wahl 1988, fig.3, desenho: S.Mahiuet).

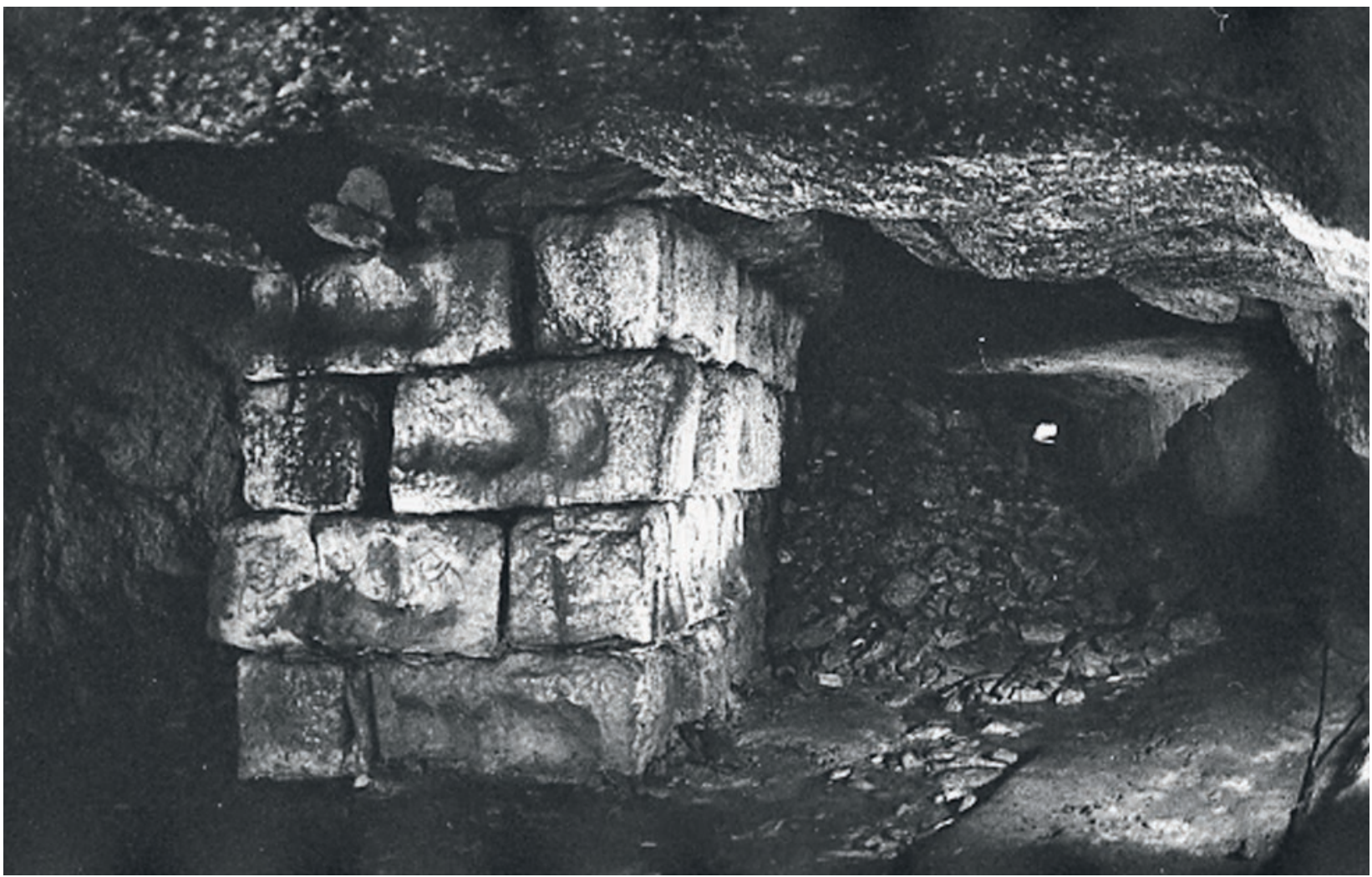

Fig. 3.3-17: Territorium metallorum Tresminas /Jales, Tresminas, Corta de Covas, Galeria do Pilar. à esquerda: o pilar epónimo, e à direita a extensão para o transporte e para a drenagem. O ponto claro ao fundo da imagem é a entrada. Vista de sul (fotografia: C. Wahl).

3.3 As galerias de Tresminas

149 


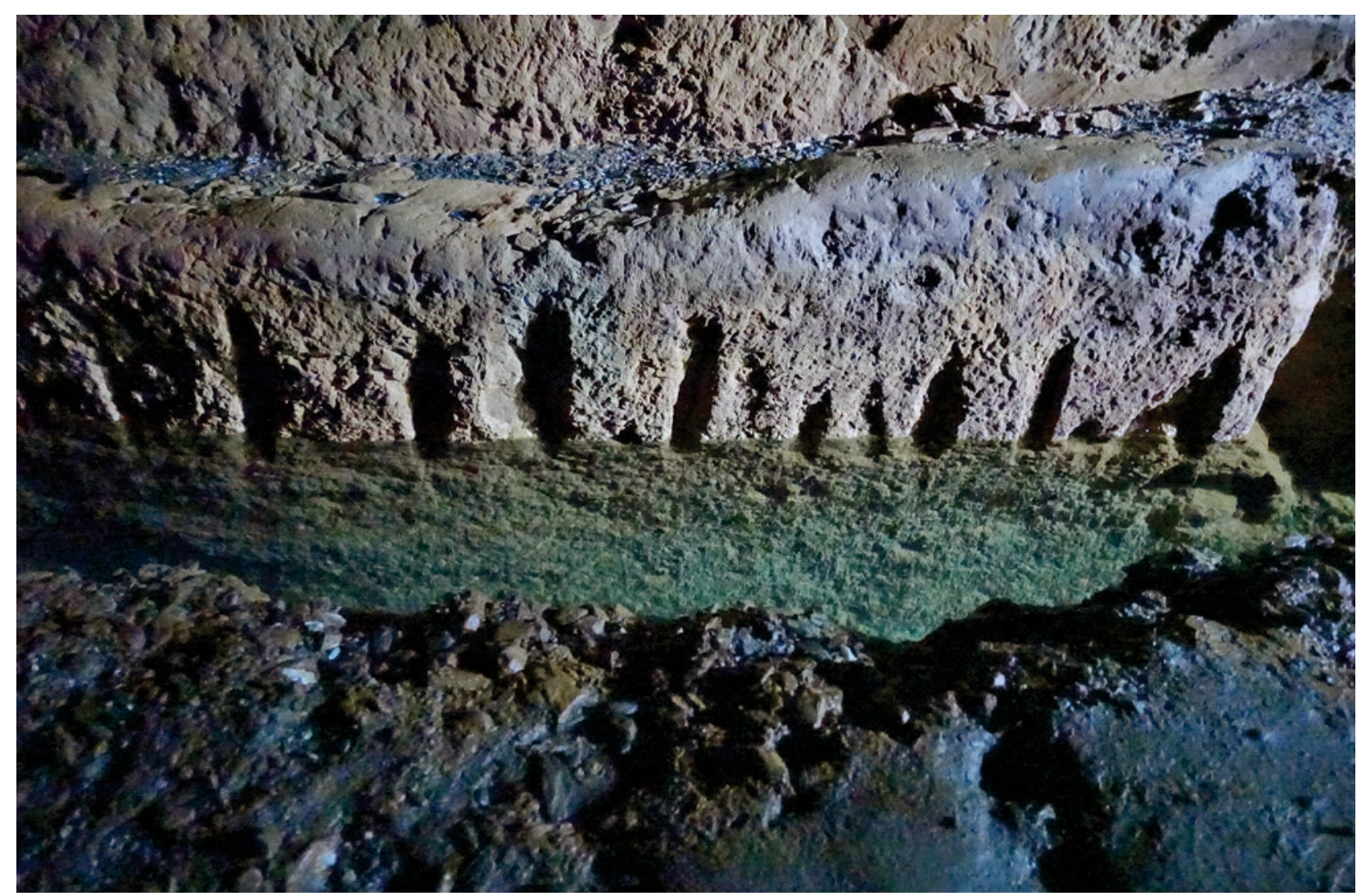

Fig. 3.3-18: Territorium metallorum Tresminas / Jales, Tresminas, Corta de Covas, Galeria do Pilar: cavidades para a cobertura do canal com madeira (fotografia: R. Wahl-Clerici).

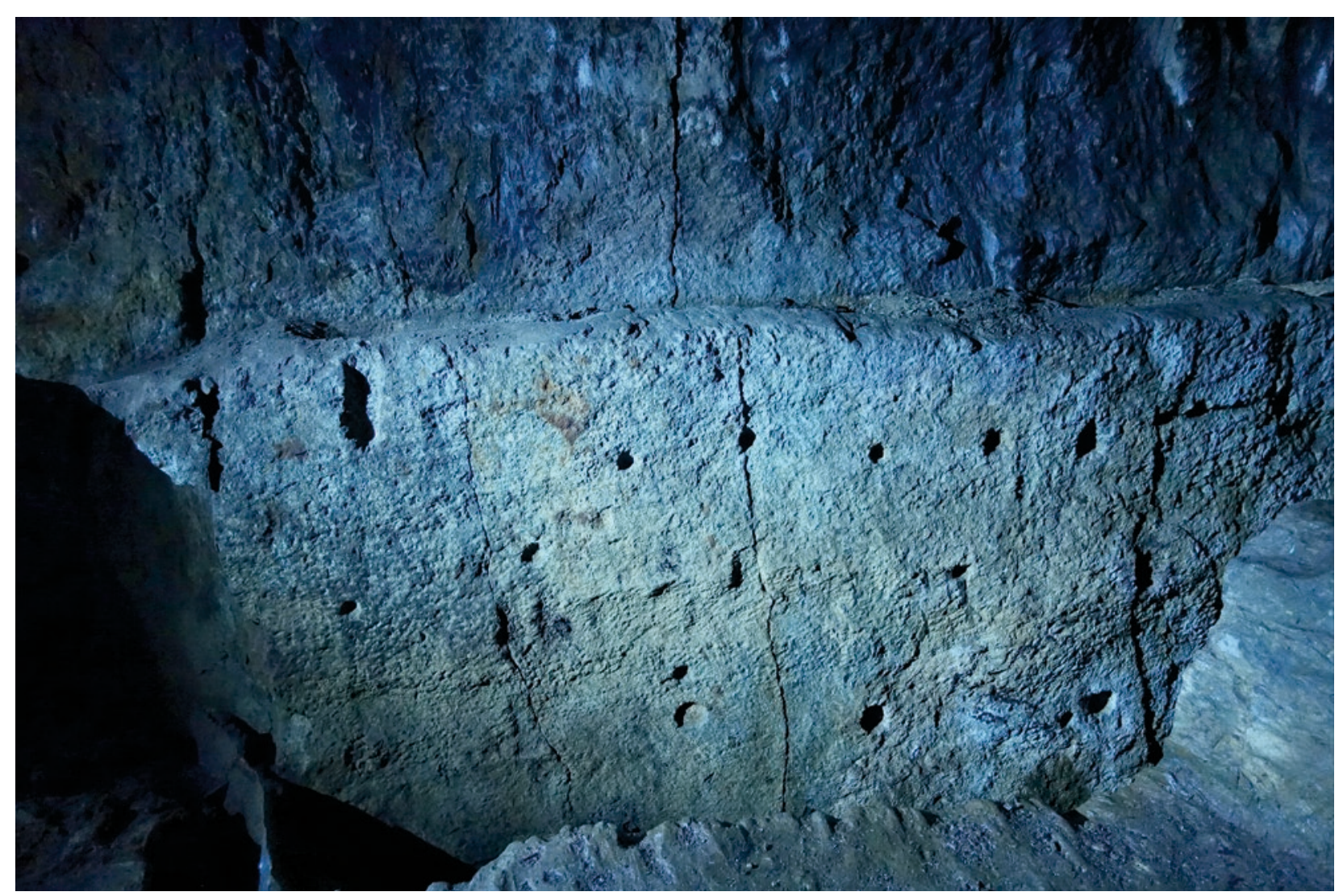

Fig. 3.3-19: Territorium metallorum Tresminas / Jales, Tresminas, Corta de Covas, Galeria do Pilar: as cavidades para a colocação da cobertura do canal, assim como os vestígios para a fixação de suportes em madeira, perto da estrutura de elevação por cabrestante (fotografia: $R$. Wahl-Clerici). 


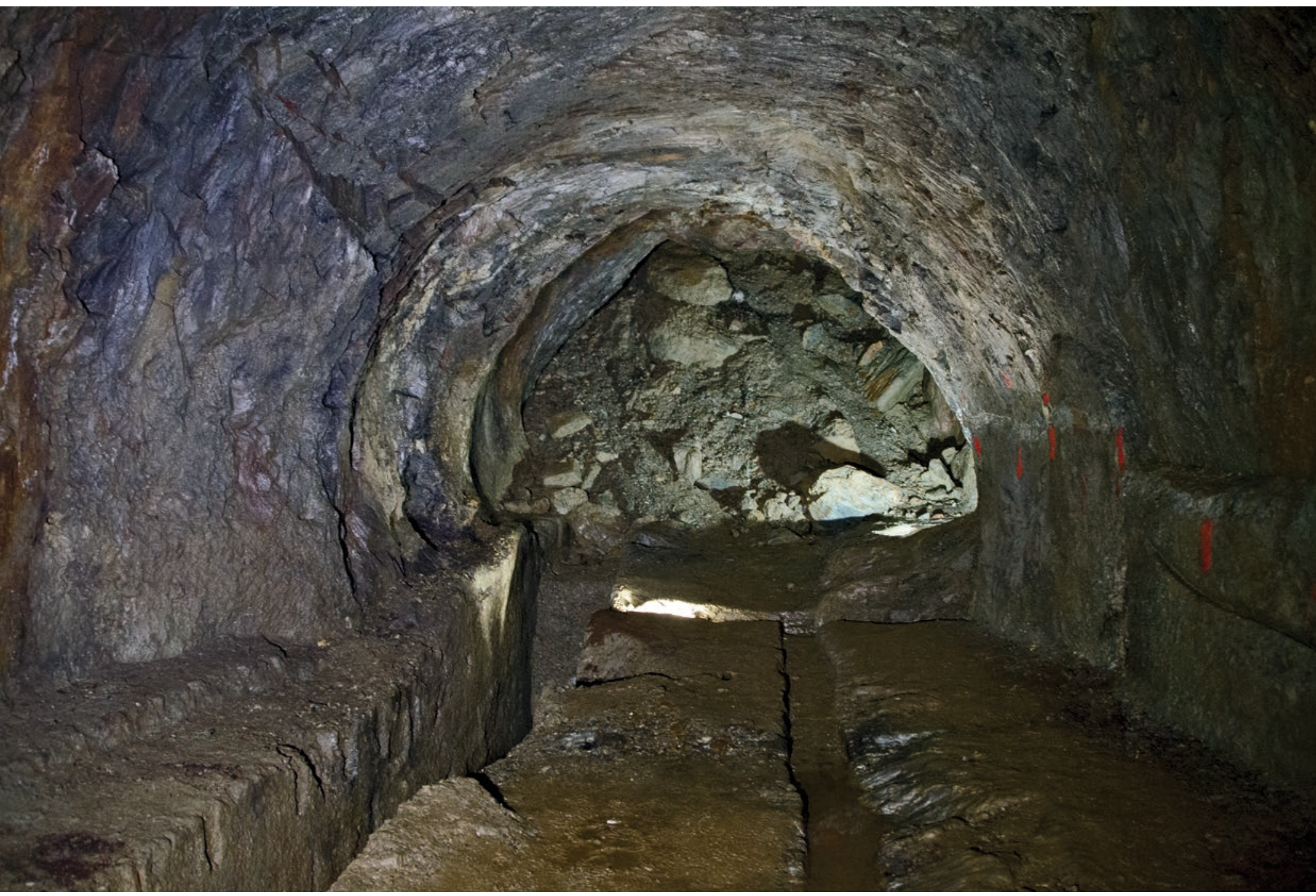

Fig. 3.3-20: Territorium metallorum Tresminas/Jales, Tresminas, Galeria do Pilar: transição da mina a céu aberto para a galeria (fotografia: A. Wilson). 


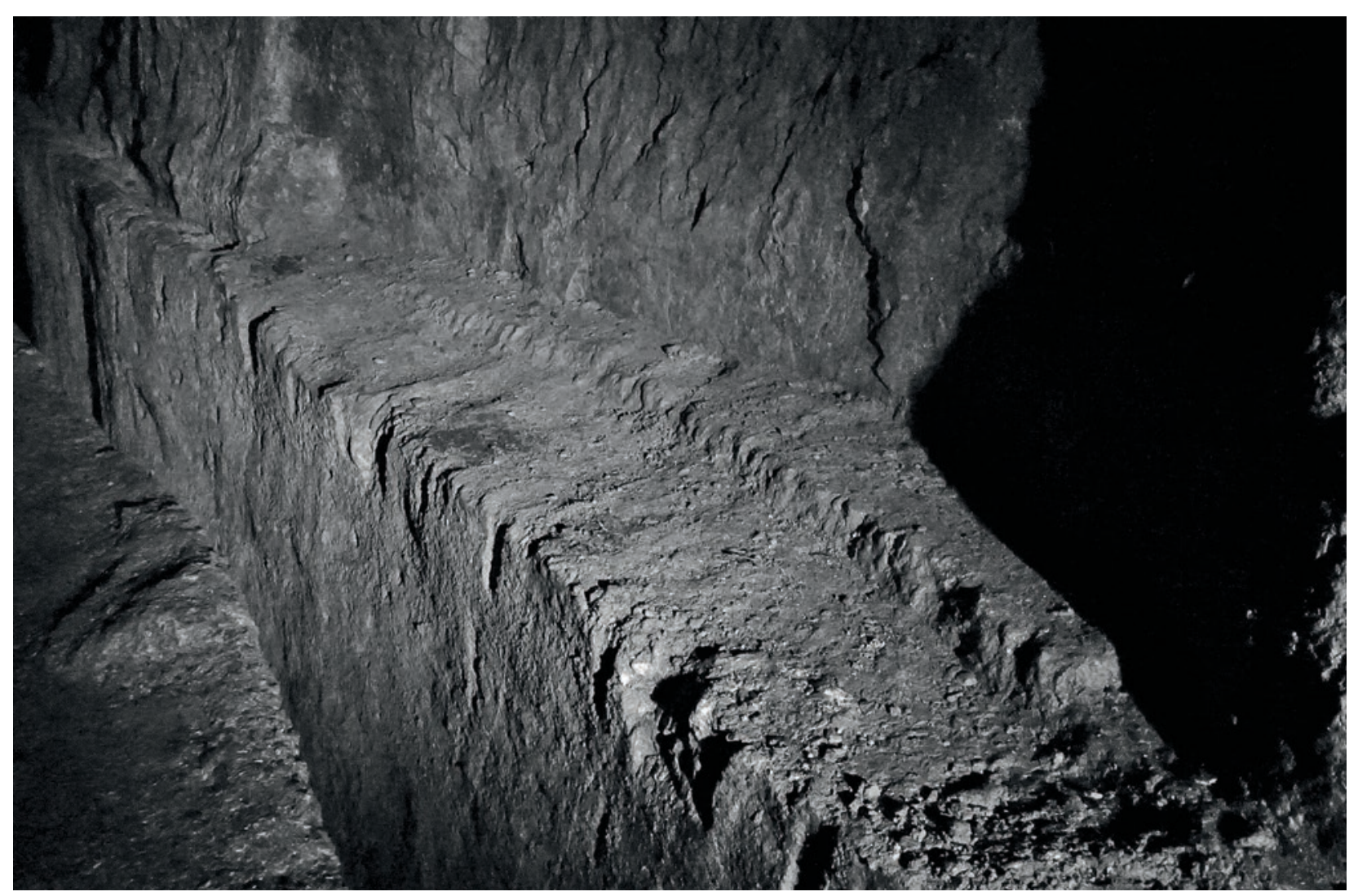

Fig. 3.3-21: Territorium metallorum Tresminas/Jales, Tresminas, Corta de Covas, Galeria do Pilar: parede a leste. Aprofundamento do piso na zona destinada à estrutura de elevação acionada por cabrestante (fotografia: $R$. Wahl-Clerici).

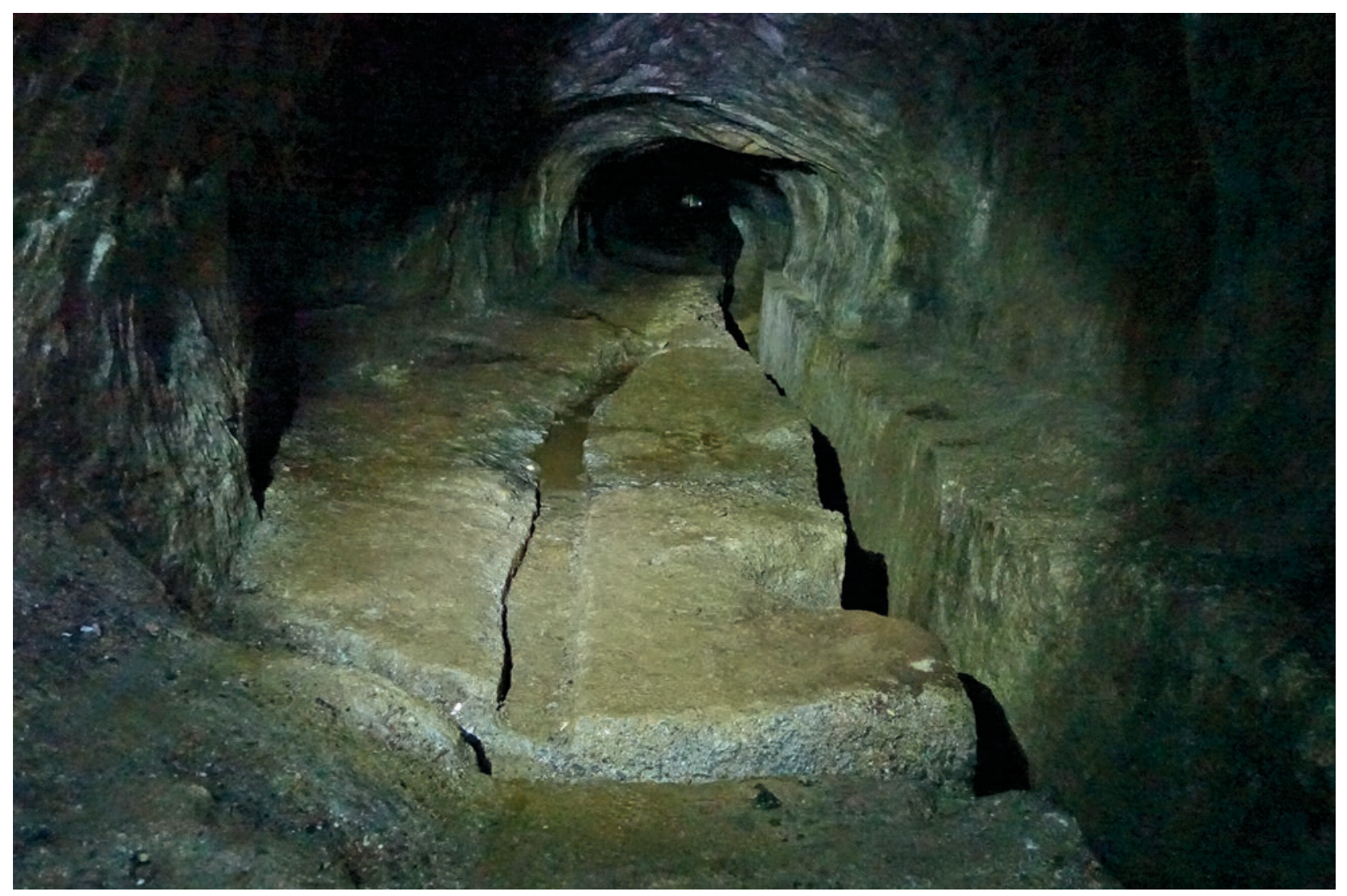

Fig. 3.3-22: Territorium metallorum Tresminas/Jales, Tresminas, Corta de Covas, Galeria do Pilar: vista sobre as cavidades, construídas em primeiro lugar para poder aprofundar o piso todo. Visto de sul (fotografia: R. Wahl-Clerici). 


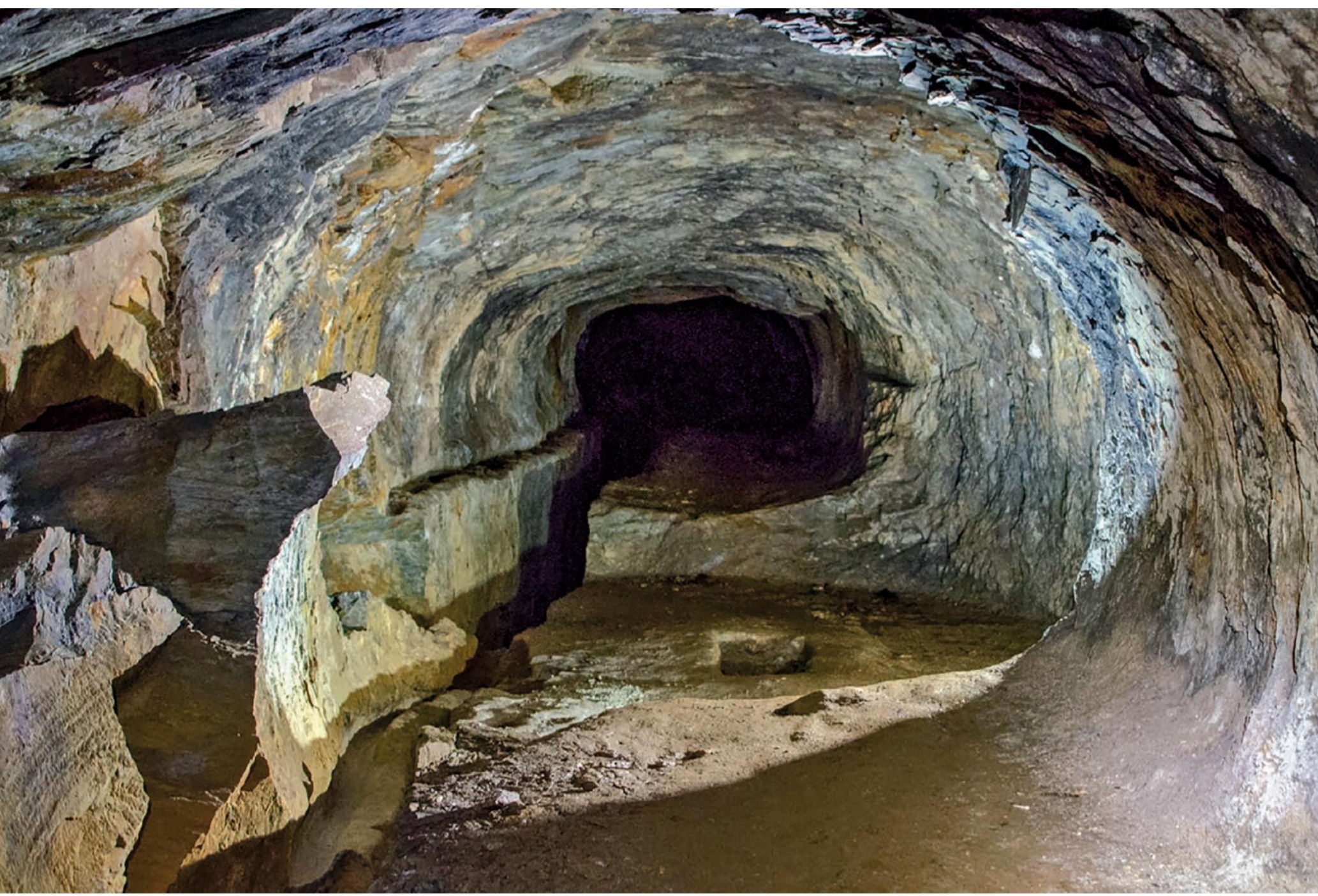

Fig. 3.3-23: Territorium metallorum Tresminas /Jales, Tresminas, Corta de Covas, Galeria do Pilar; a extensão em forma de cúpula com cavidades para a fixação de uma construção de elevação acionada por cabrestante. O piso foi aprofundado. Vista de norte (fotografia: A. Wilson).

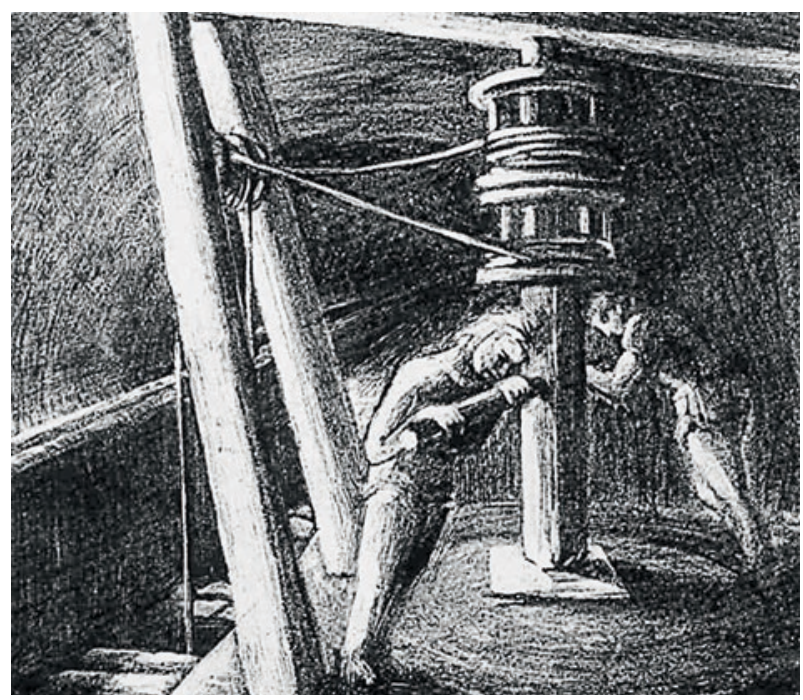

Fig. 3.3-24: Territorium metallorum Tresminas/Jales, Tresminas, Corta de Covas, Galeria do Pilar: reconstrução de uma estrutura de elevação acionada por um cabrestante (desenho: F. Boldt.). 


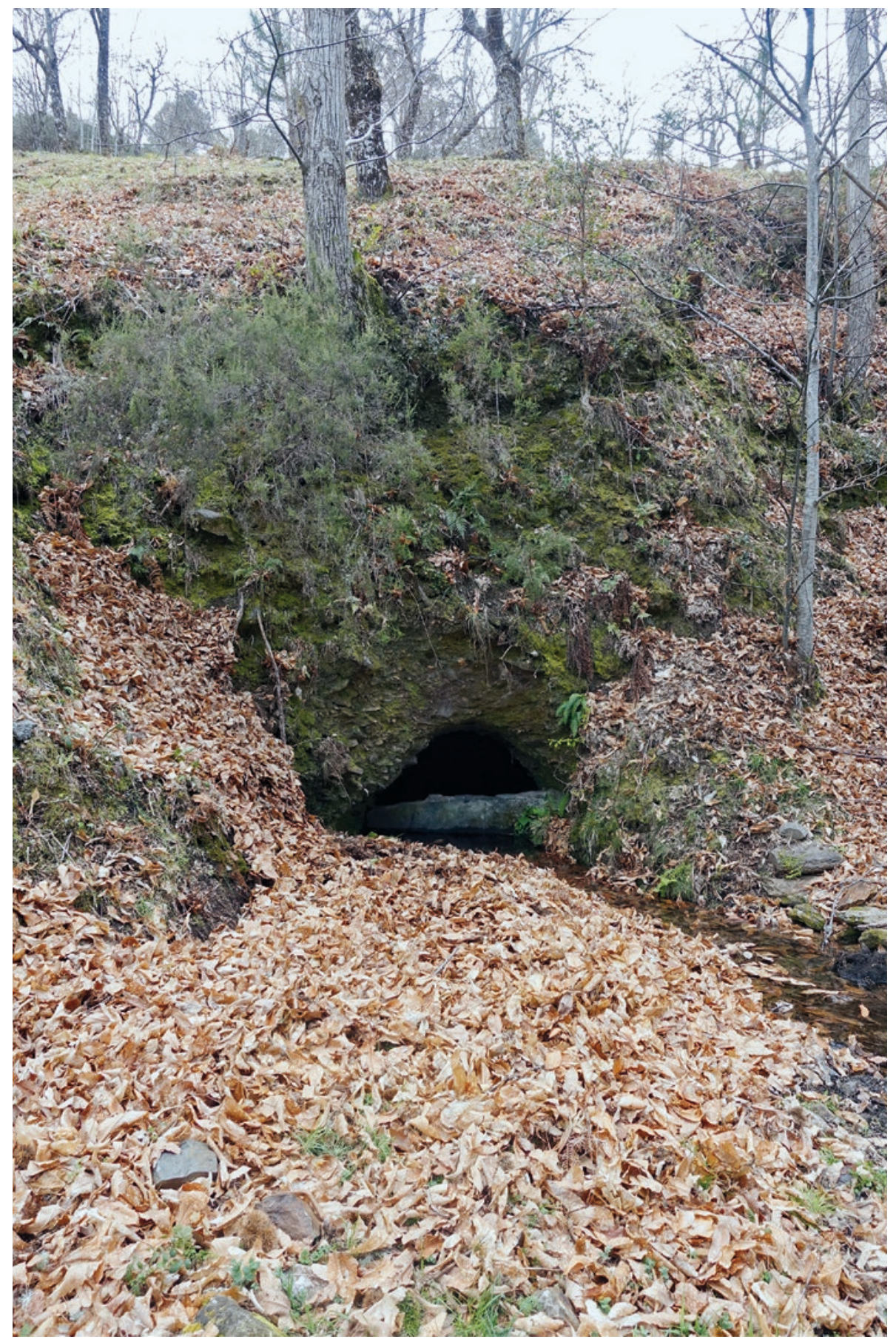

Fig. 3.3-25: Territorium metallorum Tresminas / Jales, Tresminas, Corta de Covas, Galeria do Texugo: boca, vista de norte (fotografia: $R$. Wahl-Clerici) 


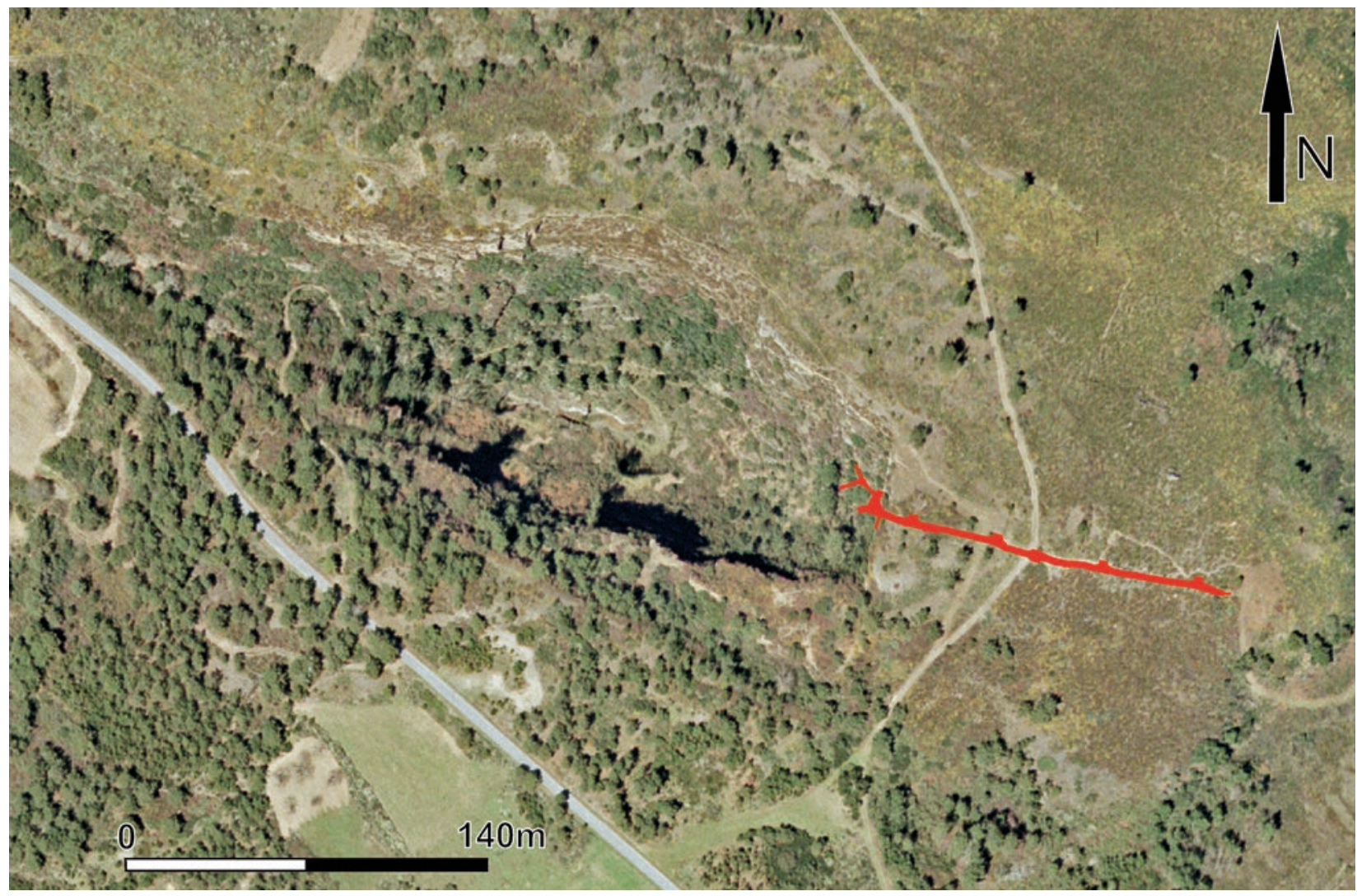

Fig. 3.3-26: Territorium metallorum Tresminas /Jales, Tresminas, Galeria dos Alargamentos: no ponto onde os dois túneis se encontram, é visível uma extensão não intencional, o que demonstra que os dois túneis não se encontraram exatamente frente a frente (Ortofotomapa 1: 5000 Câmara Municipal de Vila Pouca de Aguiar. Registo, processamento e apresentação: M. Helfert).

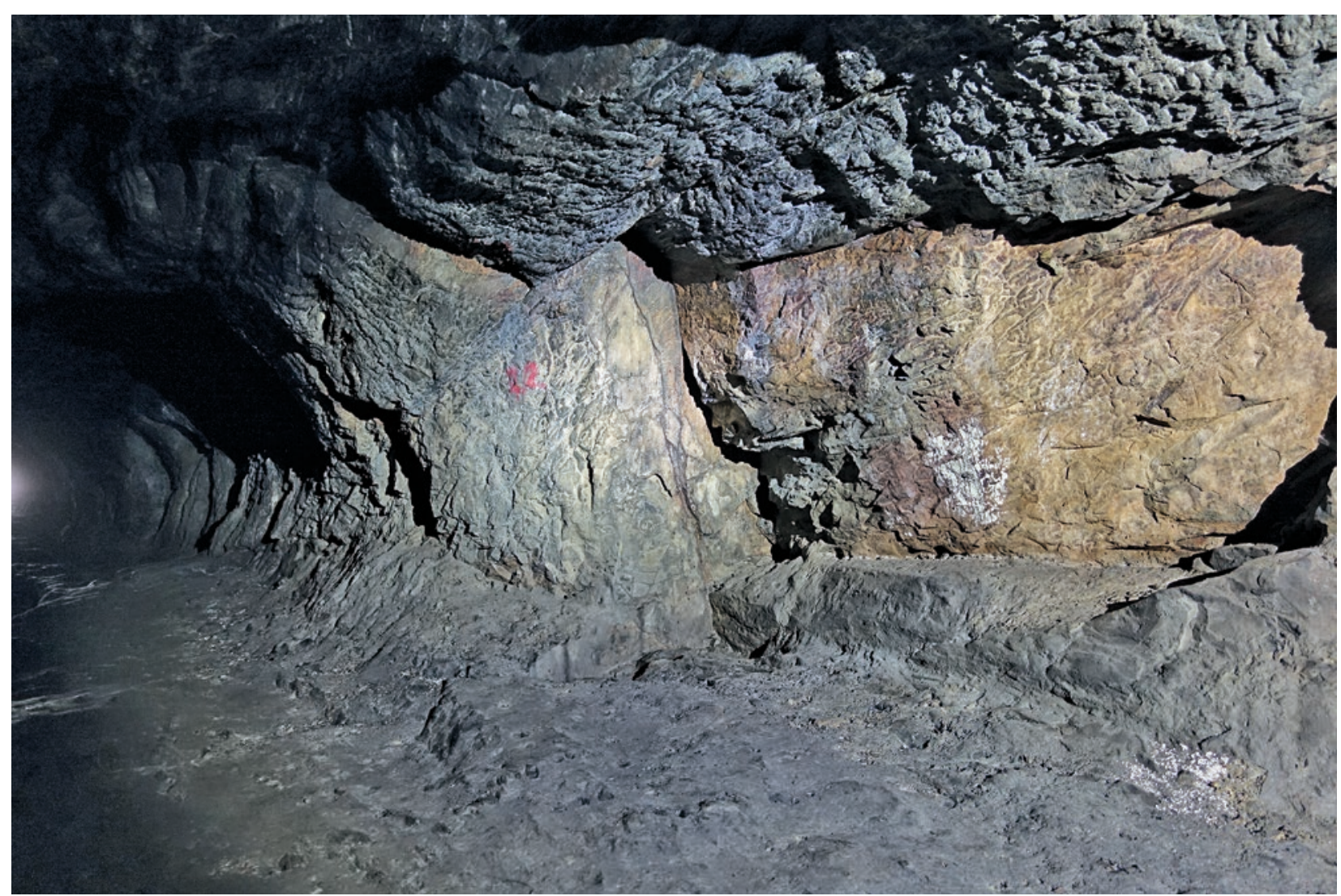

Fig. 3.3-27: Territorium metallorum Tresminas / Jales, Tresminas, Galeria dos Alargamentos: vista para o canto sudeste da zona de cruzamento dos dois eixos (fotografia: R.Wahl-Clerici). 


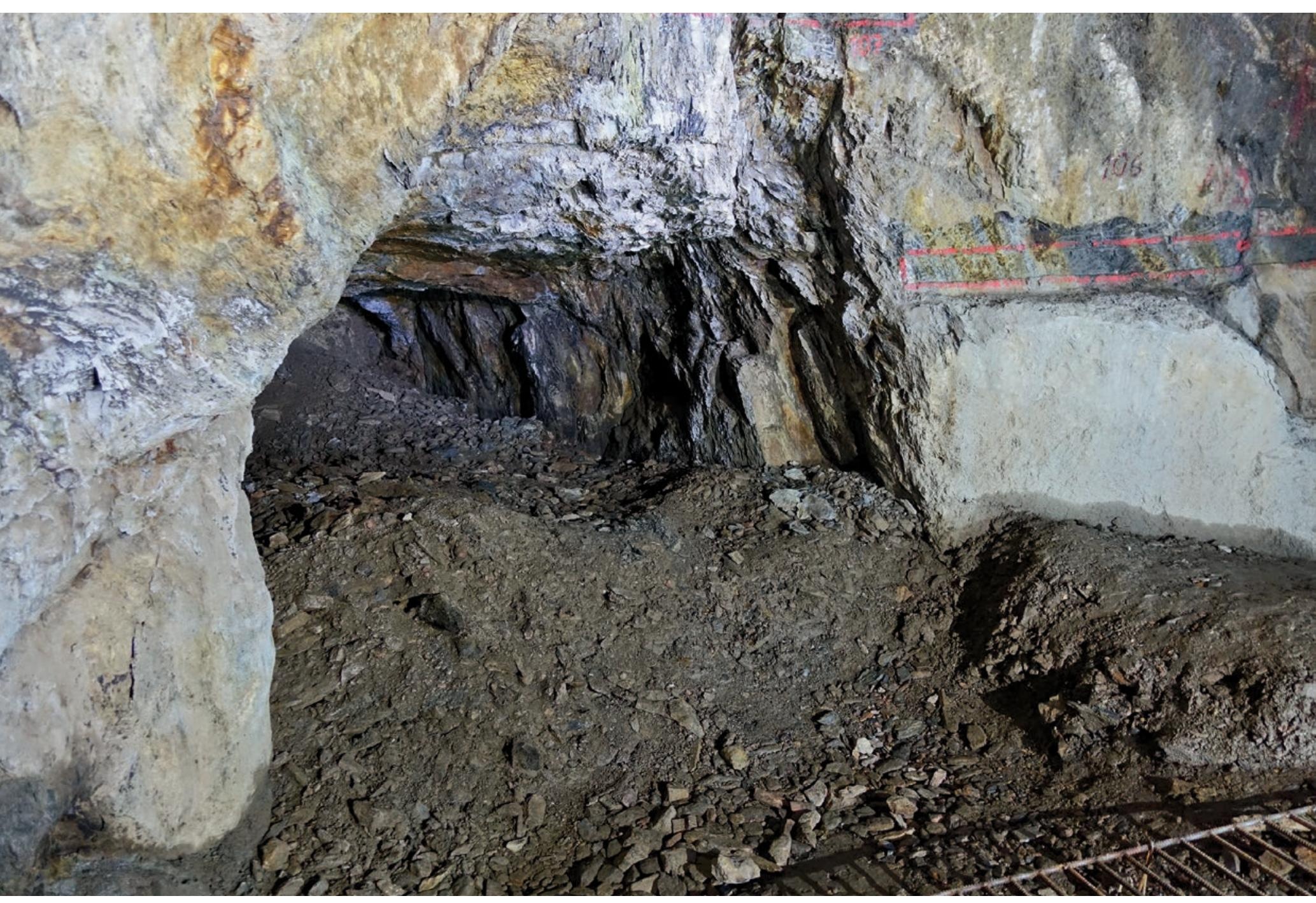

Fig. 3.3-28: Territorium metallorum Tresminas / Jales, Galeria dos Alargamentos: vista de leste para a extensão de prospeção G (Fig. 2.0-10). Esta antiga extensão foi ampliada nos tempos modernos (fotografia: R.Wahl-Clerici).

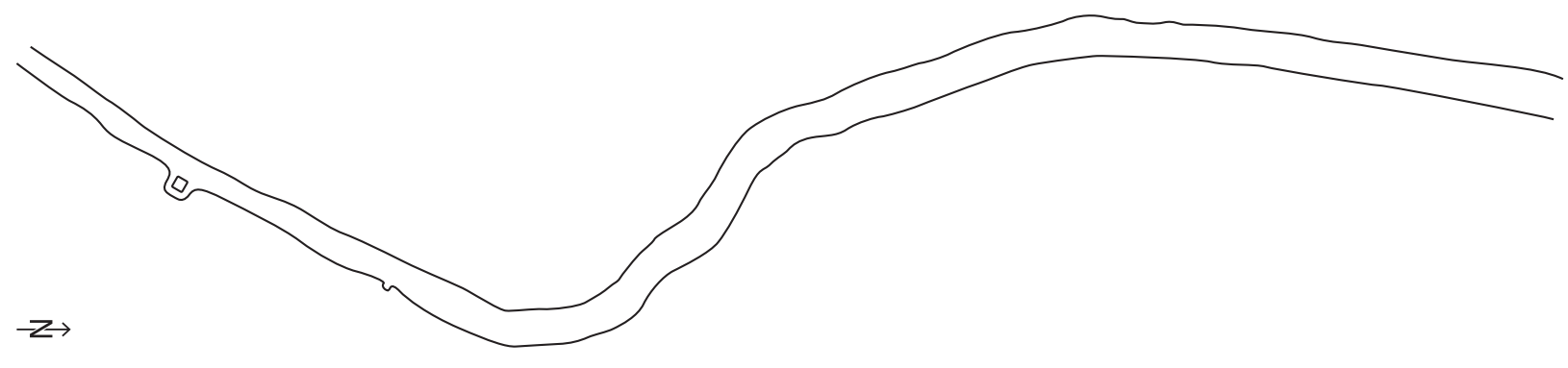

$100 \mathrm{~m}$

Fig. 3.3-29: Territorium metallorum Tresminas / Jales, Tresminas, Corta da Ribeirinha: plano da Galeria dos Morcegos (com base nos documentos do Serviço de Fomento Mineiro, desenho: J.Wahl, S.Mathiuet). 


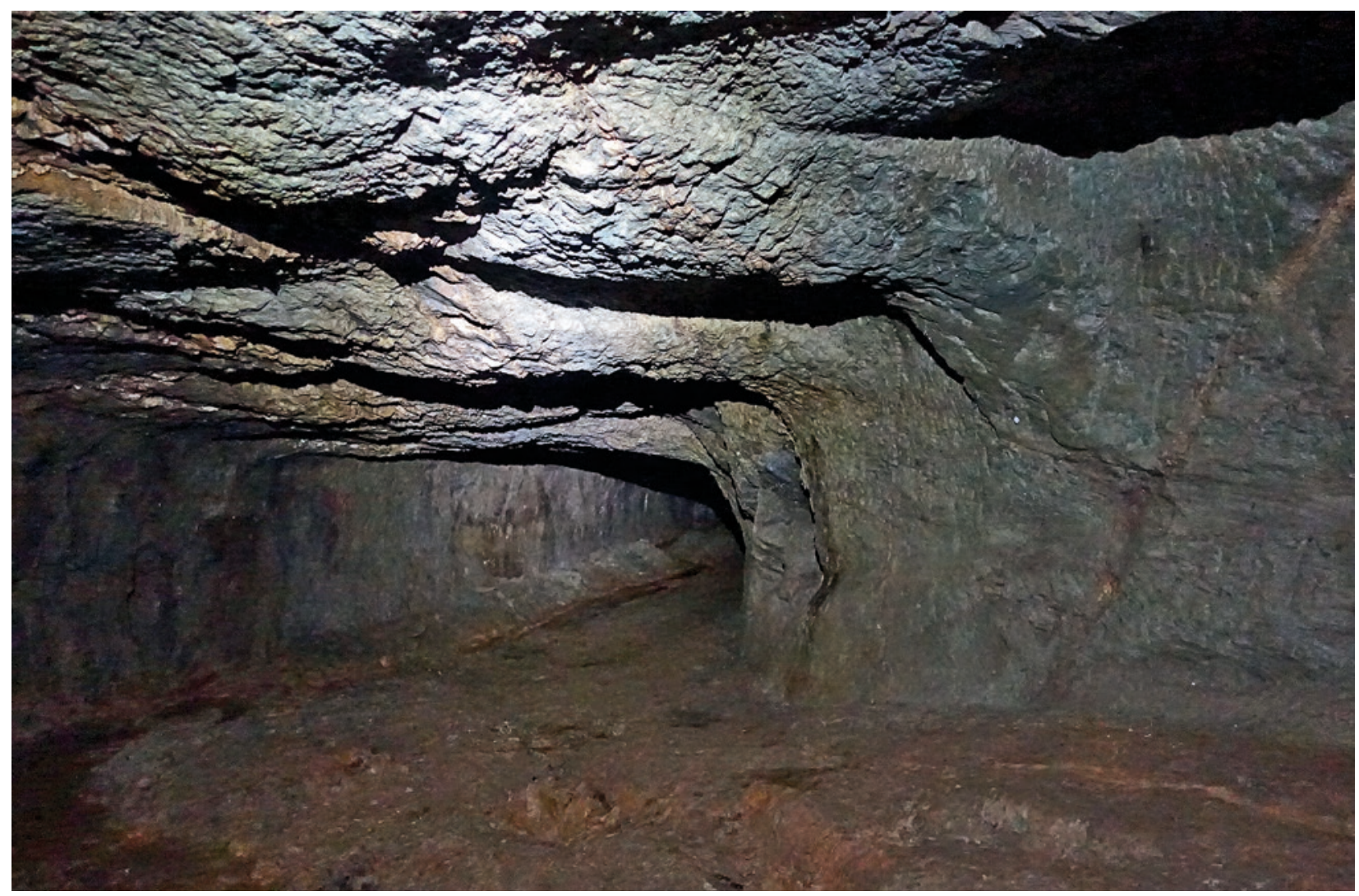

Fig. 3.3-30: Territorium metallorum Tresminas /Jales, Tresminas, Corta da Ribeirinha, Galeria dos Morcegos: zona na área da primeira mudança de direção, a partir da entrada com uma largura alvo de 3,85 m. No tecto, são bem visiveis os antigos pontos de ataque e as zonas de impacto intermediárias (fotografia: R. Wahl-Clerici).

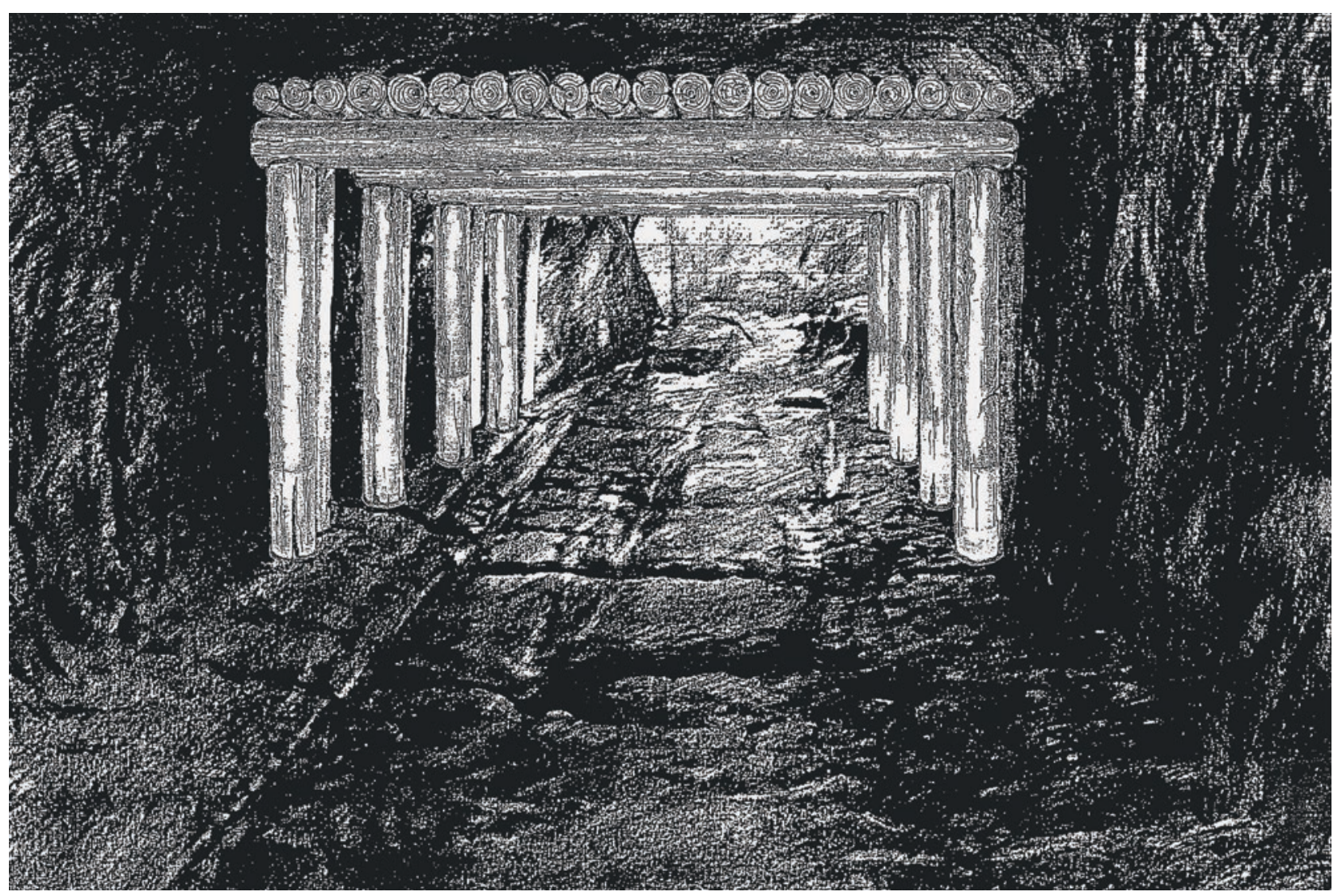

Fig. 3.3-31: Territorium metallorum Tresminas/Jales, Tresminas, Corta da Ribeirinha, Galeria dos Morcegos: a reconstrução das estruturas de entivação baseou-se nas cavidades encontradas no piso (desenho: P. Moser). 


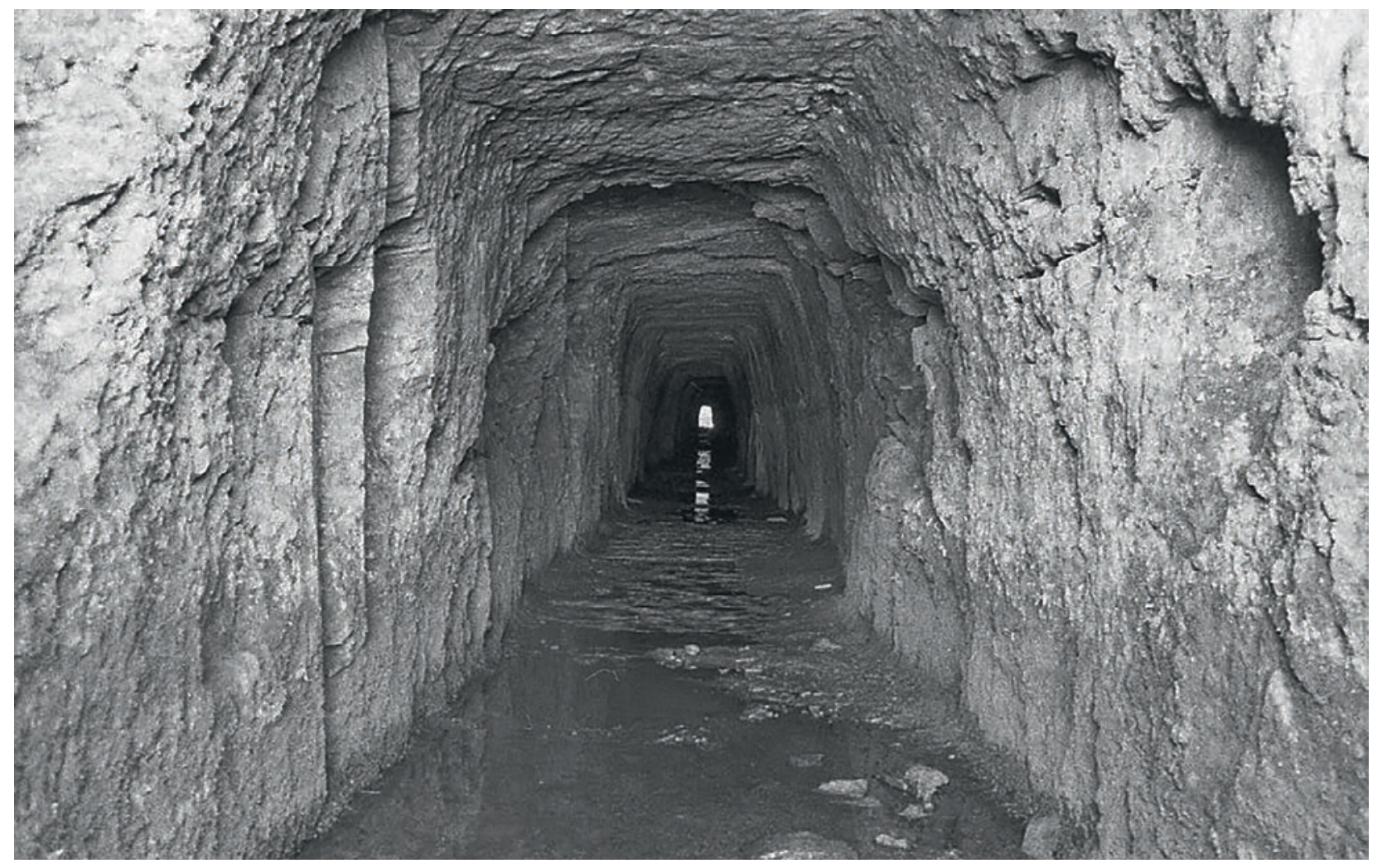

Fig. 3.3-32: Territorium metallorum Tresminas / Jales, Tresminas, Corta da Ribeirinha, Galeria do Buraco Seco. Vista de norte (fotografia: J. Wahl). 


\subsubsection{Avanço e extensão das galerias e dos poços}

A construção de cavidades em montanhas vem sempre acompanhada do risco de derrocadas. Além da estabilidade da própria montanha, a secção transversal das cavidades é crucial, especialmente em construções a nível horizontal. Ao abrir uma cavidade, os romanos tinham de confiar na sua experiência em relação às condições naturais encontradas. Atualmente, através da mecânica das rochas, que trata da estática e da dinâmica das rochas sólidas, é possível proceder à abertura controlada de cavidades subterrâneas. ${ }^{146}$

As cavidades abertas em Tresminas pelos romanos mantiveram-se preservadas durante cerca de 2000 anos, com apenas pequenas alterações. A seguir, pretende-se discutir os detalhes de construção de vários túneis, galerias, poços em escada e poços face às suas condições naturais.

\section{As secções transversais}

Em princípio, é possível distinguir na construção de túneis as seções transversais que suportam e as que impedem a estabilidade da cavidade. O esboço na fig. 3.3.1-1 mostra o estado natural de tensão numa montanha, o que permite verificar que as forças de pressão agem de cima para baixo, tendo como resultado o desvio para o lado das montanhas subjacentes. Durante a construção de um túnel trata-se sempre de desviar a pressão da rocha o mais próximo possível para as laterais da cavidade. Nos esboços das figs. 3.3.1-2a-d é possível observar claramente as condições de pressão. ${ }^{147}$

Contrariamente a estas circunstâncias, as seções transversais das galerias com larguras particularmente grandes - a Galeria do Pilar mede 4,20 m e a Galeria dos Morcegos 3,85 m -, correspondem a um retângulo mais largo do que alto (figs.3.3.1-2b, 3.3.1-3, 3.3.1-4, 3.3-30 e 3.3-31). Embora esta forma não seja de todo ideal no que diz respeito à pressão na montanha, as galerias mantêm-se estáveis há quase 2000 anos devido à estabilidade da rocha. Ao que nos parece, o retângulo era considerado como forma ideal para a construção destas galerias (figs. 3.3.1-3-3.3.1-6). O arqueamento das paredes na Galeria do Pilar (fig. 3.3.1-3) surgiu muito provavelmente devido à técnica usada na extensão da cavidade (ver abaixo).

Uma fenda na Galeria do Pilar levou a que parte do piso se partisse, caindo no canal, o que, provavelmente, está relacionado com essa cavidade extra (fig. 3.3.1-5). O tecto na área da entrada da Galeria dos Morcegos encontra-se igualmente marcado por vários colapsos, embora isto se deva, principalmente, à espessura da montanha muito fina por cima da entrada, pois mais no interior da montanha o tecto mantém-se estável (figs. 3.3.1-6 e 3,3-31).
Os cortes transversais da Galeria Esteves Pinto e da Galeria do Texugo encontram-se próximos de um segmento ideal em círculo (figs. 3.3.1-7 e 3.2-13b) ${ }^{148}$, pelo que permitiam a passagem de um carrinho de cada vez. Na Galeria dos Alargamentos, as seções transversais são diferentes, tanto na parte virada para o vale, como na parte voltada para a montanha. Assim sendo, a primeira assemelha-se às secções transversais nas galerias Esteves Pinto e Texugo, enquanto que a segunda foi adaptada à forma de um segmento de círculo mais plano (figs. 3.3.1-6, 3.3-4, 3.3-13 e 3.3-25).

Outras seções transversais, observáveis em Tresminas, assumem a forma de um trapézio (figs.3.3.1-2c, 2.0-15, 3.3.1-9, 3.3.1-10, 2.0-17 e 3.0-18) ou de um retângulo vertical. Estes últimos podem ser encontrados sobretudo em túneis e poços relativamente curtos, abertos para prospeção. Por exemplo, na Corta de Covas, apenas o poço em escada entre as duas zonas mineiras (sul e norte) foi até ao momento inequivocamente identificado como um retângulo alto. Para facilitar o trabalho de exploração, aproveitou-se um fosso natural, presente na parede oriental (fig. 3.0-7). $\mathrm{Na}$ Corta da Ribeirinha o poço com escada em espiral foi construído em forma retangular (fig. 3.3.1-8).

Para prospeção abriram-se dois túneis com tectos mais ou menos semicirculares. Um deles faz parte de um sistema de prospeção, construído ainda antes da abertura da Galeria Jürgen Wahl, a partir do poço entre a Galeria Jürgen Wahl e a Galeria do Pilar (fig. 2.0-13). O outro, faz parte do complexo sistema de prospeção construído $100 \mathrm{~m}$ a leste de Lagoinhos (figs. 2.0-20 e 2.0-21).

De particular interesse é a galeria superior, que se abriu paralelamente à antiga entrada a oeste da Corta da Ribeirinha e que foi afundada várias vezes (fig. 3.3.1-9). Originalmente, o túnel aproximava-se da forma de um trapézio, contudo, no decorrer dos afundamentos adicionais, não se aumentou a largura do piso, pelo que se criou um retângulo vertical.

A galeria subjacente, que serviu igualmente para prospeção de norte para sul, é claramente trapezoidal (figs. 2.015 e 3.3.1-10). É possível observar ainda outras seções transversais na galeria de prospeção sem nome a leste da Corta da Ribeirinha (fig. 2.0-17).

146 Katzenbach/TU Darmstadt. file://F:/Book_Grafische_Gestaltung_2/Doppelstollen/Tunnelbau/14_-_Einfuehrung_in_die_Felsmechanik_11-10-06.pdf. Consultado em 15.10.2018.

147 Modelo para o esboço: Dr. Rudolf Schindlmayr, Bergische Universität Wuppertal.

148 Na construção moderna de tuneis dá-se preferência a este tipo de secção transversal. Veja-se o túnel em San Gottardo, Suíça. Neste caso, foram abertas por máquinas duas cavidades circulares independentes, cujos pisos foram preenchidos, servindo para a incorporação de caris. Veja-se https://de.wikipedia.org/wiki/Gotthard-Basistunnel. 


\section{Abertura das galerias}

As galerias e os túneis em Tresminas foram abertos com recurso a vários métodos, nomeadamente:

1. A construção segundo o método 'Qanat', aplicada em todos os túneis conhecidos do sistema de abastecimento de água.

2. A abertura de uma galeria-piloto que, através das frentes de desmonte nas paredes, era aumentada até atingir a largura desejada; neste caso incluem-se a Galeria do Pilar, a Galeria dos Alargamentos e a Galeria dos Morcegos.

3. Conduta direta da galeria na largura e altura desejadas. Segundo os nossos conhecimentos atuais, a Galeria do Buraco Seco foi construída desta forma, tal como a galeria de prospeção sem nome no extremo oriental da Corta da Ribeirinha, assim como o sistema de túneis, galerias e poços multiníveis, preservado paralelamente à entrada ocidental da Corta da Ribeirinha.

Devido à sua acessibilidade parcial, mantém-se a incerteza quanto ao método de construção utilizado nas galerias Esteves Pinto, Jürgen Wahl e Texugo.

De particular interesse revestem-se os vários métodos de medição utilizados para a construção, sendo que já é possível distinguir entre o método em Qanat, previamente mencionado, a medição sobre a montanha, bem como a localização a partir da encosta oposta.

A definição do método de construção em Qanat deriva dos acessos subterrâneos a fontes subterrâneas, os chamados qanats, abertos em regiões áridas da Terra. Os seus inícios remontam aos princípios do primeiro milénio a.C. Exemplos particularmente antigos podem ser encontrados no Irão, onde até hoje se encontram em funcionamento 37000 qanats. ${ }^{149}$

O método de construção em Qanat, inicia-se pela marcação alinhada do percurso do túnel na superfície de montanha. A seguir, abrem-se poços (verticais) até ao piso previsto, passando depois à ligação entre esses poços (fig. 3.3.111). ${ }^{150}$ Este método tem a vantagem significativa de as distâncias entre os poços serem relativamente curtas, pelo que dificilmente seria posto em risco o encontro entre os poços, ao contrário do que acontecia no método de construção a partir de lados opostos (ver abaixo). Dependendo da profundidade dos poços, era possível reduzir o tempo de construção, dada a existência de dois lados de escavação por poço. Por outro lado, isto significava um esforço considerável, mas pelo que parece foi aceite, uma vez que permitia evitar erros de medição que poderiam levar a grandes atrasos e custos adicionais.

Os exemplos mais conhecidos da antiguidade são os túneis de ligação ao túnel de Eupalinos, que garantia o fornecimento de água a Samos (Grécia) no século VI a.C. ${ }^{151} \mathrm{e}$ enquanto este túnel principal foi aberto através do método de construção por lados opostos, nos túneis de ligação recorreu-se ao método de construção em Qanat. ${ }^{152}$

Em Tresminas, todos os túneis para o abastecimento e escoamento de água conhecidos e acessíveis foram construídos com recurso ao método de construção em Qanat. ${ }^{153}$ As típicas depressões suaves, ainda são facilmente reconhecíveis, com os montes de entulho por trás, que se estendem em linha sobre a montanha (fig. 3.3.1-12).

Um outro método para a orientação de um túnel consistia no recurso a um poço de observação, que em Tresminas apenas se pode encontrar na Galeria Esteves Pinto. Para este efeito, aprofundava-se o piso de um poço, imediatamente a seguir à entrada, de modo a definir um corredor de visualização para a orientação do túnel, conforme ilustrado na figs. 3.3-13a/b. ${ }^{154}$

O método de medição usando um ponto fixo na encosta oposta possibilitou a construção em linha reta, como aconteceu no caso da Galeria do Pilar. Neste túnel com mais de $280 \mathrm{~m}$ de comprimento, consegue observar-se a luz, que penetra através da entrada, mesmo a partir da posição mais recuada (figs. 3.3.1-14, 3.3.1-9 e 3.3-16).

A definição de um ponto fixo na encosta oposta permitiu ao topógrafo projetar o sistema conectado à Galeria Jürgen Wahl no interior da montanha, apoiando-se, ao mesmo tempo, num eixo longo. Deste modo, foi igualmente possível construir a galeria em linha reta ${ }^{155}$, o que implicava que a abertura só poderia ser feita do lado da encosta, resultando no dobro de tempo de construção. Para poder reduzir esse tempo de construção, abria-se primeiro um túnel com espaço para um único trabalhador, que depois era expandido em ambos os lados por pontos de ataque adicionais (figs. 3.3.1-4 e 3.3.1-5).

A construção da Galeria do Texugo representou um desafio especial, uma vez que a extensão tinha de ser ligada ao poço em frente à entrada da Galeria do Pilar. As dificuldades menores, resultantes deste processo, foram muito provavelmente resolvidas sem grande esforço, conforme demostra o percurso da galeria (figs.3.3-16 e 3.3.1-15).

149 Grewe 1998, 33-40; Veja-se a palestra do Dr. Ali Ashgar Semsar Yazdi (Centro Internacional em Qanats e Estruturas Hidráulicas Históricas, Irão), WWAC Coimbra 2016.

150 No caso do túnel Claudius, junto do lago Fucino em Avezzano, Itália, recorreu-se, excecionalmente, à abertura de poços inclinados. Grewe 1998, 91-98; Cech 2017, Fig. 12.

151 O túnel de Eupalinos foi construído com recurso ao método de escavação a partir de lados opostos. Veja-se a descrição em detalhe em Kienast 1995, Plan 2 e Grewe 1998, 58-69.

152 Grewe 1998, 55-59.

153 O aqueduto T2 (Pedroso), o aqueduto T4 (Castanheiro Afumado e Alto da Capelinha). Ainda incerto: T1 (entre Tinhela-de-Baixo e a ligação que parte da rua sem saída para Filhagosa/Revel), C1 (Lomba dos Corvos do Muro).

154 Relativamente ao poço de observação no túnel de Eupalino em Samos: Kienast 1995, 179—241; Grewe 1998, 60—62, fig. 85-86.

155 Grewe 1998, fig. 85 
Em princípio, devido ao percurso surpreendentemente reto da Galeria do Buraco Seco (fig. 3.3-32) e do túnel sem nome na área da antiga entrada oriental para a Corta da Ribeirinha (fig. 2.0-17), que, provavelmente, terá sido originalmente um túnel de prospeção, poderá supor-se que foi utilizado o método de medição com recurso a um ponto fixo na encosta oposta. Além disso, tanto na galeria como no túnel não existem poços de observação. Contudo, os locais para os possíveis pontos fixos nas encostas opostas situam-se a pelo menos $300 \mathrm{~m}$ de distância, pelo que, provavelmente, se terá recorrido à medição sobre a montanha sem poço de observação (fig. 3.3.1-16).

A forma mais difícil de construção de túneis representava o método de escavação a partir de lados opostos, utilizado na construção da Galeria dos Alargamentos (figs. 3.3.1-17a/b). ${ }^{156}$ Aqui é possível distinguir dois eixos que se encontraram quase exatamente no centro, dando a impressão que se trata de mais uma extensão (figs. 3.3-26 e 3.3-27). O facto de uma das entradas no final de um poço se situar a cerca de $50 \mathrm{~m}$ de profundidade e, portanto, no subsolo, representava uma dificuldade acrescida (figs. 3.3-9 e 3.3-10). Embora a medição tivesse de ser feita sobre a montanha, prescindiu-se da construção de um poço de observação. Por conseguinte, a abertura da Galeria dos Alargamentos pode ser considerada uma obra-prima da arte romana em agrimensura e escavação de túneis.

Este sistema de construção mais difícil exige uma precisão extrema dos topógrafos, uma vez que os mais pequenos desvios resultavam em grandes erros. ${ }^{157} \mathrm{O}$ eixo que começava no interior da montanha representava uma dificuldade adicional, pois encontrava-se $50 \mathrm{~m}$ abaixo da superfície, além do mais, tinha de se ter em conta que a abertura da galeria a partir da encosta apresentava uma ligeira inclinação. Os topógrafos de Tresminas resolveram a tarefa com mestria, dado que não só as duas equipas de trabalho se encontraram no local pretendido, como também foi possível manter na horizontal o eixo iniciado no interior da montanha, impedindo assim que durante a construção da galeria a água fluísse constantemente para o poço de extração, presumivelmente, aprofundado em simultâneo. Deve notar-se ainda que os dois eixos diferem apenas ligeiramente no seu comprimento.

No caso da Galeria dos Morcegos, que foi igualmente aberta por via da encosta, constata-se mais uma vez a competência elevada dos engenheiros romanos. Esta galeria não podia ser escavada partindo do percurso com a menor distância entre a entrada à superfície e a entrada na zona de exploração, dado que se encontravam grandes montes de entulho nessa área, suscetíveis de serem aumentados durante o período de construção. Os métodos de medição modernos mostram que o percurso inicial visava diretamente o ponto final desejado, no entanto, pouco tempo depois procedeu-se a uma correção da direção, seguida por nada menos do que quatro outras correções, conseguindo assim finalmente alcançar o ponto final original (fig. 3.3-29).
Usando o exemplo da Galeria dos Morcegos, que, como sabemos, nunca foi terminada e nunca foi colocada em funcionamento, podemos observar os métodos romanos para a construção de túneis em Tresminas. Inicialmente, contruía-se uma galeria-piloto, que poderia ter de ser ajustada várias vezes até atingir o nível desejado (figs. 3.3.1-4 e 3.3.118). Para a extensão deste túnel, construído inicialmente com o tamanho para um único homem, abriam-se na parede a leste novos pontos de ataque adjacentes (fig. 3.3.119), o que permitia que, a seguir, vários trabalhadores procedessem à extensão em simultâneo, aumentando, embora pouco significativamente, o tempo de construção. Na Galeria dos Morcegos é possível identificar 30 frentes de desmonte, ou seja, pontos dos quais partiam os trabalhos de extensão da galeria (fig. 3.3.1-20). Uma grande parte destas frentes foi abandonada a meio do processo de extensão, todavia, no geral, ainda são identificáveis, mesmo depois de se ter fraturado a rocha intermédia e suavizada a parede (figs.3.3.1-18 e 3.3.1-19). Este processo poderia, em princípio, ser repetido até se atingir a largura desejada.

Na Galeria do Pilar e na Galeria dos Alargamentos foi possível identificar vestígios de três cabrestantes. No primeiro, também se podem encontrar zonas de trabalho em ambas as paredes laterais, ao contrário do que acontece na Galeria dos Morcegos

\section{Os poços em escada}

Todos os poços em escadas atualmente conhecidos têm entre 1 e 1,20 m de largura e apresentam uma forma retangular predominantemente vertical (figs. 3.3.1-8, 2.0-20, 2.021, 2.1-3a / b-2.1-5, 2.2-1-2.2-7 e 3.0-7). Tratando-se em todos os casos de estruturas de prospeção, eram sempre abertas partindo de uma posição mais alta para prospetar as zonas mais profundas.

\section{Os poços verticais}

A maioria dos poços nas áreas de exploração de Tresminas e Gralheira apresenta um corte transversal em quadrado. $\mathrm{O}$ mesmo se aplica ao poço de ligação entre a Galeria Jürgen Wahl e a Galeria do Pilar. Dado que era necessário atravessar a escombreira em frente à galeria, situada a um nível mais alto, presume-se que se recorreu a uma construção em madeira.

156 Veja-se: Fontvieille (França), Tunnel Les Taillades em Grewe 1999, $101-102$ e figs. $151-152$.

157 A inscrição de Nonius Datus (CIL VII 2728 e 18122), que iniciou o seu trabalho como topógrafo na marcação do percurso da conduta de água subterrânea para Saldae (agora Bejaja, Argélia) e que, após as equipas de trabalho ainda não se terem encontrado, assumiu, já como veterano, a correção do percurso para que o trabalho fosse concluído com sucesso, é a testemunha mais famosa deste problema, vide Grewe 1998, 24 e 135-139. 


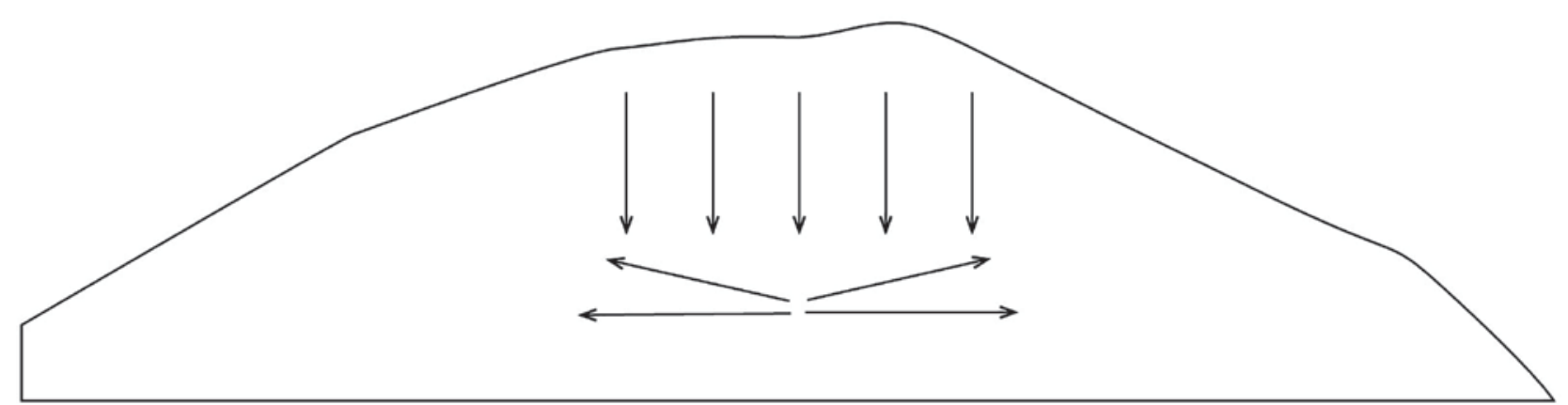

Fig. 3.3.1-1: O estado natural de tensão nas montanhas (modelo: R. Schindlmayr, execução: $R$. Wahl-Clerici)

Excecionalmente, é possível encontrar um retângulo alongado no antigo poço de entrada para a extração de minério em Lagoinhos (figs.3.3-3 e 3.3.1-21). O túnel de observação, necessário para a construção da Galeria Esteves Pinto, é mais uma exceção, pois é redondo (fig.3.3.1-22).

As formas dos vários poços, cuja entrada se encontra vedada pelo detrito das encostas e o entulho, são desconhecidas, o que acontece tanto no caso dos poços de prospeção, como no caso dos poços necessários para a construção em Qanat do sistema de abastecimento de água (ver o capítulo: Sistema de Abastecimento de Água).

Os poços gémeos escavados para a prospeção e que hoje são visíveis na encosta oriental da Corta de Covas, graças a uma derrocada natural das rochas, apresentam um caso especial. O material era transportado através do poço a norte, que perfura a câmara terminal da Galeria dos Alargamentos. A sul ainda são visíveis as cavidades para a fixação das vigas; este poço não alcançava a câmara final. Muito provavelmente existiam passagens de ligação entre os dois poços, nas quais, de acordo com o que é visível atualmente, só se passava rastejando (figs.3.3-9).

$\mathrm{O}$ avanço em profundidade de um poço exigia medições cautelosas, dado que, ao proceder à extensão, havia o risco de o percurso não seguir completamente em linha vertical. Este problema é verificável no poço que faz a ligação entre a área de entrada da Galeria Jürgen Wahl e a Galeria do Pilar. A medição mostrou que em termos topográficos as duas entradas diferem ligeiramente uma da outra. ${ }^{158}$

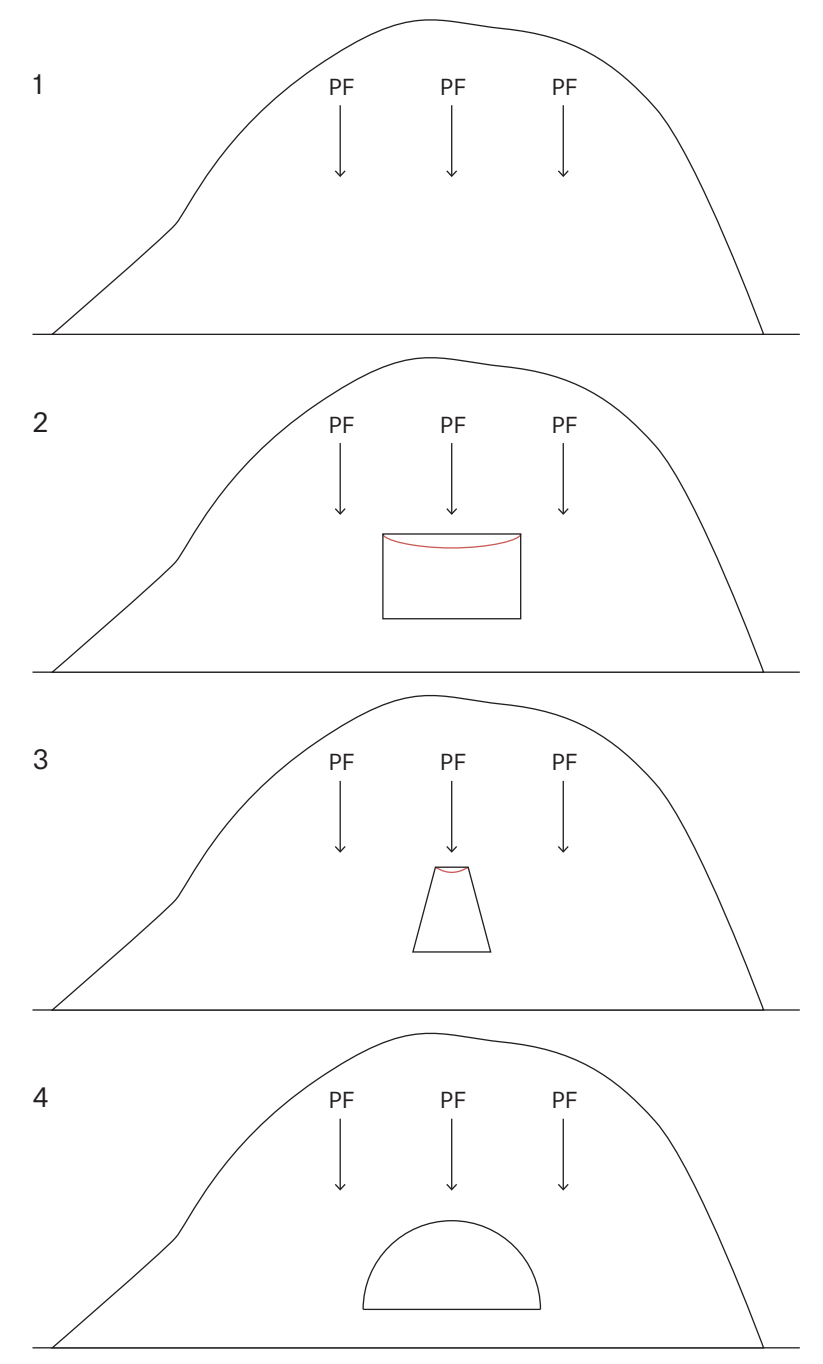

Fig. 3.3.1-2a/b/c/d: $2 a$ As forças naturais de pressão nas montanhas, sem perturbação. $2 b$ O efeito das forças de tração numa secção transversal em retângulo. 2 c O mesmo caso numa seç̧ão transversal trapezoidal. $2 d \mathrm{O}$ mesmo caso numa secção transversal correspondente a um segmento circular (modelo: R. Schindlmayr, execução: R. Wahl-Clerici). 


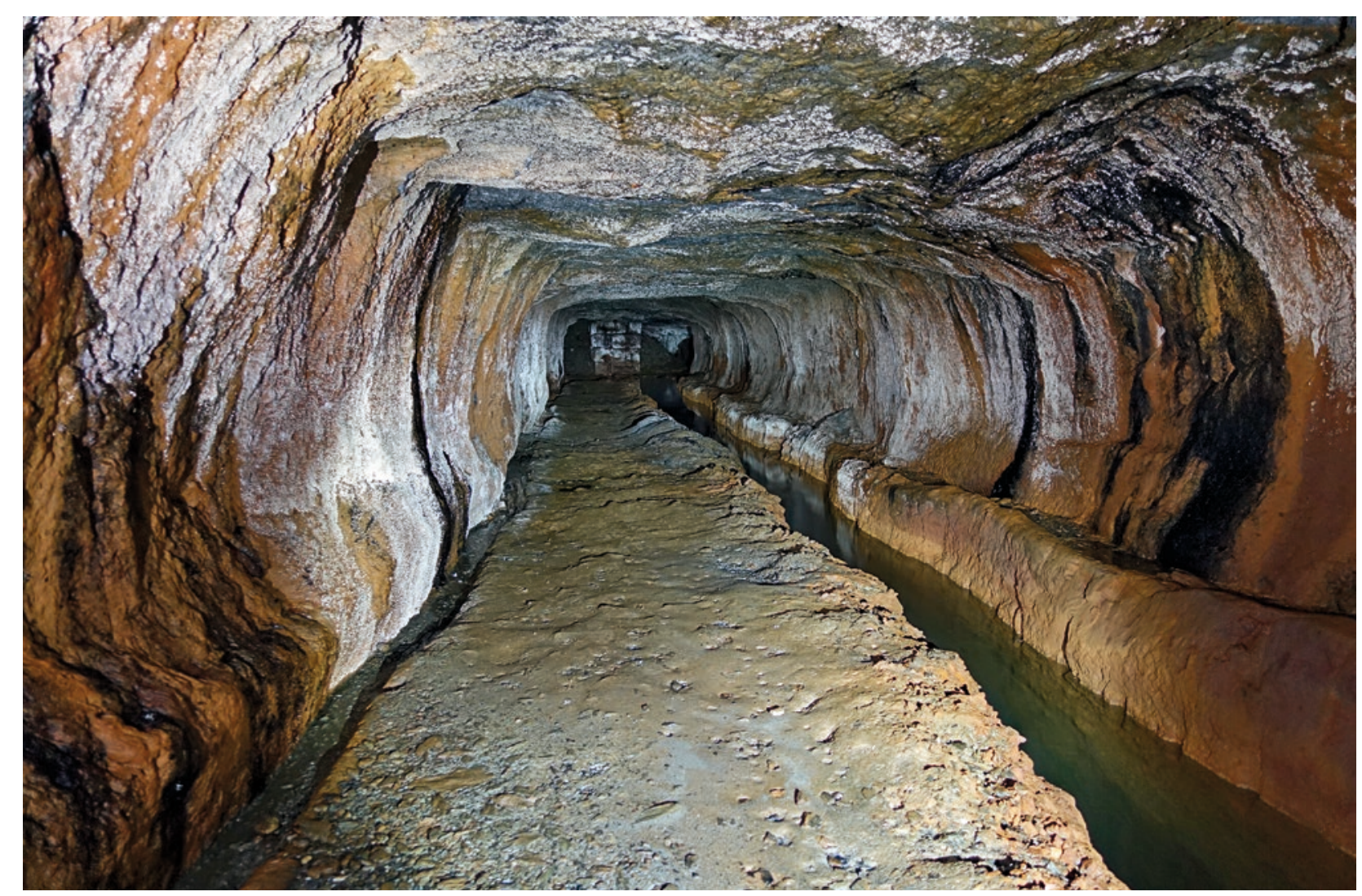

Fig. 3.3.1-3: Territorium metallorum Tresminas / Jales, Tresminas, Galeria do Pilar: situação atrás do Pilar. A irregularidade notável nas paredes deve-se às várias frentes de desmonte utilizadas para a expansão da cavidade. Vista para a boca situada na encosta (fotografia: $R$. Wahl-Clerici)

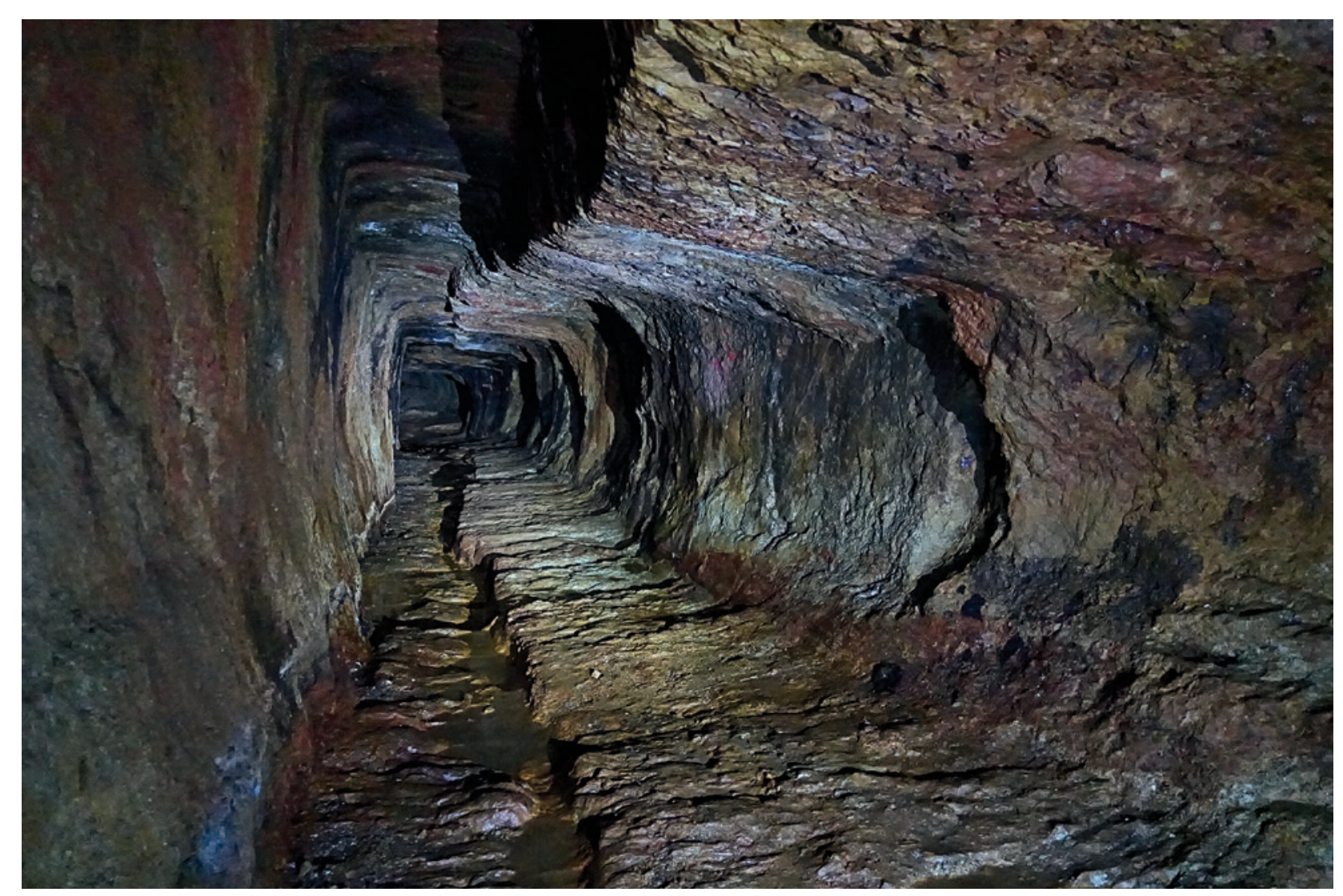

Fig. 3.3.1-4: Territorium metallorum Tresminas / Jales, Tresminas, Corta da Ribeirinha, Galeria dos Morcegos: parte do túnel abaixo da mina a céu aberto; depois de aprofundar o primeiro túnel (à esquerda), a extensão foi ampliada para leste (fotografia: R.Wahl-Clerici). 


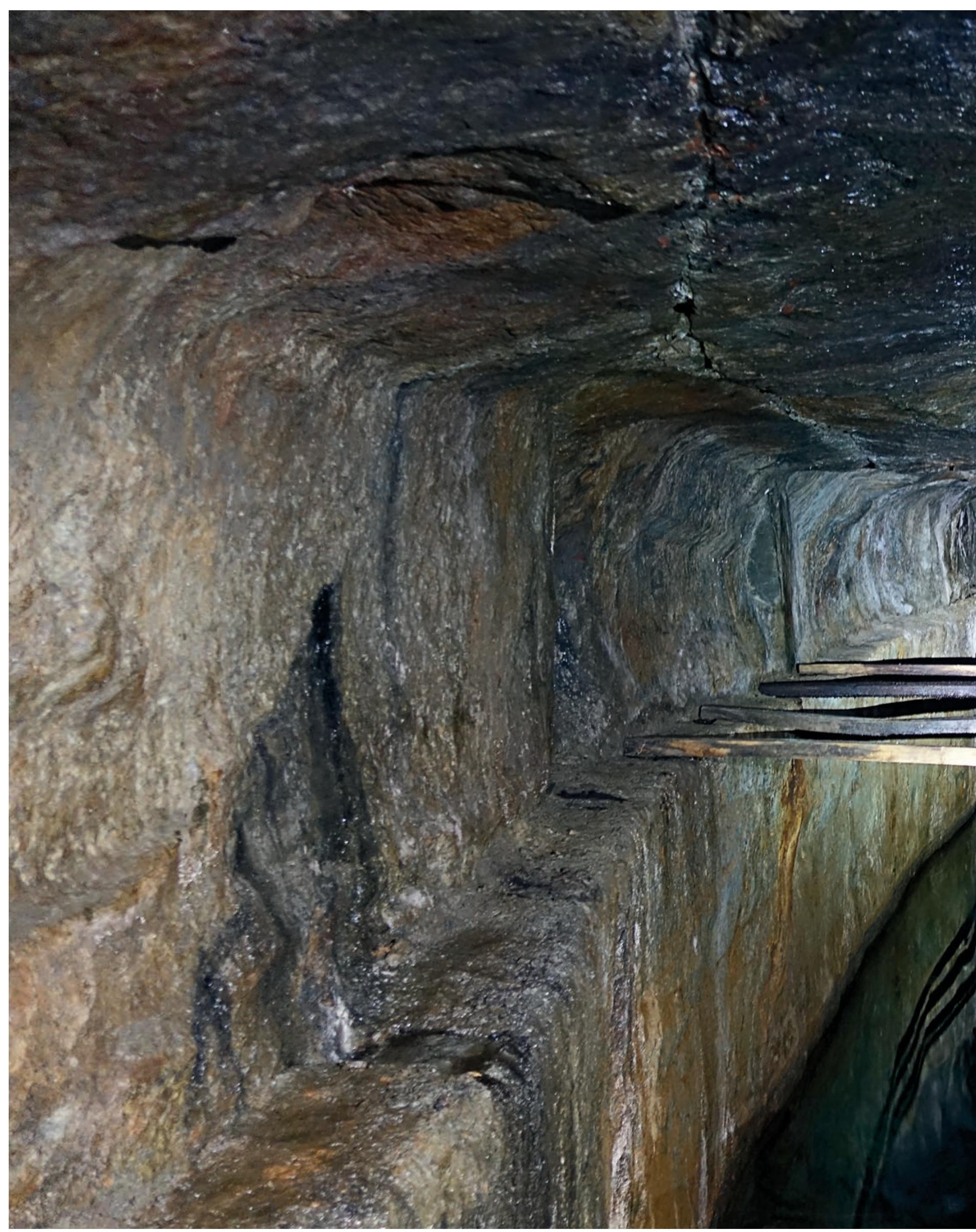




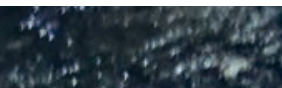

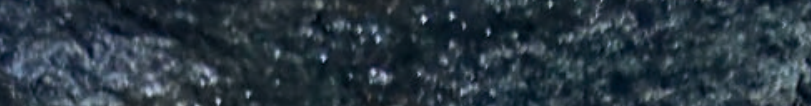

5.

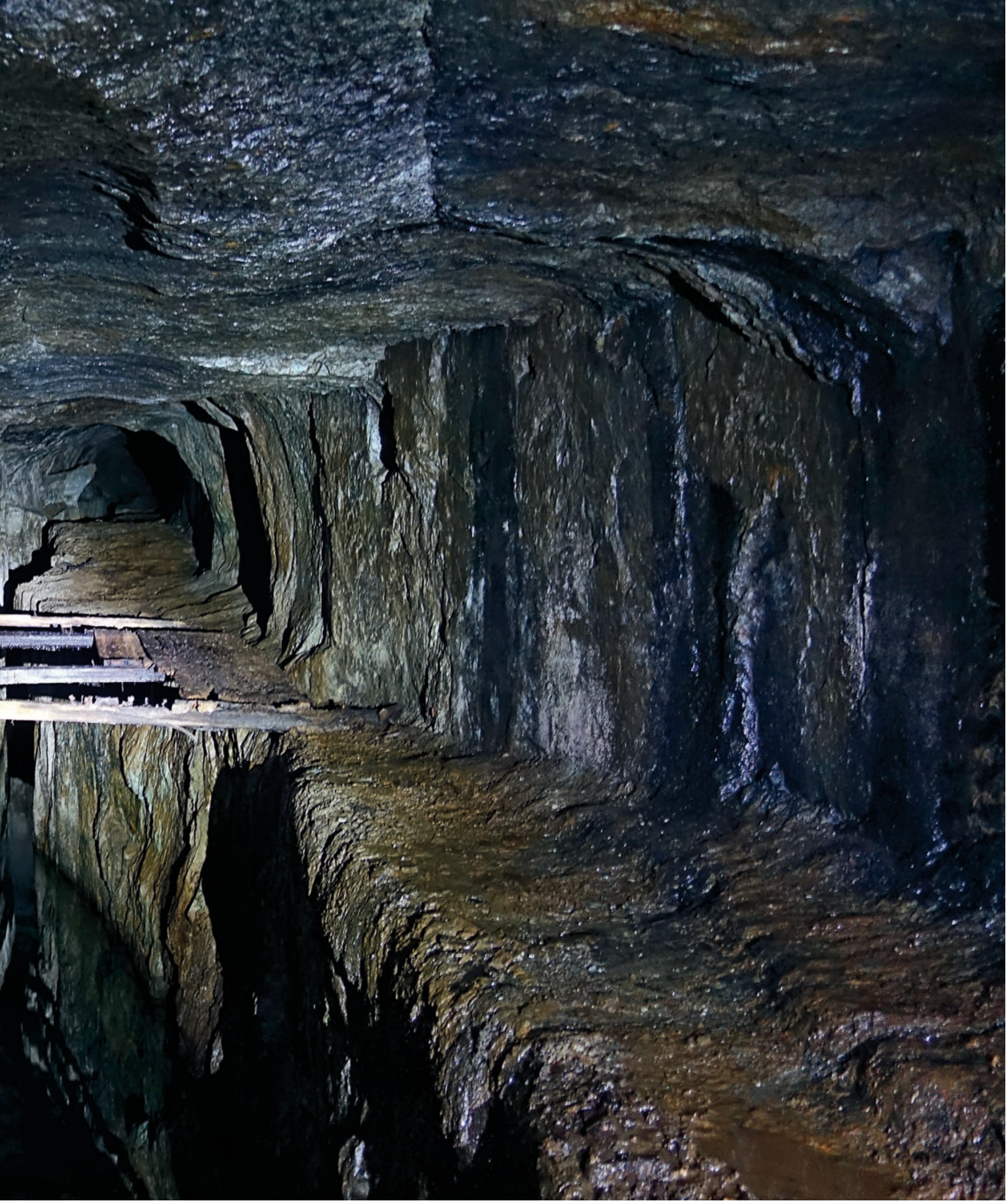

Fig. 3.3.1-5: Territorium metallorum Tresminas / Jales, Tresminas, Galeria do Pilar: derrocada da parede ocidental do canal, com os vestígios de uma ponte moderna. No tecto ainda é visivel o primeiro túnel (fotografia: $R$. Wahl-Clerici). 


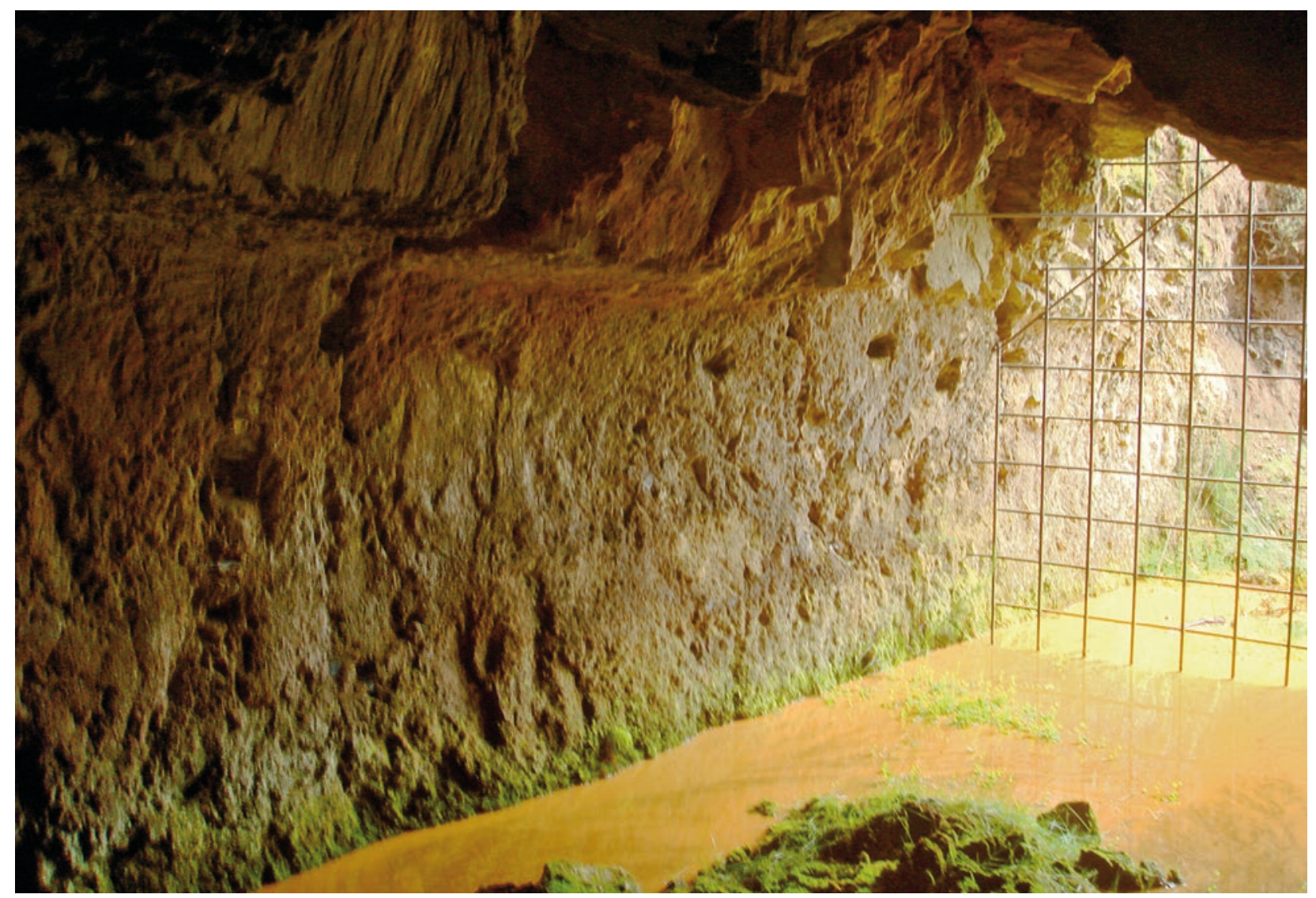

3.3.1-6: Territorium metallorum Tresminas /Jales, Tresminas, Galeria dos Morcegos: zona de entrada. Na parede vertical a oeste são visiveis as cavidades para as lucernas, necessárias para os trabalhos de expansão do poço de orientação. Devido às várias derrocadas, apenas é visível uma parte do estado original do tecto (fotografia: R. Wahl-Clerici).

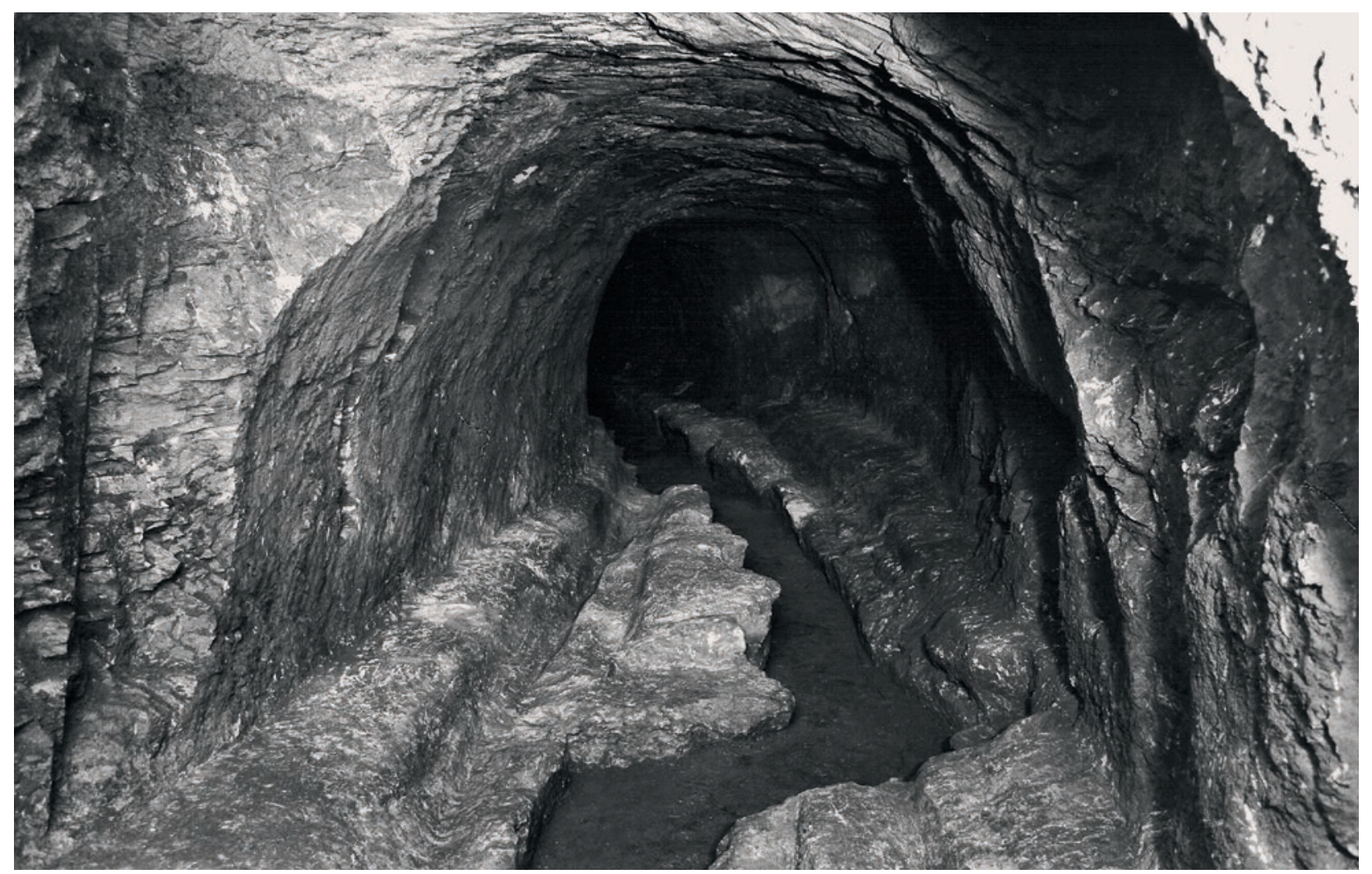

Fig. 3.3.1-7: Territorium metallorum Tresminas/Jales, Tresminas, Galeria Esteves Pinto: a seç̧ão transversal aproxima-se da forma de um segmento de um círculo, área de entrada do exterior (fotografia: J. Wahl). 


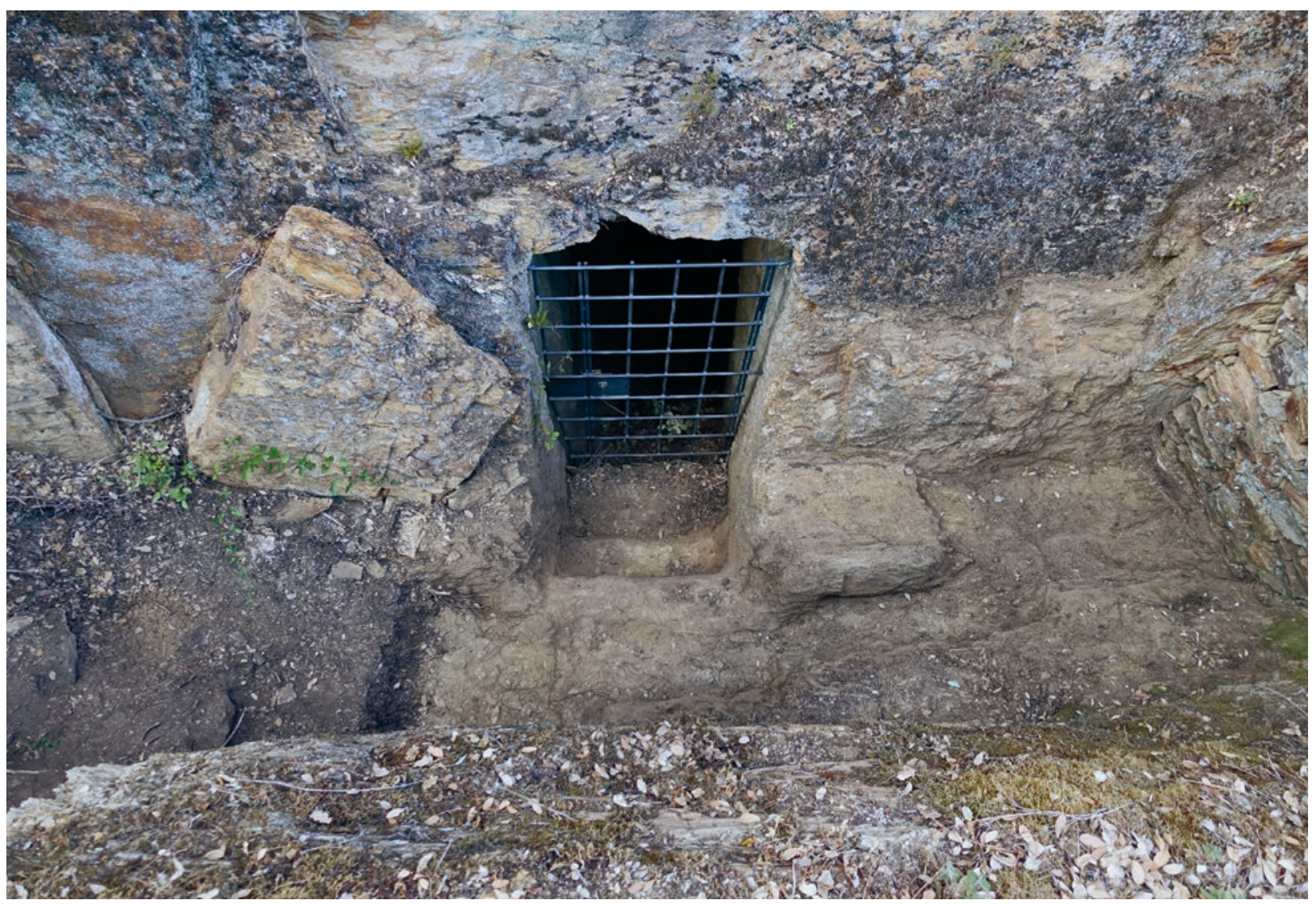

Fig. 3.3.1-8: Territorium metallorum Tresminas/Jales, Tresminas, Corta da Ribeirinha: boca do poço em espiral (fotografia: R. Wahl-Clerici). 


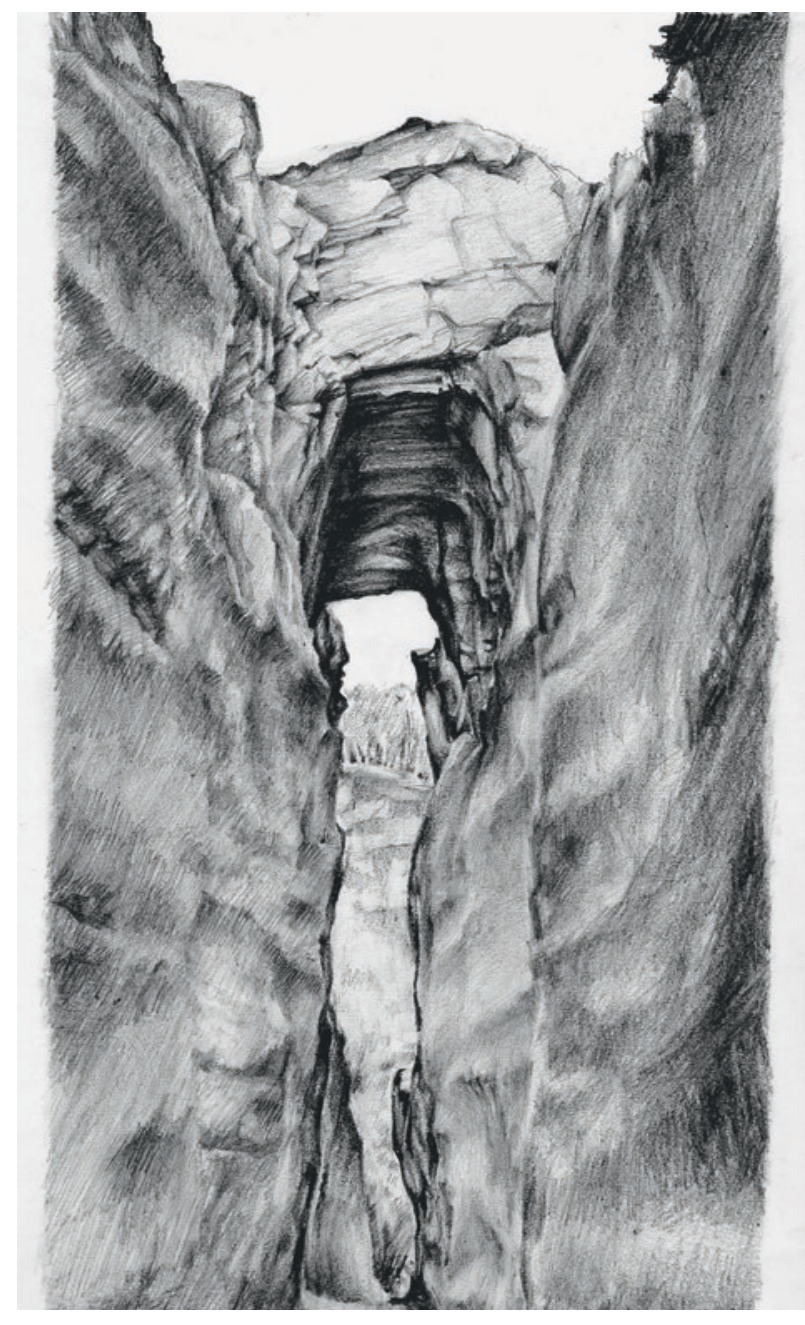

Fig. 3.3.1-9: Territorium metallorum Tresminas/Jales, Tresminas, Corta da Ribeirinha: abertura tipo túnel. Provavelmente, para a prospeção das zonas de extração por baixo da montanha, em paralelo à entrada ocidental da mina a céu aberto. O corte transversal trapezoidal e o aprofundamento gradual do piso são muito bem visíveis. Vista de norte (desenho: P. Moser).

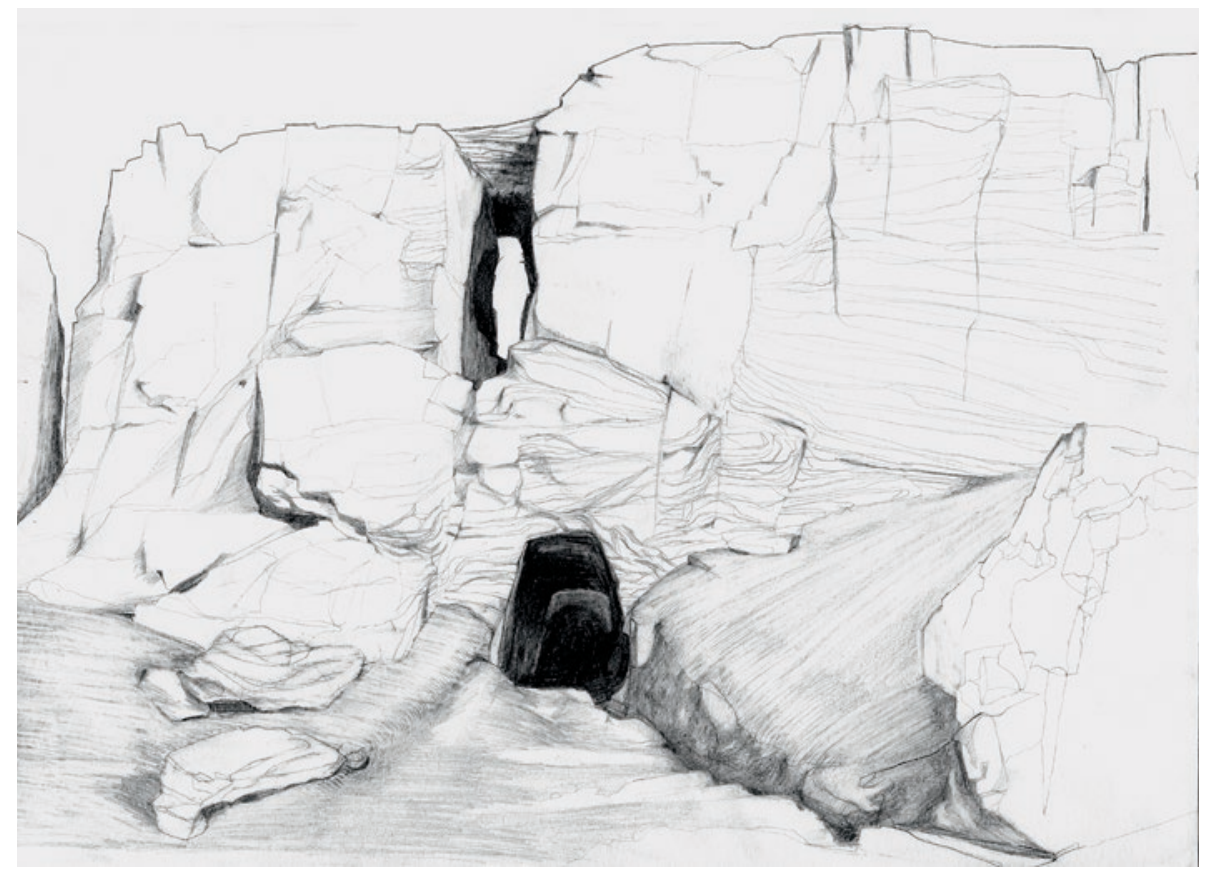

Fig. 3.3.1-10: Territorium metallorum Tresminas/Jales, Tresminas, Corta da Ribeirinha: diferentes fases de prospeção da montanha por baixo das zonas de exploração, em paralelo à entrada ocidental da mina a céu aberto (desenho: P. Moser). 


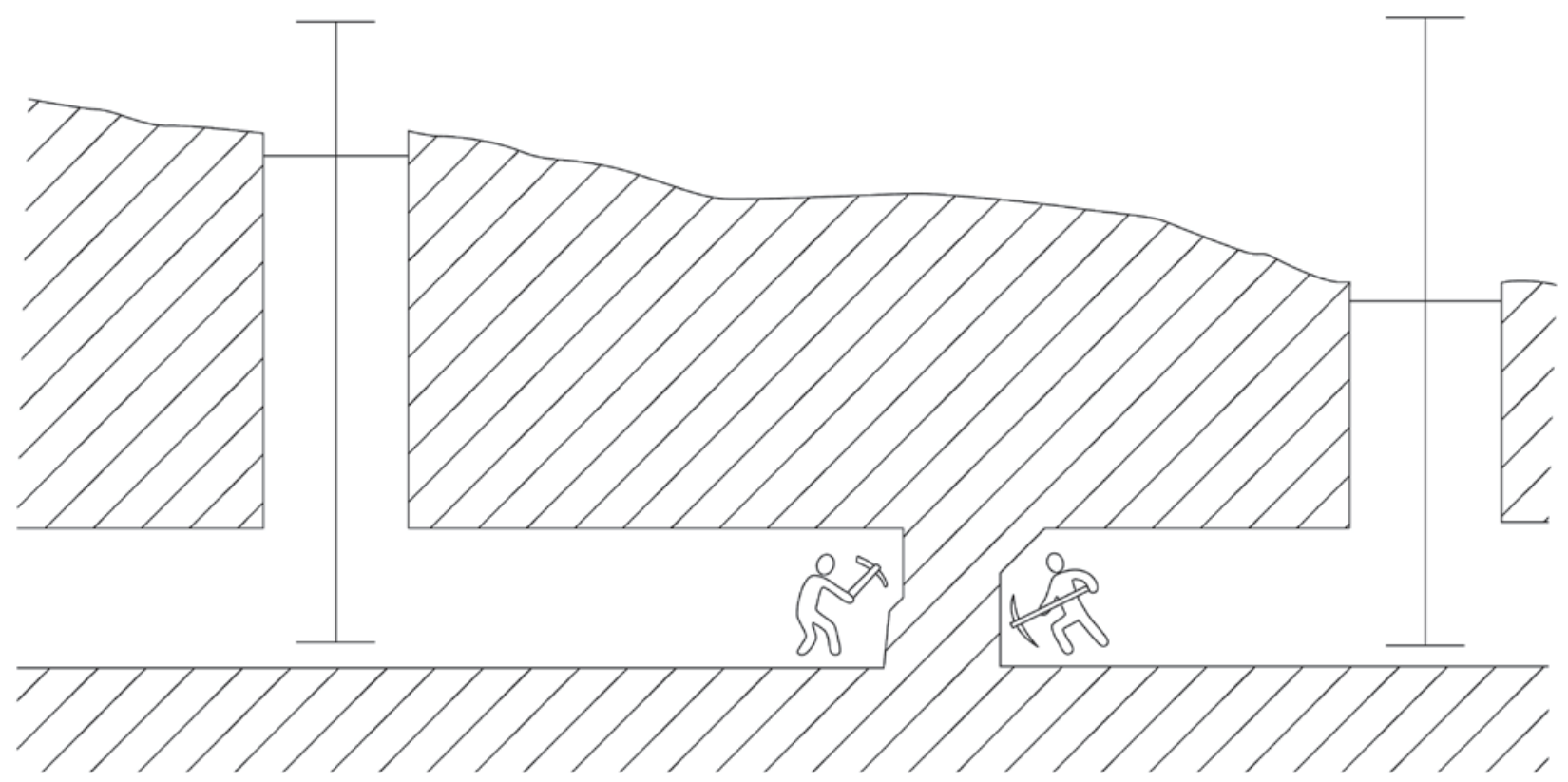

Fig. 3.3.1-11: Ilustração esquemática da construção de um túnel em método Qanat (modelo: Grewe (1998, Fig. 27), ilustração: S. Mathiuet).

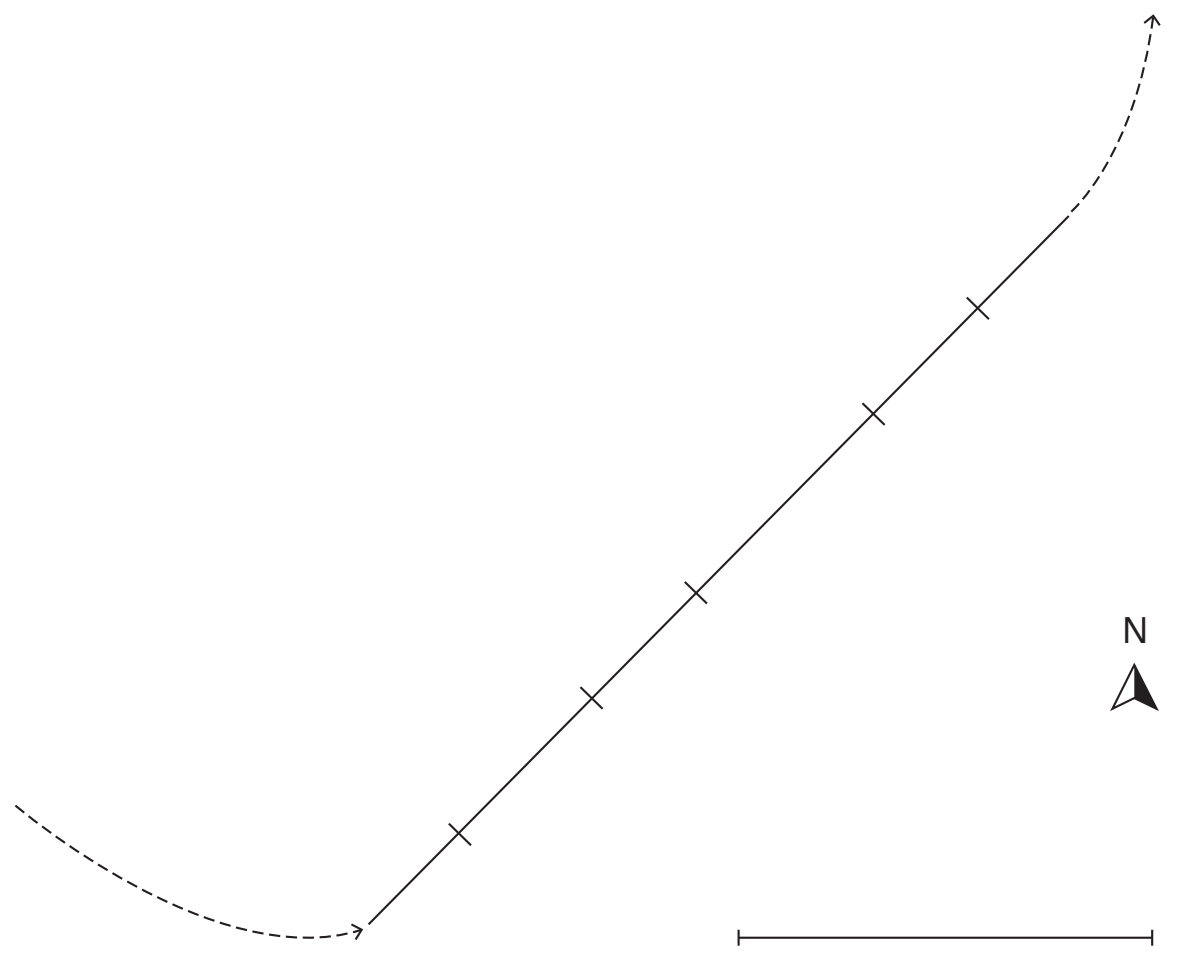

$100 \mathrm{~m}$

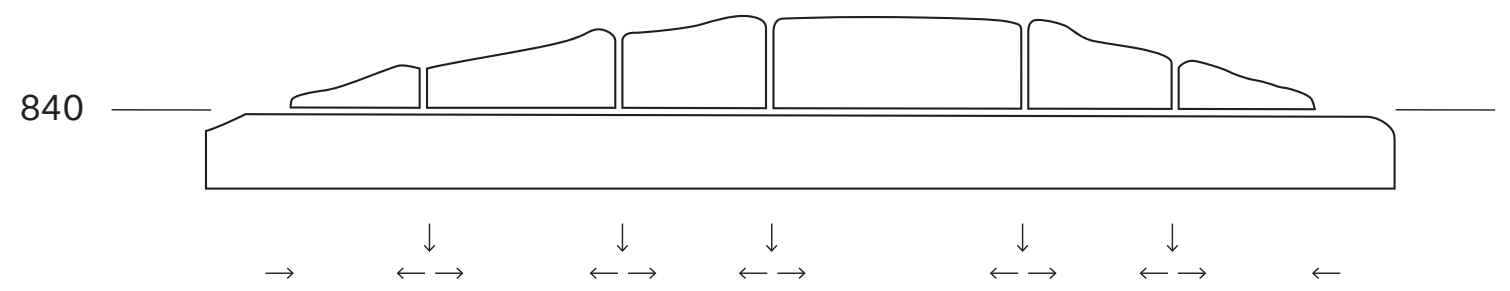

Fig. 3.3.1-12: Territorium metallorum Tresminas/Jales: túnel do aqueduto T2 (registo: J. Wahl, R. Wahl-Clerici, ilustração: R. Wahl-Clerici, S. Mathiuet). 

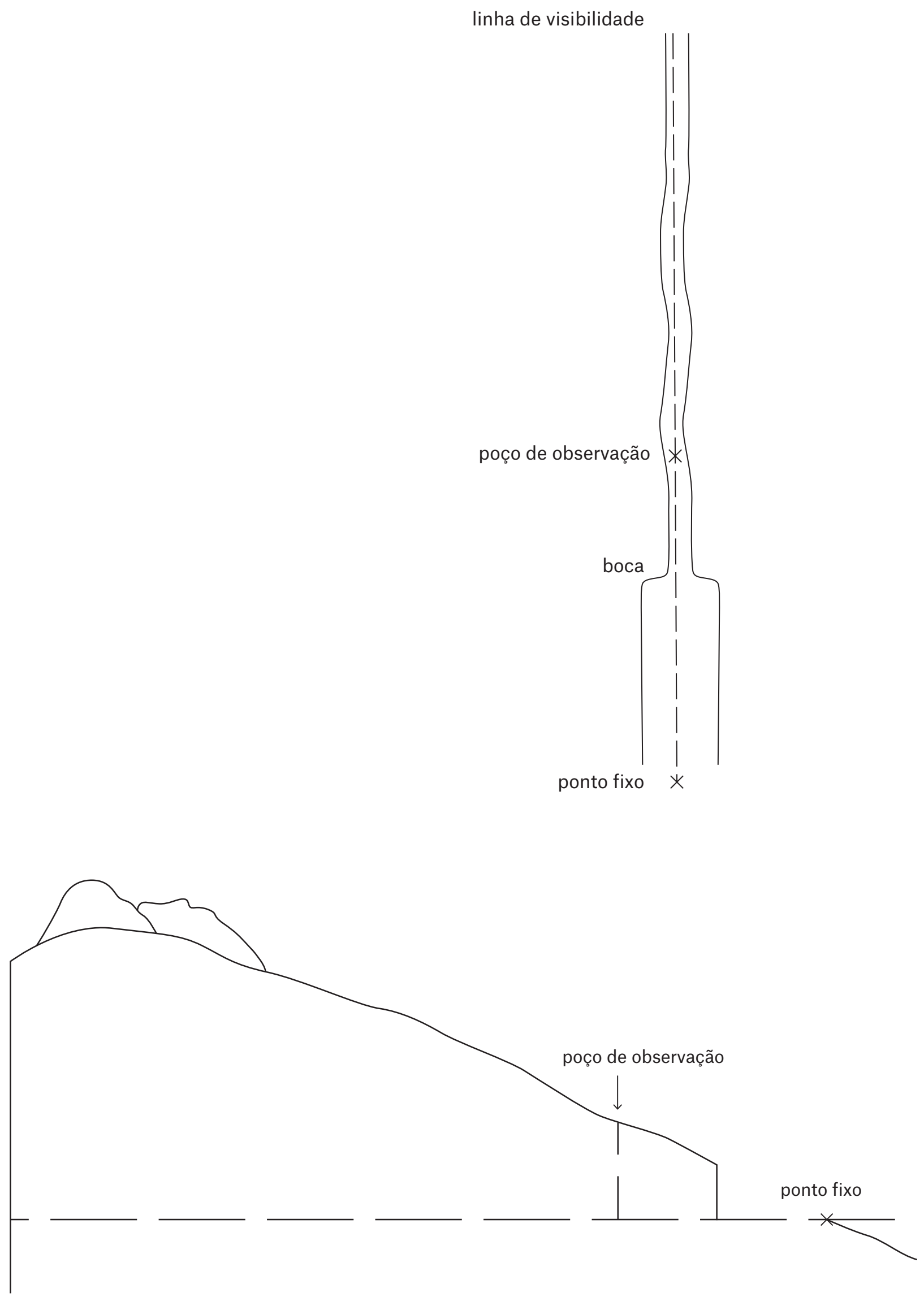

Fig. 3.3.1-13a / b a) Ilustração esquemática (planta) da construção de um túnel através de um poço de observação (modelo: Grewe (1998, Fig. 86), ilustração S. Mathiuet) b) Ilustração esquemática (vista lateral) da construção de um túnel através de um poço de observação (modelo: Grewe (1998, Fig. 86), ilustração: S. Mathiuet). 


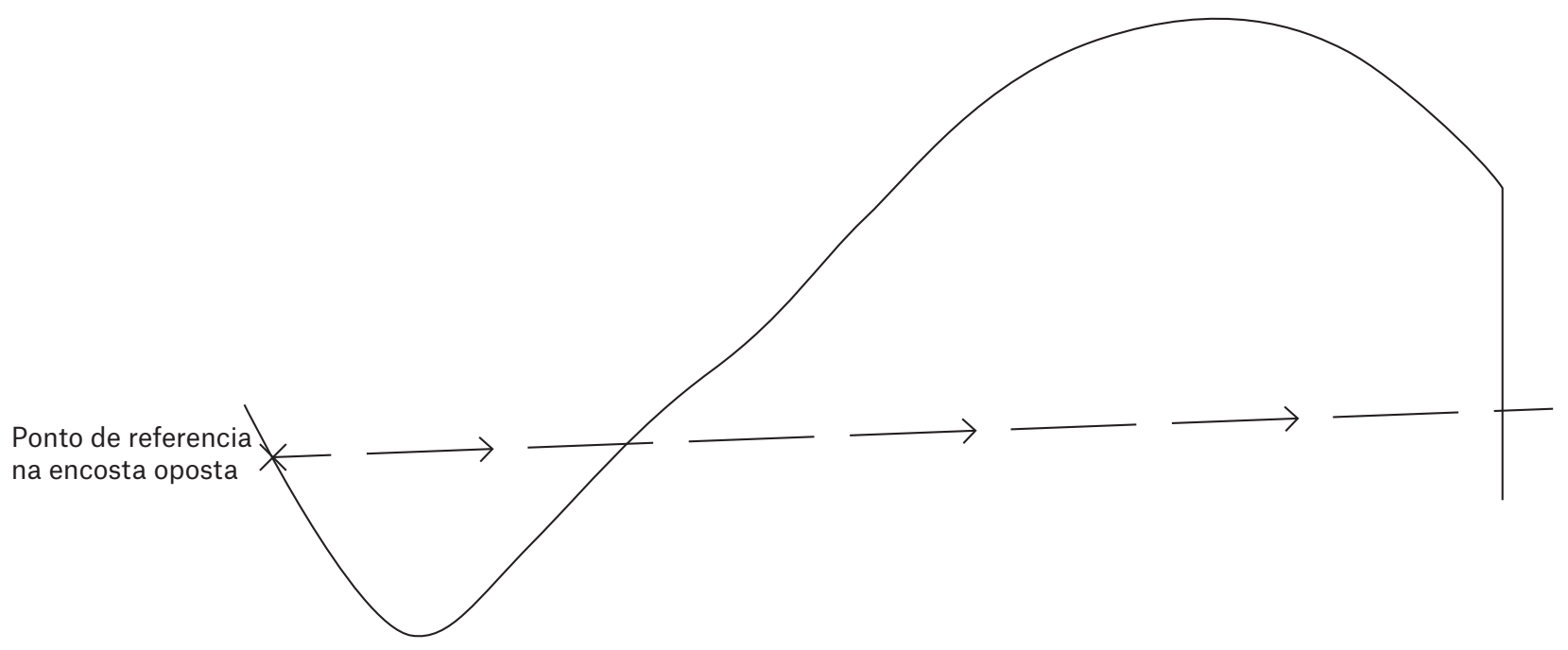

Fig. 3.3.1-14: Ilustração esquemática (projeção lateral) da construção de um túnel através de um ponto fixo na encosta oposta. A linha em picotada indica a inclinação do túnel (Modelo: de Grewe (1998), Fig. 85, ilustração de S. Mathiuet). 


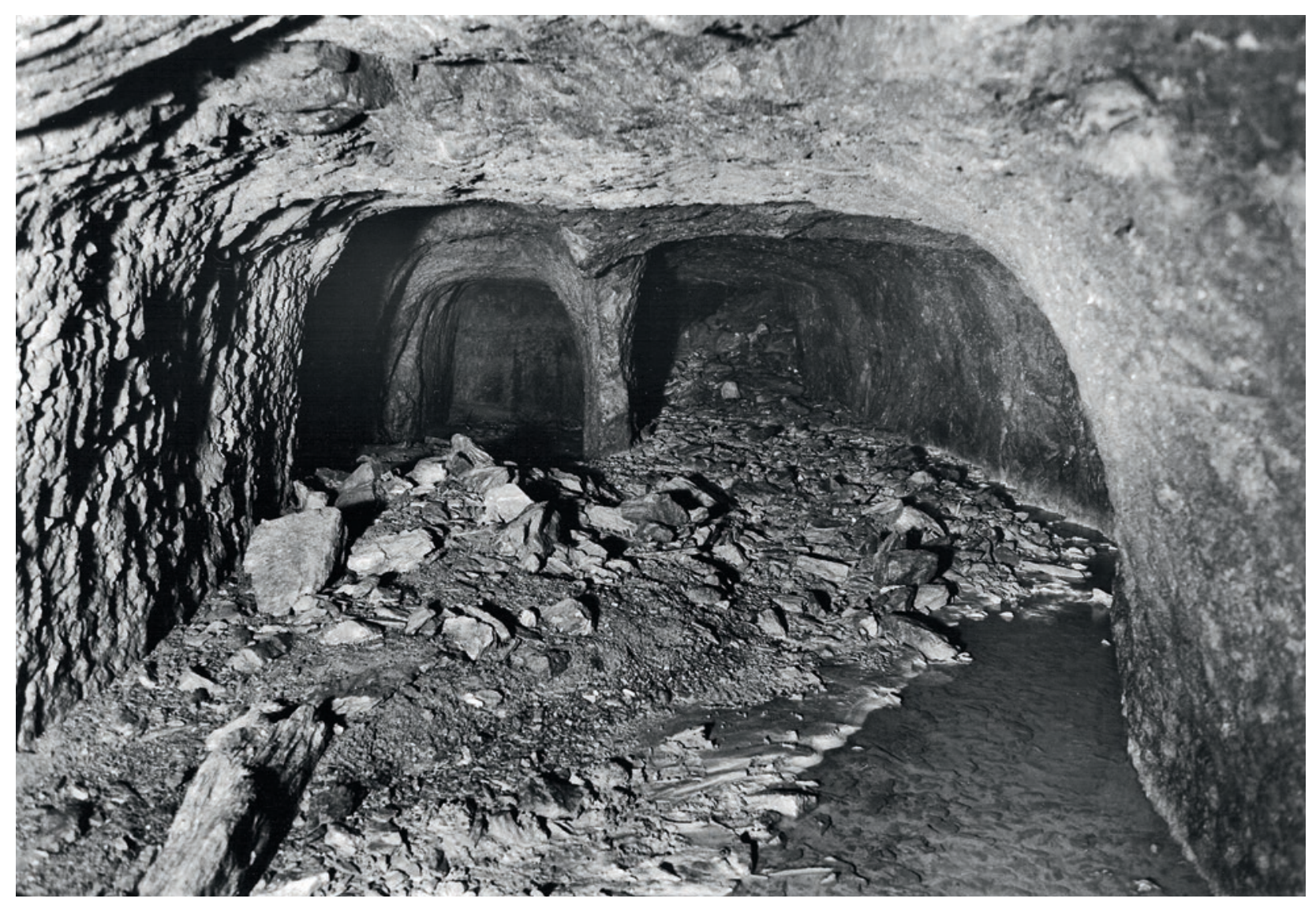

Fig. 3.3.1-15: Territorium metallorum Tresminas /Jales, Tresminas, Galeria do Texugo: alteração do percurso original da galeria na zona do poço de ligação, junto da boca da Galeria do Pilar (fotografia: J. Wahl). 


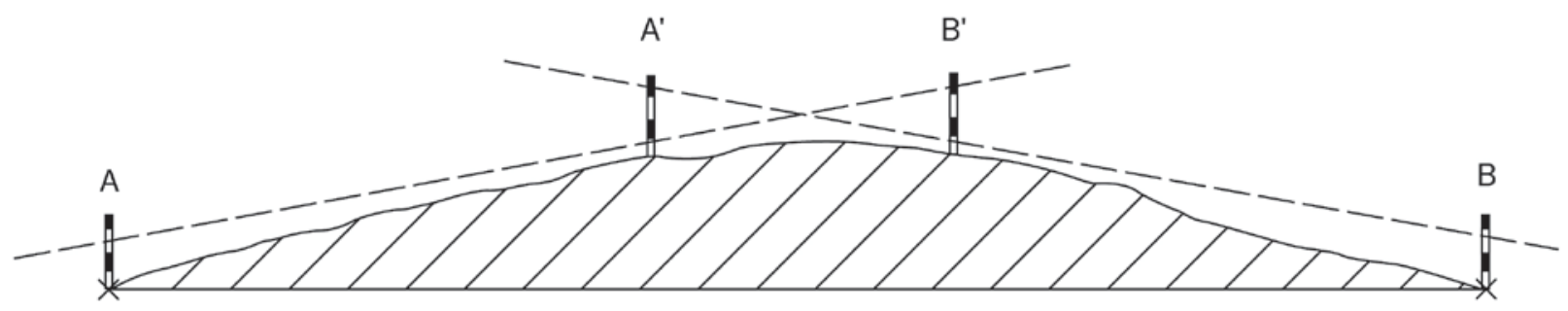

Fig. 3.3.1-16: Ilustração esquemática de uma medição sobre a montanha (modelo: Grewe (1998, Fig. 26), ilustração: S. Mathiuet).
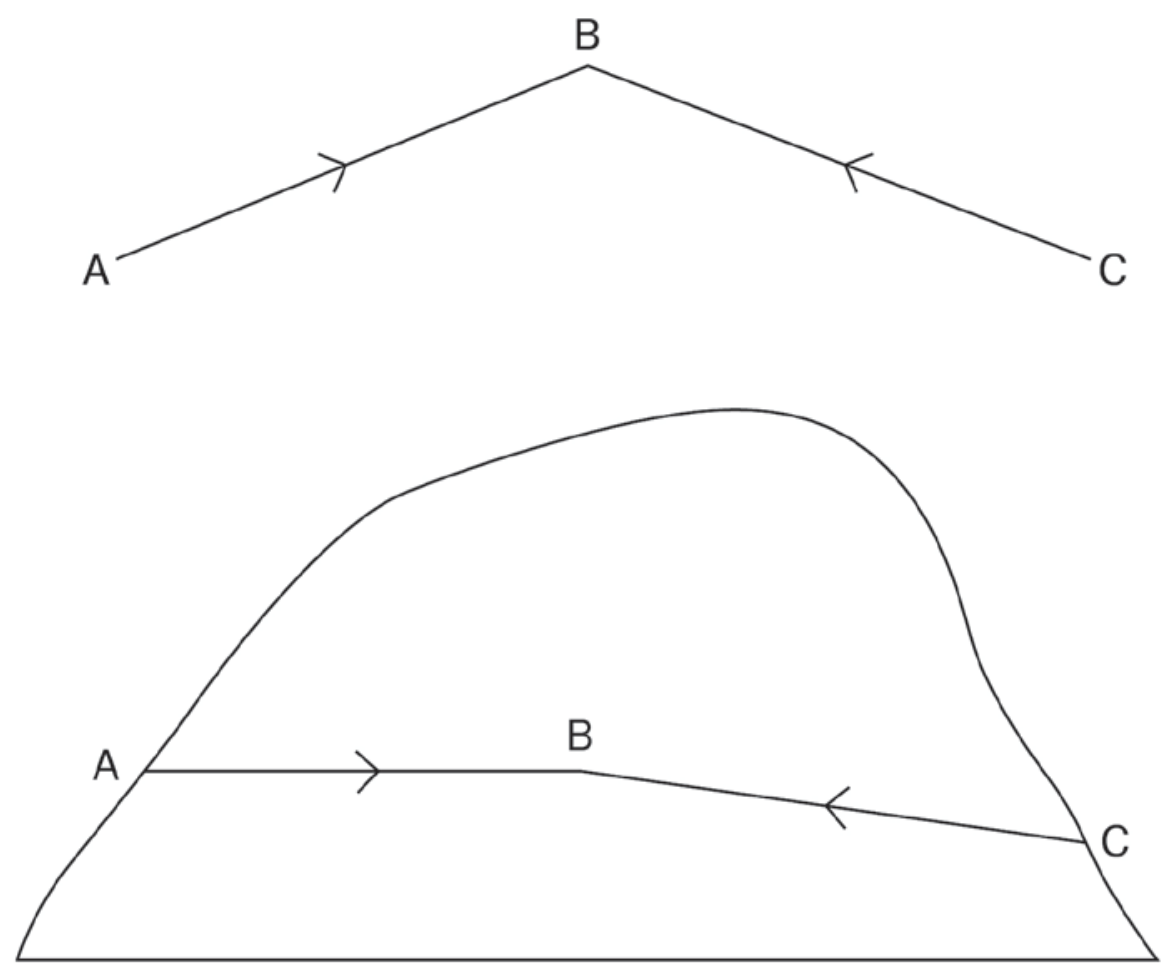

Fig. 3.3.1-17a / b: Ilustração esquemática da abertura de uma galeria por lados opostos. $17 a=$ planta, $17 b=$ vista lateral. Cada eixo era aberto seguindo o mesmo ângulo, aqui representado de forma exagerada. Na galeria dos Alargamentos o ângulo a nível horizontal é marcadamente pequeno e a nível vertical o eixo aberto pelo lado da encosta apresenta uma inclinação. O eixo aberto a partir do interior da montanha é horizontal (modelo: Grewe 1998, Fig. 17 e 1985, 69, ilustração: S. Mathiuet). 


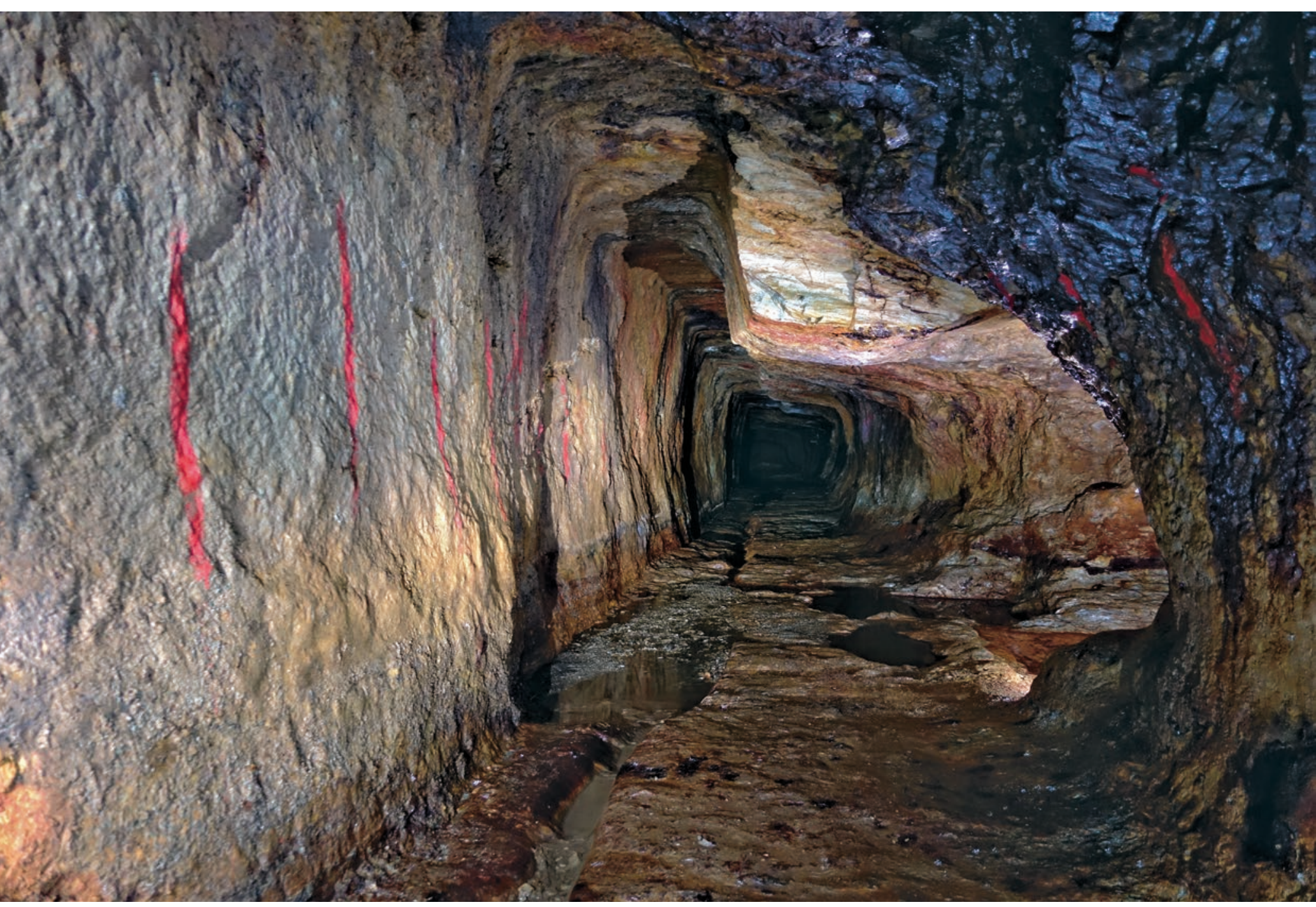

Fig. 3.3.1-18: Territorium metallorum Tresminas /Jales, Tresminas, Galeria dos Morcegos: em algumas partes, a galeria de extensão teve de ser aprofundada até $80 \mathrm{~cm}$. Foi aberta uma pequena extensão na área do poço de prospeção na parede ocidental. Vista de sul (fotografia: R. Wahl-Clerici). 


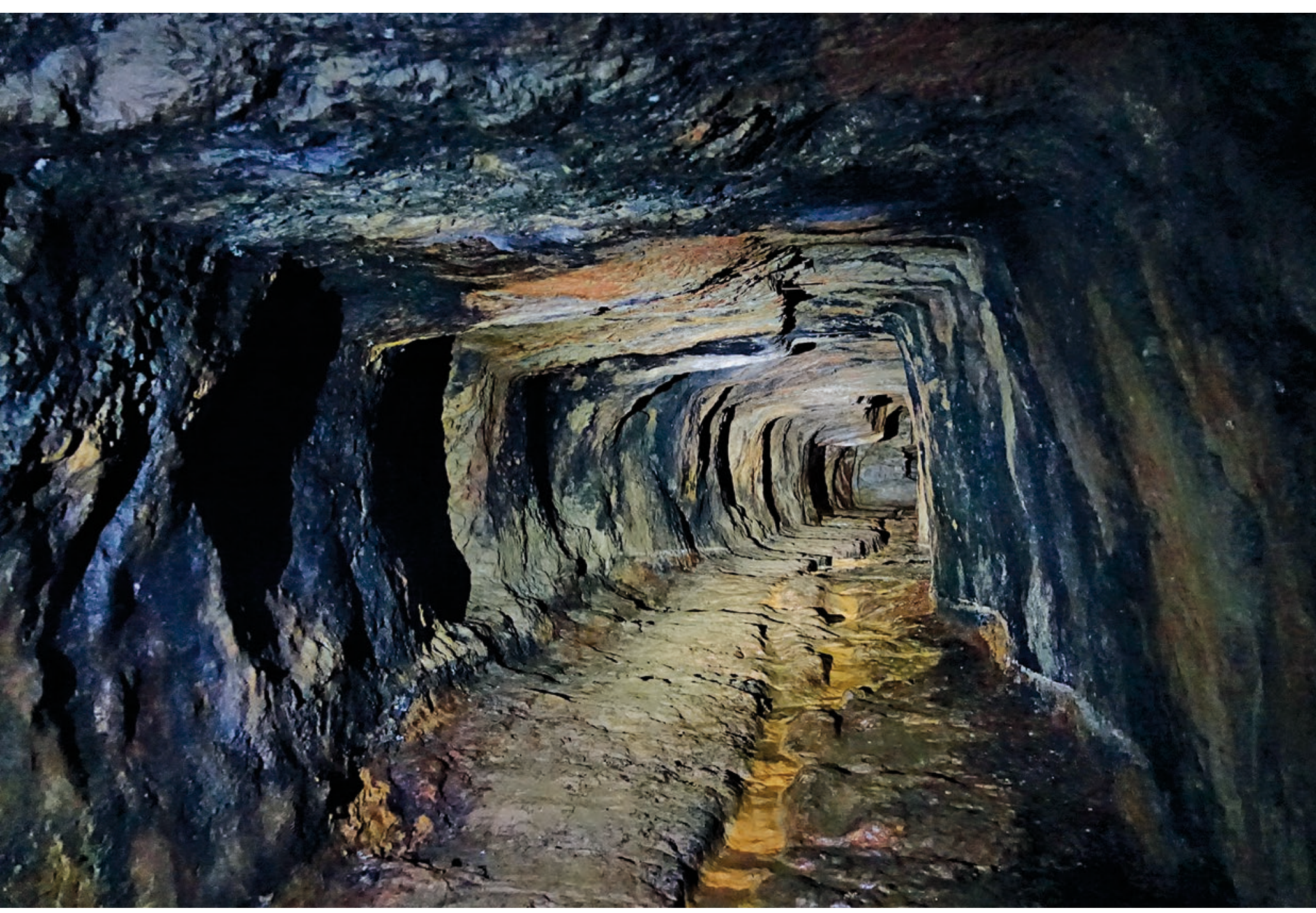

Fig. 3.3.1-19: Territorium metallorum Tresminas / Jales, Tresminas, Galeria dos Morcegos: são visíveis na parede oriental a frente de desmonte para a extensão da cavidade, assim como a rocha remanescente. Vista de norte (fotografia: $R$. Wahl-Clerici). 


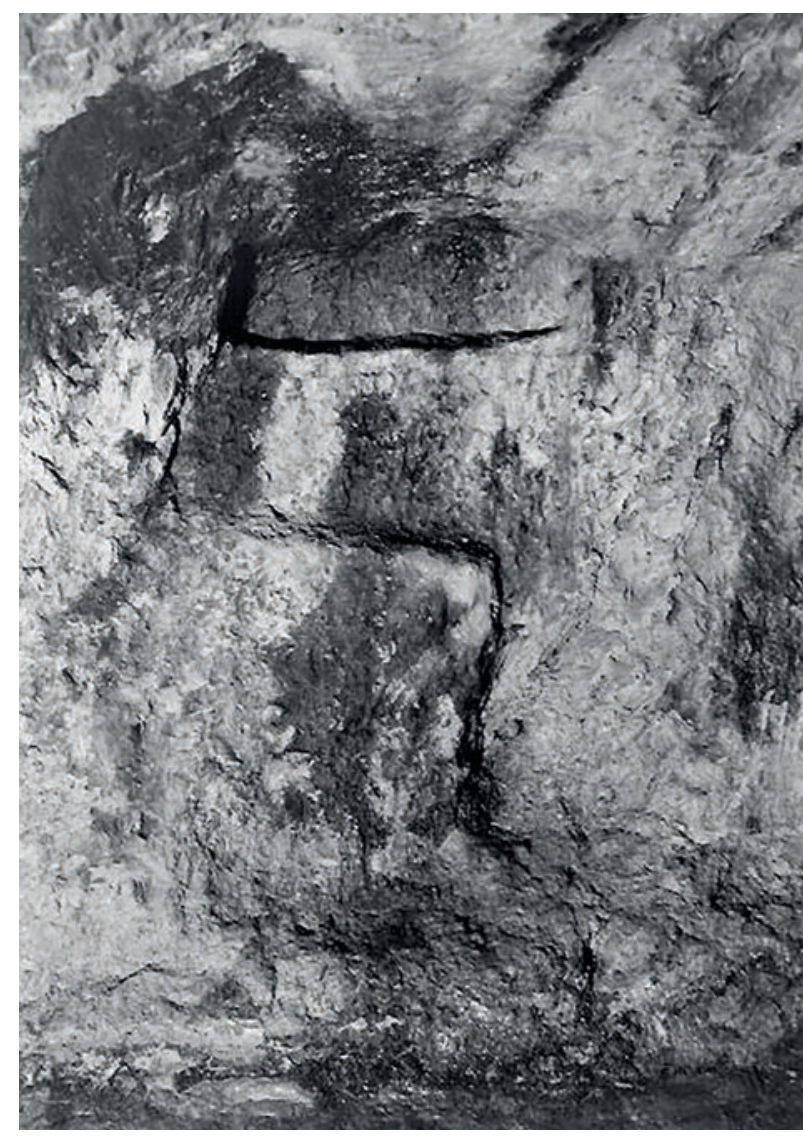

Fig. 3.3.1-20: Territorium metallorum Tresminas/Jales, Tresminas, Galeria dos Morcegos: frente de desmonte. A expansão seguia de cima para baixo, conforme visivel pelas diferentes fases de extensão (fotografia: J. Wahl).

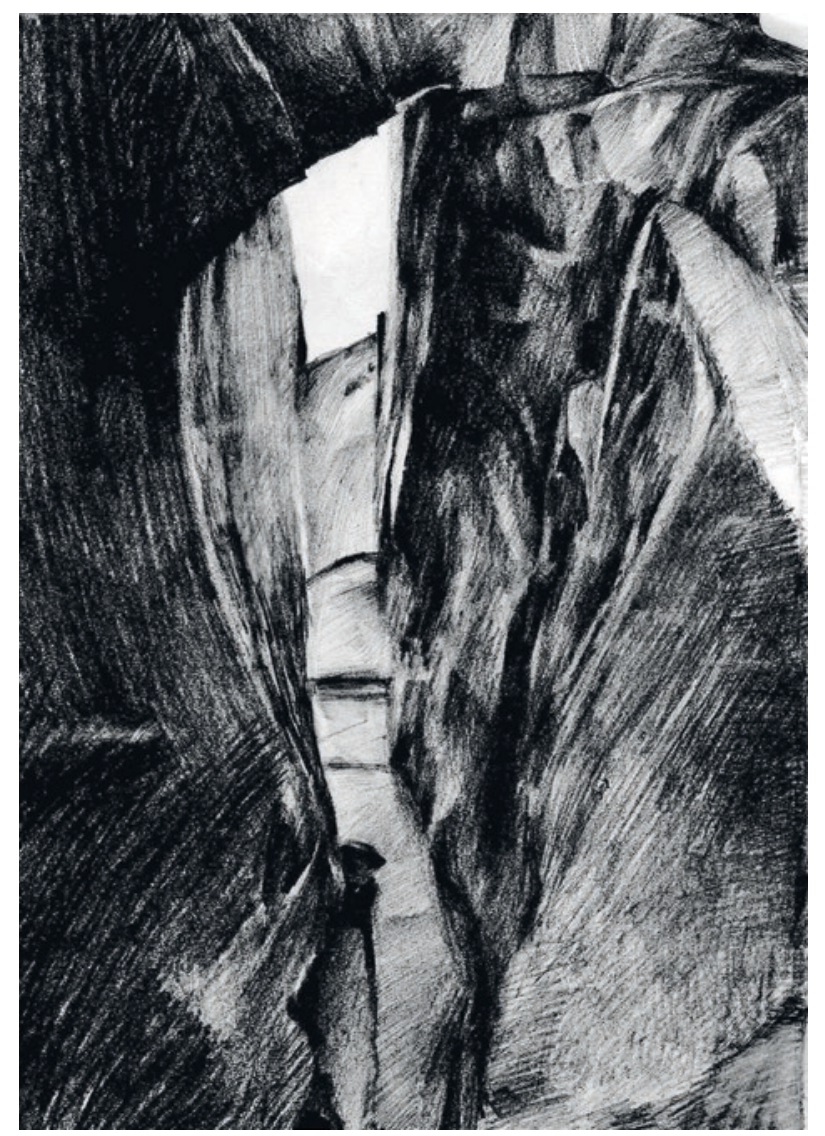

Fig. 3.3.1-21: Territorium metallorum Tresminas/Jales, Tresminas,

Lagoinhos: poço de entrada para a zona de exploração em forma retangular (desenho: P. Moser). 


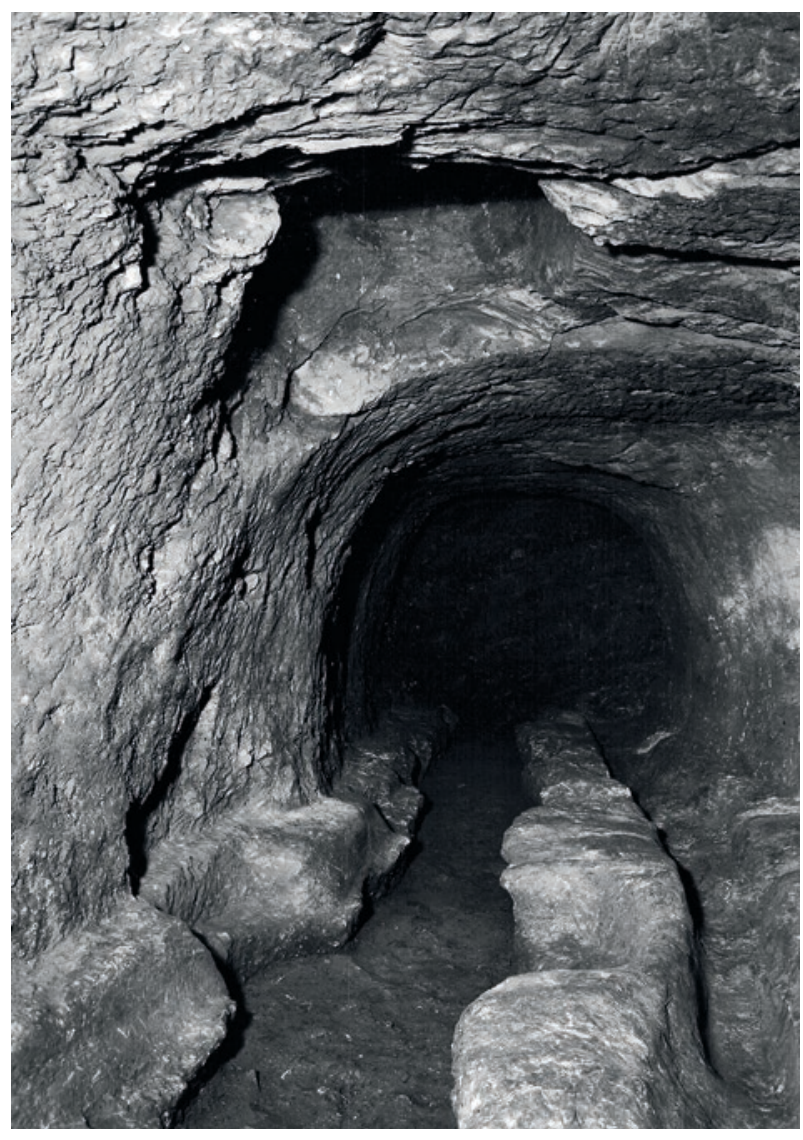

Fig. 3.3.1-22: Territorium metallorum Tresminas/Jales, Tresminas, Corta de Covas, Galeria Esteves Pinto: o poço de observação necessário para construir a galeria foi mais aprofundado do que o piso futuro (fotografia: J.Wahl). 


\subsection{Escombreiras}

As escombreiras, ou seja, a quantidade de material extraído para proceder à mineração no territorium metallorum Tresminas/Jales são indicadores fiáveis para o cálculo da dimensão das zonas de exploração. Além disso, assinalam os túneis e poços que nunca fizeram parte da atividade de exploração.

É justamente nas proximidades das minas A (Corta de Covas) (fig. 3.4-1) e B (Corta da Ribeirinha) que se acumulam as escombreiras. Por outro lado, no local de exploração C (Lagoinhos) encontram-se apenas acumulações mínimas de entulho (fig. 3.0.1-19). As escombreiras mais notáveis situam-se em frente às bocas das galerias e são o resultado do depósito do escombro acumulado pela abertura da galeria, conforme observável nos casos da Galeria dos Alargamentos e da Galeria dos Morcegos, onde podem ser encontradas escombreiras de tamanho considerável (figs. 3.4-1 e 3.4-2). $\mathrm{Na}$ galeria dos Alargamentos, juntou-se ainda o material resultante das construções de prospeção às escombreiras (fig. 3.4-3).

Foi graças às escombreiras à superfície que se tornou possível identificar o elevado número de poços abertos para a prospeção da zona entre as duas minas a céu aberto, uma vez que, na sua grande maioria, se encontram completamente subterrados ou são apenas detetáveis através de pequenas depressões (fig. 3.4-4).

As escombreiras dos túneis construídos nos vários aquedutos, recorrendo ao método em Qanat, também são um indicador importante para a sua descoberta. As pequenas colinas, que se ligam às depressões vale abaixo, e que estão sempre dispostas em linha reta sobre a montanha, não podem ser interpretadas de maneira diferente, mesmo não havendo vestígios de um canal nos pontos de entrada e saída (fig. 3.4-5).

Em princípio, o tamanho da escombreira, assim como as acumulações dos moinhos de pilões e de minério, fornecem informações importantes sobre a quantidade de material tratado nesse local. No entanto, é preciso ter em conta a quantidade de blocos levados para as aldeias como material de construção. As escombreiras em frente às galerias Esteves Pinto e Texugo sofreram alterações devido às atividades agrícolas, pelo que já não é possível identificá-las sem recurso a medição por laser 3D. Além disso, as escombreiras em frente à Galeria dos Alargamentos e do Pilar não correspondem de todo à sua forma original (em forma de uma colina), situação especialmente observável na Galeria dos Alargamentos ao comparar-se a escombreira em relação ao percurso da entrada original.

Na Corta de Covas encontra-se uma escombreira de dimensões impressionantes. A sul da mina aberta, atraves- sada por uma estrada construída na década de 1940, erguem-se pequenas montanhas que continuam em direção a sudeste e que, até aos dias de hoje, terminam na encosta leste da mina a céu aberto (figs. 3.4-1 e 3.4-6a / b). Em determinados lugares, a escombreira encontra-se por cima de algumas casas do povoamento, uma vez que, numa zona de mineração, a exploração tinha sempre prioridade (fig. 3.47).

A norte da Corta de Covas estendem-se outras escombreiras, ao longo de todo o comprimento da mina a céu aberto e, essencialmente, sobre todo o flanco da encosta (fig. 3.4-1). As escombreiras menores situam-se a leste da mina a céu aberto e contêm sobretudo o material estéril produzido durante a escavação dos dois poços ligados à Galeria dos Alargamentos (fig. 3.4-8). As escombreiras mais a sul surgiram com a exploração na Corta de Covas e, até ao momento, não foi possível calcular sequer aproximadamente as suas dimensões.

Particularmente notáveis são as duas escombreiras em frente à Galeria Jürgen Wahl e à Galeria do Pilar (figs. 3.4-1 e 3.4-2). A primeira é atravessada pelo poço que termina na Galeria do Pilar, feita a partir do material estéril que resultou da sua construção e da posterior exploração. As rochas que continham minério eram tratadas um pouco a leste da escombreira, onde se encontram concentrações impressionantes de moinhos de pilões e de minério. A escombreira em frente à entrada da Galeria do Pilar é de grandes dimensões e destaca-se bastante do meio envolvente, sendo constituída por pedras selecionadas e por material estéril, resultante do material extraído. Até hoje, ainda é possível encontrar moinhos de pilões e moinhos rotativos de minério em frente à Galeria do Pilar, apesar da sua grande maioria ter sido levada para a aldeia de Ribeirinha.

Na Corta da Ribeirinha, as escombreiras situam-se do lado norte da encosta norte da mina a céu aberto. Nestas escombreiras foi possível identificar numerosos elementos do processo de tratamento. Salienta-se ainda a dimensão reduzida da escombreira em frente à Galeria dos Morcegos, o que pode ser facilmente explicado com o recurso ao material necessário para a expansão. A escombreira em frente à Galeria do Buraco Seco era muito provavelmente de grandes dimensões, no entanto, uma vez que se encontra totalmente coberta por vegetação, torna-se impossível percorrer a sua área.

A jazida da Gralheira é delimitada por colinas de escombro bem visíveis (figs. 3.4-9, 3.0-37, 3.0-28 e 4.0-1d), contudo, ainda não é possível determinar com precisão até que ponto as construções modernas vieram a alterar a imagem em certas áreas. 


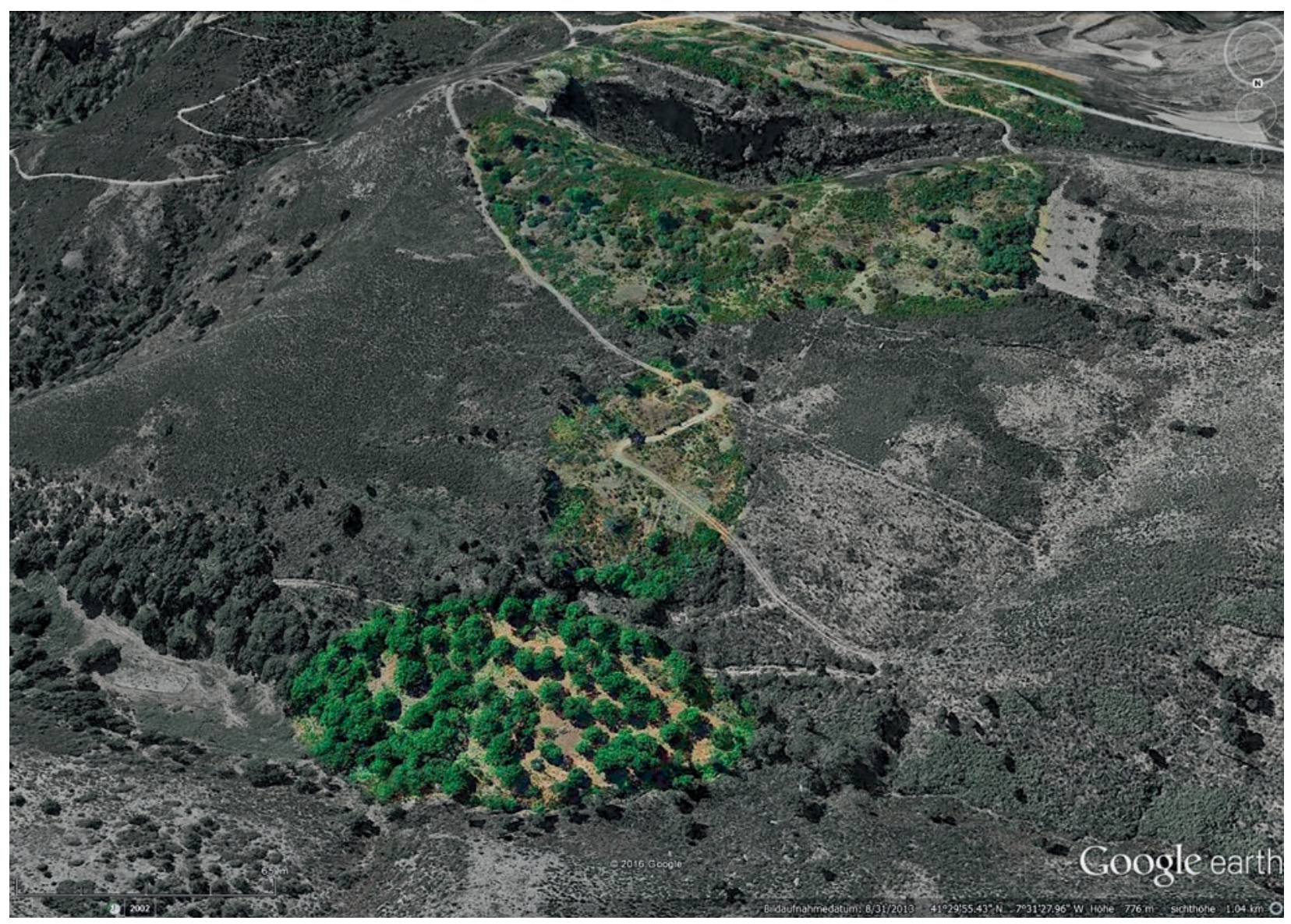

Fig. 3.4-1: Territorium metallorum Tresminas /Jales, Tresminas: a Corta de Covas vista de norte com as escombreiras a sul e norte da zona de extração. As áreas com as principais escombreiras estão marcadas a cor (Google Earth, última vista: 15.01.2020, desenho: S.Mathiuet). 


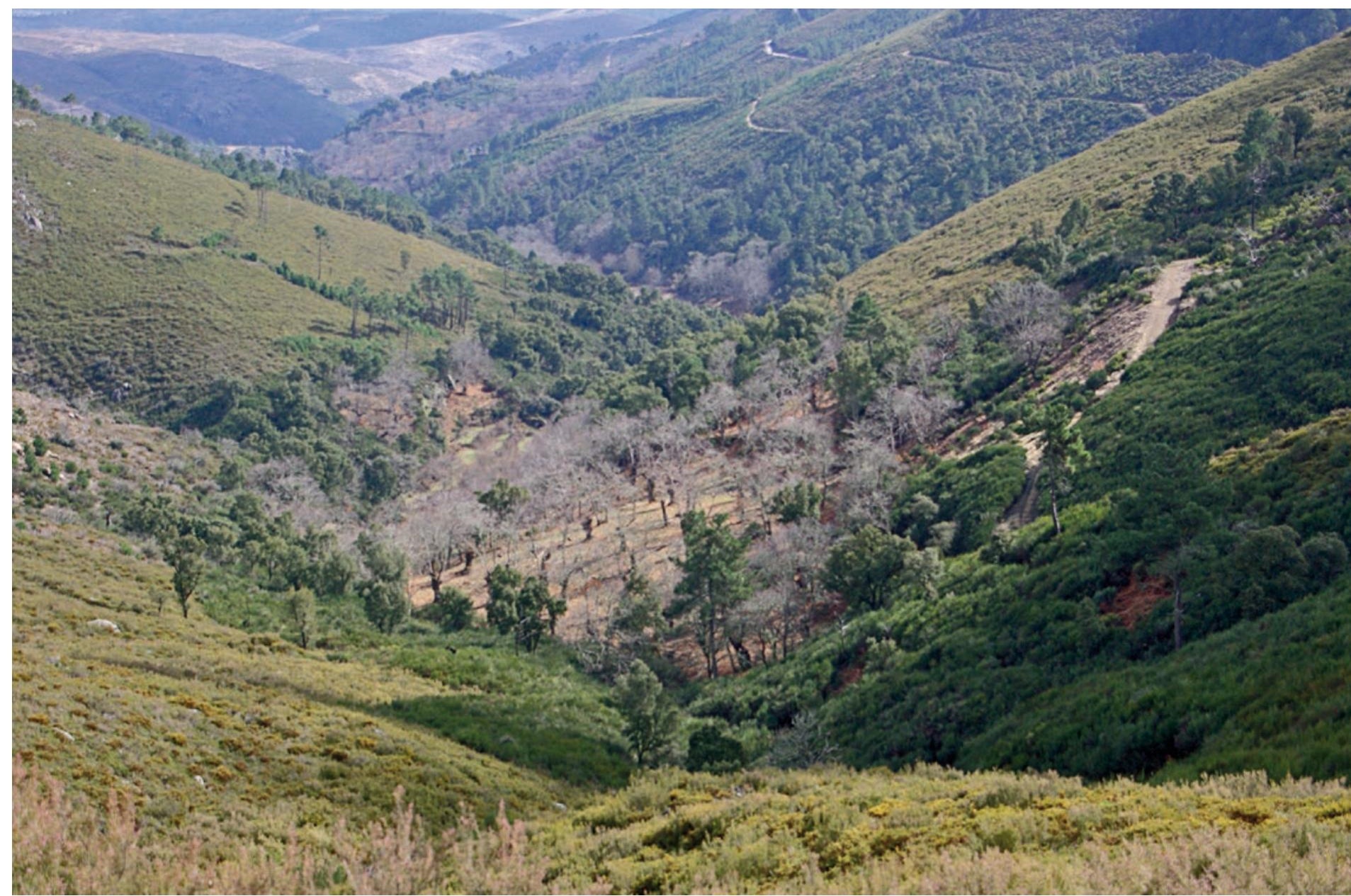

Fig. 3.4-2: Territorium metallorum Tresminas / Jales, Tresminas: vista sobre o vale da Ribeirinha. Em primeiro plano, é visível a escombreira em frente à Galeria do Pilar, com os castanheiros sem folhas. Visto de oeste (fotografia: C. Wahl).

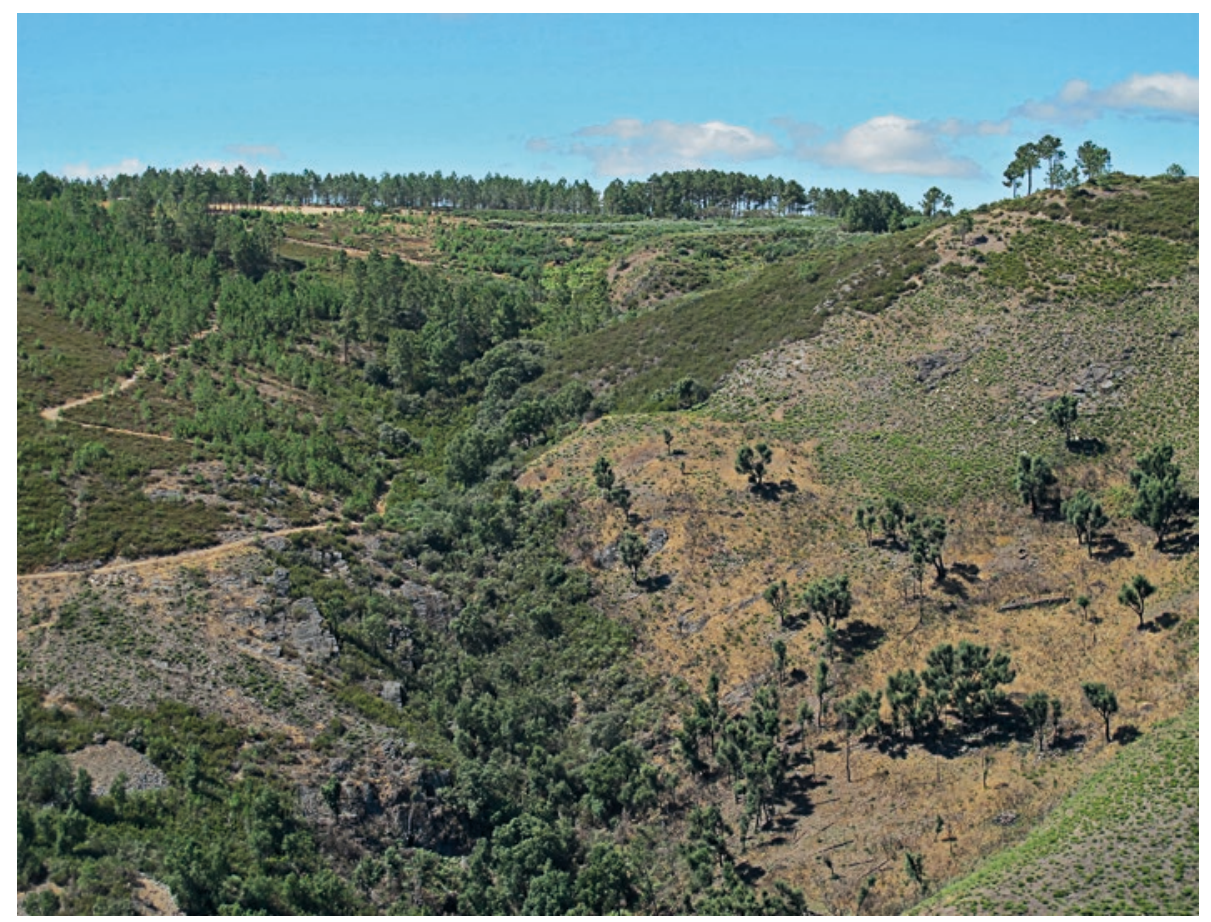

Fig. 3.4-3: Territorium metallorum Tresminas/Jales, Tresminas: é claramente visível a grande escombreira em frente à Galeria dos Alargamentos. No canto inferior esquerdo da imagem, encontram-se outras escombreiras de uma estrutura de prospeção, identificável através da acumulação de pedras claras. Vista de norte (fotografia: R. Wahl-Clerici). 


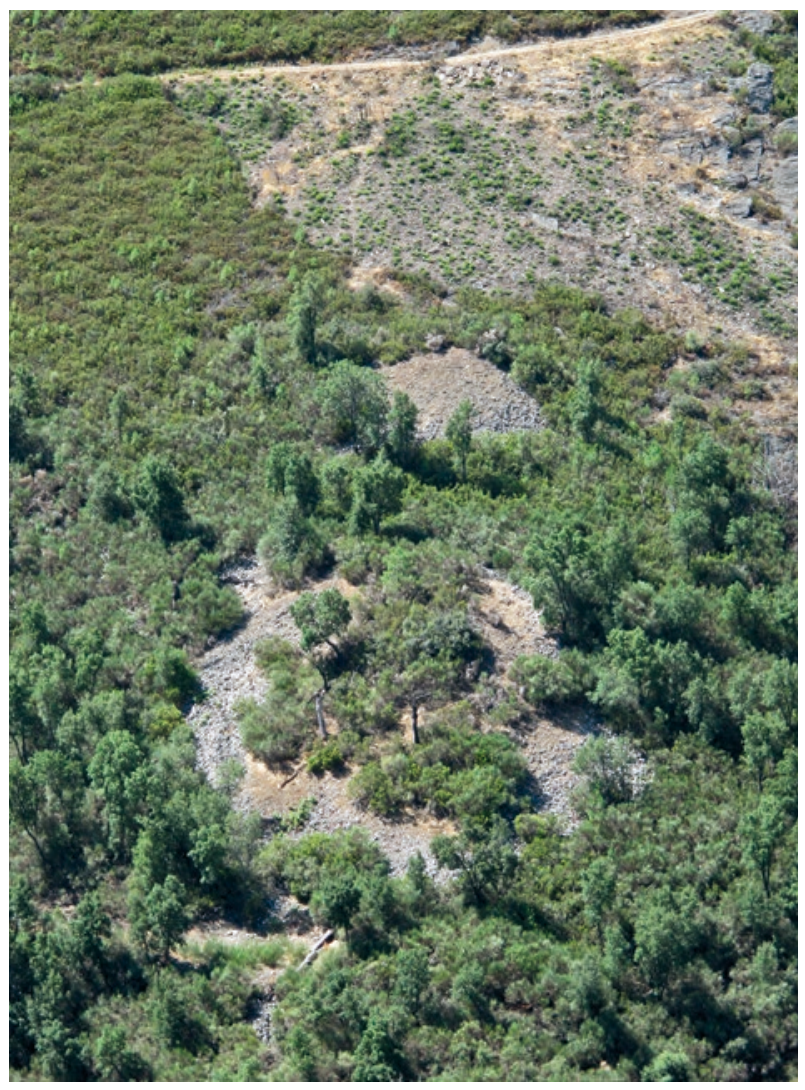

Fig. 3.4-4: Territorium metallorum Tresminas/Jales, Tresminas: no centro da imagem são visíveis dois montes de quartzo, resultante das construções para a prospeção da jazida de quartzo estéril que se estende desde a extremidade oeste da Corta da Ribeirinha, pelo vale a norte, até ao topo da próxima colina. Vista de norte (fotografia: R. Wahl-Clerici).

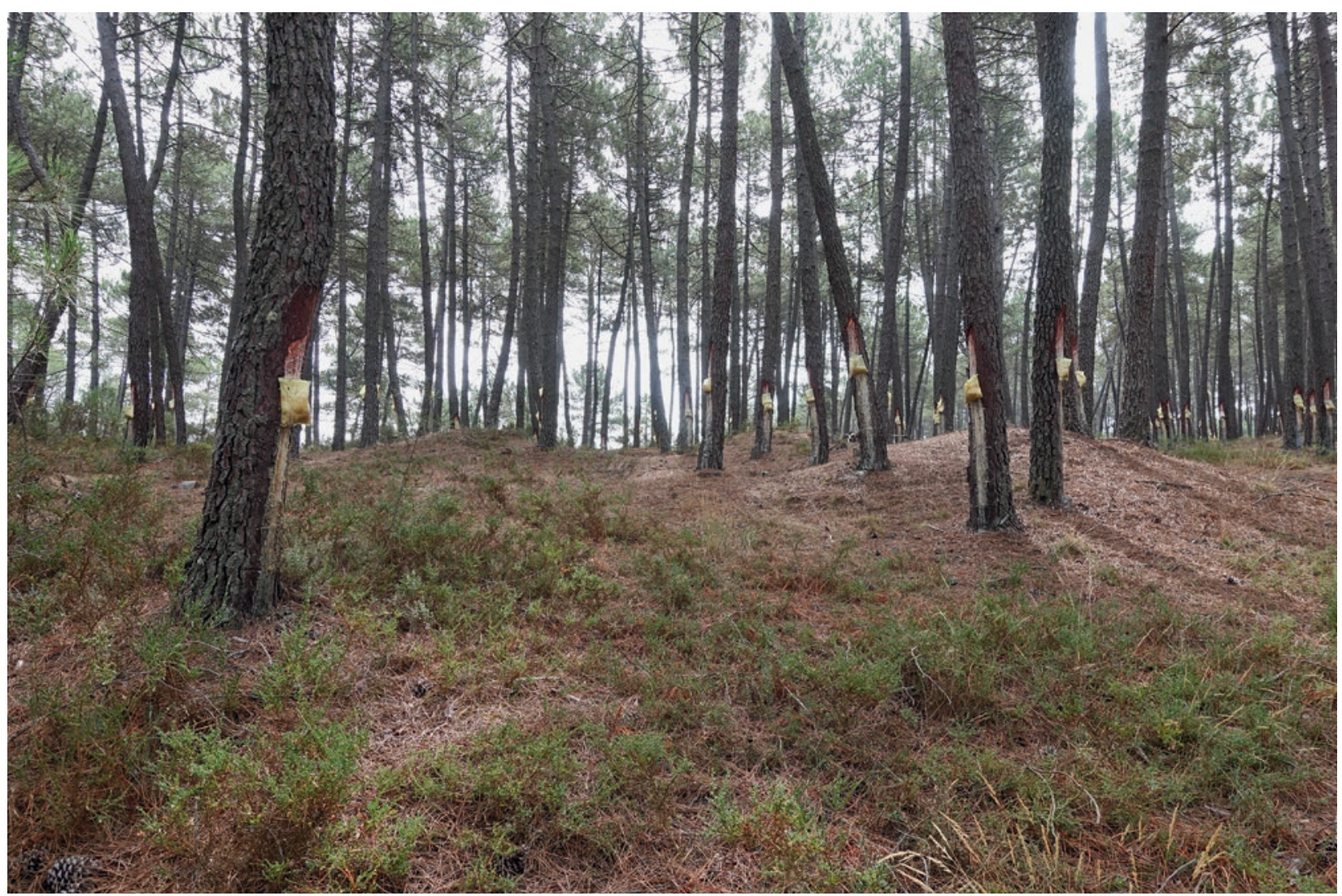

Fig. 3.4-5: Territorium metallorum Tresminas / Jales, Tresminas: as escombreiras pouco visíveis fazem parte da construção de uma conduta tipo Qanat para o sistema de abastecimento de água (fotografia: Th. Schierl). 


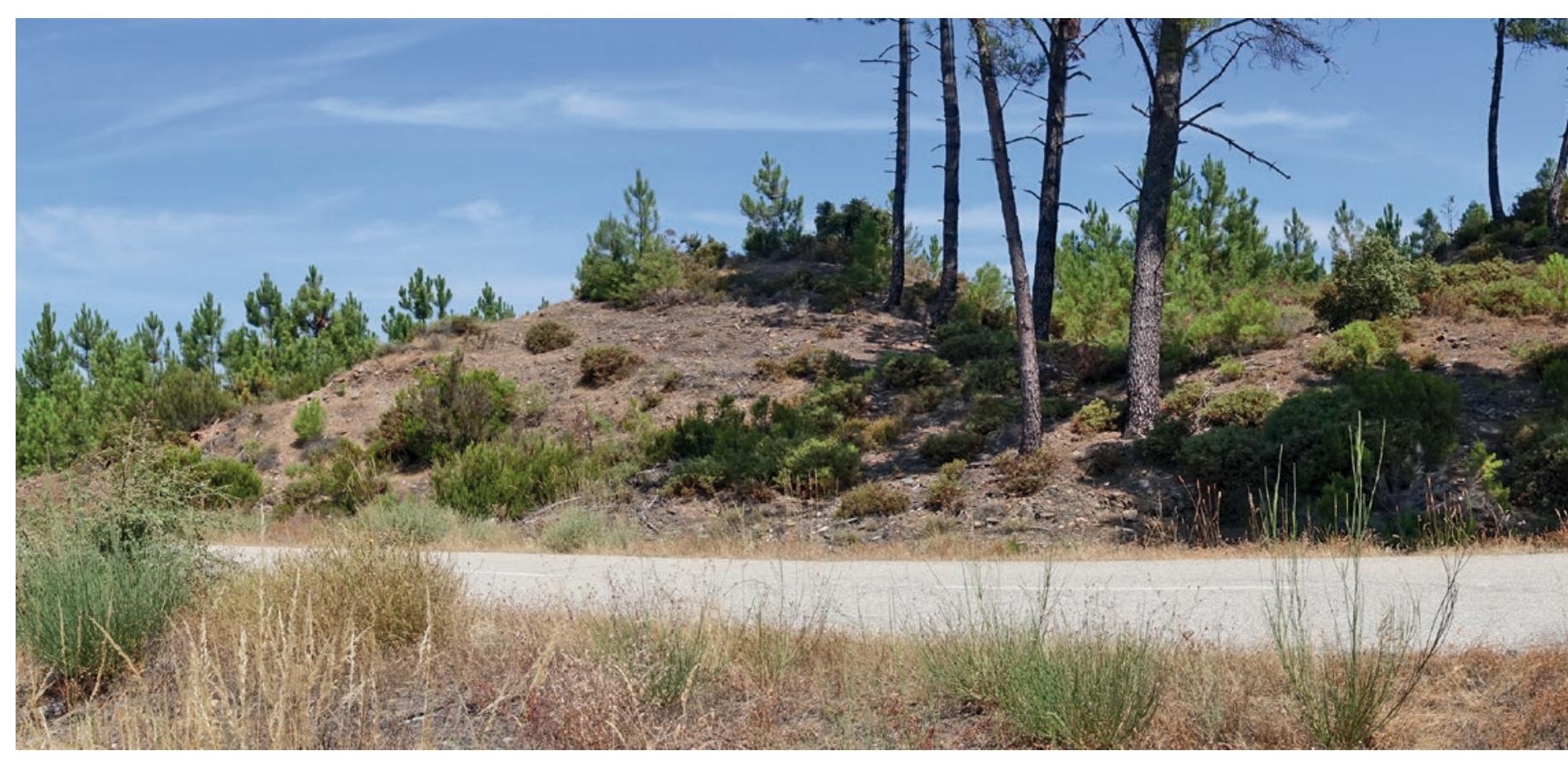




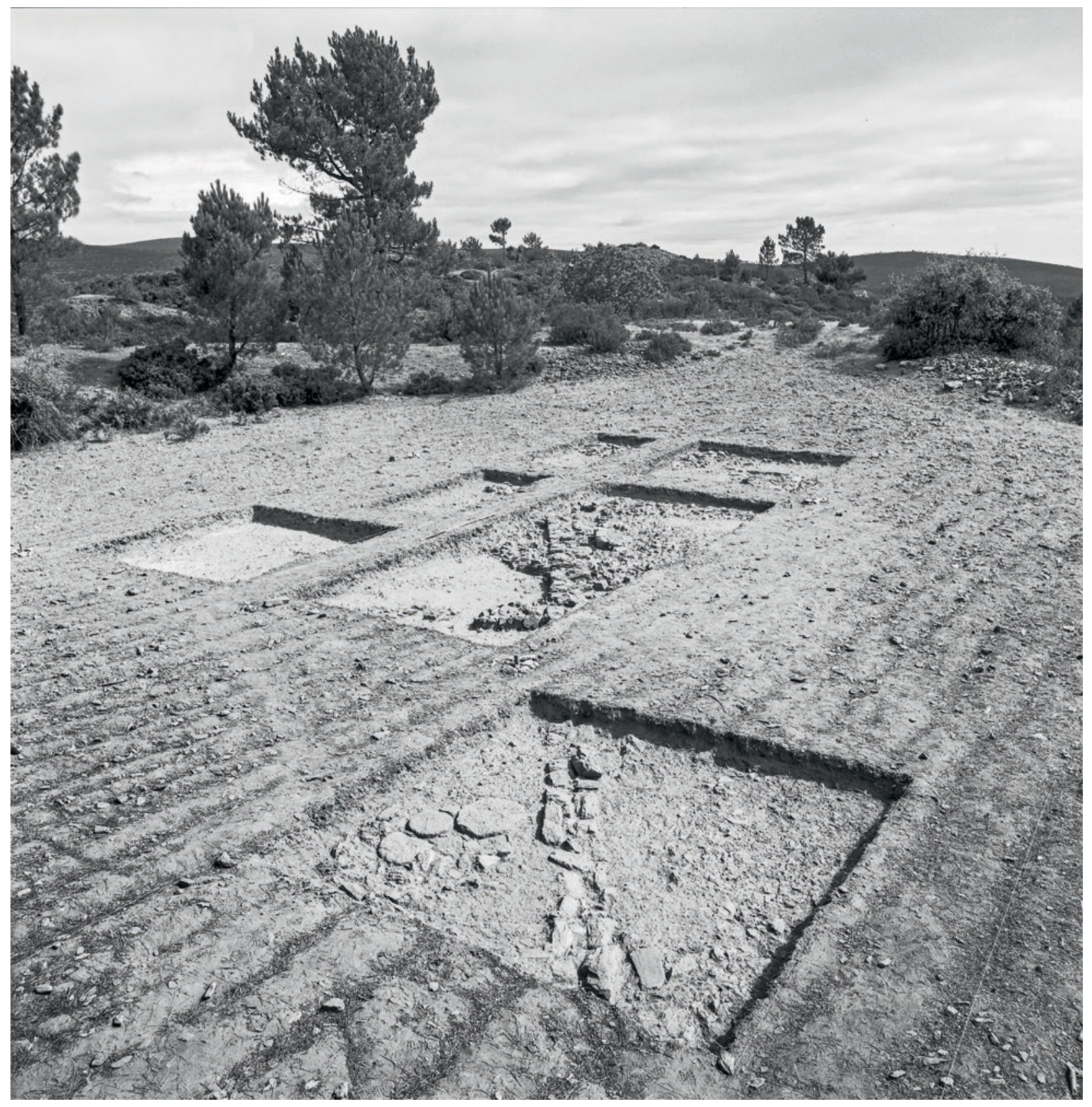

Fig. 3.4-7: Territorium metallorum Tresminas /Jales, Tresminas: ao fundo, são visíveis as escombreiras a sudeste da Corta de Covas, que cobrem parcialmente as casas (fotografia: D-DAI-MAD-WIT-R-141-86-13). 


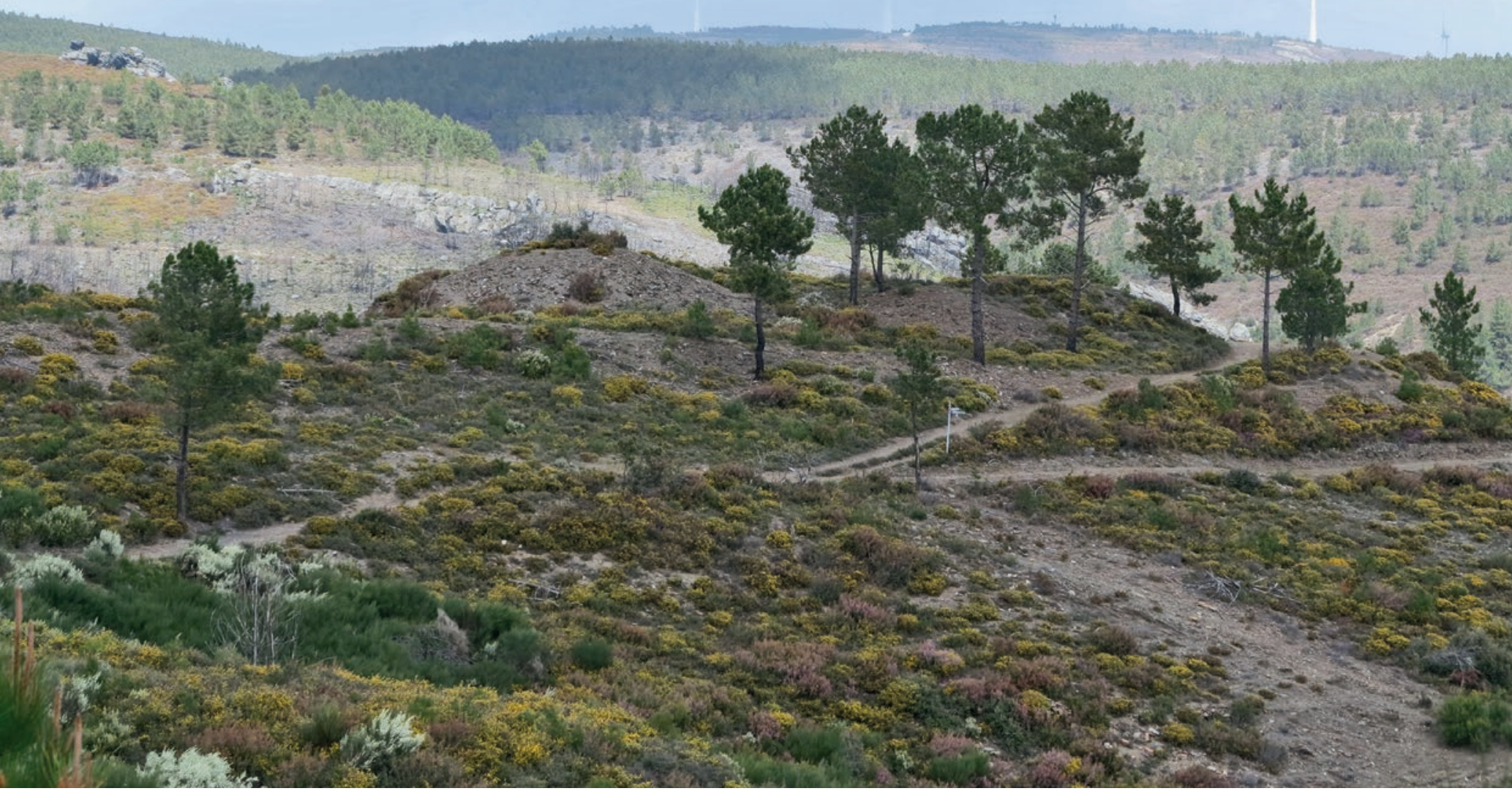

Fig. 3.4-8: Territorium metallorum Tresminas/Jales, Tresminas: as escombreiras sobre a encosta oriental da Corta de Covas. Vista de sul (fotografia: R. WahlClerici). 


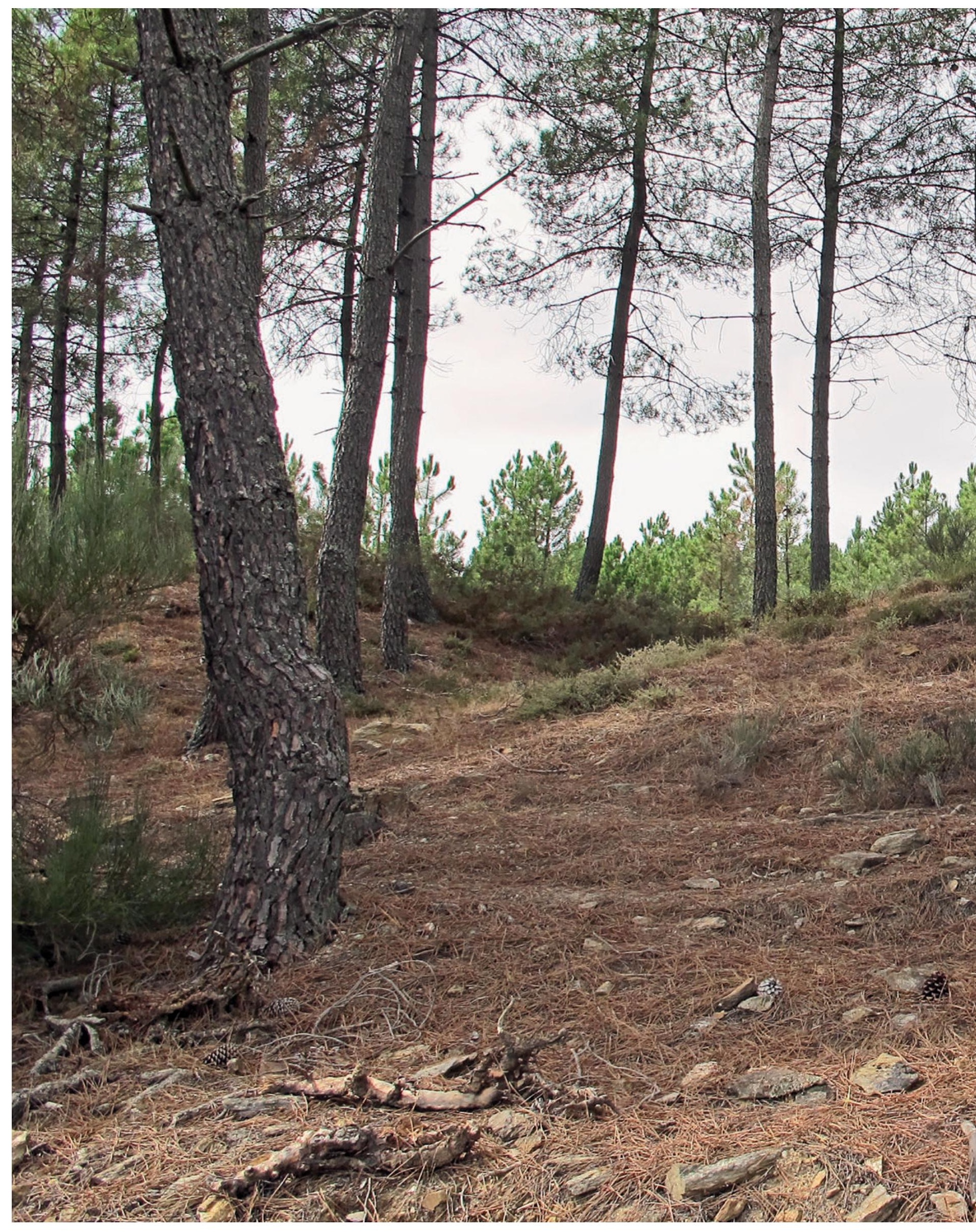




\subsection{Tratamento do minério e fundição no territorium metallorum de Tresminas / Jales ${ }^{159}$}

As operações necessárias para o tratamento de minérios dependem sempre diretamente das condições presentes na jazida, ou seja, do tipo de mineralização. Este princípio também se reflete nos vestígios relacionados com o tratamento nos diferentes locais de trabalho no territorium metallorum de Tresminas/Jales.

Apesar de terem sido encontrados minérios polimetálicos com alto teor de ouro nas três jazidas (Tresminas, Gralheira e Jales), a forma como os metais se encontram depositados é diferente. Enquanto nas minas de Gralheira e de Jales foi possível explorar os filões claramente definidos, a mineralização em Tresminas revelou ser mais complexa (figs. 4.0-1a-e). ${ }^{160}$ Consequentemente, foi necessário extrair e processar muito mais material, uma circunstância que se reflete igualmente nos vestígios do processamento preservados. De acordo com o conhecimento atual, o trabalho nos depósitos de Gralheira e Jales concentrava-se numa única área, o Forno dos Mouros, no Rio Tinhela, enquanto que os locais de processamento em Tresminas se encontram espalhados por vários sítios (figs. 4.0-2 e 4.0-3).

Por conseguinte, conseguimos identificar e delinear as diferentes fases do processamento do minério no territorium metallorum de Tresminas / Jales, assim como cada local de trabalho onde foram concretizadas. Apenas no Forno dos Mouros é possível comprovar a execução de todos os processos de tratamento num único local, já que em todos os outros espaços, as respetivas atividades se limitavam a subsecções. ${ }^{161}$

\section{Os mecanismos do processamento}

Nas jazidas de Tresminas, Gralheira e Jales, o ouro não surge apenas em forma de grão, que em parte é visível a olho nu, mas também sob forma do designado ouro refratário. Isto significa que o ouro se encontra muito finamente ligado ou atomicamente incorporado na rede cristalina de um mineral. O tamanho do grão de ouro pode ir de 3,6 milímetros a um milésimo de milímetro. ${ }^{162}$

Diodoro Sículo, que viveu na primeira metade do século I a. C., descreve em detalhe os processos de tratamento que ele observou nas minas do deserto egípcio $(3,13,1-2)$ :

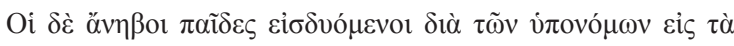

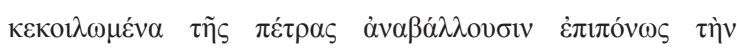

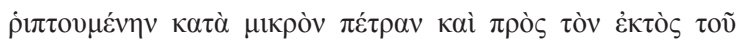

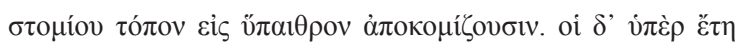

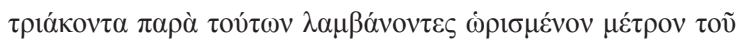

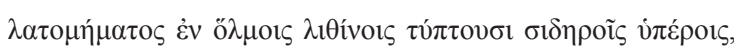

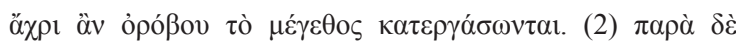

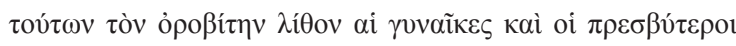

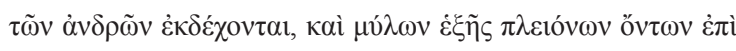

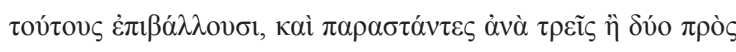

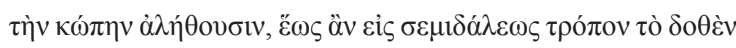

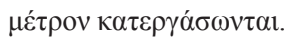

Os rapazes que ainda não chegaram à maturidade, entrando através dos túneis nas galerias formadas pela remoção da rocha, recolhem laboriosamente a rocha à medida que ela é lançada pedaço a pedaço para a levar para o exterior da entrada. Depois, aqueles que têm mais de trinta anos de idade pegam nessa pedra extraída e com pilões de ferro batem uma determinada quantidade dessa pedra em argamassa de pedra, até atingir o tamanho de uma ervilhaca. (2) De seguida, as mulheres e os homens mais velhos recebem essas pedras e deitam a quantidade que lhes é entregue nos vários moinhos, que se encontram colocados em linha, e, em grupos de dois ou três, tomam os seus lugares nas varas ou nos puxadores de cada moinho, para as moerem até ficarem com a consistência de farinha fina.

A seguir aos processos de trituração e de moagem Diodorus descreve o processo de lavagem de minério no deserto egípcio $(3,14,1-2)$ :

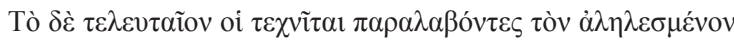

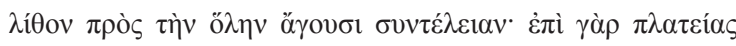

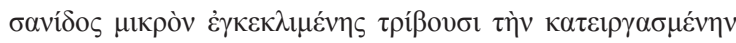

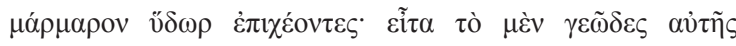

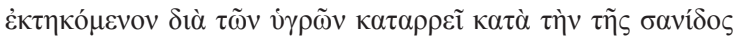

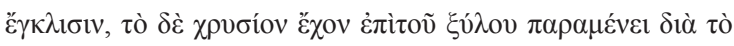

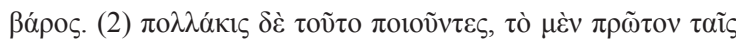

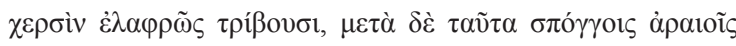

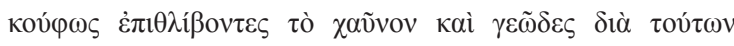

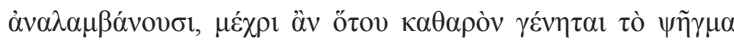

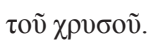

Nas últimas etapas, os trabalhadores especializados recebem a pedra moída em pó para completar os procedimentos finais; esfregam o mármore trabalhado sobre

159 Bachmann 1993; Wahl 1988: 230-234; Wahl-Clerici / Wiechowski 2012; Wahl-Clerici et al. 2012b; Martins 2017.

160 Bachmann 1993; Noronha etal. 2000; Rosa 2001; Rosa/Romberger 2003.

161 Wahl-Clerici/Wiechowski 2012.

162 Wahl-Clerici/Wiechowski 2012, 328 
uma tábua larga e ligeiramente inclinada, regando-a constantemente com água; assim, a terra derrete com a água e escorre pelo tabuleiro inclinado, enquanto que o ouro permanece na madeira devido ao seu peso (figs. 4.0-4 e 4.0-5). (2) Repetindo isso várias vezes, eles esfregam-no com as mãos, e depois pressionam-no levemente com esponjas de textura larga para, dessa forma, remover tudo o que é poroso, assim como toda a terra, até que reste apenas o puro pó de ouro.

De seguida descreve o processo de fundição $(3,14,3-4)$ :

$\tau$

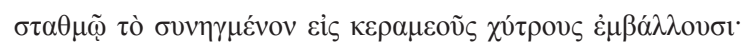

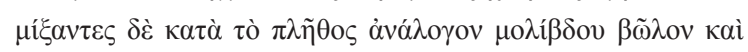

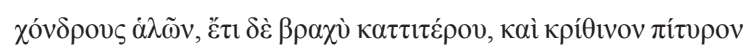

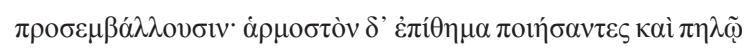


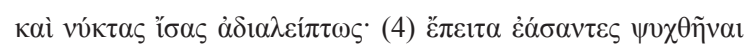

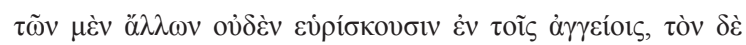

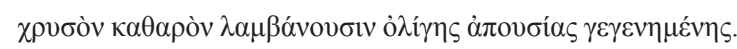

Então, finalmente, outros trabalhadores especializados pegam no que foi recuperado e colocam-no com medida e peso fixos em recipientes de barro, misturando-lhe um pedaço de chumbo proporcional à massa, pedaços de sal e um pouco de estanho, adicionando ainda farelo de cevada; depois, colocam-lhes uma tampa bem fechada esfregando-a cuidadosamente com lama e cozem-nos no forno durante cinco dias e cinco noites consecutivos; (4) no final desta fase, despois de deixarem esfriar os jarros, não restam vestígios das matérias nos recipientes, exceto o ouro que eles recuperam em forma pura, havendo pouco desperdício.

No seguinte excerto, Plínio reduz ao essencial o tratamento mecânico-térmico do minério extraído (N.H.33, 69):

Quod effossum est, tunditur, lavatur, uritur, molitur in farinam a pila scudem vocant

... A substância escavada é esmagada, lavada, aquecida e moída até se transformar num pó macio.

A sequência improvável destes processos deve-se possivelmente a uma tradução errada do texto, que deveria ter a seguinte redação:

O minério é triturado, moído, lavado, ustulado. ${ }^{163}$

Por conseguinte, ambos os autores descrevem os processos necessários para extrair o ouro em jazidas como as de Tresminas, Gralheira e Jales. Enquanto o ouro em grão mais grosso podia ser obtido lavando o minério triturado, o mi- nério contendo o ouro refratário tinha de ser tratado através de um processo relativamente complicado (ustulação, fundição) após o tratamento mecânico. Os princípios básicos destes processos já haviam sido descritos por Estrabão, baseado em Políbio, para a prata de Laurion. ${ }^{164} \mathrm{O}$ esquema de tratamento dos mecanismos de fundição compilado por Bachman fig. 4.0-6, apresenta os procedimentos necessários. ${ }^{165}$

Assim, o processo de tratamento difere fundamentalmente das jazidas aluviais, como em Las Médulas ou Las Omañas (Província de León, E), onde o ouro está embutido em forma de flocos ou nuggets (pepitas). O mesmo se aplica ao ouro nas zonas de alteração, como nas jazidas do Alto del Palo (Província das Asturias, E) ou na Serra de Teleno (Província de León, E). É particularmente notável que em todos esses lugares não existem, ou existem pouquíssimas bases de moinhos de pilões e moinhos para minério, o que significa que a rocha não precisava de ser partida, e caso assim fosse, apenas em quantidades muito pequenas.

Basicamente, o tratamento é dividido em tratamento com mecanismo a seco, tratamento com mecanismo de água e fundição. O tratamento a seco inclui a seleção, a britagem e a moagem do minério, distinguindo-se a lavagem como operação com mecanismo de água. Durante a fundição são extraídos tanto o ouro como a prata do concentrado de minério. Nas fontes não é mencionado o tratamento por lançamento que consiste no lançamento das pedras extraídas pelo poço para as partir. Esta primeira forma de tratamento pode ser explorada com base nos contextos arqueológicos, pelo que deve ser atribuída aos processos de mecanismo a seco.

\section{Os processos de tratamento a seco}

\section{A Seleção}

Presumivelmente, a seleção era um assunto tão óbvio para Plínio que ele não considerou necessário mencioná-lo. Durante a seleção é feita a triagem das pedras obtidas durante a extração. Nas escombreiras, que em Tresminas se encontram junto às minas de céu aberto e às galerias, empilhavam-se esses estéreis (figs. 4.0-7a / b e3.4-9). ${ }^{166}$

163 Rosumek 1982, 181-182; Wahl 1988, 230.

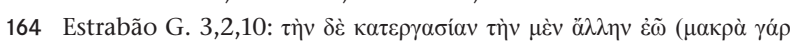

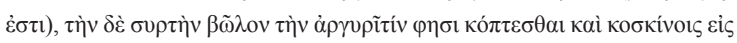

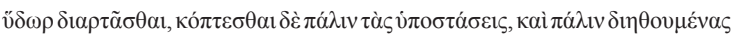

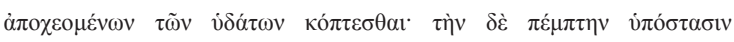

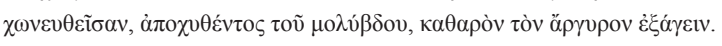
Vou omitir o resto do processo, uma vez que é muito longo, mas no que concerne ao minério de prata, ele diz-nos que é partido e peneirado sobre a água; o que resta é novamente partido e depois de deixar escorrer a água é peneirado pela terceira vez. Os restos que permanecem após a quinta vez são derretidos e o chumbo é despejado, pelo que a prata é obtida em estado puro.

165 Bachmann 1993, 154, nota 4; Martins 2008, Fig. 19.

166 Agricola et al. 1950, 268. 


\section{Tratamento por lançamento}

Este método corresponde a uma forma simples, mas eficiente, de fragmentar o material extraído através de demolição para facilitar os demais processos de separação, pelo que o material extraído era lançado por um poço para um nível inferior. ${ }^{167}$ Os testemunhos mais importantes deste processo são os dois poços que fazem a ligação entre a Galeria Jürgen Wahl e a Galeria do Pilar (a $40 \mathrm{~m}$ de altura de queda), e a Galeria do Pilar e a Galeria do Texugo (30 m de altura de queda). A partir daí, o material era levado para a superfície e submetido aos processos habituais de tratamento.

\section{Tundere $=$ triturar $/$ britar}

A britagem consistia num processo mecânico com recurso a pilões de madeira que embatiam regularmente no material extraído (figs. 4.0-8 e 4.0-9). A grande quantidade de vestígios conservados, nomeadamente, as bases de moinhos, são cubos monolíticos de granito biotítico com um peso de 700 a $800 \mathrm{~kg}$. Devido ao seu comprimento aproximado de 90, 100 e $110 \mathrm{~cm}$ podemos dividi-los, grosso modo, em três tipos de tamanho. Não é possível determinar com precisão a largura e a altura dos blocos devido aos seus sinais de desgaste. As dimensões registadas variam entre um pouco menos de $40 \mathrm{~cm}$ e um pouco mais de $50 \mathrm{~cm}$. Portanto, é possível reconstruir um tamanho base de $3 \times 1,5 \times 1,5$ pés romanos como referência para o tamanho dos blocos usados (figs. 4.0-10 e 4.0-11). ${ }^{168}$

Basicamente, verificam-se quatro cavidades nas faces desgastadas de todas as bases de moinho. As cavidades estão dispostas de forma que permaneça vazia, de um lado, uma faixa de $15-20 \mathrm{~cm}$ de largura, cuja função ainda é desconhecida, mas que está provavelmente relacionada com a estrutura do moinho de pilões. Assim que as cavidades se tornassem demasiadamente profundas para que os pilões pudessem pisar corretamente, ou seja, a superfície estivesse demasiado desgastada, a pedra era simplesmente virada e utilizava-se a outra face. Essas marcas de desgaste podem ser geralmente encontradas em três ou quatro lados dos blocos (fig. 4.0-12).

A uniformização dos blocos de pedra e a regularidade dos vestígios de desgaste são indicadores de que os blocos eram usados como peças permutáveis em moinhos mecanicamente operados. As quatro concavidades parecem ser a norma, como demonstram os exemplos comparativos de Espanha, País de Gales e do Kosovo. ${ }^{169}$

A reconstrução gráfica de um moinho de pilões da época romana (fig. 4.0-8) está limitada à bigorna e aos pilões, uma vez que só podem ser feitas suposições sobre o seu sistema de acionamento. As ilustrações de Agricola, aproximadamente 1400 anos mais recentes, apresentam uma construção precisa para o acionamento dos martelos de britagem (figs. 4.0-14a/b). Uma vez que nos tempos romanos tais estruturas também eram feitas de madeira, é pouco provável que se venham a encontrar vestígios das mesmas.
Os moinhos de pilões em Tresminas eram muito provavelmente acionados por uma construção movida à força muscular humana ou animal. A suposição repetida de que os pilões eram acionados através de energia hidráulica pode ser excluída com elevada probabilidade, devido à inexistência das quantidades necessárias de água para esse tipo de acionamento, além do facto de que as mesmas teriam de exercer uma pressão bastante considerável. ${ }^{170}$

O número de bases de moinhos de pilões encontradas em Tresminas excede em cem vezes o que foi encontrado em todas as outras minas do Império Romano (figs. 4.0-9 e 4.0-14)

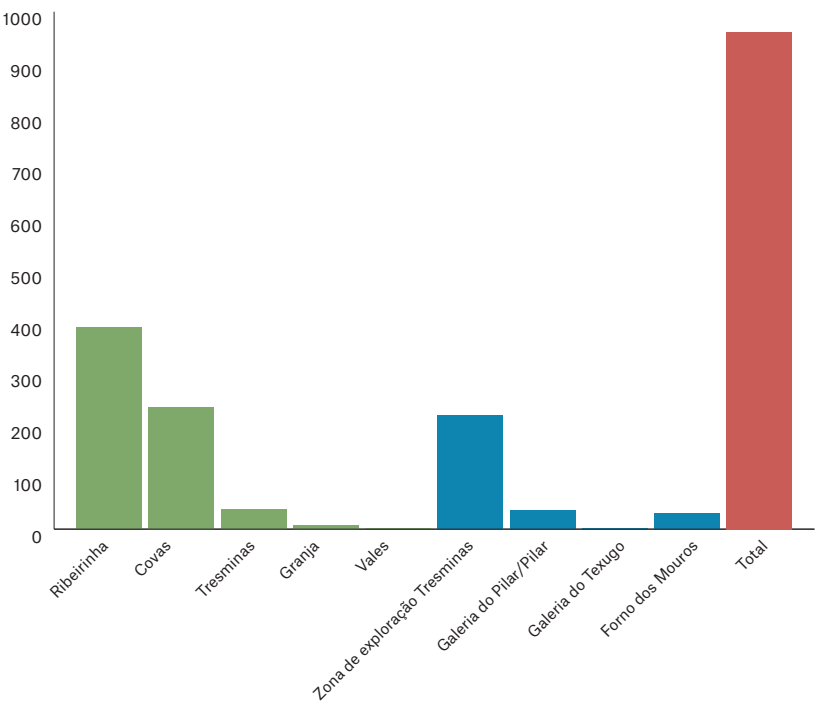

Fig. 4.0-15: Territorium metallorum Tresminas/Jales: distribuição dos moinhos de pilões pelas aldeias (verde) e nos locais onde foram encontrados na zona de exploração de Tresminas e do Forno dos Mouros (azul) (registo: R. Caflisch, R. Wahl-Clerici, desenho: R. Wahl-Clerici).

167 Rosumek (1982: 80-81).

168 Wahl 1988, 230-234. Podemos excluir com certeza a hipótese considerada por Rosumek 1982, 86-87 de correspondem a partes de molae trusatiles. «A rocha era esmagada por uma placa de cobertura áspera que era movida a todo o comprimento do bloco ou através de uma pequena pedra movida à mão em círculos e por secções, o que levava à origem de várias cavidades.» Presumivelmente, a reconstrução de Rosumek baseou-se nos moinhos gregos de vaivém, como os que foram encontrados em Laurion, não tendo em conta o tremendo peso das bases de moinhos de Tresminas. Também é improvável a interpretação adotada por Sánchez-Palencia 1979 e 1984 / 85, que considerava as bases de moinhos um meio de apoio para a lavagem do ouro, apoiando-se para esse efeito na interpretação geral de Conophagos 1989, 100 sobre as pedras circulares com ligeiras cavidades, encontradas em Laurion. Veja-se também a palestra não publicada do Prof. Dr. Papadimitriou por ocasião da reunião da Sociedade Alemã da História da Água em Atenas, de 5 a 17 de março de 2015. As cisternas e as estruturas de lavagem do minério no pequeno vale de Drymos (Souriza) perto de Agia Triada, na área das minas de prata do Ático de Laurion, já foram retratadas por Daremberg-Saglio 1863, fig. 5009.

169 Sánchez-Palencia 1984/85: Fresnedo (Pola de Allande, Astúrias, Espanha), Cecos (Ibias, Astúrias, Espanha); García Romero 2002, 358 fig. 111: Córdoba / E; Burnham / Burnham 2004, 283 fig. 4.55: Dolaucothi «Carreg-Pumsaint» (País de Gales, Reino Unido); Domergue 1990: Las Rubias (León, Espanha); Um exemplar inédita encontra-se em exposição no Museu de León (Espanha).

170 Wilson 2000, 23; Hirt 2010, 35. 
Até ao momento, foi possível encontrar três fragmentos de pelo menos duas bases de moinhos de pilões de quartzito. A sua massa e os sinais de desgaste correspondem basicamente aos dos blocos de granito, embora tenham sido provavelmente usados apenas de dois lados devido à qualidade da pedra (figs. 4.0-16 e 4.0-17).

A pedra coberta de pequenas cavidades na superfície de fricção, encontrada num moinho para minério romano de granito biotítico, é um exemplo único (fig. 4.0-18). Isto leva a crer que as pedras deste género tinham um uso secundário e de suporte no processo de britagem. De acordo com a ilustração de Agricola, as rochas de minério eram britadas manualmente em tais peças (fig. 4.0-19). ${ }^{171}$ Dado que é desconhecida a localização exata dessa pedra dentro da zona de mineração de Tresminas, são possíveis duas interpretações. A pedra podia ter sido usada para britar as amostras retirados da Galeria dos Alargamentos, uma vez que na boca da galeria se encontram apenas moinhos para minério. Por outro lado, essa forma inicial de britagem pode ter ganho importância quando a exploração mineira organizada pelo estado foi abandonada.

As bases de moinhos de pilões são apenas encontradas nas minas onde o minério tinha de ser triturado para dar continuidade ao processo de tratamento. Portanto, não é de surpreender que nas grandes áreas de extração com depósitos aluviais como, por exemplo, Las Médulas ou em zonas de alteração, como no Alto del Palo ou na Serra de Teleno, sejam encontradas muito poucas bases de moinhos de pilões. Nestes depósitos de ouro era necessário instalar sistemas de lavagem complexos para obter o metal cobiçado. As bases de moinhos de pilões preservadas em Pozos (León, Espanha), que foram parcialmente usadas na construção de casas, eram provavelmente necessárias apenas para o tratamento do minério que foi extraído do poço que faz parte da aldeia (figs. 4.0-20 e 4.0-21). ${ }^{172}$

\section{Molire in farinam $=$ moagem fina}

De seguida, a pedra aurífera com tamanho de ervilha era finamente moída em moinhos rotativos. Este processo corresponde ao chamado molire in farinam de Plínio (Historia natural 33,69). Os vestígios encontrados nas povoações romanas demonstram que as mós não utilizadas eram usadas como material de construção. A tentativa de contar as mós não utilizadas, incluindo fragmentos, teve de ser abandonada devido ao seu elevado número e à, por vezes, forte fragmentação. A acumulação de mós em vários locais, geralmente em conjunto com fragmentos de bases de moinhos de pilões, indica a localização de locais de tratamento.

Os moinhos redondos - molae versatiles - têm um diâmetro de dois pés romanos (aproximadamente $60 \mathrm{~cm}$ ). O seu acervo é composto quase exclusivamente de moedores em forma de disco com superfícies de moagem planas ou planas cónicas. Os traços característicos do seu uso são as ranhuras concêntricas, bem como as estrias radiais que tornam ásperas as superfícies lisas (figs. 4.0-23 e 4.0-24).
Apenas um único exemplar de uma pedra movente (catillus) de um moinho do tipo de Pompeia manteve-se preservado em Tresminas (fig. 4.0-25). Trata-se de uma mó com finas cavidades de encaixe para o mecanismo de acionamento. Foi ainda possível identificar a base de um moinho do mesmo tipo, porém nem a massa nem a qualidade da pedra apontam para o facto de se tratar de um único moinho (fig. 4.0-26).

Uma vez que os moinhos para minério têm um diâmetro de aproximadamente $60 \mathrm{~cm}$, necessitam de maior potência de acionamento para o processo de moagem do que os moinhos de farinha com um diâmetro de aproximadamente $45 \mathrm{~cm}$. Por conseguinte, pode presumir-se que, no caso dos primeiros, as componentes das máquinas eram acionadas por pelo menos duas pessoas ou animais.

\section{A lavagem de minério ${ }^{173}$}

Após o tratamento a seco, passava-se à separação do ouro dos constituintes mais leves da rocha através de lavagem.

\section{Os sistemas de lavagem de minério}

As instalações de tratamento com mecanismo de água estão entre os maiores monumentos preservados no contexto das jazidas de Tresminas. Numa encosta íngreme com um declive relativamente regular preservaram-se dois alinhamentos paralelos, cada um com 17 plataformas dispostas uma abaixo da outra. Alem disso, uma em cada duas plataformas na linha ocidental é complementada de cada lado por um tanque redondo de sedimentação (figs. 4.0-27a / b / c-4.031). As plataformas eram provavelmente usadas para colocar lavatórios de madeira, nos quais o minério finamente moído se depositava de acordo com a sua densidade. ${ }^{174}$

Cerca de 1500 anos mais antiga do que as instalações de lavagem de Tresminas é a do deserto Núbio, onde também existia uma instalação inclinada, bem como um tanque no início e no fim da plataforma. Um canal conduzia do tanque de lavagem de volta ao tanque à cabeceira da plataforma, de onde era necessário retirar a preciosa água para a plataforma garantindo assim um fluxo constante (figs. 4.04). ${ }^{175} \mathrm{O}$ texto de Diodoro, citado no início deste capítulo, menciona explicitamente uma tábua de lavar de madeira, sobre a qual se deitava água para remover a terra do ouro que ficava preso na tábua devido ao seu peso.

171 Agricola $1556 / 1984,233-234$.

172 Em várias minas romanas foram encontradas bases de moinhos de pilões com apenas uma única cavidade, todavia, bastante profunda (figs. 4.0-20-4.0-22b). Os exemplos de Pino del Oro (Provincia Zamora/E) sugerem que o minério extraído era provavelmente triturado e apenas ocasionalmente britado numa das inúmeras cavidades quadradas no granito, distribuídas por toda a área. Todavia, não sabemos até que ponto esse elevado número de cavidades pode estar ligado com o tratamento de minério de menor qualidade (fig. 4.0-22a / b). Ver Sánchez-Palencia et al. 2012, 200-208.

173 Wahl-Clerici 2016; Wahl-Clerici 2017.

174 Wahl 1997, 66, fig. 15

175 Castiglioni et al. 1995, 31.175. 
Manteve-se preservada uma tábua de lavar nas antigas minas de Seix (Dép. Ariège), nos Pirenéus franceses. Esta impressionante tábua tem $4 \mathrm{~m}$ de comprimento, $1,10 \mathrm{~m}$ de largura e é composta por 9 elementos unidos (fig. 4.0-5). ${ }^{176}$

Quase idêntica ao exemplar do antigo egípcio é a representação de uma plataforma de lavagem no livro Schwazer Bergbuch (Schwaz/Tirol, A) (figs. 4.0-4 e 4.0-32). ${ }^{177}$ Através do orifício na vasilha garantia-se um fluxo de água regular, que não fosse nem muito forte nem muito fraco.

No vale de Drymos (Souriza), perto de Agia Triada (Grécia), mantiveram-se particularmente bem preservadas as instalações para o tratamento de minérios nas minas de prata do Ático (fig. 4.0-33). ${ }^{178}$ Para a lavagem de minério criavam-se áreas com 4 a 20 m (máximo) de comprimento lateral, delimitadas por valetas de drenagem às quais estavam ligados tanques de sedimentação. Na parte da frente desse quadrado construía-se um tanque de água que era rebocado com opus signinum. A parede virada para a plataforma era finamente perfurada em intervalos regulares (fig. 4.0-34). Provavelmente, era através dessas aberturas que a água passava para as plataformas de lavagem inclinadas. Assim, a água suja dos vários tanques de sedimentação, que se encontravam parcialmente interconectados, era limpa para poder ser reutilizada. ${ }^{179}$

Outro tipo de instalação de lavagem pode ser encontrado nas áreas de extração de jazidas em zonas de alteração, como, por exemplo, na Serra de Teleno (província de León) ou em Alto del Palo (província das Astúrias), ambas na Espanha. Aqui serviam particularmente as longas trincheiras verticais com vários degraus para o depósito do ouro, o que pode ser indicado pelas represas no topo das aberturas, que com a devida alimentação de água podem ser relacionadas com o processo de lavagem (figs. 4.0-35 e 4.0-36). ${ }^{180}$

Estas aberturas correspondem às agogae descritas por Plínio (N.H.33,76-78):

fossae, per quas profluat, cavantur-agogas vocant-; hae sternuntur gradatim ulice. frutex est roris marini similis, asper aurumque retinens. latera cluduntur tabulis, ac per praerupta suspenduntur canales. ita profluens terra in mare labitur ruptusque mons diluitur, ac longe terras in mare his de causis iam promovit Hispania. (77) in priore genere quae exhauriuntur inmenso labore, ne occupent puteos, in hoc rigantur. aurum arrugia quaesitum non coquitur, sed statim suum est. inveniuntur ita massae, nec non in puteis, et denas excedentes libras; palagas, alii palacurnas, iidem quod minutum est balucem vocant. ulex siccatur, uritur, et cinis eius lavatur substrato caespite herboso, (78) ut sidat aurum.

São escavados regos para a água fluir — o seu nome em grego significa «chumbo»; e estas, que descem em degraus, são pavimentadas com tojo - uma planta parecida com o alecrim, que é áspera e retém o ouro. As laterais são tapadas com tábuas, e os canais são transportados em arcos sobre os degraus íngremes. Assim, a terra transportada no riacho desliza para o mar e a montanha fragmentada é lavada; e por esta altura, devido a estas causas, a terra de Espanha seguiu um longo caminho para o mar. (77) O material extraído com tão grande trabalho no primeiro tipo de mineração, para não encher os poços é lavado neste último processo. O ouro obtido por meio de uma arrúgia não tem de ser derretido, pois é ouro puro de imediato. Neste processo são encontradas pepitas e também nos poços, que podem pesar mais de dez libras. São chamadas de palagae ou palacurnae, e o ouro em grãos muito pequenos é chamado de baluce. O tojo é seco e queimado e as suas cinzas são lavadas num substrato de relva (78) para que o ouro se deposite sobre ele.

Finalmente, surge a questão sobre quando foram construídas as bem conservadas instalações de lavagem em Tresminas. Devido à sua localização, não se pode excluir a possibilidade de que foram construídas juntamente com a barragem de terra e o aqueduto $\mathrm{C} 2$, numa altura em que a extração já estava numa fase avançada, o que significa que já existiam instalações de lavagem de minério mais antigas. Isto é sustentado pelo facto de que grande parte das condutas de água seram levadas para a zona de extração. Muito provavelmente, essas instalações de lavagem estavam localizadas nas imediações dos moinhos de pilões e dos moinhos para minério.

\section{A fundição}

Em 1993, H.-G. Bachmann desenvolveu um esquema hipotético de tratamento e fundição para os minérios de Tresminas e Jales, que veio a expandir posteriormente (fig. 4.0-6). ${ }^{181}$

Como modelo, recorreu a uma sequência de procedimentos, como as que são conhecidas do séculoXIX, por exemplo, para os minérios de Freiberg na Saxónia (Alemanha) ou de St. Andreasberg em Harz (Alemanha). Seguiu igualmente F. A. Harrison que, devido à descoberta de escória, suspeitou que o chumbo desempenhasse um papel importante no processo polimetalúrgico usado pelos romanos. ${ }^{182}$ As investigações de Bachmann levadas a cabo no minério extraído, no ouro solto e num concentrado de flotação, a partir do veio de Jales, assim como as análises da escória e das cinzas do Forno dos Mouros sustentam essa hipótese (fig. 4.0-37). Além disso, conseguiu relacionar

176 Daremberg/Saglio 1877, 1863 fig. 5010.

177 Bartels et al., Vol. 1 2006, 150

178 Ardaillon 1897, Fig. 20 e Fasc. LXXVII; Daremberg/Saglio 1877, 1862 -1863 com ilustração detalhada das várias plataformas de lavagem, fig. 5008; Conophagos 1980, 19 figs. 4-5, 20 fig. 3.

179 Daremberg/Saglio 1877, 1862-1863.

180 Bird 1972, 46 Fig. 8; Essas covas não foram criadas para retirar amostras da superfície da encosta, como sugerido por Domergue 1987, 423; Wahl-Clerici 2017, esp. figs. 6 e 7.

181 Bachmann 1993, 159; Wahl 1998, 67; See also Martins 2008, fig. 19.

182 Harrison 1931, 141.

183 Bachmann 1993, 156

184 Harrison 1931, 141. 
bem este esquema com as passagens sobre o ouro referidas nos capítulos da História Natural de Plínio, o Velho (33, 66-78).

Após a britagem e a moagem, o minério pulverizado era lavado para obter o ouro através da separação por gravidade. O ouro refratário, que estava muito bem fundido com sulfuretos, tais como pirite, pirrotite, arsenopirite e galena, ou atomicamente incorporado na estrutura de cristal de pirite e arsenopirite, tinha de ser fundido. Para este efeito, os sulfuretos eram primeiro ustulados. A ustulação também era necessária para destruir os altos níveis de arsênio (FeAS) e pirite (FeS2) uma vez que, em particular, os níveis de arsénico impediriam o processo seguinte. Durante a ustulação, o enxofre e o arsénico eram libertados em forma dos gases dióxido de enxofre ou trióxido de arsénio.

Uma indicação sobre o processo de ustulação é-nos fornecida por uma amostra do tipo escória (fig. 4.0-38, tabela 1 , amostra W2), que se desintegrou em pó preto durante a trituração e cujos valores analíticos e constituintes indicam tratar-se de um concentrado de minério ustulado e finamente moído, o que significa que se trata de um resíduo do processo de aquecimento.

De seguida, o material ustulado era moído e fundido juntamente com chumbo e carvão. Nesta fase formava-se chumbo fluído. No seu estado fundido o chumbo tem a propriedade de ligar metais preciosos como ouro e prata. $\mathrm{O}$ resultado da fundição é o chamado chumbo rico e contém os metais preciosos. Posteriormente, esse chumbo rico era colocado no forno com o lote seguinte até que o chumbo fundido possuísse um teor de metal suficientemente alto e o processamento adicional para a extração dos metais preciosos valesse a pena. A quantidade de ferro, gerada no material durante estas fases, era removida através da adição de quartzo.

As análises por fluorescência de raios-X de Bachmann ${ }^{183}$ e Wiechowski (fig.4.0-38), assim como a determinação dos constituintes por microscopia e análise por difração de raios-X, confirmam que se tratava de típicas escórias de silicato de ferro com teor de sulfureto e chumbo. De acordo com Harrison, a escória ainda continha gotas de chumbo com conteúdo enriquecido de ouro e prata. ${ }^{184} \mathrm{Ba}$ chmann observa a este respeito:

Aparentemente, este material [a escória] foi tratado mecanicamente tal como o minério. A escória esmagada e moída é comum em locais de fundição antigos. Tentavam separar as gotas de metal ou outros materiais valiosos presos na escória (por exemplo, cobre sulfídrico e/ou chumbo/pedra), da matriz da escória de silicato que não tinha valor e era descartável.... Também não é possível excluir que as escórias tenham sido britadas e possivelmente moídas. Harrison ressalta que as mós e as bases de moinhos de pilões são frequentemente encontradas in situ, onde também são descobertas escórias.
Por conseguinte, Bachmann enfatiza que os processos de britagem e moagem não foram usados exclusivamente no tratamento de minério, mas provavelmente também nas escórias, cujo tratamento poderia valer a pena, devido às gotas de chumbo que continham metais preciosos (chumbo rico). O produto de tratamento rico em metais preciosos era novamente sujeito à fundição com chumbo. ${ }^{185}$

De seguida era necessário extrair o ouro e a prata do chumbo e de outros metais, o que acontecia através da chamada «copelação» (extração). Neste processo, o chumbo aquecido transforma-se facilmente num óxido, o litargírio, que era removido deixando permanecer apenas uma liga de ouro e prata. O litargírio era levado ao forno juntamente com os minérios ustulados para servir novamente como aglomerante de metais preciosos.

Plínio também descreve o processo de copelação (N.H. 33, 60):

\section{|... ut purgitur, cum plumbo coqui. \\ ... para a limpeza (o ouro) é cozido com chumbo.}

A barra de chumbo encontrada em Campo de Jales atesta essa abordagem. Uma vez que o teor de chumbo no filão de Jales era de aproximadamente $5,5 \%$, pode concluir-se que o chumbo obtido localmente era usado em grande parte no processo de fundição.

A separação do ouro e da prata ocorria com a ajuda da «cementação». Para este efeito, aquecia-se a liga de ouro e prata em brasas vivas dentro de recipientes com sal e outros componentes. O ouro não era afetado durante esse processo, enquanto que a prata passava para escória, que posteriormente poderia ser tratada para a produção de prata (através da fundição com chumbo ou da copelação).

Curiosamente, Plínio descreve a cementação no contexto do ouro como se fosse um remédio, dizendo o seguinte (N.H. 33, 84-85):

Torretur et cum salis gemino pondere, triplici misys ac rursus cum duabus salis portionibus et una lapidis, quem schiston vocant. Ita virus trahit rebus una crematis in fictili vase, ipsum purum et incorruptum.

O ouro é ustulado com o dobro de seu peso em sal e com o triplo do seu peso em piritas de cobre ${ }^{186}$, depois é novamente ustulado com duas partes de sal e uma de pedra, a que eles chamam de «schistos» ${ }^{187}$. Assim, quando essas coisas são queimadas juntamente com o ouro dentro de um vaso de barro, extrai-se o veneno, pois o ouro é deixado em estado puro e incorrupto.

185 Não deve ser excluída a possibilidade de que os moinhos de pilões, encontrados em jazidas secundárias e em zonas de alteração, foram utilizados no âmbito do processo de tratamento aqui descrito. 186 misy=calopirita desgastada?: Fuchs et al. 1993, 24-25, 44. 187 schiston = xisto aluminífero?: Fuchs et al. 1993: 24-25, 44. 


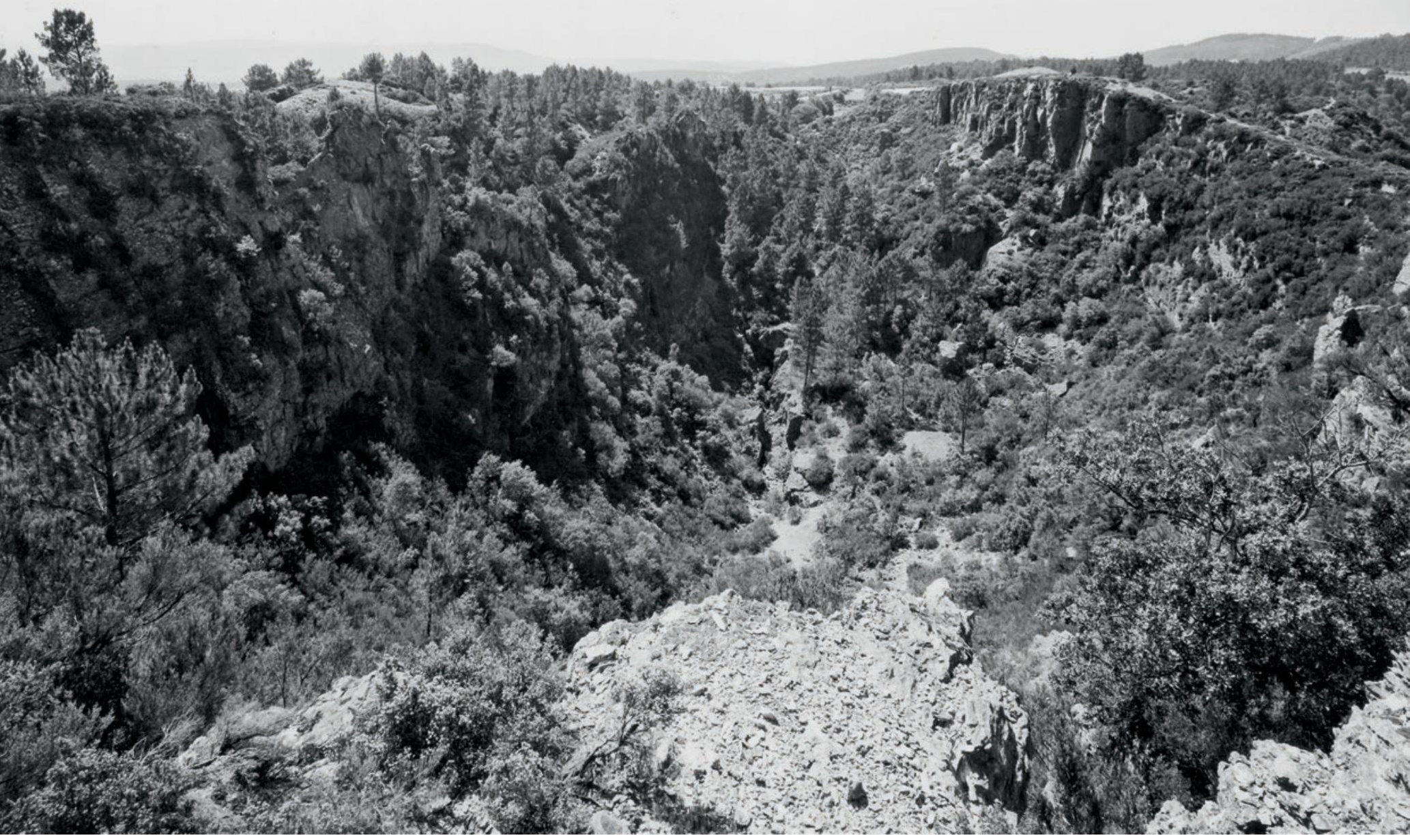

Fig. 4.0-1a: Territorium metallorum Tresminas /Jales, Tresminas, Corta de Covas: vista de leste (fotografia: J.Wahl). 


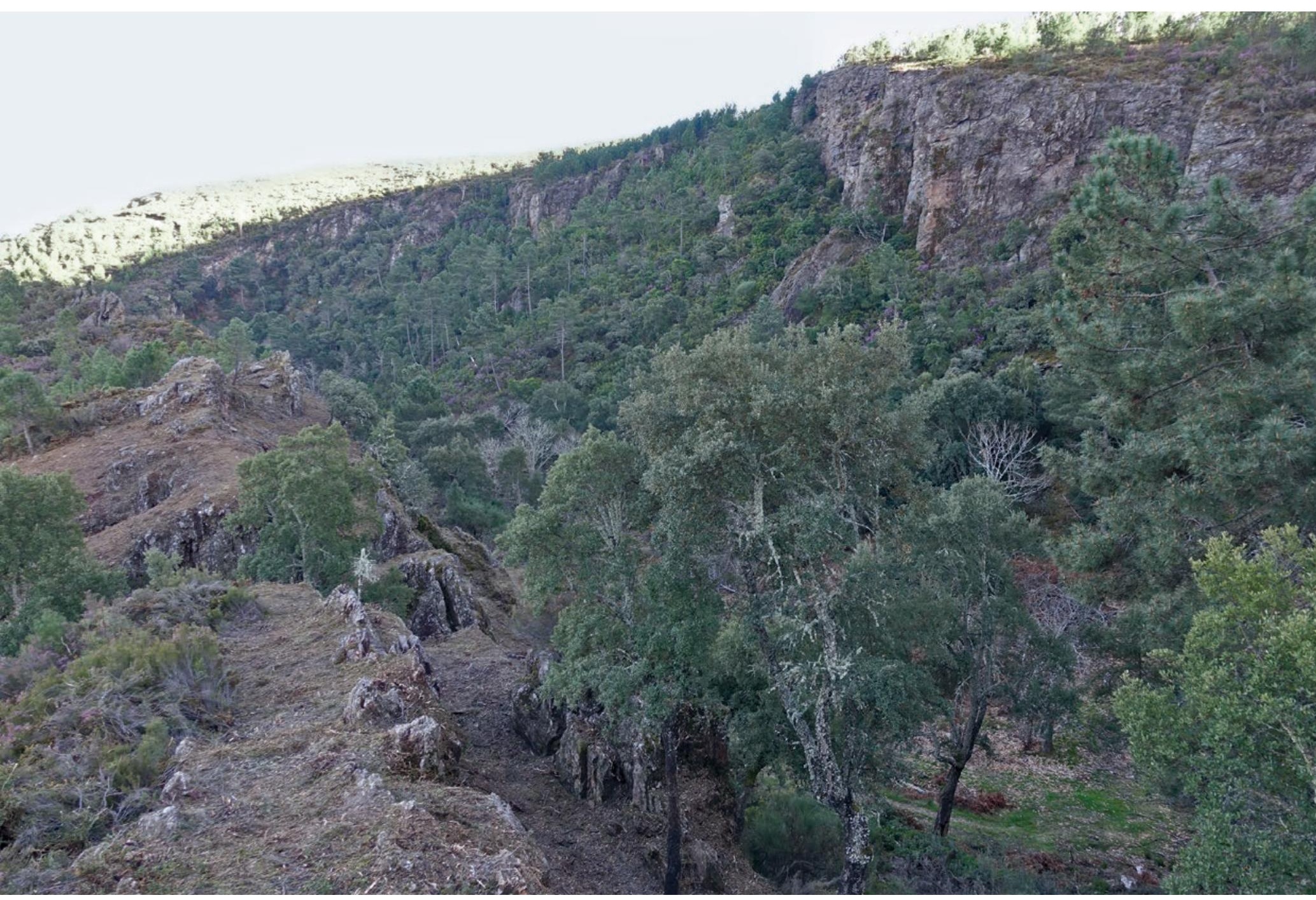

Fig. 4.0-1b: Territorium metallorum Tresminas/Jales, Tresminas, Corta da Ribeirinha: vista de oeste (fotografia: R. Wahl-Clerici). 


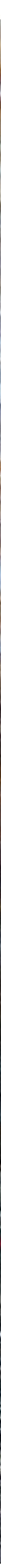

Fig. 4.0-1c: Territorium metallorum Tresminas / Jales, Tresminas: exploração subterrânea em Lagoinhos. Visto de oeste (fotografia: R. Wahl-Clerici). 


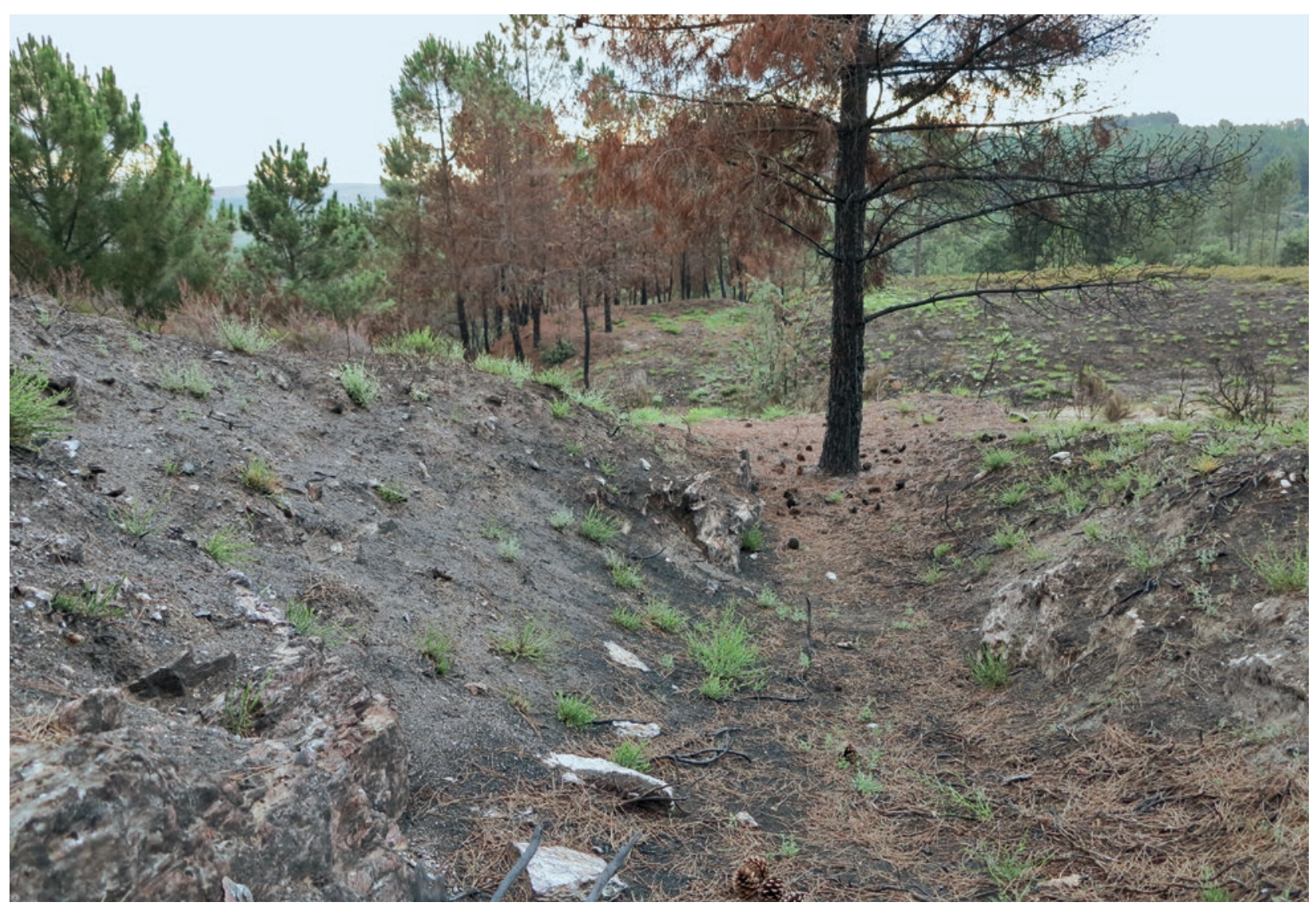

Fig. 4.0-1d: Territorium metallorum Tresminas/Jales, Gralheira: remanescentes das áreas de exploração e das escombreiras. Visto de leste (fotografia: R. WahlClerici).

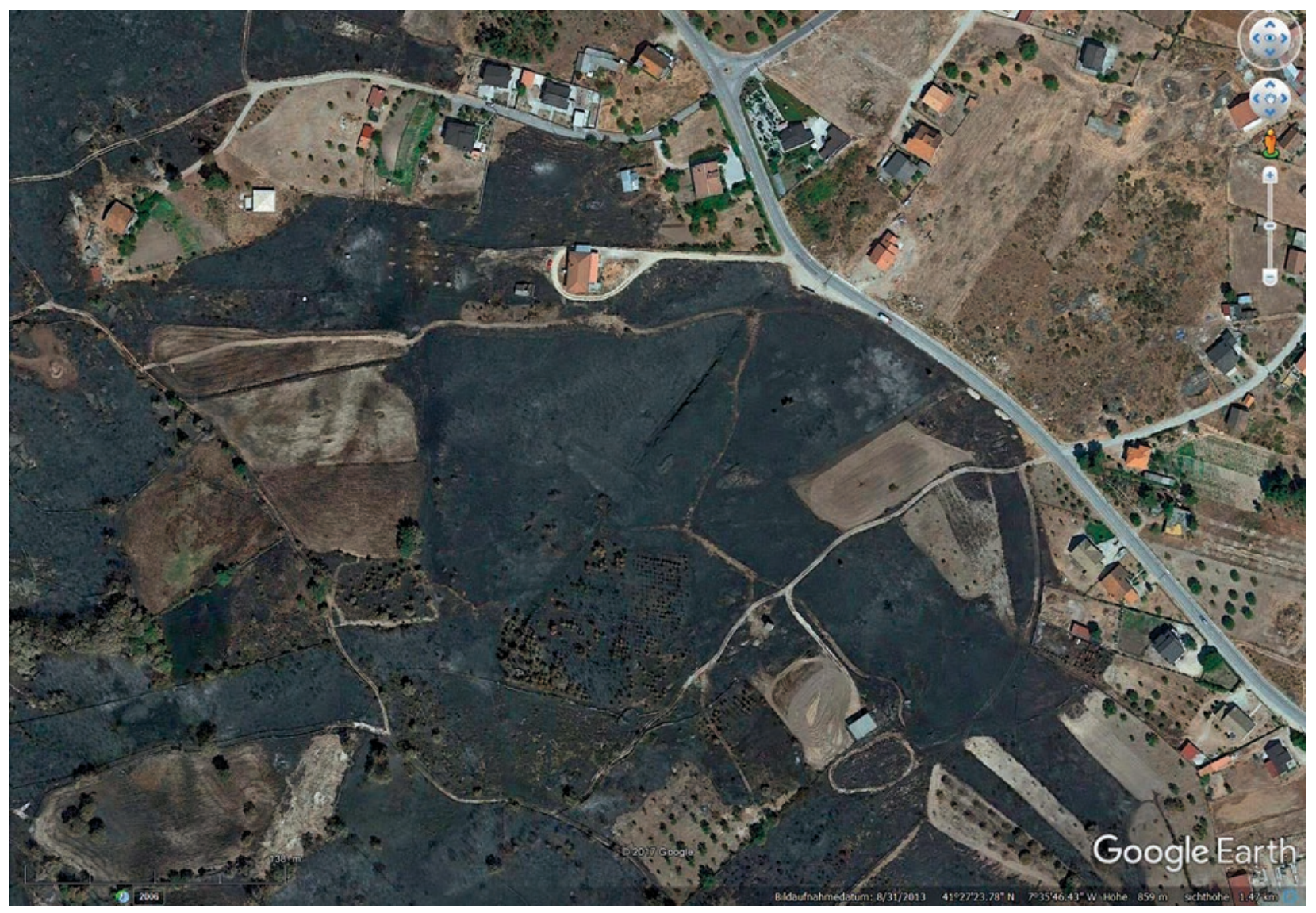

Fig. 4.0-1e: Territorium metallorum Tresminas /Jales, Jales: remanescentes da exploração romana em Campo de Jales a sudoeste da estrada nacional N212 (Google Earth. Imagem de 31.08.2013, última visualização: 02.07.2017). 


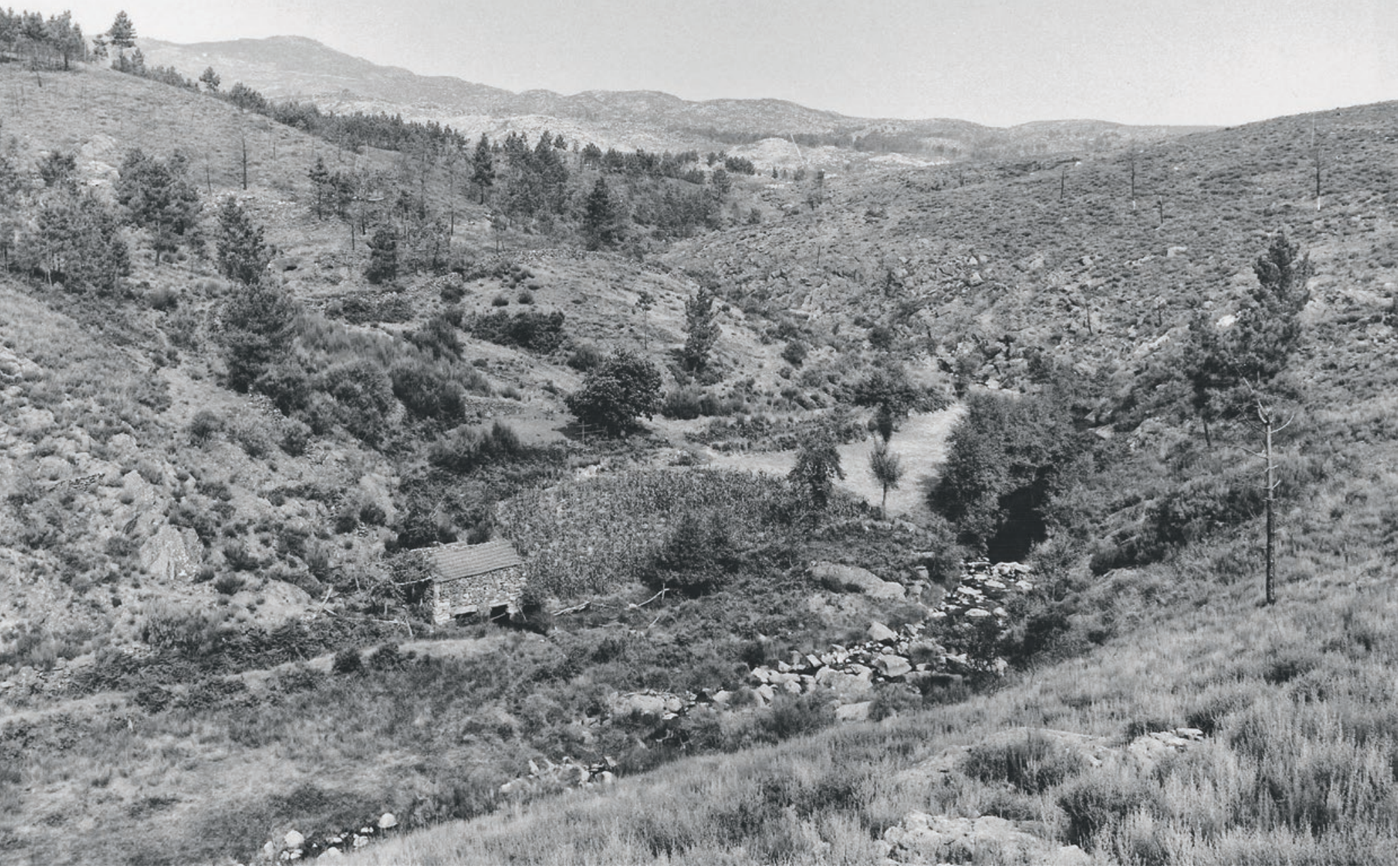

Fig. 4.0-2: Territorium metallorum Tresminas /Jales: local de tratamento em Forno dos Mouros. Vista de su-sudeste (fotografia: J. Wahl). 


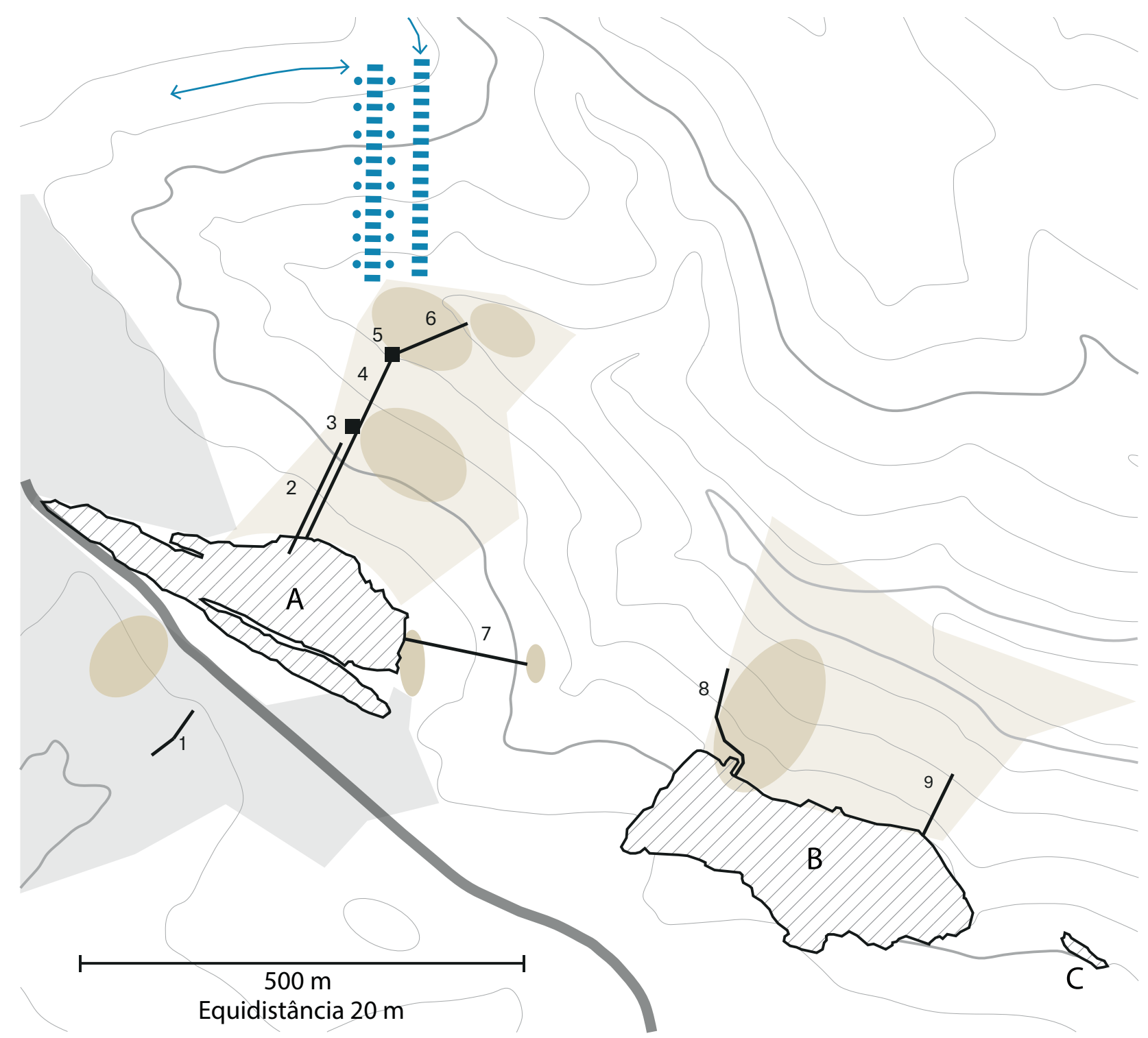

Fig. 4.0-3: Territorium metallorum Tresminas/Jales, Tresminas: vista sobre as áreas de tratamento na zona central.

Sombreado escuro: locais de processamento com altas concentrações de bases de moinhos de pilões e de moinhos para minérios, bem como material estéril, que pode ter sido processado.

Sombreado claro: zonas com bases de moinhos de pilões e moinhos para minério dispersos

Sombreado cinzento: zona do povoado

(Documentação: R.Wahl-Clerici, A.Wiechowski, modelo: J.Wahl, R.Wahl-Clerici, desenho: R.Wahl-Clerici). 

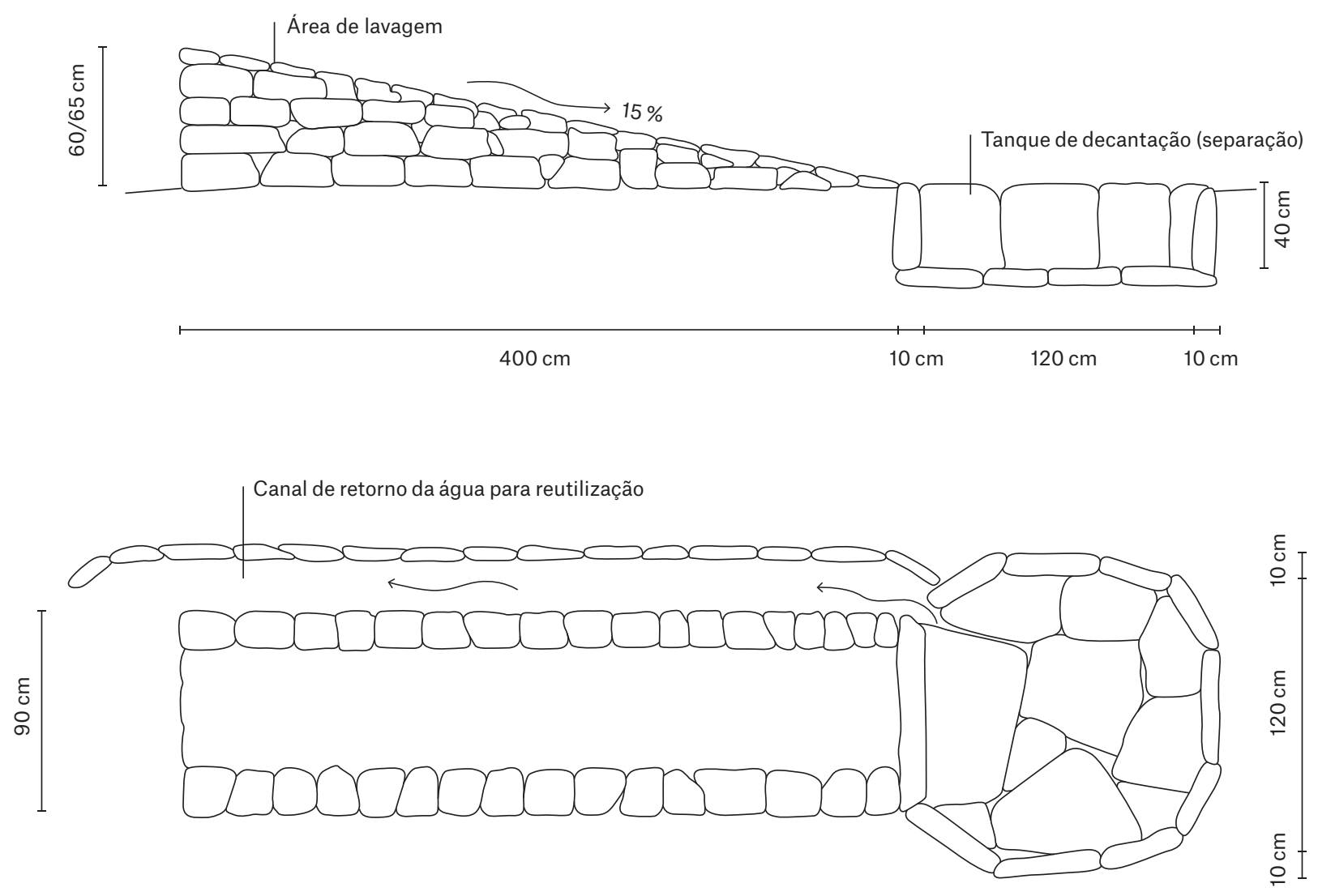

Fig. 4.0-4: Nubia: plataforma de lavagem de minério da Idade do Bronze (segundo Castilglioni etal. (1998: 175).

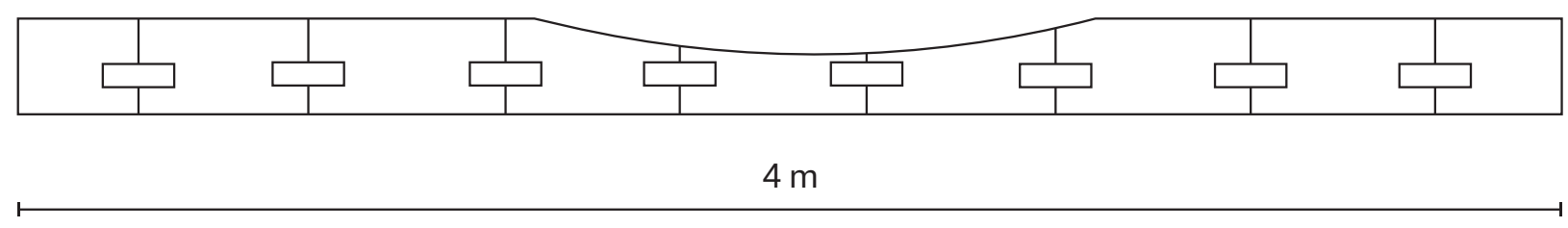

Fig. 4.0-5: Desenho de uma tábua de lavagem, pertencente às minas de Seix (Ariège, F). (de acordo com Daremberg e Saglio (1877: Fig. 5010). 


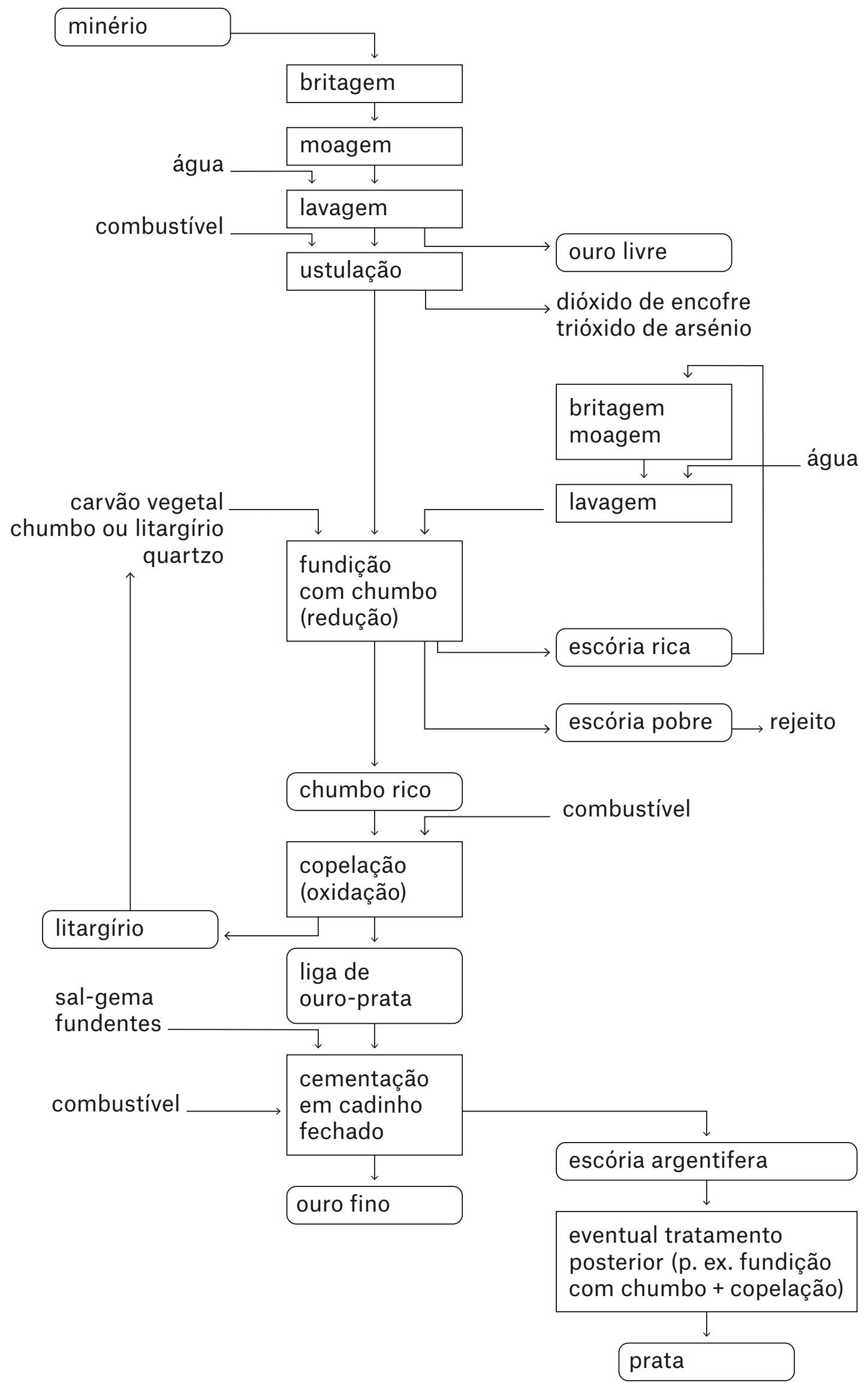

Fig. 4.0-6: O processamento romano de minérios de ouro e prata de Tresminas e Campo de Jales. Proposta para uma possível sequência de procedimentos (segundo H.G. Bachmann (1993: Fig. 1). 


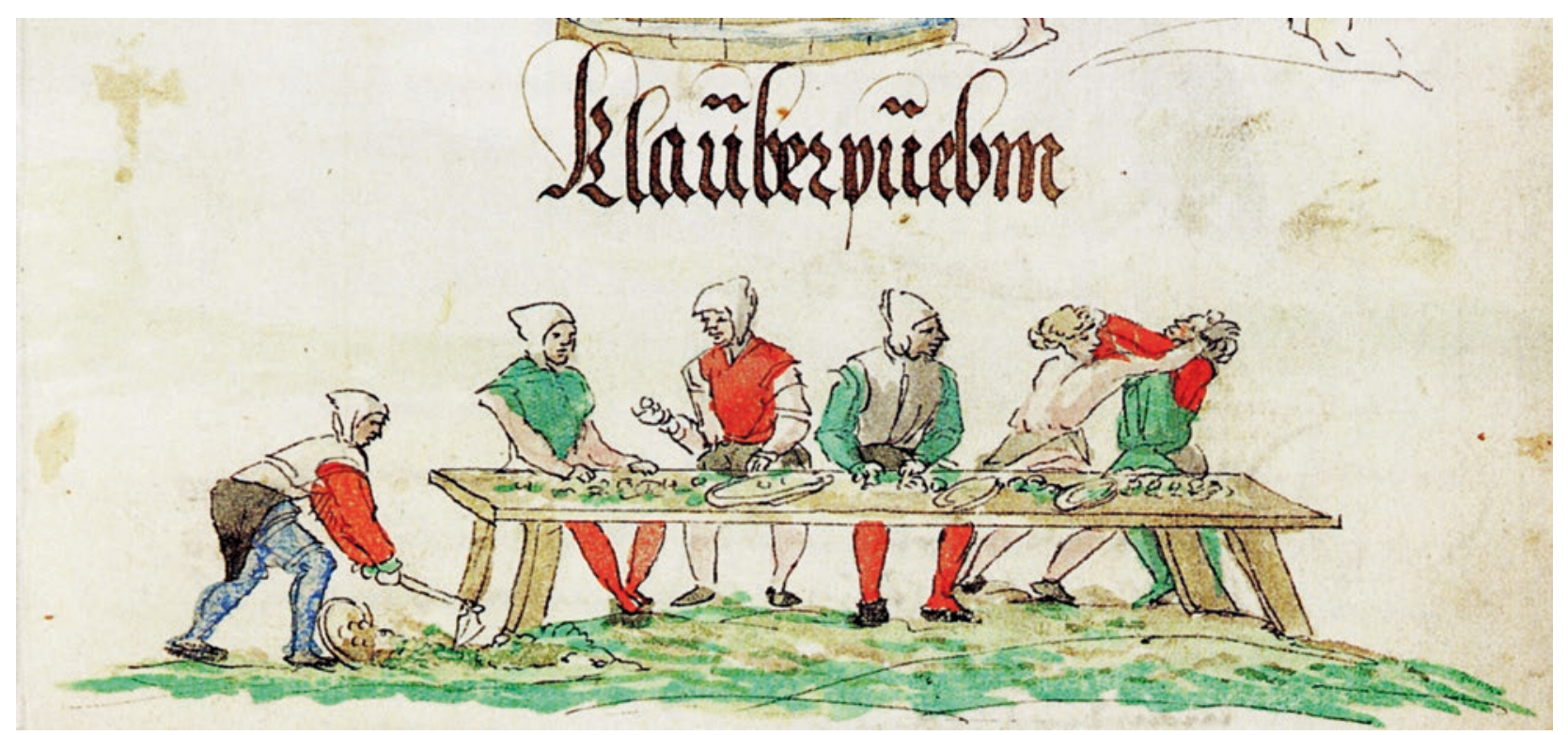

Fig. 4.0-7a: Schwazer Bergbuch: Rapazes a escolher as pedras (Klauberbuben) (Bartels etal. 2006, 149).

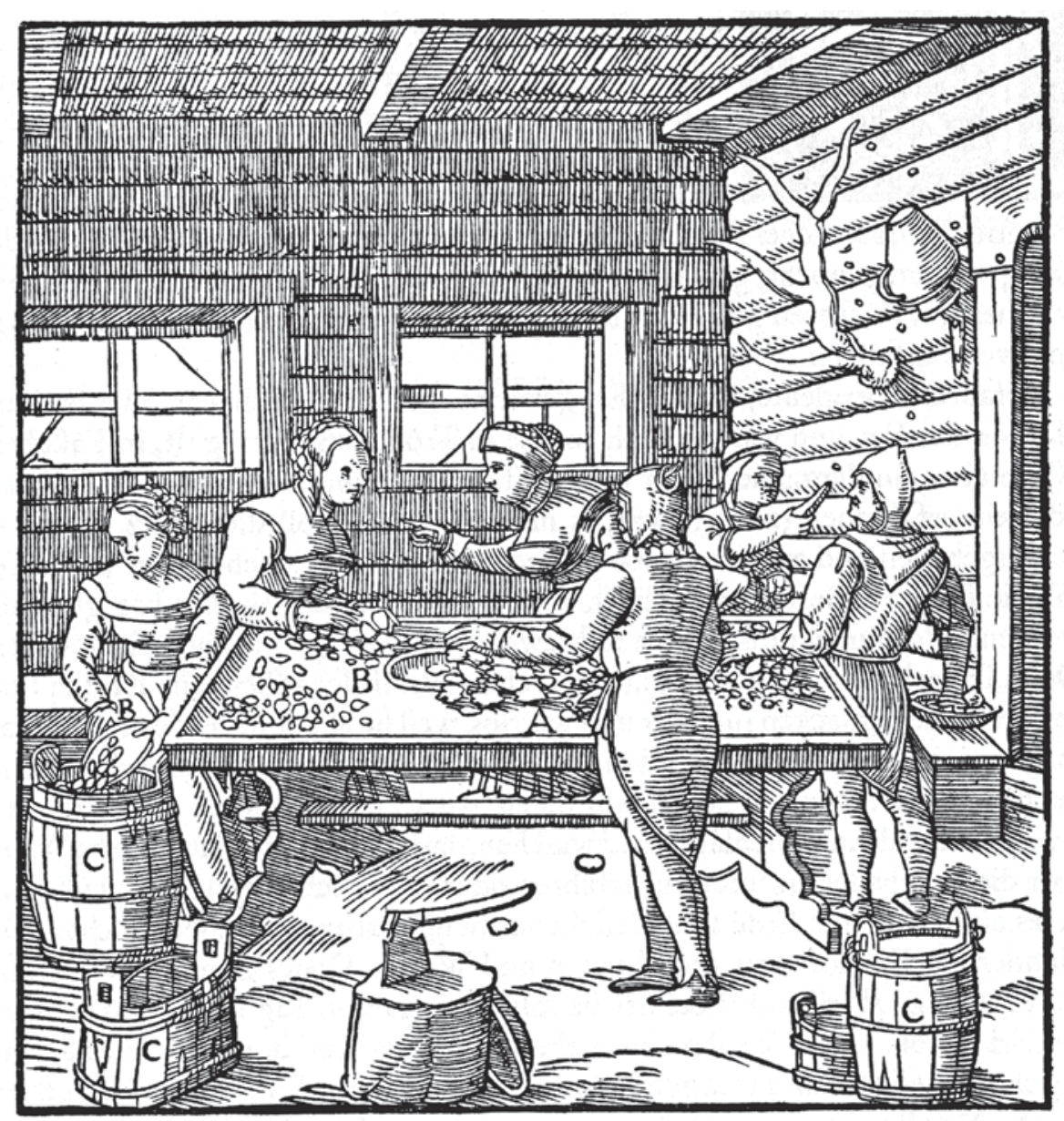

Eine lange Klaubetafel A. Tröge B. Erzfäßchen $C$.
Fig. 4.0-7b: Agricola (1556/1884, 232). Separadores de minério. Mesa comprida A; tabuleiro B; barris $C$. 


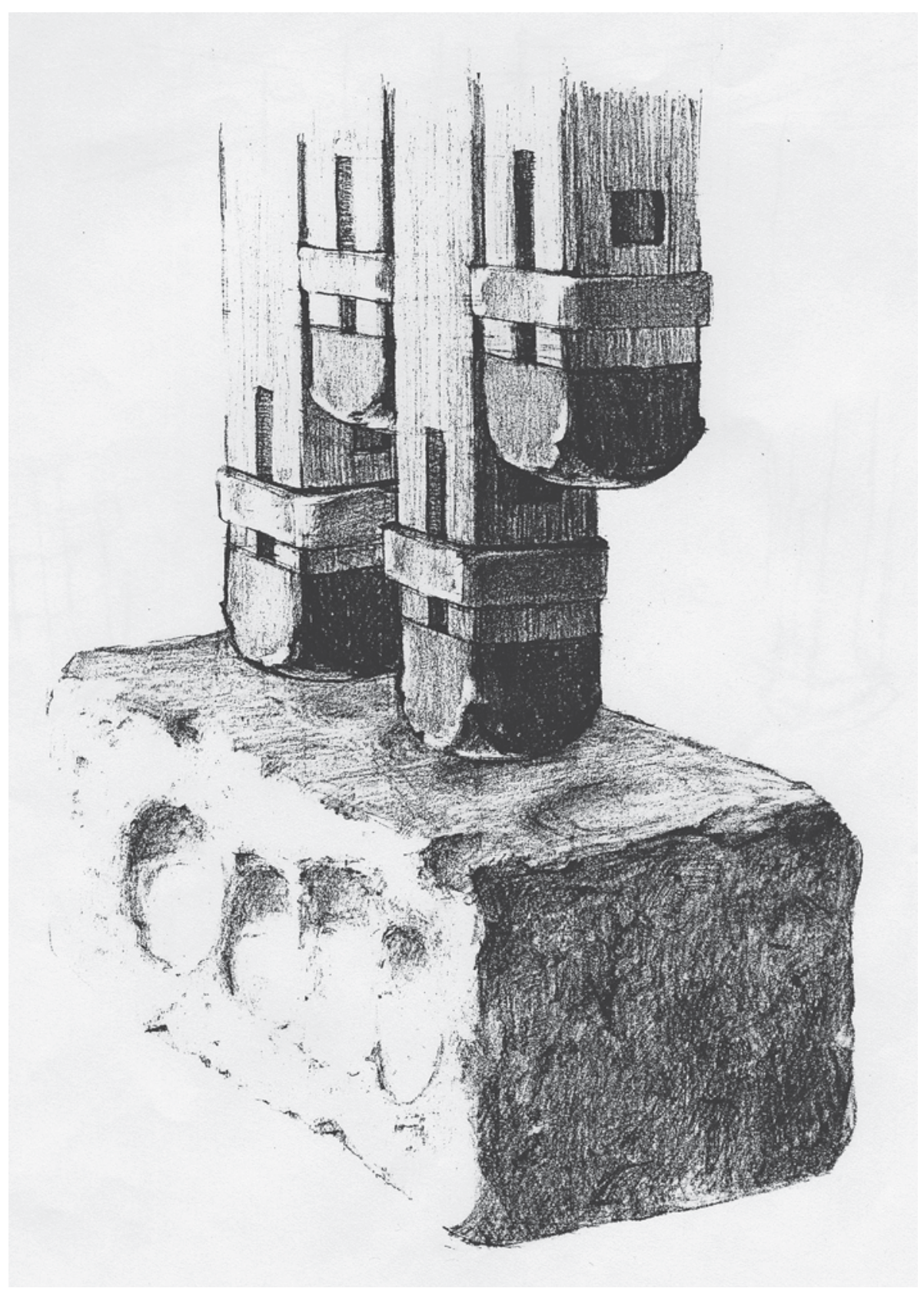

Fig. 4.0-8: Territorium metallorum Tresminas / Jales: reconstrução parcial de um moinho de pilões (modelo: J. Wahl, execução: P. Moser). 


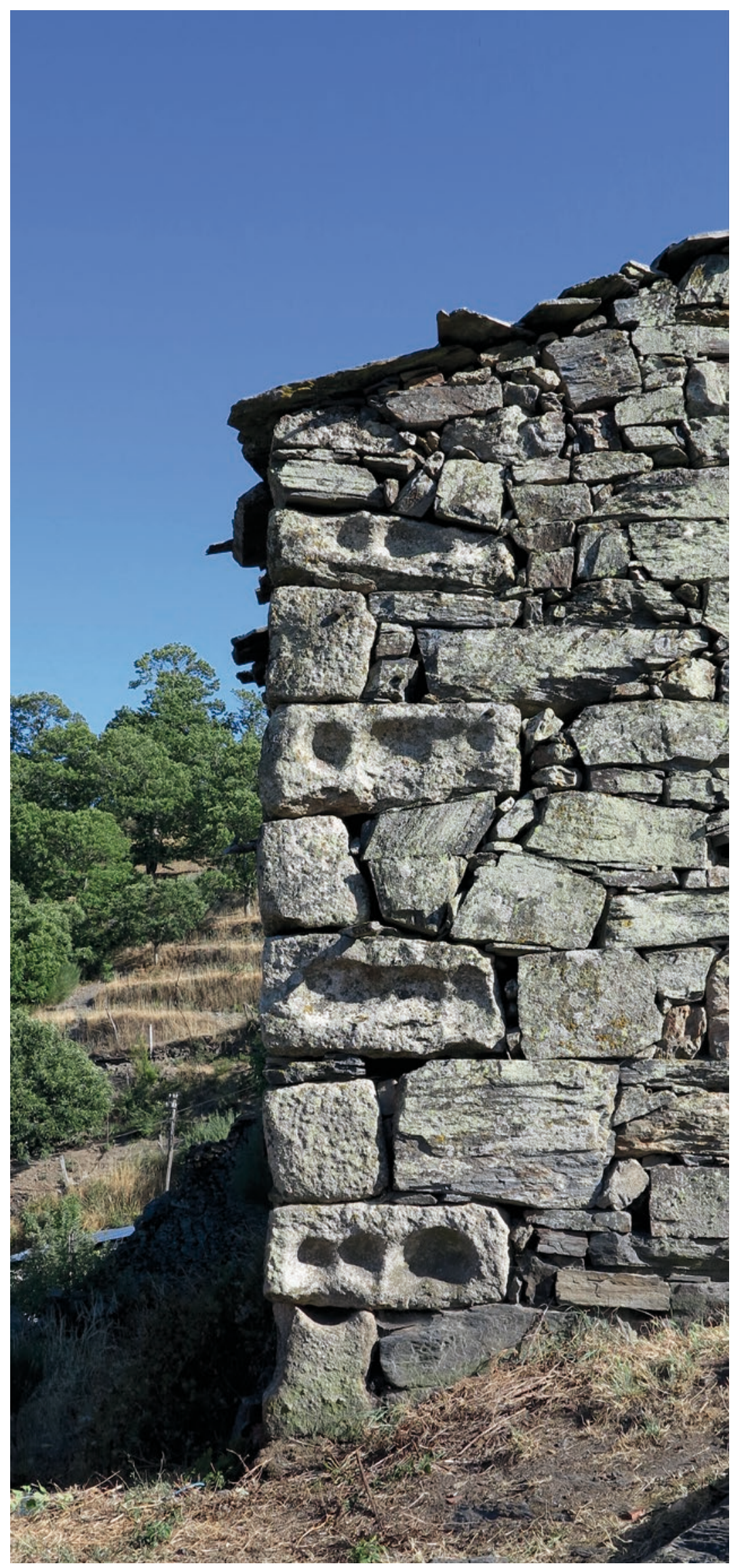

Fig. 4.0-9: Territorium metallorum Tresminas / Jales, Ribeirinha: bases de moinhos de pilões romanos reutilizadas numa construção (fotografia: $R$. Wahl-Clerici). 

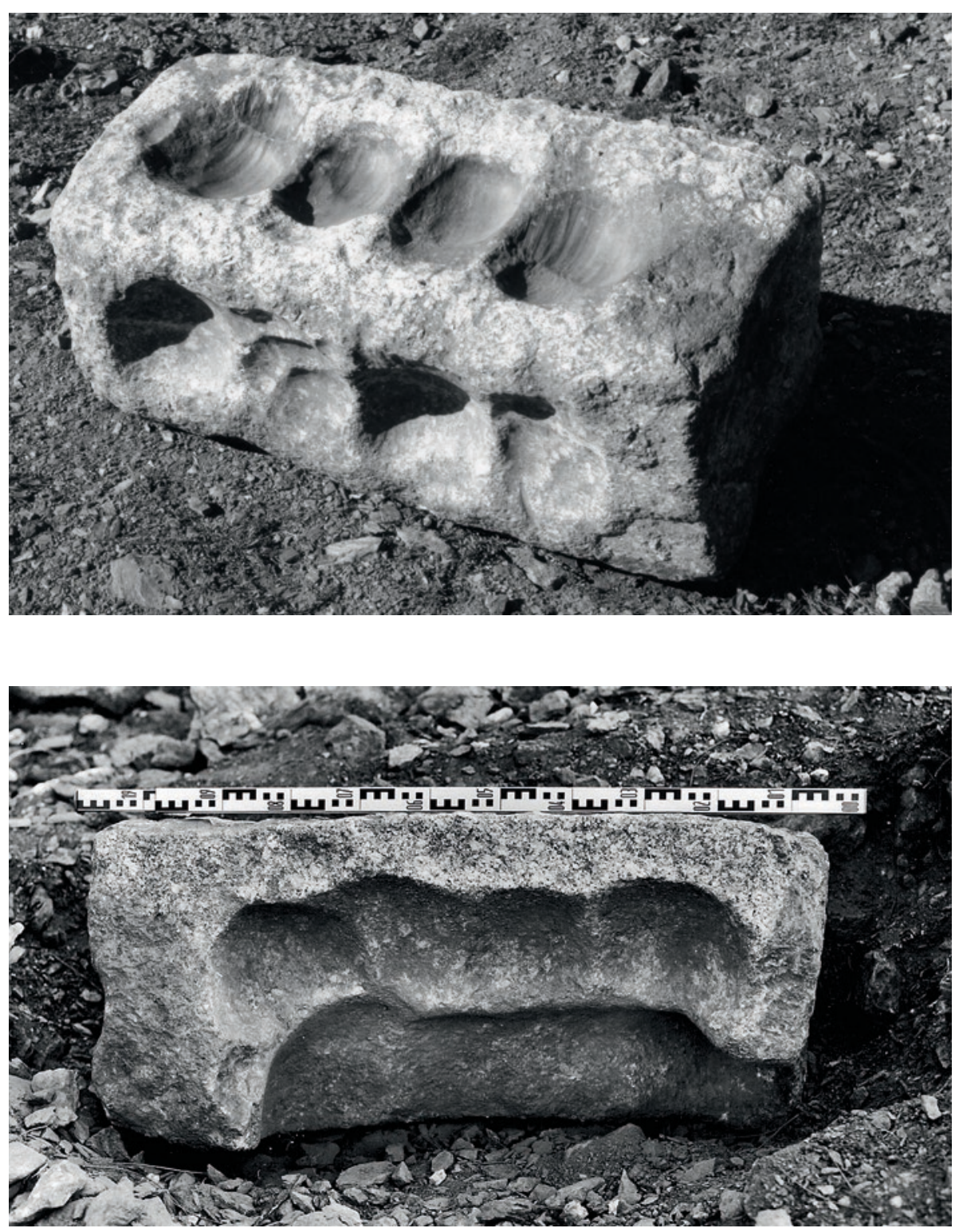

Fig. 4.0-10: Territorium metallorum Tresminas/Jales, Forno dos Mouros: base de um moinho de pilões. As cavidades não se encontram distribuídas

uniformemente, uma vez que era necessária uma área não utilizada de cerca de 15-20 cm para a fixação do pedra na britadeira. Nas cavidades do lado inferior esquerdo são visíveis interrupções no processo de trabalho (fotografia: J. Wahl).
Fig. 4.0-11: Territorium metallorum

Tresminas /Jales, Tresminas: base de um moinho de pilões fortemente desgastada (fotografia: J. Wahl).

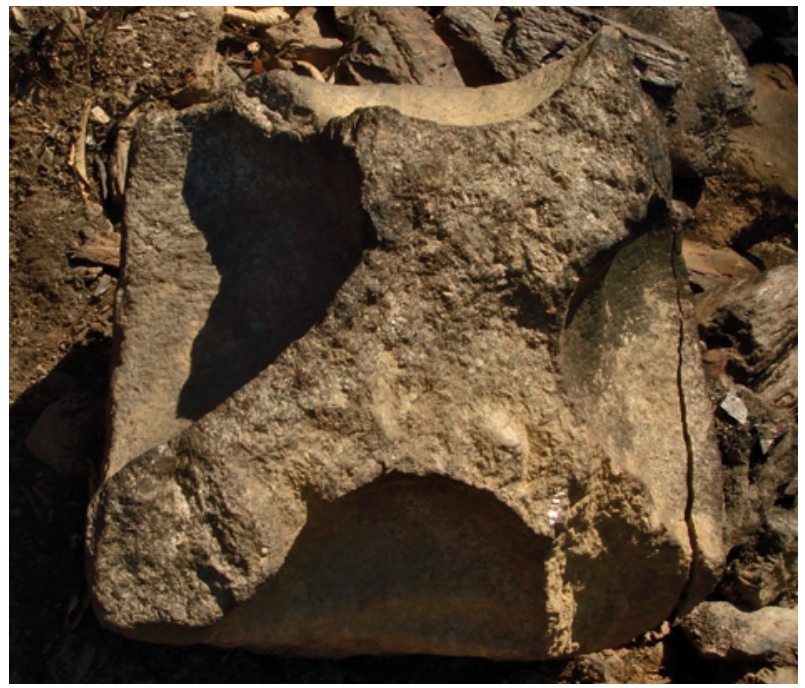

Fig. 4.0-12: Territorium metallorum Tresminas/Jales, Tresminas: uma base de um moinho de pilões partida a meio e utilizada dos quatro lados. A profundidade irregular das cavidades indica os diferentes níveis de desgaste (fotografia: R. Wahl-Clerici). 


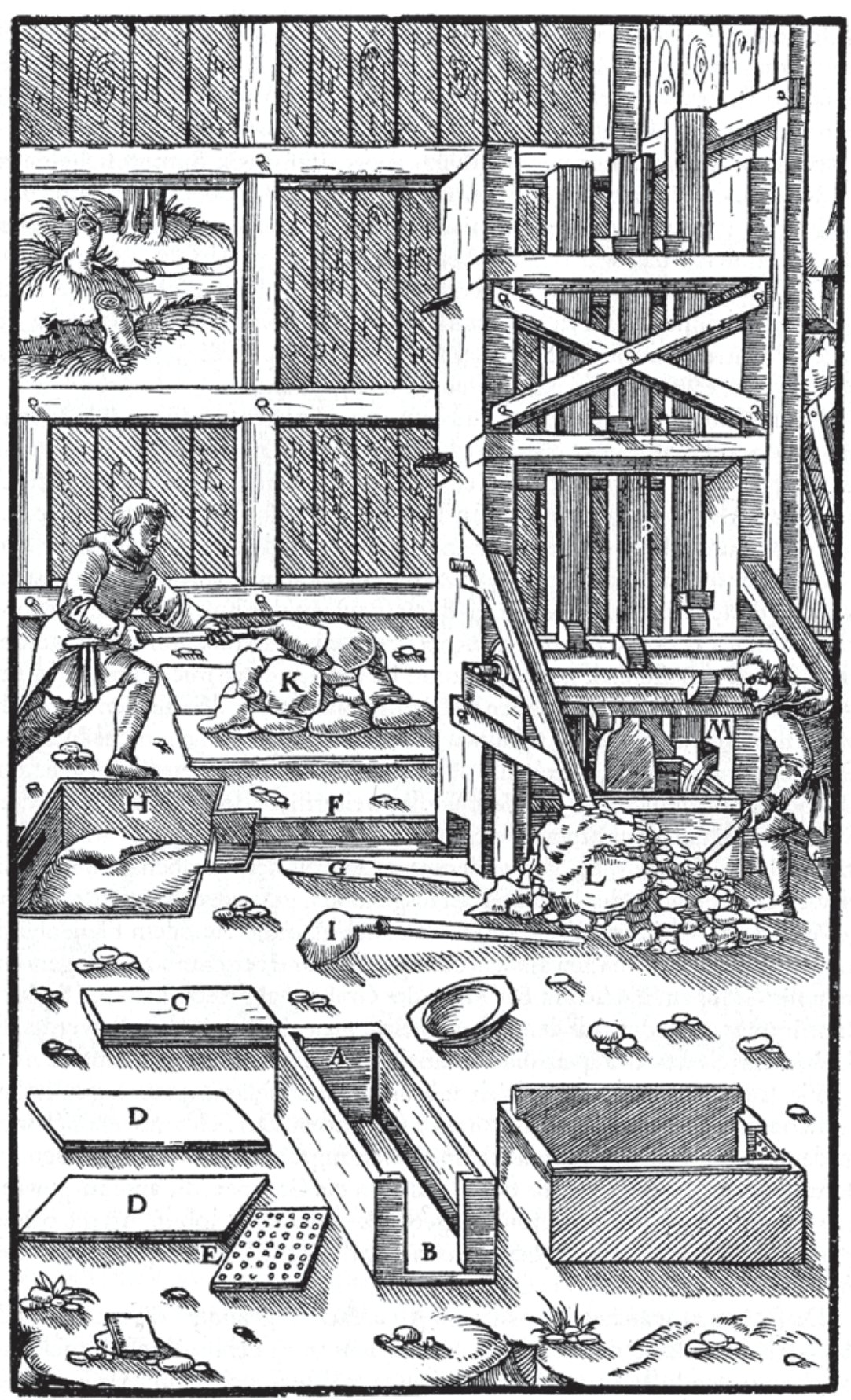

Der Pochtrog A. Die offene Seite des Pochtroges B. Der Sohlftein C. Die eiferne Pochfohle D. Das gelochte Blech E. Das Gerinne F. Die hölzerne Schaufel G. Der Sumpf H. Die ei Jerne SchaufelI. Ein Haufen gepochtes Erz K. Das Erz, welches gepocht werden foll L. Der WafferzuflußM.

Fig. 4.0-13: Representação de um moinho de pilões (segundo Agricola 1556/1984: 271). Base A; extremidade aberta da base B; laje de pedra C; placas de ferro D; peneira E; lavador F; pá de madeira G; tanque de sedimentação $H$; pá de ferro I; porção de material sedimentado K; minério que requer britagem L; pequeno lavador $M$. 


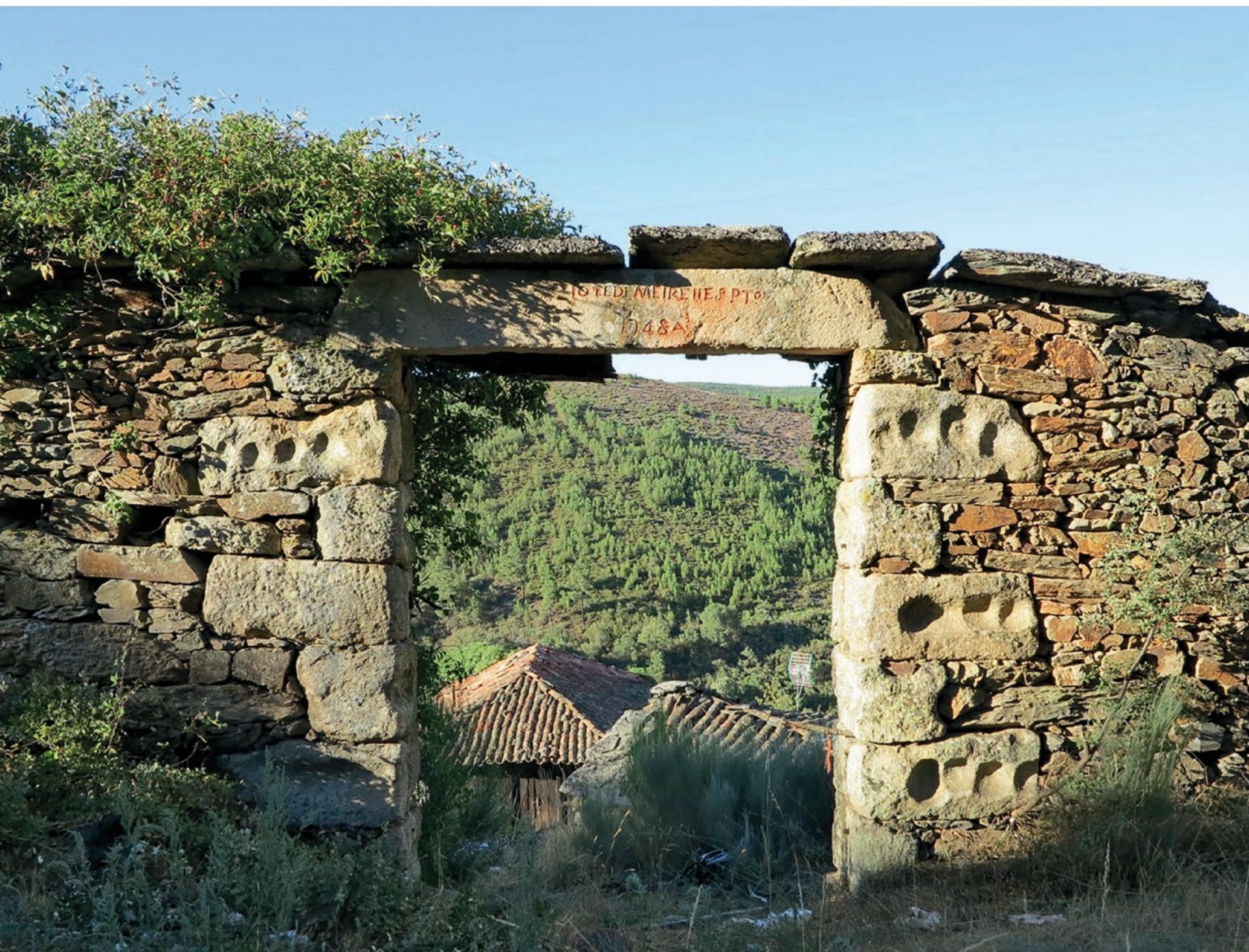

Fig. 4.0-14: Territorium metallorum Tresminas /Jales, Ribeirinha: fachada construído com bases de moinhos de pilões (fotografia: R. Wahl-Clerici). 


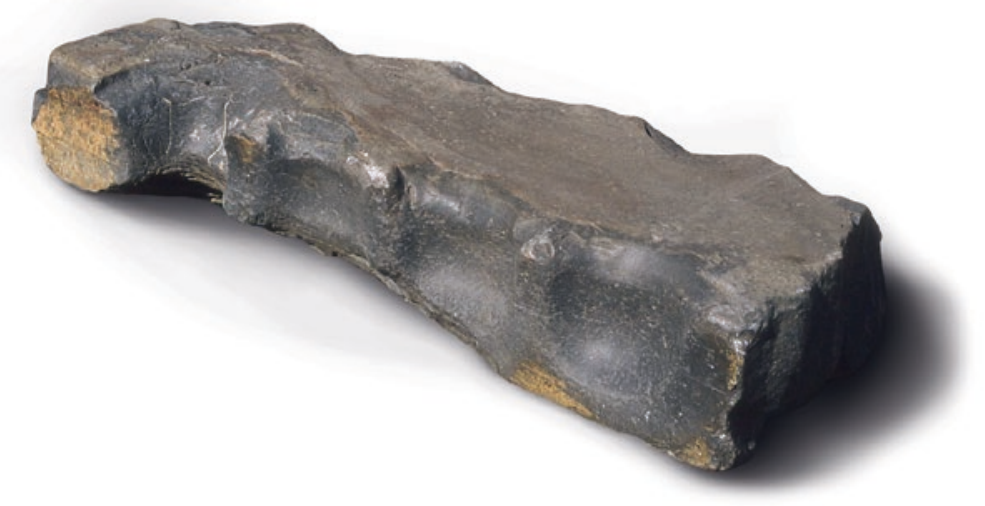

Fig. 4.0-16: Territorium metallorum Tresminas /Jales: parte de um moinho de pilões de quartzito usado de ambos os lados e reutilizado como degrau de uma escada na localidade de Covas (fotografia: $R$. Wahl-Clerici).

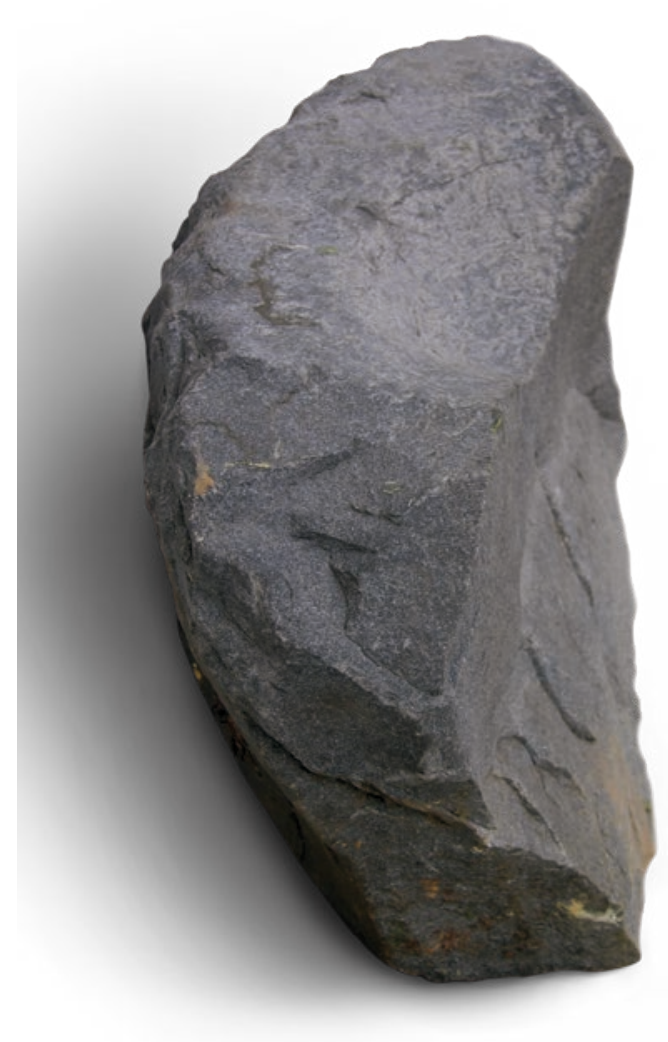

Fig. 4.0-17: Territorium metallorum Tresminas/Jales. Tresminas: fragmento da base de um moinho de pilões de quartzito (fotografia: $R$. Wahl-Clerici).

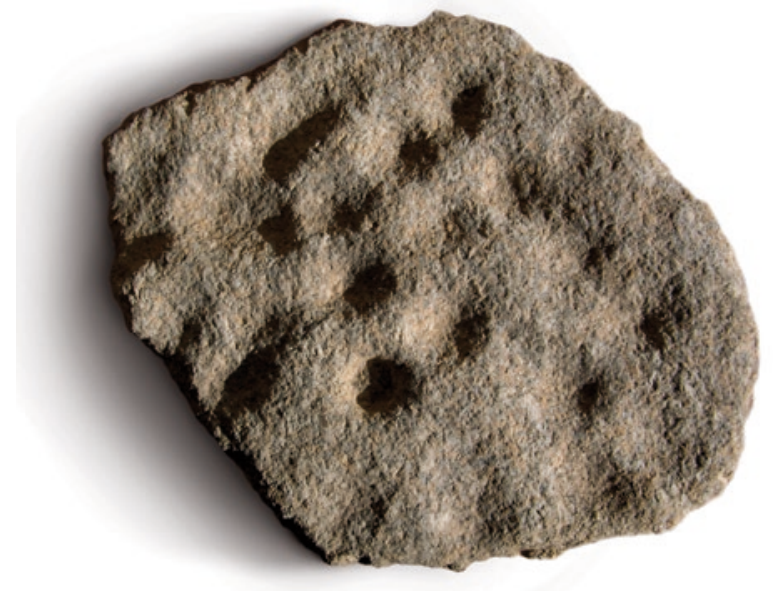

Fig. 4.0-18: Territorium metallorum Tresminas /Jales, Tresminas: mó (meta), utilizada na britagem de minério e usada como apoio para a britagem manual (fotografia: R. Wahl-Clerici). 


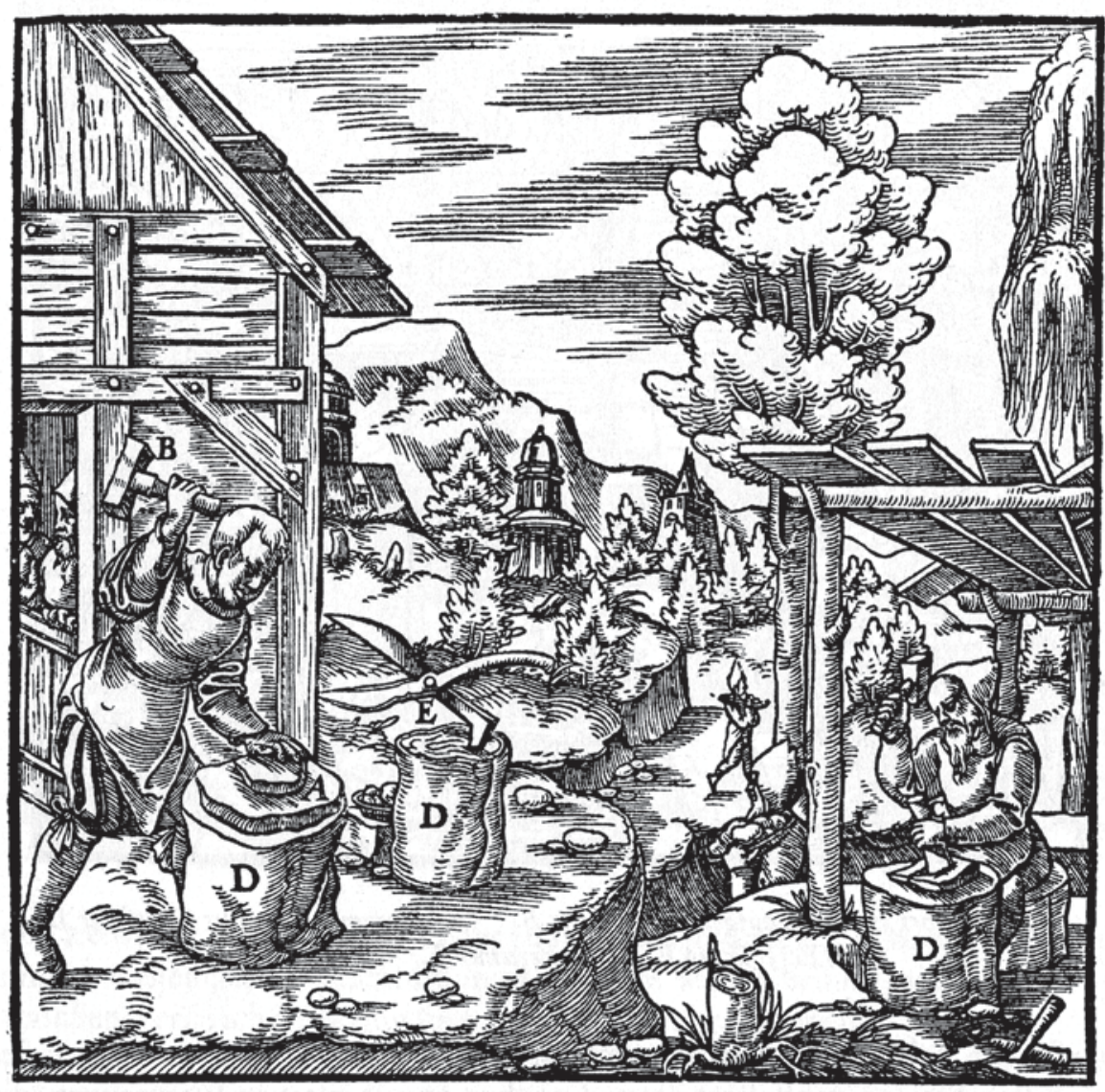

Eine Stufe Erz A. Der Quet/cher B. Der eiferne Meißel C. Der Stock D. Die Schere E.

Fig. 4.0-19: Britagem manual (Agricola 1556/ 1984: 233). Massas de metal A; martelo B; cinzel C; cepos D; ferramenta de ferro semelhante a um par de tesouras $E$. 


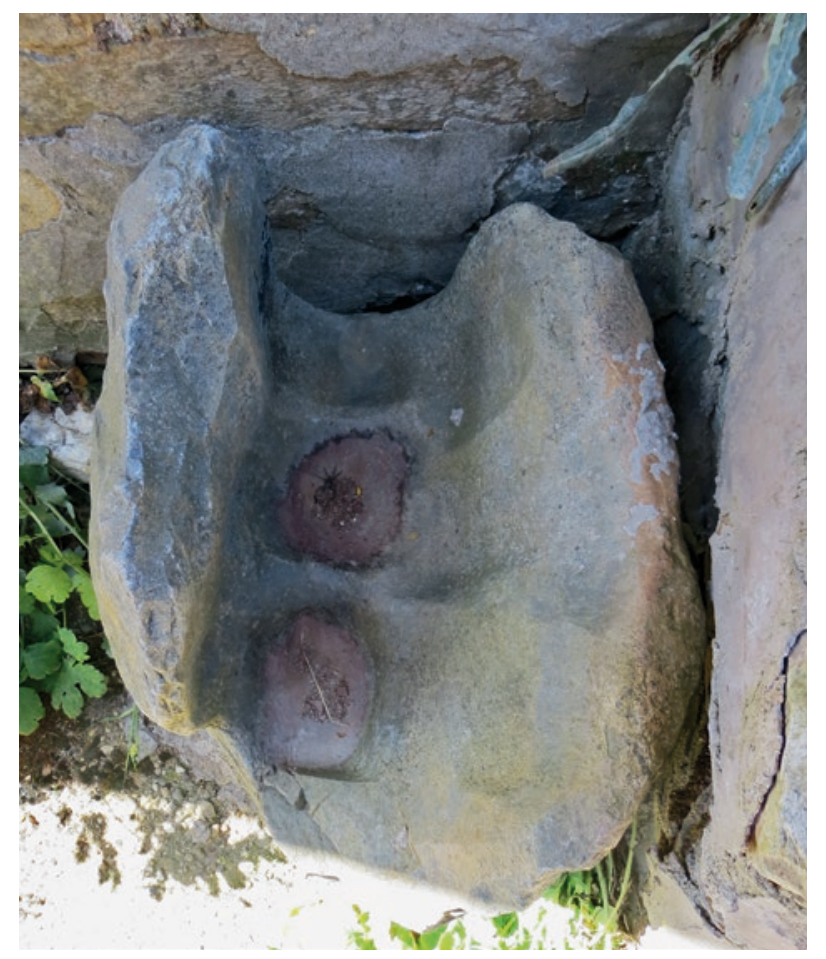

Fig. 4.0-20: Pozos (provincia de León, E): a base de um moinho de pilóes para pelo menos três pilões, fortemente desgastada (fotografia: $R$. Wahl-Clerici).

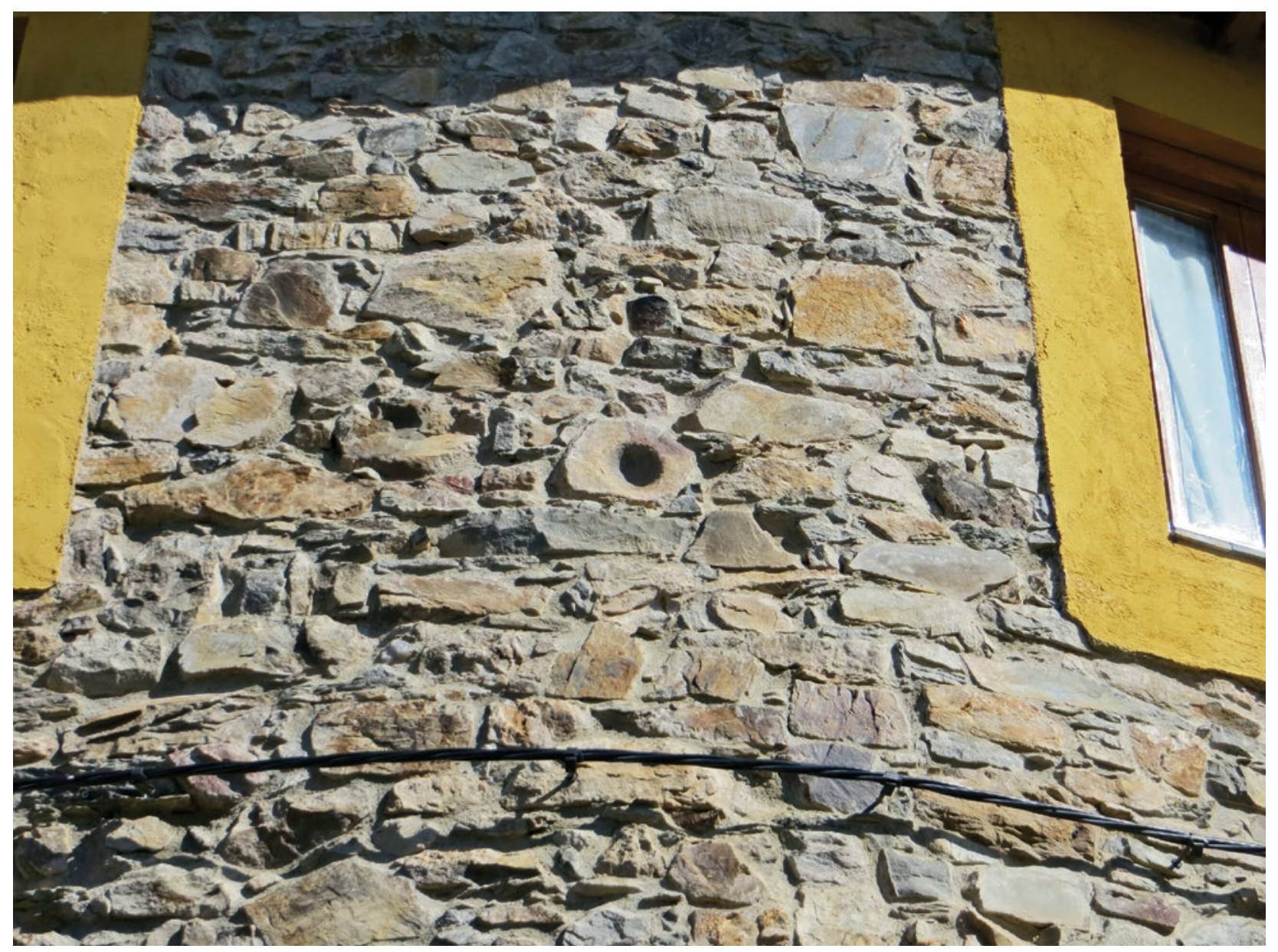

Fig. 4.0-21: Pozos (província de León, E): a base de um moinho de pilões fortemente desgastada e reutilizada na construção de uma casa (fotografia: R. WahlClerici). 


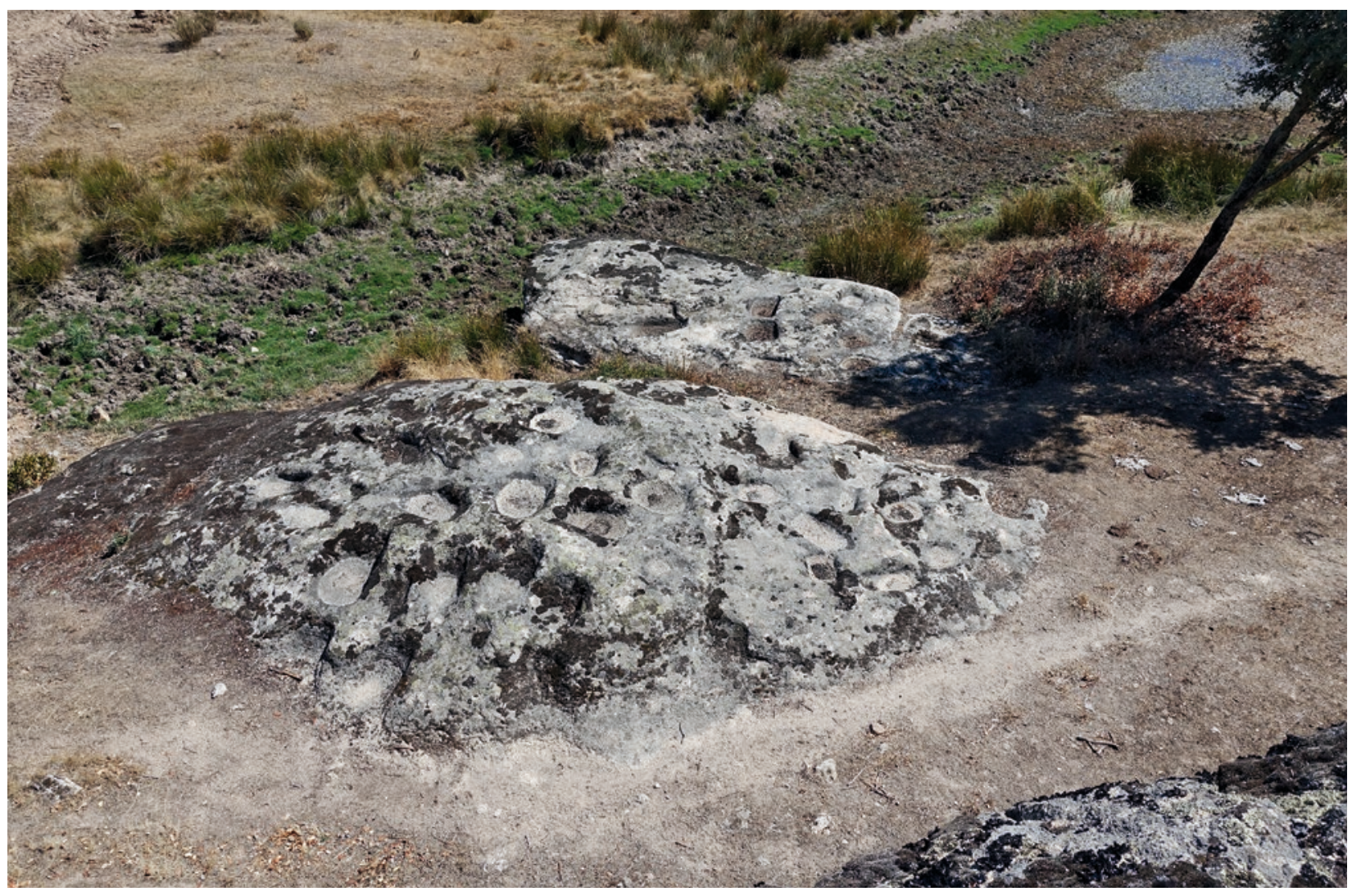

Fig. 4.0-22a: Pino del Oro (Provincia de Zamora, E): possíveis zonas para a britagem do minério extraído. Essas zonas de britagem encontram-se distribuídas por grande parte do terreno (fotografia: $R$. Wahl-Clerici).

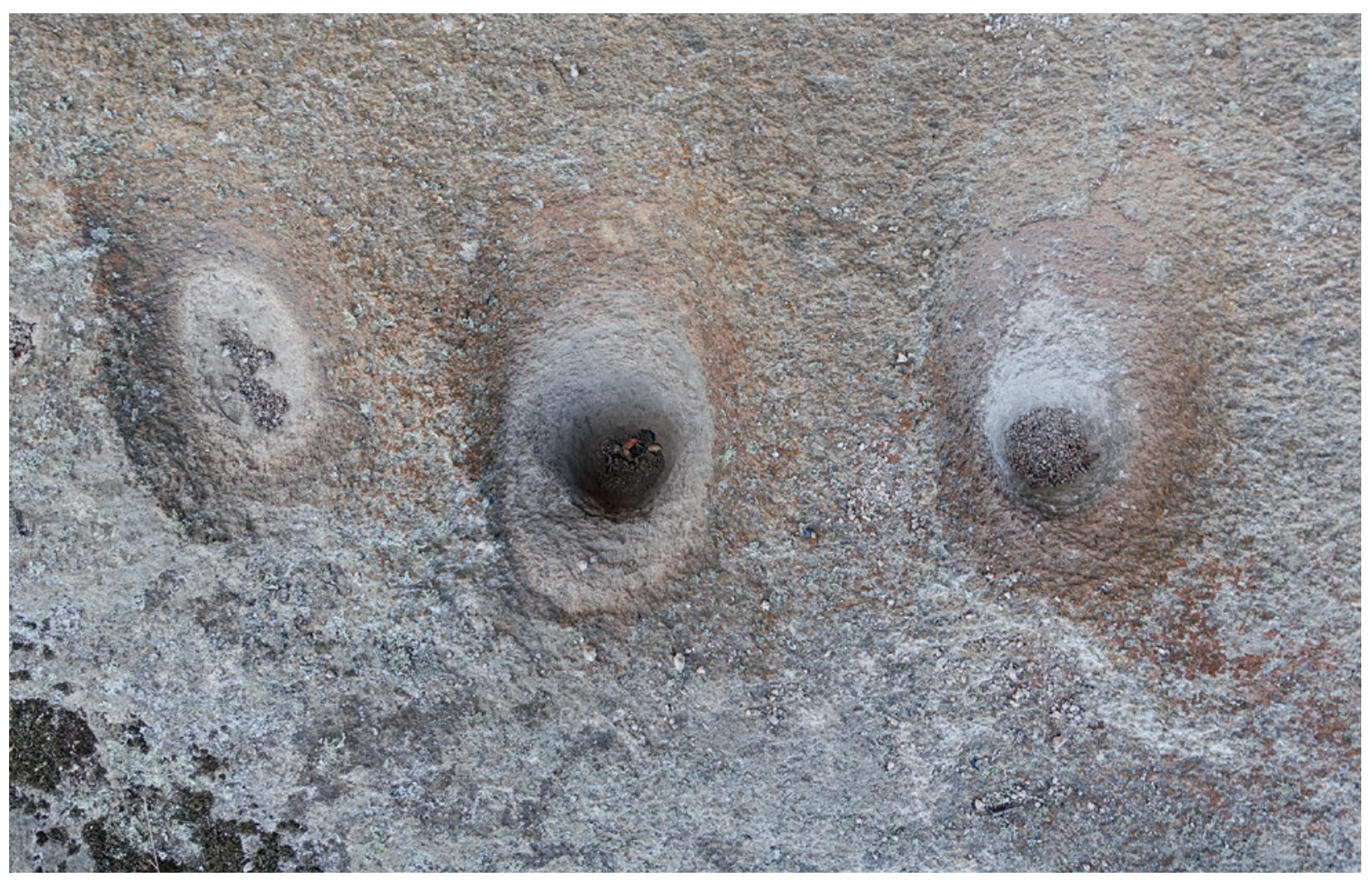

Fig. 4.0-22b: Pino del Oro (Provincia de Zamora, E): zona de britagem com cavidade ao centro (fotografia: $R$. Wahl-Clerici). 


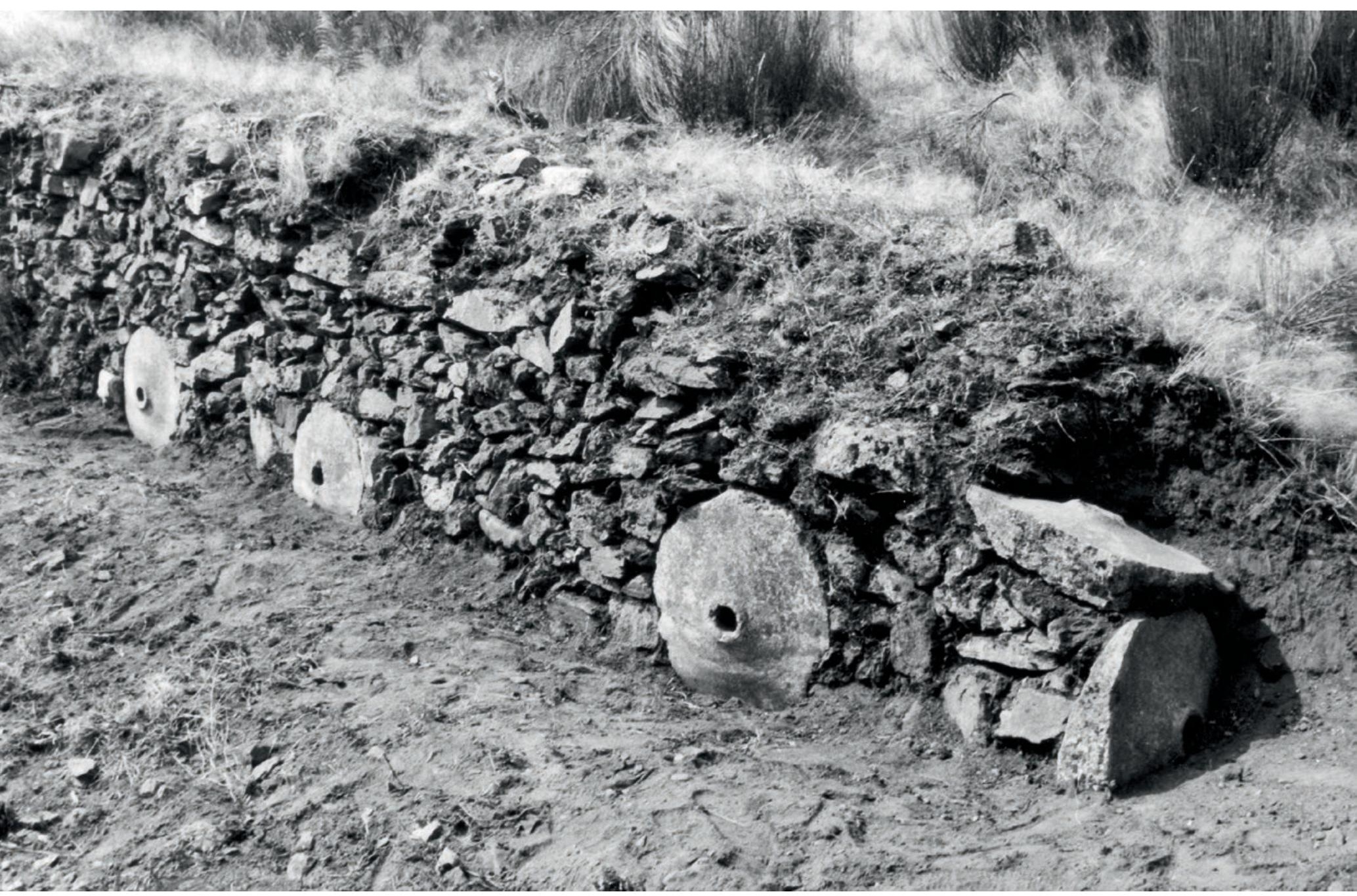

Fig. 4.0-23: Territorium metallorum Tresminas / Jales, Forno dos Mouros: parede moderna, construída com mós de moinhos para o minério (fotografia: J. Wahl). 

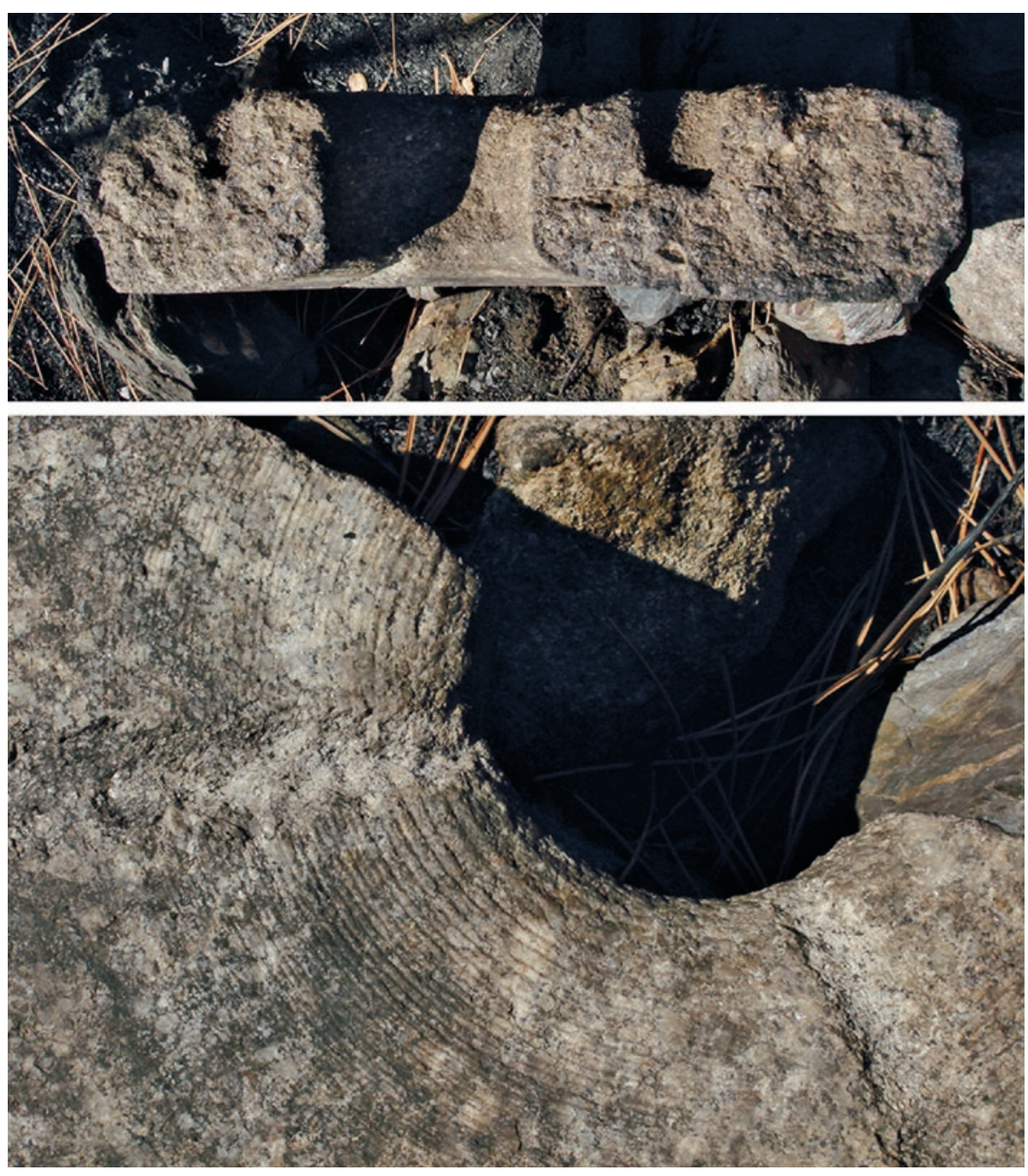

Fig. 4.0-24: Territorium metallorum Tresminas / Jales, Tresminas: mó de um moinho para minério com ranhuras de desgaste e entalhes de afiação, a) de cima, b) ponto de quebra com as cavidades para a fixação do mecanismo de acionamento bem visiveis (fotografia: $R$. Wahl-Clerici).

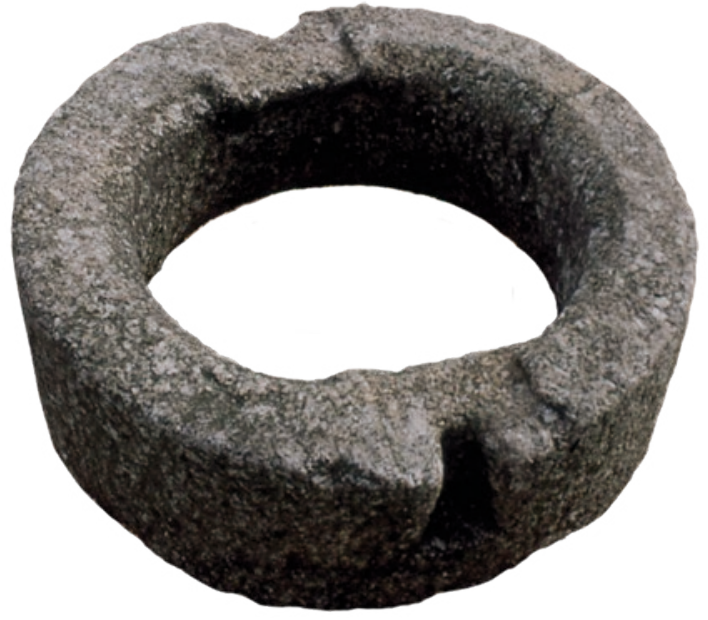

Fig. 4.0-25: Territorium metallorum Tresminas/Jales, Tresminas: uma mó de granito de um tipo diferente de moinho para a moagem posterior do minério britado, encontrada à superfície (fotografia: R.Wahl-Clerici).

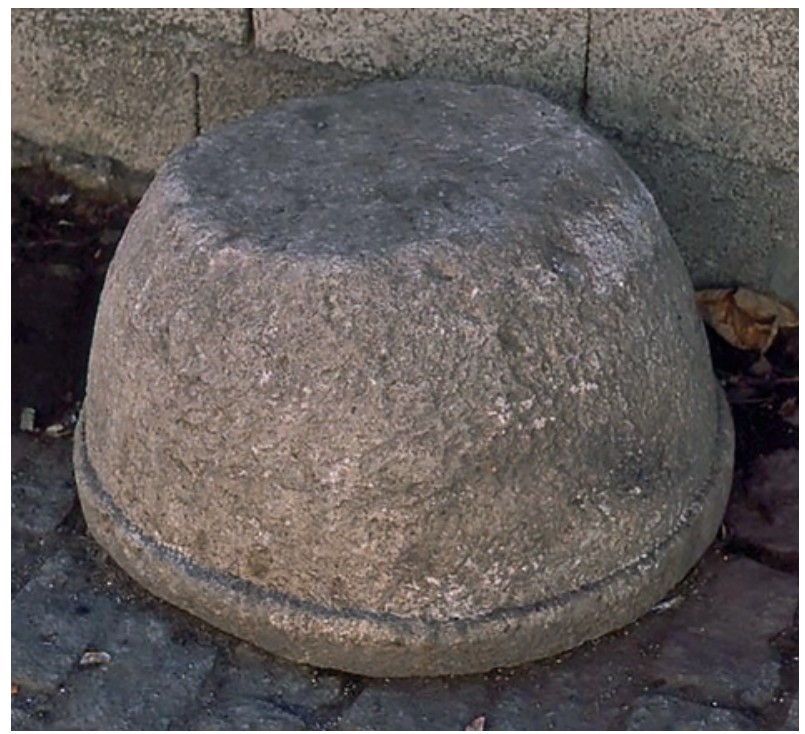

Fig. 4.0-26: Territorium metallorum Tresminas/Jales, Tresminas: uma base de mó de granito de um tipo diferente de moinho para a moagem posterior do minério britado, encontrada à superfície (fotografia: R.Wahl-Clerici). 


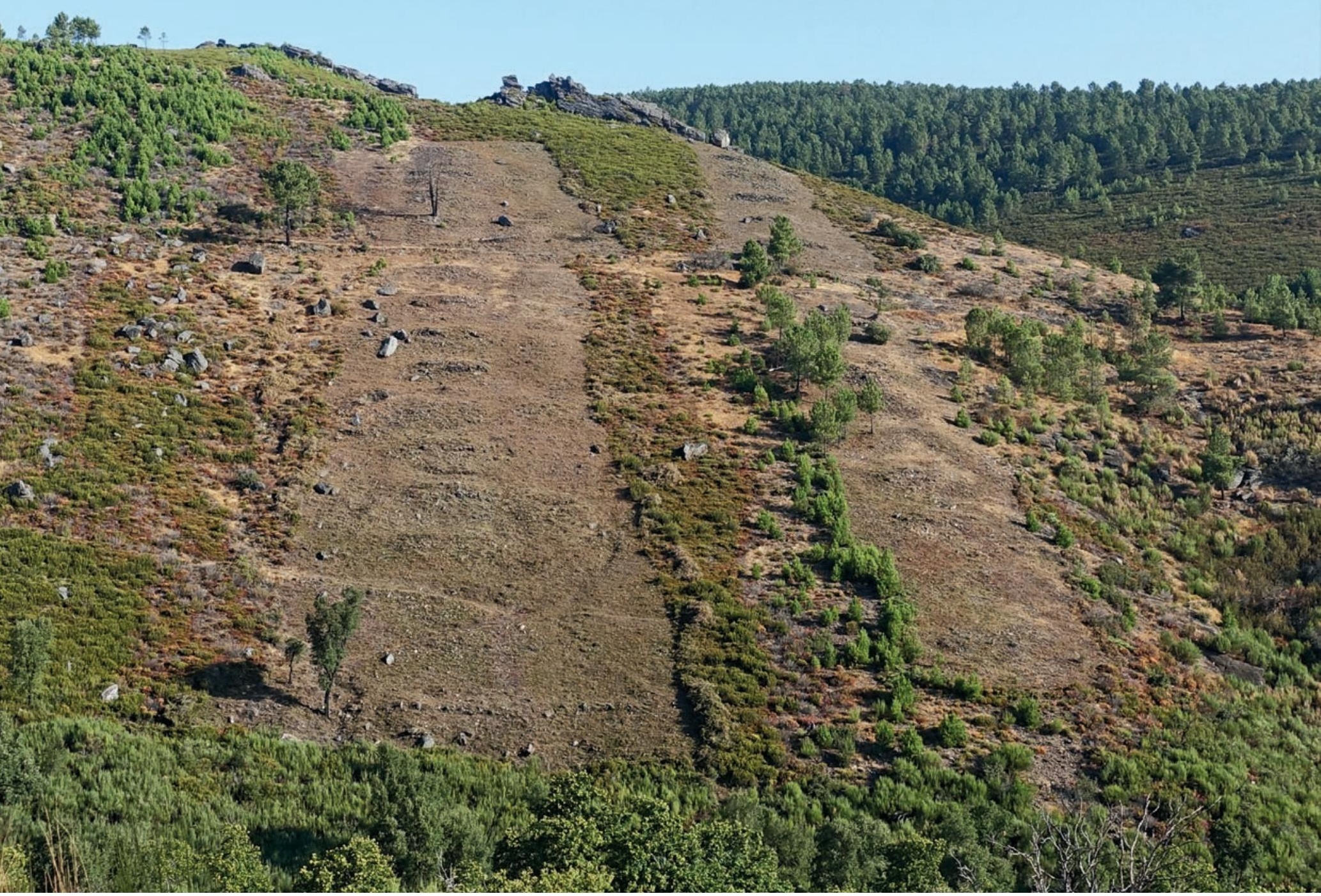

Fig. 4.0-27a: Territorium metallorum Tresminas/Jales, Tresminas: os locais de lavagem de minério, visto de sul. Em cada segunda plataforma da fila ocidental encontram-se dois tanques de sedimentação (fotografia: $R$. Wahl-Clerici). 


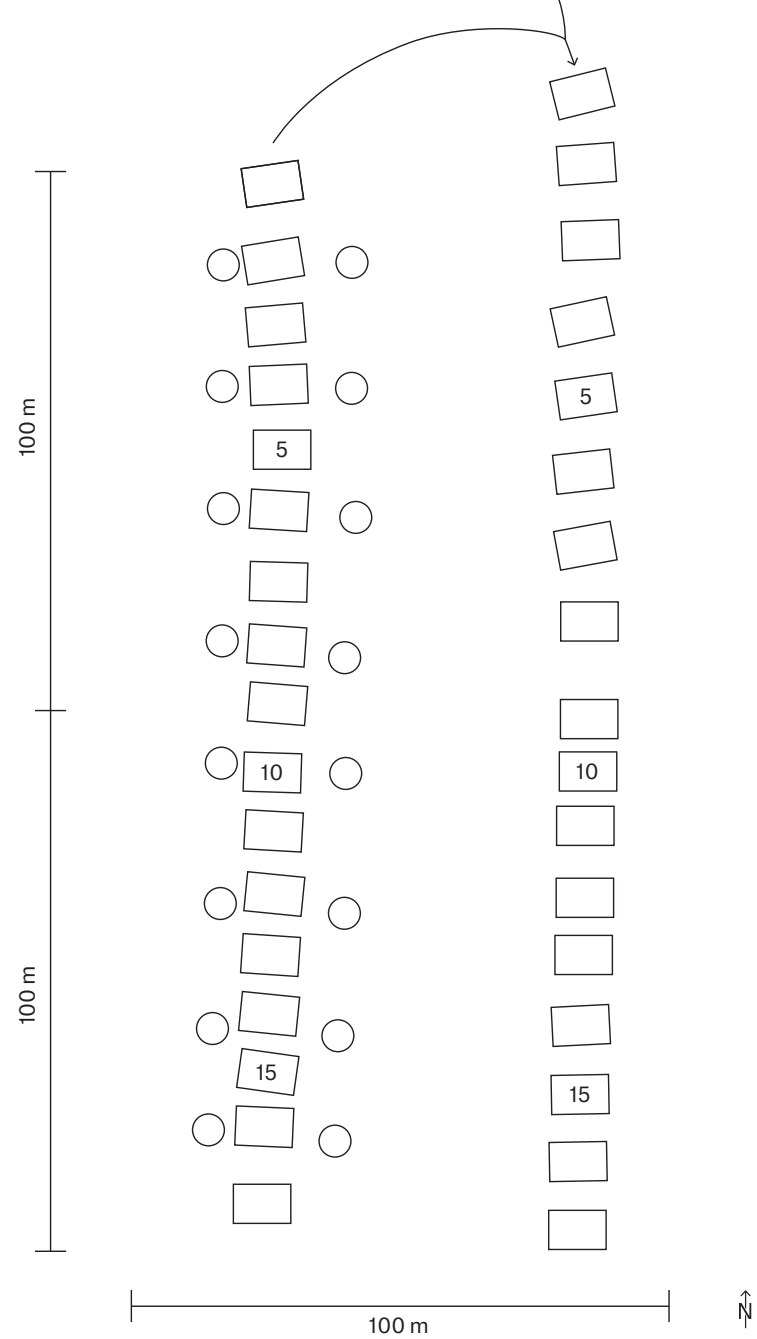

Fig. 4.0-27b: Territorium metallorum Tresminas/Jales, Tresminas: planta das plataformas das instalações de lavagem de minério (documentação: J. Wahl, R. Wahl-Clerici; desenho: R. Wahl-Clerici). , 


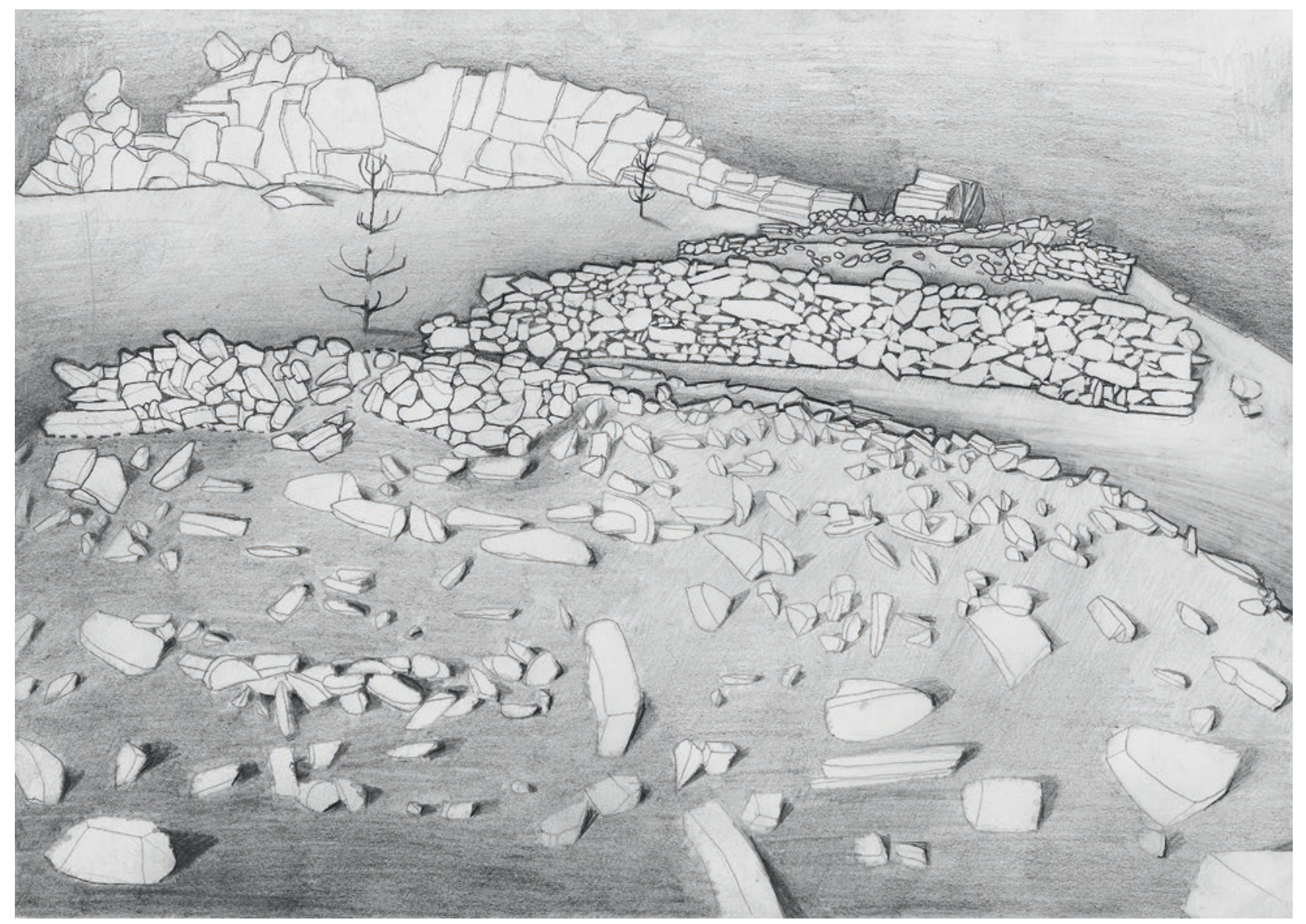

Fig. 4.0-28: Territorium metallorum Tresminas/Jales, Tresminas: as plataformas 1 - 4 (de cima para baixo) da linha leste. Ao fundo, é visivel a abertura na rocha para o abastecimento de água (fotografia: P. Moser).

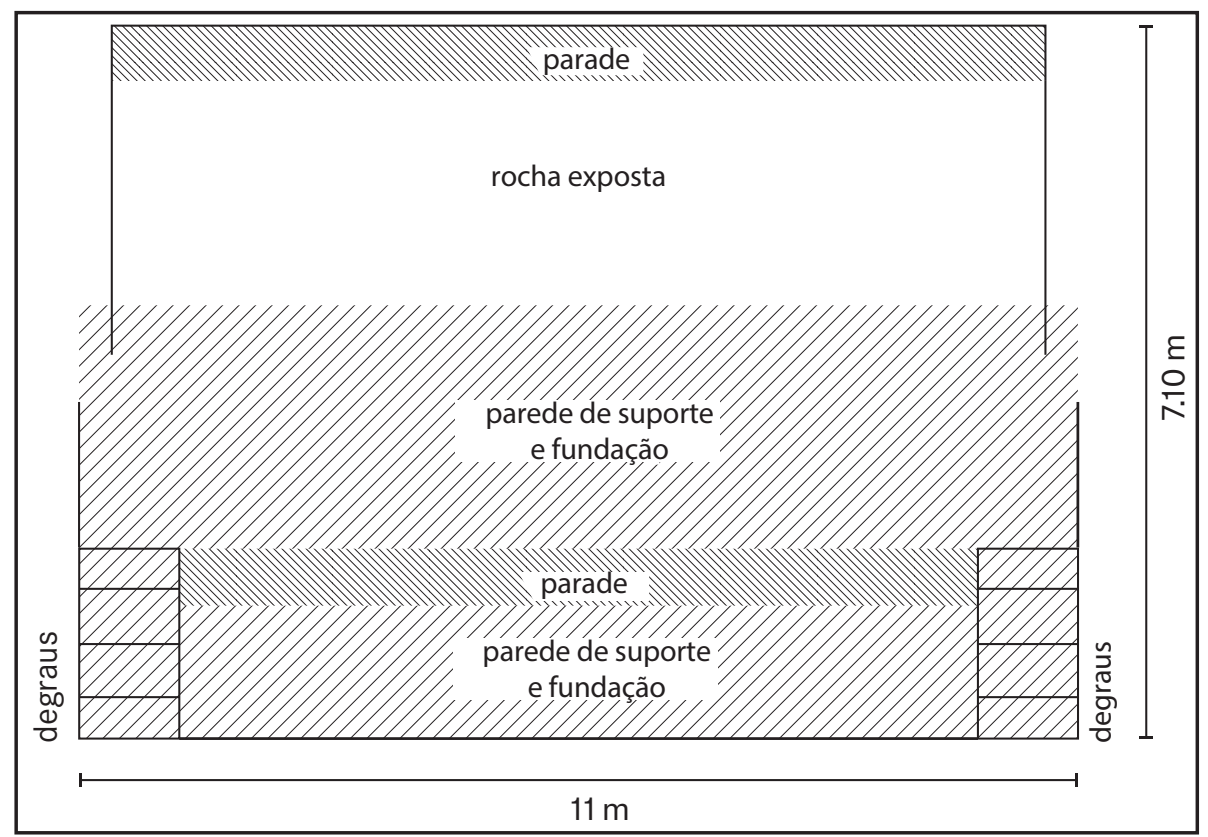

Fig. 4.0-29: Territorium metallorum Tresminas / Jales, Tresminas: planta esquematizada de uma plataforma de lavagem de minério escavada (registo: A. Wiechowski, $R$. Wahl-Clerici, desenho: $R$. Wahl-Clerici). 


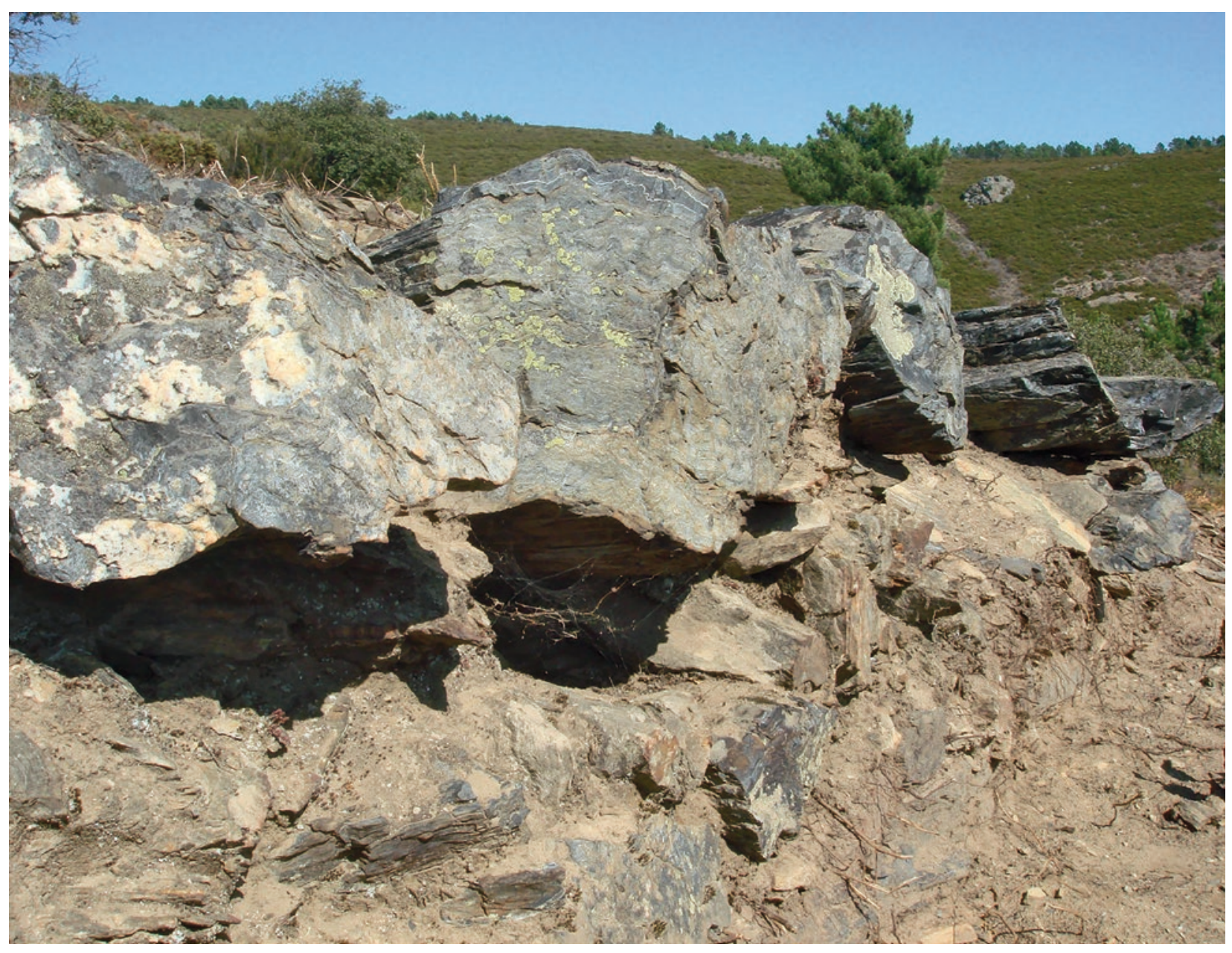

Fig. 4.0-30: Territorium metallorum Tresminas /Jales, Tresminas: parede de apoio de uma plataforma de lavagem da linha leste (fotografia: R. Wahl-Clerici) 


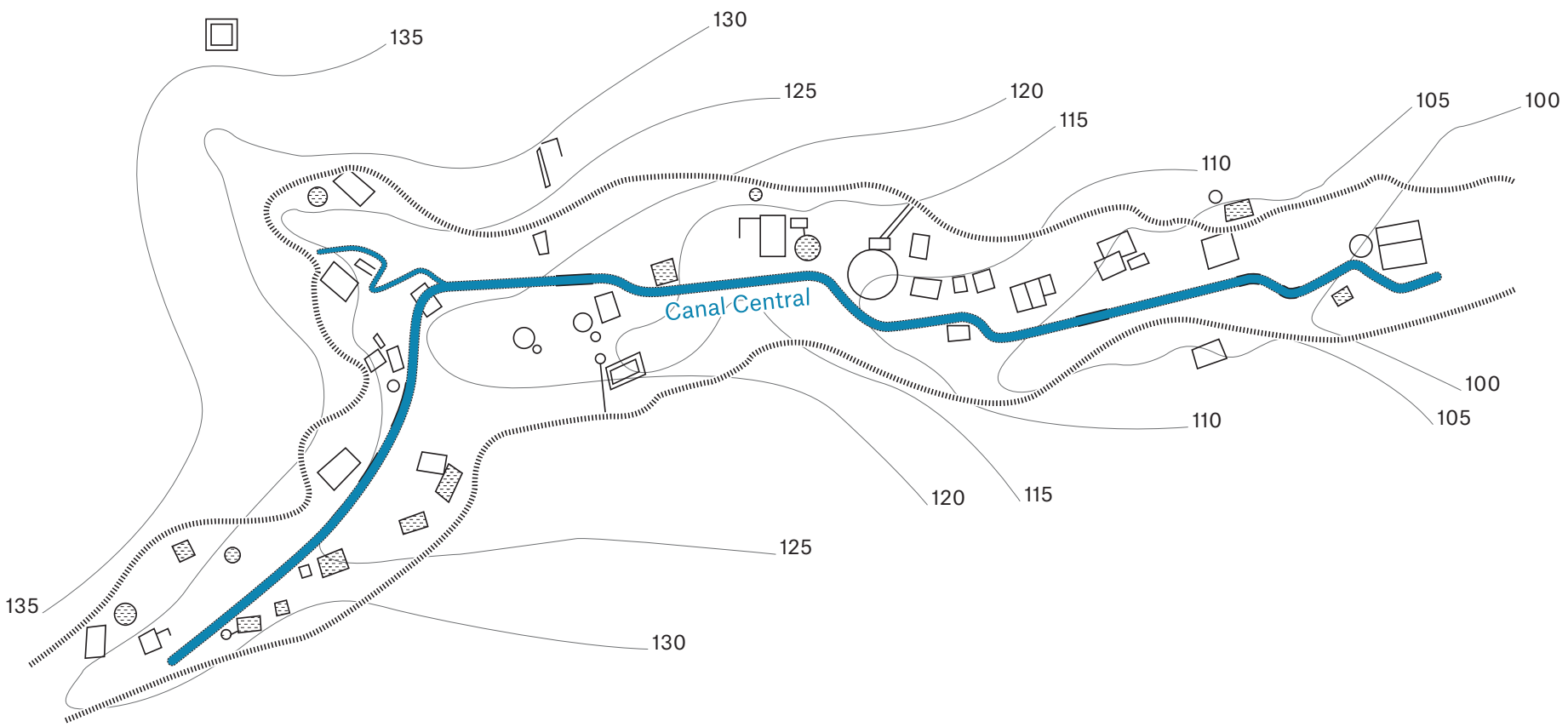

Fig. 4.0-33: Instalações de lavagem de minério das minas de prata de Laurion em Drymos (Souriza), perto de Agia Triada (Attica / GR) (segundo Daremberg/Saglio 1896, fig.5009, desenho: S.Mathiuet).
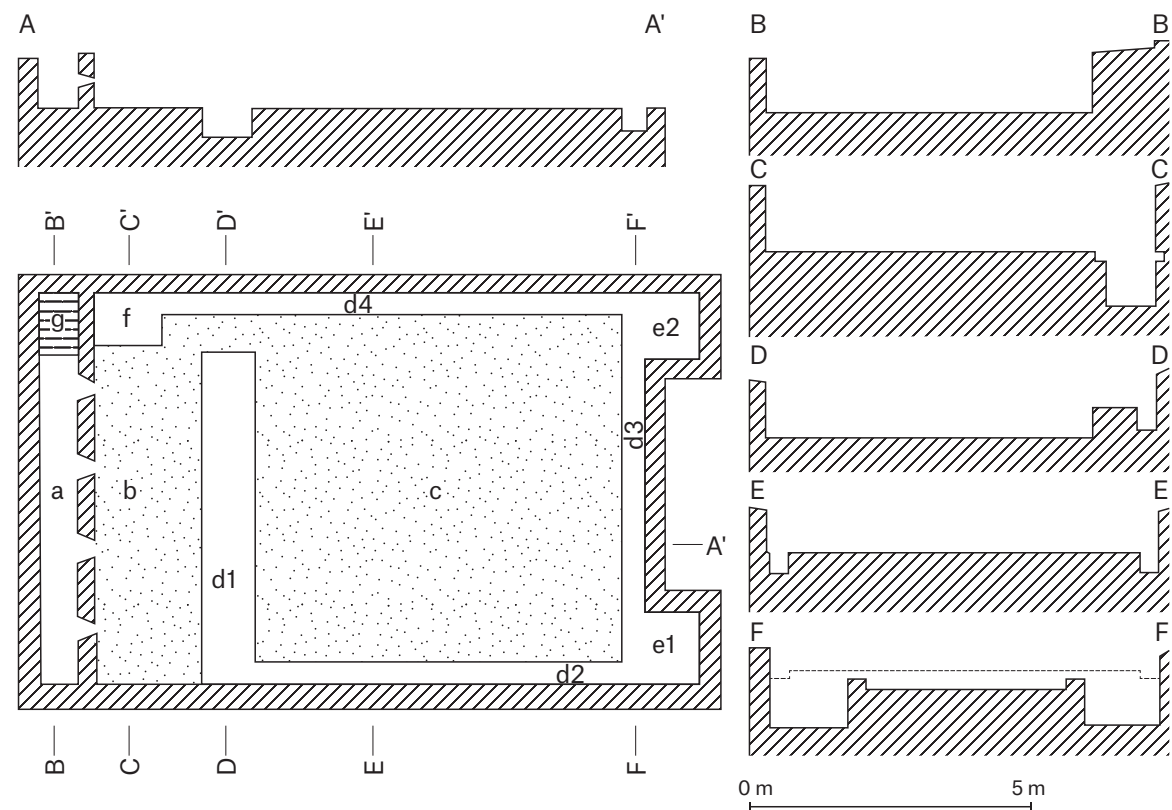

Fig. 4.0-34: Instalações de lavagem de minério das minas de prata de Laurion no vale do Drymos (Ática/ GR): plataforma de lavagem com tanques de sedimentação interligados (segundo Domergue 2008: 149 fig.92, desenho: S.Mathiuet). 


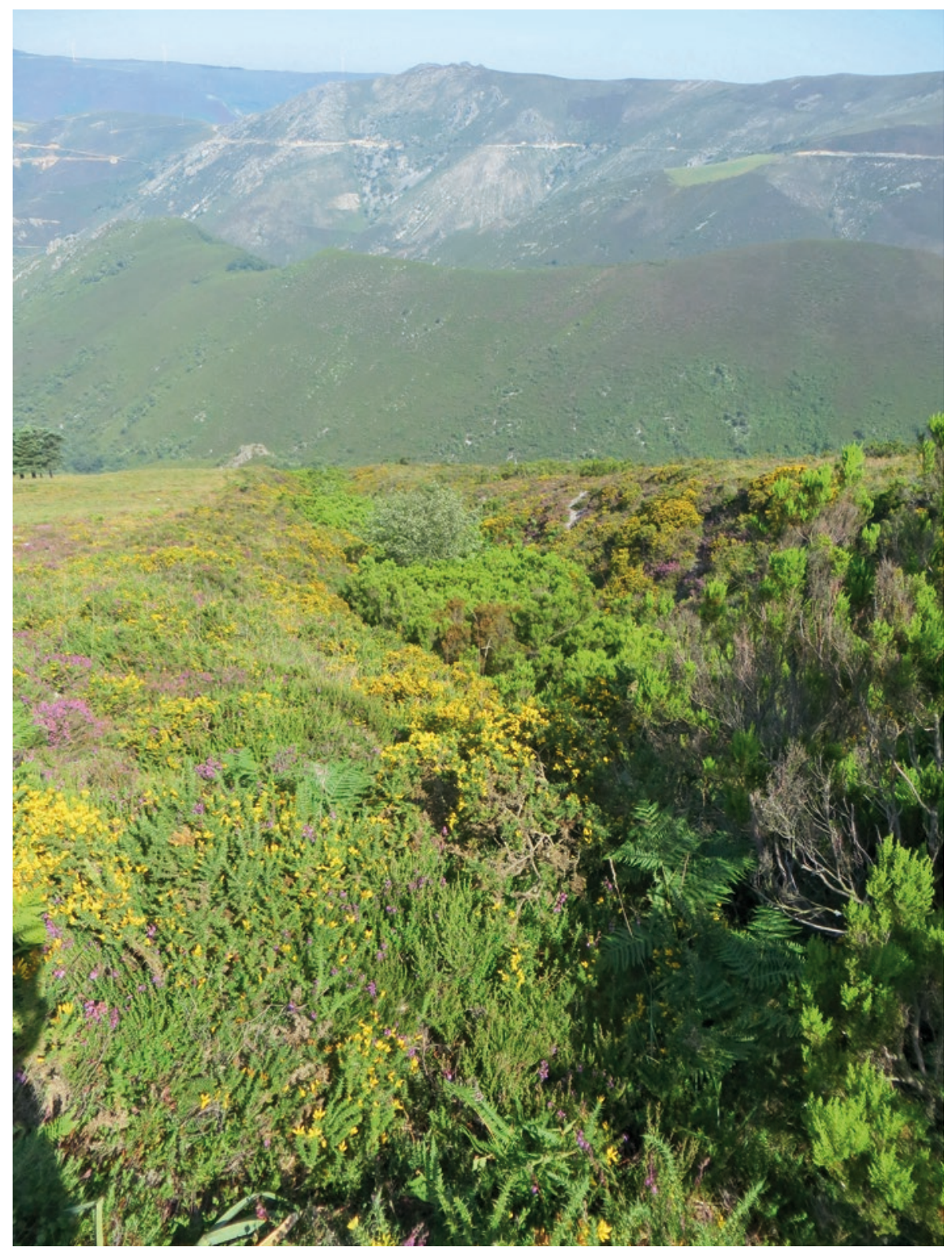

Fig. 4.0-35: Alto del Palo (Astúrias, E): instalação de lavagem do minério vista de cima. A vegetação marca os degraus individuais, ou melhor, os rebordos entre eles (fotografia: $R$. Wahl-Clerici). 

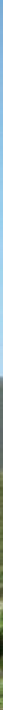

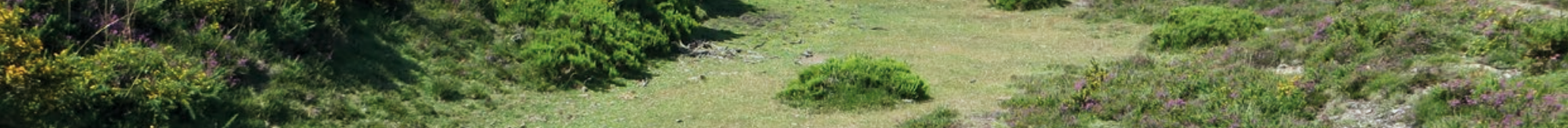

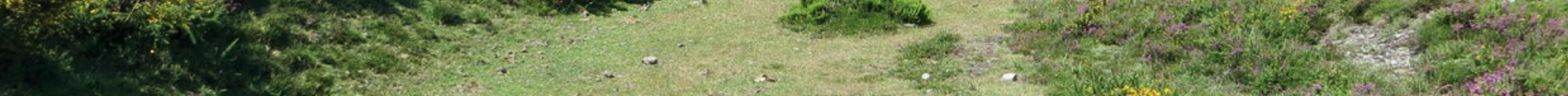
A. W.

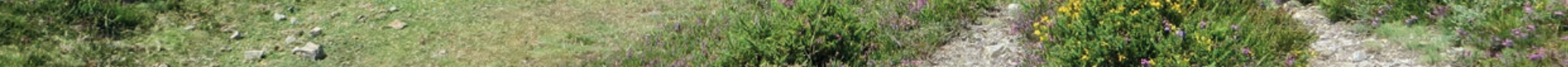

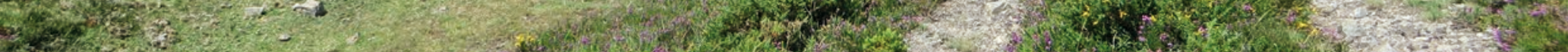

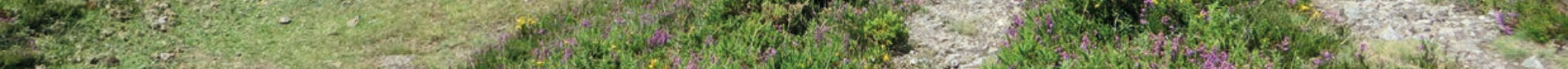
27. C.

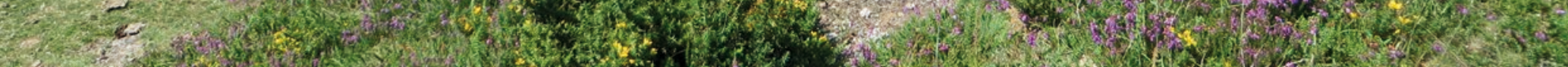

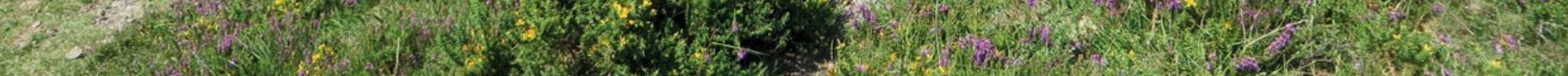
1.6.

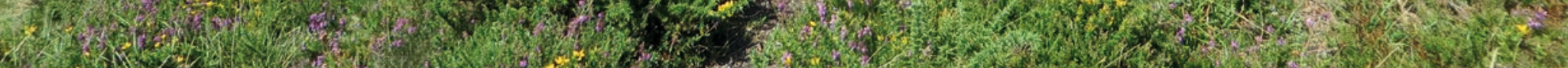
(1)

Fig. 4.0-36: Alto del Palo (Asturias, E): tanque de água acima da plataforma de lavagem (fotografia: R. Wahl-Clerici). 


\begin{tabular}{|c|c|c|c|c|c|c|c|c|}
\hline & Bachmann & Amostra 18 & Bachmann & Amostra 21 & Amostra W1 & Amostra W3 & Amostra W4 & Amostra W2 \\
\hline $\mathrm{Fe}_{2} \mathrm{O}_{3} \%$ & 28.9 & 31.88 & 37.90 & 35.01 & 35.91 & 12.52 & 24.57 & 62.00 \\
\hline $\mathrm{MnO}$ & 0.2 & 0.14 & 0.20 & 0.25 & 0.21 & 0.05 & 0.05 & 0.04 \\
\hline $\mathrm{TiO}_{2}$ & 0.4 & 0.37 & 0.30 & 0.58 & 0.58 & 0.74 & 0.58 & 0.05 \\
\hline $\mathrm{SO}_{3}$ & 2.3 & 0.54 & 4.00 & 0.69 & & & & \\
\hline $\mathrm{CaO}$ & 2.9 & 2.39 & 3.70 & 2.63 & 6.94 & 0.39 & 1.27 & 0.10 \\
\hline $\mathrm{K}_{2} \mathrm{O}$ & 2.2 & 2.09 & 2.00 & 2.71 & 3.08 & 2.91 & 2.06 & 0.18 \\
\hline $\mathrm{P}_{2} \mathrm{O}_{5}$ & 0.4 & 0.71 & 0.30 & 0.54 & 0.67 & 0.17 & 0.41 & 0.05 \\
\hline $\mathrm{Al}_{2} \mathrm{O}_{3}$ & 8.8 & 6.99 & 5.80 & 8.13 & 9.34 & 15.19 & 10.6 & 1.09 \\
\hline $\mathrm{SiO}_{2}$ & 48.5 & 40.33 & 39.50 & 49.46 & 42.74 & 50.94 & 36.96 & 3.31 \\
\hline $\mathrm{MgO}$ & 0.4 & 0.84 & 0.40 & 0.78 & 1.12 & 1.22 & 0.42 & 0.04 \\
\hline $\mathrm{Na}_{2} \mathrm{O}$ & & 1.06 & & 0.76 & 0.39 & 0.26 & 0.19 & 0.06 \\
\hline $\mathrm{ZnO}$ & 1.6 & 1.95 & 2.50 & 0.31 & 1.27 & 1.25 & 1.14 & 0.72 \\
\hline $\mathrm{PbO}$ & 2.6 & 3.12 & 2.50 & 0.99 & 3.70 & 4.70 & 4.70 & 4.59 \\
\hline $\mathrm{CuO}$ & 0.3 & 1.46 & 0.30 & 0.15 & 0.16 & 0.32 & 0.41 & 4.33 \\
\hline $\mathrm{As}_{2} \mathrm{O}_{3}$ & 0.1 & 1.4 & 0.10 & 0.02 & 0.05 & 0.1 & 0.16 & 0.32 \\
\hline Loi\% & & 4.61 & & 3.2 & -3.38 & 2.94 & 10.58 & 13.36 \\
\hline Au ppm & & 7.4 & & 5.4 & 1.1 & 13 & 43 & 2.4 \\
\hline $\mathrm{Ag}$ & & 188 & & 20 & 52.4 & 255 & 312 & 550 \\
\hline $\mathrm{Ba}$ & & $<5$ & & 90 & 454 & 671 & 326 & 31 \\
\hline $\mathrm{Ni}$ & & 21 & & 23 & 13 & 18 & 17 & 337 \\
\hline Co & & 38 & & 20 & 7 & 6 & 5 & 38 \\
\hline $\mathrm{Cr}$ & & 18 & & 22 & 29 & 72 & 40 & 12 \\
\hline Cs & & 7 & & 11 & 14 & 20 & 10 & $<0.5$ \\
\hline $\mathrm{Hf}$ & & 5 & & 6 & 5 & 3 & 4 & $<0.5$ \\
\hline $\mathrm{Rb}$ & & 100 & & 140 & 211 & 175 & 129 & 47 \\
\hline $\mathrm{Sb}$ & & 500 & & 62 & 537 & 427 & 846 & 320 \\
\hline Sc & & 6.5 & & 7.2 & 8 & 14 & 10 & 0.5 \\
\hline $\mathrm{Ta}$ & & 96 & & 290 & 88 & 21 & 62 & 2.4 \\
\hline $\mathrm{Ce}$ & & 350 & & 210 & 58 & 71 & 46 & $<0.3$ \\
\hline
\end{tabular}

Fig. 4.0-38: Territorium metallorum Tresminas /Jales, Forno dos Mouros: análise de escória por XRF e ativação de neutrões (tabela: A. Wiechowski). 


\subsection{Locais de tratamento do minério}

Tresminas é notável entre as minas romanas, porque a partir dos achados nas áreas de tratamento podemos identificar tanto os locais como os processos com os quais o minério foi tratado para extrair o ouro. É possível identificar com absoluta certeza como locais de tratamento o Forno dos Mouros e as instalações de lavagem. Na área de desmonte de Tresminas foi ainda possível identificar outros locais de tratamento.

\section{Forno dos Mouros}

O Forno dos Mouros está seguramente associado às zonas de extração da Gralheira (fig. 4.0-2), conforme indica a proximidade da Galeria Minhoteira. O local de tratamento situa-se cerca de $300 \mathrm{~m}$ a montante do rio onde existe um alargamento do vale. ${ }^{188}$ Não é possível afirmar com segurança se era neste espaço que era tratado todo o minério extraído na Gralheira e Campo de Jales, até porque a configuração de toda a área se apresenta substancialmente alterada em consequência da exploração mineira do século XX.

Partindo dos vestígios que se preservaram no Forno dos Mouros podem comprovar-se os processos de britagem e moagem, bem como os de fundição (figs. 4.1-1, 4.0-23 e 4.0-37). As provas da lavagem do minério já tratado a seco e a repetição da britagem das escórias ricas são fornecidas não só pelas investigações de Bachmann (abordadas acima no contexto do processamento do minério), mas também pelo aqueduto que transportava a água do Ribeira da Peliteira para a área.

Na zona localizada abaixo do Forno dos Mouros, bem como no campo de cultivo situado na margem do rio, foram detetados altos teores de arsénio e chumbo (até 1,3 peso\% e 0,3 peso\%) atribuídos aos resíduos da mineração (fig. 4.12), criados em parte do fumo resultante do aquecimento do minério. Os valores anormalmente elevados de arsénio são mais uma prova de que o Forno dos Mouros era um local de tratamento e fundição do minério. ${ }^{189}$

\section{Locais de tratamento na área de exploração de Tresminas}

Em Tresminas podem-se identificar vários locais de tratamento (fig. 4.0-3). Nitidamente visíveis são as instalações de lavagem que se estendem no outro lado do vale ao longo da encosta a norte da Corta de Covas (figs. 4.0- 27a/b/c-4.0-31, 4.1-3 e 3.4-2). Mesmo que os resíduos dos processos de tratamento mecânico a seco estejam espalhados por toda a zona mineira, as notáveis concentrações de vestígios apontam no sentido de existirem pelo menos sete locais onde o minério era britado e moído. Mais difícil de localizar são os locais de fundição do minério. Numa das áreas de tratamento encontraram-se fragmentos de uma escória rica em prata resultante da cementação. O achado poderá significar que no mesmo local se processava uma fase posterior de tratamento. É interessante referir que no mesmo local de tratamento se identificaram ainda restos de um canal com um máximo de $45 \mathrm{~cm}$ de largura, que não é atribuível a qualquer um dos aquedutos principais. Muito provavelmente estaria relacionado com trabalhos de tratamento do minério.

Os locais de tratamento do minério caracterizam-se pela presença de vários achados e respetivos contextos, que podem ser vestígios de instalações necessárias para o efeito, tais como restos de bases de moinhos de pilões e mós, ou resíduos resultantes do processo de tratamento, tais como escórias.

Por conseguinte, os pontos para definir um local de tratamento do minério são os seguintes:

- Concentração considerável de bases de moinhos de pilões e mós, completas ou em fragmentos (figs. 4.0-3, 4.0-24, 4.1-1, 4.1-4-4.1-6).

- Grande acumulação de resíduos resultantes deste processo de tratamento (por exemplo, pedras pequenas nas escombreiras diante da abertura da Galeria do Pilar) (fig. 3.4-2).

- Vestígios de processos específicos de tratamento (por exemplo, as instalações de lavagem em Tresminas ou a escombreira no Forno dos Mouros) (figs. 4.0$27 \mathrm{a} / \mathrm{b} / \mathrm{c}-4.0-31)$

- Instalações de fornecimento de água (figs. 4.1-3).

- Fragmentos de escórias que só podem resultar de processos de tratamento (por exemplo, a escória rica em prata de Tresminas, no Forno dos Mouros).

Relativamente aos dois primeiros pontos, deve especificar-se que a concentração de bases de moinhos por si só não é suficiente para identificar um local de tratamento, uma

188 A Galeria Minhoteira, originalmente da época romana, foi utilizada para prospeção nos anos de 90 do século XX, tendo sido alargada e aumentada mediante a abertura de pequenas galerias laterais. 189 Wahl-Clerici/Wiechowski 2012, 335. 
vez que as bases aproveitáveis foram levadas para as aldeias vizinhas em tempos pós-romanos, onde viriam a servir de material para a construção civil (vide figs. 4.0-9 e 4.0-14). Ou seja, para identificar um local de tratamento, para além da existência de bases de moinhos, é essencial a sua localização relativamente à zona de extração. Por exemplo, na zona de entrada da Galeria dos Alagamentos, só se encontraram quatro ou cinco mós circulares, mas a sua localização é suficiente para se concluir que lá existiu um local de tratamento de minério. Bastavam poucas mós para moer a pequena quantidade de minério deste local (fig. 4.1-4). ${ }^{190}$

Igualmente importante é a concentração de bases de moinhos e mós circulares encontradas na zona da entrada da Galeria Jürgen Wahl, pois confirma a importância deste túnel para a exploração a céu aberto (fig. 4.1-5). ${ }^{191}$ Além disso, o aqueduto $\mathrm{T} 4$ terminaria provavelmente nesta área, o que é um indício de que aqui existiram instalações de lavagem numa fase inicial do desmonte, provavelmente ainda em meados do século I d. C. Aliás, até agora ainda não foi possível comprovar arqueologicamente a sua existência, possivelmente devido à escombreira que lá se encontra e ao seu desmoronamento. Do exposto pode concluir-se que as instalações de lavagem na encosta a norte da Corta de Covas são mais recentes.

É possível identificar outro local de processamento, provavelmente relacionado com um acesso anterior à zona sul de extração da Corta de Covas, a partir da combinação de bases de moinhos de pilões, moinhos para minério, o abastecimento de água e as escórias de prata encontrados no local (fig.4.0-3).

Revestem-se ainda de especial interesse quatro nichos situados na encosta norte da Corta da Ribeirinha, uma vez que abaixo dos mesmos se encontrou uma grande concentração de bases de moinhos e fragmentos de mós. Perante isto, pode concluir-se que eram antigos locais de tratamento do minério (fig. 4.1-6). Os vestígios recolhidos comprovam que, em princípio, o minério era tratado o mais próximo possível do local de extração. É esse o caso das três bases de moinhos encontradas na Corta da Ribeirinha e dos vários fragmentos de bases de moinhos e mós encontrados acima do atual caminho.
190 É possível que o moinho redondo reutilizado como base de moinho de pilões também tenha tido origem na área de entrada da Galeria dos Alargamentos, ver fig.4.0-19.

191 Ao percorrer atentamente a zona a leste e a baixo da abertura da galeria, A. Wiechowski e a autora encontraram mais de 300 fragmentos de mós e bases de moinhos à superfície das escombreiras, tendo uma parte desses exemplares sido utilizada em época recente para a construção das paredes dos socalcos. 


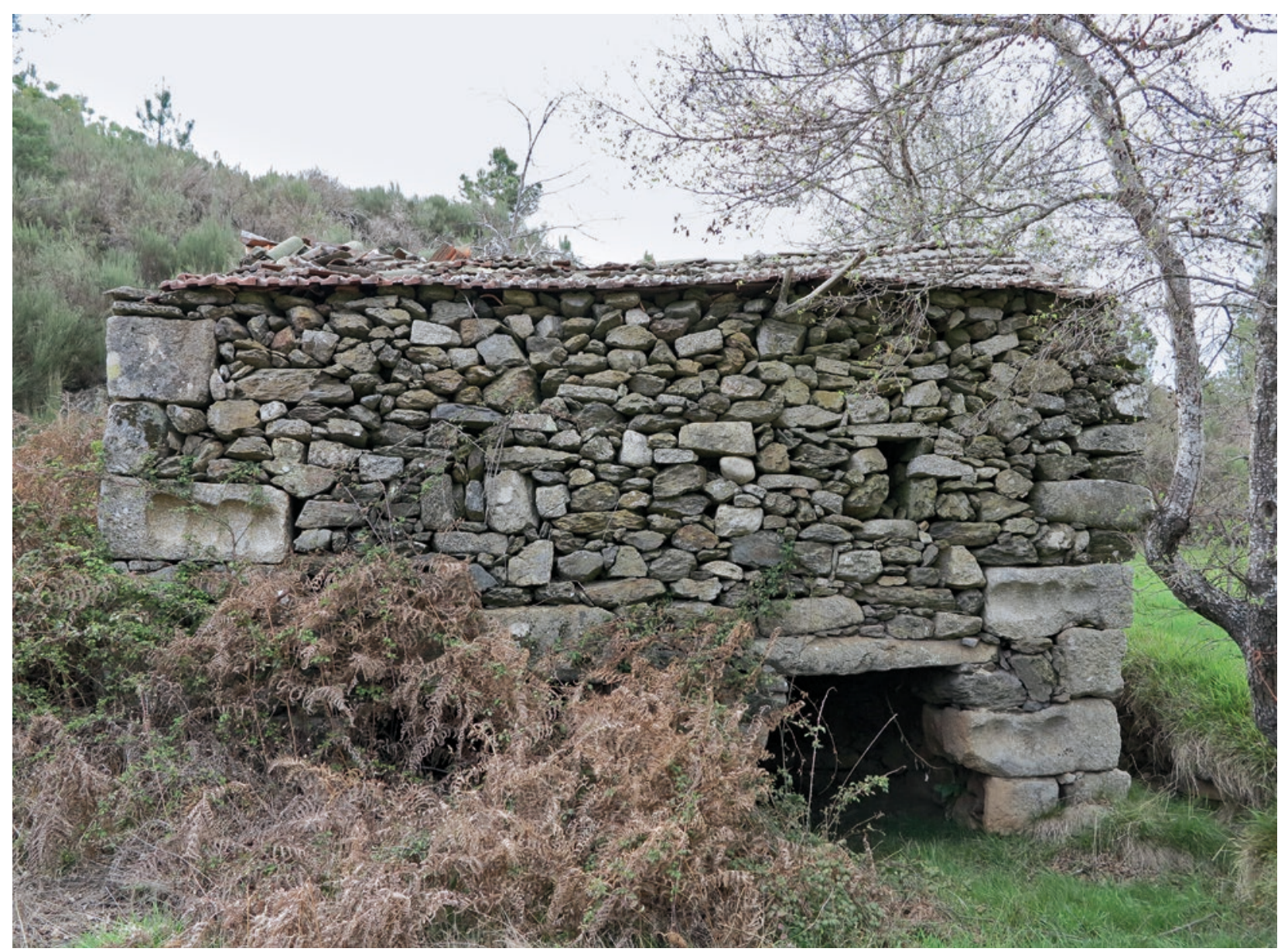

Fig. 4.1-1: Territorium metallorum Tresminas / Jales, Forno dos Mouros: um moinho moderno, construído com alguns moinhos de pilões romanos (fotografia: R. Wahl-Clerici).

\begin{tabular}{llll}
\hline $\begin{array}{l}\text { Elementos } \\
\text { vestigiais }\end{array}$ & Amostra 1 & Amostra 2 & Amostra 3 \\
\hline $\mathrm{As}$ & 590 & 1300 & 800 \\
\hline $\mathrm{Cu}$ & 60 & & \\
\hline $\mathrm{Pb}$ & 482 & 601 & 348 \\
\hline $\mathrm{Zn}$ & 297 & 456 & 246 \\
\hline $\mathrm{Ag}$ & 2.3 & 2 & 1.7 \\
\hline $\mathrm{Ni}$ & 43 & 25 & 20 \\
\hline $\mathrm{V}$ & 66 & 1 & 1 \\
\hline $\mathrm{Be}$ & 8 & 510 & \\
\hline $\mathrm{Sn}$ & 7 & 2 & 10 \\
\hline $\mathrm{Au}$ & 342 & 982 & 343 \\
\hline $\mathrm{Co}$ & 8.3 & 9 & 13 \\
\hline $\mathrm{Mo}$ & 4 & 1 & 1 \\
\hline $\mathrm{Sb}$ & 5.7 & 0.4 & 7.7 \\
\hline $\mathrm{W}$ & 13 & 32 & 4 \\
\hline
\end{tabular}

Fig. 4.1-2: Territorium metallorum Tresminas / Jales, Forno dos Mouros: alguns elementos vestigiais de duas amostras de campo em solo aluvial (1 e 2) e uma amostra de sedimento (3) do Forno dos Mouros. Dados em ppm, Au em ppb (tabela: A. Wiechowski). 


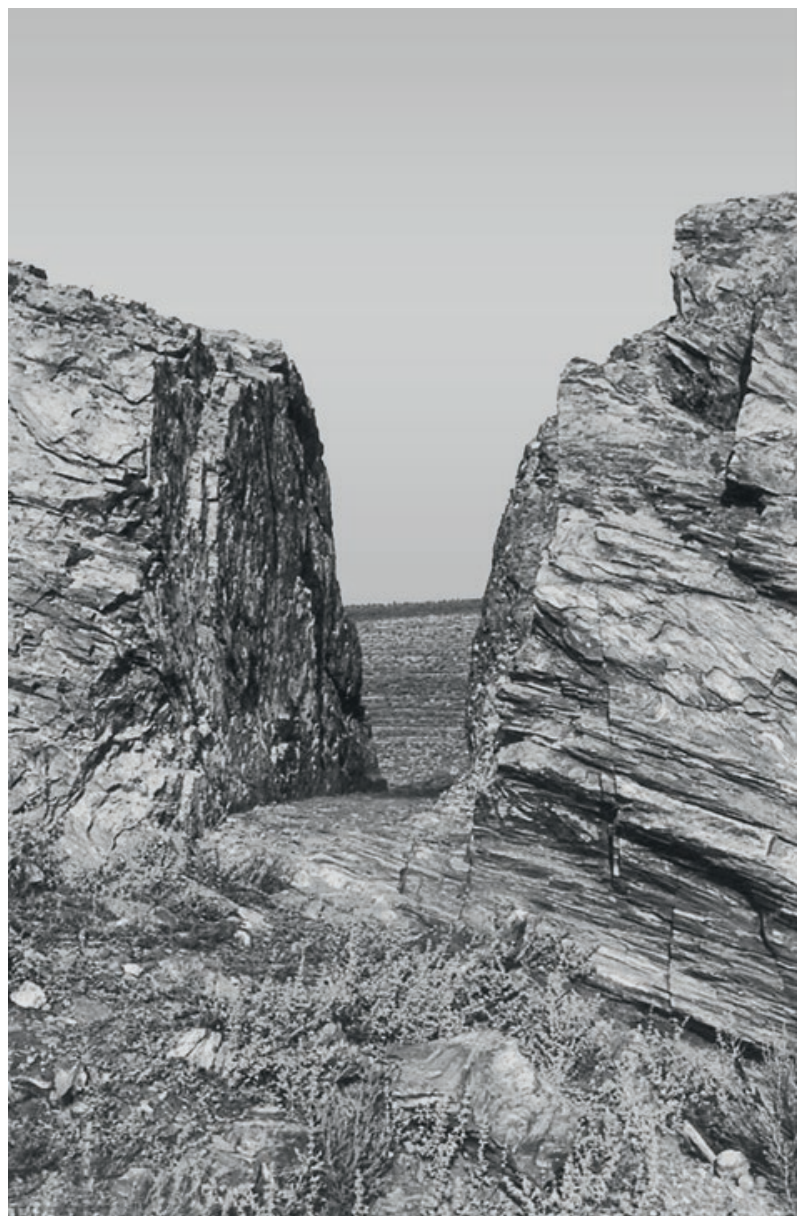

Fig. 4.1-3: Territorium metallorum Tresminas / Jales, Tresminas: corte na rocha para o aqueduto C2, acima das instalações de lavagem de minério (fotografia: J. Wahl). 


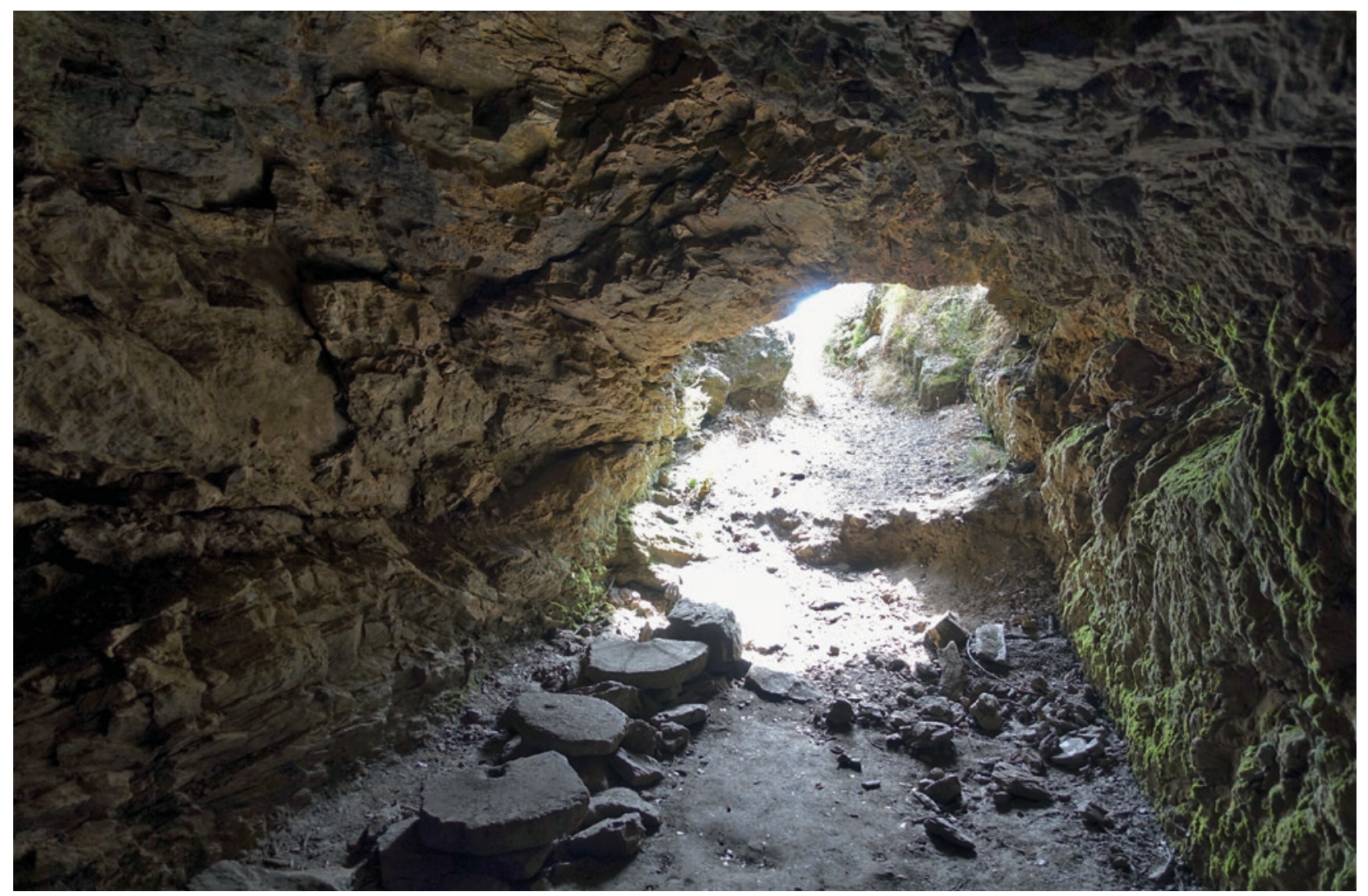

Fig. 4.1-4: Territorium metallorum Tresminas/Jales, Tresminas: área da boca da Galeria dos Alargamentos. As mós foram deslocadas e encontravam-se originalmente no exterior da galeria (fotografia: $R$. Wahl-Clerici).

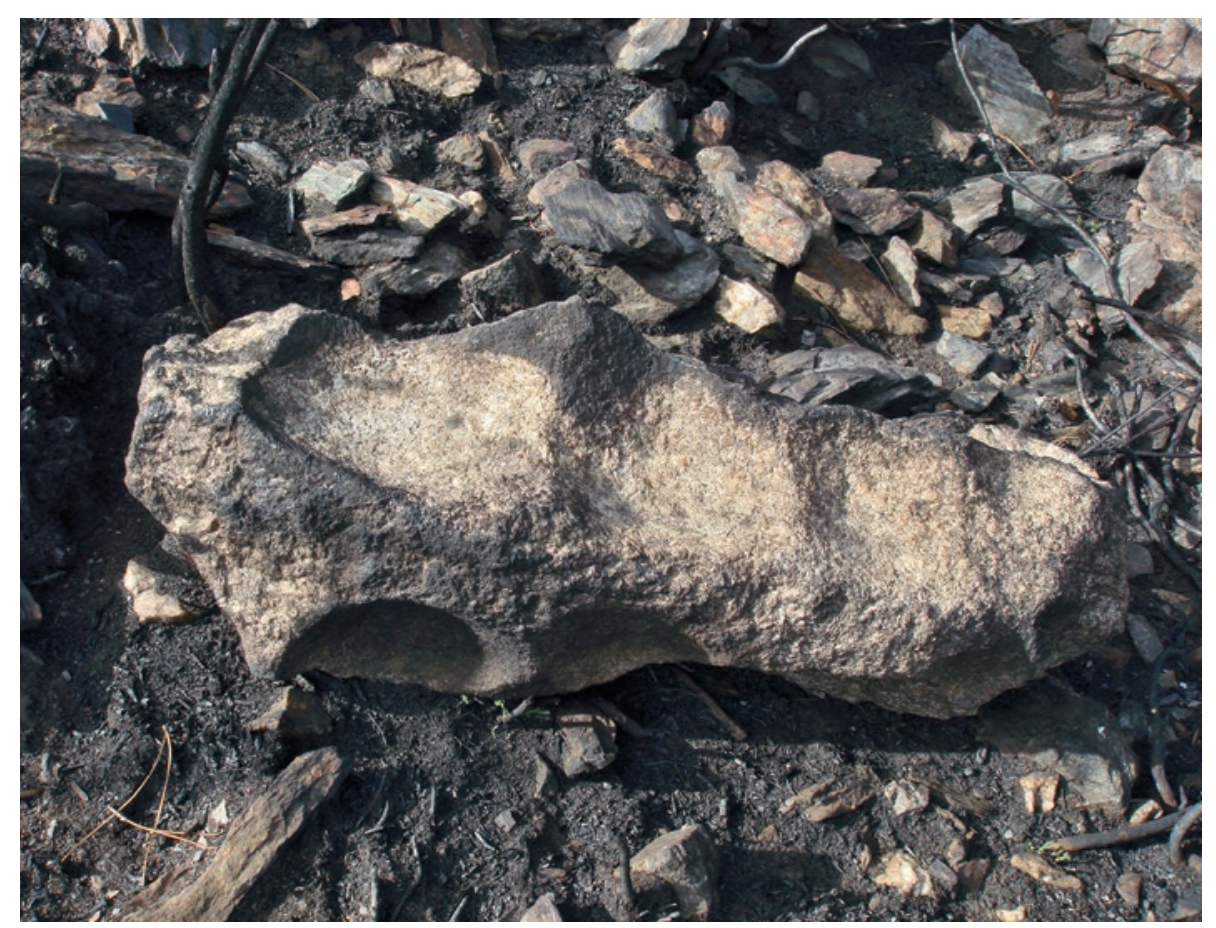

Fig. 4.1-5: Territorium metallorum Tresminas / Jales, Tresminas: moinho de pilões fortemente desgastado e provavelmente reutilizado em época pós-romana no local de tratamento de minério da Galeria Jürgen Wahl (fotografia: R. Wahl-Clerici). 


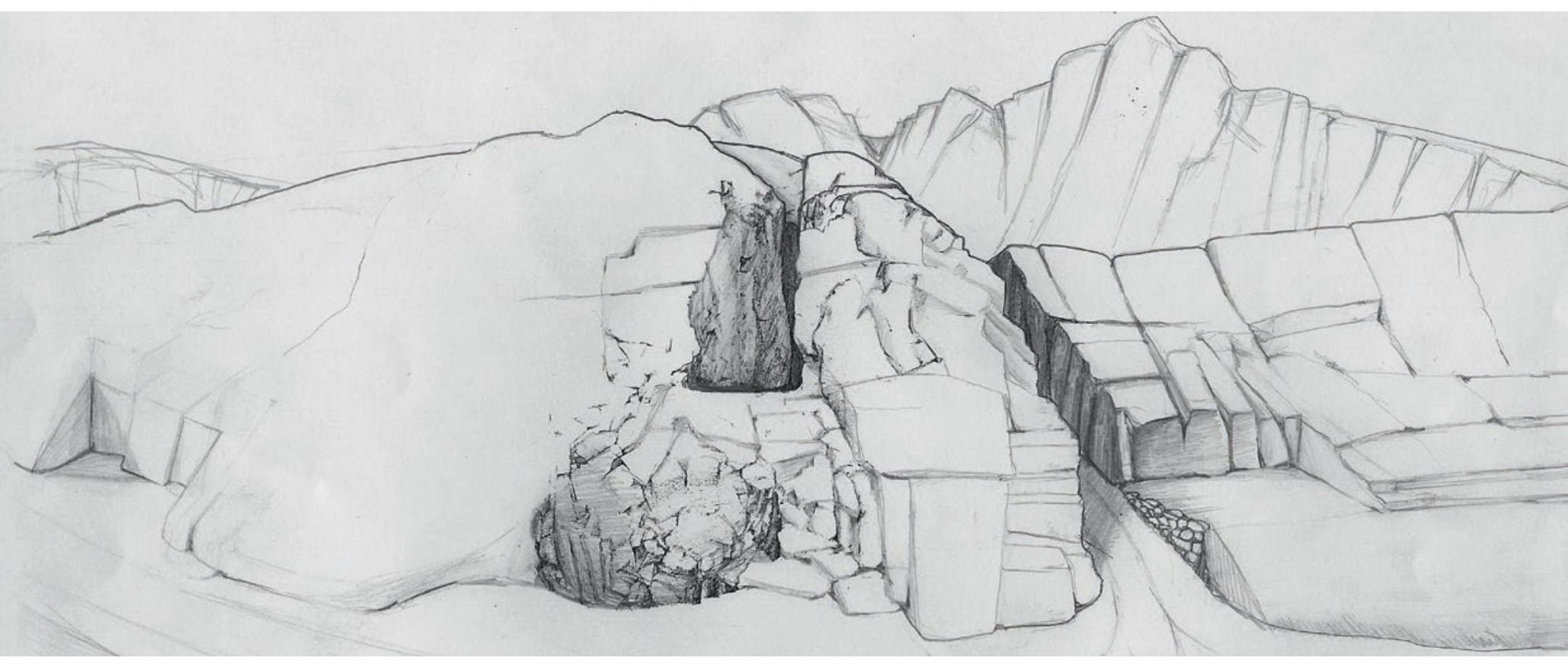

Fig. 4.1-6: Territorium metallorum Tresminas / Jales, Tresminas: entrada oeste da Corta da Ribeirinha. Os locais de tratamento de minério foram construídos na montanha (desenho: P. Moser). 


\subsection{Os conteúdos de ouro nas jazidas de Tresminas, Jales e Gralheira ${ }^{192}$}

Como se deve presumir que os romanos utilizaram as suas impressionantes técnicas para explorar todas as áreas que continham minério rentável, é impossível conhecer o conteúdo exato de ouro extraído em Tresminas. Contudo, pretendemos, mesmo assim, procurar descobrir o valor reconstruível dos depósitos de ouro dignos de exploração nas jazidas de Tresminas, Gralheira e Jales. A base para tais reflexões reside nas prospeções levadas a cabo no século XX por instituições estatais, como os Serviços de Fomento Mineiro, hoje conhecido como Laboratório Nacional de Energia e Geologia, mas também por empresas privadas, na sua grande maioria dirigidas ao mercado internacional e especializadas em prospeção. ${ }^{193}$ As investigações de Diogo Rosa são de particular importância para este tema, uma vez que na sua dissertação tratou do ouro nas jazidas de Tresminas, Gralheira e Campo de Jales, o que significa num contexto científico e não económico. ${ }^{194}$

Os resultados disponíveis ajudam a tirar conclusões sobre o depósito de metais preciosos nas rochas exploradas. Ao mesmo tempo, deve ter-se em consideração que não podemos presumir com segurança que o abandono da exploração em certas áreas se deveu somente ao baixo teor de metais preciosos. Pelo contrário, as transformações estruturais por altura de 200 d. C. resultaram em mudanças significativas na economia romana, o que não deixou de ter um impacto na produção de metais preciosos organizada pelo Estado.

A respeito da lista publicada por Domergue sobre o ouro extraído no tempo dos romanos, o autor declara simplesmente que «(...) les quantités produites ont été faibles, eu égard aux statistiques actuelles». ${ }^{195}$ Para esse efeito, baseia-se nos poucos números até agora publicados sobre a quantidade total de produção (20toneladas de ouro em Tresminas e 4,7 toneladas em Las Médulas ${ }^{196}$ ) e, em seguida, refere-se à diferença entre as afirmações de Plínio (N.H.34,78) sobre o montante de exploração nas minas asturianas, galegas e lusitanas, de 20000 libras de ouro por ano, ou seja, pouco mais de $6500 \mathrm{~kg}$, e que em nenhuma outra parte do mundo a produtividade se mantem há tantos séculos. ${ }^{197}$

vicena milia pondo ad hunc modum annis singulis Asturiam atque Gallaeciam et Lusitaniam praestare quidam prodiderunt, ita ut plurimum Asturia gignat. neque in alia terrarum parte tot saeculis perseverat haec fertilitas.

Como alguns indicaram, as Astúrias, a Galiza e a Lusitânia fornecem cada um 20000 libras [ouro] por ano, sendo que as Astúrias produzem a maior quantidade.
Em nenhuma outra parte do mundo essa produtividade se mantém há tantos séculos.

De facto, neste texto, Plínio refere-se expressamente ao ouro extraído de depósitos aluviais, indicando que o ouro extraído das jazidas primárias no territorium metallorum Tresminas / Jales poderá ter sido registado separadamente.

Essas breves declarações demonstram claramente que o cálculo das quantidades de ouro extraídas se baseia em pressuposições. Uma vez que as fontes escritas não nos fornecem informações suficientes, temos de basear os nossos cálculos em quatro aspetos:

- O teor de ouro por tonelada de minério.

- O grau de pureza.

- O volume de exploração.

- A proporção entre o minério e o amontoado de estéreis.

\section{O teor de ouro por tonelada de material explorado}

No âmbito das suas investigações sobre o tratamento e a fundição de minérios de ouro em Tresminas, Gralheira e Jales, Bachmann publicou, em 1993, informações sobre o

192 Wahl-Clerici, Considerations on the Profitability of Roman Gold Mining in the Northwest oft he Iberian Peninsula during the 1st and 2nd Centuries A.D

193 Compilação em Martins e Martins 2017.

194 Rosa 2001.

195 Domergue 2008, 209-210. (Trad.) Em comparação com as estatísticas atuais, as quantidades produzidas são baixas. - Produção de ouro em 2016: 3260,1 t da nova exploração de minas e $1297 \mathrm{t}$ da produção de reciclagem, de acordo com https://www.solit-kapital. de/goldangebot. As seguintes informações sobre a reciclagem de ouro podem ser encontradas no mesmo site: «Por exemplo, 41 telemóveis contêm a mesma quantia de ouro que 1 tonelada de minério de ouro.» Consultado em 15.04.2018. — Veja-se também https:/www.gold.de/artikel/wie-viel-gold-im-handy/: um telemóvel contém 0,024 g de ouro. Consultado em 29.04.2018. — Assim sendo, na página supracitada, parte-se de um teor de $1 \mathrm{~g} / \mathrm{t}$ de ouro numa t de minério de ouro.

196 Bachmann 1993, 154; Sánchez Palencia 2000, 157, 188; Sánchez Palencia calcula 190 toneladas para todo o noroeste de Espanha, com base na hipótese de $50 \mathrm{mg} \mathrm{Au} / \mathrm{m}^{3}$ de material extraído. Com um peso específico de 2,25 toneladas de brita compactada $/ \mathrm{m}^{3}$, o resultado é um rendimento médio de $0,022 \mathrm{~g} / \mathrm{t}$ de material explorado.

197 A referência de Plínio ao facto de a produção em Itália, que era ainda mais rica em metais, ter cessado há muito tempo como resultado de uma antiga proibição, imposta pelos antepassados, é provavelmente um tributo ao seu patriotismo. 
teor de ouro, baseando-se nas afirmações de Frank A. Harrison, publicadas na revista Mining Magazine em $1931{ }^{198}$, cujas prospeções nos filões de Jales e Gralheira determinaram teores de 25 a $75 \mathrm{~g} \mathrm{Au} / \mathrm{t}$ e calcularam valores médios de cerca $15 \mathrm{~g} \mathrm{Au} / \mathrm{t}$. ${ }^{199}$ Seguidamente, Bachmann parte de uma concentração de cerca de $10 \mathrm{~g} \mathrm{Au} / \mathrm{t} .{ }^{200}$ Este montante baseia-se, essencialmente, nos relatórios de Jones (1938) e Reynolds (1965). Este, por sua vez, apoia as suas afirmações num relatório perdido de Skelton, engenheiro de minas dos anos 1930. Assim, todos apresentam um valor médio de $10,8 \mathrm{~g} \mathrm{Au} / \mathrm{t}$, embora não fique claro, a partir destas publicações, se este número se aplica a todas as três mineralizações do territorium metallorum de Tresminas/Jales (Tresminas, Gralheira e Jales) ou somente a uma. ${ }^{201}$ Estudos mais recentes sobre a mineralização aurífera no norte de Portugal apontam para valores entre 2,05 g e 22,8 g Au / $\mathrm{t}$ no xisto silesiano de Tresminas. ${ }^{202}$

Nas plantas das prospeções em Tresminas, realizadas pelo Serviço de Fomento Mineiro durante os anos 1970 e 1980, são apresentados o teor de ouro e de prata, assim como o tamanho das amostras. Ainda se consegue identificar claramente os pontos de amostragem numerados e assinalados a vermelho, pelo que é possível localizar sem grandes dúvidas os espaços que contêm metais preciosos (figs. 4.2-1 e 4.2-2). No decurso destas investigações, verificamos que apenas um pequeno número de amostras continha ouro, cujos valores passamos a abordar de seguida.

\section{Corta de Covas}

Nos locais do desmonte a fogo, detetou-se apenas numa amostra o nível mais elevado de 33,25 g Au/t (fig. 4.2-3). De seguida, identificaram-se mais 4 valores entre $0,02 \mathrm{~g}$ e $1,12 \mathrm{~g} \mathrm{Au} / \mathrm{t}$. As sondagens na Galeria do Pilar, feitas por trás do encaixe do dispositivo de elevação acionado por cabrestante, analisaram as zonas por baixo da área de exploração romana e apresentaram valores entre $22,4 \mathrm{~g}$ e 20,4 g Au/t. Foram medidos teores auríferos entre $0,5 \mathrm{~g}$ e $4,8 \mathrm{~g}$ e entre $0,0 \mathrm{~g}$ e $6,6 \mathrm{~g} \mathrm{Au} /$ ton na rocha a partir de amostras subsequentes 203

\section{Corta da Ribeirinha}

A rocha proveniente da perfuração de sondagens na área da Corta da Ribeirinha apresentou valores significativamente inferiores $(2 \mathrm{~g}, 2,7 \mathrm{~g}$ e $3 \mathrm{~g} \mathrm{Au} / \mathrm{t})$, porém, na maioria das amostras apenas foram encontrados vestígios de ouro. Na sondagem da Galeria dos Morcegos detetou-se um teor de ouro ligeiramente mais elevado (11,6g Au/t).

A Galeria Cardoso Pinto, explorada a partir do séculoXX, e as áreas adjacentes à Corta da Ribeirinha também foram analisadas. Graças à densa amostragem, foi possível identificar áreas de concentração, o que significa que os valores se agrupam geralmente por área. Por exemplo, os valores 40,7 g; 18,8 g; 9,0 g e 3,6 g Au / t ou mesmo 25,4 g;
$1,2 \mathrm{~g} \mathrm{e} 0,9 \mathrm{~g} \mathrm{Au} / \mathrm{t}$ foram medidos em locais próximos. No total, foi encontrado ouro em 25 das 116 amostras. ${ }^{204}$

O filão de quartzo que fecha a Corta a oeste e que se estende desde o sul da colina até ao vale da encosta a norte foi analisado diversas vezes, tendo-se constatado que é completamente estéril.

\section{Lagoinhos 205}

Em Lagoinhos foram recolhidas 48 amostras na parte superior da mina subterrânea, das quais 38 continham apenas vestígios de ouro. Nas 10 amostras restantes, salientam-se somente os dois valores de 27,7 g e 12,3 g Au / $\mathrm{t}$. Todos os outros teores de ouro identificados variam entre $0,8 \mathrm{~g}$ e 3,6g $\mathrm{Au} / \mathrm{t}$. Nesta área verifica-se igualmente uma certa tendência para a concentração por área de teores auríferos específicos (figs. 4.2-1, 4.2-2 e 3.0.1-6).

\section{Gralheira}

Nesta jazida obtiveram-se apenas alguns valores, todavia, altos. Por exemplo, 'St. Elias Mines' publicaram no seu site informação sobre conteúdos entre $8 \mathrm{~g}$ e a concentração extremamente alta de $130 \mathrm{~g} \mathrm{Au} / \mathrm{t}$. Harrison fala de valores na ordem dos 77,8g, $42 \mathrm{~g}, 28 \mathrm{~g}$ e $24 \mathrm{~g} \mathrm{Au} / \mathrm{t}$. Uma compilação de Martins / Martins (2017) apresentou valores entre 3,2 e 143,0 g Au/t com concentrações significativamente diferentes na jazida. ${ }^{206}$ Para a veia da Gralheira Rosa calculou

198 O cálculo de Harrison baseou-se no sistema não-métrico. 1 tonelada longa $=1016,05 \mathrm{~kg}$. Essa diferença de menos de $2 \%$ é irrelevante neste contexto; Quiring adotou as informações de Harrison na sua publicação «Geschichte des Goldes» [N.d.T.: A História do Ouro] 1948, 128-130.

199 No seu relatório, Jones 1938 apresenta ainda um valor de $98 \mathrm{~g}$ $\mathrm{Au} / \mathrm{t}$. Uma vez que a designação de origem da amostra não é clara, este valor não pode ser excluído.

200 Bachmann 2013, 153

201 Jones 1938; DG Reynolds, Tres Minas Property. December 1965.

202 Noronha etal. 2000, 213, Tabela 1; Os valores médios indicados por Machado etal. 2006, 1033 para o teor de ouro são de 0,8242 g $\mathrm{Au} / \mathrm{t}$ na Corta de Covas e 0,5361 g Au/t na Corta da Ribeirinha, encontram-se claramente abaixo dos valores aqui listados, devido à sistemática consideração de todas as amostras.

203 Dias de Carvalho 1979, 143-144, Fig. 2; Martins 2017, Tab. 2: Teores de ouro e prata no minério de algumas explorações no ano de 1936: Corta de Covas. 11,8 g Au/t, 67,9g Ag/t.

204 Martins 2017, Tab. 2: Teores de ouro e prata no minério de algumas explorações no ano de 1936: Corta da Ribeirinha: 4,1 g Au / t, 16,9g $\mathrm{Ag} / \mathrm{t}$.

205 Wahl-Clerici et al. 2017

206 Martins / Martins 2017, 160; Figs. 8-9 com a distribuição dos valores medidos; Em Kernow Resources \& Developments Ltd. (KRD), são apresentados valores entre 2,0—140,0 g / t de ouro para a jazida da Gralheira. file://C:/Users/regul/Desktop/4.2\%20in\%20Bearbeitung/postt809.html. (Consultado em 12 de novembro de 2019). 
uma reserva de 5,8 toneladas de ouro com um grau de 6,1 $\mathrm{g} / \mathrm{t}$ a uma profundidade de $180 \mathrm{~m} .{ }^{207}$

\section{Campo de Jales}

O plano com a representação esquematizada dos teores de ouro na mina contemporânea de Campo de Jales, na qual a extensão da exploração romana é indicada por uma linha tracejada, mostra a distribuição dos graus de minério (Fig. 4.2-4). Por conseguinte, as zonas com mais de $7 \mathrm{~g} \mathrm{Au} / \mathrm{t}$ são significativas, mas representam apenas cerca $40 \%$ do volume de minério e em algumas áreas foram encontradas $5-7 \mathrm{~g} \mathrm{Au} / \mathrm{t}$. O valor de 12,98g Au/t na mina contemporânea em Jales é, portanto, mais ou menos equivalente ao valor encontrado na rocha explorada durante a época romana. ${ }^{208}$

\section{Resultado}

De acordo com o referido, todas as amostras das zonas de exploração de Tresminas provêm necessariamente das áreas que já não são exploradas e, atualmente, não é possível determinar com clareza se o abandono da jazida se deveu ao declínio do teor de ouro ou a eventos históricos.

Os valores surpreendentemente altos que surgem esporadicamente são conhecidos como nugget effect ou efeito pepita. Devido à distribuição muito irregular do ouro na jazida, as amostras analisadas não são representativas e os grãos de ouro aleatoriamente encontrados podem distorcer a imagem. ${ }^{209}$

\section{O grau de pureza}

Além do tamanho e do teor de ouro de uma jazida, são ainda importantes as proporções do teor de ouro e de outros metais de valor. Este grau de pureza já era conhecido em tempos antigos. Plínio escreve a este respeito (N.H.33, 80):

Omni auro inest argentum vario pondere, aliubi decuma
parte, aliubi octava. In uno tantum Gallaeciae metallo,
quod vocant Albucrarense, tricensima sexta portio inveni-
tur; ideo ceteris praestat. Ubicumque quinta argenti portio
est, electrum vocatur. Scobes hae reperiuntur in canaliensi.

Todo o ouro contém prata em várias proporções, em alguns lugares um décimo, em outros um oitavo. Apenas na única mina de Gallaezia, a chamada mina de Albucrarens, existe um caso com uma trigésima sexta parte; pelo que este [ouro] é mais valioso do que todos os outros. Onde quer que a proporção de prata seja de um quinto, o minério é chamado electrum; os grãos deste são encontrados em pequenos pedaços no ouro explorado nas minas. ${ }^{210}$
Rosa foi capaz de demonstrar este elevado teor de ouro no depósito de Tresminas. Na sua dissertação «Metallogenesis of the Jales Gold district, northern Portugal», de 2001, cita na fig. 48 um histograma com os graus de pureza de ouro nas jazidas de Campo de Jales (560-840), Gralheira (600-760) e Tresminas (900-940). ${ }^{211}$

\section{O volume de exploração}

Além destes valores, é importante determinar o volume explorado para o cálculo do rendimento total. No caso de Tresminas, Harrison apresenta um volume de 20 milhões de toneladas. ${ }^{212}$ Uma vez que o esboço que ele publicou sobre a área de exploração da Corta de Covas em Tresminas está errado e, por conseguinte, a sua base de cálculo, colocamos em causa o volume por ele indicado. ${ }^{213}$ Assim, na sua secção transversal A da Corta de Covas é representada a exploração completa da área norte, até pelo menos ao nível da Galeria do Pilar. No caso desta posição não legendada poderia tratar-se igualmente da Galeria do Texugo que fica mais abaixo (Fig. 4.2-5).

No entanto, o aspeto atual da Corta de Covas, baseia-se em grande parte em rochas naturalmente fraturadas e a exploração mais profunda ocorreu somente numa zona relativamente pequena, conforme documentado pelo Ser-

207 Rosa 2001, 9 declara, portanto, que estas são reservas relativamente pequenas, e ao baixo preço do ouro de 1998 dificilmente valem o esforço de mineração; O preço do ouro 1997 / 98: 262 Euro / onça; 16.05.2020: 1582 Euro/onça, por outras palavras, o preço do ouro aumentou aproximadamente seis vezes durante este período.

208 www.steliasmines.com/storage/news_releases/Sli-News-2009-01-Jales-Drill-Hole-FINDAL.pdf (Consultado em 2 de março de 2017). Esta página também menciona a jazida da Extensão de Jales, localizada entre os filões de Jales e Gralheira, pelo que se conclui que se trata de um sistema de depósito único. - Veja-se ainda Dias de Carvalho 1979, 143; Martins / Martins 2017, 165 Fig. 12: A Mina de Jales produzia 23,5 g Au / $\mathrm{t}$, com um valor médio de 12,9g $\mathrm{Au} / \mathrm{t}$; Kernow Resources \& Development Ltd. (KRD) indica uma classificação média de $12,9 \mathrm{~g} / \mathrm{t}$ de ouro na mina de Campo de Jales para o período de mineração do século XX. file://C:/Users/regul/ Desktop/4.2\%20in\%20Bearbeitung/postt809.html.(Consultado em 12 de novembro de 2019).

209 Wahl-Clerici et al. 2017, 4.

210 Plínio continua a passagem com a observação que o electrum artificial também foi produzido com uma relação de 3-4 partes de ouro para 1 parte de prata, para melhor processamento. König/ Winkler 1984, 152-153.

211 De acordo com o estado atual da investigação sobre as jazidas de ouro no noroeste da Península Ibérica, não é possível determinar se o elevado grau de pureza do ouro na jazida de Tresminas é suficiente para considerar o local como sendo o metallum albucrarense. Rodriguez Colmenero 1999.

212 Harrison 1931, 142.

213 Harrison 1931, 144, fig. 4. 
viço de Fomento Mineiro (figs. 4.2-6a). Além disso, Harrison partiu de duas covas longitudinais na parte sul, em vez de uma. Até mesmo a suposição sobre a altura da montanha original não corresponde aos conhecimentos atuais. Com base nestes critérios, o volume de exploração em Tresminas deve ser reduzido para um máximo de 8-10 milhões de toneladas, isto é, no máximo metade da tonelagem assumida pela Harrison.

Naturalmente, as diferenças nas jazidas de Tresminas, Gralheira e Jales também são visíveis no volume explorado. Pelo que sabemos, em Tresminas procurava extrair-se o menos possível de escombros, todavia, tinha de ser tratado um volume maior para recuperar o ouro nas zonas de concentração em que não era visível o xisto silicificado (figs. 4.2-2, 4.2-3, 4.2-6 e 4.2-7). A situação é diferente nas jazidas de Jales e Gralheira. Devido às limitações de espaço apenas se extraiu a quantidade suficiente de escombros das jazidas para poder permitir a continuação dos trabalhos (figs. 4.2-2, 3.0$26-3.0-28,3.0-30$ e 3.0-32). As escavações alongadas com os diferentes vestígios de extração e as escombreiras acumuladas lateralmente são prova disso.

As plantas anteriormente mencionadas, referentes às zonas de exploração romana, em grande parte destruídas, sugerem um volume de cerca de meio milhão de toneladas de rocha explorada. No que diz respeito a Gralheira, não existem atualmente informações suficientes para determinar a dimensão de rocha explorada.

A diversidade das jazidas e, portanto, da exploração é refletida não apenas no tamanho das zonas de exploração, mas também nas escombreiras, assim como nos vestígios de processamento preservados. Isto torna-se evidente nos locais de tratamento, dos quais nas áreas de Jales e Gralheira apenas é conhecido o Forno dos Mouros, com cerca de 30 bases de moinhos de pilões ${ }^{214}$. Por outro lado, foram identificadas na área de Tresminas várias estações de tratamento e foram documentadas cerca de 1000 bases de moinhos de pilões nas proximidades. Estes números confirmam a diferença entre os volumes extraídos e os volumes tratados nas várias jazidas.

\section{A relação entre o minério e as escombreiras}

Bachmann apresenta na sua investigação sobre o teor de ouro no territorium metallorum Tresminas/Jales uma relação hipotética de 10: 1 (escombro para minério) com base na totalidade de material explorado. ${ }^{215}$ Esta estimativa pura pode aplicar-se à exploração das jazidas de Jales e Gralheira, mas torna-se mais difícil aplicá-la à situação em Tresminas, devido às condições únicas e complexas das jazidas. O trabalho de campo meticuloso ajuda a tornar a abordagem dos romanos mais compreensível. Assim, torna-se claro que as zonas de exploração eram direcionadas para as áreas que continham ouro, isto é, eram restritas às zonas de xisto silicificado, para que não se produzisse demasiados escombros. Uma vez que as escombreiras em Tresminas ainda não foram devidamente medidas, apenas foi possível calcular aproximadamente o seu volume. Portanto, é difícil determinar a relação entre o minério extraído e os escombros. Além disso, após a britagem, a moagem e a lavagem, uma boa parte do material tratado depositava-se em forma de pó nos vales. Apesar dessas reservas, também nos baseamos no valor estimado de minério para escombro, numa relação de 1:10, para proceder ao cálculo da totalidade do ouro.

\section{Resultados}

A hipótese de um volume máximo de exploração em Tresminas, Gralheira e Jales de 10 milhões de toneladas, numa relação de 1:10 de minério para escombro, com um teor de aproximadamente $10 \mathrm{~g} \mathrm{Au} / \mathrm{t}$ no minério, resulta numa produção total de $10000 \mathrm{~kg}$ de ouro bruto. Convertido para uma produção de cerca de 150 a 200 anos, poderia contar-se com uma produção anual média de 50-67 kg. Ao usar moldes de fundição comparáveis aos de Magdalensberg (Carinthia/A) a produção anual resultava em cerca de 9-12 lingotes pequenos ou 3,5-4,5 lingotes grandes. ${ }^{216}$ Isto corresponderia a uma produção média anual entre 6100 e 8200 aurei de 8,19 gramas.

214 Harrison 1931, 140 menciona vários lugares onde supostamente ainda existe escória que contém ouro. No entanto, as suas afirmações não são específicas, pelo que não ajudam numa nova identificação desses locais de fundição.

215 Bachmann 1993, 154

216 Gostencnik 2016, 28-32: A oficina Imperial de fundição de ouro e os moldes para lingotes encontrados. As inscrições nos moldes demonstram claramente que o ouro pertencia ao imperador Calígula. O pequeno molde possibilitava fundir um lingote de $5,615 \mathrm{~kg}$ $=17$ libras romanas e o grande permitia fundir um lingote de $14,538 \mathrm{~kg}=\sim 44$ libras romanas; Neste contexto, é ainda feita referência às 15 barras de ouro de Sírmio (Sremska Mitrovica, Serbia), que pesavam entre 248 e $500 \mathrm{~g}$. Eles tinham retratos dos três imperadores Graciano (375-383), Valens (328-378) e Valentiniano II(419-455); Ver também Kenner 1888, 19-46; Segundo Speidel 1996, 75-76, o pagamento calculado de 8 milhões de HS para o forte Vindonissa (Suíça) teria significado 8,1ton de moedas de prata ou $656 \mathrm{~kg}$ de moedas de ouro por ano. Ver também Wahl-Clerici (em impressão), Considerações sobre a rentabilidade da exploração mineira de ouro romana no Noroeste da Península Ibérica durante os séculos I e IId.C 
Amostra com conteúdo em ouro e prata

\begin{tabular}{lllllllllll}
\hline Amostra & 146 & 147 & 150 & 155 & 156 & 160 & 161 & 165 & 173 & 174 \\
\hline Comprimento em m & 0.3 & 0.4 & 0.45 & 0.45 & 0.35 & 0.55 & 0.35 & 0.5 & 0.3 & 0.7 \\
\hline Conteúdo g/T Au & 1.4 & 27.7 & 3.2 & 0.8 & 1.8 & 0.9 & 3.6 & 1.9 & 1.6 & 12.3 \\
\hline Conteúo g/T Ag & 0.2 & 6.8 & 2.1 & 3.9 & 2.3 & 3.5 & 4.4 & 0.9 & 2.7 & 3.8 \\
\hline
\end{tabular}

Fig. 4.2-1: Territorium metallorum Tresminas / Jales, Tresminas, Lagoinhos: lista de amostras que continham ouro, com base nas informações do SFM 1985.

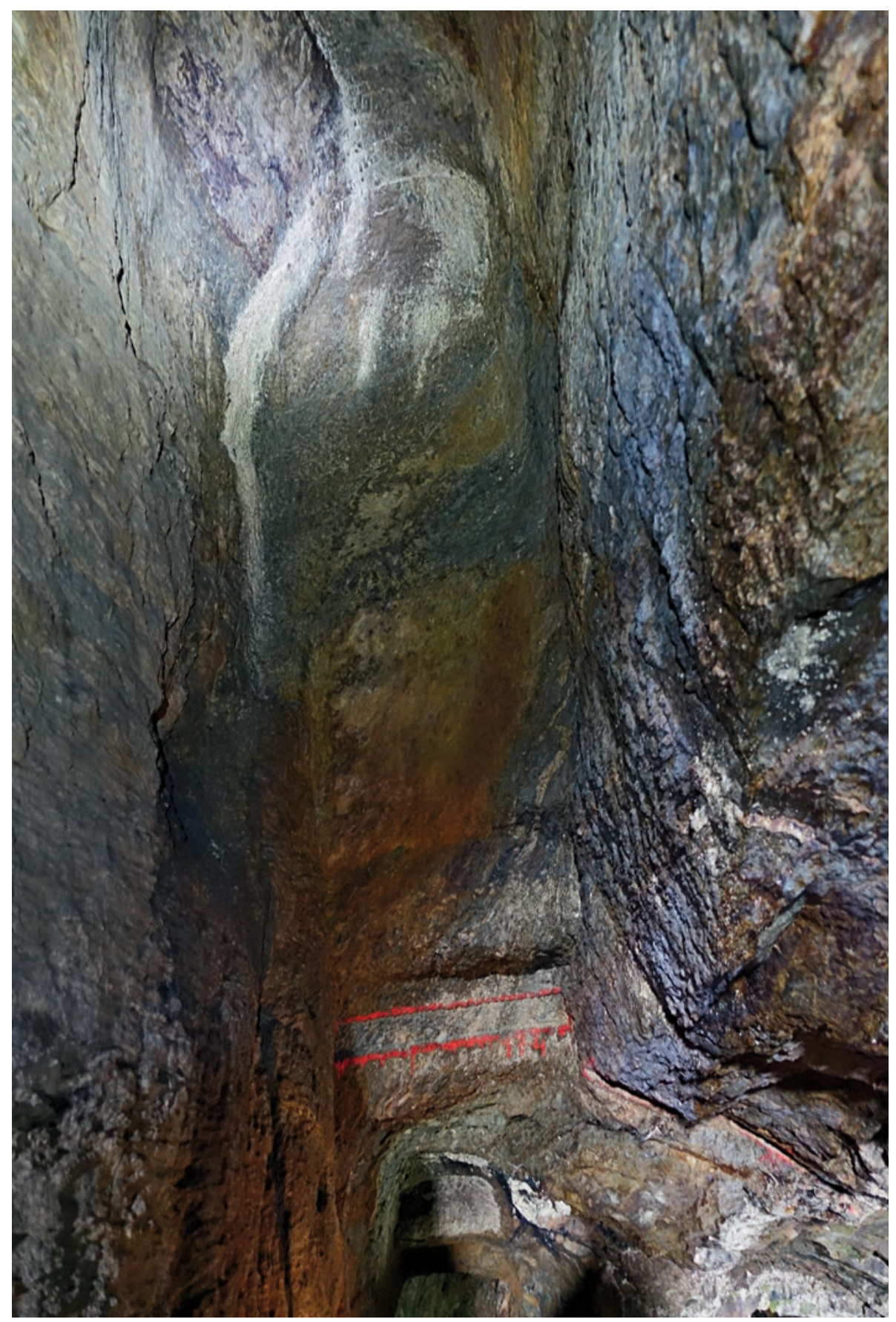

Fig. 4.2-2: Territorium metallorum Tresminas / Jales, Tresminas, Lagoinhos: vista sobre a zona mineira no interior da montanha de Lagoinhos. É visivel que o abandono teve lugar por fases. A amostra 174 foi retirada do patamar mais profundo. A parte inferior da parede sudeste desintegrou-se (fotografia: R. Wahl-Clerici). 


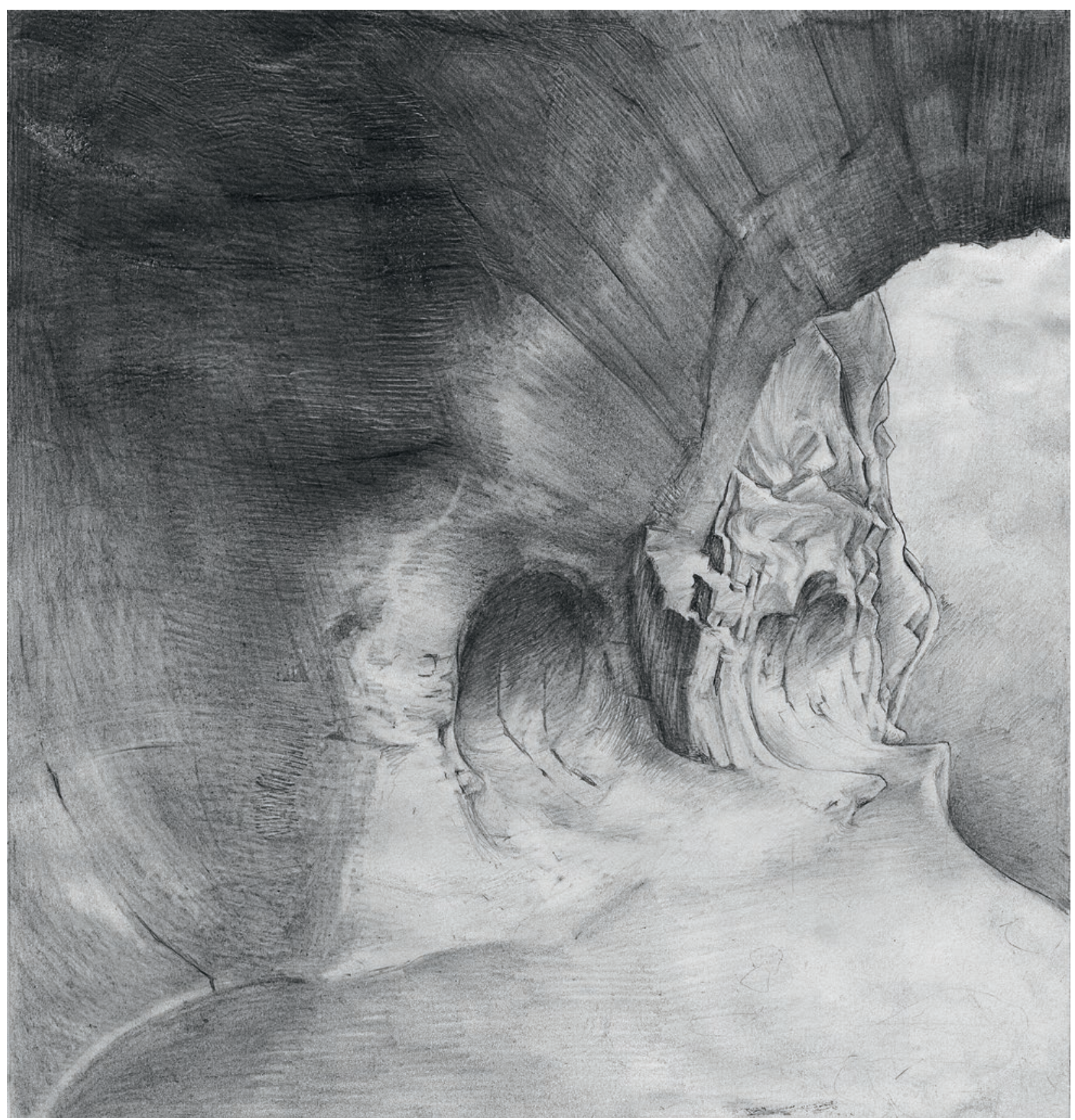

Fig. 4.2-3: Territorium metallorum Tresminas /Jales, Tresminas, Corta de Covas: área de ataque por fogo, onde foi encontrado o maior teor de ouro em Tresminas (desenho: P. Moser). 


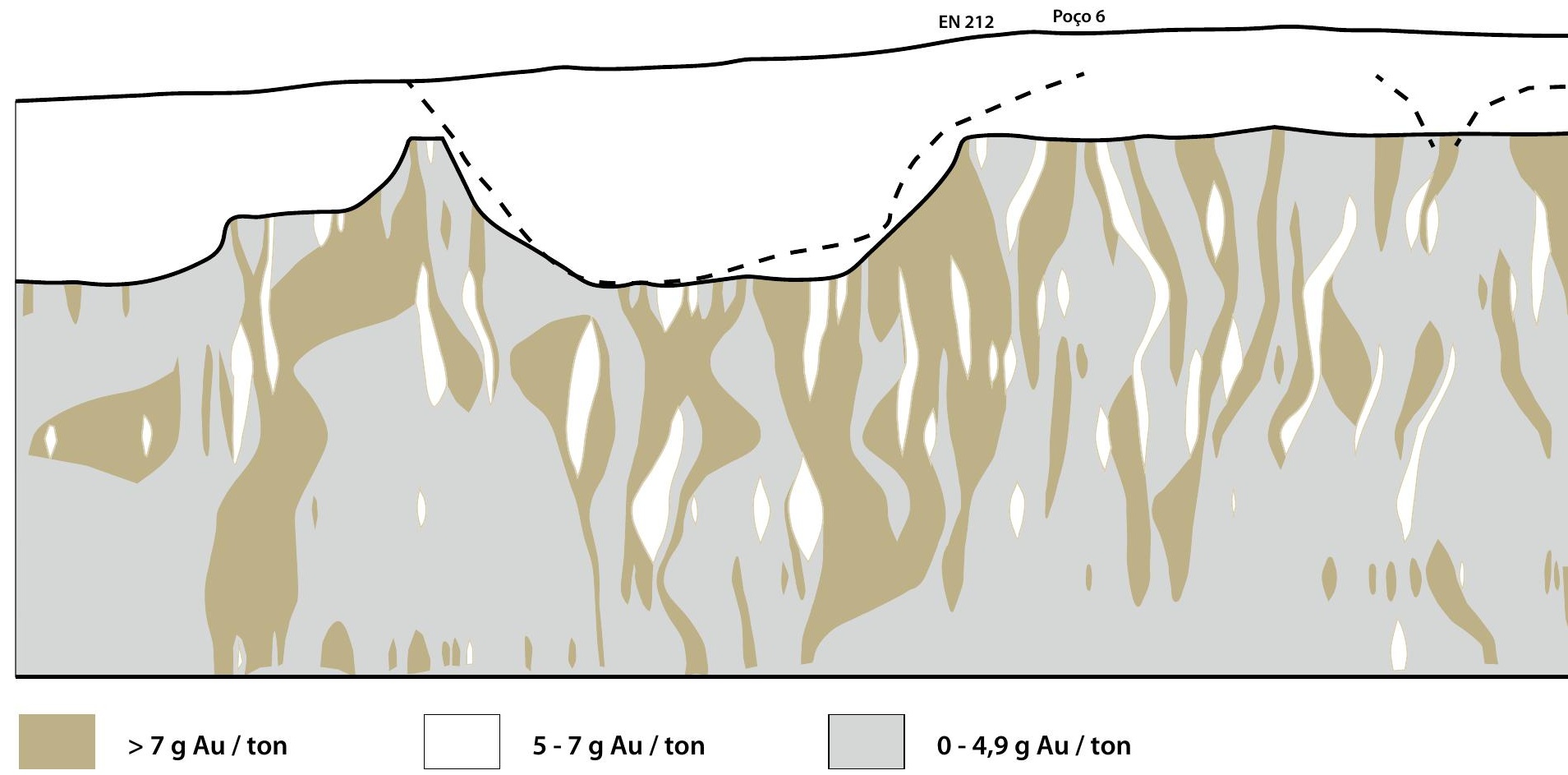

Fig. 4.2-4: Territorium metallorum Tresminas / Jales, Jales: corte longitudinal pelo filão de Campo de Jales com o registo das concentrações de ouro. A linha tracejada marca aproximadamente o limite da exploração romana (elementos fornecidos por Minas de Jales Ltda., desenho: R. Wahl-Clerici). 


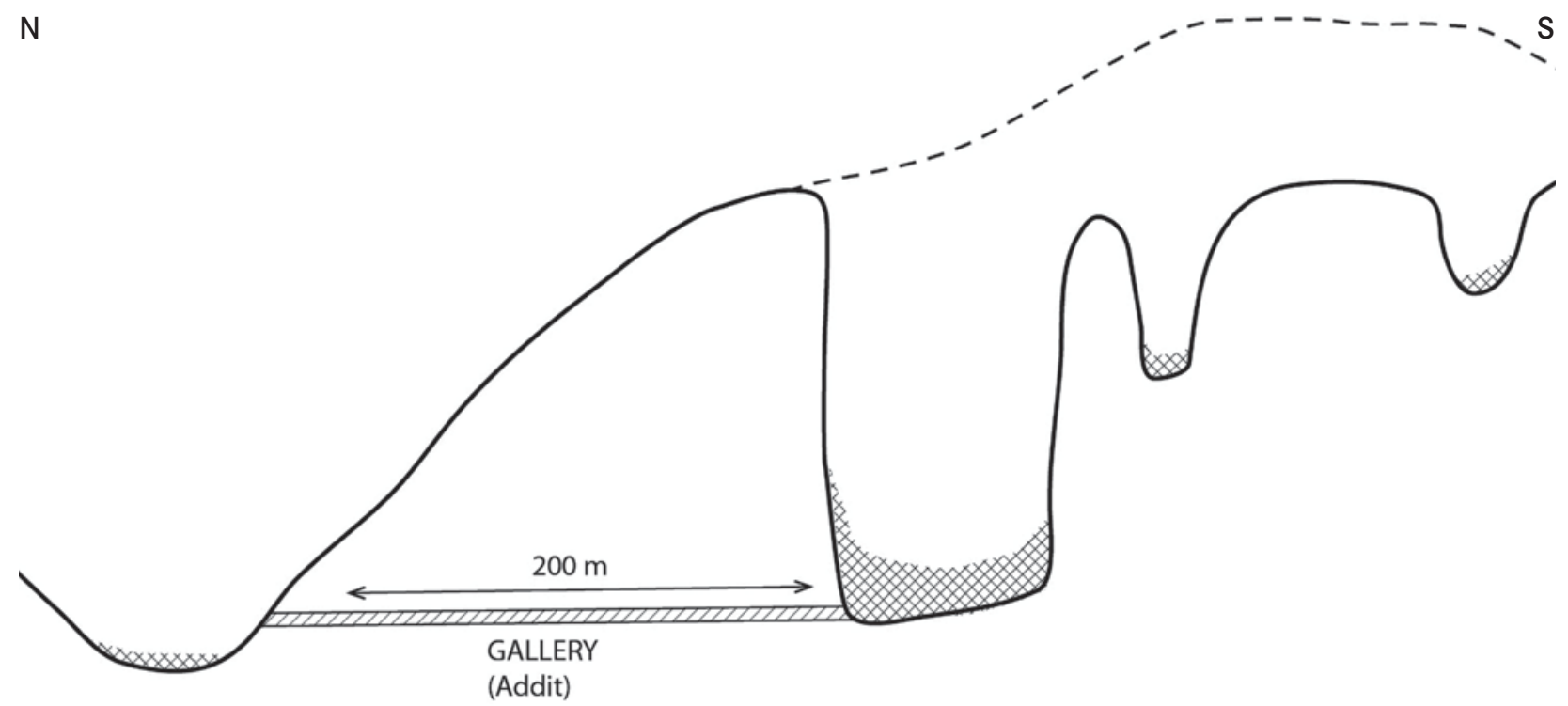

Fig. 4.2-5: Territorium metallorum Tresminas / Jales, Tresminas, Corta de Covas: secção transversal da Corta de Covas segundo Harrison 1931 (desenho: R. Wahl-Clerici).

S

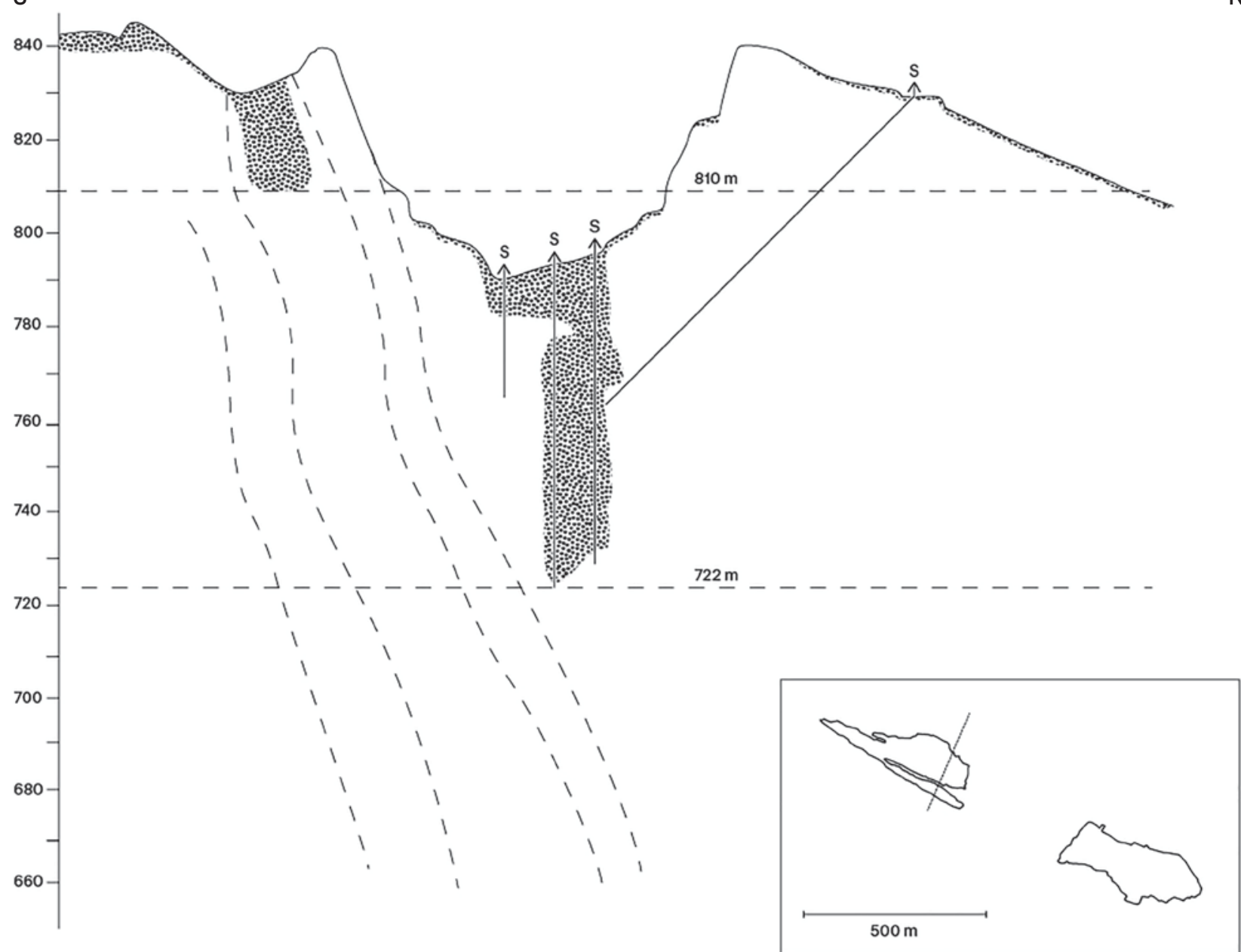

Fig. 4.2-6: Territorium metallorum Tresminas /Jales, Tresminas, Corta de Covas: secção norte-sul através da Corta no ponto mais baixo sondado (S = sondagem). A profundidade da zona sul de mineração foi adaptada ao nível da Galeria Esteves Pinto. Lado inferior direito: posição da sondagem (conforme Direção Geral de Geologia e Minas, Serviço de Fomento Mineiro, Divisão de Prospeção de Minérios Metálicos, SFM-SPE-1987-88, desenho: R.Wahl-Clerici, S.Mathiuet). 


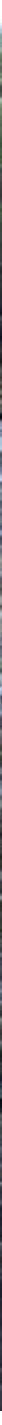

Fig. 4.2-7: Territorium metallorum Tresminas /Jales, Tresminas, Corta da Ribeirinha: escavação na parte ocidental (fotografia: R. Wahl-Clerici). 


\subsection{Sistema Hidráulico: Distribuição e Aproveitamento da Água no Territorium Metallorum Tresminas / Jales ${ }^{217}$}

0 sistema de abastecimento e utilização da água num complexo mineiro tem por base a satisfação de necessidades completamente diversas das de uma cidade romana. Enquanto nos centros urbanos se tratava de equipamentos cuja função primordial era fornecer água corrente em quantidade suficiente para responder às necessidades do dia-a-dia, nos distritos mineiros serviam essencialmente para fins industriais (figs. 5.0-1, 4.0-27a/b/c-4.0-31). Simultaneamente, permitiam abastecer, por exemplo, a população do povoado de Tresminas, bem como as oficinas artesanais sem recorrer a encargos adicionais. No entanto, não encontramos aqui as construções magníficas, típicas da engenharia hidráulica romana, tais como as grandes pontes-aqueduto que atravessam vales e que ainda hoje se encontram entre as estruturas hidráulicas antigas mais visitadas, nem tão pouco os nymphaea (ninfeus), ricamente ornamentados e tão comuns na paisagem urbana romana, como mostra o exemplo em Sagalasso (província de Burdur, Tr) (fig. 5.0-2) ${ }^{218}$.

A simplicidade, a funcionalidade e a eficácia caracterizavam os sistemas de abastecimento de água em Tresminas e noutras áreas mineiras do noroeste da Península Ibérica. As construções simples, desprovidas de monumentalidade, indicam que se tratava de investimentos necessários, e que deviam ser reduzidos, tanto quanto possível, quando comparados com os das grandes cidades. De facto, estes sistemas hidráulicos nunca eram baratos, mas quando eram monumentais, tornavam-se extremamente dispendiosos (fig. 5.0-4) ${ }^{219}$ e a disponibilidade de água para fins industriais tinha de ser barata, uma vez que qualquer investimento servia unicamente para poder assegurar a continuidade da produção.

A área de exploração do minério, no povoado do territorium metallorum, bem como uma grande parte das instalações do tratamento do minério, situam-se em locais altos com escassos recursos para o abastecimento de água. Em contrapartida, os percursos de água mais importantes (o rio Tinhela, o rio Curros e seus afluentes, e a ribeira da Peliteira) levavam água todo o ano, pelo que eram aproveitados para abastecer o distrito mineiro. Contudo, devido ao forte declive das encostas foi necessário criar um complexo e vasto sistema hidráulico (fig. 5.0-3).

Um sistema hidráulico é constituído por diversos componentes e no territorium metallorum Tresminas/Jales encontramos muitos desses componentes nas suas mais variadas versões. Basicamente, podemos distinguir entre o armazenamento, o abastecimento e o aproveitamento da água, assim como os problemas de escoamento, específicos de uma exploração mineira.

\section{Armazenamento}

- Bacias hidrográficas

- Barragens e reservatórios (albufeiras)

- Açudes ou represas

- Tanques

\section{Abastecimento}

- Aquedutos, incluindo túneis

\section{Aproveitamento}

- no tratamento e fundição do minério

- nas oficinas artesanais

- no povoado, onde era necessária água de alta qualidade para consumo, assim como água de menor qualidade para os animais e a lavagem, etc.

\section{Escoamento}

- da água da montanha

- das águas residuais industriais

- das águas residuais dos povoados

\section{Armazenamento 220}

\section{Bacias hidrográficas (fig. 5.0-5)}

Numa bacia hidrográfica, toda a água do respetivo território conflui para alimentar um ou vários canais. No distrito mineiro de Tresminas / Jales, consoante os sistemas fluviais

217 Desde 1988, todo o sistema hidráulico foi sistematicamente investigado e documentado por Jürgen Wahl e Regula Wahl-Clerici (publicação em preparação), Wahl 2003; Wahl-Clerici 2016.

218 O consumo diário de água per capita para o século IId. C. em Roma foi calculado entre 100 a 1501, e em Pérgamo em 2501 (Ausbüttel, 2005: 116). Na Península Ibérica mantiveram-se preservados vários aquedutos, como por exemplo em Mérida, Tarragona, Segóvia, etc.

219 A Aqua Marcia em Roma custou em 144 a. C. 180 milhões Sestércios $(H S)=45000000$ denários. O de Alexander Troas (época de Adriano), na Província da Ásia, custou 7 milhões de dracmas (= 28000000 HS = 280000 áureos). Há conhecimento de aquedutos que não foram financiados pelo Imperador, por exemplo, o aqueduto de Aspendos na Panfília (Província de Antália, Tr), que custou 8000000 HS (= 80000 áureos). Para financiar um empreendimento tão dispendioso como a construção de um aqueduto, na cidade romana Colonia Iulia Genetiva Urso (hoje Osuna, província de Sevilla, E) foi necessária a aprovação de um mínimo de dois terços dos dióscuros presentes (Ausbuettel, 2005: 116-117). A fim de reduzir os custos e o tempo de construção, os aquedutos em Roma eram construídos uns sobre os outros, sempre que possível. Por exemplo, Aqua Tepula foi construído no topo de Aqua Marcia, e por cima deste Aqua Julia (Aicher, 1995, fig. 22).

220 Wahl-Clerici 2017 
utilizados, podemos constatar a existência de três bacias hidrográficas distintas:

- $\quad$ Tinhela (1)

- Curros (2)

- $\quad$ Peliteira (3)

Com a ajuda destes sistemas, os romanos conseguiam utilizar as fontes naturais de água disponíveis de forma mais eficiente para a indústria mineira. Estes sistemas concentravam-se principalmente nas terras planas da Serra da Padrela, cujos solos relativamente pantanosos ainda hoje são maioritariamente arborizados por árvores que requerem um abastecimento abundante de água, tais como as bétulas e os amieiros. ${ }^{221}$

\section{(a) Barragens e Albufeiras}

No territorium metallorum Tresminas/Jales conservam-se duas barragens de aterro (figs. 5.0-6 e 5.0-7). Trata-se das represas do Outeiro (figs. 5.0-8 e 5.0-9) e Sainça (5.0-10), documentadas desde o tempo de Jerónimo Contador de Argote. Menos conhecida é a barragem de aterro semiconstruída que comporta a água da ribeira da Peliteira acima do Campo de Jales (figs. 5.0-11 e 5.0-12), assim como a já não existente barragem de Tazém (fig. 5.0-13), que outrora represava a água da ribeira de Frades. A sua localização pode ser claramente identificada graças às escavações na pedra destinada ao canal C2, que conduzia a água às plataformas de lavagem de Tresminas.

A barragem do Outeiro tem aproximadamente $65 \mathrm{~m}$ de largura na sua base e um comprimento máximo de $150 \mathrm{~m}$. Inicialmente tinha uma altura máxima de cerca de $21 \mathrm{~m}$, sendo considerada uma das barragens mais altas da época romana e ainda hoje impressiona quem a observa. ${ }^{222}$

A barragem de aterro na várzea de Sainça tem uma largura de $40 \mathrm{~m}$ na sua base e originalmente tinha aproximadamente $12 \mathrm{~m}$ de altura máxima. O seu comprimento máximo é de $170 \mathrm{~m} .^{223}$

Para construir ambas as barragens, foi escolhida a localização mais propícia, nomeadamente, o local onde existia um estreitamento da rocha, pois permitia uma considerável poupança de meios. O mesmo se aplica à barragem de Tazém, hoje totalmente destruída, bem como à barragem de aterro no percurso superior da ribeira da Peliteira.

Na construção das barragens de aterro utilizava-se a terra avermelhada, fortemente barrenta, que já na época romana era extraída junto da barragem do Outeiro (fig. 6.028). Na área de xisto na zona mineira havia uma grande quantidade desses depósitos, de maior ou menor dimensão (fig. 5.0-14). Em contato com a água, este material rico em barro forma uma superfície estanque e impermeável, evitando assim, por questões de segurança, o revestimento no interior com placas de pedra. Isto explica porque até hoje não foram encontradas no local placas de pedra, que noutros casos eram utilizadas para o efeito. A barragem de aterro da ribeira da Peliteira localiza-se numa zona de gra- nito, razão pela qual aqui foram utilizadas placas de granito (fig. 5.0-12).

A construção das paredes das barragens é menos evidente. São conhecidas a barragem do ribeiro do Muro, situada abaixo da aldeia de Vilarelho (figs. 5.0-15 e 5.0-16) e a barragem que captava a água da ribeira da Peliteira, aproximadamente $150 \mathrm{~m}$ a montante da sua entrada no rio Tinhela. Para construir esta barragem aproveitou-se um estreitamento do leito do rio, onde existia uma cascata natural. Também neste caso foi possível determinar a sua localização com base nas escavações na rocha que indicam a saída principal (fig. 5.0-17). ${ }^{224}$

A parede da barragem de Vilarelho ainda se conserva até dois terços da sua altura original, que pode ser traçada pelas posições de elementos importantes e não destruídos da barragem, juntamente com a estrutura atual. Ainda hoje é possível localizar o a saída inferior, a saída principal do canal e o transbordo do aqueduto (fig. 5.0-18).

Na parede incompleta da barragem da ribeira da Peliteira conservam-se a saída inferior e o canal de alimentação do aqueduto, que teriam sido cobertos, caso a construção tivesse continuado. Recorrendo a uma pedra cuidadosamente trabalhada com um orifício vedável, era possível regular o caudal no início da conduta, conforme as necessidades (fig. 5.0-19).

O canal de alimentação conduzia a água para o aqueduto. Na barragem de Vilarelho, para além deste canal, distinguem-se nitidamente as escavações na rocha que provavelmente serviam para colocar uma construção de madeira que teria por objetivo regular o caudal. Com base noutros vestígios conservados, pode afirmar-se que se tratava provavelmente de um canal de transbordo para evitar inundações. Este exemplo demonstra como era complexo canalizar a água para alimentar um aqueduto já existente. No sistema de abastecimento de Tresminas pode comprovar-se a existência de mais três exemplos semelhantes, contudo, o de Vilarelho é o que se encontra em melhor estado de conservação.

Nos vales da região do territorium metallorum, frequentemente muito estreitos, a maioria dos canais era alimentada por açudes, o que permitia posicionar a entrada da água no canal à altura desejada, independentemente da topografia do local. As construções que se conservam em Sevivas, na ribeira de Sevivas (figs. 5.0-20 e 5.0-21) e no Vale Curtinhas (Tinhela de Baixo) no rio Tinhela (fig. 5.0-22), demonstram que também nestes dois casos se represava a água para poder regular mais facilmente as quantidades necessárias, garantindo disponibilidade de água suficiente. ${ }^{225}$ No ponto de passagem do rio para o canal colocava-se uma

221 Uma bétula necessita de mais de 1001 de água por dia no clima quente da região.

222 Wahl 2003, 497.

223 Wahl 2003, 498.

224 Wahl-Clerici / Wiechowski 2012, 334, fig. 12

225 Wahl-Clerici 2020. 
comporta para regular o caudal; caso a água transbordasse, escorria para um nível inferior do leito do rio (fig. 5.0-23).

\section{O tanque do povoado de Tresminas}

O grande tanque de Tresminas, que se encontra no limite do povoado, também faz parte dos reservatórios de água (figs. 5.0-24 e 5.0-25). Neste tanque a água potável era limpa de detritos que inevitavelmente se acumulavam, dado que a água corria em canais abertos. Hoje o tanque está atulhado de sedimentos que se foram acumulando no decurso da sua utilização e que chegam a atingir a altura máxima da parede do tanque. Este material fino e argiloso encontra-se misturado com pedras pequenas e é bastante duro.

No campo de cultivo situado a leste do tanque foram observados fragmentos de opus signinum que denunciam a localização do principal distribuidor da água, o ninfeu.

\section{Abastecimento}

O abastecimento da água era feito por aquedutos, desde a sua captação e entrada no canal até ao local de consumo. Os aquedutos eram compostos por canais abertos, galerias e túneis (figs.5.0-3 e 5.0-26 até 5.0-28).

Até agora já foram identificados em Tresminas pelo menos 12 aquedutos. Sete conduziam a água do rio Tinhela de oeste para o complexo mineiro e as respetivas zonas de desmonte (T0-T6) e outros quatro $(\mathrm{C} 1-\mathrm{C} 4)$ levavam a água de leste até Tresminas. Foi ainda construído um aqueduto para conduzir a água para a zona de tratamento de minério no Forno dos Mouros (fig. 5.0-17).

Devido a vários fatores, o estado de conservação dos aquedutos é muito variável. Nas áreas particularmente íngremes as escavações na rocha são muitas vezes os únicos vestígios de um aqueduto (figs. 5.0-28 até 5.0-35a / b). Além disso, grande parte das condutas foi destruída pela exploração agrícola e florestal. Até finais do século XX, os habitantes da região utilizavam as pedras das paredes dos canais como material de construção, por lhes ser facilmente acessível. Graças à investigação e documentação dos achados arqueológicos, levadas a cabo durante dezenas de anos, conseguiu-se, apesar destas dificuldades, reconstituir o percurso de 12 aquedutos e identificar partes soltas, localizadas a grande distância umas das outras, como pertencentes a um mesmo conjunto (fig. 5.0-3).

Além disso, foi possível definir a localização das represas que alimentavam todos os aquedutos através da projeção inversa da altura do aqueduto, mesmo não tendo sido possível identificar as construções correspondentes. Há a acrescentar, que, ao medir a altura absoluta de partes conservadas foi possível concluir que fragmentos encontrados dispersos a grande distância pertenciam juntos. Mais difícil é identificar o fim a que se destinava cada um dos aquedutos, e, portanto, o seu uso original. É esse o caso da maioria dos canais, com exceção do canal C2 (figs. 5.0-34a / b e 4.1-
3), que conduzia a água para as instalações de lavagem, e do canal que levava a água para a zona de tratamento do minério no Forno dos Mouros (fig. 5.0-17).

\section{Aproveitamento da água}

Na zona mineira a água era utilizada para diversos fins e era essencial dispor de água suficiente para lavar o minério triturado e moído ${ }^{226}$. Sabemos que, muito provavelmente, as grandes instalações de lavagem de minério a norte da Corta de Covas (fig. 5.0-1) substituíram as instalações mais antigas, localizadas nas entradas para as zonas mineiras ou junto das bocas na encosta. Contudo, ainda não foi possível determinar se a água era utilizada para acionar os moinhos de pilões e de minério ou se se recorria à força humana ou animal para esse efeito. Não se deve descartar a possibilidade de a água ter sido usada para humedecer o material no processo de trituração (fig. 4.0-13).

No processo de desmonte a fogo é provável que, depois de atear o fogo, os mineiros molhassem a pedra para a desintegrar antes de ser triturada. Embora, de acordo com Plínio (N.H. 33,71) fosse preferível o vinagre:

\section{«[...] hos igne et aceto rumpunt $[. .]$. \\ «[...] estes desmontam-se a fogo e vinagre $[. .]$.}

Nas cortas de Tresminas, Gralheira e Jales é de excluir que se tenha utilizado água para remover as pedras partidas. Este pressuposto baseia-se na ideia de que se cortava por baixo a rocha (que continha o minério), provocando assim o seu desmoronamento - semelhante ao caso em Las Médulas — descrito por Plínio (n.h. 33,66) como ruina montium. Assim, supostamente, o material extraído era transportado através dos túneis por via do fluxo de água. Contudo, esta hipótese já foi refutada em Tresminas, Gralheira e Jales. ${ }^{227}$

A água era igualmente decisiva para as oficinas de ferreiros e outras oficinas artesanais existentes no territorium metallorum Tresminas/Jales. A lex metallis dicta de Vipasca (Aljustrel/Portugal) menciona oficinas de cordoaria, curtumes, manufaturas de lanifícios, entre outras, provavelmente relacionadas com as atividades mineiras. ${ }^{228}$

Dada a localização geográfica de Tresminas seria absolutamente essencial prover o abastecimento diário de água corrente, uma vez que nas imediações não existem ribeiras que levam água todo o ano (figs. 5.0-24 e 5.0-25). Isto aplicava-se não só à água potável, como também às instalações

226 Resultados da análise dos vestígios de material resultante do tratamento do minério presentes nos tanques de sedimentação das instalações de lavagem no territorium metallorum Tresminas/Jales (em preparação).

227 Wahl-Clerici 2013, 43-44; veja-se ainda Domergue 1970, $162-163$.

228 Veja-se: as tábuas de bronze de Vipasca d'Encarnação 1984, $204-211$ 
de banho. O banho fazia parte do dia-a-dia dos mineiros, conforme documentam as ruínas na proximidade da corta de Las Rubias no maciço Teleno, bem como as tábuas de bronze de Vipasca (que mencionam as instalações de banho para os mineiros) e as instalações de banho no povoado pertencente às pedreiras no deserto oriental do Egito, onde a água era um bem precioso e, portanto, racionada. ${ }^{229}$

\section{Escoamento}

De acordo com os conhecimentos atuais, as águas residuais produzidas pelo processo de tratamento eram descarregadas num esgoto em Forno dos Mouros. No povoamento, havia vários esgotos mais pequenos e um de grande dimensão. Aparentemente, estes foram construídos tanto para as oficinas dos artesãos como para a parte residencial do povoado.

\section{Extração}

Um dos problemas logísticos numa mina é a água proveniente naturalmente da montanha, a que se juntam as águas pluviais numa exploração a céu aberto. Estas águas tinham de ser drenadas, sob pena de deixar de ser possível o trabalho de extração. Em particular no sul da Península Ibérica conservam-se equipamentos mecânicos usados na época romana. Neles incluem-se noras, bombas, parafusos de Arquimedes e pás, frequentemente utilizados em várias combinações. ${ }^{230}$

Em Plínio encontramos referência a este problema e, simultaneamente, a forma mais fácil de o solucionar (N.H., 33, 96):

ad MD passus iam cavato monte, per quod spatium aquatini stantes noctibus diebusque egerunt aquas lucernarum mensura amnemque faciunt.

(...) quando o desmonte já tinha atingido uns 150 pés, posicionam-se homens ao longo dessa distância, que de dia e de noite, por turnos de trabalho, despejam a água, formando um rio.

Na zona das cortas do territorium metallorum Tresminas/Jales, sempre que possível, a água era conduzida das galerias até à superfície através de canais escavados na rocha (figs. 5.0-36 e 3.3-4). Este método continuou a ser utilizado ainda até ao séc. XIX, ou seja, até ao surgimento das bombas mecânicas. ${ }^{231}$

Todavia é possível que o mecanismo de elevação acionado por nora, construído na Galeria do Pilar, tivesse ter sido usado não só como monta-cargas, como também para elevar a água proveniente de superfícies mais profundas que o canal. Devido à topografia era inevitável utilizar mecanismos hidráulicos na parte sul da corta de Jales. ${ }^{232}$ Na verdade, há notícia da existência de uma nora, mas a documentação a este respeito não é conclusiva, pelo que se mantém apenas uma hipótese. ${ }^{233}$ Também já não é possível avaliar se o vaso de bronze da coleção das Minas de Jales Lda. (outrora Campo de Jales e hoje Museu Municipal Padre José Rafael Rodrigues de Vila Pouca de Aguiar) fazia parte de uma nora, dado não haver indicações sobre o seu contexto e a sua forma não ser seguramente identificável (fig. 5.0-37). ${ }^{234}$

\section{Tratamento do minério}

A quantidade de água necessária para o tratamento do minério não deve ter sido grande, mas tinha de estar permanentemente disponível. Todavia, com exceção de uma pequena construção na zona do Forno de Mouros, em grande parte coberta de entulho que se desprendeu da encosta (fig. 5.0-38), não existem vestígios de canais, o que leva a concluir que a água residual escorria pela encosta abaixo.

\section{Povoado}

As águas residuais do povoado eram recolhidas em pequenos canais, conforme acontecia frequentemente nos povoados romanos (fig. 5.0-39). Realça-se ainda a existência de um canal com aproximadamente $70 \mathrm{~cm}$ de largura e $1 \mathrm{~m}$ de profundidade que atravessa a parte sul do povoado e recolhe a água de outros canais circundantes (fig. 5.0-40). Infelizmente o troço escavado é demasiado curto para determinar com exatidão o sentido do desnível. Por isso é impossível determinar para onde este canal transportava as águas residuais.

229 Veja-se: as instalações romanas de banho na zona de exploração de minério de Las Rubias no maciço Teleno: Domergue, 2012, figs. 19-23; Vipasca: d'Encarnação 1984, 204-211; Relativamente às instalações de banho: Peacock/Maxfield 1997, 122-134 e Hirt 2010, 217-218. A água era fornecida a partir das nascentes e das cisternas naturais subterrâneas sob supervisão militar; Hirt 2010, 168 - 169: A água era estritamente racionada de acordo com a hierarquia, pelo que era atribuído aos militares uma parte maior do que aos civis, devido à sua posição. Hirt 2010, 208-209: A maior atribuição conhecida era de 1 keramion $=6,51$ por dia. Legionários, cavaleiros, veterinários e arquitetos recebiam 5,4 litros. A maioria dos trabalhadores tinha de se satisfazer com 3,25 litros e os trabalhadores de posição inferior com apenas 2,16 litros. Desconhece-se se estas quantidades continham apenas água para consumo ou também água para banhos.

230 Oleson 1984; Domergue 2008, 122-130.

231 O túnel Rothschönberger (Erzgebirge, Alemanha), construído entre 1844-1882, conduzia a água da montanha, desde o distrito mineiro até Triebisch (Saxónia/Alemanha), numa distância de $50,9 \mathrm{~km}$ com um desnível de 0,033\%, para o local onde este desagua no rio Elbe, aproximadamente $12 \mathrm{~km}$ a norte de Meissen (Saxónia / Alemanha).

232 Os habitantes mais idosos de Cidadelha falam de uma «mina» através da qual era possivelmente escoada a água da zona norte de Jales.

233 Oleson 1984, 228-229: Mina dos Mouros / Portugal. Com base no conhecimento atual, trata-se do objeto citado (Mina dos Mouros) e da Galeria do Pilar com o canal ao longo da sua parede leste, mas a descrição feita por Harrison 1931 e Davies 1933 não corresponde à realidade.

234 Vitruvius, De architectura 10,4,4: recipientes de bronze, cada um contendo cerca de 3.281 (Fensterbusch 1964, 483). 


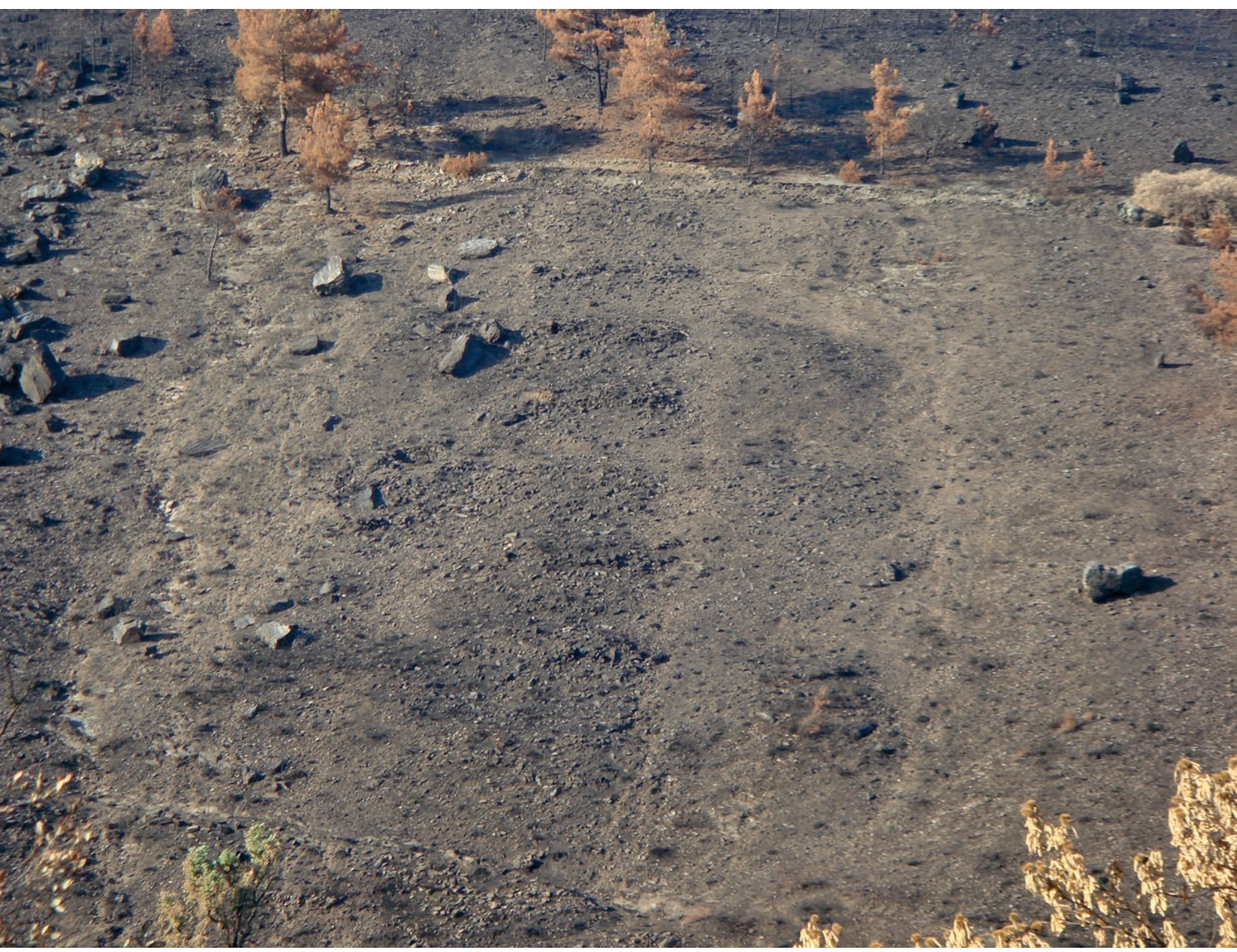

Fig. 5.0-1: Territorium metallorum Tresminas / Jales, Tresminas: as plataformas 5 a 10 da fila ocidental das instalações de lavagem de minério; as plataformas 6, 8, e 10 são completadas de cada lado com bacias de sedimentação (fotografia: R.Wahl-Clerici). 


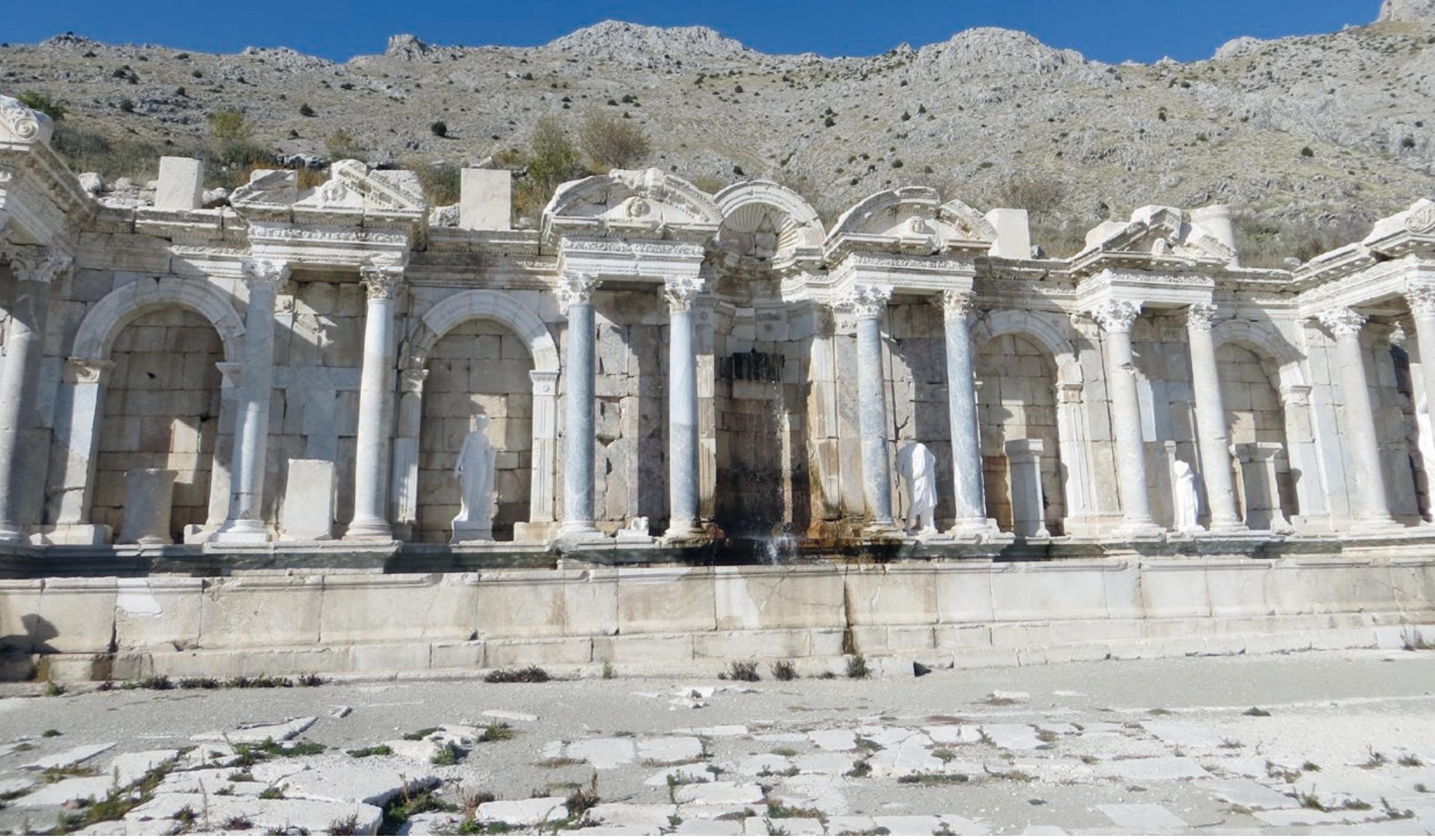

Fig. 5.0-2: Sagalasso (provincia de Burdur, Tr): Ninfeu (fotografia: R. Wahl-Clerici) 
Fig. 5.0-3: Territorium metallorum Tresminas / Jales: vista geral do sistema de abastecimento de água (modelo Ortofotomapa 1:10000 Vila Pouca de Aguiar, registo de 1990-2018 por J.Wahl, R.WahlClerici, A.Wiechowski e R. Schindlmayr, desenho: $R$. Wahl-Clerici). $\frac{510}{000} \stackrel{245000}{246 / 000} \quad \stackrel{247000}{248 / 000} \quad \stackrel{249 \mid 000}{1}$

$\frac{508}{000}$

$\frac{507}{000}$

$\frac{506}{000}$

$\frac{502}{000}$

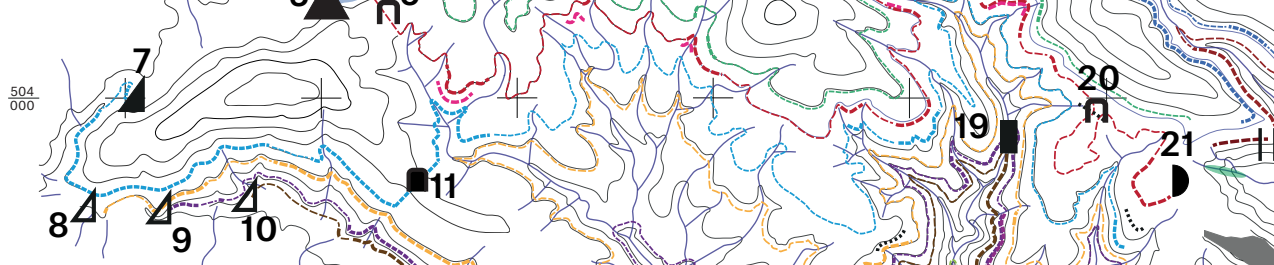

$\frac{503}{000} \quad+$
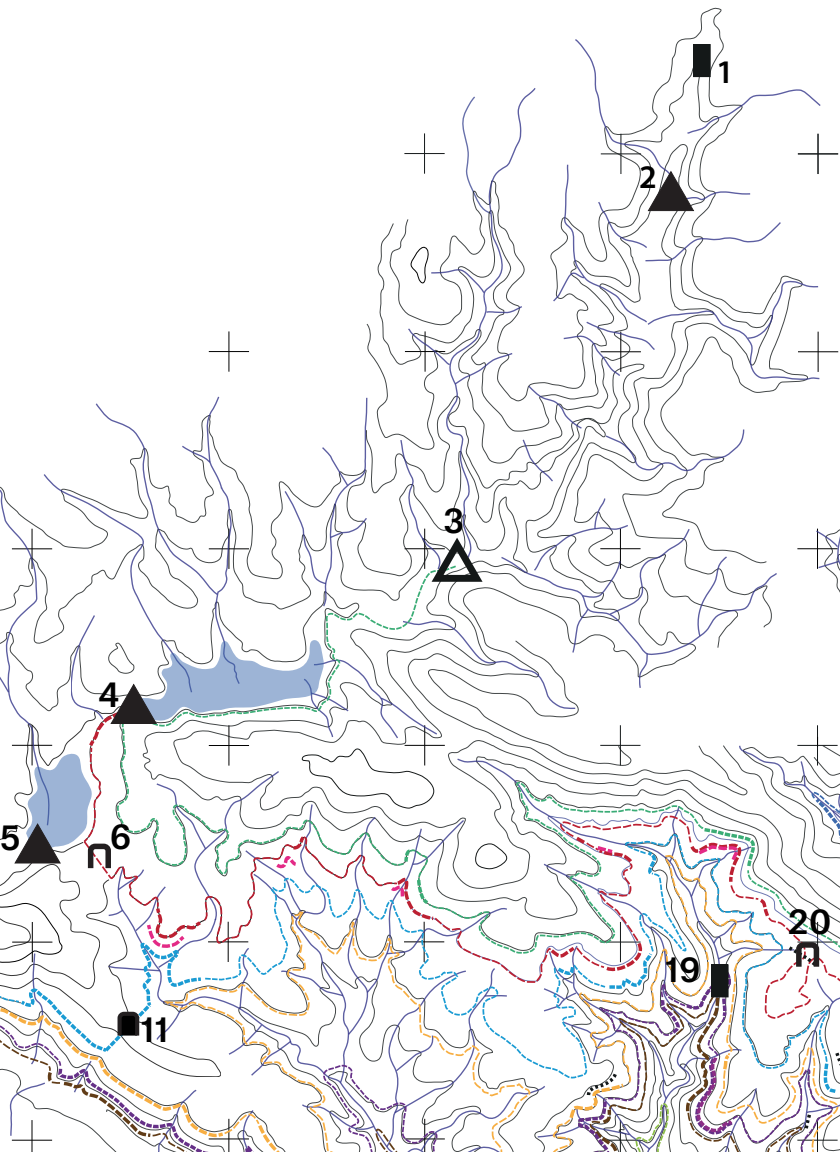

4
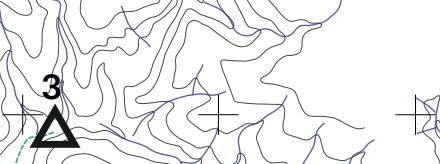

Sistema do Rio Tinhela

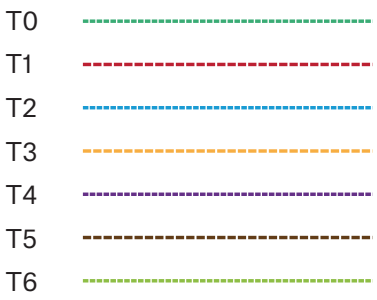

Sistema do Rio Curros

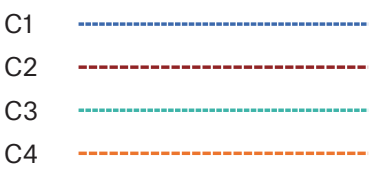

Sistema do Forno dos Mouros

Bacia e aqueduto até

à mina de estanho romana? / medieval $\frac{499}{000}$

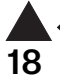

$\frac{500}{000}$

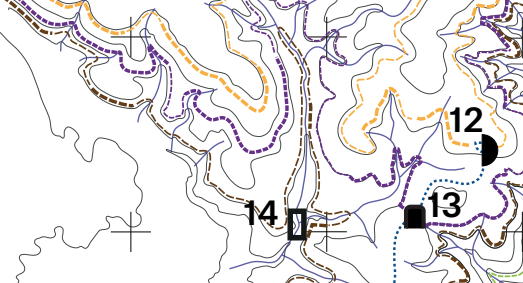

15.<smiles>C1CCC2CCCC2C1</smiles>

$\frac{501}{000}$
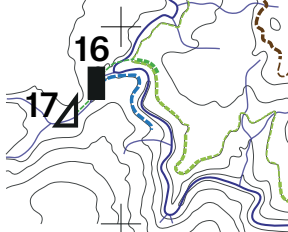

174

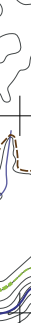




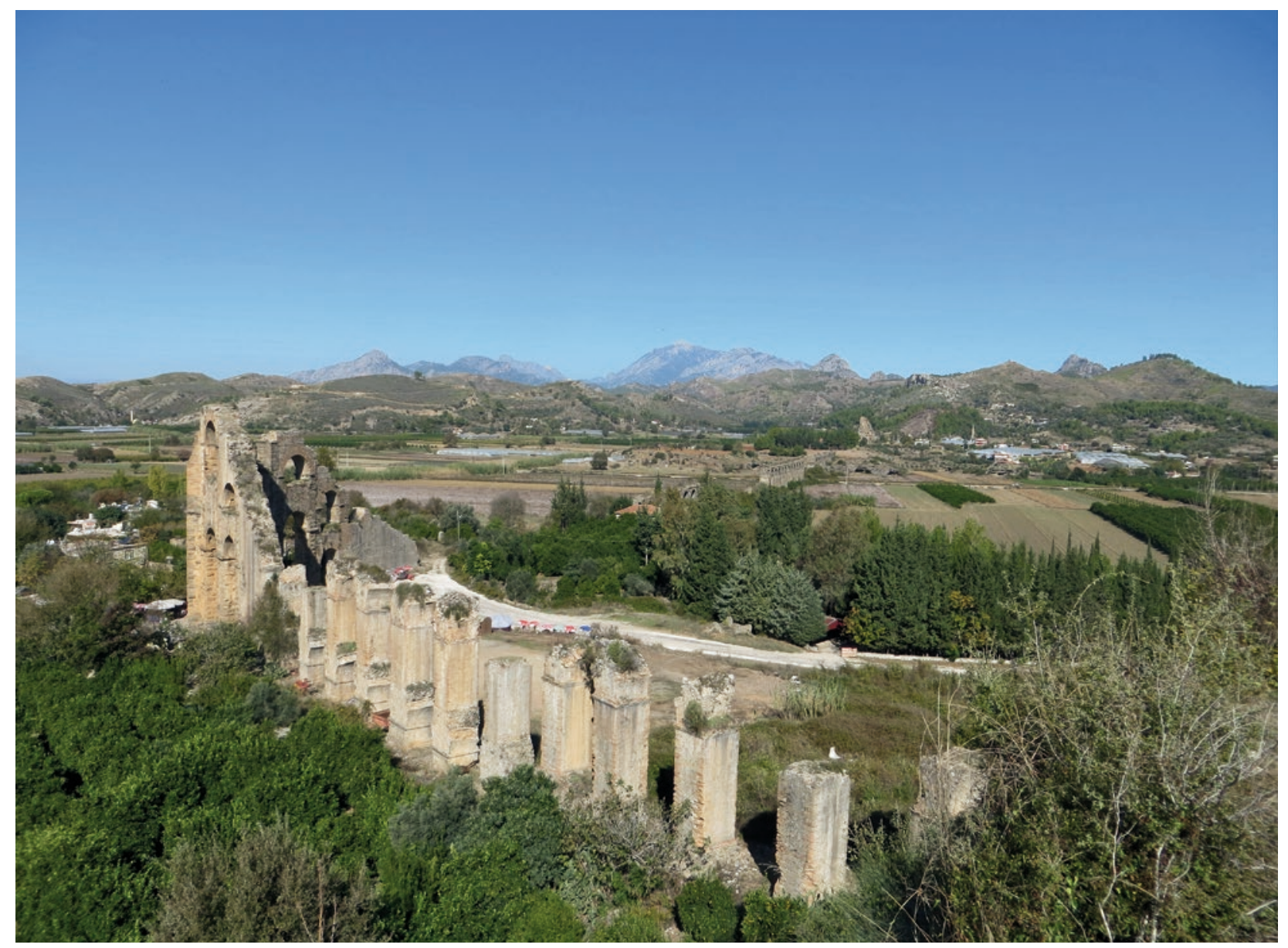

Fig. 5.0-4: Aspendos (província de Antália, Tr): ponte-aqueduto sobre o vale (fotografia: R. Wahl-Clerici). 


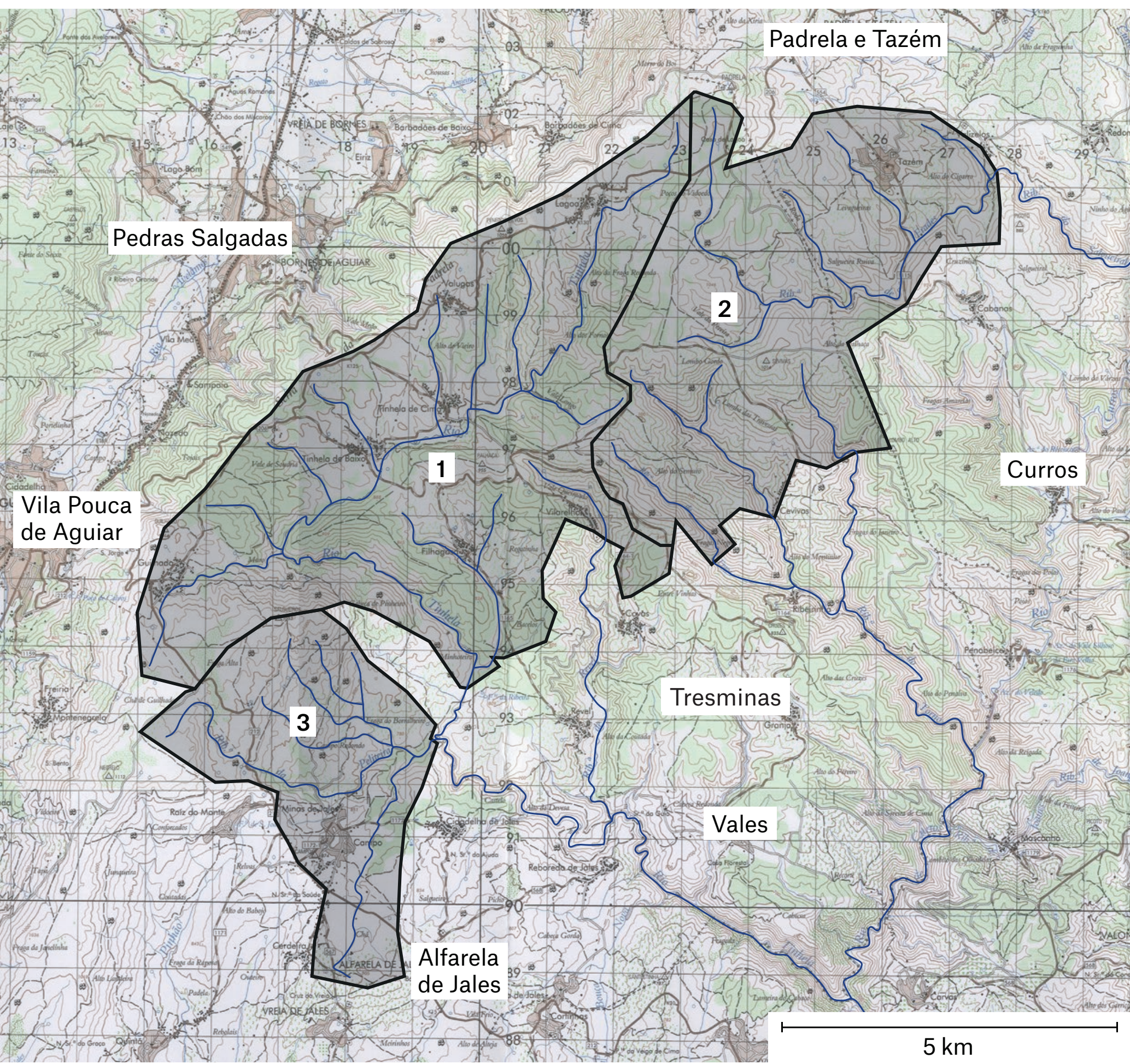

Fig. 5.0-5: Territorium metallorum Tresminas / Jales: panorâmica das bacias hidrográficas. A água do Rio Tinhela e dos afluentes do alto oeste do Rio Curros foi direcionada para a zona de mineração de Tresminas enquanto a água da ribeira da Peliteira e dos seus afluentes foi maioritariamente para a zona de tratamento do Forno dos Mouros. (Modelo: Carta Militar de Portugal 1:50000 (folhas 6-2 e 10-1), adaptada por R. Wahl-Clerici). 


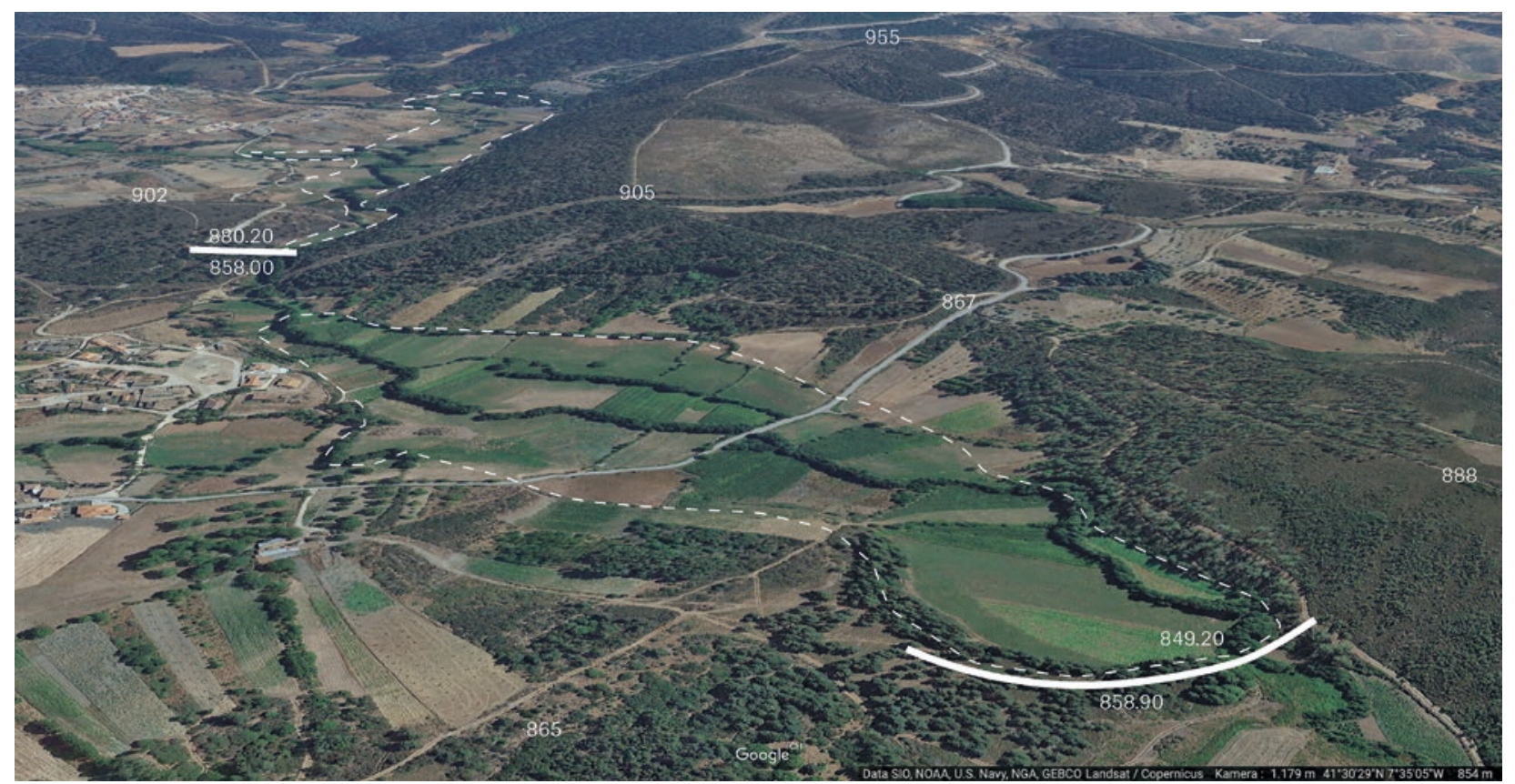

Fig. 5.0-6: Territorium metallorum Tresminas / Jales: resumo esquemático das barragens de Outeiro e da várzea de Sainça, assim como o seu nível de água mais elevado possivel. (Modelo Google Earth, 14.12.2015, inclinação com altura de visualização de 1,19 km, execução: R. Wahl-Clerici).

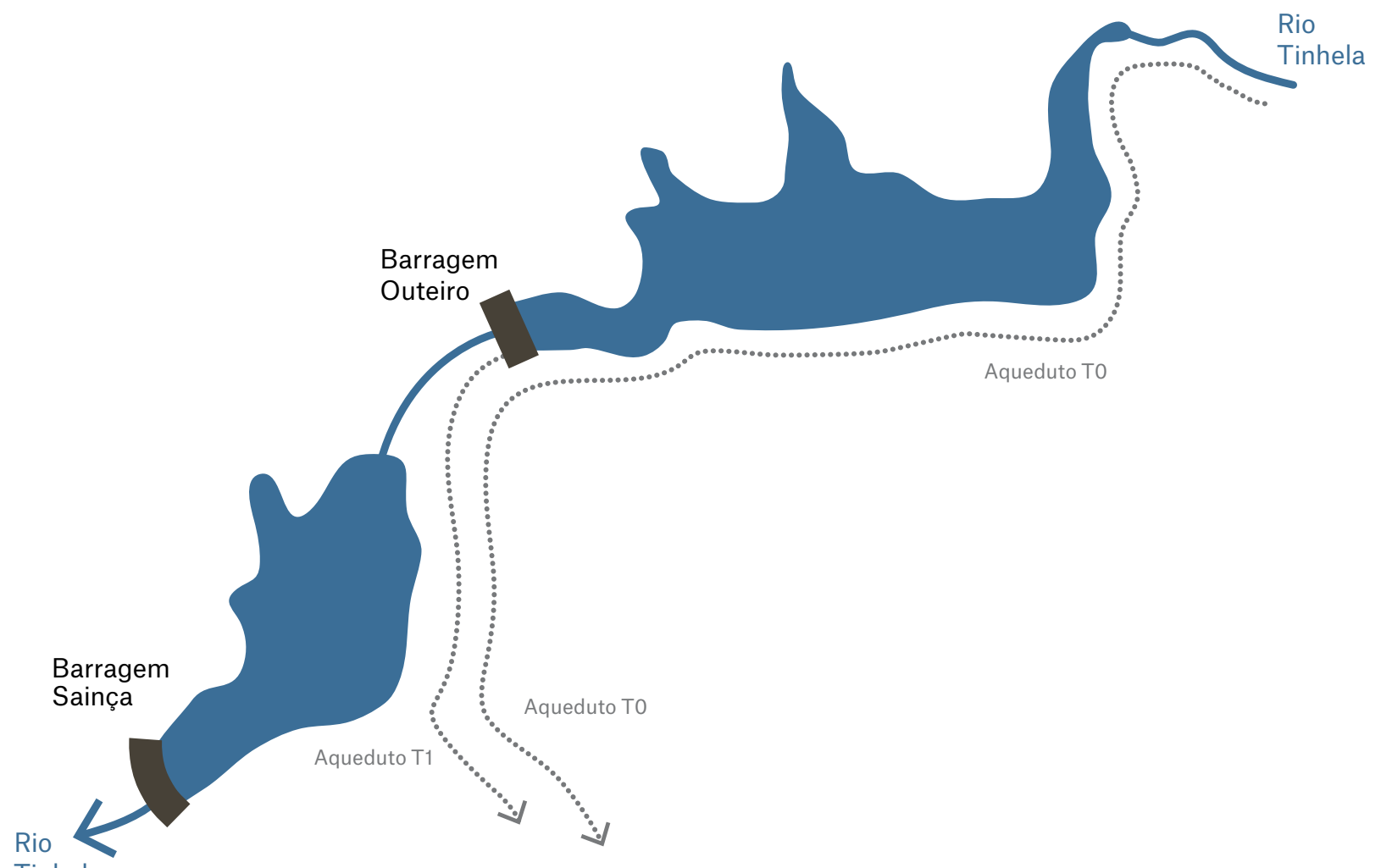

Tinhela

\section{$500 \mathrm{~m}$}

Fig. 5.0-7: Territorium metallorum Tresminas / Jales: os reservatórios de Outeiro e da várzea de Sainça com o nível máximo de água. (Modelo: Ortofotomapa 1:10'000 Vila Pouca de Aguiar, documentação e execução: J. Wahl e R. Wahl-Clerici). 


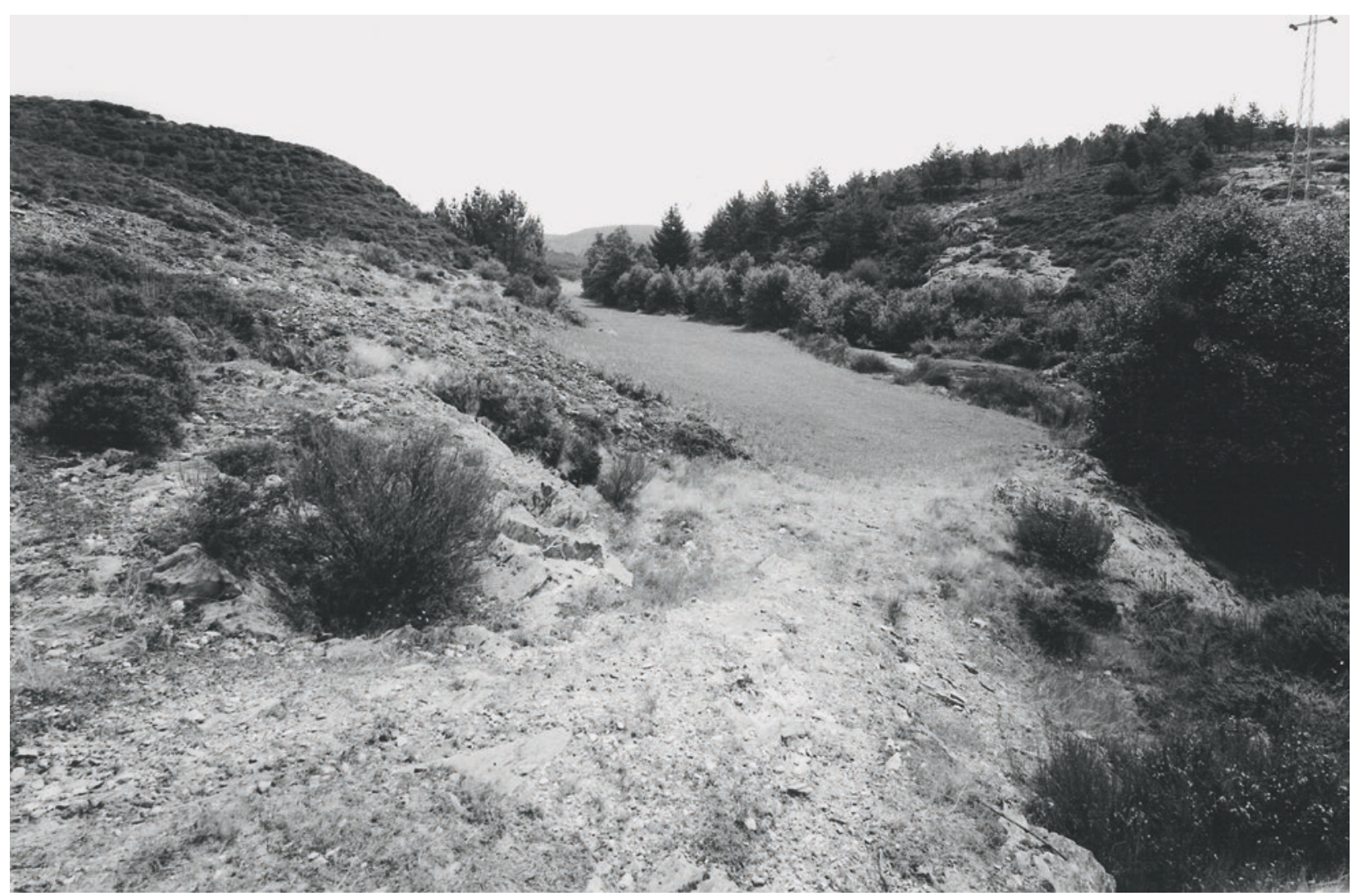

Fig. 5.0-8: Territorium metallorum Tresminas / Jales: barragem de aterro de Outeiro. São visiveis as laterais preservadas. Visto de oeste (fotografia: J. Wahl).

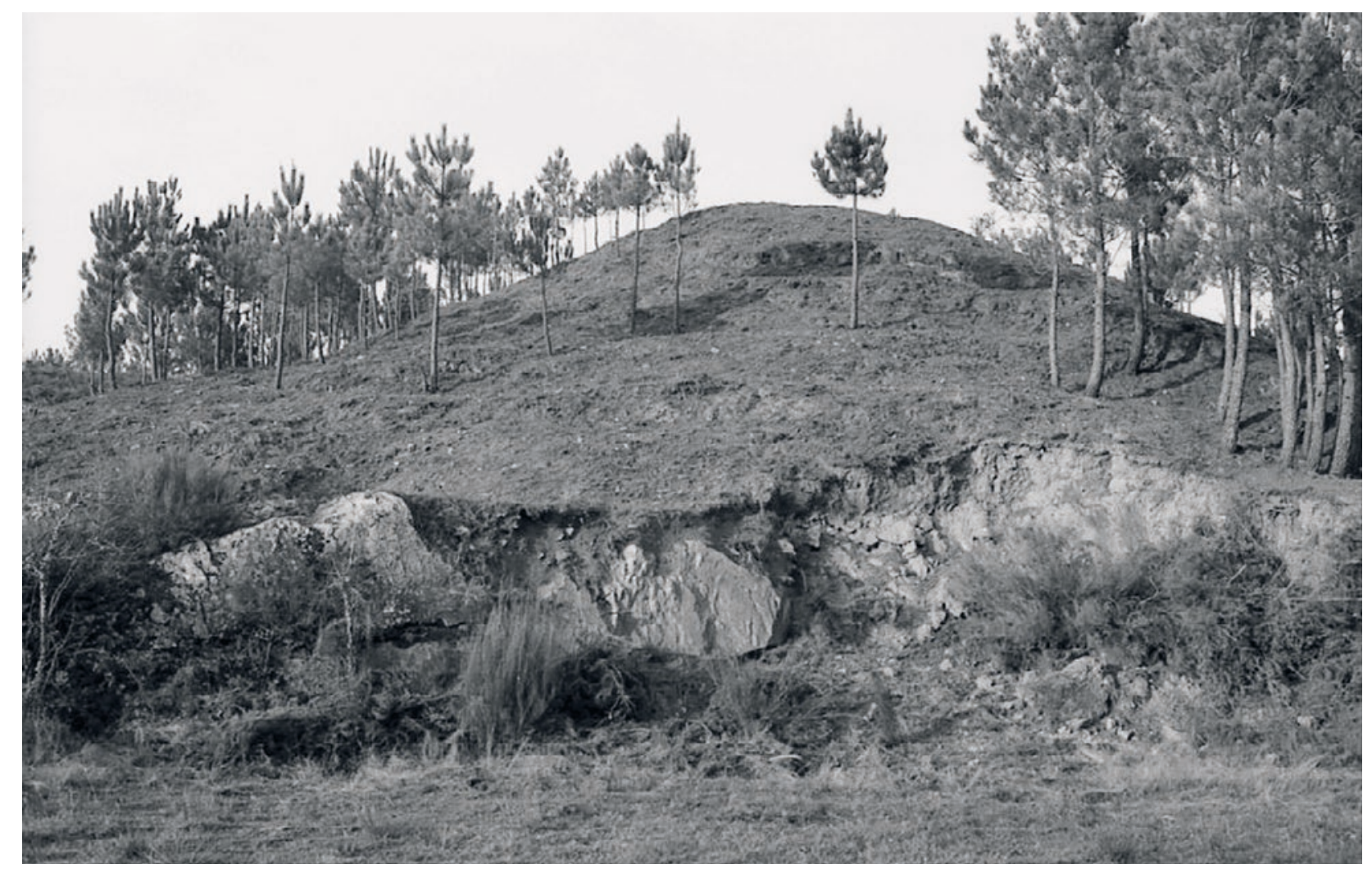

Fig. 5.0-9: Territorium metallorum Tresminas / Jales: barragem de aterro de Outeiro. Em primeiro plano, é visível a rocha usada como base. Vista de oeste (fotografia: $R$. Wahl-Clerici). 


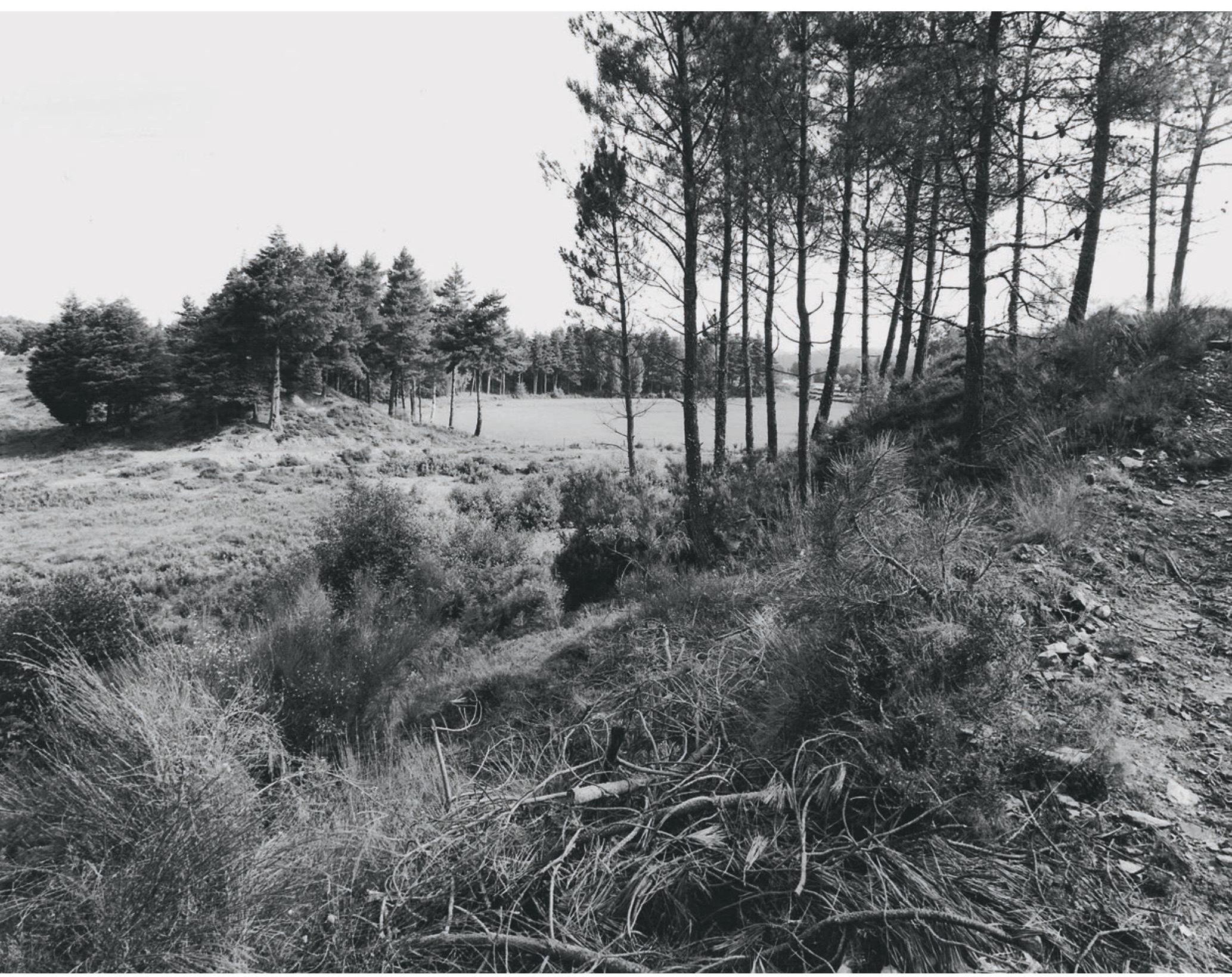

Fig. 5.0-10: Territorium metallorum Tresminas / Jales, de oeste-sudoeste: barragem de aterro de Outeiro, com base rochosa e terra empilhada (fotografia: J.Wahl). 


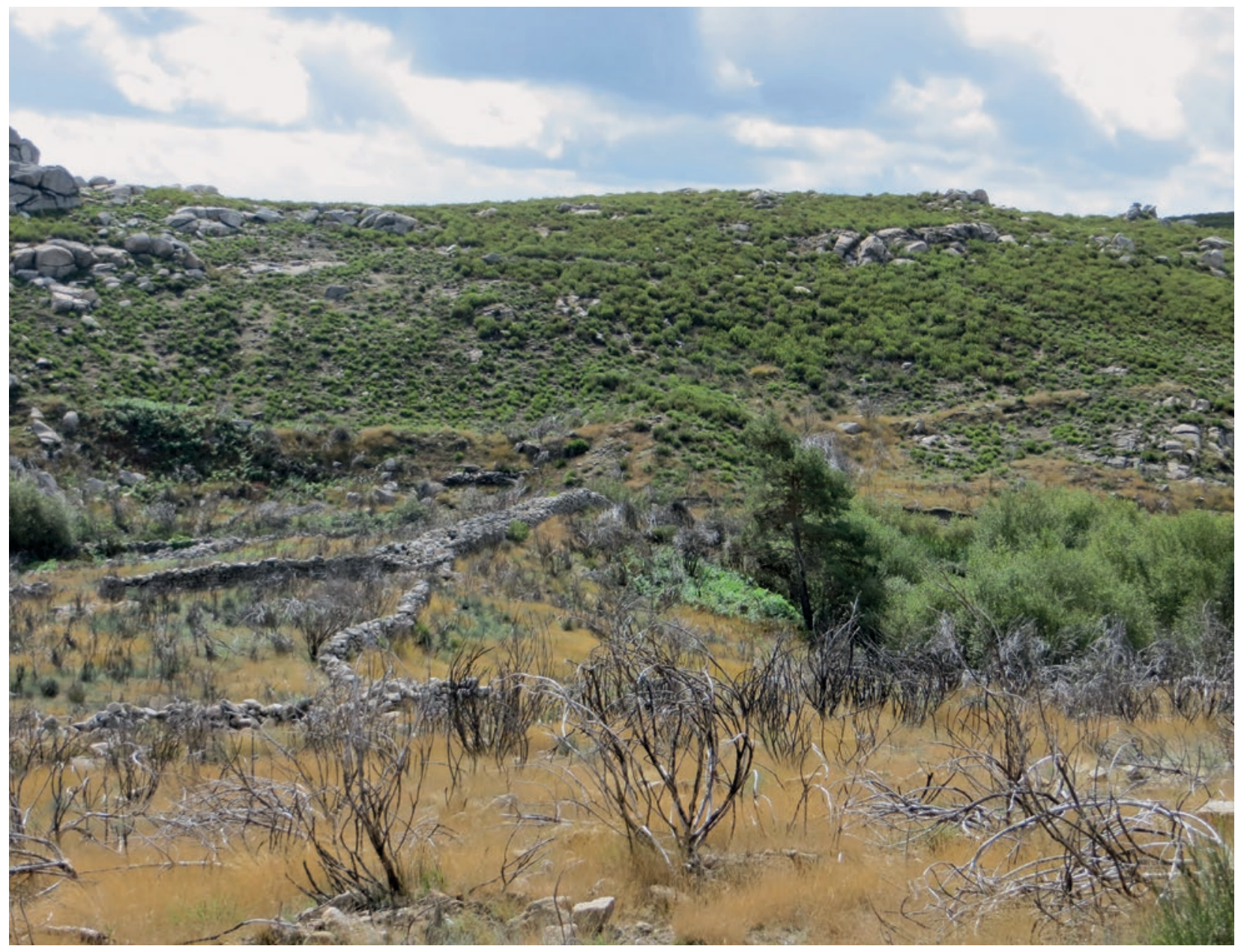

Fig. 5.0-11: Territorium metallorum Tresminas/Jales: barragem de aterro na nascente da ribeira da Peliteira. O muro largo (moderno) no centro da imagem encontra-se acima da coroa mural antiga. A sul da ribeira da Peliteira foi construída uma colina para construir a barragem. Vista de norte (fotografia: $R$. WahlClerici).

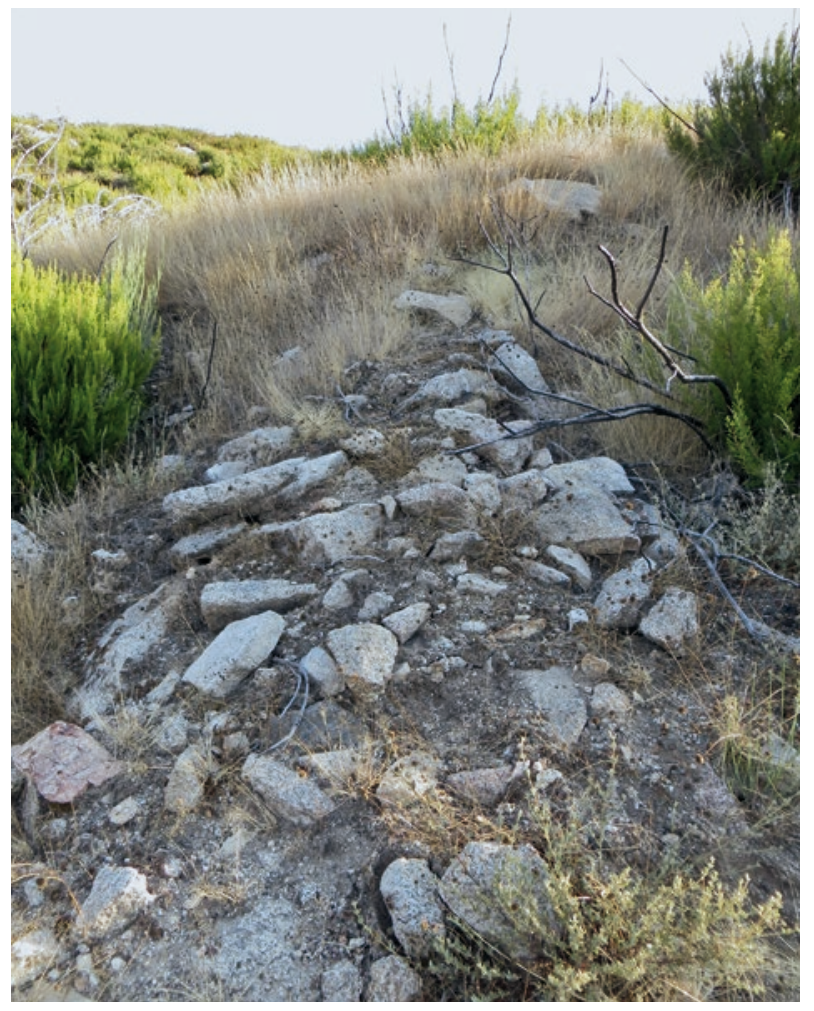

Fig. 5.0-12: Territorium metallorum Tresminas / Jales: detalhe do lado sul da barragem de aterro na nascente da ribeira da Peliteira (fotografia: $R$. WahlClerici). 


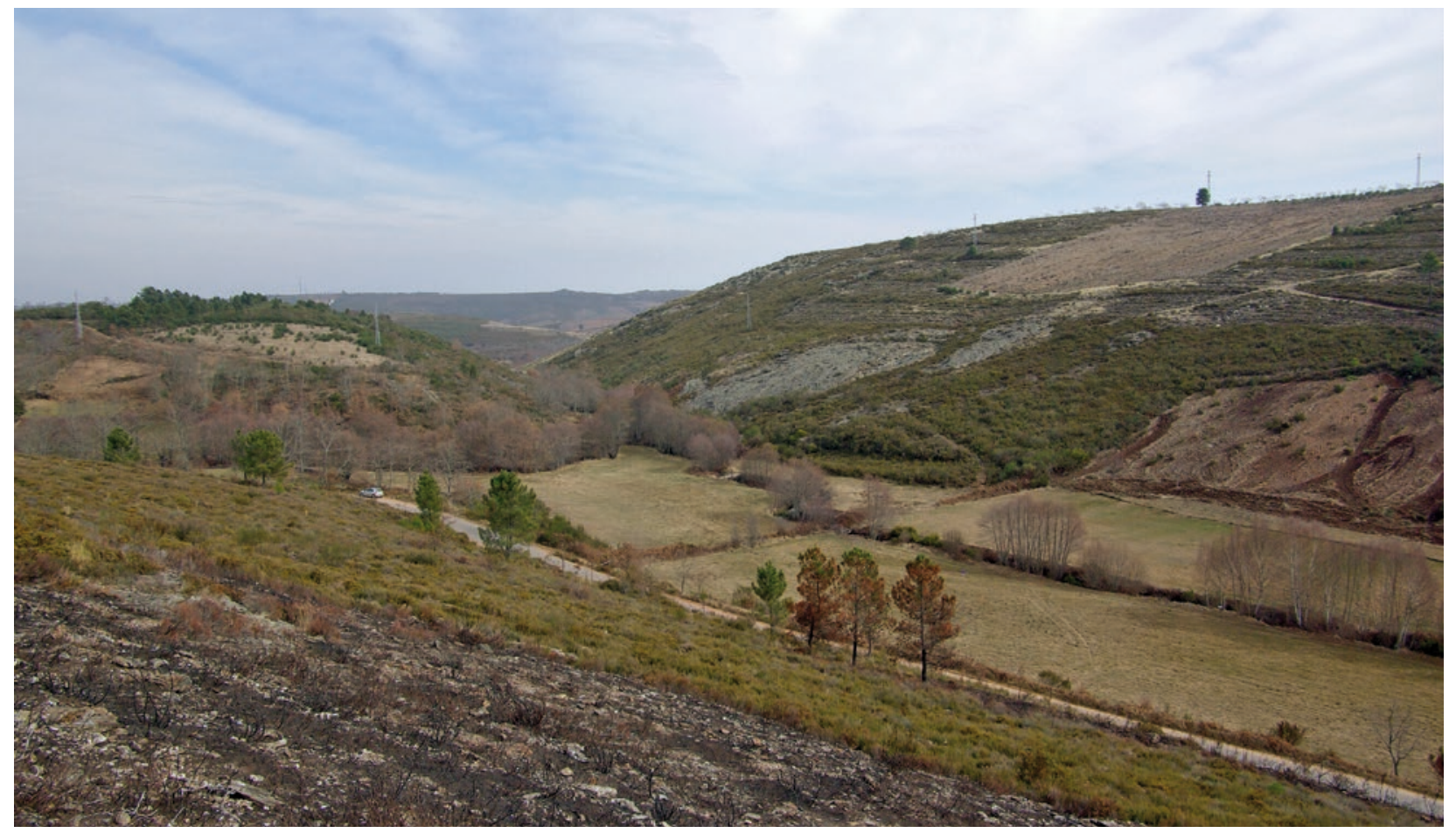

Fig. 5.0-13: Territorium metallorum Tresminas / Jales: vista da posição da antiga barragem na Ribeira de Frades, entre Tazém e Cabanas (freg. Carrazedo de Montenegro, conc. de Valpaços). Em primeiro plano é visivel a zona do antigo reservatório. Vista de sudoeste (fotografia: C. Wahl).

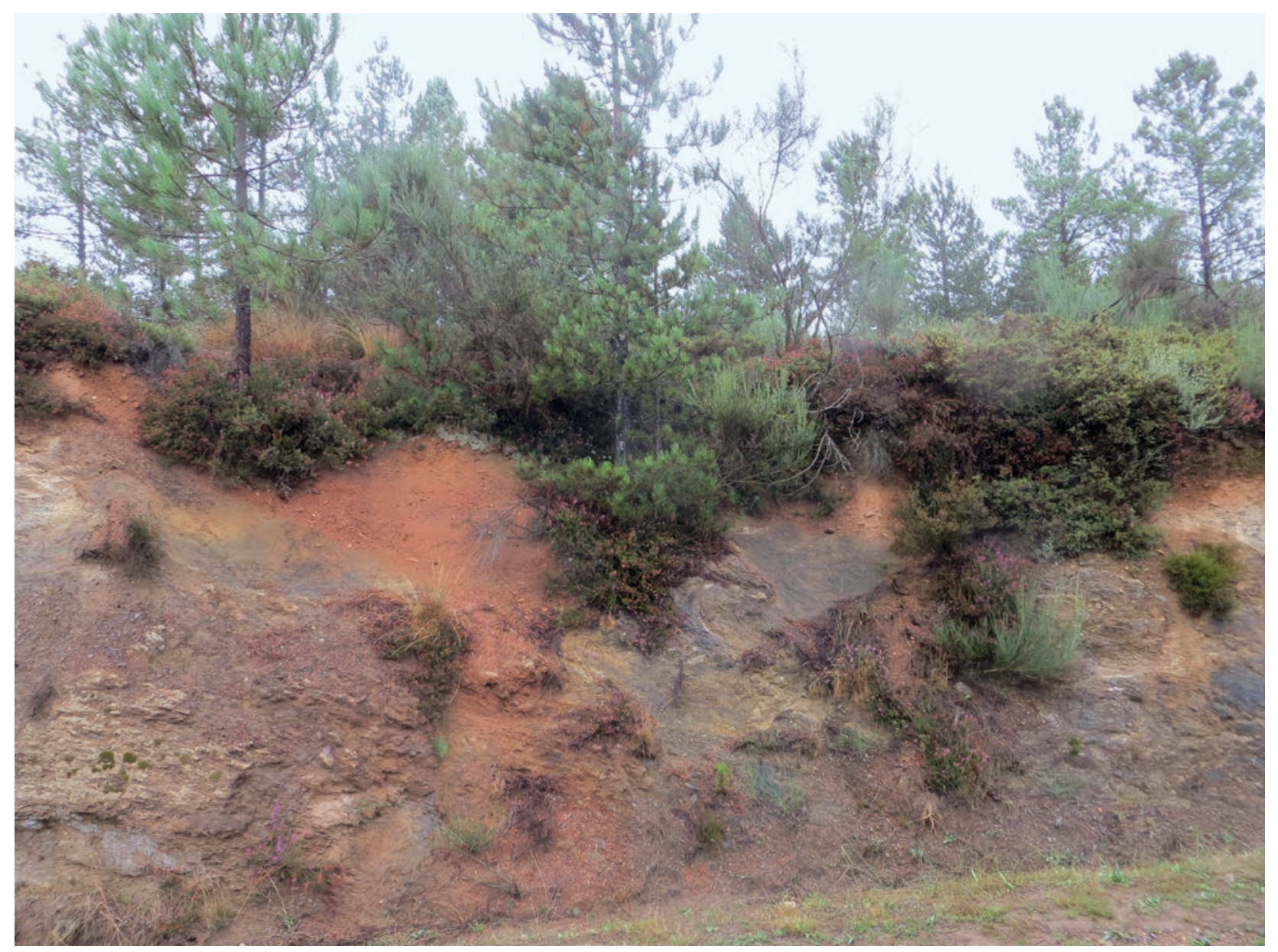

Fig. 5.0-14: Territorium metallorum Tresminas / Jales: neste fosso natural, junto da estrada de Tinhela de Baixo para Tresminas, é visivel o material avermelhado e argiloso utilizado para construir as barragens de terra (fotografia: $R$. Wahl-Clerici). 


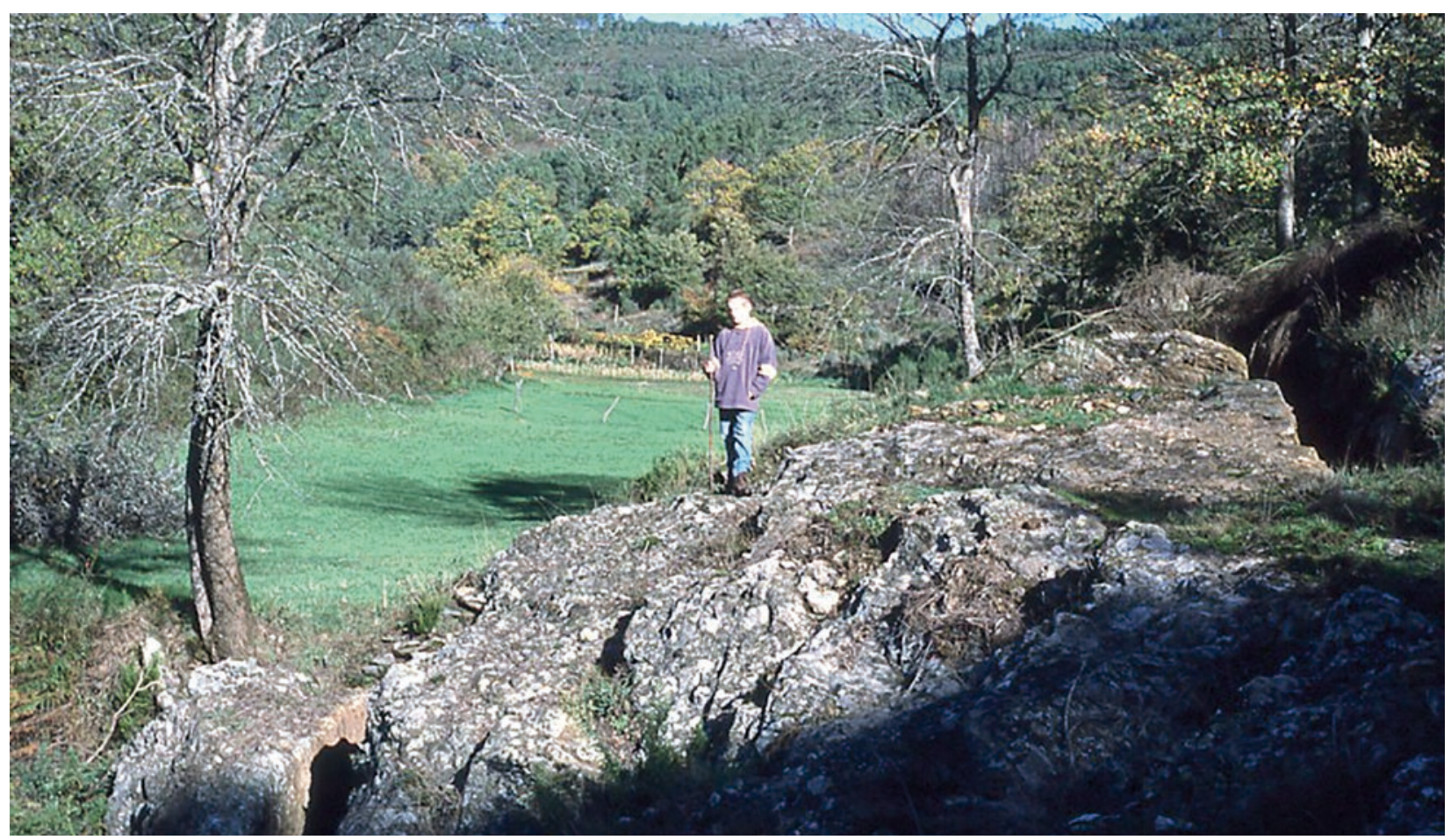

Fig. 5.0-15: Territorium metallorum Tresminas / Jales: barragem no Ribeiro do Muro a sudeste de Vilarelho. Em primeiro plano, são visíveis várias escavações nas rochosas que serviam para a entrada e saída de água. A antiga barragem encontra-se coberta por vegetação (fotografia: $R$. Wahl-Clerici).

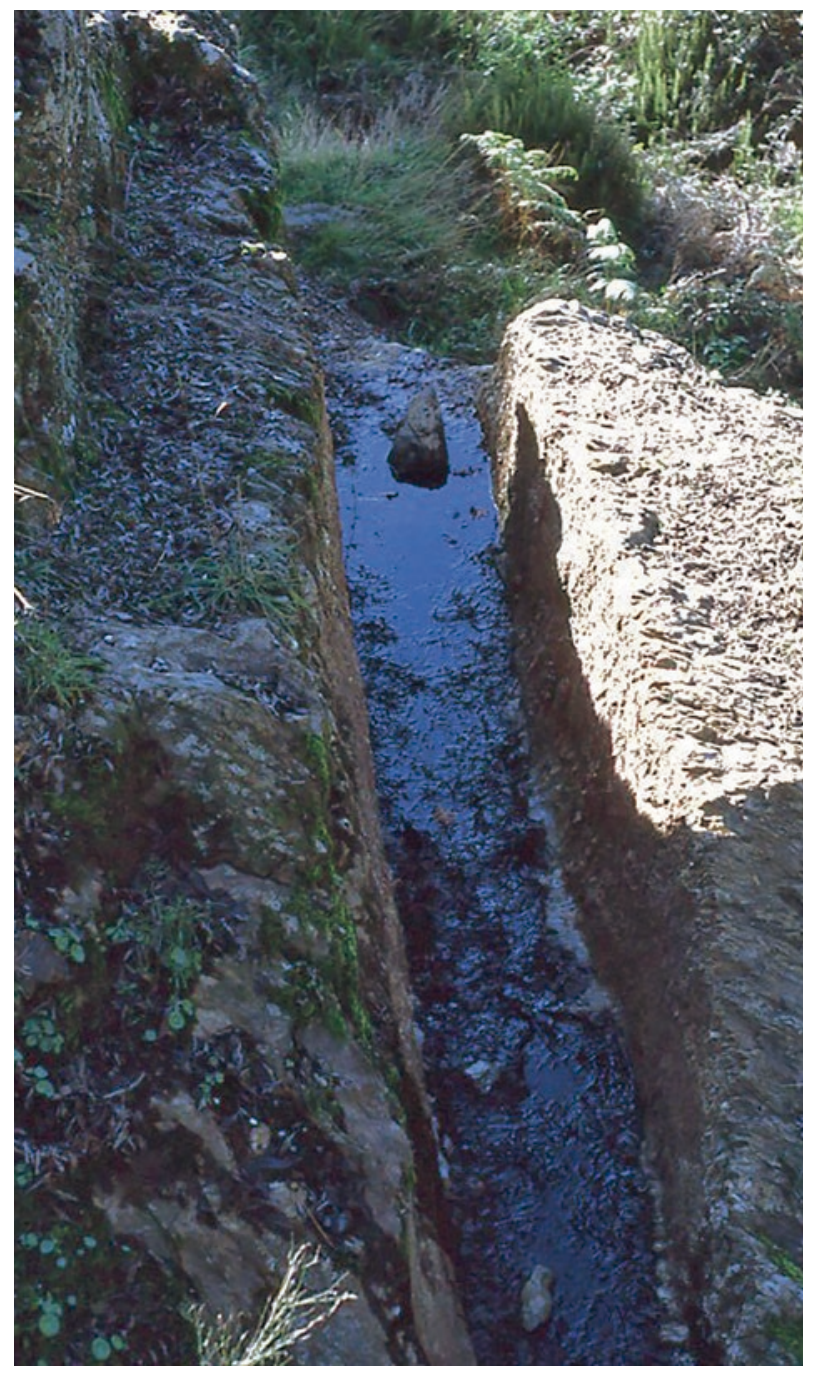

Fig. 5.0-16: Territorium metallorum Tresminas/Jales: detalhe da construção da barragem no Ribeiro do Muro, a sudeste de Vilarelho (fotografia: R. WahlClerici). 


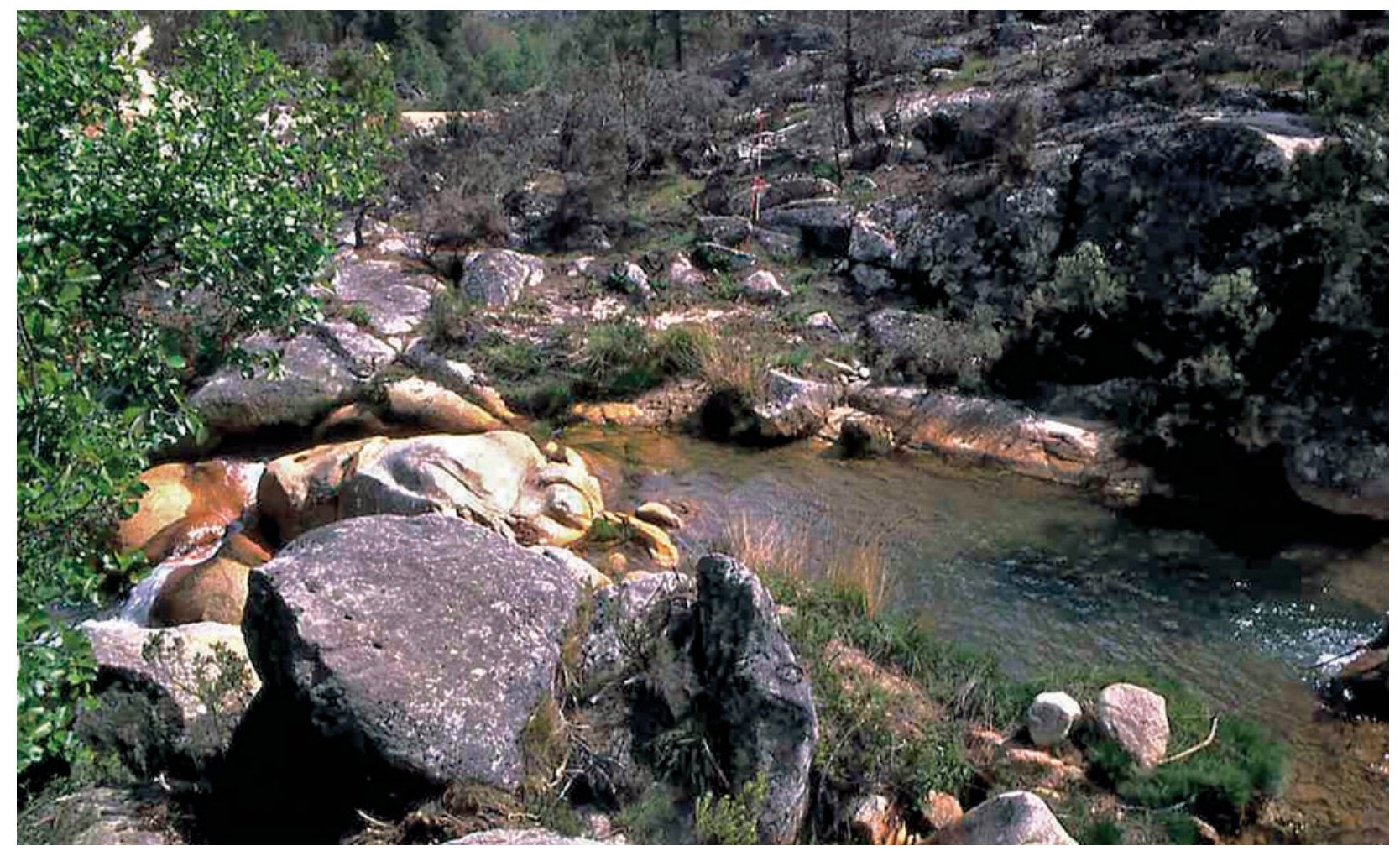

Fig. 5.0-17: Territorium metallorum Tresminas / Jales: fundação da barragem da ribeira da Peliteira. O aqueduto que levava a água até à zona de tratamento no Forno dos Mouros era abastecido a partir deste ponto. A saída principal é indicada pelo marco. Visto de noroeste (fotografia: R. Wahl-Clerici). 


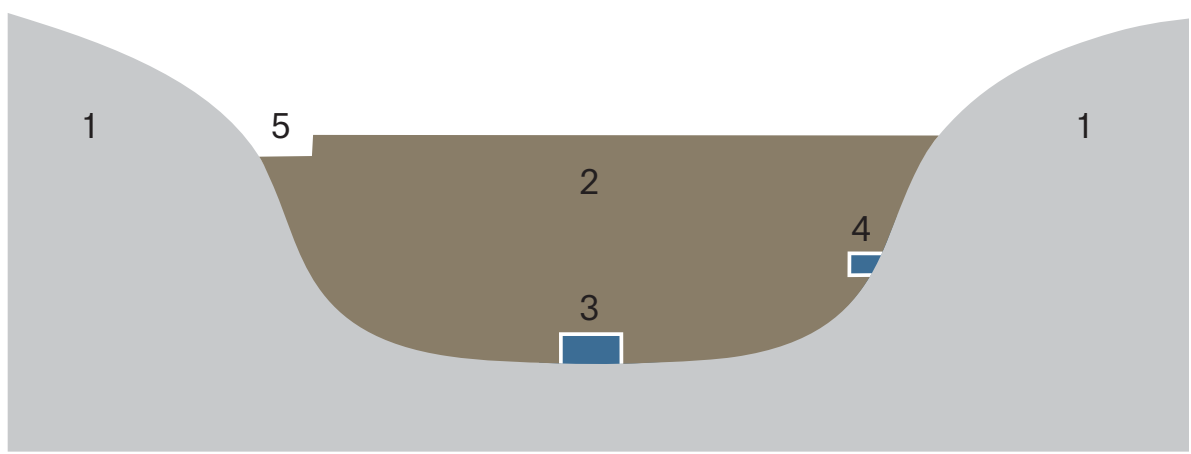

Fig. 5.0-18: Esquema de barragem e escoamentos. 1 = rocha, $2=$ barragem, $3=$ saída inferior, $4=$ saída principal, 5 = transbordo. (modelo: R.Wahl-Clerici, desenho: S.Mathiuet).

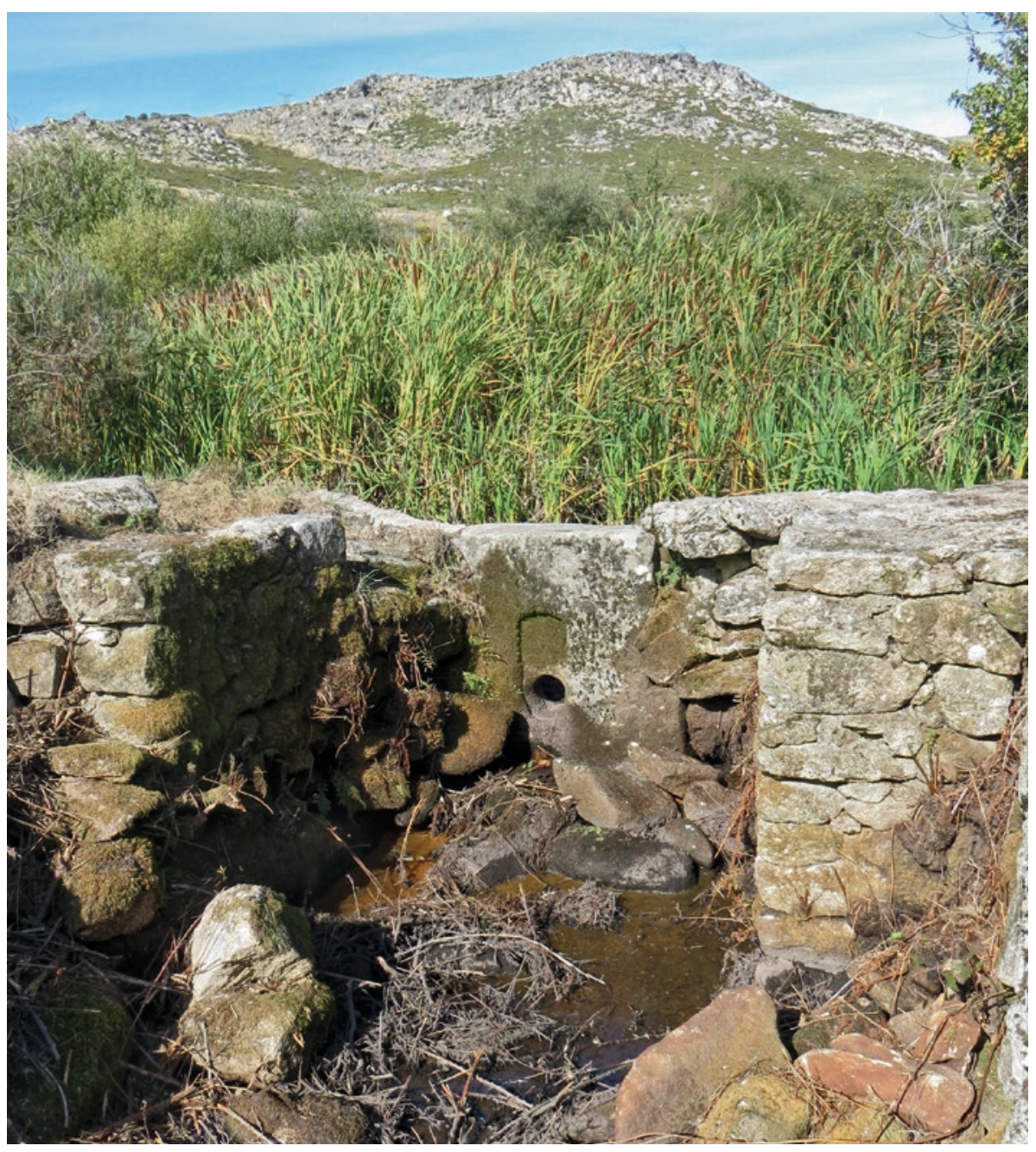

Fig. 5.0-19: Territorium metallorum Tresminas / Jales: barragem de aterro na nascente da ribeira da Peliteira. A saída inferior é separada da área do reservatório por um grande bloco de pedra com um dispositivo para regular o fluxo. Vista do lado do vale (fotografia: R. Wahl-Clerici). 


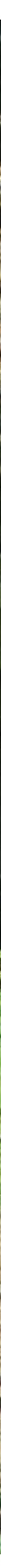

Fig. 5.0-20: Territorium metallorum Tresminas / Jales: açude de Sevivas. O aqueduto C4 para a zona mineira de Tresminas era alimentado a partir daqui. Os cortes na rocha grande marcam o início do canal (fotografia: $R$. Wahl-Clerici). 


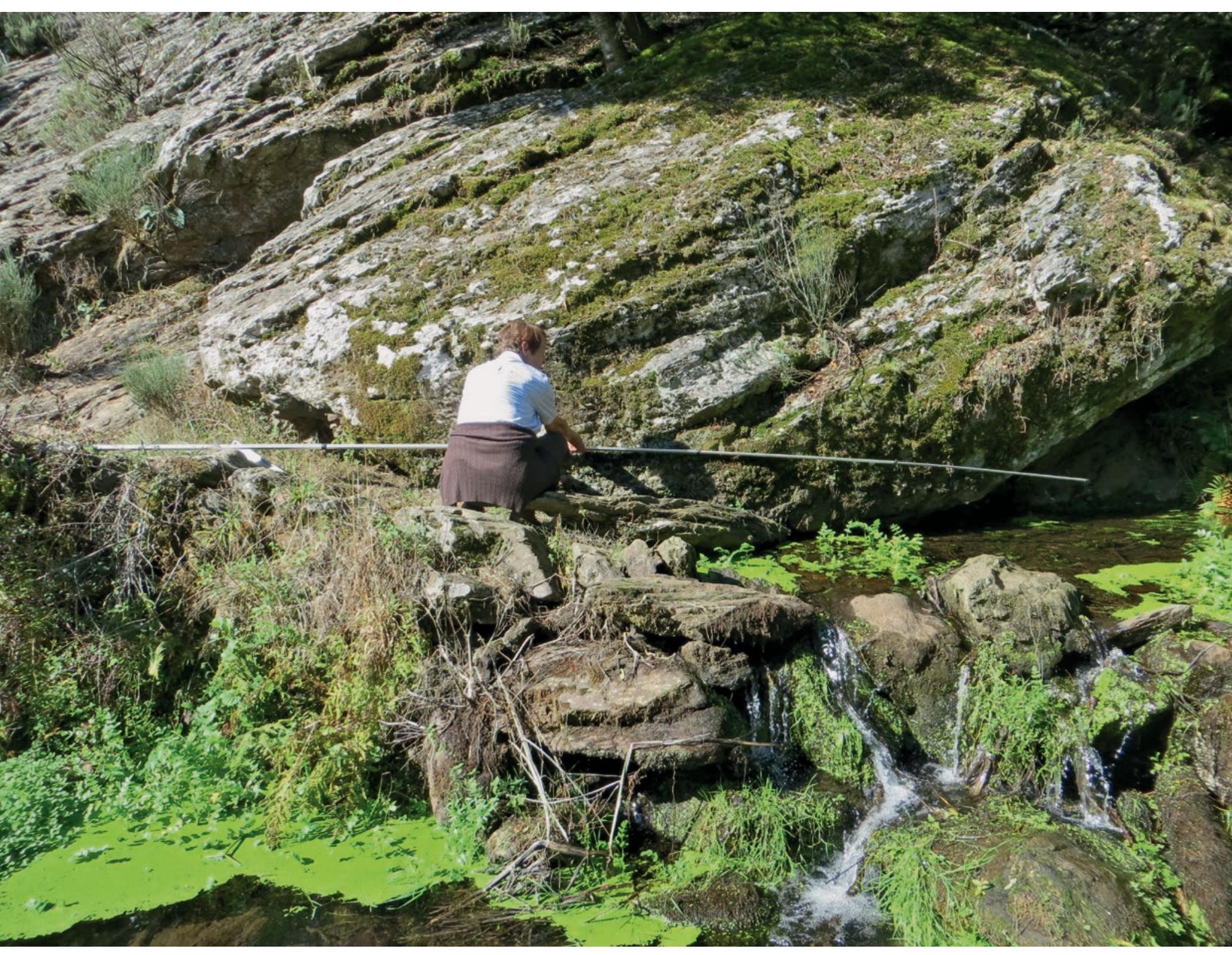

Fig. 5.0-21: Territorium metallorum Tresminas /Jales: açude de Sevivas: o aqueduto C4 era abastecido neste ponto. A vara de medição marca o nível do aqueduto que pode ser captado a partir do lado do vale (fotografia: $R$. Wahl-Clerici). 


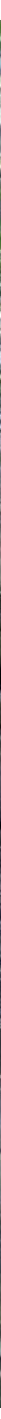

Fig. 5.0-22: Territorium metallorum Tresminas /Jales: açude no Rio Tinhela em Vale Curtinha. Vista do lado do vale. A saída inferior encontra-se escondida debaixo da rocha grande em posição transversal. Vista de oeste (fotografia: $R$. Wahl-Clerici). 


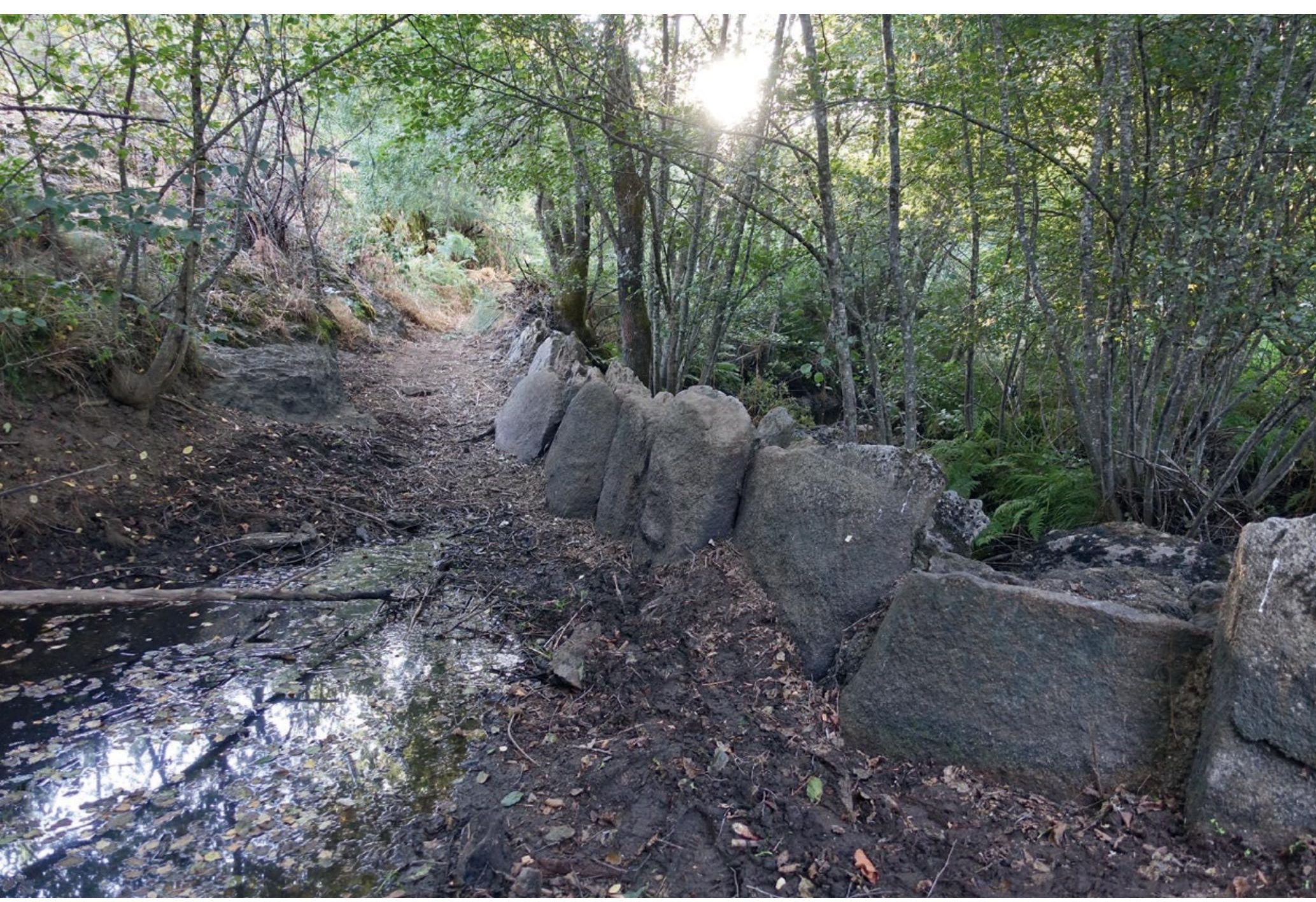

Fig. 5.0-23: Territorium metallorum Tresminas / Jales: açude no Rio Tinhela no Vale Curtinha. Vista sobre o reservatório com as placas graníticas protetoras, a saída encontra-se entre a rocha trabalhada e as placas de granito. Vista de norte (fotografia: R. Wahl-Clerici). 


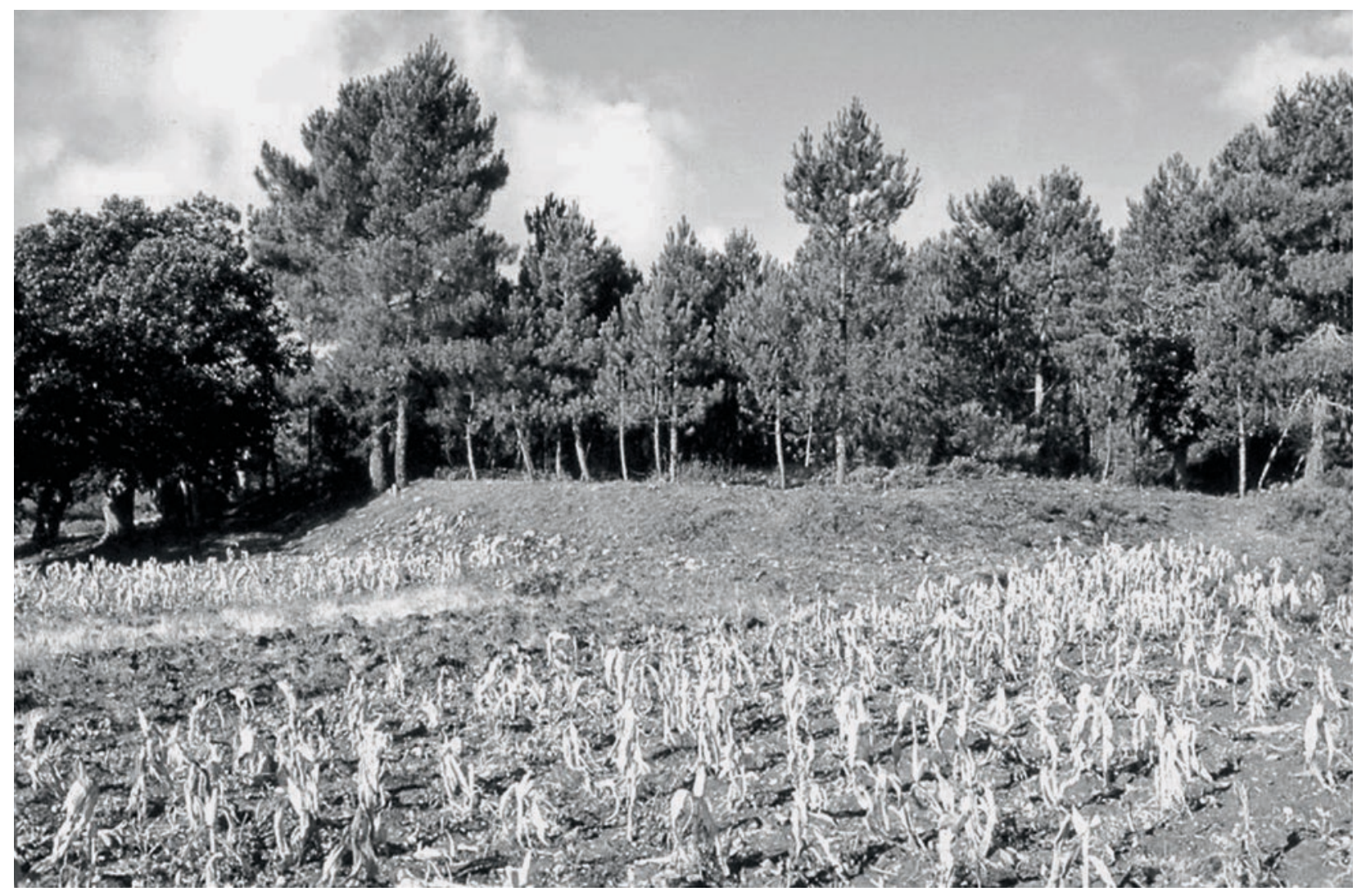

Fig. 5.0-24: Territorium metallorum Tresminas / Jales. Tresminas: vista sobre a parede exterior do tanque de sedimentação na área do povoado (fotografia: J. Wahl).

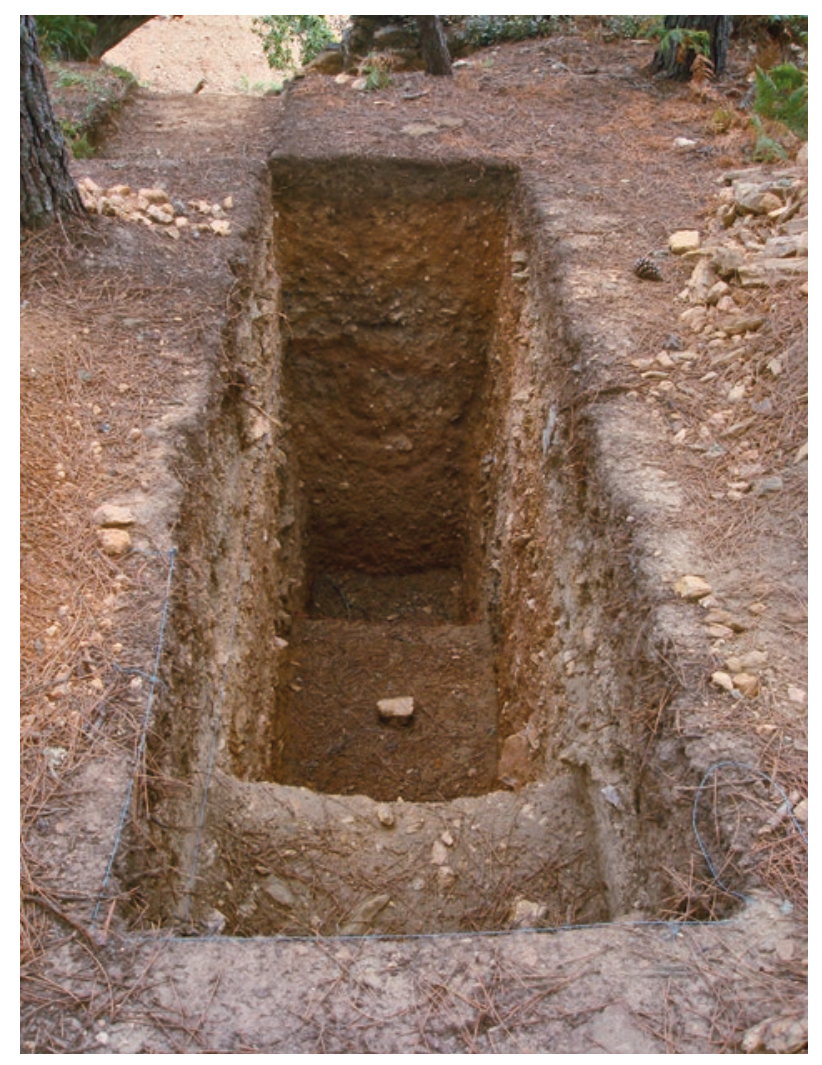

Fig. 5.0-25: Territorium metallorum Tresminas/Jales. Tresminas: vista sobre uma seç̧ão do tanque de água na área do povoado. O material muito duro é intercalado com pequenas pedras (fotografia: $R$. Wahl-Clerici). 


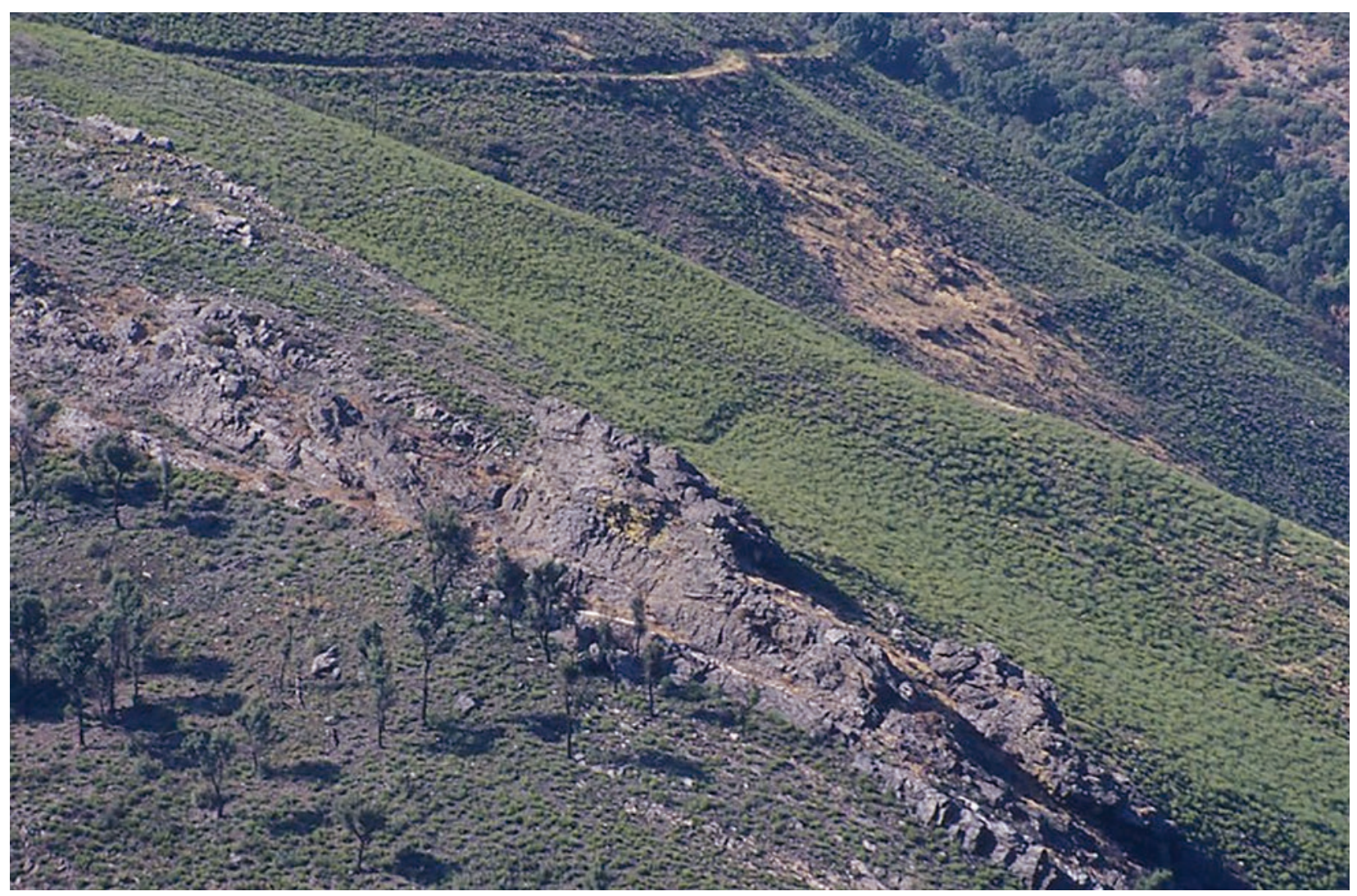

Fig. 5.0-26: Territorium metallorum Tresminas/Jales: a elevação na encosta apresenta o percurso do aqueduto C4, que continua na rocha cortada nas figuras 5.0-27a/b/c, 5.0-28 (fotografia: J. Wahl). 


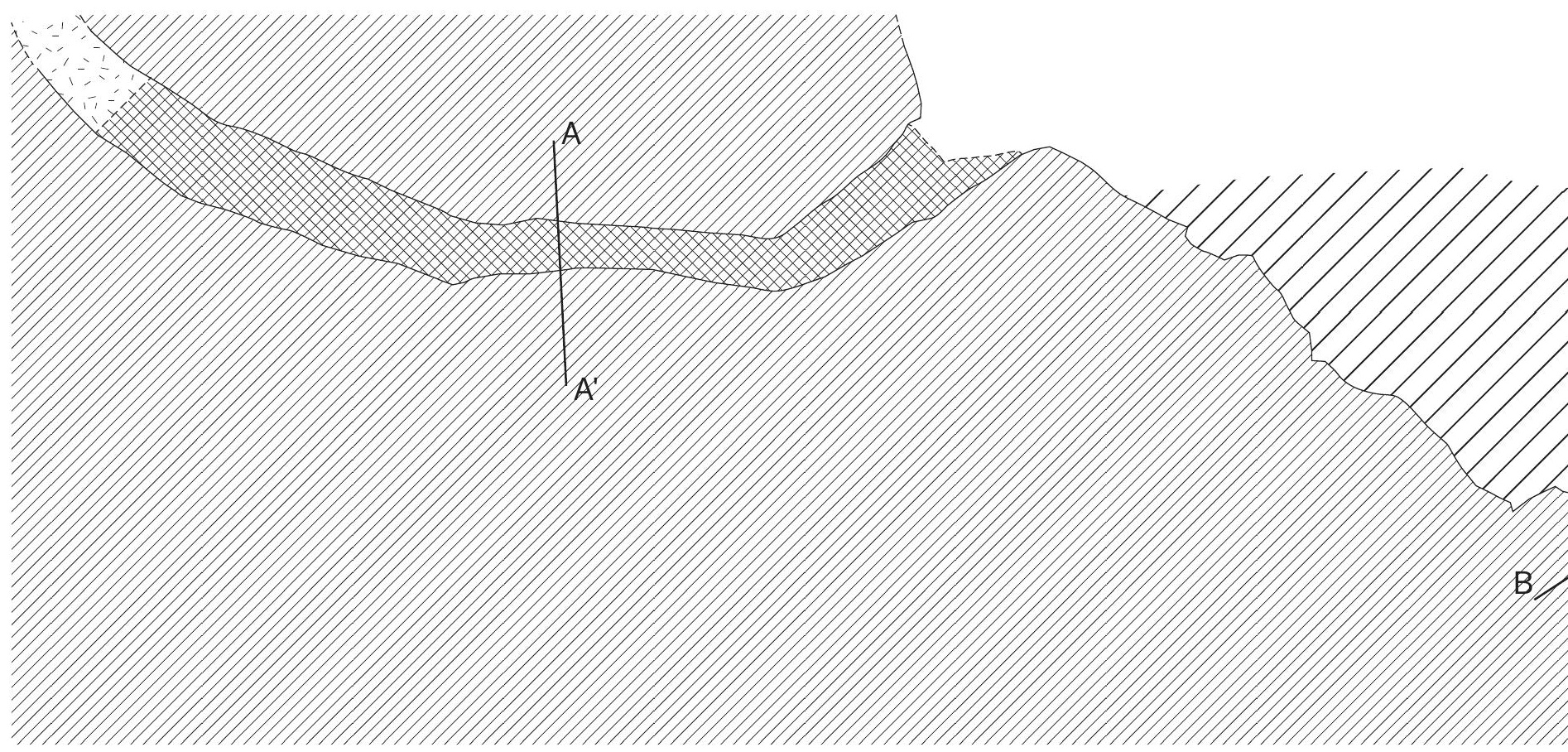

Nível da conduta de água

\section{P/A Subestrutura do muro}

\section{Rocha}

A

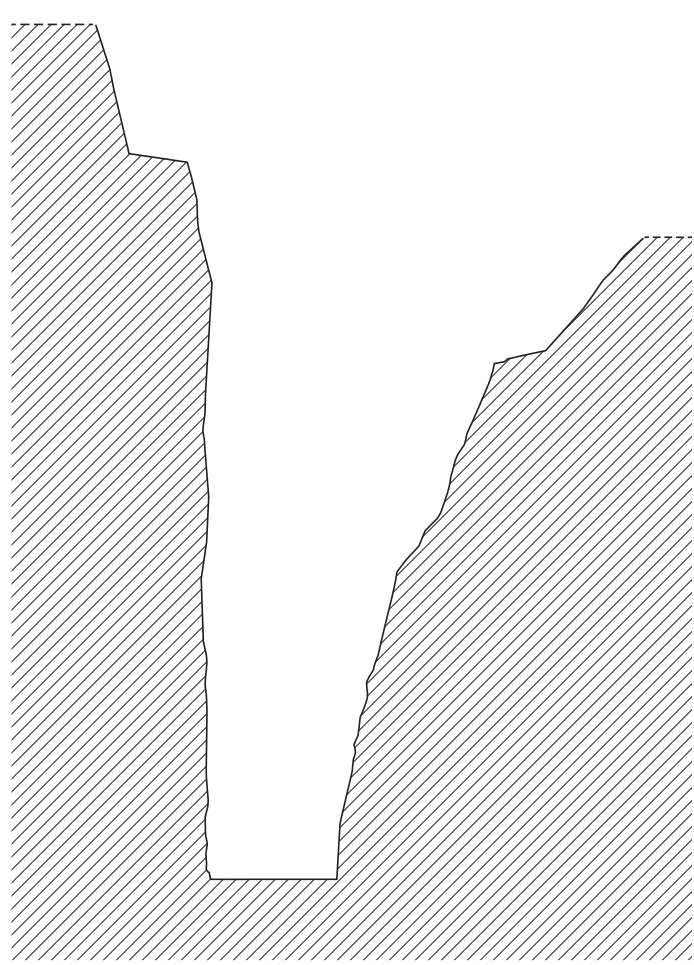

$1 \mathrm{~m}$

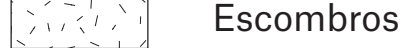

प[ए] Vestígios do muro de contenção

Fig. 5.0-27b: Territorium metallorum Tresminas/Jales: corte na rocha do aqueduto C4 acima da Ribeirinha.

Secção A - A' (documentação: E. Andenmatten 18.09.2000, desenho: $R$. Wahl-Clerici 2013) 

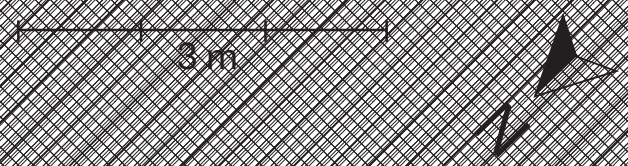

Fig. 5.0-27a: Territorium metallorum Tresminas / Jales: esquema do corte na rocha do aqueduto C4 acima da Ribeirinha (documentação: E. Andenmatten 18.09.2000, desenho: R. Wahl-Clerici 2013).

B

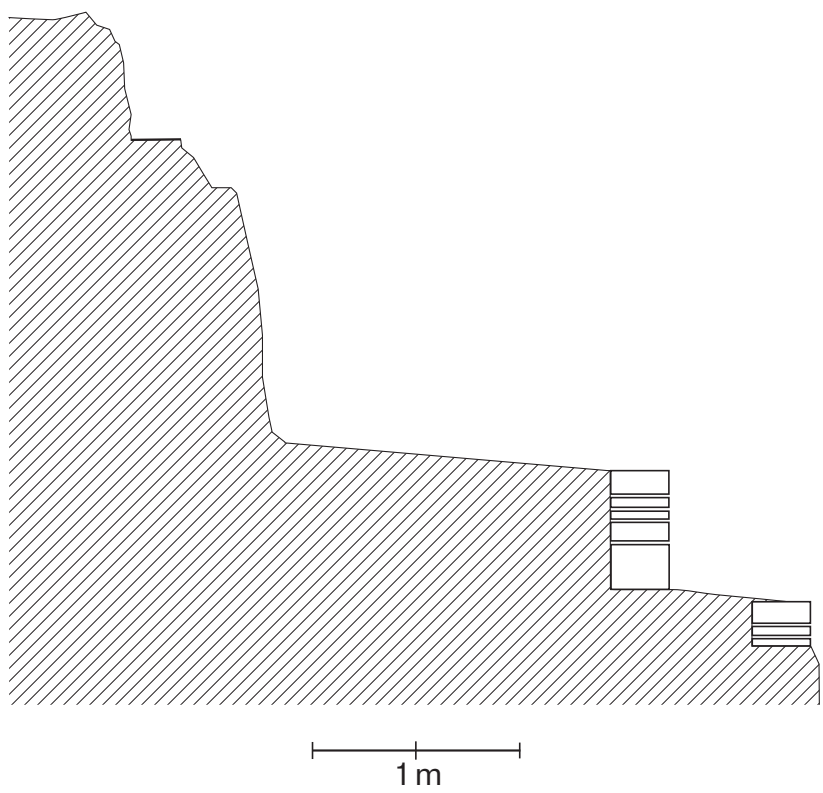

$B^{\prime}$

Fig. 5.0-27c: Territorium metallorum Tresminas / Jales: corte na rocha do aqueduto C4 acima da Ribeirinha. Secção B - B‘ (documentação: E. Andenmatten 18.09.2000, desenho: R. Wahl-Clerici 2013). 


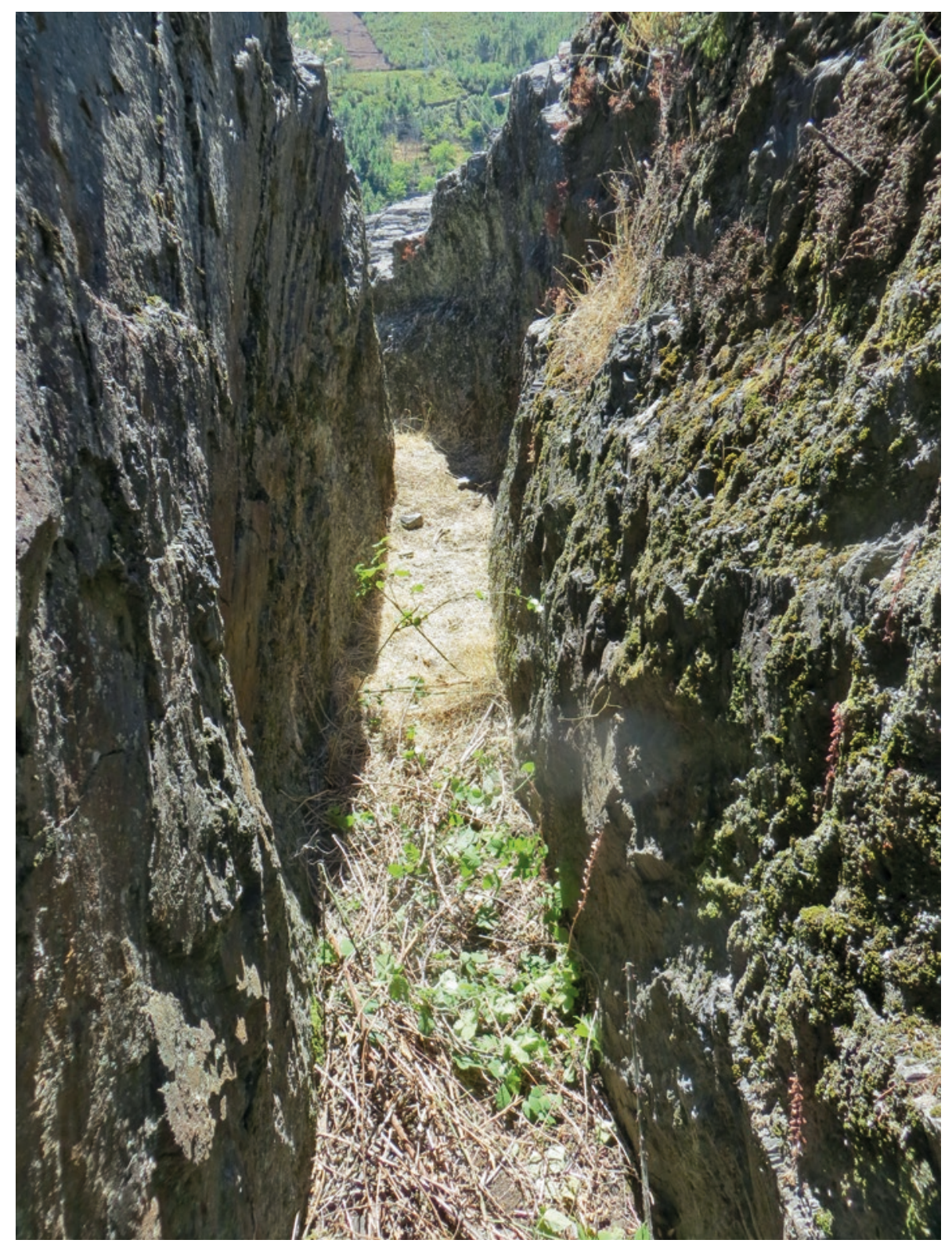

Fig. 5.0-28: Territorium metallorum Tresminas / Jales: corte na rocha do aqueduto C4 acima da Ribeirinha. Vista em direção a sul (fotografia: $R$. Wahl-Clerici). 


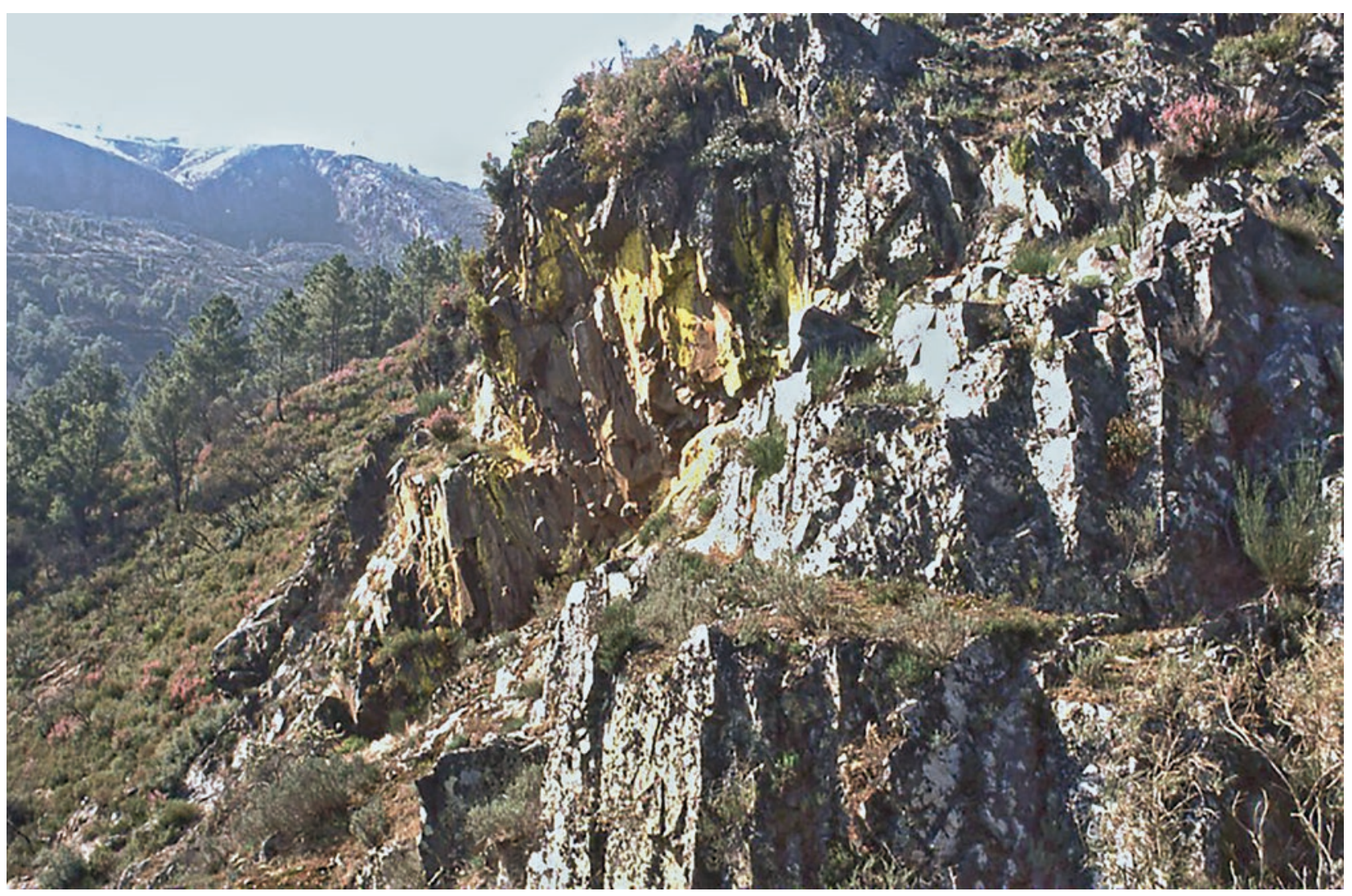

Fig. 5.0-29: Territorium metallorum Tresminas / Jales: escavações na rocha para o aqueduto C4 no flanco norte do vale da Ribeirinha (fotografia: J. Wahl). 


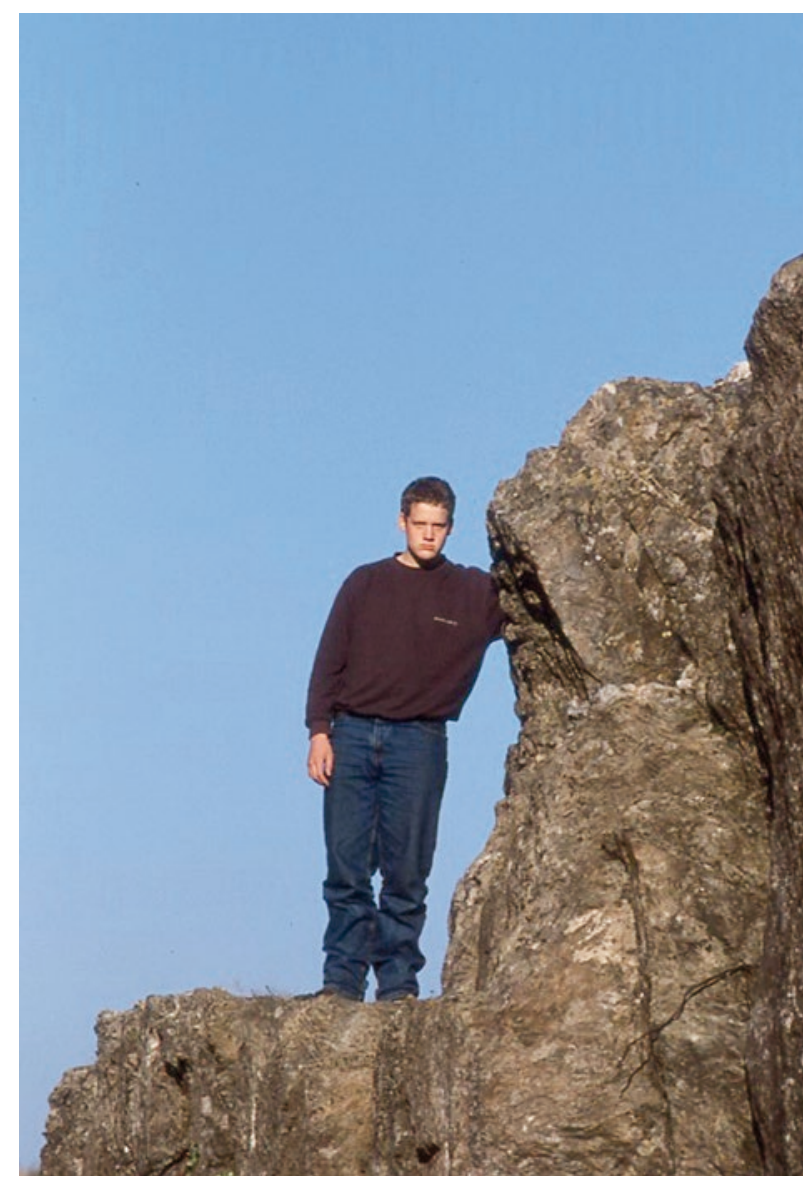

Fig. 5.0-30: Territorium metallorum Tresminas / Jales: incisões na rocha do aqueduto T2 (fotografia: $R$. Wahl-Clerici).

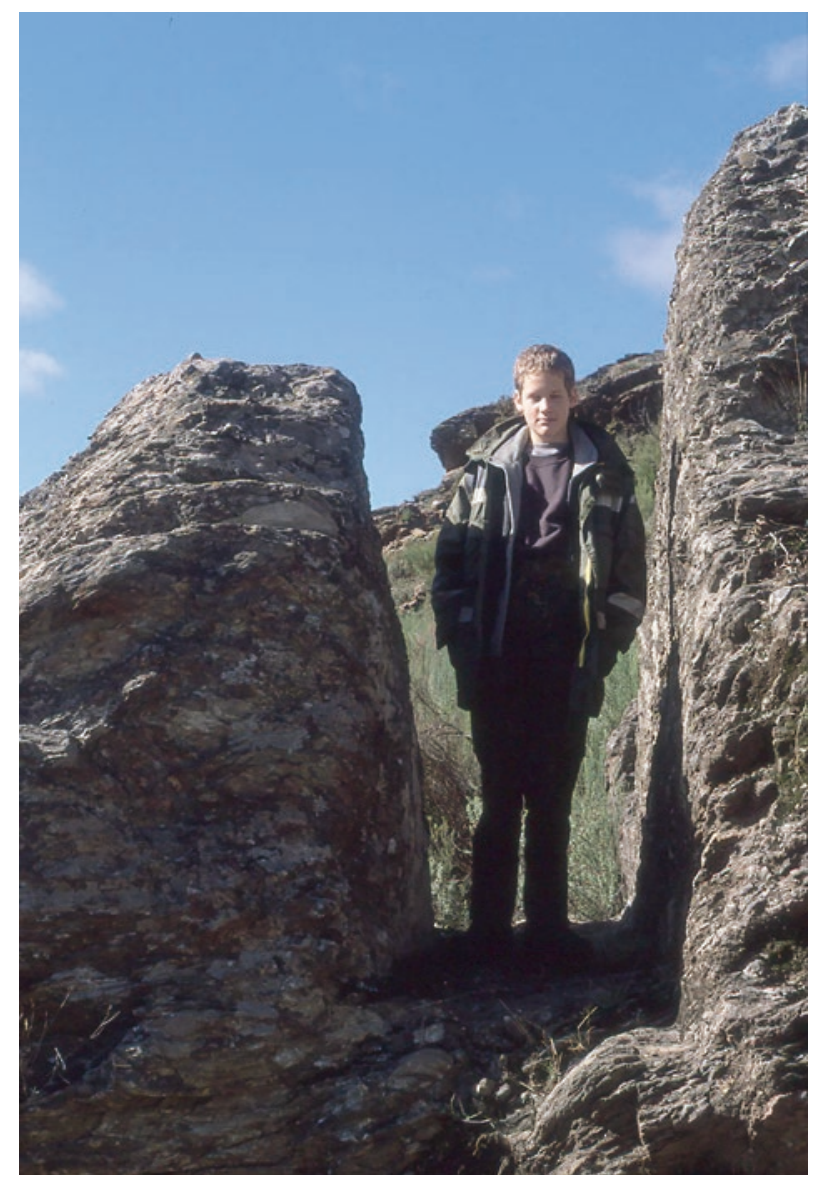

Fig. 5.0-31: Territorium metallorum Tresminas/Jales: corte na rocha em Fragas Amarelas para o aqueduto C3 perto de Cabanas (Freg. Carrazedo de Montenegro, Conc. Valpaços) (fotografia: R. Wahl-Clerici).

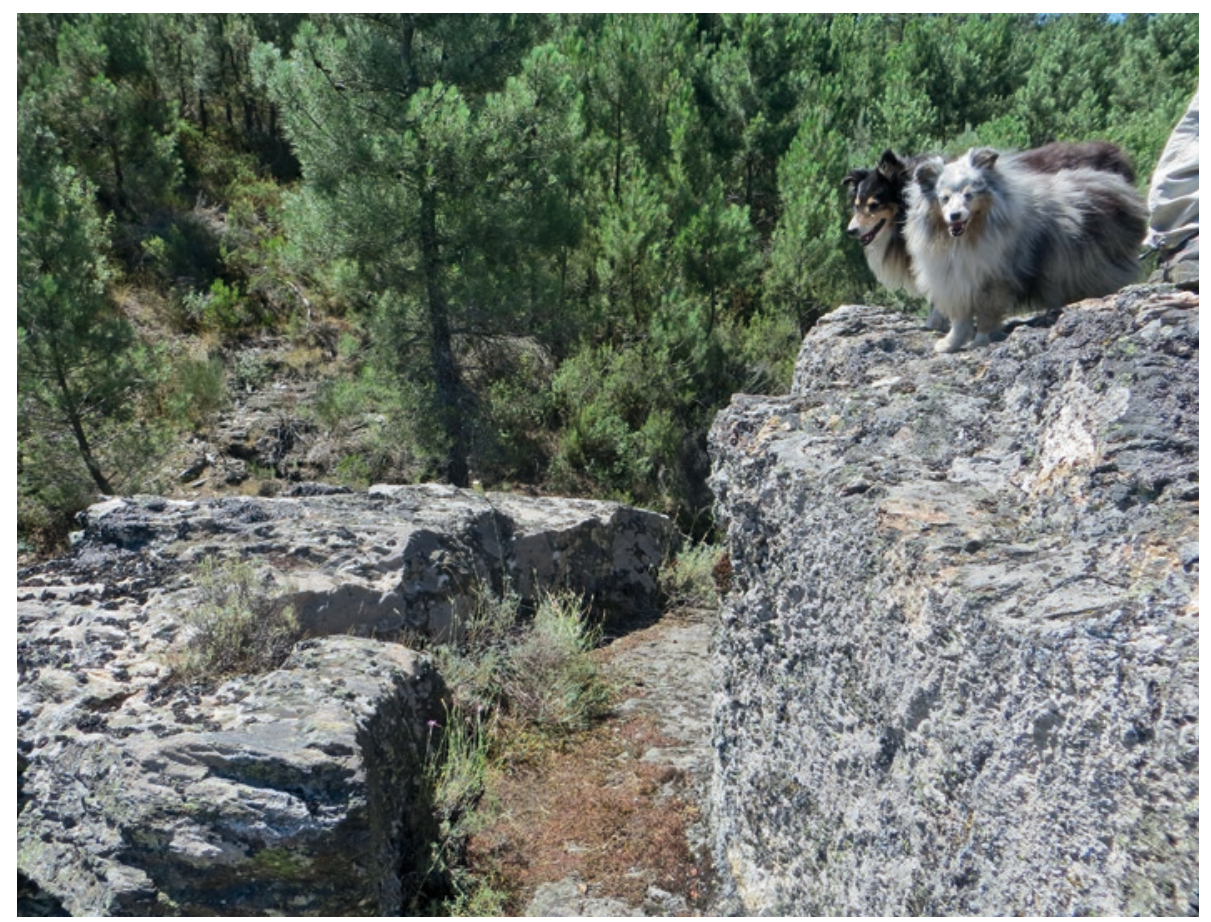

Fig. 5.0-32: Territorium metallorum Tresminas / Jales, Fragas Cortadas: incisões na rocha no aqueduto C3 (fotografia: R. Wahl-Clerici). 


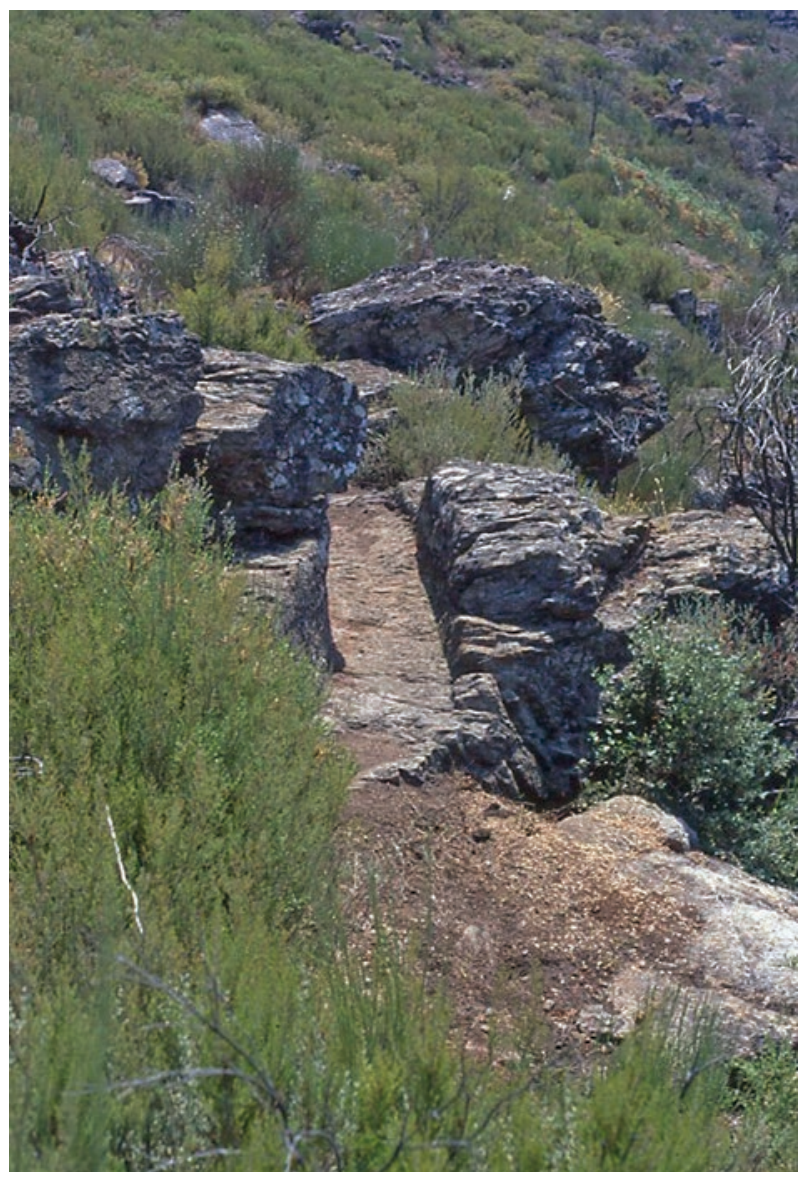

Fig. 5.0-33: Territorium metallorum Tresminas/Jales: o aqueduto T6 no vale do Rio Tinhela, em frente à zona de tratamento do Forno dos Mouros (fotografia: R. Wahl-Clerici).

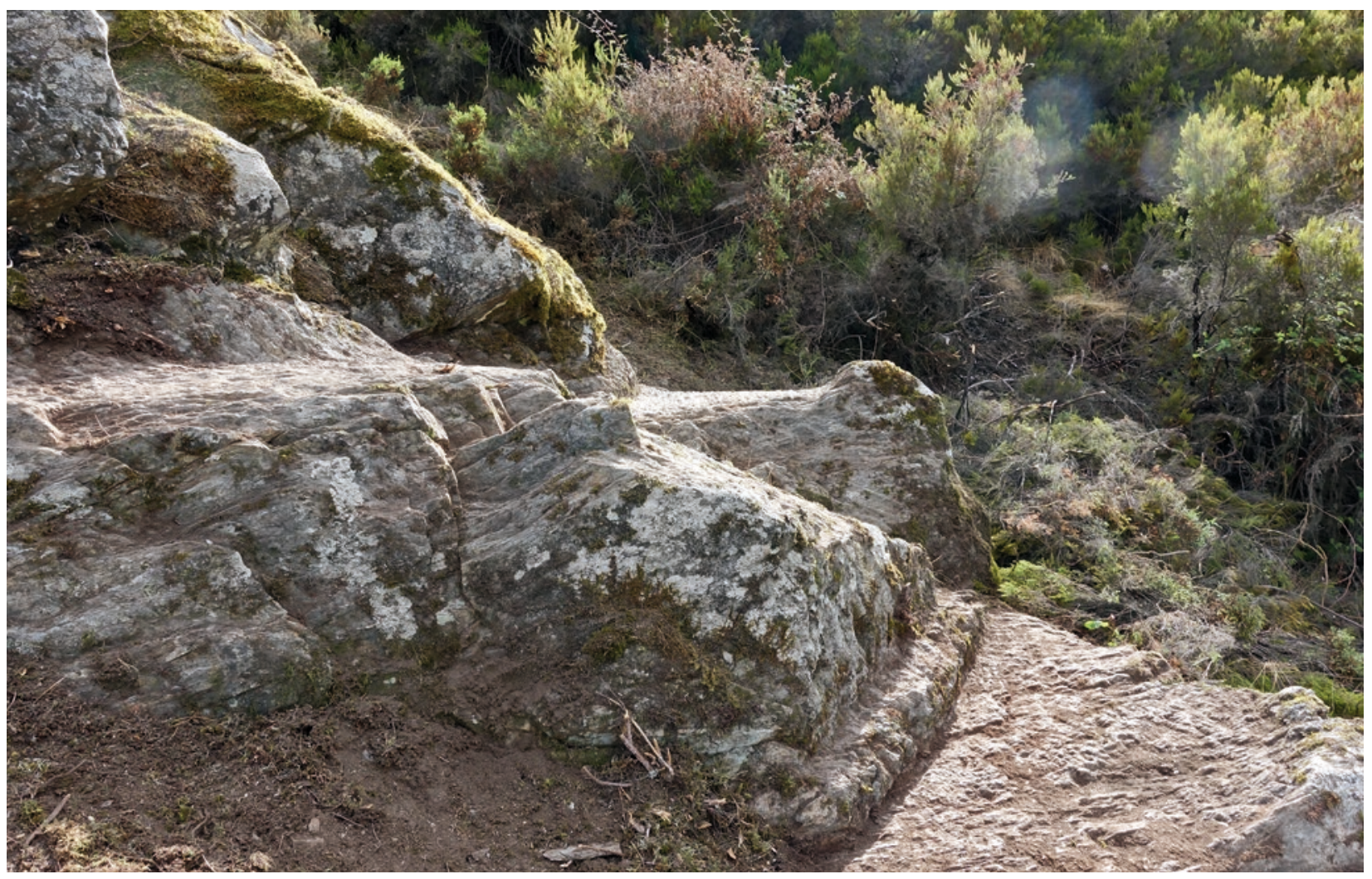

Fig. 5.0-34: Territorium metallorum Tresminas/Jales, Vilarelho, aqueduto T1: ponto de ligação de dois troços de construção (fotografia: R. Wahl-Clerici). 

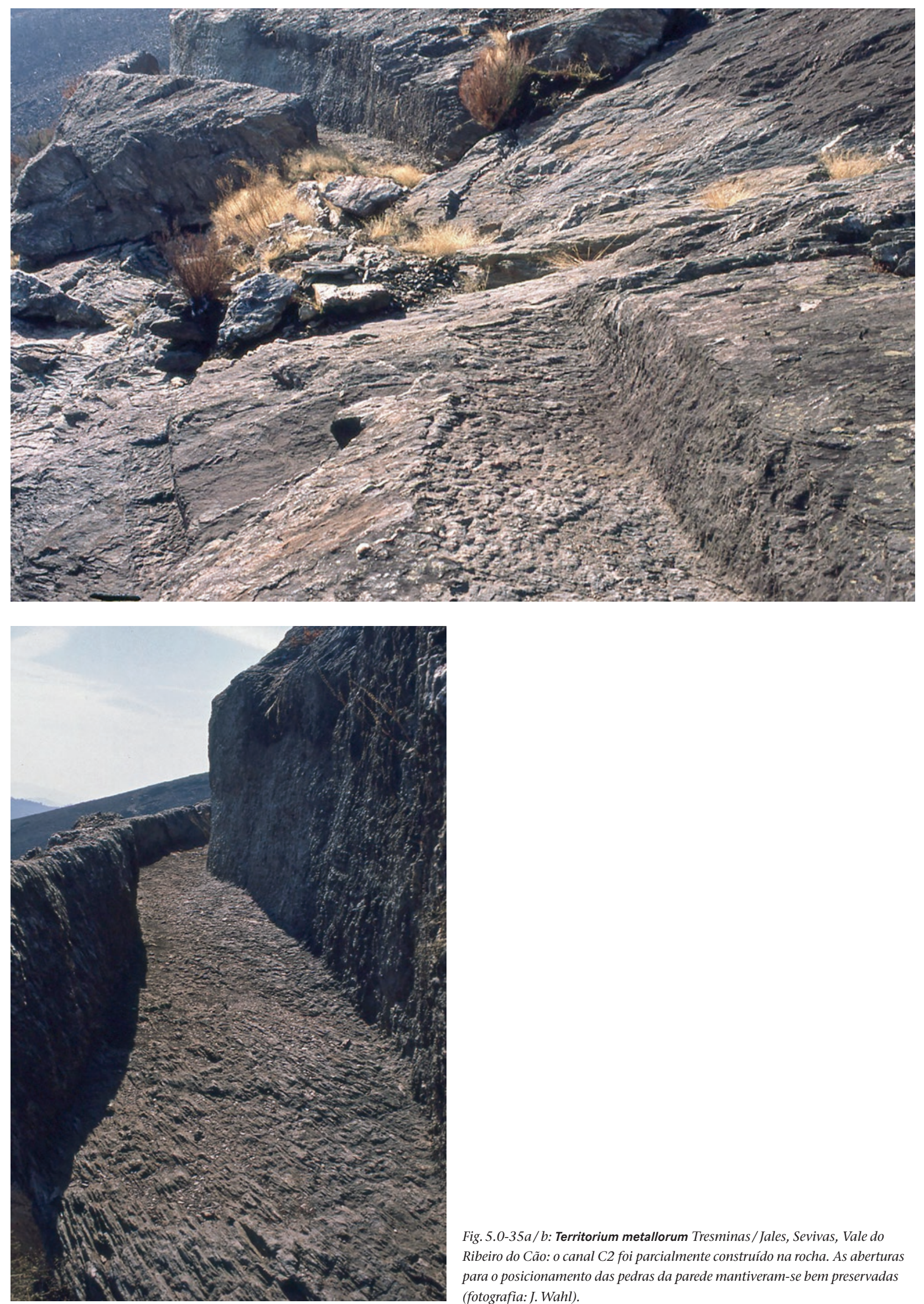

Fig. 5.0-35a/b: Territorium metallorum Tresminas/Jales, Sevivas, Vale do Ribeiro do Cão: o canal C2 foi parcialmente construído na rocha. As aberturas para o posicionamento das pedras da parede mantiveram-se bem preservadas (fotografia: J. Wahl). 


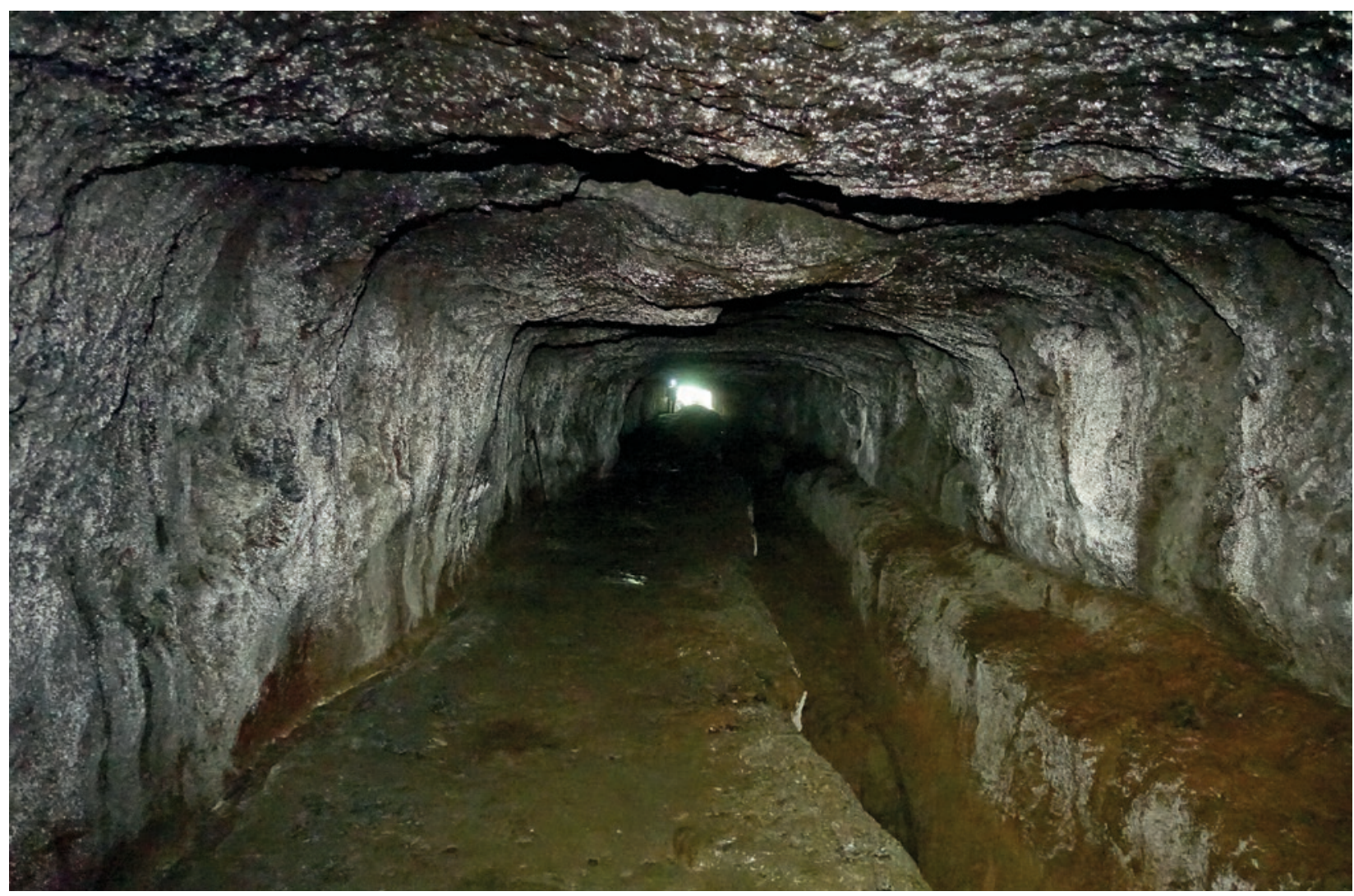

Fig. 5.0-36: Territorium metallorum Tresminas /Jales, Tresminas, Galeria do Pilar, vista de sul: canal de drenagem na zona oriental de trabalho (foto: R.WahlClerici). 


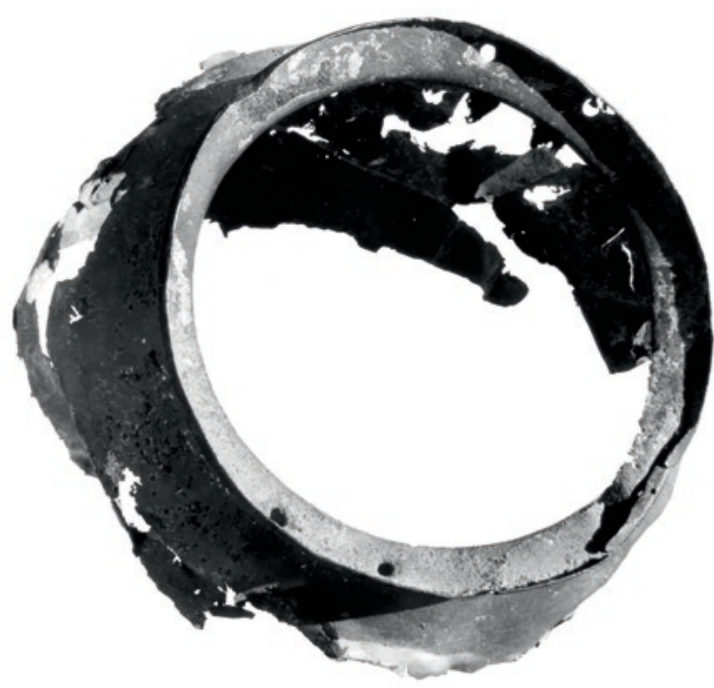

Fig. 5.0-37: Territorium metallorum Tresminas/Jales, Campo de Jales: um recipiente de bronze, provavelmente pertencente a uma nora. (Museu Municipal Padre José Rafael Rodrigues de Vila Pouca de Aguiar, fotografia: J. Wahl).

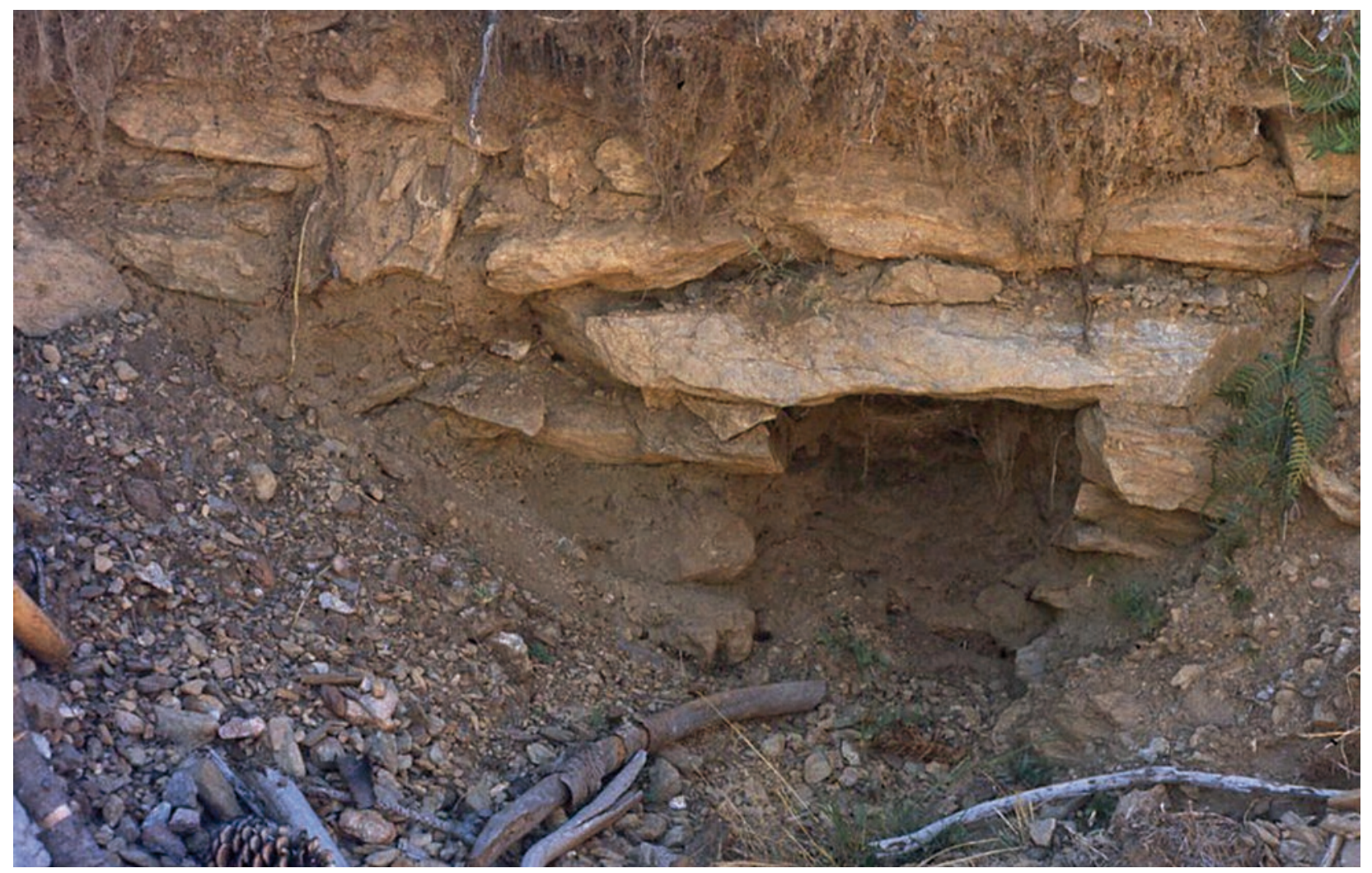

Fig. 5.0-38: Territorium metallorum Tresminas /Jales, Forno dos Mouros: canal de escoamento cuidadosamente construído e com pedra angular larga (fotografia: R. Wahl-Clerici). 


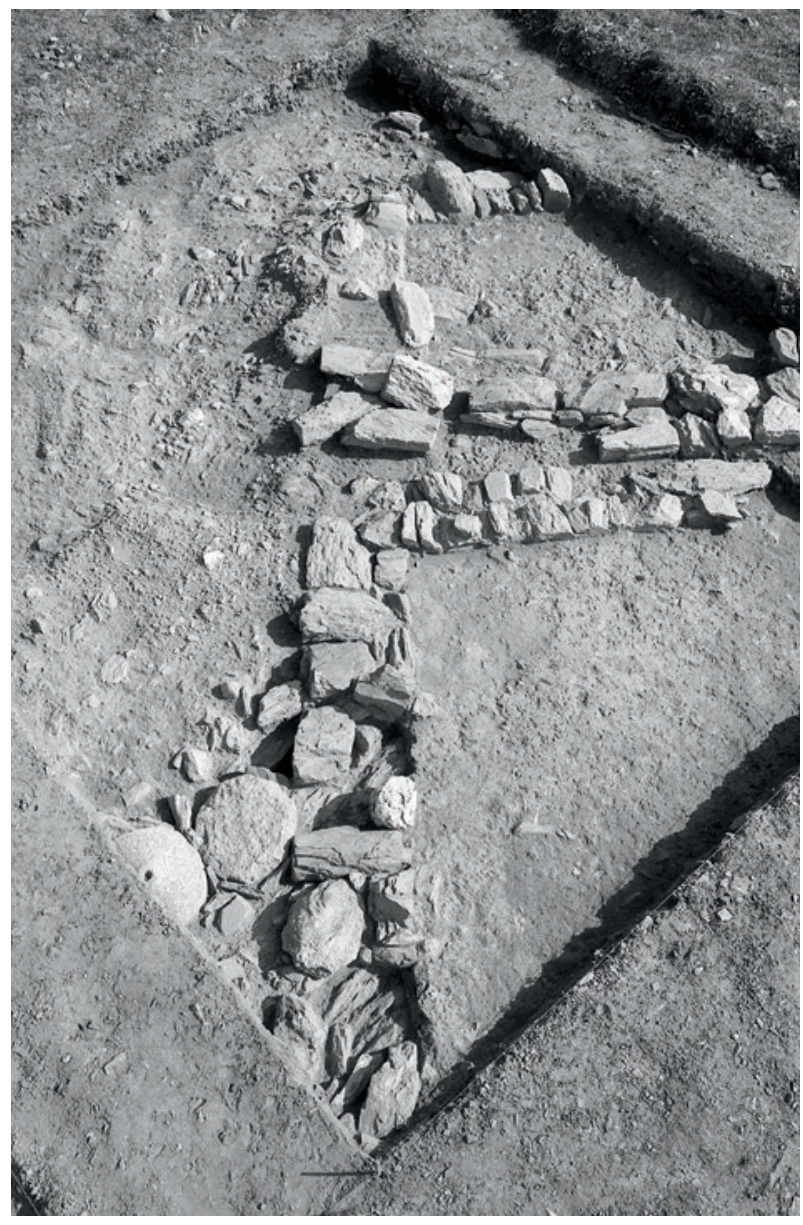

Fig. 5.0-39: Territorium metallorum Tresminas/Jales, Tresminas: canal de escoamento no povoado, coberto com mós do processamento do minério. (D-DAI-MAD-WAHL-KB-81-86-24),

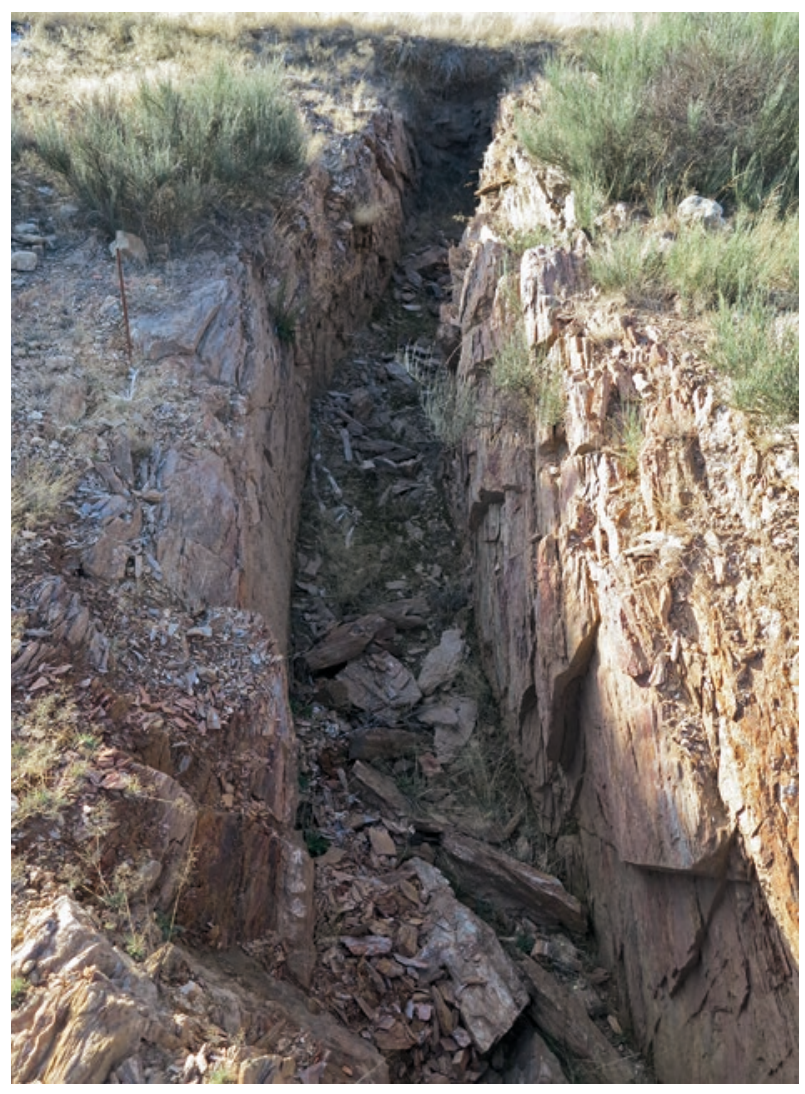

Fig. 5.0-40: Territorium metallorum Tresminas/Jales, Tresminas: canal de escoamento no local do povoado (fotografia: $R$. Wahl-Clerici). 


\subsection{As pedreiras}

No territorium metallorum Tresminas/Jales, a região é rica em rochas de elevada qualidade, como o demonstra a extração de granito no Concelho de Vila Pouca de Aguiar, que ainda hoje é rentável. Na Antiguidade extraía-se aqui rocha em diversos sítios, assim como terra ${ }^{235}$. Essas extrações eram normalmente feitas nas imediações da obra, com o propósito de reduzir custos e esforços. É possível comprovar a exploração local de material de construção, não só para a obra da «Ponte do Arco», mas também para a construção de instalações de lavagem de minério de Tresminas, entre outras obras.

Serviram como material de construção o granito (granito biotítico e granito de duas micas), o xisto e também o material terá terra rica em argila (figs.6.0-1 e 6.0-2). É determinante identificar em todos os casos, tanto o local de extração, como a utilização do material, para ter a certeza de que o material era utilizado para a construção de instalações ligadas à exploração mineira. Por conseguinte, é frequentemente possível determinar a proveniência dos produtos finais (por exemplo, bases de moinhos de pilões, moinhos ou altares) encontrados nas zonas da indústria mineira, que, por sua vez, permitem conclusões em relação à organização da mina. No entanto, no caso de alguns objetos, a determinação exata da origem só será possível depois uma análise geoquímica.

\section{Pedreiras de granito}

Em princípio, podemos pressupor que para o tratamento dos granitos eram utilizados sobretudo blocos de origem erosiva, espalhados no local (fig. 6-0-3). Em casos isolados, é possível comprovar vestígios da extração na rocha matriz ou nos blocos que ainda estão meio cobertos por terra (figs. 6-0-4 até 6.0-7).

Fazem também parte das pedreiras de granito os locais de trabalho dispersos por toda zona envolvente, caracterizados sobretudo pela ausência de blocos de granito, um acentuado amontoamento de extrações da rocha e pela eventual presença de pedras de trabalho descartadas (figs. 6.0-8a/b).

\section{$\mathrm{O}$ granito biotítico}

O granito biotítico, duro e simultaneamente resistente à pressão, encontra-se no vale de Vila Pouca de Aguiar. A qualidade extraordinária desta rocha justifica a sua extração desde os tempos romanos até à atualidade. Além das pedreiras contemporâneas, que não passam despercebidas nem no Google Earth, encontram-se muitas zonas de extração mais antigas, onde a rocha era explorada através de métodos idênticos aos utilizados na época romana. Os poucos vestígios da exploração mineira, claramente romanos, comprovam a existência de pelo menos uma exploração acima da igreja de São Martinho de Bornes, ou seja, na zona com granito biotítico mais próxima de Tresminas (fig. 6.0-4)

Provavelmente o granito biotítico era usado exclusivamente para a produção de bases de moinhos de pilões e mós de britagem, as quais surgiram em grande concentração na proximidade dos locais onde eram executados os processos de tratamento a seco. ${ }^{236}$ As mós de britagem aparecem com relativa frequência como spolia no povoado romano, enquanto as bases de moinhos de pilões foram apenas usadas sob a forma de fragmentos. No entanto, a maior parte das peças foi levada para as aldeias perto das zonas de exploração de Ribeirinha, Covas ou Tresminas (figs. 6.0-9a / b). Em tempos romanos foi construído, com pelo menos 36 bases de moinhos de pilões, o pilar que deu o nome à Galeria do Pilar (fig. 6.0-10). Por último, encontramos na Galeria do Texugo uma base de moinhos de pilões isolada (fig.3.2$13 b)$.

Outro local importante é a zona de tratamento denominada «Forno dos Mouros», na área das jazidas de Gralheira e Campo de Jales (fig. 6.0-2). Neste caso, a maior parte dos objetos graníticos foi encontrada integrada como spolia na construção do moinho moderno, situado abaixo da zona de tratamento (fig. 4.1-1).

Em relação ao granito biotítico, destacam-se os seguintes aspetos:

- O granito biotítico utilizado nas zonas mineiras de Tresminas e Gralheira/Jales foi extraído o mais perto possível, ou seja, perto da zona de transição para a área de xisto, bastante acima do fundo de vale de Vila Pouca de Aguiar.

235 Sousa 2013; O Concelho de Vila Pouca de Aguiar, no qual se situa o território romano metallorum Tresminas / Jales, é também denominado de „Capital de Granito«. Não é conhecida a origem do granito utilizado para revestir a parede exterior do Castro Celtiberiano dos Mouros (Cidadelha, Freg. Alfarela de Jales, Conc. Vila Pouca de Aguiar), localizada numa zona de xisto (fig.2 .0-3).

236 Até à data, foram identificados três moinhos de pilões de quartzito, todos originários da zona a sul da mais antiga zona mineira P1, da Corta de Covas. Todos os moinhos para minério são de granito biotítico. 
- De acordo com os conhecimentos atuais, o granito biotítico foi utilizado exclusivamente para a produção de bases de moinhos de pilões e moinhos redondos.

- Neste contexto surge a seguinte questão: será que estamos perante pedreiras e objetos que ficavam na posse exclusiva do estado?

- Em caso afirmativo, é possível que esses objetos fossem libertados da propriedade do estado após a sua utilização original. A distribuição desses objetos na zona do povoado antigo sugere essa hipótese. Contudo, a área do povoado investigado arqueologicamente é pequena demais para tirar conclusões assertivas sobre a presença generalizada destes objetos.

\section{O granito de duas micas}

O granito de duas micas não era adequado para a produção de moinhos para minério e era utilizado exclusivamente para moinhos de farinha, lápides e para elementos de construção (figs. 6.0-11 e 6.0-12a/b). A produção mais extensa e versátil de objetos pode ser encontrada na pedreira da Fonte da Ribeira, que se situa numa zona de granito que penetra profundamente a zona do xisto. ${ }^{237}$ Foi ainda possível identificar outras pedreiras a partir da pedra utilizada diretamente no local.

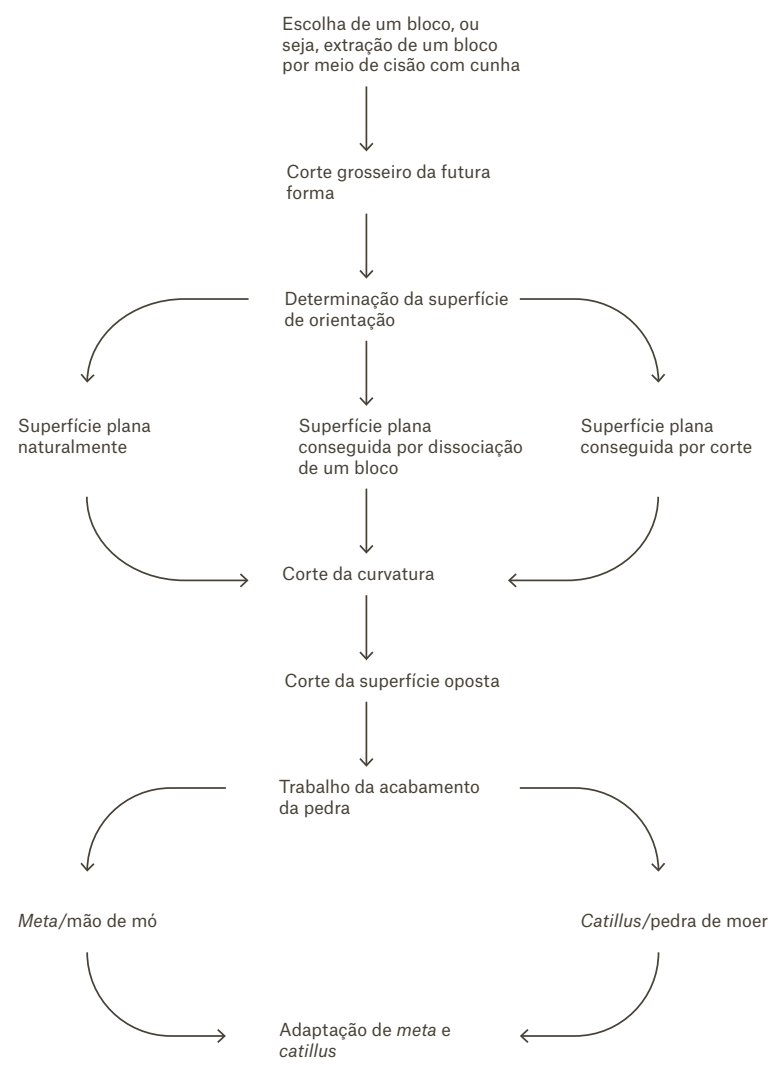

Fig. 6.0-14a: Representação esquemática dos passos necessários para produzir uma mó de granito de duas micas na pedreira da Fonte da Ribeira (modelo: R. Wahl-Clerici, desenho: S. Mathiuet).
As pedras na pedreira da Fonte da Ribeira, descartadas durante as várias fases de tratamento, permitem compreender passo a passo a produção dos moinhos circulares (fig. 6.0$13 a / b)$.

Primeiro, era selecionado um bloco adequado, que também podia ser obtido por fragmentação, e que em duas dimensões tinha de ser $15-20 \mathrm{~cm}$ maior que a mó (figs. 6.0-3 e 6.0-7). Seguidamente, era talhado até atingir uma forma aproximadamente redonda. É difícil atribuir os blocos espalhados na pedreira a esta fase de trabalho, uma vez que, em princípio, poderiam ter sido preparados para outros objetos, como elementos de construção.

Para a fase seguinte de preparação da mó, tinha de ser determinada a área de orientação, que já podia existir naturalmente (fig. 6.0-15), ser obtida por fragmentação (fig. 6.016), ou por corte (fig. 6.0-17). Seguidamente, a pedra era arredondada. Conforme visível na figura 6.0-18 a superfície de orientação não tinha de ser trabalhada com muito cuidado para os passos seguintes.

Em pelo menos duas pedras descartadas foi possível verificar que o lado oposto também era talhado. Para isso,

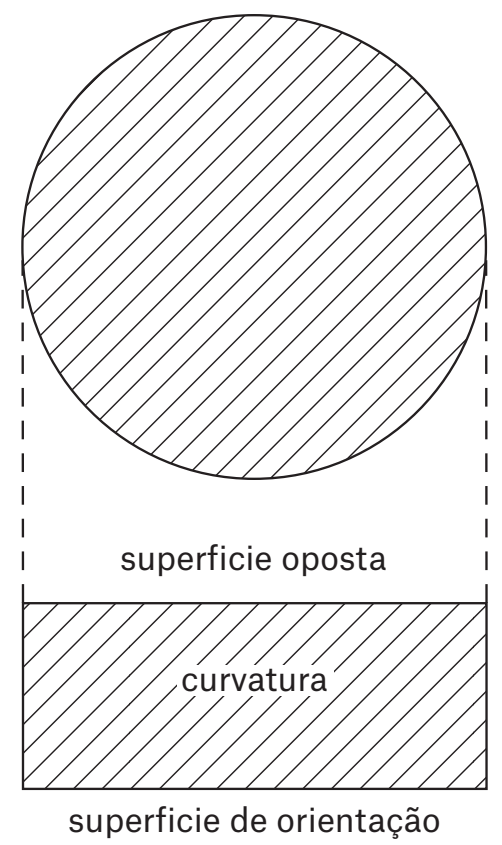

Fig. 6.0-14b: Esquema com as designações da superfície de orientação, da superfície oposta e da curvatura (modelo: $R$. Wahl-Clerici).

a pedra supérflua era eliminada progressivamente. Estes exemplares encontrados devem ter sido descartados devido às suas pequenas fissuras naturais, que só se tornaram percetíveis durante este processo (figs. 6.0-13a / b e 6.0-19a / b). Era provavelmente nesta fase que se tomava a decisão de produzir a meta, a base, ou a catillus, a pedra de moer, antes de começar a talhar a superfície oposta. No caso da catillus, era essencial formar um cilindro o mais perfeitamente pos- 
sível para poder posicionar e finalizar o orifício central da melhor forma (figs. 6.0-20a / b / c). Contudo, o desperdício de pedra produzido durante este delicado processo de preparação era elevado (figs.6.0-21 e 6.0-22). A meta - base - não necessitava de ser trabalhada com tanto cuidado (figs. 6.0-23a/b/c). O ajustamento das meta e das catillus ocorria muito provavelmente apenas no local da sua utilização.

\section{Ponte do Arco}

Para a construção da Ponte do Arco, que fazia parte da estrada de ligação para sul, em direção ao Douro, foram principalmente utilizadas pedras soltas e dispersas, como demonstra a estranha ausência de blocos na formação rochosa adjacente. Na realidade, só se conservaram vestígios da exploração em dois sítios (fig.6.0-24), o que é comum de observar em construções maiores nas áreas graníticas. ${ }^{238}$

\section{As pedreiras de xisto}

O xisto dos afloramentos locais era o material de construção mais utilizado na atividade mineira romana de Tresminas. Todos os edifícios do povoado mineiro eram compostos predominantemente por xisto, incluindo o anfiteatro e o tanque de água no extremo do povoado, destacando-se ainda as bem conservadas instalações de lavagem do minério.

As duas pedreiras na margem sul do povoado mineiro romano são ainda hoje visíveis (Fig. 6.0-25 até 6.0-27). Presumivelmente, era aqui que se cortavam as pedras para os edifícios do povoado. Apesar da ausência das paredes, podemos supor que as pedras pertencentes aos vestígios das construções romanas, quer no povoado quer nas condutas de água, foram sistematicamente removidas e utilizadas nas aldeias ou nas muralhas do campo mais recentes.

As duas pedreiras correspondem a cortes alongados na superfície da encosta, sendo que no caso da pedreira 2 já não é possível determinar com certeza as suas dimensões, uma vez que os contornos foram parcialmente alterados devido à exploração agrícola. Pela mesma razão, não foi possível determinar o fundo das zonas de exploração. Somente na pedreira 1 mantiveram-se preservados evidentes vestígios de mineração.

Pedreira 1: Comprimento máximo $90 \mathrm{~m}$, largura superior $24,30 \mathrm{~m}$, largura inferior cerca de $17 \mathrm{~m}$, profundidade visível atualmente de aproximadamente $4 \mathrm{~m}$; volume total mínimo $2700 \mathrm{~m}^{3}$.

Pedreira 2: Comprimento máximo $51 \mathrm{~m}$, largura máxima $24 \mathrm{~m}$, altura máxima $2 \mathrm{~m}$; volume total mínimo $1500 \mathrm{~m}^{3}$.

\section{A cova de extração de material em Outeiro no Rio Tinhela}

Aproximadamente $250 \mathrm{~m}$ a sul da grande barragem de terra de Outeiro (figs.5.0-7 até 5.0-9), foi possível identificar uma depressão no terreno da encosta interpretada como cova de extração de material. Trata-se de uma cova irregular e em forma de um retângulo alongado, com as seguintes dimensões: $46 \mathrm{~m}$ de comprimento máximo, $30 \mathrm{~m}$ de largura máxima e profundidade máxima de $7 \mathrm{~m}$, na parte mais elevada (fig. 6.0-28).Daqui se extraiu um material terroso muito rico em argila, que foi utilizado para a construção das barragens de terra e para o preenchimento das juntas dos aquedutos. O cálculo de volume da barragem de Outeiro mostra que a quantidade de material extraído não podia, de forma alguma, ter sido suficiente para esta construção, que mediria, pelo menos, quase $21 \mathrm{~m}$ de altura e cerca de $150 \mathrm{~m}$ de comprimento, com uma largura na base de cerca de $65 \mathrm{~m}$. Temos de assumir que também foram exploradas outras covas com material semelhante. No entanto, estas desapareceram em grande parte.

\section{Resultados}

As numerosas pedreiras no territorium metallorum Tresminas / Jales cobrem toda a procura de material de pedra. Pode ser feita uma distinção entre as pedreiras onde era extraído material específico para uma utilização especializada, tal como o granito biotítico, utilizado para as bases de moinhos de pilões e moinhos para minério, e o granito de duas micas, utilizado nos moinhos para a farinha, nas pedras de inscrição, nos elementos de construção, etc. Em contrapartida, as duas pedreiras de xisto a sul do povoado mineiro de Tresminas, foram utilizadas para extrair material de construção menos específico, utilizado em casas, etc.

Embora sejam conhecidas as pedreiras de granito do Império Romano, o mesmo parece não se aplicar às pedreiras de xisto e à cova de material da barragem de Outeiro, tratando-se assim de objetos por observar e documentar. Em princípio, é ainda de assumir que os blocos ou pedras resultantes dos trabalhos de fundação fossem incorporados em construções futuras, visível no caso do anfiteatro e das instalações de lavagem de minérios.

238 Por exemplo, no caso da barragem de Alcantarilla, a sul de Toledo (E). Arenillas Parra / Barahona Oviedo (2009). 


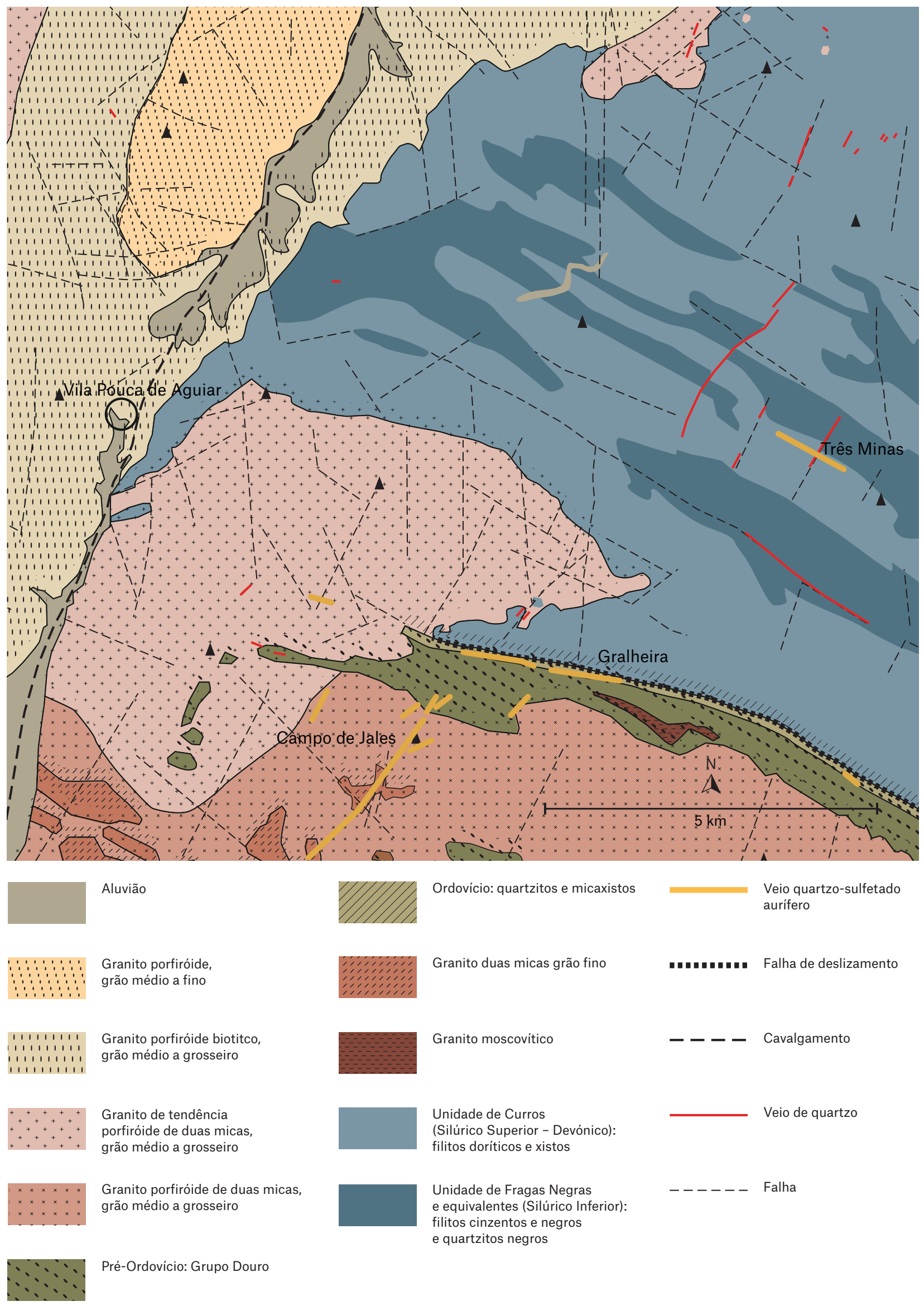

Fig. 6.0-1: Mapa geológico da região de Vila Pouca de Aguiar (de acordo com Sousa Oliveira 2013, 16 e Rosa / Romberger 2003, 647, reformulado por R.Wahl-Clerici). 


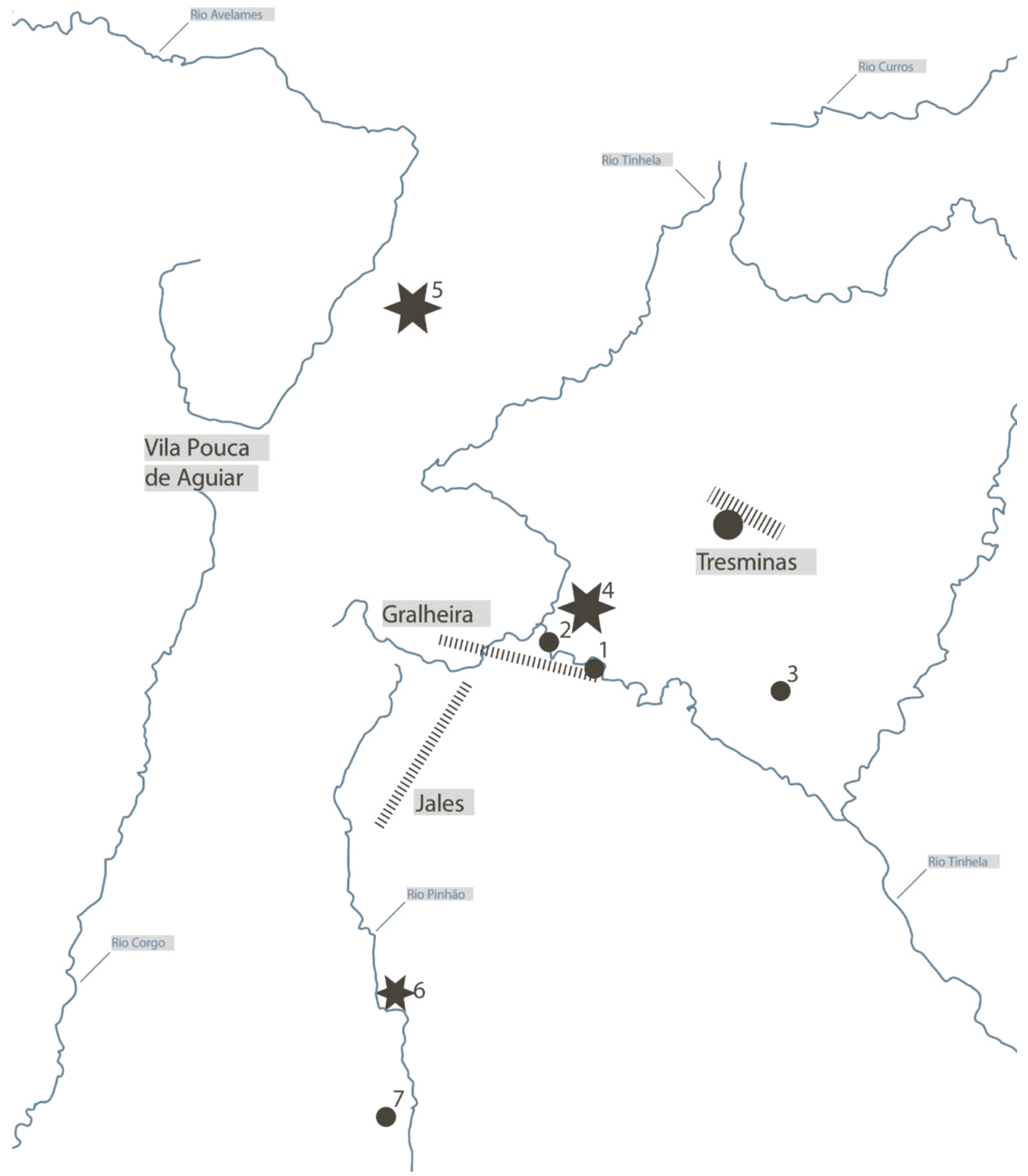

Fig. 6.0-2: Territorium metallorum Tresminas / Jales: estrelas: 4 Pedreira de Fonte da Ribeira, 5 Pedreira de São Martinho de Bornes, 6 Pedreira de Ponte do Arco; 1 Castelo dos Mouros, 2 Forno dos Mouros, 3 Quinta de Vales, 7 Ponte da Cheira (Modelo: Carta Militar de Portugal 1:50'000 (folhas 6-2 e 10-1), edição R. Wahl-Clerici e S. Mathiuet). 


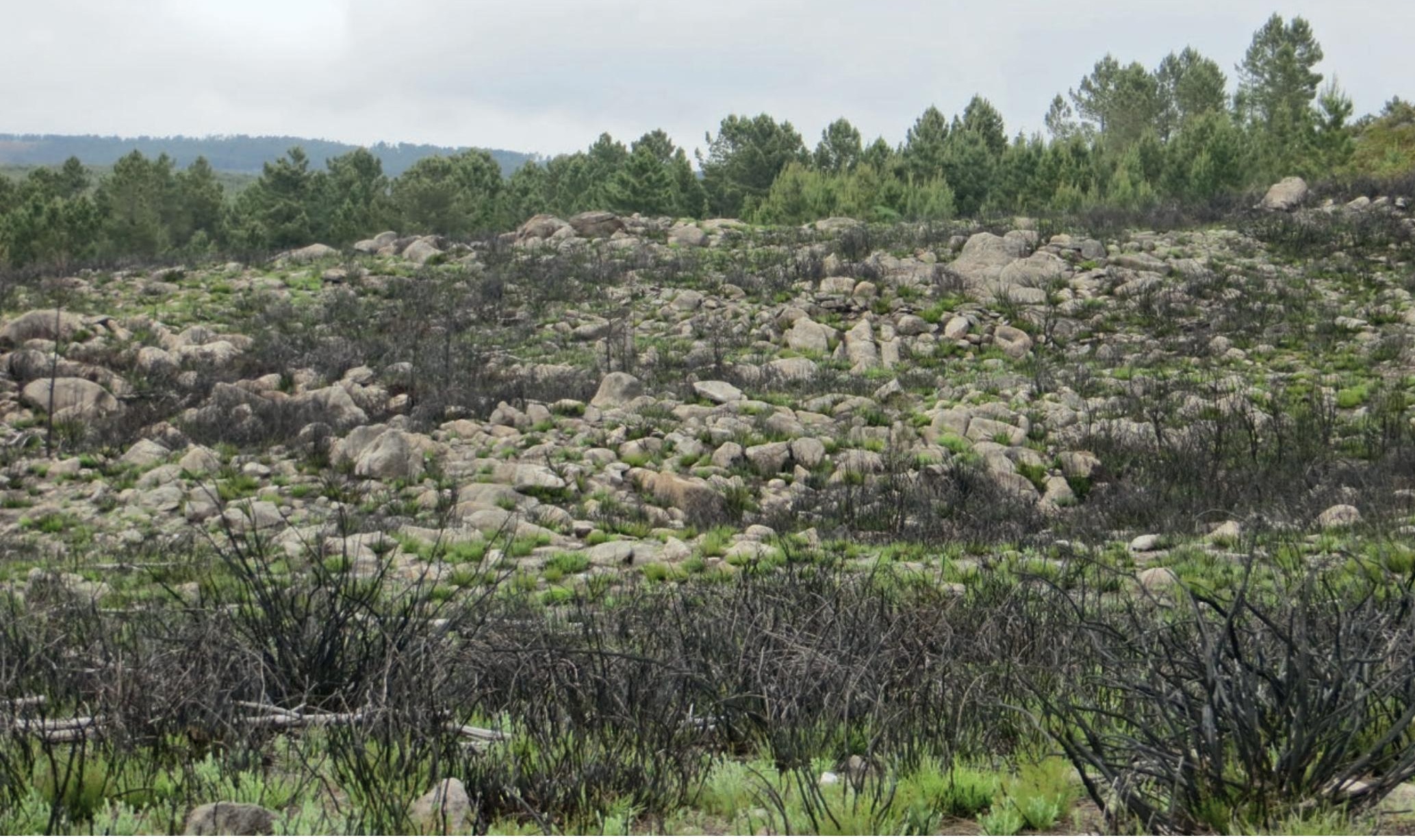

Fig. 6.0-3: Territorium metallorum Tresminas / Jales. Pedreira da Fonte da Ribeira: a zona encontra-se coberta com blocos de diferentes tamanhos (fotografia: R. Wahl-Clerici). 


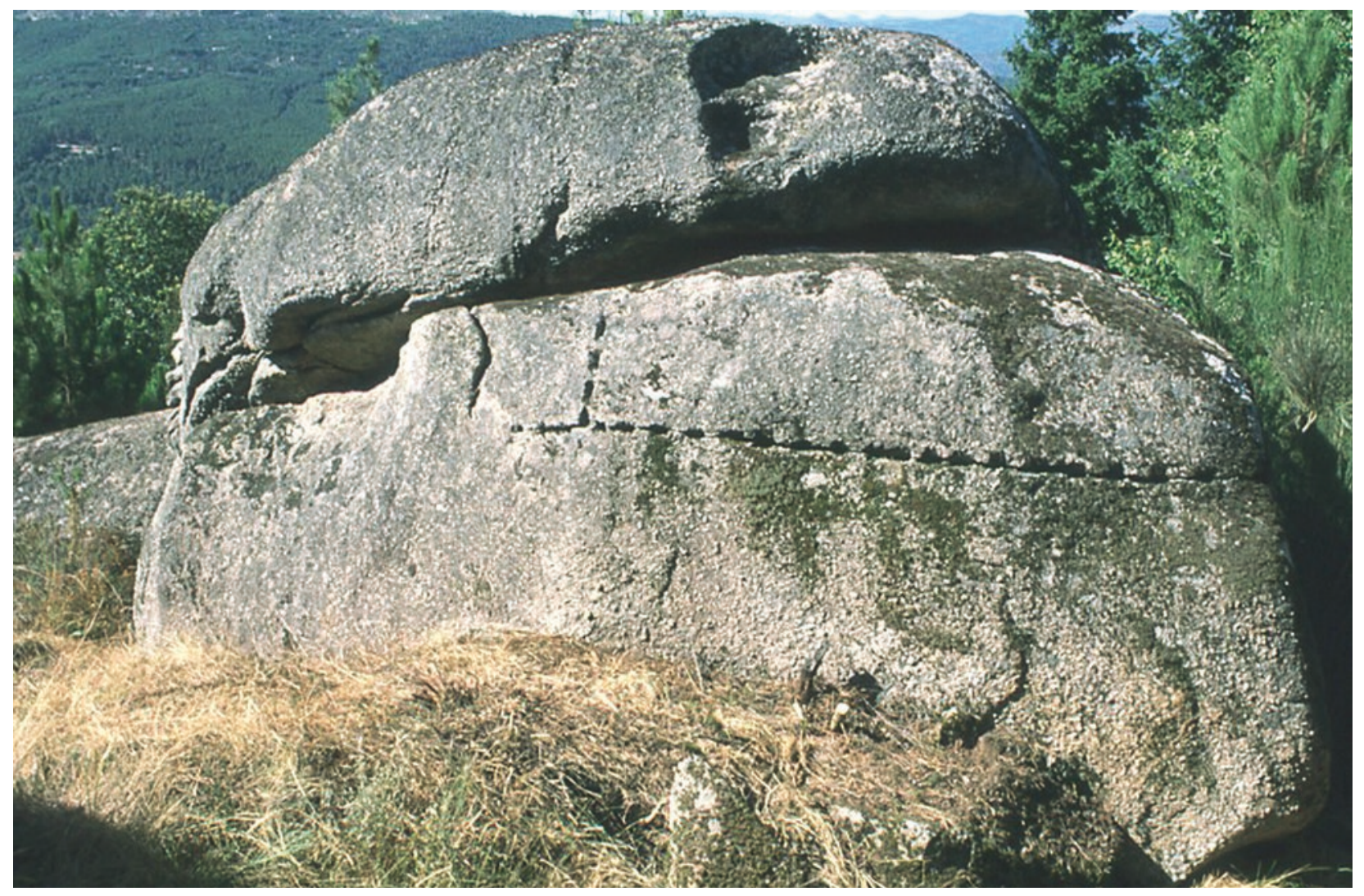

Fig. 6.0-4: Territorium metallorum Tresminas /Jales: pedreira romana acima da igreja de São Martinho de Bornes. São visíveis os trabalhos preliminares de levantamento e corte (fotografia: J. Wahl).

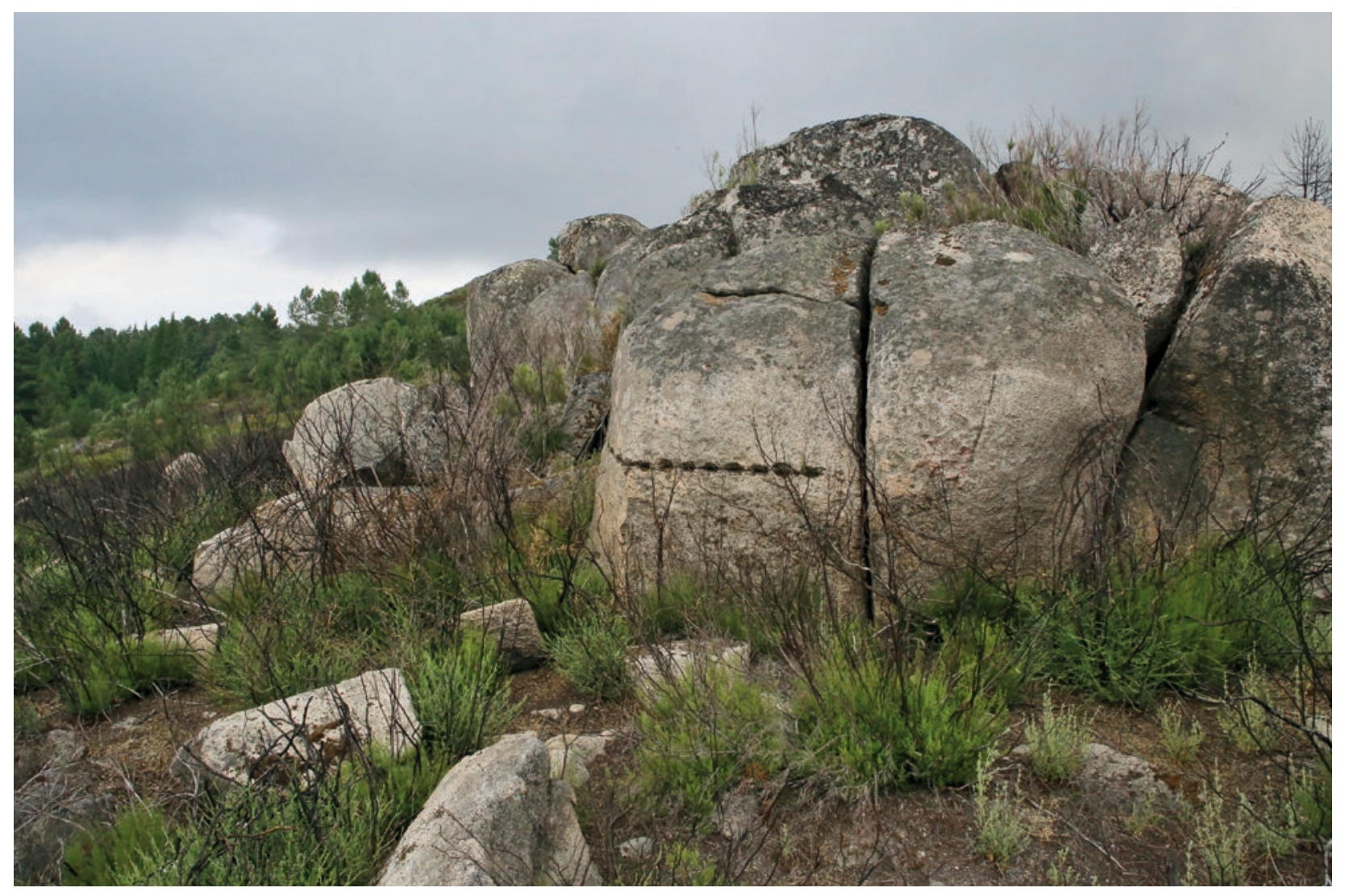

Fig. 6.0-5: Territorium metallorum Tresminas / Jales. Pedreira da Fonte da Ribeira: trabalhos preliminares para o levantamento (fotografia: R. Wahl-Clerici). 


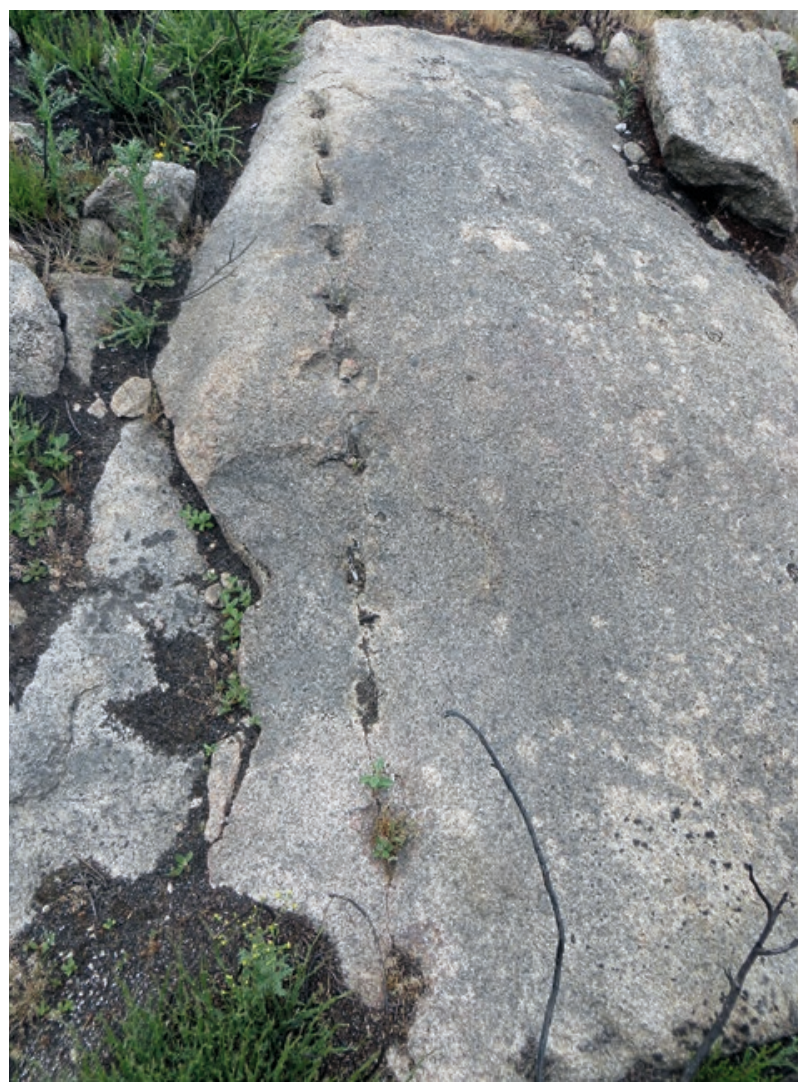

Fig. 6.0-6: Territorium metallorum Tresminas / Jales. Pedreira da Fonte da Ribeira: um bloco preparado para ser partido, destinado para um objeto alongado, em grande parte soterrado (fotografia: $R$. Wahl-Clerici).

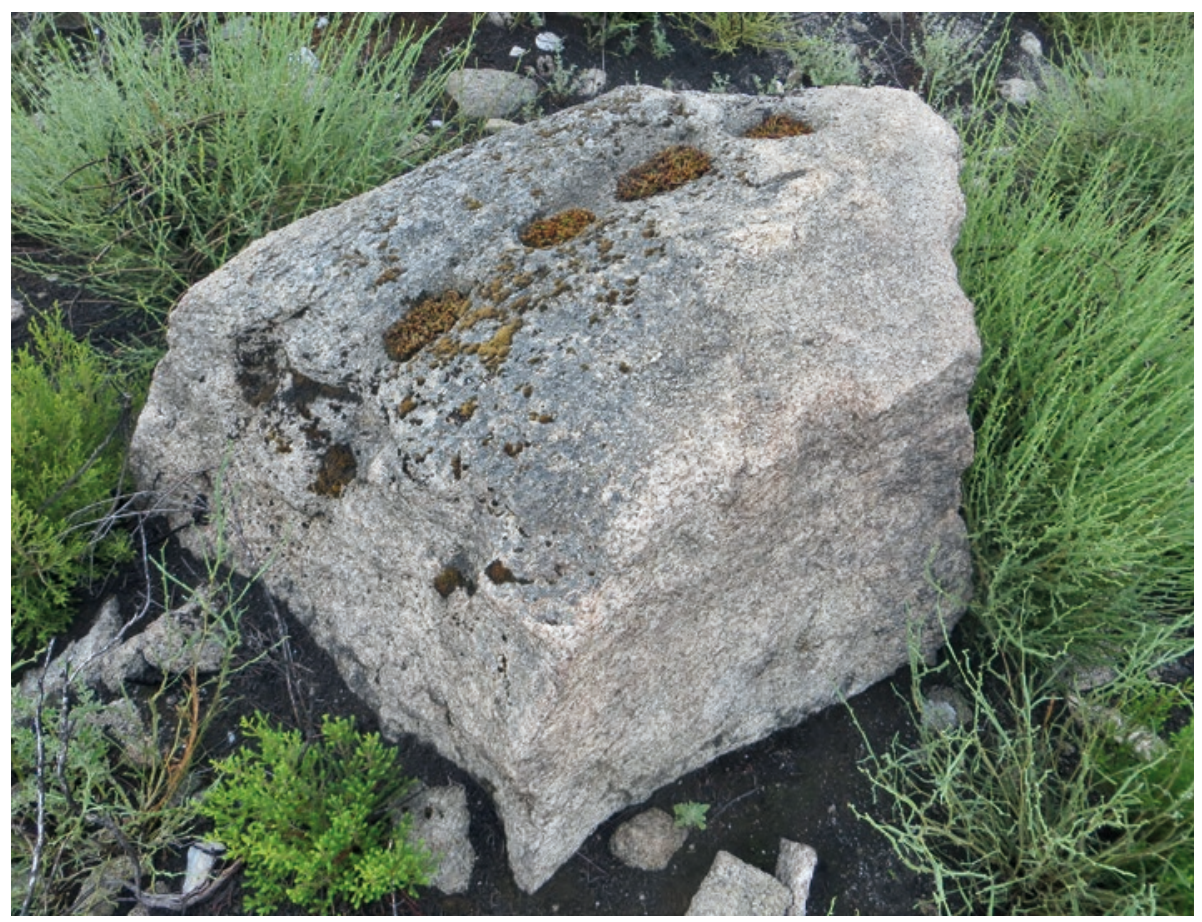

Fig. 6.0-7: Territorium metallorum Tresminas / Jales. Pedreira da Fonte da Ribeira: um bloco preparado para ser partido, do qual já foram extraídas algumas partes, tanto de frente e de lado (fotografia: $R$. Wahl-Clerici). 


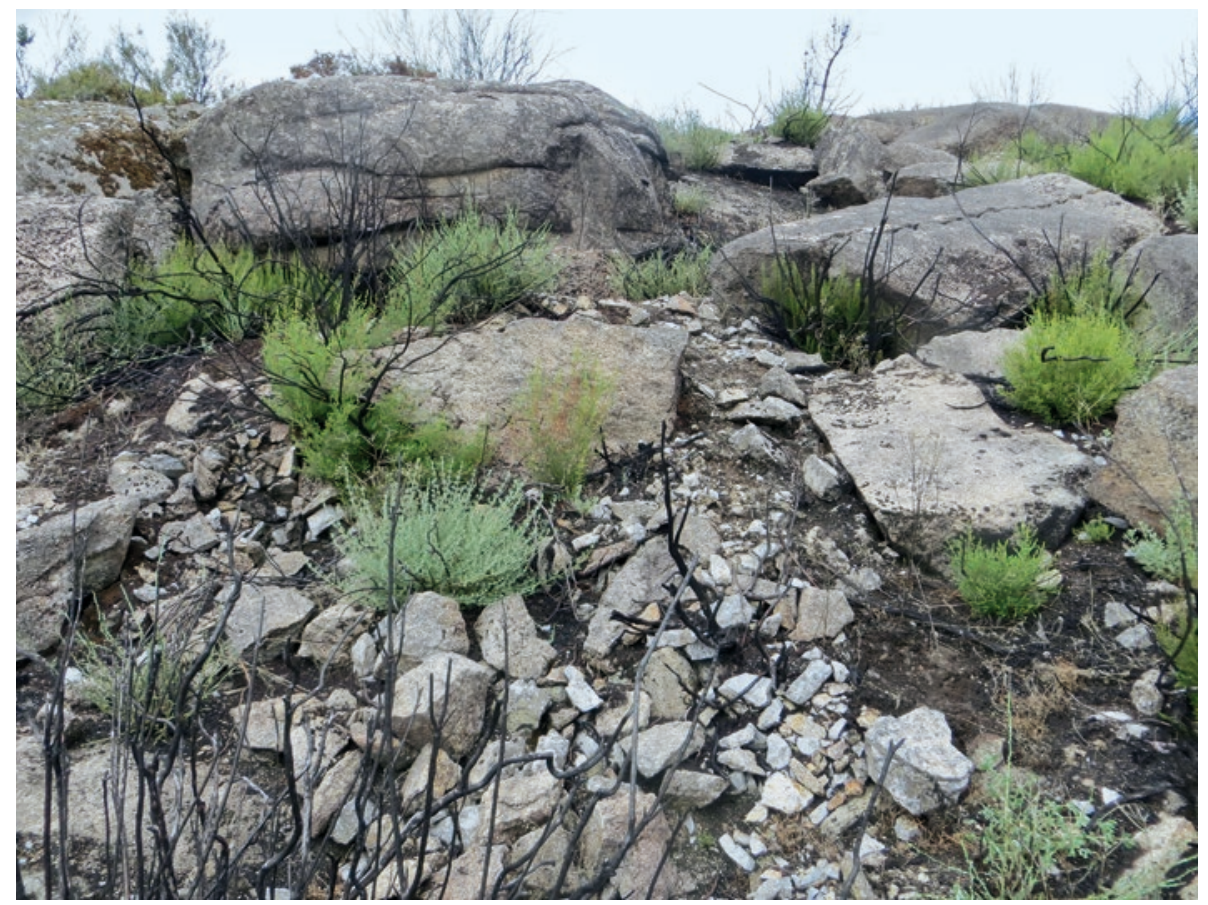

Fig. 6.0-8a: Territorium metallorum Tresminas / Jales. Pedreira da Fonte da Ribeira: local de trabalho com as típicas sobras de pedra afiadas, resultantes do corte. À direita, no fundo, encontra-se um bloco preparado para ser partido (fotografia: R. Wahl-Clerici).

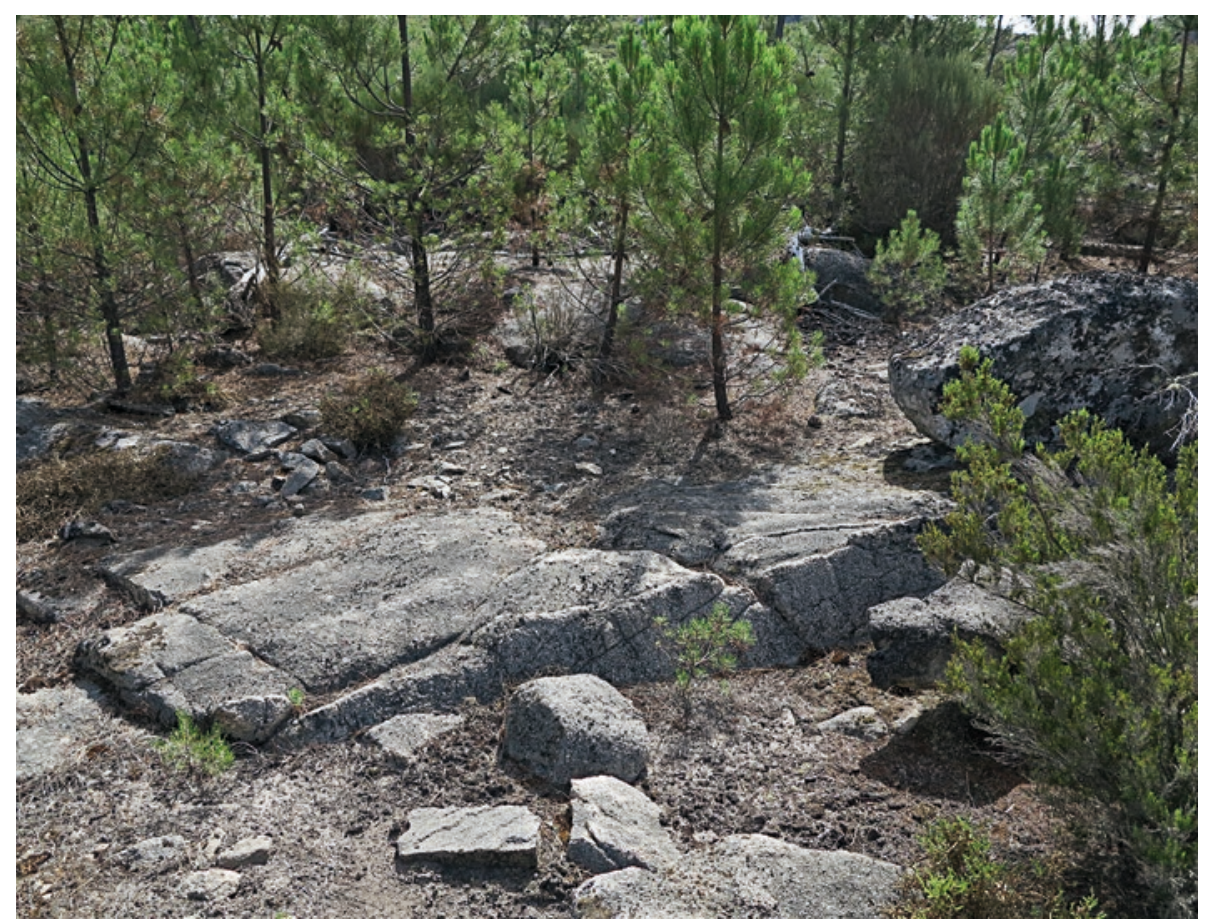

Fig. 6.0-8b: Territorium metallorum Tresminas / Jales, pedreira da Fonte da Ribeira: local de trabalho caracterizado pela ausência de blocos de granito (fotografia: R.Wahl-Clerici). 


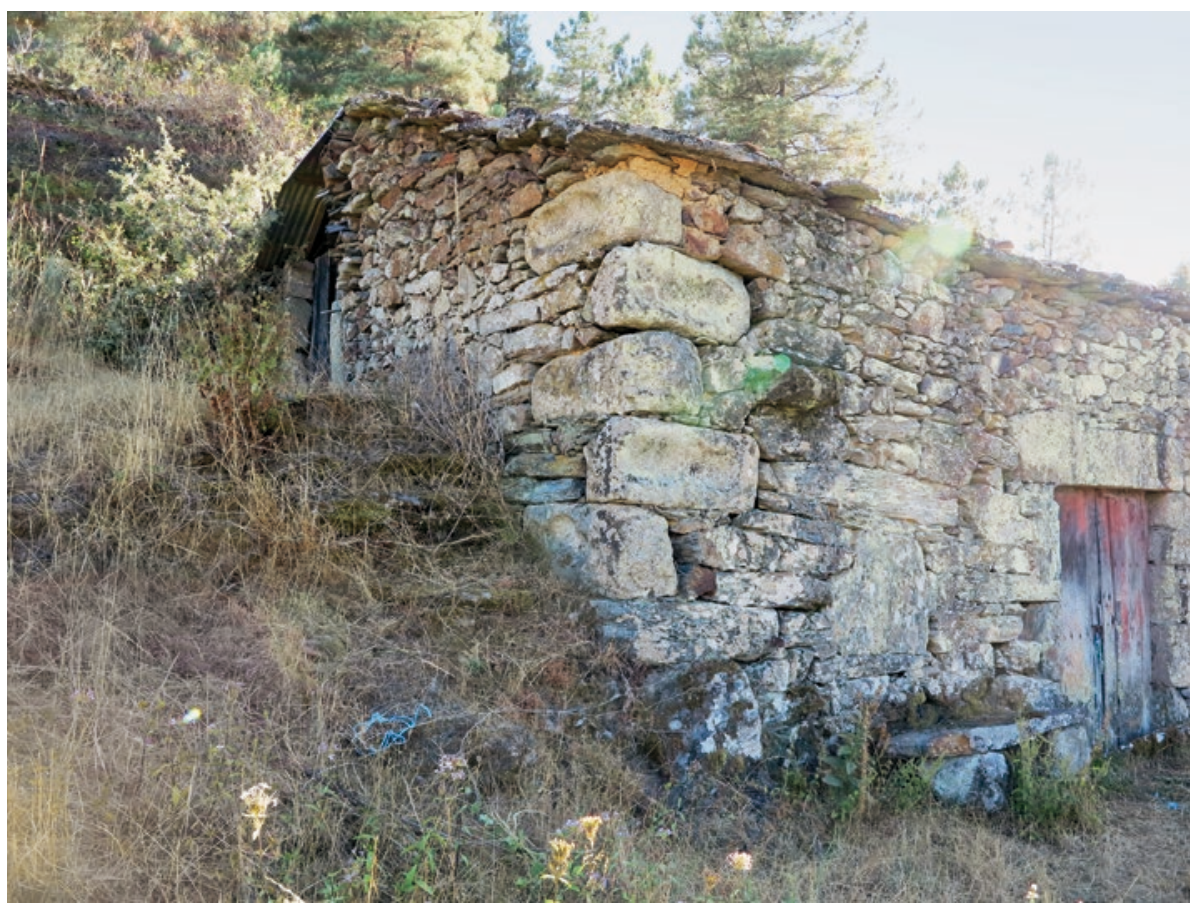

Fig. 6.0-9a: Territorium metallorum Tresminas / Jales, Ribeirinha (aldeia): moinhos de pilões reutilizados (fotografia: R.Wahl-Clerici).

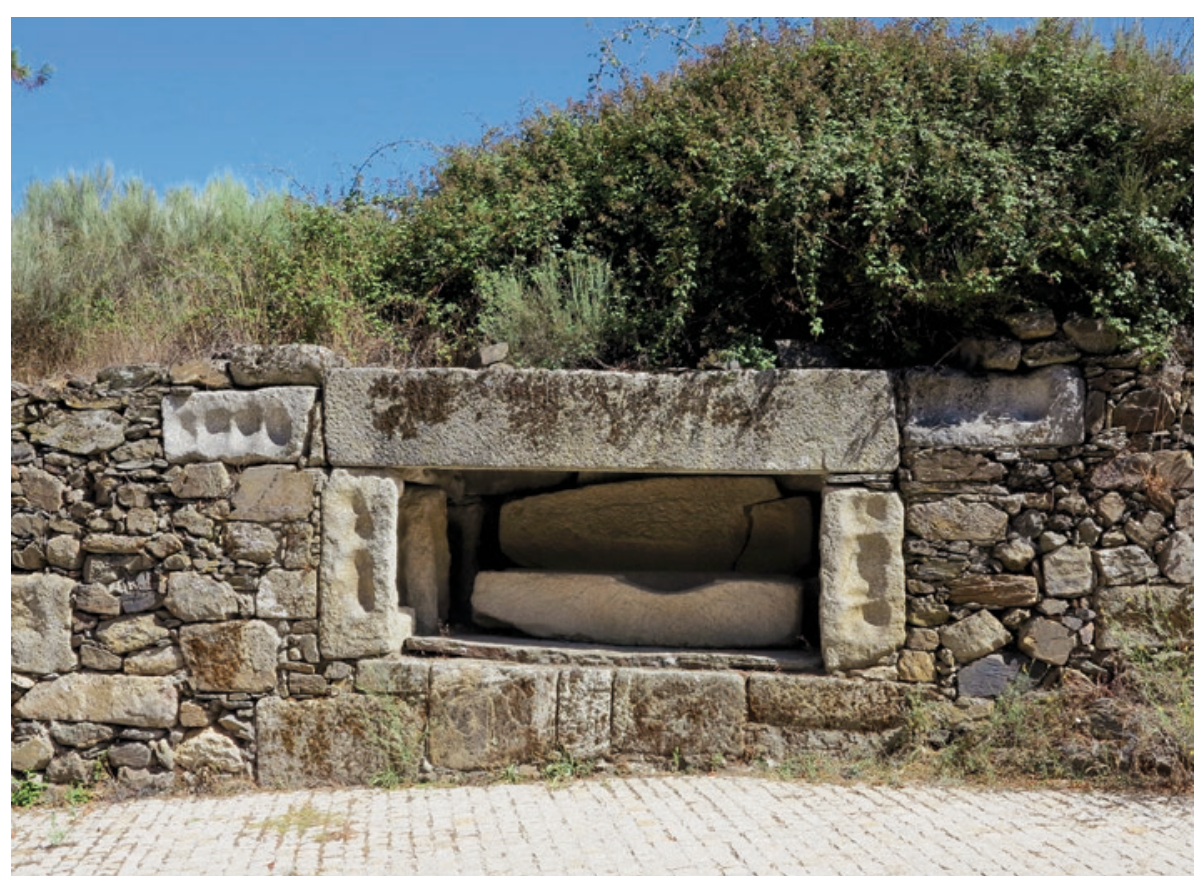

Fig. 6.0-9b: Territorium metallorum Tresminas /Jales, Tresminas (aldeia): reconstrução idealizada de um túmulo pré-histórico, utilizando um sarcófago medieval e as bases de moinhos de pilões romanos (fotografia: R.WahlClerici). 


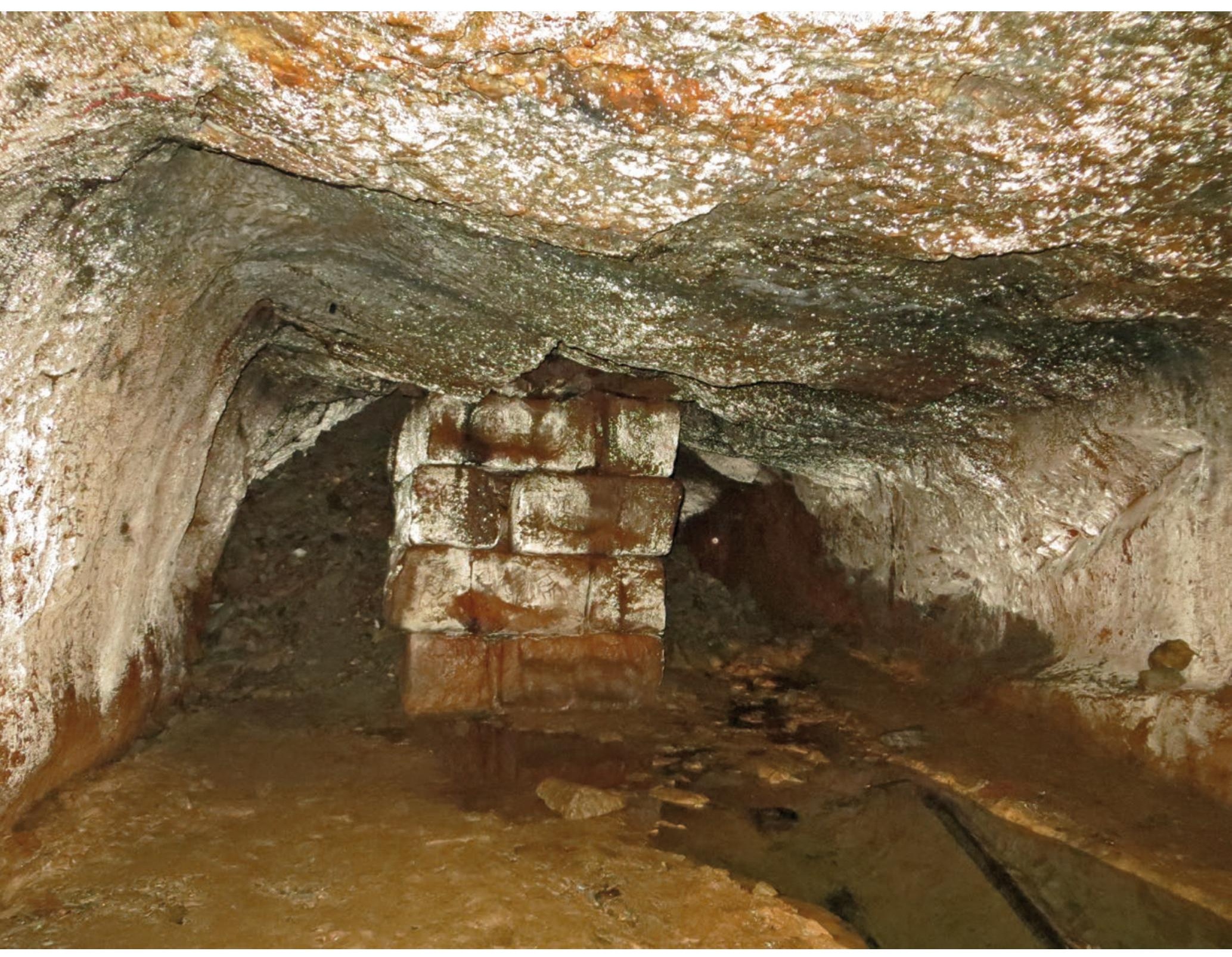

Fig. 6.0-10: Territorium metallorum Tresminas / Jales. Corta de Covas. Galeria do Pilar. O pilar foi construído com pelo menos 36 bases de moinhos de pilóes de granito biotítico. Fotografia tirada em direção à boca (fotografia: $R$. Wahl-Clerici). 


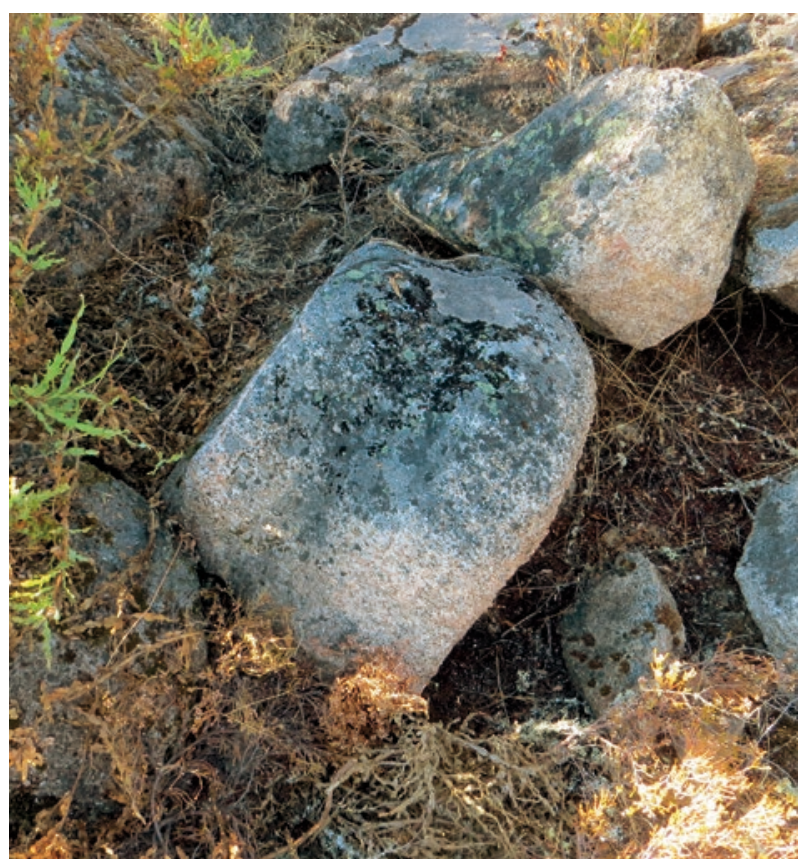

Fig. 6.0-11: Territorium metallorum Tresminas / Jales. Pedreira da Fonte da Ribeira: base de uma coluna incompleta ou capitel. Diâmetro $50 \mathrm{~cm}$, altura max. $23 \mathrm{~cm}$ (fotografia: $R$. Wahl-Clerici).
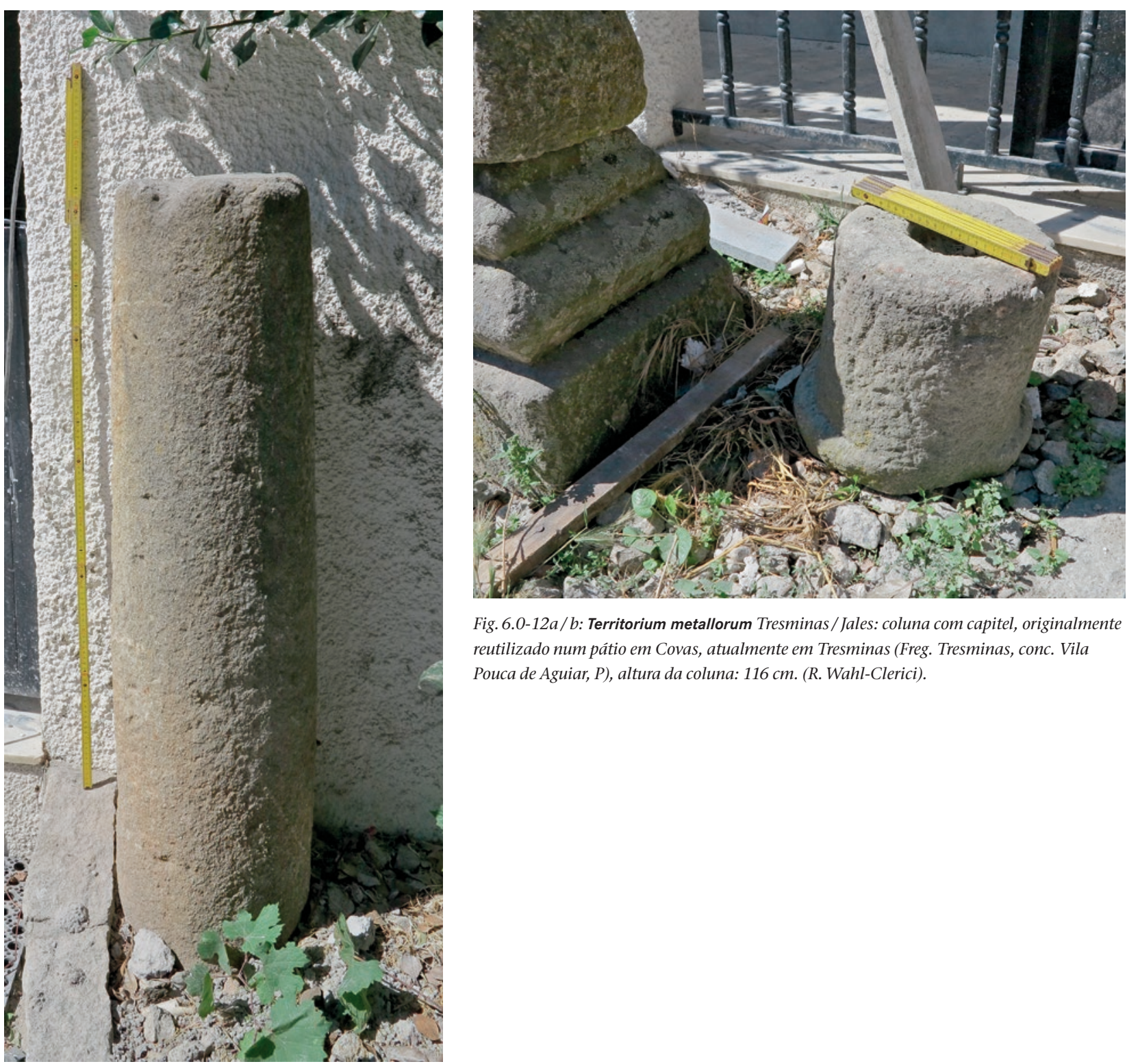

Fig. 6.0-12a/b: Territorium metallorum Tresminas / Jales: coluna com capitel, originalmente reutilizado num pátio em Covas, atualmente em Tresminas (Freg. Tresminas, conc. Vila Pouca de Aguiar, P), altura da coluna: $116 \mathrm{~cm}$. (R. Wahl-Clerici). 

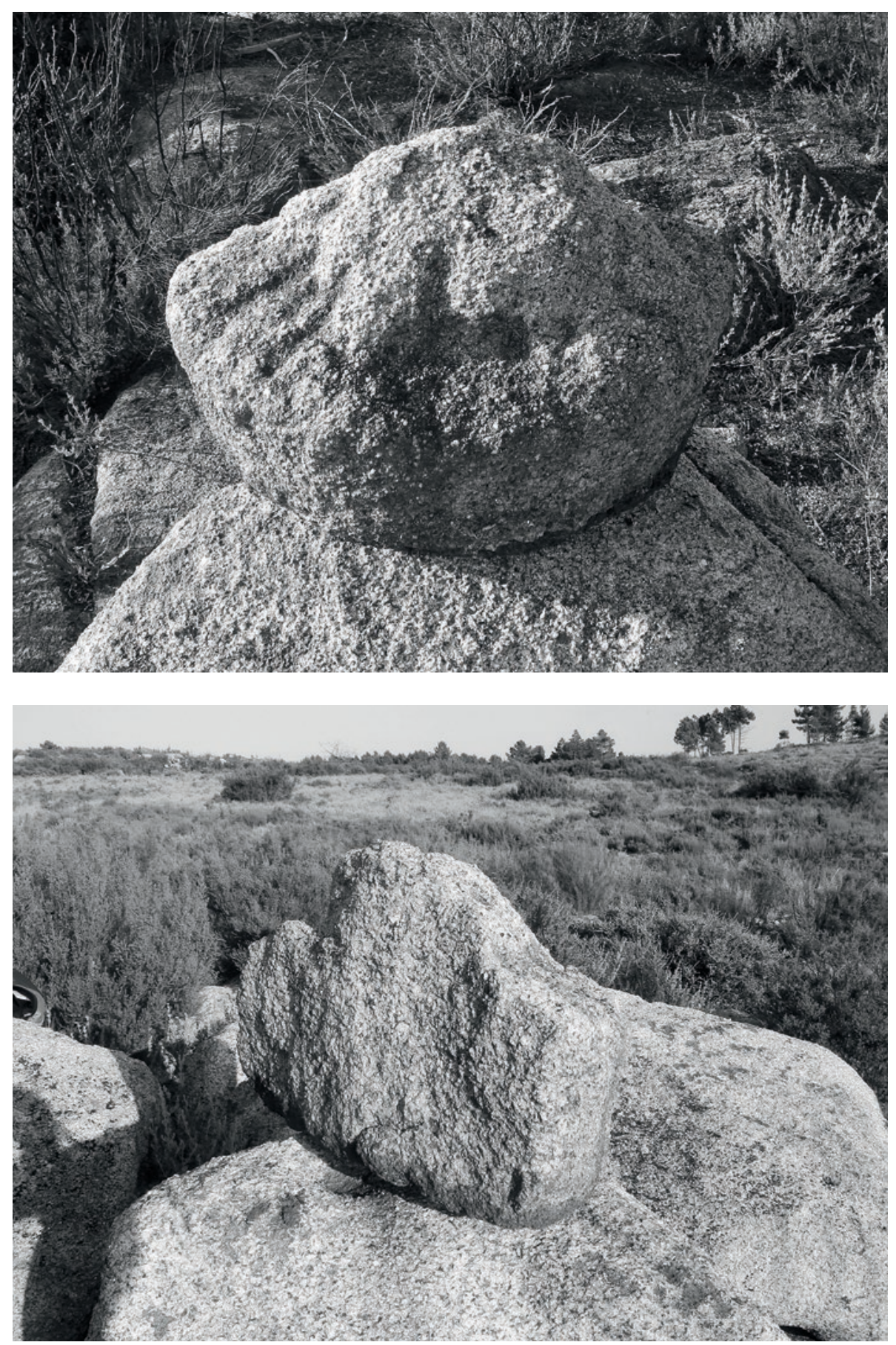

Fig. 6.0-13a / b: Territorium metallorum Tresminas / Jales. Pedreira da Fonte da Ribeira: pedra de cantaria, preservada em metade. Superfície de orientação e curvatura acabados. A pedra partiu-se durante o processo de trabalho na superfície oposta. Os vestígios de corte estão bem preservados. Dimensão $45 \mathrm{~cm}$, Altura max. $29 \mathrm{~cm}$, altura pretendida $16-17,5 \mathrm{~cm}$ (fotografia: $R$. Wahl-Clerici). 


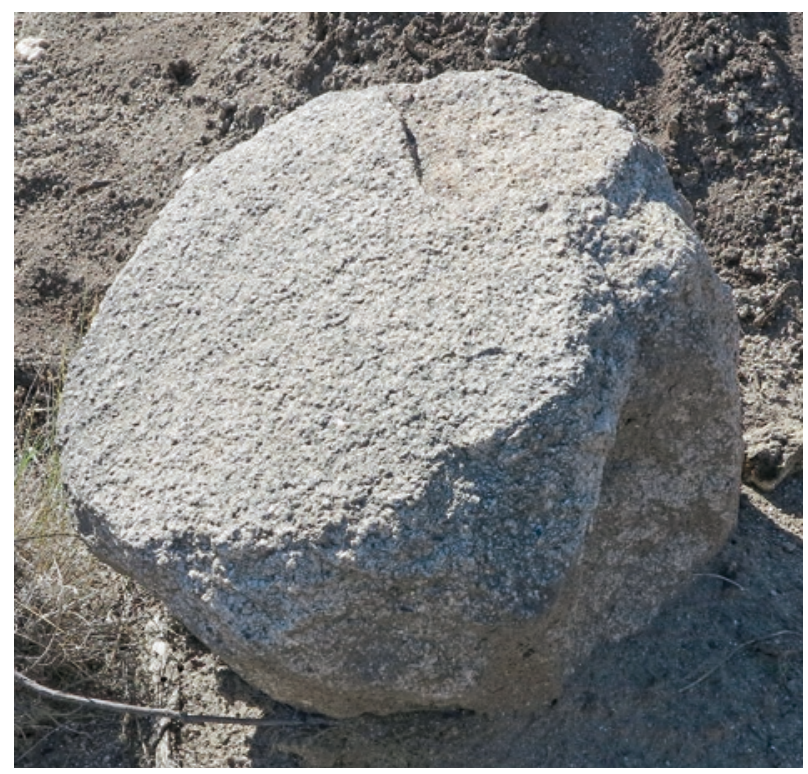

Fig. 6.0-15: Territorium metallorum Tresminas / Jales. Pedreira Fonte da Ribeira: bloco em bruto grosseiramente talhado com uma superfície de orientação naturalmente plana. Diâmetro mínimo $47 \mathrm{~cm}$, altura mínima $34 \mathrm{~cm}$ (fotografia: R. Wahl-Clerici).

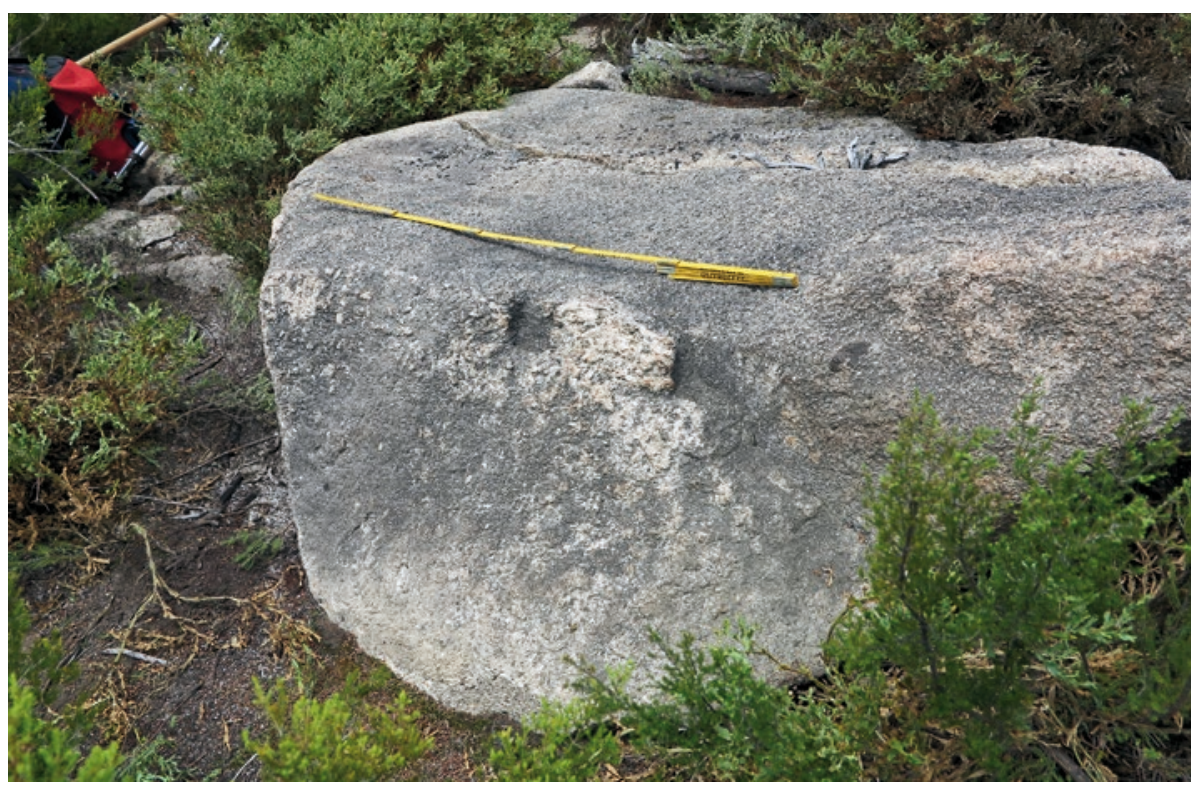

Fig. 6.0-16: Território metallorum Tresminas / Jales. Pedreira Fonte da Ribeira: a partir de um veio aplítico, foi possivel obter uma superfície uniforme num bloco (fotografia: $R$. Wahl-Clerici).

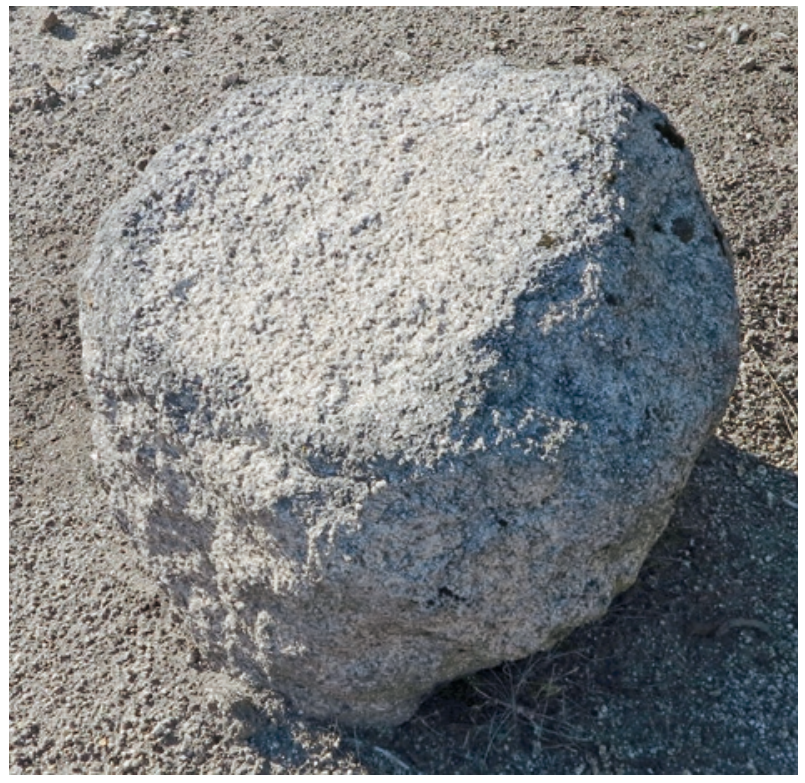

Fig. 6.0-17: Territorium metallorum Tresminas / Jales. Pedreira Fonte da Ribeira: bloco em bruto grosseiramente talhado. Diâmetro da área exposta $49 \mathrm{~cm} \times 54$ cm; altura min. $33 \mathrm{~cm}$ (fotografia: $R$. Wahl-Clerici). 

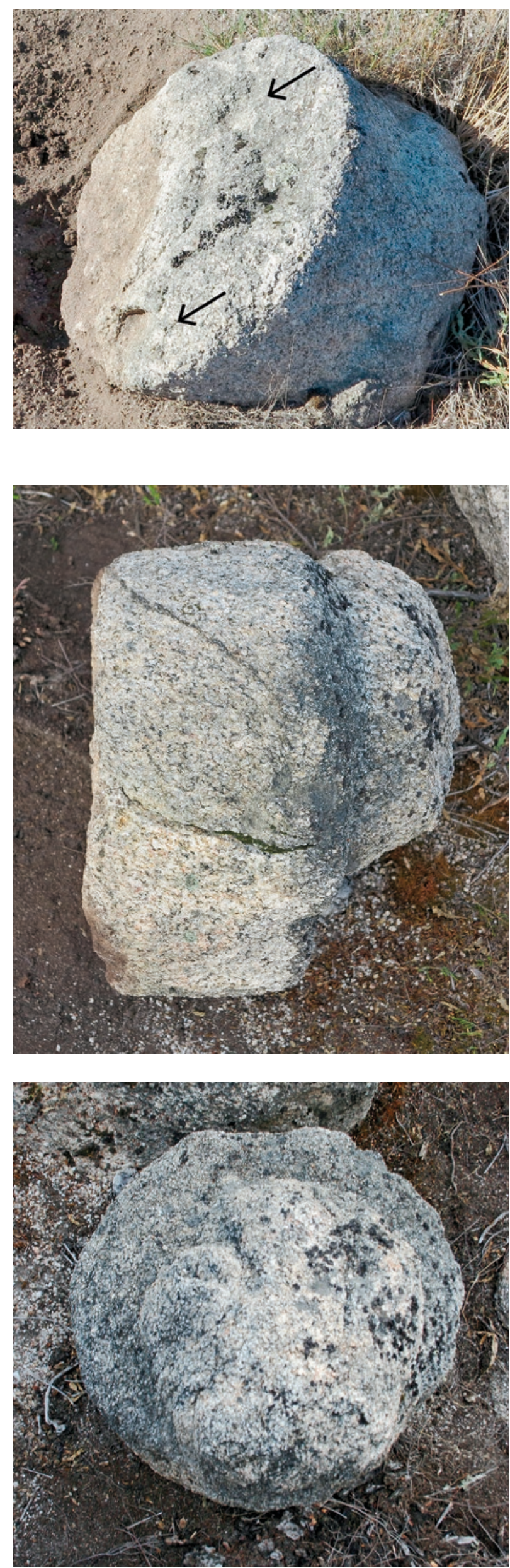

Fig. 6.0-19a / b: Territorium metallorum Tresminas / Jales. Pedreira Fonte da Ribeira: devido às suas fissuras, a pedra teve de ser descartada durante o processo de alisamento do lado oposto. Diâmetro $42 \mathrm{~cm}$, altura max. $38 \mathrm{~cm}$, altura pretendida $19 \mathrm{~cm}$. (fotografia $a:$ R. Wahl-Clerici, fotografia $b$ : T. Schierl). 

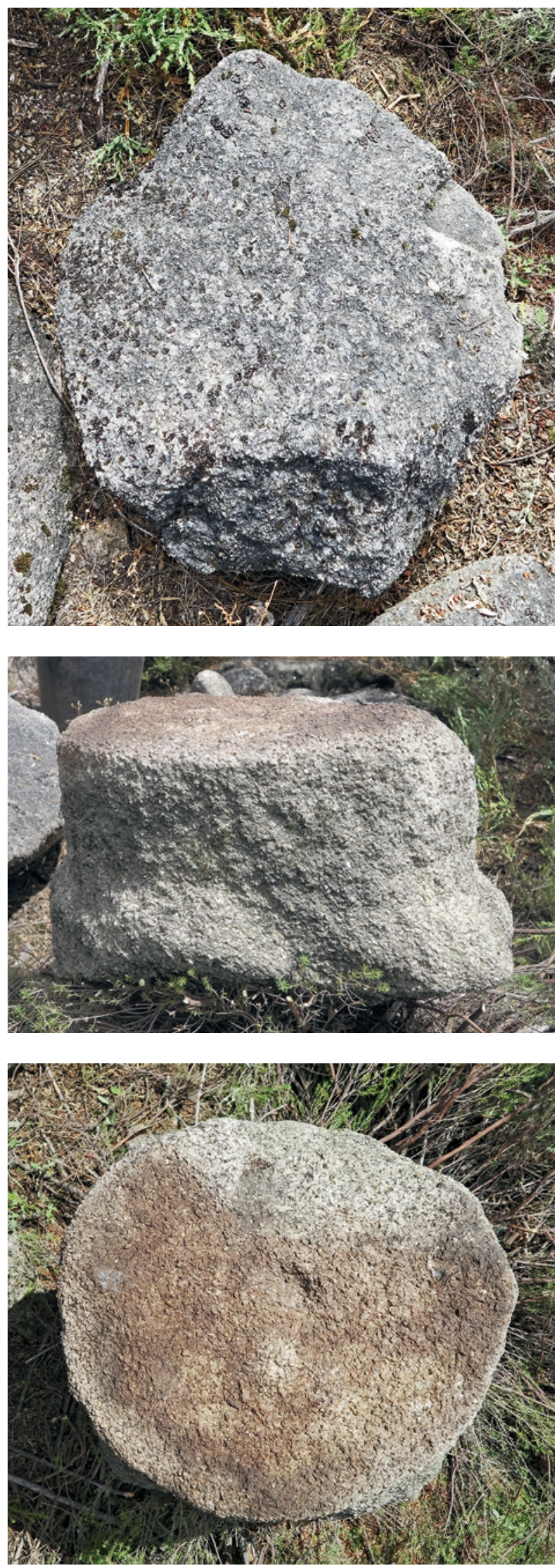

Fig. 6.0-20a/b/c: Territorium metallorum Tresminas / Jales. Pedreira Fonte da Ribeira: pedra trabalhada com superfície de orientação perfeitamente acabada e curvatura com marcação central. A superfície oposta não foi mais trabalhada, uma vez que a pedra ficou inutilizável devido a uma falha. Na parte ainda não trabalhada manteve-se preservada uma cavidade de corte por cunha triangular. Diâmetro da parte talhada $40 \mathrm{~cm}$, altura max. $31 \mathrm{~cm}$, altura pretendida 14,5 $\mathrm{cm}$, cavidade de corte: comprimento $10 \mathrm{~cm}$, profundidade $6 \mathrm{~cm}$, lagura não determinável (fotografia: R. Wahl-Clerici) 

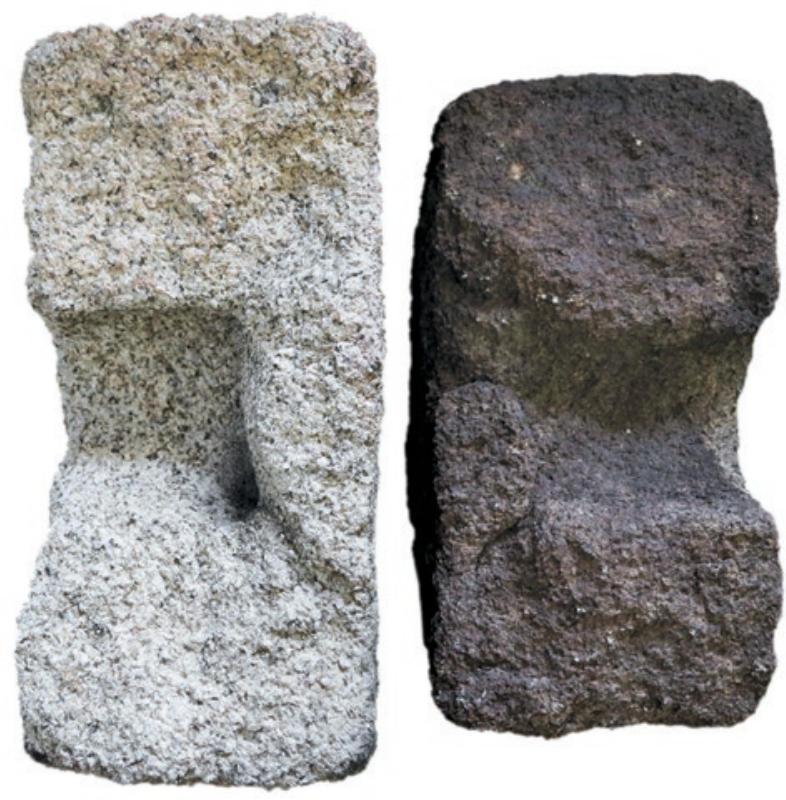

Fig. 6.0-21: Territorium metallorum Tresminas / Jales. Pedreira Fonte da Ribeira: a pedra de moer com furo central mal posicionado, partida em duas metades. Diâmetro max. $42.5 \mathrm{~cm}$, diâmetro do orifício central min. $7.5 \mathrm{~cm}$, max. 10.5 cm, altura max. $19 \mathrm{~cm}$ (fotografia: R. Wahl-Clerici).

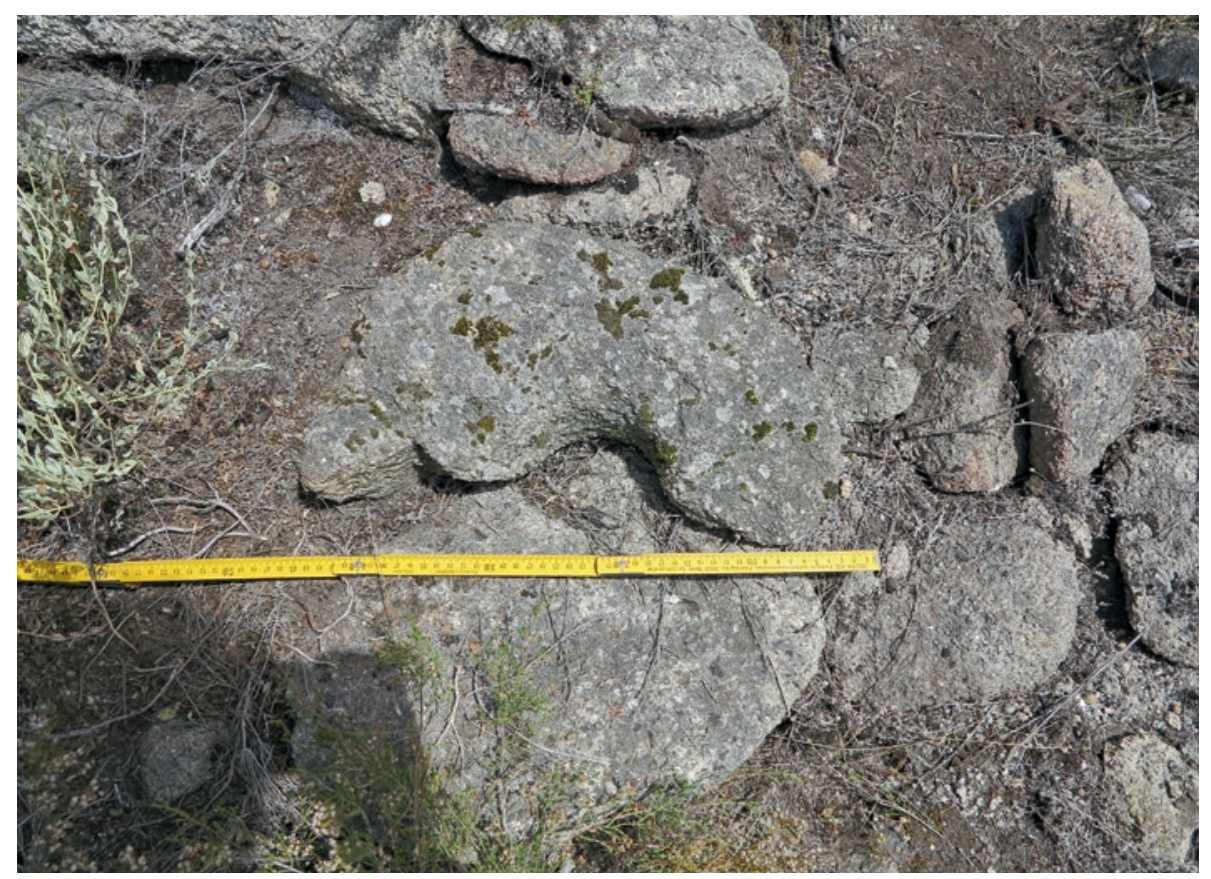

Fig. 6.0-22: Territorium metallorum Tresminas / Jales. Fonte da Ribeira. Fragmento de uma catillus. Diâmetro max. $40 \mathrm{~cm}$, Diâmetro do orifício central preservado: $9 \mathrm{~cm}$, altura $9 \mathrm{~cm}$ (fotografia:R. Wahl-Clerici) 

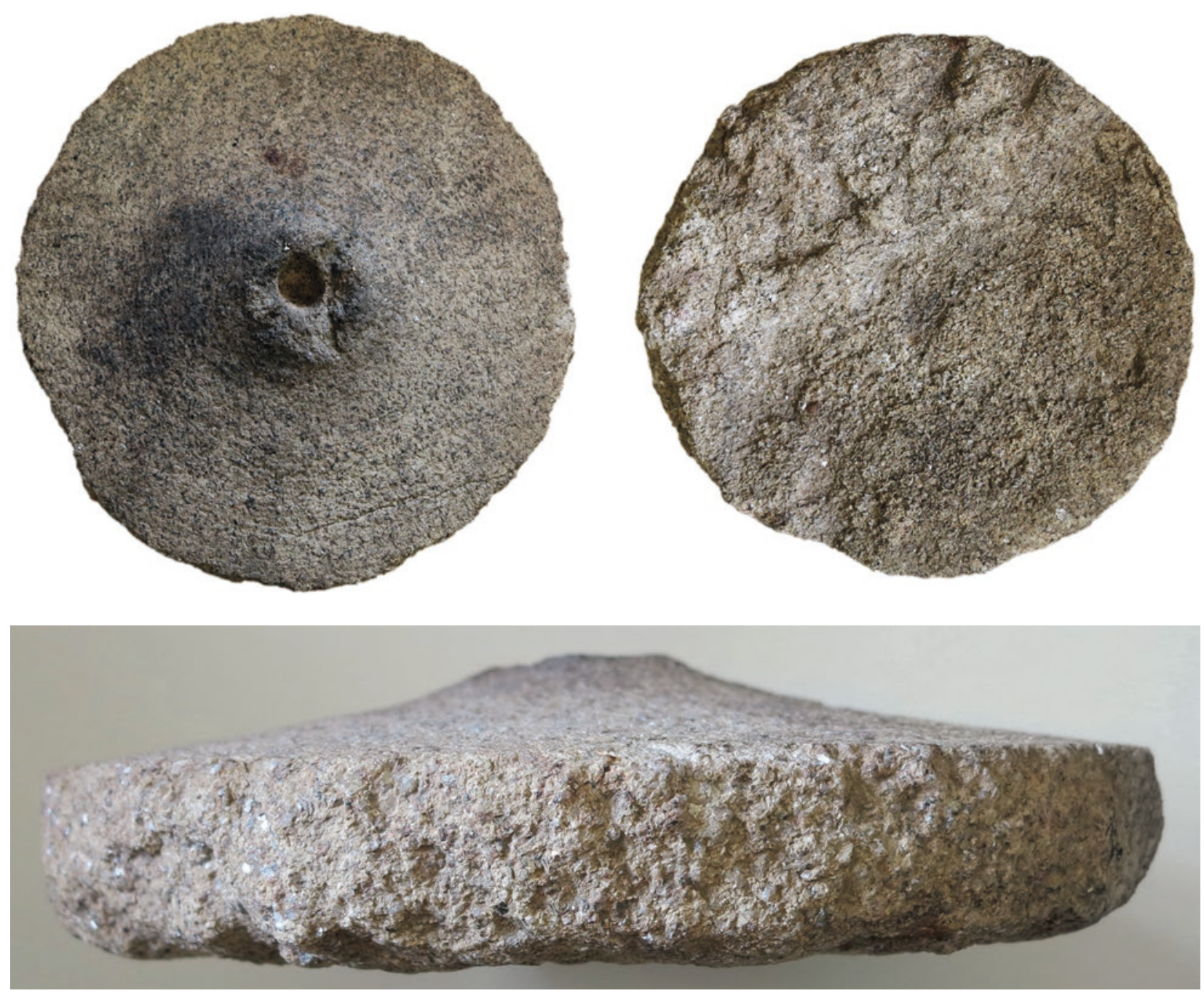

Fig. 6.0-23a/b/c: Territorium metallorum Tresminas / Jales. Tresminas: meta (base) com vestígios claros de uso encontrada no povoado mineiro. A área que era usada como base para o chão foi apenas grosseiramente trabalhada. Na zona do orifício central, são visíveis vestígios de fraturas, que explicam a eliminação da pedra ou que podem ter sido criados mais recentemente. Diâmetro max. $41 \mathrm{~cm}$, altura max. $9 \mathrm{~cm}$ (fotografia: $R$. Wahl-Clerici). 


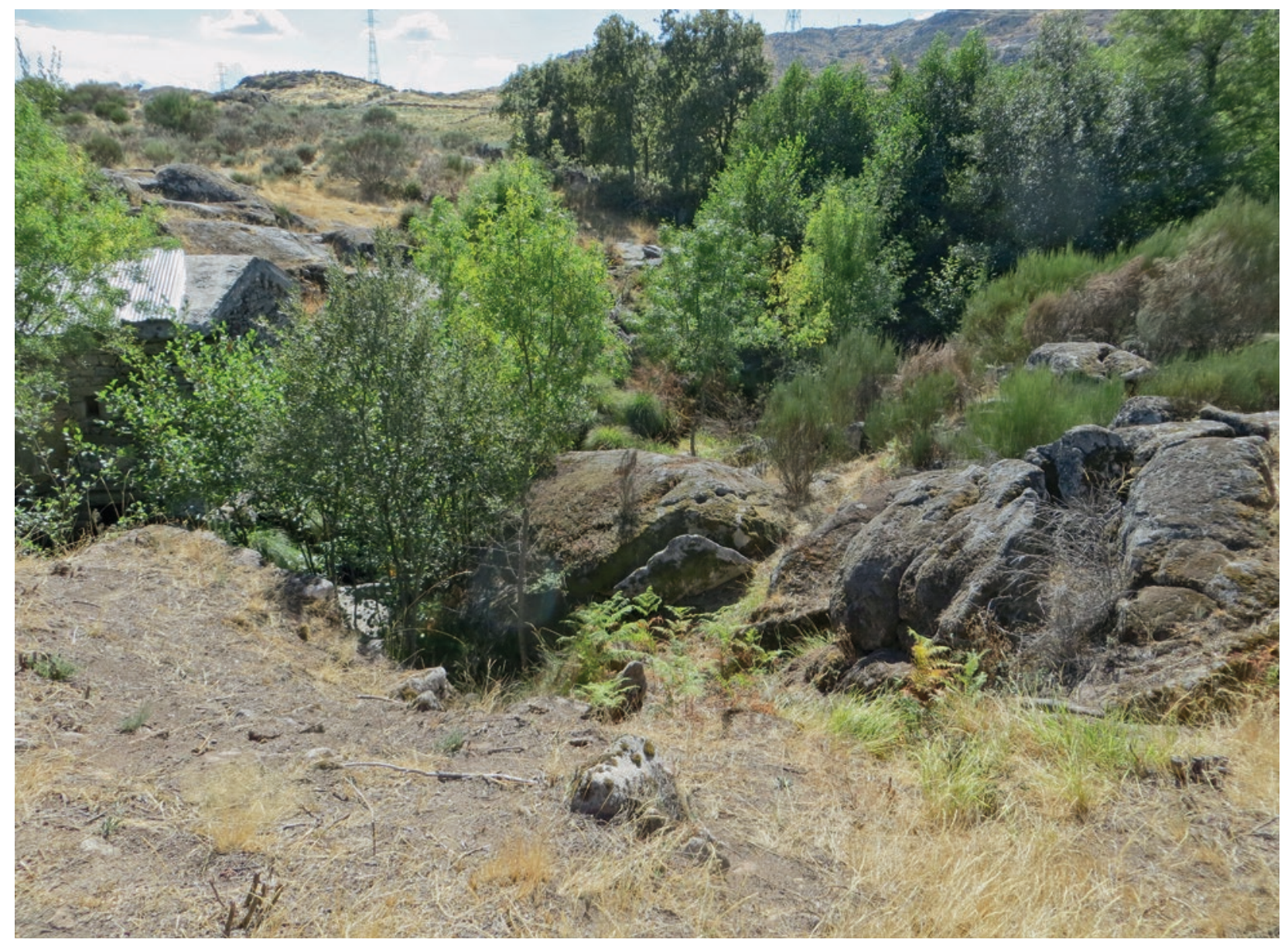

Fig. 6.0-24: Territorium metallorum Tresminas/Jales. Ponte do Arco: ao centro é visivel um rochedo com cavidades de corte por cunha. Visto de norte (fotografia: R. Wahl-Clerici)

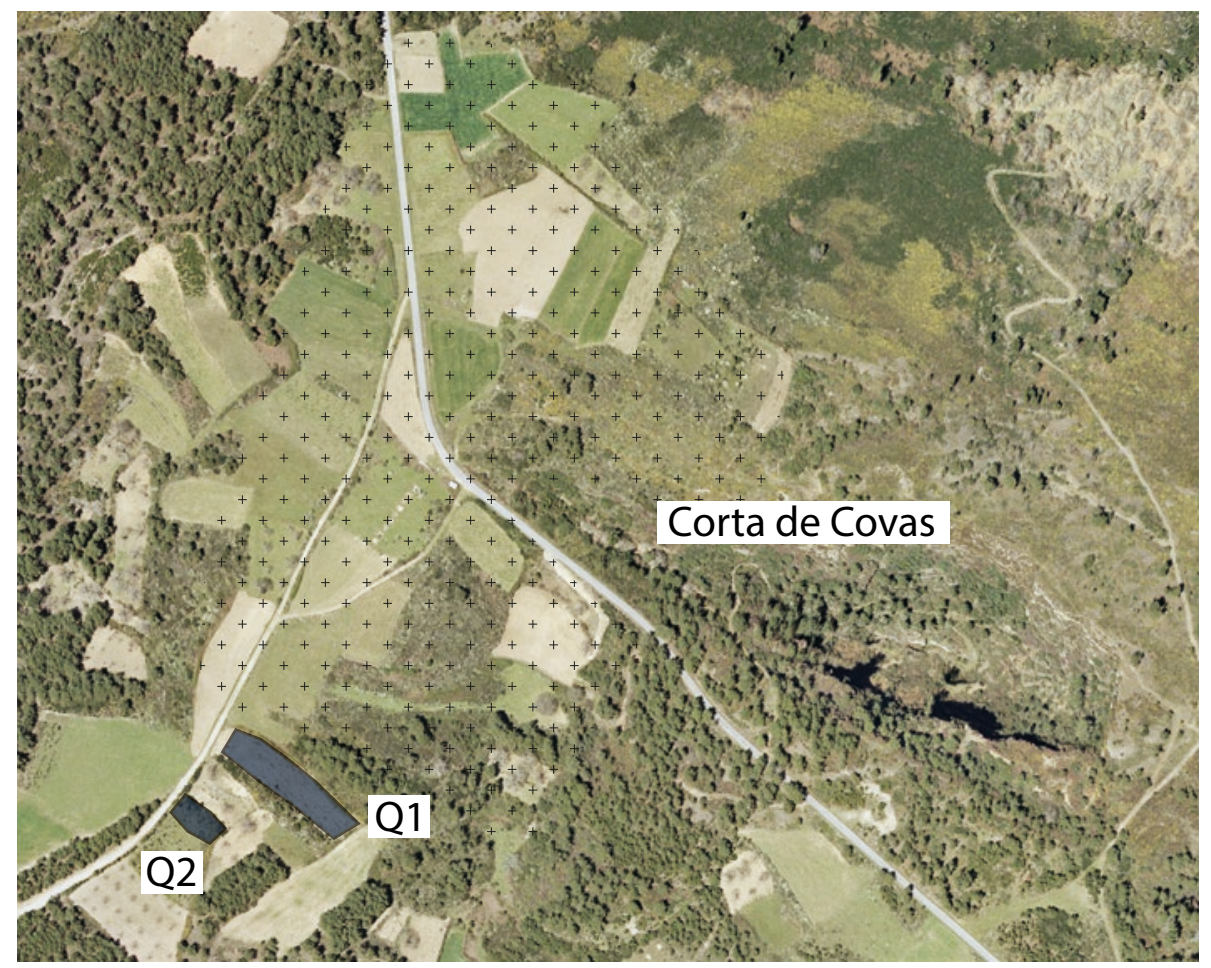

Fig. 6.0-25: Territorium metallorum Tresminas/Jales. Tresminas: posição das pedreiras de xisto 1 e 2 a sul do povoado da mina. (Modelo Ortofotomapa 1:5000, folha 7531, Vila Pouca de Aguiar, desenho: R. Wahl-Clerici). 


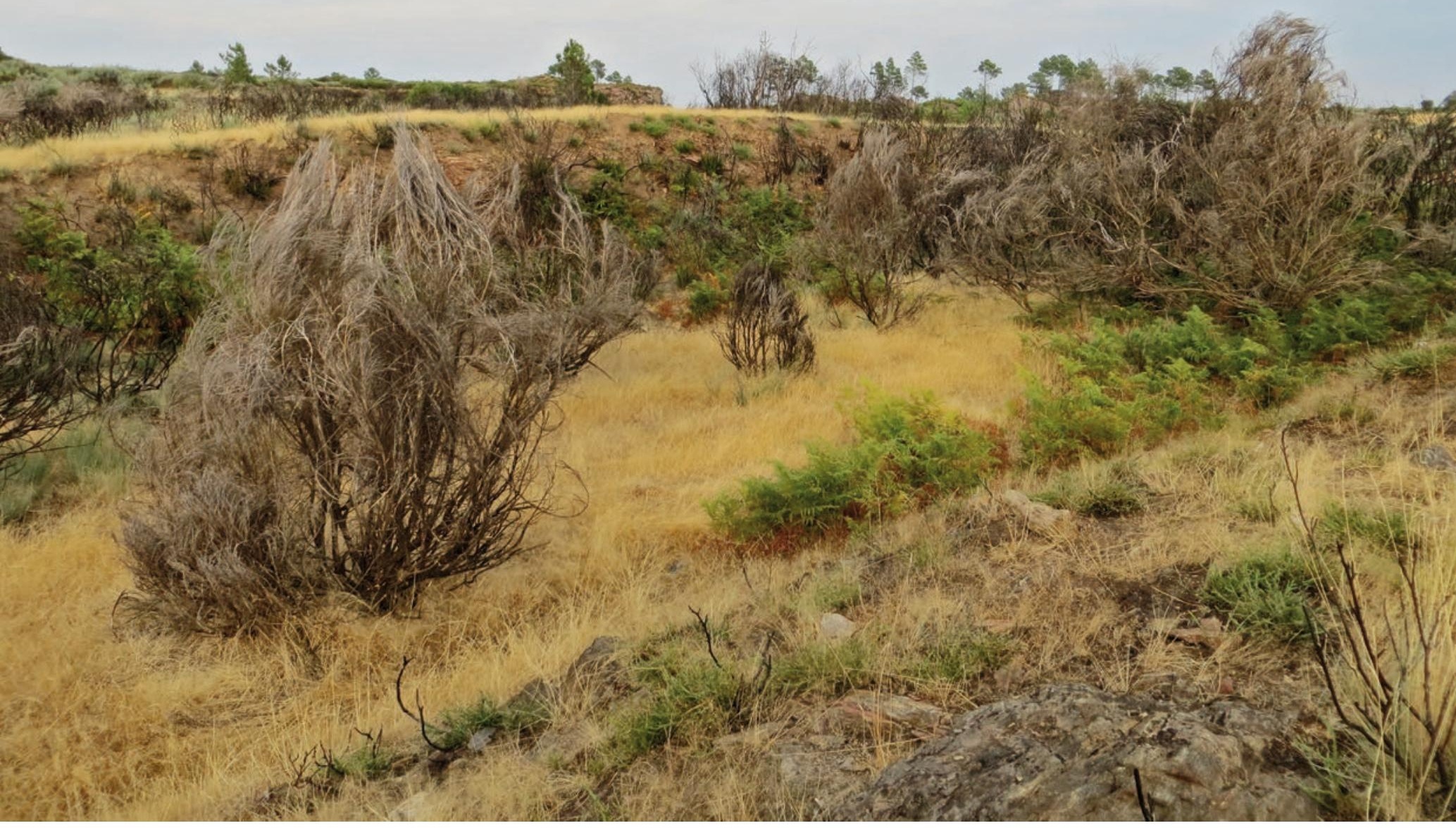

Fig. 6.0-26: Territorium metallorum Tresminas /Jales. Tresminas: vista de sudoeste para a pedreira de xisto Q1 sul do povoado da mina (fotografia: R. Wahl-

Clerici). 


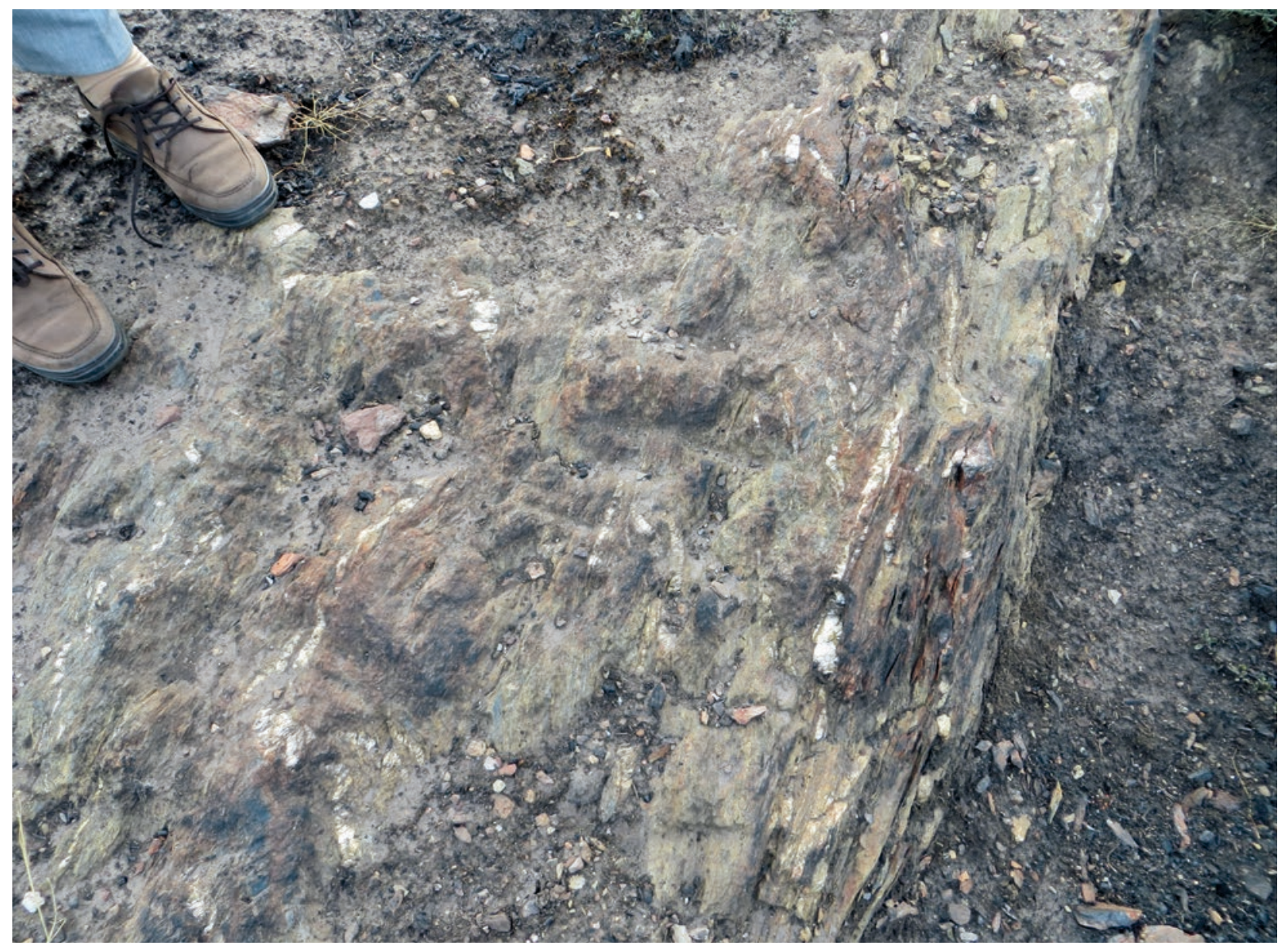

Fig. 6.0-27: Territorium metallorum Tresminas / Jales. Tresminas: vestígios de desmonte na encosta norte da pedreira de xisto Q1 (fotografia: R. Wahl-Clerici) 


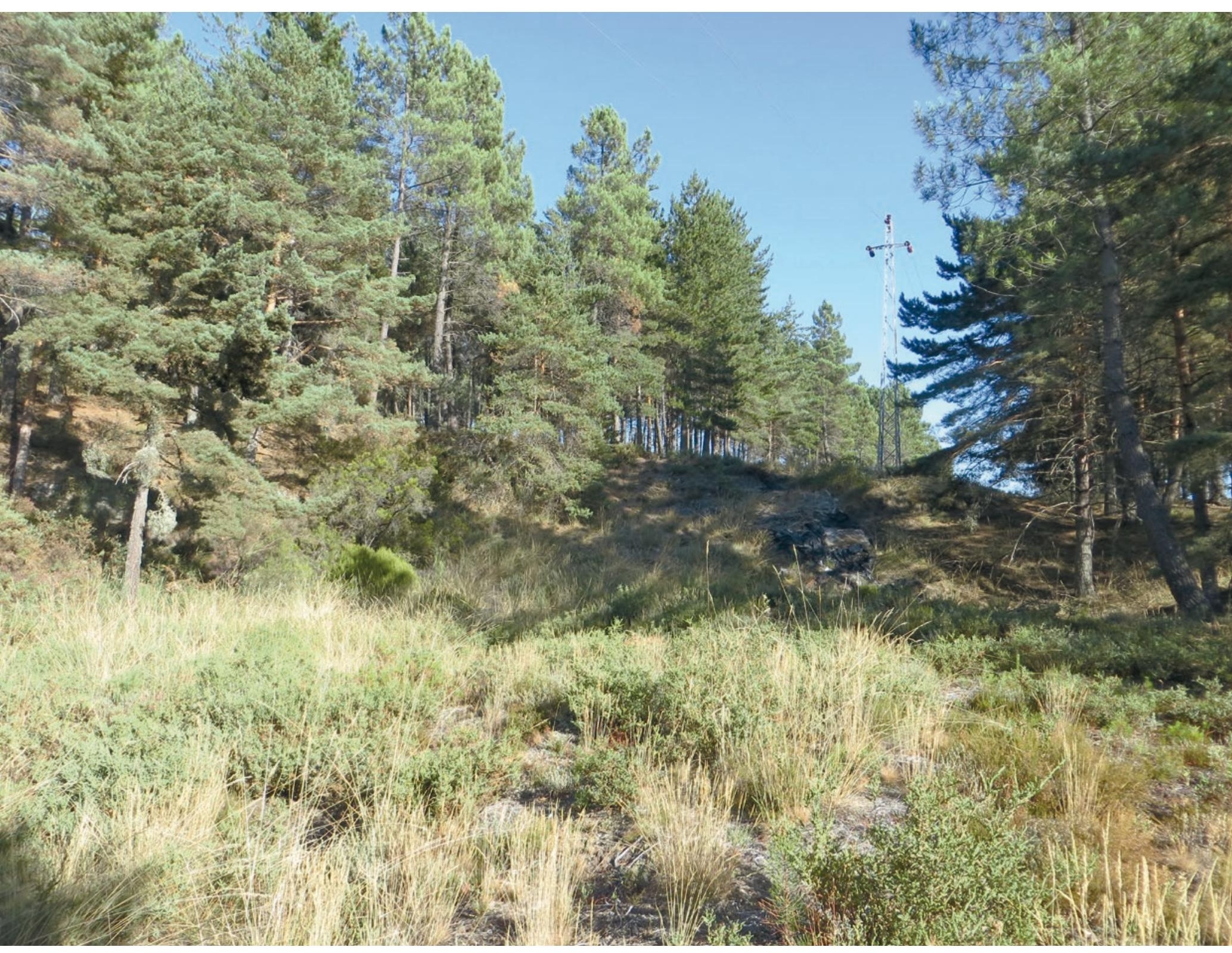

Fig. 6.0-28: Território metallorum Tresminas / Jales. Outeiro: vista para cova onde se extraía a terra (fotografia: R. Wahl-Clerici). 

AGRICOLA 1556 / 1984 G. AGRICOLA, De re metallica (Basel 1556, reprint München 1984).

AGRICOLA et al. 1950 G. AGRICOLA / H. C. HOOVER / L. H. HOOVER, De re metallica. Translated from the first Latin edition of 1556 with biographical introduction, annotations and appendices upon the development of mining methods, metallurgical processes, geology, mineralogy \& mining law from the earliest times to the 16th century (New York 1950).

AICHER 1995 P. J. AICHER, Guide to the aqueducts of ancient Rome (Wauconda 1995).

ALARCAO 1997 A. M. Alarcao (ed.), Portugal Romano. A exploracao dos recursos naturais (Lisboa 1997).

ALARCÃo 1988 J. de ALARCÃo, O domínio romano em Portugal. Forum da história 1 (Mem Martins 1988).

ALbuQueraue E CAStro, 1965 L. DE ALbuQueraue E CASTRO, Trêsminas - arqueologia mineira. In: Actas do Congresso internacional de etnografia promovido pela Câmara municipal de Santo Tirso de 10 a 18 de julho de 1963 (Lisboa 1965) 129-142.

ALFöLDY 1984 G.ALFöLDY, Römische Sozialgeschichte. Wissenschaftliche Paperbacks Sozial- und Wirtschaftsgeschichte 8 (Wiesbaden 1984).

ALFÖLDY 2000 G. ALFÖLDY, Das neue Edikt des Augustus aus El Bierzo in Hispanien. Zeitschrift für Papyrologie und Epigraphik 131, 2000, 177-205.

ALMEIDA 1970 F. A. D. ALMEIDA, Minas de ouro na Gallaecia portuguesa. In: Legio VII Gemina (Leon 1970) 291-296.

ANREITER etal. 2013 P. ANREITER / K. BRANDSTÄTTER / G. GOLDENBERG (eds.), Mining in European history and its impact on environment and human societies. Proceedings for the 2 nd Mining in European History-Conference of the SFB-HIMAT, 07.-12. November 2012, Innsbruck. Conference series (Innsbruck 2013).

ARENILLAS PARRA / BARAHONA OVIEDO 2009 M. ARENILLAS PARRA / M. BARAHONA OVIEDO, La presa romana de La Alcantarilla en el abastecimiento de agua a Toledo. In: S. Huerta / R. Marín / R. Soler / A. Zaragozá (eds.), Actas del Sexto Congreso Nacional de Historia de la Construcción. Valencia, $21-24$ de

octubre de 2009. Textos sobre teoría e historia de las construcciones (Madrid 2009) 95-105.

BACHMANN 1993 H.-G.BACHMANN, Zur Metallurgie der römischen Goldgewinnung in Três Minas und Campo de Jales in Nordportugal. In: H. Steuer (ed.), Montanarchäologie in Europa. Berichte zum Internationalen Kolloquium „Frühe Erzgewinnung und Verhüttung in Europa“ in Freiburg im Breisgau vom 4. bis 7. Oktober 1990. Archäologie und Geschichte 4 (Sigmaringen 1993) 153-160.

BARCELó 1998 P. BARCELó, Die Darstellung von Naturkatastrophen in der spätantiken Literatur. Stuttgarter Kolloquium zur Historischen Geographie des Altertums 6, 1998, 99-104.

BARTELS 2006 C. BARTELS (ed.), Das Schwazer Bergbuch. „1556 Perkwerch etc.“. Veröffentlichungen aus dem Deutschen BergbauMuseum Bochum 142 (Bochum 2006).

BATATA 2006 C. A. M. BATATA, Explorações mineiras antigas entre os Rios Zêzere, Tejo e Ocreza. In: Actas do $3^{\circ}$ Simpósio sobre mineração e metalurgia históricas no Sudoeste Europeu (Porto 2006) 67-77.

BATATA 2009 C. A. M. BATATA, Resultados das escavações arqueológicas de 2007 e 2008 realizadas no complexo mineiro romano de Três Minas e Jales. Revista Aquae Flaviae 41, 2009, 417-431.
BATATA 2017 C. A. M. BATATA, A mineração romana no complexo de Tresminas e Jales (Trás-os-Montes, Portugal) <https: / / dspace. uevora.pt / rdpc/ bitstream / 10174 / 23065 / 5 / CapaContra\%20 Pr\%C3\%A9textoTese.pdf>.

BATATA etal. 2008 C. A. M. BATATA / N. BORGES / H. CORREIA / H. de sousA, Carta Arqueologica do Concelho de Vila Pouca de Aguiar (Vila Pouca de Aguiar 2008)

BECKMANN 2002 M. BECKMANN, The Columnae Coc(h)lides of Trajan and Marcus Aurelius. Phoenix. The Journal of the Classical Association of Canada. Revue de la Société canadienne des études classiques 56,3, 2002, 348-357.

BIRD 1972 D. G. BIRD, The Roman gold mines of North-West Spain. Bonner Jahrbücher 172, 1972, 36-64.

BLECH etal. 2002 M. BLECH / M. KOCH / M. KUNST, Denkmäler der Frühzeit. Hispania Antiqua 5 (Mainz 2002).

BOST 2012 J.-P. BOST (ed.), L'eau: usages, risques et représentations dans le Sud-Ouest de la Gaule et le Nord de la Péninsule Ibérique, de la fin de l'âge de Fer é l'Antiquité tardive (IIe s. a. C. - VI s. p. C.). Collection Suppléments Aquitania 21 (Bordeaux 2012).

BOTELHO 1907 H. BOTELHO, Lápides com inscrições romanas do distrito de Vila Real. O Arqueólogo português 12, 1907, 26-31.

BOWMAN / WILSON 2018 A. K. BOWMAN / A. I. WILSON (eds.), The Roman agricultural economy. Organization, investment, and production. Oxford studies on the Roman economy (Oxford 2018).

BREDOW 1998 I. V. BREDOW, Die mythischen Bilder der Naturkatastrophen. In: E. Olshausen (ed.), Naturkatastrophen in der Antiken Welt. Stuttgarter Kolloquium zur Historischen Geographie des Altertums 6, 1996. Geographica historica 10 (Stuttgart 1998) 162-168.

BUCHSENSCHUTZ et al. 2011 O. BUCHSENSCHUTZ / L. JACCOTTEY / F. JODRY / J. L. BLANCHARD (eds.), Évolution typologique et technique des meules du néolithique à l'an mille. Actes des IIIe Rencontres archéologiques de l'archéosite Gaulois. Collection Suppléments Aquitania 23 (Bordeaux 2011).

BURNHAM / BURNHAM 2004 B. BURNHAM / H. BURNHAM, Dolaucothi-Pumsaint. Survey and excavations at a Roman gold-mining complex 1987-1999 (Oxford 2004).

CAMINO MAYOR / PERALTA LABRADOR 2015 J.CAMINO MAYOR / E. J. PERALTA LABRADOR (eds.), Las guerras astur-cántabras (Gijón 2015).

CARDOZo 1954 M.CARDozo, A propósito da lavra do ouro na Província de Trás-os Montes durante a época romana. Comunicação apresentada ao IV Congresso Internacional de Ciências Pré-históricas e Proto-históricas, realizado em Madrid em Abril de 1954, seguida de um Relatório sobre o mesmo Congresso, Guimarães. Revista de Guimarães 64, 1954, 120-133.

CARVALHO / DA VEIGA FERREIRA 1954 J. S. CARVALHO / O. DA VEIGA FERREIRA, Algumas lavras auríferas romanas. Estudos, notas e trabalhos do Serviço de Fomento Mineiro 9, 1954, 20—46.

CASTIGLIONI / LIPPERT 1998 A. CASTIGLIONI / B. LIPPERT, Das Goldland der Pharaonen. Die Entdeckung von Berenike Pancrisia (Mainz 1998).

CASTRO hipólito 1961 M. D. CAStRo hipólito, Dos tesouros de monedas romanas em Portugal. Conimbriga 2, 1961, 1-166.

CAUUET 2005 B. CAUUET, Mines d'or et d'argent antiques de Dacie. Le district d'Alburnus Maior (Rosia Montana, Roumanie). Les Nouvelles de l'Archéologie 100, 2005, 38-43.

CECH 2017 B. CECH, Technik in der Antike (Darmstadt 2017).

CONOPHAGOS 1980 C. CONOPHAGOS, Le Laurium antique et la technique grecque de la production de l'argent (Athen 1980). 
CONTADOR DE ARGOTE 1734 J. CONTADOR DE ARGOTE (ed.), Memórias para a História Eclesiástica do Arcebispado de Braga, Primaz das Espanhas II(Lisboa 1734).

costA-GARCÍA et al. 2015 J.-M. costA-GARCÍA / R. BLANCO ROTEA / M. GAGO MARIÑO / J. FINTE, Novedades sobre la presencia del ejército romano en al occidente galaico. In: J. Camino Mayor / E. J. Peralta Labrador (eds.), Las guerras astur-cántabras (Gijón 2015) $285-289$.

DAREMBERG / SAGLIO 1877-1919 C. DAREMBERG / E. SAGLIO (eds.), Dictionnaire des Antiquités grecques et romaines (1877-1919).

DIAS DE CARVALHO 1979 A. DIAS DE CARVALHO, Breves referências sobre jazigos auríferos portugueses. Boletim de Minas 16,3, 1979, 139-150.

DIEULAFAIT 2011 c. DIEULAFAIT, L'établissement romain de Las Rubias, dans les mines d'or de la Sierra de Teleno (Corporales, province de León, Espagne). Actas del Quinto Congreso Internacional sobre Minería y Metalurgia Históricas en el SE Europeo (León, 2008), 2011, 59-98.

DOLENZ 2015 H. DOLENZ, Die Goldbarrengießerei in der Stadt auf dem Magdalensberg. Einblicke in einen kaiserlich römischen Hightec-Betrieb. In: T. Stöllner / K. Oeggl (eds.), Bergauf bergab. 10000 Jahre Bergbau in den Ostalpen (Bochum 2015) 383-388

DOMERGUE 1983 C. DOMERGUE, La mine antique d'Aljustrel (Portugal) et les tables de bronze de Vipasca. Collection de la Maison des Pays Ibériques 12 (Paris 1983).

Domergue 1987 C. Domergue, Catalogue des mines et des fonderies antiques de la Péninsule Ibérique. Publications de la Casa de Velázquez Série archéologie 8 (Madrid 1987).

DOMERGUE 1989 c. DOMERGUE (ed.), Mineria y metallurgia en las antiguas civilizaciones mediterraneas y europeas. Coloquio internacional asociado, Madrid, 24-28 oct. 1985, organizado por el Departamento de Historia Antigua de la Universidad Complutense (Madrid) y l'URA 997 CNRS de l'Université de Toulouse Le Mirail (Madrid 1989).

domergue 1990 C. Domergue, Les mines de la Péninsule Ibérique dans l'antiquité romaine. Collection de l'École Française de Rome 127 (Rome 1990).

DOMERGUE 2008 C. DOMERGUE, Les mines antiques. La production des métaux aux époques grecque et romaine. Antiqua (Paris 2008).

Domergue 2012 C. Domergue, L'eau et les mines. In: J.-P. Bost (ed.), L'eau: usages, risques et représentations dans le Sud-Ouest de la Gaule et le Nord de la Péninsule Ibérique, de la fin de l'âge de Fer é l'Antiquité tardive (IIe s. a. C. - VI s.p. C.). Collection Suppléments Aquitania 21 (Bordeaux 2012) 111-140.

EDMONDSON 1987 J.C. EDMONDSON, Two industries in Roman Lusitania. Mining and garum production. BAR international series 362 (Oxford 1987)

EDMONDSON 1992 / 1993 J.C. EDMONDSON, Creating a provincial landscape. Roman imperialism and rural change in Lusitania. In: J. G. Gorges / M. Salinas de Frias (eds.), Actas de la mesa redonda internacional El medio rural en Lusitania romana. Formas de habitat y ocupación del suelo, Studia historica / Historia antigua (Salamanca 1992 / 1993) 13-30.

FARINHA RAMOS 2017 J. M. FARINHA RAMOS, Alguns aspectos da geologia e recursos minerais da região de Vila Pouca de Aguiar (Vila Pouca de Aguiar 2017).

FENSTERBUSCH 1964 Vitruv, Zehn Bücher über Architektur. Lateinisch und deutsch. Übersetzt und mit Anmerkungen versehen von Curt Fensterbusch (Darmstadt 1964)

FERnÁNDEZ NIETO 1970-71 F. J. FERnÁNDEZ NIETO, Aurifer Tagus. Zephyrus 21-22, 1970-71, 245-259.

FERREIRA ALMEIDA 1973 A. FERREIRA ALMEIDA, Aspectos da mineração romana de ouro em Jales e Tresminas (Tras-os-Montes). In: XII Congreso Nacional de Arqueología: Jaén, 1971 (Zaragoza 1973) $553-562$.

FLACH 1979 D. FLACH, Die Bergwerksordnungen von Vipasca. Chiron 9, 1979, 399-448
FLACH 1989 D. FLACH, Teilpacht im römischen Bergbau. In C. Domergue (ed.), Mineria y metallurgia en las antiguas civilizaciones mediterraneas y europeas. Coloquio internacional asociado, Madrid, 24-28 oct. 1985, organizado por el Departamento de Historia Antigua de la Universidad Complutense (Madrid) y l'URA 997 CNRS de l'Université de Toulouse Le Mirail (Madrid 1989) 133-137.

FONTE / COSTA-GARCÍA 2016 J. FONTE / J.-M. costA-GARcíA, Alto da Cerca (Valpaços, Portugal): um assentamento militar romano na Serra da Padrela e sua relação com o distrito mineiro de Tresminas. Estudos do Quaternário 15, 2016, 39-58.

FRIEDMAN 2018 H. FRIEDMAN, Agriculture in the Faynan. Food Supply for Industry. In: A. K. Bowman / A. I. Wilson (eds.), The Roman agricultural economy. Organization, investment, and production. Oxford studies on the Roman economy (Oxford 2018) $307-322$.

FUCHS etal. 1993 R. FUCHS / B. KLEINMANN / H. KNOLL, Gold und Vergoldung bei Plinius dem Älteren. Gold und Vergoldung in der Naturalis Historia des Älteren Plinius und anderen antiken Texten mit Exkursen zu verschiedenen Einzelfragen. Naturalis Historia 33, 58-68; 33, 80-94; 33, 99-100; 123; 125. Werkhefte der Universität Tübingen: Reihe A, Naturwissenschaften 13 (Tübingen 1993)

FUENTES PRIETO et al. 2011 M. N. FUENTES PRIETO / J. M. MATA PERELLÓ / L. TORRÓ I ABAT / A. NEIRA CAMPO / O. PUCHE RIART (eds.), Actas del Quinto Congreso Internacional sobre Minería y Metalurgia Históricas en el SE Europeo (León, 2008). Libro en homenaje a Claude Domergue (Madrid 2011)

GALSTERER 1976 H. GALSTERER, Bemerkungen zur Integration vorrömischer Bevölkerungen auf der iberischen Halbinsel. In: A. Tovar / M. Faust / F. Fischer / M. Koch (eds.), Actas del II Coloquio sobre Lenguas y Culturas Preromanas de le Peninsula Iberica (Salamanca 1976) 453-464.

GALSTERER 2009 H. GALSTERER, Statthalter und Stadt im Gerichtswesen der westlichen Provinzen. In: W. Eck (ed.), Lokale Autonomie und Ordnungsmacht in den kaiserzeitlichen Provinzen vom 1. bis 3. Jahrhundert. Schriften des Historischen Kollegs 42 (Berlin / Boston 2009) 243-256.

GARCÍA MARCOS / MORILLO CERDÁN 2015 V. GARCÍA MARCoS / Á. MORILLO CERDÁN, León, campamento romano. In: L. A. Grau (ed.), ArqueoLeón II: Historia de León a través de la arqueología : actas, Museo de León, noviembre 2013 - marzo 2014 (León 2015) 91-112.

GARCÍA MERINO 1973 C. GARCÍA MERINO, Las tierras del NO de la Península Ibérica, foco de atracción para los emigrantes de la Meseta en época romana. Hispania antiqua (Valladolid): revista de historia antigua 3, 1973, 9-28.

GARCíA ROMERo 2002 J.GARCíA Romero, Minería y metalurgia en la Córdoba romana (Córdoba 2002).

GARCÍA SANDOVAL 1966 E. GARCíA SANDOVAL, Informe sobre las casas romanas de Mérida y excavaciones en la "Casa del Anfiteatro". Excavaciones arqueológicas en España 49 (Madrid 1966).

GARCÍA SANDOVAL 1969 E. GARCíA SANDOVAL, La Casa Romana del Anfiteatro (Badajoz 1969).

GONZALEZ AGUILERA etal. 2015 D. GONZALEZ AGUILERA / F. REMONDINO / J. BOEHM / T. KERSTEN / T. FUSE (eds.), 6th International Workshop 3D-ARCH 2015: "3D Virtual Reconstruction and Visualization of Complex Architectures”, 25 - 27 February 2015 , Avila, Spain. Inernational Archives of Photogrammetry, Remote Sensing and Spatial Information Sciences XL 5 / W4 (Avila 2015).

GORGES / NOGALES BASARRATE 2010 J. G. GORGES / T. NOGALES BASARRATE (eds.), Naissance de la Lusitanie romaine (Ier av. - Ier ap. J.-C.). VIIe Table ronde internationale sur la Lusitanie romaine (Toulouse 8-9 novembre 2007) (Toulouse 2010).

GORGES / SALINAS DE FRIAS 1992 / 1993 J.G.GORGES / M. SALINAS DE FRIAS (eds.), Actas de la mesa redonda internacional El medio rural en Lusitania romana. Formas de habitat y ocupación del suelo. Studia historica / Historia antigua (Salamanca 1992 / 1993). 
GOSTENČNIK 2016 K. GOSTENČNIK, Eisen-Bronze-Gold. zum Metallhandwerk in der römischen Stadt „Alt-Virunum“ auf dem Magdalensberg. Carinthia I 206, 2016, 11-35.

GRAU 2015 L. A. GRAU (ed.), ArqueoLeón II: Historia de León a través de la arqueología: actas, Museo de León, noviembre 2013 marzo 2014 (León 2015).

GREWE 1985 K. GREWE, Planung und Trassierung römischer Wasserleitungen. Schriftenreihe der Frontinus-Gesellschaft Supplementband 1 (Wiesbaden 1985).

GREWE 1998 K. GREWE, Licht am Ende des Tunnels. Planung und Trassierung im antiken Tunnelbau. Zaberns Bildbände zur Archäologie (Mainz 1998).

HALEY 1991 E. W. HALEY, Migration and economy in Roman imperial Spain. Avrea Sæcvla 5 (Barcelona 1991).

HARRIS 2018 W. V. HARRIS, The Indispensable Commodity. Notes on the Economy of Wood in the Roman Mediterranean. In: A. I. Wilson / A. K. Bowman (eds.), Trade, commerce, and the state in the Roman world. Oxford studies on the Roman economy (Oxford, United Kingdom 2018) 211-236.

HARRISON 1931 F. A. HARRISON, Ancient Mining Activities in Portugal. The Mining Magazine 45, 1931, 137-145.

HEIL 2012 M. HEIL, Die Bergwerksprocuratoren der römischen Kaiserzeit. In: E. Olshausen / V. Sauer (eds.), Die Schätze der Erde. Natürliche Ressourcen in der antiken Welt; Stuttgarter Kolloquium zur Historischen Geographie des Altertums, 10, 2008. Alte Geschichte 28 (Stuttgart 2012) 155-173.

HELFERT et al. 2013 M. HELFERT / B. RAMMINGER / R. WAHL-CLERICI, Underground surveying with 3D-laserscanning of the "Galeria dos Alargamentos" in the Roman gold mining district of Três Minas and Campo De Jales (Northern Portugal). In: P. Anreiter / K. Brandstätter / G. Goldenberg (eds.), Mining in European history and its impact on environment and human societies. Proceedings for the 2nd Mining in European History-Conference of the SFB-HIMAT, 07.-12. November 2012, Innsbruck. Conference series (Innsbruck 2013) 207-214.

HELFERT et al. 2019 M. HELFERT / R. WAHL-CLERICI / M. LINDSTAEDT / K. MECHELKE, Tresminas - römischer Stollen nach 25 Jahren wieder zugänglich. Archäologie in Deutschland 6, 2019, 40-43.

HIRT 2010 A. M. HIRT, Imperial mines and quarries in the Roman world. Organizational aspects $27 \mathrm{BC}$ - AD 235. Oxford scholarship online (Oxford 2010).

HOLLERAN 2016 C. HOLLERAN, Labour Mobility in the Roman World: A Case Study of Mines in Iberia. In: L. de Ligt/L. E. Tacoma (eds.), Migration and mobility in the early Roman empire. Studies in global migration history volume 7 (Leiden / Boston 2016) 95-137.

HUERTA etal. 2009 S. HUERTA / R. MARÍN / R. SOLER / A. ZARAGOZÁ (eds.), Actas del Sexto Congreso Nacional de Historia de la Construcción. Valencia, 21-24 de octubre de 2009. Textos sobre teoría e historia de las construcciones (Madrid 2009).

JONES 1938 W. R. JONES, Relatório sobre os depósitos auríferos da Mina dos Mouros, Filões da Gralheira e Três Minas, situados no norte de Portugal (London 1938)

JORGE / HAUSCHILD 2000 v. o. JORGE / T. HAUSCHILD (eds.), 3. Arqueologia da antiguidade na península ibérica: actas: UTAD, Vila Real, setembro de 1999 Vol. 6. Arqueologia da Antiguidade na Península Ibéric (Porto 2000).

KENNER 1888 F. KENNER, Römische Goldbarren mit Stempeln. Numismatische Zeitschrift 20, 1888, 19.46

KERSTEN etal. 2013 T. KERSTEN / M. LINDSTAEDT / K. MECHELKE / B. VOGT, Terrestrisches Laserscanning auf der Osterinsel. Dokumentation der Moai und der archäologischen Grabungen. Zeitschrift für Archäologie Aussereuropäischer Kulturen 5, 2013, 67-112.

KERSTEN etal. 2014 T. KERSTEN / K. MECHELKE / M. LINDSTAEDT / F. TSCHIRSCHWITZ / K. SCHREYER / L. MAZIULL, Bildbasierte Low-Cost Systeme zur automatischen Generierung von 3D-Modellen archäologischer Fundstücke in Äthiopien und Ka- tar. In: T. Luhmann / C. Müller (eds.), Photogrammetrie, Laserscanning, optische 3D-Messtechnik. Beiträge der Oldenburger 3D-Tage 2014 [vom 12. bis 13.02.2014 (Berlin 2014) 210-222.

KERSTEN etal. 2015 T. KERSTEN / K. MECHELKE / L. MAZIULL, 3D-Model of Al Zubarah Fortress in Qatar - Terrestrial Laser Scanning vs. Dense Image Matching. In: D. Gonzalez Aguilera / F. Remondino/J. Boehm/T. Kersten / T. Fuse (eds.), 6th International Workshop 3D-ARCH 2015: “3D Virtual Reconstruction and Visualization of Complex Architectures”, 25-27 February 2015, Avila, Spain. Inernational Archives of Photogrammetry, Remote Sensing and Spatial Information Sciences XL 5 / W4 (Avila 2015) $1-8$.

KIENAST 1995 H. KIENAST, Die Wasserleitung des Eupalinos auf Samos, Samos 19 (Bonn 1995)

KÖNIG / WIN KLER 1984 R. KöNIG / G. WIN KLER, C. Plinius Secundus, Naturkunde XXXIII. Metallurgie (München / Zürich 1984).

LE ROUX 1985 P. LE ROUX, Procurateur affranchi in Hispania. Saturninus et l'activité minière. Madrider Mitteilungen 26, 1985 , $218-233$.

LEITE 2006 A. LEITE (ed.), Actas do III Simpósio de Mineração e Metalurgia Históricas do Sudoeste Europeu (Porto 2006).

LEITE DE VASCONCELLOS 1904 J. LEITE DE VASCONCELLOS, Três inscrições romanas inéditas do concelho de Vila Pouca de Aguiar. Revista de Arqueologia 3, 1904, 193-195.

LIGT / TACOMA 2016 L. de LIGT / L. E. TACOMA (eds.), Migration and mobility in the early Roman empire. Studies in global migration history volume 7 (Leiden / Boston 2016).

LUHMANN / MÜLLER 2014 T. LUHMANN / C. MÜLLER (eds.), Photogrammetrie, Laserscanning, optische 3D-Messtechnik. Beiträge der Oldenburger 3D-Tage 2014 [vom 12. bis 13.02.2014 (Berlin 2014).

MACHADO 2017 P. MACHADO, Contributo para o estudo da Paróquia de São Miguel de Tresminas. In: C. M. B. Martins / P. Machado/J. I. F. de Paiva Martins (eds.), Territorium Metallorum Tresminas. Jales, Vila Pouca de Aguiar: I Simpósio internacional [Vila Pouca de Aguiar, 6-7 de Dezembro de 2014] (Vila Pouca de Aguiar 2017) 135-145.

MACHADO etal. 2006 P. MACHADO / S. BARBOSA / A. DÓRIA / A. RIBEIRO, Jazigo aurífero de Três Minas. Tratamento de dados de campanhas de prospecção e estudo petrográfico de sondagens. In: J. Mirão / A. Balbino (eds.), VII Congresso Nacional de Geologia. Livro de Resumos 3 (Estremoz 2006) 1031-1034.

MARESCH 1999 W. V. MARESCH (ed.), Referate der Vorträge und Poster, 77. Jahrestagung der Deutschen Mineralogischen Gesellschaft im Rahmen der MinWien 1999 vom 28. August bis 1. September 1999 in Wien. Berichte der Deutschen Mineralogischen Gesellschaft 1 (Stuttgart 1999).

MARTINS 2008 C. M. B. MARTINS, A exploração mineira romana e a metalurgia do ouro em Portugal. Cadernos de Arqueologia 14 (Braga 2008).

MARTINS 2017 C. M. B. MARTINS, Arqueoletalurgia no territorium metallorum de Tresminas / Jales, Vila Pouca de Aguiar. In: C. M. B. Martins / P. Machado/J. I. F. de Paiva Martins (eds.), Territorium Metallorum Tresminas. Jales, Vila Pouca de Aguiar: I Simpósio internacional [Vila Pouca de Aguiar, 6-7 de Dezembro de 2014] (Vila Pouca de Aguiar 2017) 95-133.

MARTINS etal. 2011 C. M. B. MARTINS / A. M. S. BETTENCOURT / J. I. F. P. MARTINS / J. CARVALHO (eds.), Povoamento e exploração dos recursos mineiros na Europa atlântica ocidental (Braga 2011).

MARTINS etal. 2011 C. M. B. MARTINS / J.CARVALHO / F. ALMEIDA / A. CAVALHEIRO, Aplicação do geo-radar no reconhecimento de uma estrutura no complexo mineiro de Três Minas, Vila Pouca de Aguiar, Vila Real. In: C. M. B. Martins / A. M. S. Bettencourt / J. I. F. P. Martins/J. Carvalho (eds.), Povoamento e exploração dos recursos mineiros na Europa atlântica ocidental (Braga 2011) 521-533. 
MARTINS etal. 2017 C. M. B. MARTINS / P. MACHADO / J. I. F. DE PAIVA MARTINS (eds.), Territorium Metallorum Tresminas. Jales, Vila Pouca de Aguiar: I Simpósio internacional [Vila Pouca de Aguiar, 6-7 de Dezembro de 2014] (Vila Pouca de Aguiar 2017).

MARTINS / REDENTOR 2010 C. M. B. MARTINS / A. REDENTOR (eds.), Mineraçao e povoamento na Antiguidade no Alto de Trás-osMontes Ocidental (Porto 2010).

MARTINS / MARTINS 2017 J.I. F. P. MARTINS / C. M. B. MARTINS, A recuperação de ouro de Jales em época contemporânea, Vila Pouca de Aguiar. In: C. M. B. Martins / P. Machado/J. I. F. de Paiva Martins (eds.), Territorium Metallorum Tresminas. Jales, Vila Pouca de Aguiar: I Simpósio internacional [Vila Pouca de Aguiar, 6-7 de Dezembro de 2014] (Vila Pouca de Aguiar 2017) 147-183.

MATÍAS RODRÍGUEZ 2011 R. MATíAS RODRÍGUEZ, Los yacimientos auríferos primarios de la provincia de León (España). Técnicas de explotación romana. In: C. M. B. Martins / A. M. S. Bettencourt/J. I. F. P. Martins / J. Carvalho (eds.), Povoamento e exploração dos recursos mineiros na Europa atlântica ocidental (Braga 2011) $155-178$

MATTHEWS 2006 A. F. MATTHEWS, Drill results from the Jales / Gralheira Gold Project, Portugal <https: / / www.kitco. com / pr / 1129/article_03052006130010.pdf >.

MATtHEWS 2009 A. F. MATtHEWS, Drill results from the Jales / Gralheira Gold Property, Portugal <https: / www.kitco. com/pr/1129/article_01202009112551.pdf >

MENDES-PINTO 2000 J. M. S. MENDES-PINTO, Instalações mineiras romanas no Fojo das Pombas (Valongo, Portugal). In: V. O. Jorge/T. Hauschild (eds.), $3 .^{\circ}$ Arqueologia da antiguidade na península ibérica: actas: UTAD, Vila Real, setembro de 1999 Vol. 6 Arqueologia da Antiguidade na Península Ibéric (Porto 2000) $401-419$.

MENÉNDEZ-BLANCO et al. 2017 A. MENÉNDEZ-BLANCO / D. GONZÁLEZ ÁLVAREZ / J.-M. COSTA-GARCíA / J. FONTE / M. GAGO / ÁLVAREZ, MARTíNEZ, V., Seguindo os passos do exército romano. uma proposta metodológica para a deteção de assentamentos militares romanos no Noroeste Peninsular. In: L. Rosas / A. C. Sousa / H. Barreira (eds.), Genius Loci - Lugares e Significados. Places and Meanings (Porto 2017) 67-79.

MIRÃO / BALBINO 2006 J. MIRÃO / A. BALBINO (eds.), VII Congresso Nacional de Geologia. Livro de Resumos 3 (Estremoz 2006).

MORILLO / SALIDO DOMÍNGUEZ 2015 Á. MORILLO / J.SALIDO DOMíNGUEZ, Military Vici in Roman Spain. In: L. F. Vagalinski / N. Sharankov (eds.), Proceedings of the 22nd International congress of Roman frontier studies (Sofia 2015).

MORILLO CERDÁN 2017 Á. MORILLO CERDÁN, El periodo de la "PaZ Armada" en el norte de Hispania (19 / 15 a.C.-15 / 20 d.C.). ¿la creación de un sistema de defensa sin frontera? Gerión 35, 2017, $191-223$

MORILLO CERDÁN / AURRECOECHEA 2006 Á. MORILLO CERDÁN / J. AURRECOECHEA (eds.), The Roman army in Hispania. An archaeological guide (León 2006).

MÜLLER-LUCKNER 2009 E. MÜLLER-LUCKNER, Lokale Autonomie und Ordnungsmacht in den kaiserzeitlichen Provinzen vom 1. bis 3. Jahrhundert. Schriften des Historischen Kollegs 42 (Berlin/ Boston 2009).

MUSEU DO I.G.M 1999 MUSEU Do I.G.M, Actas do Seminário arqueologia e museologia mineiras. Lisboa, outubro de 1998 (Lisboa 1999)

NOESKE 1977 H. C. NOESKE, Studien zur Verwaltung und Bevölkerung der dakischen Goldbergwerke in römischer Zeit. Bonner Jahrbücher 177, 1977, 271-416.

NORONHA et al. 2000 F. NORONHA / M. CATHELINEAU / M.C. BOIRON / D. A. BANK / A. DÓRIA / M. A. RIBEIRO / P. NOGUEIRA / A. GUEDES, A three stage fluid flow model for Variscan gold metallogenensis in northern Portugal. Journal of Geochemical Exploration 71,2, 2000, 209-224.

OLESON 2008 J.P. OLESON (ed.), The Oxford handbook of engineering and technology in the classical world (Oxford 2008).
OLShausen 1998 E. OLshausen, Mit der Katastrophe leben. Mentalitätsgeschichtliche Studie zum Umgang von Menschen mit Naturkatastrophen am Beispiel des Vesuvausbruchs 79 n. Chr. In: E. Olshausen (ed.), Naturkatastrophen in der Antiken Welt. Stuttgarter Kolloquium zur Historischen Geographie des Altertums 6, 1996. Geographica historica 10 (Stuttgart 1998) 448-461.

OLSHAUSEN 1998 E. OLSHAUSEN (ed.), Naturkatastrophen in der Antiken Welt. Stuttgarter Kolloquium zur Historischen Geographie des Altertums 6, 1996. Geographica historica 10 (Stuttgart 1998).

OLShAusen / SAUER 2012 E. OLShAUSEN / V. SAUER (eds.), Die Schätze der Erde. Natürliche Ressourcen in der antiken Welt; Stuttgarter Kolloquium zur Historischen Geographie des Altertums 10, 2008. Alte Geschichte 28 (Stuttgart 2012).

PARENTE 1980 J. PARENTE, Subsídios inéditos para a história de Três Minas. In: Actas do Seminário de Arqueologia do Noroeste Peninsular (Barcelos 1980) 131-140.

PEREA / SÁNCHEZ-PALENCIA 1995 A. PEREA / F. J. SÁNCHEZ-PALENCIA, Arqueología del oro Astur. El oro de los astures (Oviedo 1995).

PY etal. 2012 V. PY / B. ANCEL / C. MARCONNET, De l'usage minier du feu: sources et expérimentations. In: A. Durand (ed.), Des outils, des machines et des hommes. Études offertes à Georges Comet. Cahier d'histoire des techniques 8 (Aix-en-Provence 2012) 133-153.

QUIRING 1933 H. QUIRING, Der römische Goldbergbau in Hispanien und die „Arrugien“ des Plinius. Zeitschrift für das Berg-, Hüttenund Salinenwesen im Deutchen Reich 81, 1933, 270-279.

RAMMINGER et al. 2011 B. RAM MINGER / M. HELFERT / R. WAHL-CLERICI, Non-invasive archaelogical research in the Roman gold mining district of Três Minas and Gralheira (Vila Pouca de Aguiar, northern Portugal). In: International Conference on Engineering UBI2011. Innovation and Development (Covilhã 2011) 1-9.

RAMMINGER / LASCH 2012 B. RAMMINGER / H. LASCH (eds.) Hunde - Menschen-Artefakte. Gedenkschrift für Gretel Gallay. Internationale Archäologie: Studia honoraria 32 (Rahden, Westf. 2012).

REDENTOR 2010 A. REDENTOR, Aproximação a um esboço social da área mineira romana da Serra da Padrela (Tresminas e Campo de Jales). In: C. M. B. Martins / A. Redentor (eds.), Mineraçao e povoamento na Antiguidade no Alto de Trás-os-Montes Ocidenta (Porto 2010) 121-162.

RIBEIRO et al. 2006 M. A. RIBEIRO / A. DóRIA / F. NORONHA, Contexto geológico da mineralização aurífera das explorações romanas de Três Minas. In: A. Leite (ed.), Actas do III Simpósio de Mineração e Metalurgia Históricas do Sudoeste Europeu (Porto 2006) 199-210.

RODRÍGUEZ COLMENERO 1999 A. RODRÍGUEZ COLMENERO, Resulta factible identificar la región minera de Três Minas, norte de Portugal, con el Metallum Albucrarense de Plinio? Madrider Mitteilungen 40, 1999, 160-167.

ROSA 2001 D. R. N. ROSA, Metallogenesis of the Jales Gold District, northern Portugal (Colorado 2001).

ROSA / ROMBERGER 2003 D. R. N. ROSA / S. B. ROMBERGER, Fluid Evolution in the Jales Au District, Northern Portugal. International Geology Review 45,7, 2003, 646-658.

ROSAS etal. 2017 L. ROSAS / A. C. SOUSA / H. BARREIRA (eds.) Genius Loci - Lugares e Significados. Places and Meanings (Porto 2017).

ROSUMEK 1982 P. RosUmeK, Technischer Fortschritt und Rationalisierung im antiken Bergbau. Habelts Dissertationsdrucke Reihe Alte Geschichte 15 (Bonn 1982)

SÁNCHEZ-PALENCIA 2006 F. J.SÁNCHEZ-PALENCIA, Las zonas mineras romanas del Noroeste peninsular. Infraestructura y organización del territori. In: Nuevos elementos de ingeniería romana. III Congreso de las Obras Públicas Romanas. Astorga 2006 (2006) $265-285$. 
SÁNCHEZ-PALENCIA 2011 F. J. SÁnCHEZ-PALEnCIA, Minería Romana en el Noroeste de Hispania. Tecnología y explotatción del territorio. In: C. M. B. Martins / A. M. S. Bettencourt/J. I. F. P Martins/J. Carvalho (eds.), Povoamento e exploração dos recursos mineiros na Europa atlântica ocidental (Braga 2011) 113-131.

SÁNCHEZ-PALENCIA 2012 F. J. SÁNCHEZ-PALENCIA (ed.), Minería romana en zonas interfronterizas de Castilla y León y Portugal (Asturia y NE de Lusitania) (León 2012).

SÁNCHEZ-PALENCIA 2015 F. J.SÁNCHEZ-PALENCIA, La zona minera de Tresminas (Vila Pouca de Aguiar). Aportaciones a partir de la fotografía aérea. Conimbriga 54, 2015, 179-223.

SÁNCHEZ-PALENCIA et al. 2006 F. J. SÁNCHEZ-PALENCIA / M. D. FERNÁNDEZ-POSSE / A. OREJAS, Roman Gold Mines of the North-Western Hispania. In: Á. Morillo Cerdán/J. Aurrecoechea (eds.), The Roman army in Hispania. An archaeological guide (León 2006) 127-150.

SÁNCHEZ-PALENCIA et al. 2012 F. J.SÁNCHEZ-PALENCIA / D. ROMERO / A. BELTRÁN / J. L. PECHARROMÁN / B. CURRÁS, La

minería romana de Pino del Oro y de su entrono inmediato (Zamora). In: F. J.Sánchez-Palencia (ed.), Minería romana en zonas interfronterizas de Castilla y León y Portugal (Asturia y NE de Lusitania) (León 2012) 181-215.

SASTRE PRATS etal. 2017 I.SASTRE PRATS / F. J.SÁNCHEZ-PALENCIA / OREJAS SACO DEL VALLE, A. / M. RUIZ DEL ÁRBol, Augusto y el control administrativo y territorial de las zonas mineras del Noroeste hispano. Gerión 35, 2017, 863-874.

SCHUBART etal. 1993 H.SCHUBART / A. ARBEITER / S. NOACK-HALEY (eds.), Funde in Portugal. Sternstunden der Archäologie 12 (Göttingen 1993).

SILVA CARVALHO / DA VEIGA FERREIRA 1954 J.SILVA CARVALHO / O. DA VEIGA FERREIRA, Algumas lavras auriferas romanas. Estudos, Notas e Trabalhos do Serviço do Fomento Mineiro 9, 1954, 30-33.

sousa 2013 L. sousA (ed.), Os granitos de Vila Pouca de Aguiar como Factor de desenvolvimento regional. Uma abordagem mulidisciplinar (Vila Real / Vila Pouca de Aguiar 2013).

SOUSA OLIVEIRA 2013 A. SousA OLIVEIRA, A geologia da região de Vila Pouca de Aguiar. In: L. Sousa (ed.), Os granitos de Vila Pouca de Aguiar como Factor de desenvolvimento regional. Uma abordagem mulidisciplinar (Vila Real / Vila Pouca de Aguiar 2013) $11-22$.

SPEIDEL 1996 A. M. SPEIDEL, Die römischen Schreibtafeln von Vindonissa (Brugg 1996).

STATIUS / SCHÖNBERGER 1998 P. P. STATIUS / O. SCHÖNBERGER, Der Kampf um Theben (Würzburg 1998).

STEUER 1993 H.STEUER (ed.), Montanarchäologie in Europa. Berichte zum Internationalen Kolloquium „Frühe Erzgewinnung und Verhüttung in Europa“ in Freiburg im Breisgau vom 4. bis 7. Oktober 1990. Archäologie und Geschichte 4 (Sigmaringen 1993).

STÖLLNER etal. 2003 T. STÖLLNER / G. KÖRLIN / G. STEFFENS / J. CIERNY (eds.), Man and Mining. Studies in honour of Gerd Weisgerber on occasion of his 65th birthday. Der Anschnitt, Beiheft 16 (Bochum 2003).

STÖLLNER / OEGGL 2015 T. STÖLLNER / K. OEGGL (eds.), Bergauf bergab. 10000 Jahre Bergbau in den Ostalpen (Bochum 2015).

TOVAR 1979 A. TOVAR, Actas del II Coloquio sobre Lenguas y Culturas Prerromanas de la Península Ibérica. (Tübingen, 17-19 junio 1976). Acta Salmanticensia Filosofía y letras 113 (Salamanca 1979).

TOVAR etal. 1976 A. TOVAR / M. FAUST / F. FISCHER / M. KOCH (eds.), Actas del II Coloquio sobre Lenguas y Culturas Preromanas de le Peninsula Iberica (Salamanca 1976).

TRANOY 1981 A. TRANOY (eds), La Galice romaine. Recherches sur le nord-ouest de la péninsule ibérique dans l'Antiquité. Publications du Centre Pierre Paris. Collection de la Maison des Pays Ibériques 7 (Paris 1981).
TRILLMICH / HESBERG 1993 W. TRILLMICH / H. VON HESBERG, Denkmäler der Römerzeit. Hispania Antiqua (Mainz am Rhein 1993).

VAGALINSKI / SHARANKOV 2015 L. F. VAGALINSKI / N. SHARANKOV (eds.), Proceedings of the 22nd International congress of Roman frontier studies (Sofia 2015).

VIEGAS / MARTINS 1992 L. F. VIEGAS / L. P. MARTINS Notas sobre a prospecção do ouro em Portugal. Estudos, Notas e Trabalhos, D. G. G. M, Lisboa 34, 1992, 95-106.

WAHL 1977 J. WAHL, Gladiatorenhelm-Beschläge vom Limes. Germania 55, 1977, 108-132.

WAHL 1988 J. WAHL, Três Minas. Vorbericht über die archäologischen Untersuchungen im Bereich des römischen Goldbergwerks 1986 / 87. Madrider Mitteilungen 29, 1988, 221-244.

WAHL 1993 J. WAHL, Römischer Goldbergbau in Tràs-os-Montes. In: H. Schubart / A. Arbeiter/S. Noack-Haley (eds.), Funde in Portugal. Sternstunden der Archäologie 12 (Göttingen 1993) 139-157.

WAHL 1993 J. WAHL, Três Minas. Vorbericht über die archäologischen Ausgrabungen im Bereich des römischen Goldbergwerks 1986 / 87. In: H. Steuer (ed.), Montanarchäologie in Europa. Berichte zum Internationalen Kolloquium „Frühe Erzgewinnung und Verhüttung in Europa" in Freiburg im Breisgau vom 4. bis 7. Oktober 1990. Archäologie und Geschichte 4 (Sigmaringen 1993) $123-152$.

WAHL 1997 J. WAHL, Aspectos da Mineração Romana no Território Português. In: A. M. Alarcao (ed.), Portugal Romano. A exploracao dos recursos naturais (Lisboa 1997) 96-123.

WAHL 1999 J. WAHL, Aspectos tecnológicos da indústria mineira e metalúrgica romana de Três Minas e Campo de Jales (Concelho de Vila Pouca de Aguiar). In: Actas do Seminário arqueologia e museologia mineiras. Lisboa, outubro de 1998 (Lisboa 1999) 57-68.

WAHL 2003 J. WAHL, Zur Wasserversorgung des römischen Goldbergbaus von Três Minas und Campo de Jales (Vila Pouca de Aguiar, Trás-os-Montes, Portugal). In: T. Stöllner/G. Körlin/G. Steffens / J. Cierny (eds.), Man and Mining. Studies in honour of Gerd

Weisgerber on occasion of his 65th birthday. Der Anschnitt, Beiheft 16 (Bochum 2003) 495-502.

WAHL / WAHL-CLERICI 1993 J. WAHL / R. WAHL-CLERICI, Minas Romanas de Três Minas. Vila Pouca de Aguiar (Vila Pouca de Aguiar 1993)

WAHL / WIECHOWSKI 2006 J. WAHL / A. WIECHOWSKI, Três Minas (Vila Pouca de Aguiar 2006).

WAHL-CLERICI 2008 R. WAHL-CLERICI, Fenster Europa. Portugal; das römische Goldbergwerk von Três Minas. Archäologie in Deutschland 5, 2008, 54-57.

WAHL-CLERICI 2010 R. WAHL-CLERICI, Untersuchungen zum Abbaufortschritt in der Corta de Covas (Tagebau A) im römischen Goldbergwerk von Três Minas (conc. Vila Pouca de Aguiar, Portugal). In: J. G. Gorges / T. Nogales Basarrate (eds.), Naissance de la Lusitanie romaine (Ier av. - Ier ap. J.-C.). VIIe Table ronde internationale sur la Lusitanie romaine (Toulouse 8-9 novembre 2007) (Toulouse 2010) 437-458.

WAHL-CLERICI 2011 R. WAHL-CLERICI, Três Minas. Quelques remarques a propos du pilier dans la «Galeria do Pilar». In: M. N. Fuentes Prieto/J. M. Mata Perelló/L. Torró i Abat/A. Neira Campo/O. Puche Riart (eds.), Actas del Quinto Congreso Internacional sobre Minería y Metalurgia Históricas en el SE Europeo (León, 2008). Libro en homenaje a Claude Domergue (Madrid 2011) $471-480$.

WAHL-CLERICI 2013 R. WAHL-CLERICI, A discussion of some aspects of the evidence for the use of water in mining. In: P. Anreiter / K. Brandstätter/ G. Goldenberg (eds.), Mining in European history and its impact on environment and human societies. Proceedings for the 2nd Mining in European History-Conference of the SFB-HIMAT, 07.-12. November 2012, Innsbruck. Conference series (Innsbruck 2013) 39-46. 
WAHL-CLERICI 2016 R. WAHL-CLERICI, Wasserbau für die Bergwerke im Nordwestern der Iberischen Halbinsel. In: G. Wiplinger (ed.), De aquaeductu atque aqua urbium Lyciae Pamphyliae Pisidiae. The legacy of Sextus Julius Frontinus: Tagungsband des internationalen Frontinus-Symposiums Antalya, 31. Oktober 9. November 2014. Babesch Supplement 27 (Leuven / Paris / Bristol, CT 2016) 285-295.

WAHL-CLERICI 2017 R. WAHL-CLERICI, Die Wasserspeicherung in den römischen Goldbergwerksbezirken im Nordwesten der iberischen Halbinsel. In: G. Wiplinger / W. Letzner (eds.), Wasserwesen zur Zeit des Frontinus. Bauwerke, Technik, Kultur: Tagungsband des Internationalen Frontinus-Symposiums, Trier, 25.-29.5.2016. Schriftenreihe der Frontinus-Gesellschaft Supplementband 4 (Leuven / Paris / Bristol, CT 2017)

WAHL-CLERICI 2018 R. WAHL-CLERICI, Das territorium metallorum Tresminas / Jales. Acta Carnuntina 8,2, 2018, 26-55.

WAHL-CLERICI 2020 R. Wahl-Clerici, Talsperre, Wehranlage und Tunnel: Der Aquädukt T2 im Territorium Metallorum Tresminas / Jales. Schriftenreihe der Frontinus-Gesellschaft 32, 2020, 109-127.

WAHL-CLERICI, MILLSTONE (IN PRINT) The millstone production in the Roman quarry at Fonte da Ribeira, territorium metallorum Tresminas /

Jales. In: N. Alonso/T. Anderson/L. Jaccotey (eds.), Querns and mills in Mediterranean Antiquity: tradition and innovation during the first millennium BC, Collège de France, Mondes méditerranéens antiques, Techniques and Economies in the Ancient Mediterranean.

WAHL-CLERICI, CONSIDERATIONS (IN PRINT) R. WAHL-CLERICI, Considerations on the Profitability of Roman Gold Mining in the Northwest of the Iberian Peninsula during the 1st and 2nd Centuries A. D., in: F. Hulek/S. Nomicos (eds.), Ancient Mining Landscapes: Panel 4.2, Archaeology and Economy in the Ancient World. Proceedings of the 19th International Congress for Classical Archaeology Cologne / Bonn 20-26 May 2018 (Heidelberg in Print).

WAHL-CLERICI / HELFERT 2017 R. WAHL-CLERICI / M. HELFERT, A Indústria Mineira do Territorium Metallorum Romano de Tresminas e Campo de Jales. In: C. M. B. Martins / P. Machado/J. I. F. de Paiva Martins (eds.), Territorium Metallorum Tresminas. Jales, Vila Pouca de Aguiar: I Simpósio internacional [Vila Pouca de Aguiar, 6-7 de Dezembro de 2014] (Vila Pouca de Aguiar 2017) 47-93.

WAHL-CLERICI / WIECHOWSKI 2012 R. WAHL-CLERICI / A. WIECHOWsKI, Der „Forno dos Mouros“. Ein Aufbereitungs- und Verhüttungsplatz im römischen Goldbergwerksdistrikt von Três Minas und Campo de Jales. In: B. Ramminger / H. Lasch (eds.), Hunde - Menschen - Artefakte. Gedenkschrift für Gretel Gallay. Internationale Archäologie: Studia honoraria 32 (Rahden, Westf. 2012) $325-337$

WAHL-CLERICI / WIECHOWSKI 2013 R. WAHL-CLERICI / A. WIECHOWSKI, Untersuchungen zur antiken Prospektion von Erzlagerstätten mit bergbaulichen Beispielen aus dem römischen Goldbergwerksdistrikt von Três Minas, Gralheira und Campo de Jales in Nordportugal. Madrider Mitteilungen 54, 2013, 299-326.

WAHL-CLERICI etal. 2011 R. WAHL-CLERICI / M. HELFERT / B. RAMMINGER, Fenster Europa. Portugal: Mit 3D unter Tage - römischen Bergbauingenieuren auf der Spur. Archäologie in Deutschland 2, 2011, 54-55.

WAHL-CLERICI et al. 2012a R. WAHL-CLERICI / M. HELFERT / A. WIECHowsKI, Três Minas: eine Bergwerkskatastrophe mit Rettungsaktion in der römischen Kaiserzeit. Frankfurter elektronische Rundschau zur Altertumskunde 17, 2012, 17-28.

WAHL-CLERICI etal. 2012b R. WAHL-CLERICI / A. WIECHOWSKI / M. HELFERT / B. RAM MINGER, Die Golderzaufbereitung im römischen Bergwerk von Três Minas und Campo de Jales in Nordportugal. Der Anschnitt 64, 2012, 109-118.

WAHL-CLERICI et al. 2015 R. WAHL-CLERICI / A. WIECHOWSKI / M. HELFERT / B. RAMMINGER / T. SCHIERL, Die Mühlsteinproduktion im Steinbruch von Fonte da Ribeira. Zum römischen Bergwerksdistrikt von Três Minas, Gralheira und Campo de Jales (Distr. Vila Real/P). Archäologisches Korrespondenzblatt 3, 2015, 99-113.

WAHL-CLERICI et al. 2017 R. WAHL-CLERICI / M. HEL-

FERT / T. SCHIERL / J. MOUTINHO / V. GANDRA, Die Abbauzone Lagoinhos im römischen territorium metallorum Três Minas / Jales (Nordportugal). Frankfurter elektronische Rundschau zur Altertumskunde 33, 2017, 1-21.

WIECHOWSKI / WAHL 2005 A. WIECHOWSKI / J. WAHL, Três Minas. Município de Vila Pouca de Aguiar (Vila Pouca de Aguiar 2005).

WIECHOWSKI et al. 1999 A. WIECHOWSKI / J. WAHL / R. SCHINDLMAYR, Amboss- und Mühlsteine als Bestandteile von Aufbereitungsmaschinen aus dem römischen Goldbergwerksgebiet von Três Minas und Campo de Jales (Nordportugal). In: W. V. Maresch (ed.), Referate der Vorträge und Poster, 77.Jahrestagung der Deutschen Mineralogischen Gesellschaft im Rahmen der MinWien 1999 vom 28. August bis 1. September 1999 in Wien. Berichte der Deutschen Mineralogischen Gesellschaft 1 (Stuttgart 1999) 242.

WILSON / BOWMAN 2018 A. I. WILSON / A. K. BOWMAN (eds.), Trade, commerce, and the state in the Roman world. Oxford studies on the Roman economy (Oxford 2018).

WILSON A. J. / WILSON 2008 WILSON A. J. / A. I. WILSON, Machines in Greek and Roman Technology. In: J. P. Oleson (ed.), The Oxford handbook of engineering and technology in the classical world (Oxford 2008) 337-366.

WIPLINGER 2016 G. WIPLINGER (ed.), De aquaeductu atque aqua urbium Lyciae Pamphyliae Pisidiae. The legacy of Sextus Julius Frontinus: Tagungsband des internationalen Frontinus-Symposiums Antalya, 31. Oktober - 9. November 2014. Babesch Supplement 27 (Leuven / Paris / Bristol, CT 2016).

WIPLINGER / LETZNER 2017 G. WIPLINGER / W. LETZNER (eds.), Wasserwesen zur Zeit des Frontinus. Bauwerke, Technik, Kultur: Tagungsband des Internationalen Frontinus-Symposiums, Trier, 25.-29.5.2016. Schriftenreihe der Frontinus-Gesellschaft Supplementband 4 (Leuven / Paris / Bristol, CT 2017).

ZICK etal. 1998 M.ZICK / A. HEROLD / E. PUSCH, Ramses II. - Der erste Grossindustrielle. Bild der Wissenschaft 12, 1998, 68-73. 


\section{Fontes clássicas}

Catullus / Tibullus, Pervigilium Veneris. Translated by F. W. Cornish, J. P. Postgate, J. W. Mackail. Revised by G. P. Goold. Loeb Classical Library 6 (Cambridge, MA 1913).

Dio Cassius, Roman History, Volume VI: Books 51 - 55. Translated by E. Cary, H. B. Foster. Loeb Classical Library 83 (Cambridge, MA 1917).

Diodorus Siculus, Library of History, Volume II: Books 2.35-4.58. Translated by C. H. Oldfather. Loeb Classical Library 303 (Cambridge, MA 1935).

Florus, Epitome of Roman History. Translated by E. S. Forster. Loeb Classical Library 231 (Cambridge, MA 1929).

Pliny, Natural History, Volume IX: Books 33-35. Translated by H. Rackham. Loeb Classical Library 394 (Cambridge, MA 1952).

Plutarch, Lives, Volume VIII: Sertorius and Eumenes. Phocion and Cato the Younger. Translated by B. Perrin. Loeb Classical Library 100 (Cambridge, MA 1919).

Seneca, Natural Questions, Volume I: Books 1-3. Translated by Th. H. Corcoran. Loeb Classical Library 450 (Cambridge, MA 1971).

Statius, Thebaid, Volume I: Thebaid: Books 1-7. Edited and translated by D. R. Shackleton Bailey. Loeb Classical Library 207 (Cambridge, MA 2004).

Strabo, Geography, Volume II: Books 3-5. Translated by H. L. Jones. Loeb Classical Library 50 (Cambridge, MA 1923).

Suetonius, Lives of the Caesars, Volume I: Julius. Augustus. Tiberius. Gaius. Caligula. Translated by J. C. Rolfe. Introduction by K. R. Bradley. Loeb Classical Library 31 (Cambridge, MA 1914).

Vitruvius, On Architecture, Volume II: Books 6-10. Translated by Frank Granger. Loeb Classical Library 280 (Cambridge, MA 1934). 

O excelente estado de conservação dos vestígios das antigas minas, nas jazidas primárias de Tresminas e Gralheira, bem como os das respetivas indústrias de acompanhamento, permitem-nos documentar e compreender as técnicas de exploração romanas. Através de décadas de investigação e cuidadosa documentação dos vestígios do territorium metallorum Tresminas / Jales foi possível demonstrar que os processos de trabalho apresentados neste volume (prospeção, extração e processamento) não dependem apenas uns dos outros, mas complementam-se substancialmente. Por conseguinte, prospeção não servia apenas para descobrir um depósito, como sabemos de fontes antigas, mas fazia parte do trabalho diário dos mineiros e assumia uma função essencial na exploração mineira.

A própria exploração mineira deixou vestígios que nos permitem seguir o progresso do trabalho em determinadas áreas, expondo o rigor romano no planeamento e execução, sugestivo de uma organização central. Prova disso são as fascinantes galerias de grande plano, cujas dimensões e estado de conservação têm impressionado visitantes e investigadores até aos dias de hoje. Para a compreensão do processo mineiro são particularmente úteis os vestígios que permaneceram inacabados, ou que foram abandonados ou destruídos na antiguidade. Entre os vestígios do processamento dos minérios auríferos encontram-se cerca de 1000 moinhos de pilões, inúmeros moinhos redondos e instalações de lavagem de enormes proporções. Adicionalmente, são brevemente apresentadas neste volume a gestão da água e a extração de pedra por serem essenciais ao complexo industrial. O contexto histórico do territorium metallorum Tresminas / Jales encontra-se resumido na introdução.

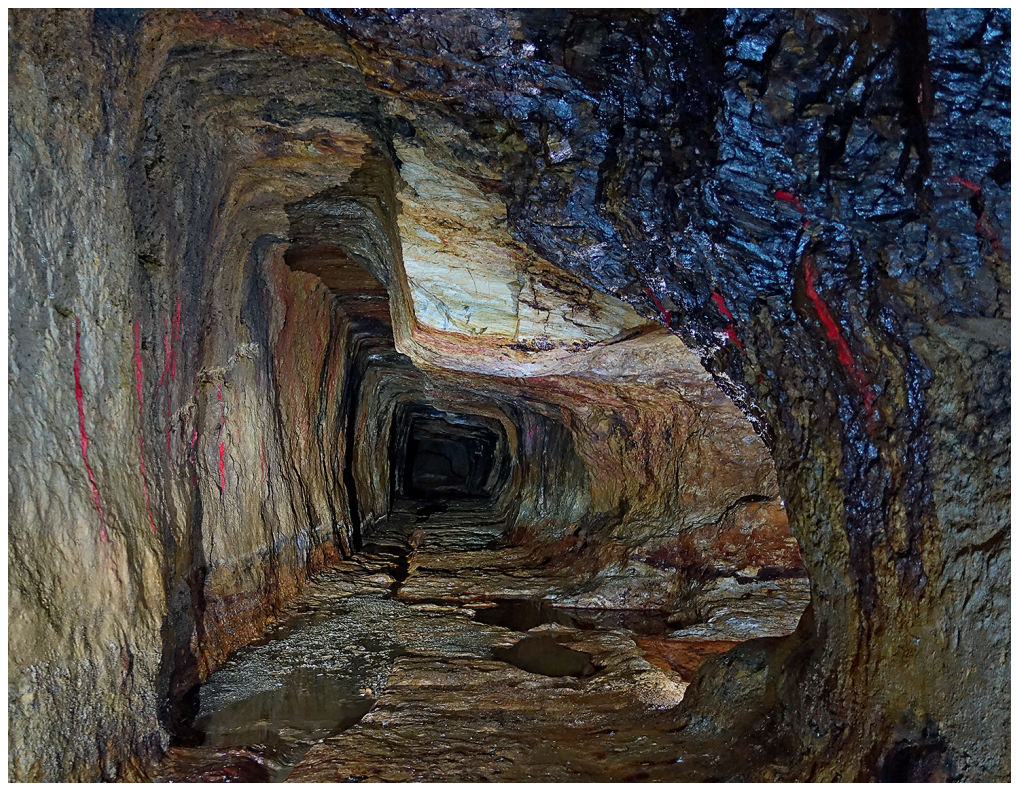

